Universidade de São Paulo

Faculdade de Filosofia, Letras e Ciências Humanas

Departamento de História

Programa de Pós-graduação em História Social

\title{
Migrantes cearenses no Pará: faces da sobrevivência (1889-1916)
}

Franciane Gama Lacerda

Tese apresentada ao Programa de Pós-Graduação em História Social, de História da Faculdade de Filosofia, Letras e Ciências Humanas da Universidade de São Paulo, para obtenção do título de Doutor em Ciências.

Orientador: Prof. Dr. Marcos Antônio da Silva

São Paulo

2006 


\section{Universidade de São Paulo}

Faculdade de Filosofia, Letras e Ciências Humanas

Departamento de História

Programa de Pós-graduação em História Social

\section{Migrantes cearenses no Pará: faces da sobrevivência (1889-1916)}

Franciane Gama Lacerda 
Para

Conceição e Francisco

Hebe e Ivan

Ester e Rafael 


\section{Agradecimentos}

Este trabalho foi possível graças ao apoio da Universidade Federal do Pará e do programa PICDT/CAPES.

Essa tese é também fruto do carinho, da atenção, da bondade e do amor de algumas pessoas que ao longo desses quatro anos, conviveram comigo, dando-me o incentivo e o apoio necessário para o término do trabalho. Nesta página, fico vendo a própria tese se delineando, na medida em que junto com a sua escrita, muitas histórias foram acontecendo.

Começo agradecendo ao meu orientador professor Marcos Antonio da Silva, hábil leitor que, com sua extrema sensibilidade, soube orientar-me e indicar-me os melhores caminhos para tese. Agradeço igualmente às professoras Yara Khoury, e Eni de Mesquita Samara, pelas contribuições dadas no exame de qualificação; sem dúvida, muito das discussões incorporadas na tese foi fruto desse momento e dos cursos que tive com essas professoras, em momentos diversos. Nesse contexto, minha orientadora de mestrado, professora Déa Ribeiro Fenelon, foi pessoa muito importante, sua amizade e inspiração acadêmica se refletem no trabalho que faço hoje. Na trilha dos orientadores, meu muito obrigada a Maria de Nazaré Sarges, a Naná, uma amiga sempre presente, sempre se alegrando.

Em momentos e lugares diversos, pude contar com a ajuda e apoio de várias pessoas. Agradeço aos colegas e amigos do Departamento de História da UFPA, em especial a Aldrin Moura de Figueiredo. Agradeço também a Pere Petit, Claudia Fuller, Alírio Cardozo e Sara Alonso. A Keila Aguiar e Raimundo Corpes. Aos meus compadres e amigos Antonio Otaviano Vieira Júnior, o Zorro, e Cristina Cancela. E à família do Zorro, Rita, Clérides e David, e também a Mardônio Guedes.

Ao longo desses quatro anos, tive dois portos seguros, a família de Castanhal e a de Campinas. Merece especial agradecimento, nesse sentido, minha irmã Maria Vitória, para mim, a sempre "maninha", para a Ester, a "Tetéia", que, acompanhada dos "pré-selvagens", esteve sempre pronta para me ajudar. O mesmo posso dizer ao Matias e à Ingrid que, junto com o Tiago, estiveram sempre muito presentes. Por fim, agradeço a Francisco e Conceição, meus pais, Hebe e Ivan, os pais do Rafael, que sofreram e se alegraram comigo ao longo da feitura desse trabalho, dando-me o incentivo e o amor necessário para que tudo corresse sempre bem. $\mathrm{O}$ mesmo vale também para meus dois amores, Rafael e Ester, que foram as pessoas fundamentais para que este trabalho ficasse concluído. Sem eles, a pesquisa e a escrita da tese não teriam tido a mesma graça e nem tão pouco a mesma importância. Ester, desde que nasceu em 2000, se viu envolvida com essa história de tese, primeiro a do pai, depois teve que esperar mais um ano pela tese da mãe. Com ela, aprendi que um trabalho acadêmico é feito com livros, fontes de arquivos, mas também com brincadeiras, trocas de fraldas, bonecas, a exemplo de Bibi e Lilica, bicicletas, pirulitos, "praias" com o Heitor, e todas as coisas que uma criança sempre pode trazer. Ao longo desse período, Rafael esteve sempre muito presente, sendo meu grande incentivador; não tenho dúvida de que sua paciência, sua tranqüilidade, sua alegria e, sobretudo, seu amor foram fundamentais. 


\title{
Resumo
}

Entre 1889 e 1916, sob a influência da economia da borracha e do interesse pelo desenvolvimento da agricultura, o Pará experimenta a chegada de grande número de migrantes cearenses que, movidos pelos problemas da seca, ou atraídos pelas alternativas de trabalho que essa região oferecia, para lá se deslocavam, vivenciando variadas experiências sociais. Esta tese discute essa experiência, examinando os muitos significados atribuídos a ela pelos migrantes, desde sua saída do Ceará até sua instalação no Pará nos núcleos coloniais, na capital paraense e nos seringais. Igualmente, trata-se de perceber os sentidos que os poderes públicos do Ceará e do Pará deram a esse processo migratório. Parte da historiografia que se debruçou sobre o tema solidificou a imagem dos migrantes cearenses como pobres flagelados pela seca ou como semi-escravos nos seringais, presos aos revezes da natureza ou à exploração de um patrão. Entretanto, a experiência migratória tem outras dimensões. Nela estão também presentes a luta pela sobrevivência, pelo trabalho e pela posse da terra, revelando conflitos, laços de afetividade com a família, com a terra natal dos migrantes, redes de solidariedade e uma estreita relação entre a floresta e a cidade.

\begin{abstract}
Between 1889 and 1916, numerous people left the state of Ceará (Brazil) and migrated to the state of Pará, influenced by the rubber boom and by an agricultural policy. These people were compelled to migrate owing to the serious droughts which afflicted their native land, and also seduced by the many labour offers in Pará, where they endured a variety of social experiences. This dissertation discusses these experiences, focusing on the meaning given by the migrants themselves to the process of migration, from the departure from Ceará until their settlement in Pará (whether in the colonies, in the capital or in the rubber fields). It also analyses the meaning given to migration by the government. Part of the historiography which has addressed these issues stresses the image of a poor and defenceless migrant, a victim of the droughts or chained to an unpredictable nature or to a ruthless employer. However, migration has many other senses. In this process, migrants also fought for their life, their labour and their land, unveiling conflicts, affective tights with their family and their native country, solidarity, and a close relation between the forest and the city.
\end{abstract}

\section{Palavras-Chave}

Migração; Amazônia; Cearenses; Séculos XIX-XX; História Social

\section{Key-words}

Migration; Amazonia; Cearenses; Nineteenth and Twentieth Centuries; Social History 


\section{Índice}

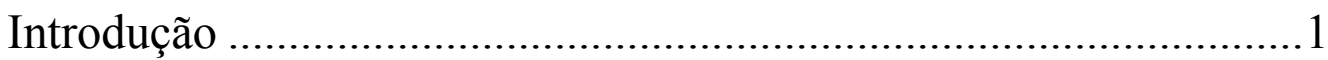

I. Migração nordestina ao Pará, historiografia e algumas propostas de trabalho ..............................14

II. Natureza cearense e natureza amazônica.......................................66

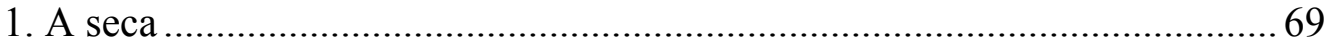

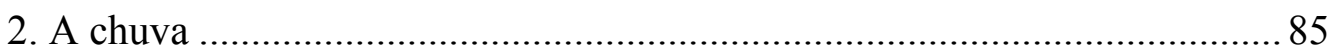

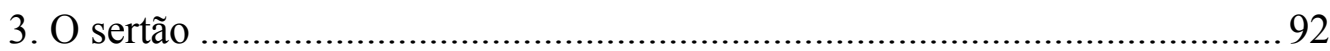

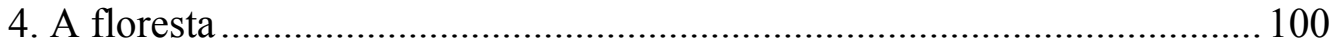

III. A saída do Ceará e a chegada ao Pará..........................................127

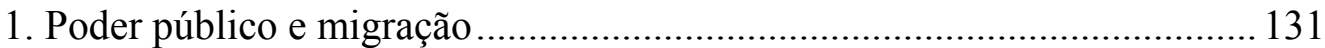

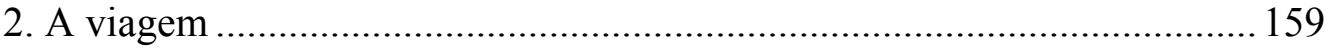

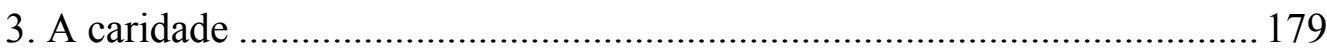

IV. Migrantes cearenses na cidade de Belém ...................................197

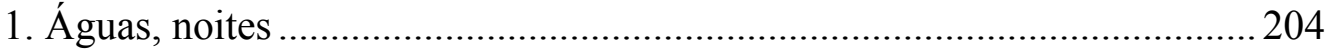

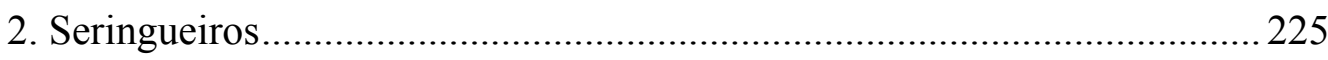

3. Cenas da vida cearense na capital do Pará ....................................................245

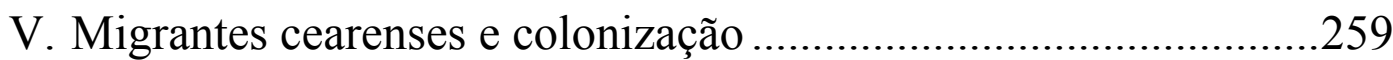

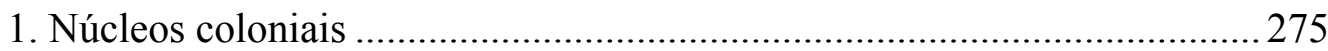

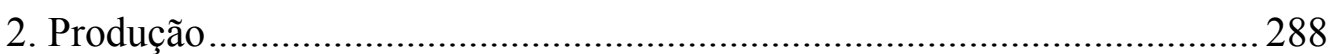

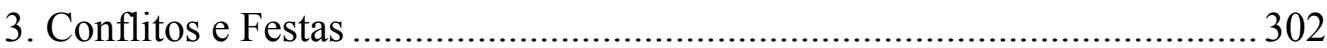

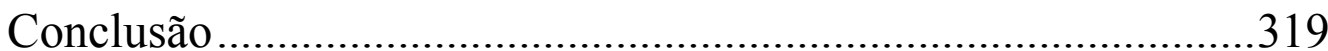

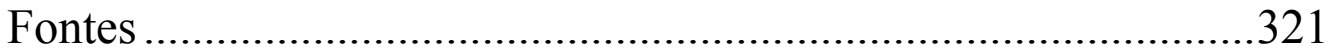

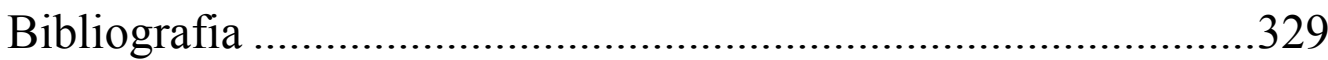




\section{Introdução}

José Luiz, Mariano José de Souza, Maria Isabel do Espírito Santo, Maria Xavier, Manuel Pereira de Melo, Juvínia Mendes da Costa, Lúcio Francisco da Frota, Manuel Caetano, João Antonio Fernandes, Francisco de Souza, Luiz Pereira de Araujo, Miguel Alves Maia, Luiza, Francisca do Espírito Santo, Maria Thereza de Jesus, Maria de Hollanda, Thereza Maria de Jesus, Francisco Pinto de Mesquita Magalhães, José Raymundo Machado Freire, Luis Leitão, Maria Ribeiro da Silva, Maria Joaquina, Antonio Ricardo, Luiz Martiniano Barbaosa, Antonio Soares de Souza, Edviges Maria de Jesus, Manoel Dantas, Firmino Ferreira de Matos, Alberto de Souza, Francisco Xavier, João Romão Capistrano, Antonia Rodrigues, Raimunda Rodrigues, Cândida Maria José, Raimunda Alves Bezerra, Antonio José de Oliveira, Vicente Ferreira Lopes, Raimundo Teles Menezes, Ângelo de Barros, Anastácio Braga, Francisca Coelho de Araujo, Honório Rosa de Oliveira, Francisca Borges de Lima, Raymunda Rosa, Vicente José da Silva, João Anselmo de Queiroz, João Anselmo de Queiroz, Misael Francisco de Lima,Vicente Timóteo da Silva, Francisco Chagas de Mello, Francisco de Souza Lima, Francisco Rodrigues de Mattos, Raimunda Maarão, Angélica de Oliveira, Maria dos Anjos, Maria Catarina, Antonio Caetano, Simplício de Barros, João Machado Pinto, Miguel Yaco, Francisco das Chagas, Manoel da Costa, João Gomes, Manoel Pereira, Manoel José da Cruz, Antonio Correa da Silva, Antonio Bento, Raymundo da Cruz do Espírito Santo, Antonio Francisco Alves, Roberto dos Santos, Francisco dos Santos, Raymundo Vieira dos Santos, dentre muitos, muitos outros, foram alguns dos migrantes que, entre 1889 e 1916, sós ou acompanhando suas famílias, não raro extensas, depois de saírem do Ceará aportaram em Belém do Pará, se deslocando para vários lugares desse estado. ${ }^{1}$

\footnotetext{
${ }^{1}$ Identificamos na documentação pesquisada os seguintes lugares no Ceará dos quais os migrantes partiam: Acarahú, Acarape, Acaraty, Aneiraz, Aquiraz, Arraial da Imperatriz, Areias, Arronches, Assaré, Barbalha, Baturité, Beberibe, Bôa Viagem, Brejo dos Santos, Brejo-Secco, Cachoeira, Camocim, Campo Grande*, Canindé, Cascavel, Cococy, Coité, Conceição, Crato, Espírito Santo de Morada Nova, Flores, Granja, Icó, Iguatú, Imperatriz, Independência, Ipú, [Ipueiras]*, Jaguaribemirim, Jardim, Lavras, Maranguape, Maria Pereira*, Mecejana, Meruoca, Milagres, Missão Velha, Nossa Senhora do Patrocínio, Pacatuba, Palma, Pedra-Branca, [Pendência], Pentecoste, Pereiro, Principe Imperial, Quixadá, Quixeramobim, Riacho do Sangue, Saboeiro, Sant'Anna, Santo Antonio do Aracaty-assú, São Benedicto, São Bento d'Amontada, São Bernardo das Russas, São José da Fortaleza, São Francisco [de Uruburetama]*, São João da Imperatriz, São João do Príncipe, São Matheus, São Pedro de Ibiapina, São Pedro da Serra do Crato*, Santa Quitéria, Sobral, Soure,
} 
Esta tese tem por objetivo contar um pouco da experiência social desse grupo em terras paraenses. Buscar registrar seus nomes e sobrenomes revela, logo de início, o desejo de demonstrar que, se essa experiência é social, ela o foi também individual e única para cada migrante, embora, na historiografia que se debruçou sobre o tema, não raro, todos sejam chamados de "cearenses" ou simplesmente de "flagelados”, numa tentativa de homogeneizar as múltiplas vivências desses homens, mulheres e crianças. Nesse sentido, trata-se de entender as muitas formas e os muitos significados que foram dados a essa experiência, tanto pelos migrantes como pelos poderes públicos e demais moradores da capital paraense ou do interior desse estado, que se viram envolvidos nesse processo.

O tema da migração de nordestinos para a Amazônia é bastante amplo, uma vez que, em momentos diversos e igualmente com objetivos variados, sobretudo a partir das últimas décadas do século XIX, ao longo de todo o século XX, e ainda hoje, observa-se a vinda de migrantes saídos de diversas áreas da região nordeste, a fim de trabalharem no Pará, no Amazonas, no Acre, em Rondônia. Neste trabalho, buscarei investigar o processo migratório verificado no estado do Pará, de maneira especial no período compreendido entre 1889 e 1916, dando maior ênfase aos grupos que se deslocaram do Ceará, uma vez que, deste Estado, é que veio o maior número de migrantes.

Esse corte cronológico se fundamenta no contexto histórico experimentado no Pará da virada do século XIX para o XX, em que se verifica uma intensa atividade econômica com a extração do látex. Aliado a isto, tem-se a nascente República brasileira, com seu ideário de progresso e civilização. A busca por construir um Estado civilizado, que representasse o desenvolvimento e o progresso que a República pretendia edificar, expressou-se no Pará de diversas formas, como no embelezamento e na urbanização da capital paraense, nas preocupações com a higienização, a disciplina e o controle do espaço urbano, na construção de uma ferrovia - a Estrada de Ferro de Bragança -, em uma preocupação com a produção agrícola, com a criação de núcleos coloniais e no incentivo à vinda de imigrantes estrangeiros, tal qual se verifica em outros estados brasileiros.

Tamboril, Trahiry, Umary, União, Varzea Alegre,Viçosa. Ver: 363-B Minutas dos ofícios da Secretaria do Governo da província do Ceará, dirigidos ao ministro dos Negócios Estrangeiros, ao ministro do Império, ao ministro da Justiça, ao ministro da Marinha. 1888. *381-B Minutas dos ofícios da Secretaria do Governo da província do Ceará, dirigidos aos Ministérios. 1889. 
Se, no Pará desse período, experimenta-se um grande crescimento econômico (pelo menos para alguns setores da população, como comerciantes e negociantes da borracha), no Ceará, crises políticas, declínio da produção agrícola e sobretudo grandes secas, como as de 1889 e a de 1915, foram elementos importantes para a ida de grande número de cearenses para a região amazônica. Os grupos de migrantes se estabeleceram em Belém, nas áreas dos seringais, ou ainda, nos vários núcleos coloniais que foram criados ao longo da Estrada de Ferro de Bragança, como forma de fomento à produção agrícola, grave problema para os poderes públicos, e igualmente para a própria população paraense.

Nesse sentido, o esforço investigativo da tese se concentra na possibilidade de rastrearmos as muitas experiências dos migrantes nesse contexto. Ao mesmo tempo, pretende-se perceber os próprios significados atribuídos por eles ao processo de migração: O que movia a vinda para o Pará? Quais eram suas expectativas em relação à nova terra para a qual se dirigiam?

Assim, tentando entender os significados das experiências dos próprios migrantes ao saírem do Ceará para se estabelecerem no Pará, a história desses grupos passa a ser compreendida dentro de um processo mais complexo, que implica investigar os conflitos, as redes de solidariedade, os elementos constitutivos da identidade do grupo, os sentidos atribuídos à família, às relações de trabalho, ao cotidiano, enfim. Dessa forma, as experiências sociais dos migrantes se ampliam, abrindo perspectivas para que se possa entrar no campo do seu imaginário sobre a Amazônia, e igualmente na forma como no Pará se representa o Ceará e seus migrantes, através da imprensa, por exemplo.

$\mathrm{Na}$ medida em que as variadas possibilidades de se pensar a experiência social dos migrantes vai emergindo, delineia-se, igualmente, a possibilidade de se rastrear variados discursos produzidos sobre a migração, buscando reconhecer uma pluralidade de versões. São problemas que se buscou investigar:

1. O que significava emigrar para os próprios cearenses, para a população paraense, para o poder público paraense e cearense?

2. Como esses grupos eram percebidos pela população e pelas autoridades locais, num tempo de pretensa busca de civilização e progresso na nascente República, e no auge da economia da borracha no estado do Pará?

3. Quais os significados atribuídos às relações familiares e à família, nesse contexto?

4. Quais os espaços ocupados e construídos por esses grupos no estado do Pará? 
Dentro dessa perspectiva, o tema da migração de nordestinos para a Amazônia pode ser interpretado a partir de significados múltiplos, evidenciando a complexidade das muitas relações sociais que se estabeleceram no contexto dessa experiência no Pará.

Diante disso, o trabalho está estruturado em cinco capítulos, que esboçam três problemas que nortearam a construção da própria tese e que nos pareceram fundamentais para entendermos a trajetória dos migrantes cearenses no Pará.

Inicialmente, trata-se das compreensões que a historiografia foi dando ao longo do tempo ao tema, cristalizando, num certo sentido, perfis dos migrantes e igualmente simplificando, numa relação de dominantes e dominados, as vivências do grupo no Pará.

Um segundo aspecto é ligado à decisão do próprio migrante de se deslocar do Ceará, o que nos levou a perceber que, longe dessa ter sido uma decisão apenas dos poderes públicos do Ceará e do Pará, os atingidos pelas secas também exprimiam seu interesse ou não de sair do sertão.

Outro ponto que nos pareceu significativo foram as muitas relações sociais que os migrantes já instalados em terras paraenses construíram entre a floresta e a cidade (Belém, capital do Pará), dando conta, à luz das interpretações de Raymond Williams, de interligadas relações mediadas justamente pelos modos de se lidar com a própria natureza e com os muitos moradores desses espaços. ${ }^{2}$

Assim, no primeiro capítulo intitulado Migração nordestina ao Pará, historiografia e algumas propostas de trabalho, discute-se como essa questão foi tratada pela historiografia. A perspectiva é rastrearmos as variadas compreensões acerca do tema. Não se trata de descrever ou analisar tudo que já foi escrito sobre o tema, para somente depois adentrar nas discussões a que a tese se propõe, mas de entender como vários autores, com propostas teóricometodológicas diferentes, e em momentos também diversos, debruçaram-se sobre o tema da migração de nordestinos para a Amazônia. Ora, vários desses estudos tiveram um papel importante na solidificação de idéias, que se tornaram lugar comum, caso dos seringueiros, sempre pensados como vítimas da natureza e dos donos de seringais. Sem, dúvida tendo como ponto de partida esses estudos, a tese buscou redimensionar algumas dessas idéias tão cristalizadas na historiografia.

\footnotetext{
${ }^{2}$ WILLIAMS, Raymond. O campo e a cidade: na história e na literatura. São Paulo: Companhia das Letras, 1989.
} 
No segundo capítulo, Natureza amazônica e natureza cearense, a tentativa é de se perceber variadas compreensões sobre a Amazônia e sobre o Ceará. Evidencia-se, assim, um imaginário sobre a natureza e os moradores desses lugares. Desse modo, a seca, a chuva, a floresta, com seus seringueiros, o sertão árido ou florido, com o sertanejo, são elementos presentes nas múltiplas formas de se entender esses espaços. Quase como uma antítese entre as águas e o sertão árido, entre os tempos de seca e os tempos de chuva, nesse capítulo, as preocupações se voltam para pensarmos na forma como muitas vezes se representou a Amazônia no Ceará, e igualmente o Ceará na Amazônia. Por outro lado, insiste-se, mesmo que de forma tangencial, em apontar um sertão e um sertanejo num contexto que não é apenas o da seca, buscando evidenciar outros elementos desse espaço.

As múltiplas experiências de viagem e os significados atribuídos ao deslocamento do Ceará pelos migrantes são o tema do terceiro capítulo, intitulado A saída do Ceará e a chegada ao Pará. Buscou-se investigar como essas viagens eram feitas, desde a partida do Ceará até o desembarque em Belém do Pará. Desse modo, as justificativas que eram dadas pelos migrantes para o seu deslocamento e, igualmente, como os poderes públicos do Pará e do Ceará entenderam esse processo são questões de destaque nesse capítulo. Além disso, a chegada de grandes levas de migrantes ao porto de Belém, em nenhum momento passou despercebida da população paraense, que, de variadas maneiras, manifestou-se sobre essa questão, fosse se preocupando com o número de pedintes nas ruas da capital, fosse criando associações de ajuda aos grupos de flagelados que aportavam no Pará, fosse criando mecanismos de disciplina em nome da Saúde Pública. Assim, investigam-se tanto as ações do Estado nesse contexto, como o papel de associações caritativas criadas no Pará em prol dos flagelados pela seca.

No quarto capítulo, Migrantes cearenses na cidade de Belém, a ênfase é dada aos modos de viver desses homens e mulheres na capital paraense. $\mathrm{O}$ destaque foi dado à figura dos seringueiros, que, ao inverso do que consagrou boa parte da historiografia regional, aqui aparecem também vivendo em uma cidade, Belém, em busca de divertimentos, de boa comida, de relações amorosas, da família, e também de produtos que pudessem consumir, fugindo completamente à imagem do "semi-escravo" preso ao trabalho da floresta. Na verdade, nesse capítulo, buscamos demonstrar o quão complexa foi a experiência dos seringueiros na Amazônia, na medida em que não se restringiu de maneira alguma somente ao espaço da floresta. Além desse grupo, outros trabalhadores cearenses também entram na pauta 
de discussão, à medida que também lutavam das mais variadas formas para encontrar seu espaço na cidade de Belém.

No quinto e último capítulo, Migrantes cearenses e colonização, o foco de discussão é o migrante envolvido no processo de colonização e povoamento, sobretudo da chamada zona bragantina do Pará. Investigaram-se, assim, os discursos e medidas dos poderes públicos em relação à imigração para a viabilização de uma política de produção agrícola para a região e, ao lado disso, as muitas experiências dos grupos de colonos cearenses nessas frentes de colonização, no espaço dos núcleos coloniais. Nesse contexto, buscou-se refletir sobre o diaa-dia do trabalho, mas também de redes de solidariedade e de divertimentos desses colonos. Ao mesmo tempo, evidenciou-se ainda a luta constante do migrante pela terra e para se manter nesse espaço através da agricultura e da extração de recursos naturais, o que foi alvo de muitas preocupações dos poderes públicos, ávidos por construir um espaço de produção agrícola.

$\mathrm{Na}$ tentativa de investigar essas muitas histórias, privilegiaram-se basicamente três tipos de documentos:

1. Aqueles produzidos pelos poderes públicos.

2. A imprensa, através dos jornais que circulavam no Pará A Folha do Norte, A Tarde e o Liberal do Pará.

3. E, finalmente, ocorrências policiais registradas pelos migrantes ou por outros, em casos em que eles se achavam envolvidos.

Esse corpus documental permitiu perceber a complexidade dessas muitas relações sociais na medida em que, para além da figura de pobres vítimas da seca, como não raro o migrante cearense é representado, vemos homens mulheres e crianças dando rumo próprio a suas vidas, mesmo que isso nem sempre correspondesse aos seus anseios de uma vida melhor.

$\mathrm{Na}$ verdade, posso dizer que trabalhei com uma documentação "tradicional", "clássica”, eu diria, sem grandes inovações ou descobertas, mas que à luz de um olhar que buscava atentamente tirar do migrante cearense a exclusiva imagem solidificada de homens miseráveis e famintos, acabou por apresentar uma abordagem diferenciada dessa experiência, na medida em que me preocupei em dar vida própria aos migrantes que aqui, mesmo que não raro a partir de registros indiretos como a imprensa, aparecem falando de si mesmos, e não apenas com meros números nos relatórios oficiais. 
A documentação do poder público investigada foi, em grande parte, as "Fallas" e Relatórios dos Presidentes da Província do Pará e do Ceará à Assembléia Legislativa Provincial, Mensagens dos governadores do Pará ao Congresso do Estado e Mensagem dos governadores do Ceará à Assembléia Legislativa. Esses registros tratam-se quase sempre de um balanço anual ou de um balanço do governo feito no término de um mandato e no início de outro. Não resta dúvida de que essa documentação expressa a imagem que cada governante teve de seu mandato, e conseqüentemente de si mesmo. Entretanto, nas “brechas” dessa mesma documentação e diante das medidas tomadas e dos problemas enfrentados para se levar adiante um projeto de civilização, de progresso e de produção agrícola entre 1889 e 1916, é possível perceber a presença dos migrantes cearenses que, no Ceará e no Pará, encheram as páginas desses documentos, ora vistos como vítimas de uma natureza inclemente, ora sendo alvo das ações dos poderes públicos.

Além desses registros, uma outra documentação também produzida nas fímbrias dos poderes públicos foi uma variedade de ofícios, tanto na Província do Pará como no Ceará, trocadas entre as repartições dessas Províncias com os seus respectivos governantes. O mesmo acontece no período republicano. São ofícios variados sobre assuntos como: fornecimento de passagens nas companhias de vapores para migrantes que pretendiam sair do Ceará ou de Belém do Pará, passagens gratuitas nos vagões da Estrada de Ferro de Bragança (Pará) para grupos de pessoas que se dirigiam para a área dos núcleos coloniais, medidas de disciplina e de segurança pública.

Essa documentação que trata das passagens, por exemplo, permitiu uma variedade de interpretações na medida em que foi possível rastrear as origens dos migrantes, a presença de grupos familiares, ou de mulheres sós nesse contexto, dando conta de outros desdobramentos desses deslocamentos que não apenas o da imagem dos homens que viajavam sozinhos, questão sempre tão evidenciada na historiografia. Além de ofícios referentes a esse trajeto entre o Ceará e o Pará, outro grupo de ofícios também consultado foi o voltado para as Obras Públicas, Terra e Colonização (Pará), em que se investigou muito da estruturação e das vivências nos núcleos coloniais.

No que se refere à imprensa, o jornal Folha do Norte ganha destaque na pesquisa. De acordo com o catálogo Jornais Paraoaras, a Folha do Norte iniciou sua publicação em 1896 encerrando-a em 1974. Inicialmente caracterizou-se como um jornal “noticioso, político e 
literário", fundado por Cipriano Santos e Enéas Martins. ${ }^{3}$ A história política dos principais fundadores desse jornal Cipriano Santos (1859-1923) e Enéas Martins (1872-1919) sem dúvida se refletirá nas páginas do periódico. Cipriano José dos Santos era médico e vinha de uma tradição de imprensa na família. Seu pai, havia sido "proprietário e redator de jornais" como o Treze de Maio e o Jornal do Pará, que circularam em Belém entre 1862 e 1878. Em 1896, juntamente com Enéas Martins e outros, funda a Folha do Norte, que nesse momento defendia Lauro Sodré. Em 1898 Lauro Sodré instala no Pará o Partido Republicano Federal “com a solidariedade de Cipriano, Folha do Norte, e quanto os apoiavam". 4

Com o rompimento político entre os Partido Republicano Federal e o Partido Republicano por volta de 1900 e a conseqüente polarização política entre lauristas e lemistas, ou seja aqueles que apoiavam Lauro Sodré ou Antonio Lemos, a Folha do Norte passa a se posicionar em favor de Lauro Sodré. ${ }^{5}$ Até então Folha do Norte mantivera boa relação com o grupo ligado ao jornal Província do Pará. Nesse contexto, Ricardo Borges afirma que aqueles que apoiavam e admiravam Lauro Sodré ajudavam Cipriano Santos na manutenção da Folha do Norte e na sua circulação "além das fronteiras paraenses", através da rede fluvial e marítima. Em 1912, com a crise política que culmina com a saída do poder de Antonio Lemos, nos novos arranjos políticos chega ao poder em 1914, Enéas Martins, "candidato e eleito por acordo unânime de três partidos, Republicano, Conservador e Federal”. Na época, ligado ao Partido Republicano Federal, Cipriano Santos acaba se desentendendo com o então governador Enéas Martins com quem rompe politicamente, de acordo com Ricardo Borges. Nesse contexto, ironicamente, a mesma Folha do Norte que Martins ajudara a fundar, agora se voltava contra este, uma vez governador. ${ }^{6}$

\footnotetext{
${ }^{3}$ Não se pode esquecer conforme lembrete que aparece logo no primeiro microfilme do jornal Folha do Norte, que corresponde ao $1^{\circ}$ semestre de 1896 , que essa coleção "apresenta faltas, páginas mutiladas, manchadas, ilegíveis com falha de impressão, com data e numeração incorretas". Microfilmes da Folha do Norte - $1^{\circ}$ semestre de 1896. Biblioteca Pública do Pará - Jornais Paraoaras: Catálogo. Belém: Secretaria de Estado de Cultura Desporto e Turismo, 1985, p. 154.

${ }^{4}$ BORGES, Ricardo. Vultos notáveis do Pará. $2^{\mathrm{a}}$ edição revista e aumentada comemorativa ao centenário de nascimento do autor. Belém: CEJUP, 1986, pp. 213-217.

${ }^{5}$ Sobre a questão ver: FARIAS, William Gaia. A construção da República no Pará (1886-1897). Rio de Janeiro: Tese de doutorado (História Social), Universidade Federal Fluminense, 2005.
}

${ }^{6}$ BORGES, Ricardo. Vultos notáveis do Pará, p.15. 
Nessa pesquisa alguns motivos principais moveram a escolha da Folha do Norte. Um deles é a variedade temática que pode ser vista nas páginas dessa gazeta, associada ao fato de que, criado em 1896, e de circulação diária, abrange boa parte do período pesquisado. Desse modo, diversos assuntos estiveram constantemente impressos nas páginas da Folha do Norte, dando a esse jornal características populares, na medida em que circulava por vários segmentos sociais, em todo o estado do Pará, e até mesmo “fora da Amazônia”, como é possível perceber pelos valores da assinatura semestral e anual do jornal, sempre anunciados na primeira página. ${ }^{7}$ Não é à toa, por exemplo, que os migrantes fizeram uso do periódico para pedirem ajuda ou para reclamarem de alguma situação que lhes parecia injusta. Igualmente, em algumas ocorrências policiais, o nome do jornal não deixou de ser citado como meio de informação sobre um dado assunto.

Essa popularidade, bem como uma pretensa imparcialidade da Folha do Norte, pretendiam ser uma marca do jornal. Logo nos seus primeiros números publicados no ano de 1896, anunciava para os leitores na primeira página que "absolutamente imparcial”, essa gazeta se propunha a publicar “todos e quaisquer artigos, notícias e informações”, desde que "lançados em termos convenientes". ${ }^{8}$ Não fica explícito o que essa conveniência queria dizer; entretanto, subentende-se que os conteúdos publicados deveriam seguir a linha política do jornal, que defendia os interesses do Partido Republicano do Pará. Assim, no campo das notícias populares, foram temas constantes trazidos para o público leitor: problemas relacionados ao que se acreditava ser uma ofensa a moral pública, casos de assassinatos, de suicídios, de mortes, de desastres, de roubos, de embustes, de bebedeiras, de defloramentos, de incestos, de adultérios, de prostituição, de mendicância, conflitos dos mais variados, enfim, no interior e na capital; reclamações de falta de limpeza, de iluminação pública, de automóveis ruidosos, de barulhos praticados por vizinhos, não raro eram noticiados na Folha do Norte, dando conta de um movimentadíssimo cotidiano na capital e no interior do estado do Pará. Se, por um lado, esse noticiário deixava clara a postura política do jornal como defensor dos ideais republicanos - portador de valores como civilização e progresso -, esse

\footnotetext{
${ }^{7}$ Sobre preços do jornal assim aparece: “Assinaturas para a Amazônia - Semestre: 16\$000; Ano: 30\$000. Assinatura para fora da Amazônia: Semestre: 20\$000; Ano: 38\$000. Número avulso do dia: 100, número atrasado: 500”. Folha do Norte. Belém, 5 de janeiro de 1896, p. 1.

${ }^{8}$ Folha do Norte. Belém, 5 de janeiro de 1896, p. 1.
} 
mesmo noticiário permite pensar como os moradores do interior do Pará e da capital paraense imprimiam significados a suas próprias vivências.

A Folha do Norte notabilizou-se, também, por ser um jornal de oposição ao intendente Antonio Lemos, principal responsável pela remodelação urbana da cidade de Belém, sendo quase sempre por meio de seus articulistas muito combativo em relação às ações de disciplina e de organização da cidade. ${ }^{9}$ De mais a mais, o mundo, o Brasil e a Amazônia chegavam diariamente à casa dos leitores através de colunas como "Ecos e Notícias”, "Reclamações do Povo”, “Jornal dos Estados”, “Notícias do Interior”, das sessões de poesias e literatura, além de textos sobre os mais variados assuntos, que iam desde as preocupações com o futuro da Amazônia com agricultura e borracha, até festas religiosas e populares, moda e comportamento, além das mais variadas propagandas. Pode-se dizer, sem exageros, que desde os assuntos aparentemente banais como a invenção de uma curiosa máquina de "por ovos", nos Estados Unidos, feitos com “água, leite, sebo, corante, um ou dois vegetais” e “sangue”, até questões de maior envergadura política como a crise econômica experimentada pela Amazônia com o declínio da economia do látex, tudo era noticiado na Folha do Norte. ${ }^{10}$ Sem dúvida, uma variedade grande de moradores das cidades paraenses passaram pelas páginas do periódico, desde os grupos populares até os grandes políticos da época, todos foram alvos do olhar dos articulistas e colunistas da Folha. Essa diversidade temática do jornal foi bastante explorada ao longo da tese, não como um conteúdo neutro que correspondia à realidade dos fatos, mas a partir dos condicionantes políticos e sociais que moveram a publicação da própria notícia e o conteúdo ideológico que se pretendia passar para o leitor.

\footnotetext{
9 Vale lembrar que o Intendente Municipal de Belém, Antonio Lemos, político comparado ao Intendente do Rio de Janeiro, Pereira Passos, foi sócio do jornal A Província do Pará um importante periódico que circulou no Pará em vários momentos. Sob a direção de Lemos circulou entre $1897 \mathrm{e}$ 1912, rivalizando através da imprensa entre 1899 e 1900 com a Folha do Norte. De acordo com Ricardo Borges, essas mudanças ocorrem "quando do rompimento dos dois Partidos Republicano $e$ Republicano Federal”. BORGES, Ricardo. Vultos notáveis do Pará, 1986 p. 246. Sobre o jornal A Província do Pará, ver: Biblioteca Pública do Pará - Jornais Paraoaras: Catálogo, pp. 72-74. Infelizmente, a pesquisa nesse periódico não foi possível de ser realizada pelo fato de que o mesmo não se encontrava disponível para o público no momento da pesquisa por motivo de restauração.
}

${ }^{10}$ Folha do Norte. Belém, 13 de janeiro de 1899, p. 1. 
Um outro jornal utilizado foi A Tarde, que teve como diretor Raymundo Moraes (18721941). ${ }^{11}$ Começa a circular na capital paraense em setembro de 1915 , não se sabendo exatamente quando deixou de ser impresso (o último número encontrado na Biblioteca Pública do Pará é do ano de 1916). Essa folha vespertina, como o próprio nome indica, era vendida "ao cair do sol, ao fechar do dia", objetivando levar aos seus leitores "as derradeiras informações do globo". ${ }^{2}$ De menor porte que a Folha do Norte, não diferia muito quanto à temática publicada. Contudo, apesar de seu diretor afirmar que o jornal era “sem ligações políticas” e "sem interesses partidários a defender”, o conteúdo publicado não deixava escapar a simpatia que ele nutria pelo antigo intendente Antonio Lemos, tratado como um "eminente estadista e grande remodelador" da cidade de Belém. ${ }^{13}$ De fato, não se pode esquecer que o próprio Raymundo Moraes, antes de ter o seu próprio jornal, havia participado da redação d'A Província do Pará. Nesse sentido, pelo menos de alguma maneira, a ausência d'A Província do Pará pode ser minimizada.

Assim, não sem razão, em 1915, alguns meses depois do lançamento do primeiro número d'A Tarde, Carlos Fernandes, que havia sido colaborador e redator de Antonio Lemos n'A Província do Pará, escrevia no jornal União, publicado na Paraíba, que A Tarde, considerada "um excelente órgão da imprensa”, continuava “em tudo" as "brilhantes tradições jornalísticas” iniciadas pela gazeta A Província do Pará que, em tempos idos, dirigida pelo "pulso forte" de Antonio Lemos, colocava Belém no rol de uma "quase metrópole intelectual do norte". 14

${ }^{11}$ Raymundo Moraes foi diretor da Biblioteca e Arquivo Público do Amazonas. Ligado a Getúlio Vargas que era "seu leitor e admirador" segundo Leandro Tocantins, foi nomeado por inspetor do ensino secundário no Ministério da Educação. Teve várias de suas obras editadas entre 1937 e 1940 pela Companhia Melhoramentos de São Paulo. Mesmo depois do término das edições de A Tarde, não deixou de colaborar na imprensa de Belém e de Manaus. De acordo com Leandro Tocantins - em uma "nota biográfica", quando do relançamento pela coleção "Reconquista do Brasil", na sua segunda série, do livro Na Planíce Amazônica - Moraes publicou dezoito livros, sendo muito difícil portanto, "separar o escritor do jornalista". TOCANTINS, Leandro. "Nota biográfica de Raymundo Moraes". In: MORAES, Raymundo. Na planície amazônica. $7^{\mathrm{a}}$ edição. Belo Horizonte; São Paulo: Editora da Universidade de São Paulo, 1987, p. 18.

${ }^{12}$ A Tarde. Belém, 23 de setembro de 1916, p. 1.

${ }^{13}$ A Tarde. Belém, 2 de outubro de 1916, p. 1.

${ }^{14}$ Folha do Norte. Belém, 27 de dezembro de 1915, p. 1. 
A Tarde também teve entre seus colaboradores intelectuais conhecidos nacionalmente, a exemplo de Coelho Neto e Humberto de Campos, que, vez por outra, tinham seus textos nela publicados. ${ }^{15}$

Ao lado dos colaboradores, o principal redator d'A Tarde foi mesmo seu diretor Raymundo Moraes, que acreditava fortemente no papel dos jornais como formadores de opinião. Desse modo, escrevia aos seus leitores, quando do aniversário de um ano dessa gazeta, que algo que certamente moveu o seu trabalho como jornalista fora o fato de que "um acontecimento simplesmente narrado em palestra" não tinha "importância igual do mesmo fato estampado pelos diários”. Sem dúvida, num tempo em que os jornais dominavam os meios de comunicação de massa, a fala de Raymundo Moraes fez bastante sentido, sendo, certamente, e tomando suas próprias palavras, “uma força poderosa” entre a população. ${ }^{16}$

Além desses dois periódicos, foram utilizados, mesmo que em menor escala, mais três jornais: O Liberal do Pará, O Holophote e “A Palavra”.

O primeiro, como o próprio nome indica, foi o órgão do Partido Liberal do Pará, "político, comercial e noticioso", e circulou diariamente ente entre 1869 e 1889.

O segundo jornal, O Holophote, de publicação bissemanal, circulou a partir de 1897, não se sabendo exatamente quando deixou de ser impresso. Era vendido em lugares freqüentados pelos segmentos sociais mais abastados, como, por exemplo, o "Café Chic”, a "Confeitaria Moura no Largo da Pólvora”, o “Café Coelho". ${ }^{17}$ Desde o seu número inaugural, trazia uma crítica ao intendente municipal que antecedeu Antonio Lemos. Seu redator, Emílio José de Melo, em seu primeiro número, numa alusão ao nome do jornal, sugeria que vinha com o seu holofote a fim de alumiar a "humanidade" naquele limiar do século. Como vários dos jornais daquele momento, mesmo demonstrando o seu descontentamento como poder público municipal, visando a dar um caráter de neutralidade ao periódico, em primeira página, o redator destacava: “não temos credo político". ${ }^{18}$ Por certo, não se caracterizou como um jornal popular.

\footnotetext{
${ }^{15}$ Folha do Norte. Belém, 23 de setembro de 1916, p. 1.

${ }^{16}$ Folha do Norte. Belém, 23 de setembro de 1916, p. 1.

${ }^{17}$ O Holophote. Belém, 24 de abril de 1897, p. 1.

${ }^{18}$ O Holophote. Belém, 22 de abril de 1897, p. 1.
} 
Quanto ao jornal A Palavra, foi um periódico "religioso de publicação bissemanal", editado em Belém entre 1910 e 1941, redigido por Paulino de Brito e Alfredo Chaves, circulando sob a responsabilidade da Arquidiocese de Belém, o que explica bem o seu conteúdo voltado para "interesses da sociedade e da família", a partir do pensamento da Igreja católica. ${ }^{19}$

${ }^{19}$ Biblioteca Pública do Pará - Jornais Paraoaras: Catálogo, p. 240. 


\section{Migração nordestina ao Pará, historiografia e algumas propostas de trabalho}

Entre finais do século XIX e início do século XX, a Amazônia, de maneira especial as regiões do Pará e do Amazonas, experimentou uma série de transformações decorrentes da exportação do látex, produto que nesse momento era de grande importância no mercado internacional, como matéria prima utilizada em indústrias da Europa e dos EUA. Ao lado disso, os argumentos de modernidade e civilização próprios da virada do século, e almejados pela nascente república brasileira, também constituíram elementos fundamentais para essas transformações, expressas na remodelação do espaço urbano destas cidades, e também numa intensa rede comercial da borracha, que se estendia desde a coleta desse produto na floresta, na vinda dele para os portos de Belém e Manaus e em sua exportação para o exterior, envolvendo nesta rede um grande número de pessoas, com papéis sociais variados. Isso era entendido como símbolo de progresso e de desenvolvimento da região. ${ }^{1}$

Não resta dúvida de que esse extrativismo gerou, de fato, riquezas para a região, e que igualmente contribuiu para a modificação desse espaço, alargando até mesmo o próprio território nacional, como foi o caso da anexação do Acre ao Brasil, na primeira década do século XX, além de ter transformado algumas das características urbanísticas de Belém e Manaus. Como bem se sabe, esse não é um aspecto apenas da Amazônia, uma vez que a ordem e o progresso idealizados pela República exigiam cidades, por assim dizer, com fisionomias mais modernas, o que se expressou no alargamento das ruas, na edificação de novos prédios, nas tentativas de impor medidas de ordenamento e de higienização do espaço

\footnotetext{
${ }^{1}$ Sobre modernidade e remodelação do espaço urbano, há uma extensa bibliografia. Ver por exemplo: a coletânea de textos organizada por PECHMAN, Robert Moses (org.). Olhares sobre a cidade. Rio de Janeiro: EdUFRJ, 1994; BRESCIANI, Maria Stella. Londres e Paris no século XIX: o espetáculo da pobreza. São Paulo: Brasiliense, 1982; CHALHOUB, Sidney. Trabalho, Lar e Botequim: o cotidiano dos trabalhadores pobres no Rio de Janeiro na belle-époque. São Paulo: Brasiliense, 1986; CHALHOUB, Sidney. "Casses Perigosas". Trabalhadores, n 6 (1990), pp. 2-22; CHALHOUB, Sidney. A cidade febril: cortiços e epidemias na corte imperial. São Paulo: Companhia das Letras, 1996, FENELON, Déa Ribeiro (org.). Cidades. São Paulo: PUC/Olho d’Água, 1999; HARDMAN, Francisco Foot. Trem Fantasma; a modernidade na selva. São Paulo: Companhia das Letras, 1988; RAGO. Luzia Maragareth. Do Cabaré ao Lar: a utopia da cidade disciplinar-1890-1930. Rio de Janeiro: Paz e Terra, 1985. Sobre esta questão na Amazônia, ver: SARGES, Maria de Nazaré. Riquezas produzindo a belle époque. Belém do Pará (1870-1910). Belém: Paka-Tatu, 2000; DIAS, Edinéa Mascarenhas. A ilusão do fausto. Manaus 1890-1920. Manaus: Valer, 1999.
} 
público, nos conflitos em torno dessas ações empreendidas pelos poderes públicos. Além disso, o próprio desenvolvimento tecnológico da virada do século com as locomotivas a vapor, o telégrafo, a energia elétrica, também gerava mudanças nos hábitos dos moradores e na forma de se organizar a cidade e o trabalho.

Em Belém, essas transformações sociais, possíveis, certamente, pelos negócios da borracha, foram marcantes na vida da população. Ainda hoje, permanecem na memória de muitos com um sentimento ufanista em relação a um passado glorioso, representado em ícones desse tempo, como o Teatro da Paz, evocado como lembrança de um tempo de riqueza e de desenvolvimento para a região. $\mathrm{Na}$ historiografia regional, é provável que esse período entre finais do século XIX e primeira década do século XX, seja o mais estudado, o mais lembrado, dada a importância que se dá à economia da borracha na Amazônia, uma vez que colocava, num certo sentido, em evidência uma parte do Brasil praticamente desconhecida por outras regiões, em contato com muito do que se considerava civilizado naquele momento. A imagem de uma cidade bela, a capital da Amazônia, como muitos se referiam a Belém, é marcante na evocação desse glorioso passado de riquezas e a historiografia regional acabou também por solidificar ainda mais tal ícone.

Se as transformações urbanísticas ganham força na historiografia, na representação desse passado de riquezas decorrentes da economia da borracha, em suas margens, encontramos também um outro elemento significativo, que são os trabalhadores extratores do látex. Estes são representados pelos seringueiros, notadamente nordestinos, vindos para a região em decorrência das secas que assolavam o sertão, vivendo na floresta amazônica quase como escravos. $^{2}$ Com estes dois elementos, a urbanização de Belém e a vinda de nordestinos para a

\footnotetext{
${ }^{2}$ Um bom exemplo disso é o romance de Ferreira de Castro (1898-1974) A selva, publicado em 1930 em Portugal. $\mathrm{O}$ autor, a partir de sua própria experiência de ter vivido quando adolescente em um seringal no rio Madeira, narra a história dos nordestinos na floresta como seringueiros. Em um diálogo do romance, entre o dois homens, fica explícita a idéia do seringueiro como um verdadeiro escravo. Nesse diálogo, um dos homens pergunta ao outro sobre 3 cearenses que haviam fugido e o interlocutor responde, diante da fuga: “-É tudo uma malandragem! Ah, bom tempo em que havia relho e tronco! Então esta canalha andava mesmo metida na ordem! Hoje, não se prende ninguém por dívidas e dizem que já não há escravos. E os outros? Os que perdem o que é seu? Vem um homem a fazer as despesas, a pagar passagens e comedorias e até emprestar dinheiro para eles deixarem às mulheres, $e$ depois tem-se este resultado!". CASTRO, José Maria Ferreira de. A Selva [1914]. 39a edição. Lisboa: Guimarães Editores, 2002, pp. 23-24. Ver também o texto de Euclides da Cunha "Judas-Asvero". CUNHA, Euclides (1866-1909). Um paraíso perdido: ensaios, estudos, e pronunciamentos sobre a
} 
região, num certo sentido, caracteriza-se tradicionalmente o Pará deste chamado período áureo da borracha. E isto não se trata apenas de discussão dos meios acadêmicos. Nas escolas de ensino médio e fundamental, essa, ainda hoje, é a imagem que se tem do Pará do tempo da borracha, sendo que o destaque maior é, de fato, a urbanização da cidade de Belém.

A partir da década de 1990, aproximadamente, com a releitura dessa historiografia outras preocupações surgem no cerne dessa questão, no sentido quase sempre de se questionar: quem são, onde estão, e o que fazem os habitantes desta região naquele momento. Percebe-se claramente que, preocupados em guardar uma memória de um passado de glórias, muitos historiadores acabaram por se dedicar muito mais a estudar a economia da borracha, ou algumas das suas conseqüências imediatas, deixando de lado os sujeitos sociais envolvidos neste processo.

$\mathrm{Na}$ verdade, estes até aparecem, mas no contexto da borracha. Por isso, para encontrá-los na produção historiográfica, obrigatoriamente, acaba-se por analisar trabalhos cujo centro de preocupações passa pela história da borracha na região. Daí porque, ao propor uma análise da emigração de cearenses para o estado do Pará, acabo por me deter principalmente nos trabalhos que se preocupam em entender a importância da borracha na região no período compreendido entre 1888 e 1916. Esse período corresponde ao chamado boom e declínio da economia gomífera, e igualmente ao grande fluxo de migrantes nacionais para esta região, em razão de duas grandes secas que aconteceram em áreas do Ceará. Corresponde, igualmente, às tentativas dos poderes públicos de implementação de núcleos coloniais com a presença de imigrantes estrangeiros e a toda uma variedade de vivências sociais decorrentes deste processo. Ora, se na historiografia rastrear a presença dos migrantes não é uma tarefa das mais fáceis, considerando que notadamente, estes aparecem sempre ligados ao universo da borracha na Amazônia, a leitura atenta de uma variada documentação a esse respeito, permite rastrear muitas das ações desses migrantes no Pará.

O exemplo que segue serve aqui como ponto de partida para adentrarmos na produção historiográfica sobre o tema da migração e, ao mesmo tempo, como fonte de reflexão para a interpretação das experiências sociais dos migrantes cearenses no estado do Pará, questão

Amazônia. Organização, introdução e notas de Leandro Tocantins. $2^{\mathrm{a}}$ edição. Rio de Janeiro: José Olympio, 1994, pp.76-81. 
principal que pretende ser investigada nesta tese. Passemos então para a história de José de Aracaty e sua família em terras paraenses.

“Uma família desgraçada”. Este era o título da notícia que, estampada na primeira página do jornal paraense Folha do Norte, em 15 de agosto de 1900, certamente chocava muitos dos que liam esse periódico na manhã daquela quarta-feira. Na ocasião, tornava-se conhecida dos leitores a trajetória de "uma pobre família cearense" no estado do Pará. Provavelmente, esse insólito episódio teria sido narrado ao redator do jornal por um dos protagonistas da história. Como se fosse um folhetim, cada parágrafo ia revelando um triste momento dessa família em terras paraenses, o que, provavelmente, interessou aos leitores da Folha do Norte, considerando-se que, naquele fim do século, Belém experimentava a presença de um grande número de famílias vindas do nordeste, tal qual essa que o jornal chamava de "desgraçada”.

Nessa crônica de desventuras familiares, falava-se de José Luiz, “mais conhecido por José Aracaty, apelido que lhe vinha do fato de ter nascido na pitoresca cidade cearense daquele nome”, e que, segundo o articulista, era o "chefe”, dessa "infeliz família”. Ao mesmo tempo, falava-se também de sua mulher, de seus filhos e filhas, e dos caminhos percorridos por estes em busca de trabalho e sobrevivência, nos últimos anos do século XIX, em vários lugares do estado do Pará. Os leitores da Folha do Norte tomam conhecimento deste grupo quando uma reduzida parte da família retorna a Belém, em 1900. Nesse tempo, José e parte da família já haviam falecido, impulsionados, de acordo com o jornal, "pelo acúmulo de malfazejas desventuras que a perseguiam, destruindo-a na sua quase totalidade". 3

Ficamos sabendo que a família chefiada por “José de Aracaty” era bastante extensa, constituída por filhos nascidos no Ceará e no Pará. Em dado momento, essa família chegou a ter 20 pessoas, os pais e mais 18 filhos. Ao que tudo indica, depois de sua chegada ao Pará, José e a família se dirigiram para a região das ilhas, onde ele "estivera empregado na extração da borracha”. Foi justamente nas ilhas que os problemas se tornaram maiores, “onde as febres endêmicas dizimaram a prole opulenta reduzindo-a a seis".

Esses desgostos fizeram com que José, incentivado por sua esposa Maria de Jesus, vendesse suas terras a um compadre, que não o pagou corretamente, vindo a se retirar para Belém, “alimentando o desejo de ir até o Ceará (...) a fim de restabelecer-se de incômodos

\footnotetext{
${ }^{3}$ Folha do Norte. Belém, 15 de agosto de 1900, p. 1.
} 
febris de que não ficara indene na malfadada região". A bordo do vapor que conduzia a família para Belém, José teve o dinheiro roubado. Diante disso, a conselho de um amigo foi "viver para o Igarapé-assú, à margem da ferrovia bragantina". ${ }^{4}$

Na zona bragantina, por volta de 1895, segundo o articulista da Folha, "abriu-se para o desgraçado então uma era em que o céu lhe sorria toucado de alvinitentes felicidades”, a qual durou muito pouco. Mais uma vez, José e a família têm que lutar contra o meio em que vivem. Livres das febres, vêem o roçado ser atacado por uma praga de saúvas, que acabou com "o melancial abotoado de frutos e o milharal já apendoado". Depois, são os sofrimentos pela morte de Maria Celeste, a filha mais velha, de 17 anos, vítima de uma surucucu que a mordeu na mão, quando a moça foi "de manhãzinha buscar lenha ao mato para ferver o café". Posteriormente, pela morte de outro filho, Lino, de 15 anos, quando cortava um "pé de jataí" e este lhe caiu em cima. E ainda pela morte de mais uma filha, Maria Pureza, de 14 anos, envenenada por ter comido "umas frutas silvestres".

Diante de tantas mortes, primeiro a esposa e depois o próprio José vieram a falecer. ${ }^{5}$ Antes disso, entretanto, segundo o jornal, o pobre "José de Aracaty" pouco falava e pouco comia. Entretanto, constantemente, perguntava aos filhos: “- Vocês não estão zangados comigo, meus filhos?” Pergunta à qual, estes respondiam: “- Zangados? Por que meu pai?” E José continuava falando: “- Não sei... Parece que estão...”. O articulista, com esse suposto diálogo entre "José de Aracaty" e seus filhos, induz o leitor, a pensar que talvez José se sentisse culpado com as dificuldades e os fracassos enfrentados por sua família no Pará. ${ }^{6}$

Para além dessas induções a que o leitor pode ser levado, a narrativa da saga da família do triste "José de Aracaty", trazida ao público pela Folha do Norte, é aqui utilizada como exemplo, pelo fato de que, num certo sentido, a trajetória desse grupo parece sintetizar muito das experiências empreendidas pelos migrantes quando aportados em Belém do Pará. Assim, de uma maneira geral, circulavam exatamente pelos mesmos espaços onde José e a família se lançaram, ou seja, a extração do látex na região das ilhas, ou em áreas mais afastadas de Belém, o trabalho na agricultura nos núcleos coloniais da chamada zona bragantina, a vida urbana na capital paraense. Por outro lado, um aspecto igualmente importante que se revela na

\footnotetext{
${ }^{4}$ Ibidem.

${ }^{5}$ Ibidem.

${ }^{6}$ Ibidem.
} 
notícia, como o fio condutor dessa história, é justamente a presença da família que aqui aparece como o centro da narrativa do jornal.

Também não se pode perder de vista uma dada representação do migrante cearense, que aparece como uma vítima do meio natural, ou com uma certa ingenuidade, como foi o caso de José, que se deixa enganar por seu compadre, e é roubado no vapor. Diante disso é que, não sem razão, as imagens dos migrantes, bem como os lugares de circulação destes, ainda no século XIX, já eram alvo de interesse de estudiosos e observadores da realidade amazônica, que deixaram suas impressões sobre os nordestinos. Muitas dessas representações, posteriormente, acabaram sendo consagradas pela própria historiografia que investigou o tema.

Nesse sentido, elementos importantes que se absorvem dessa notícia de jornal, e que também se apresentam em trabalhos que estudaram a região desde finais do século XIX, são: a família a mobilidade do migrante; o retorno para a terra natal; a natureza implacável; a atividade extrativista da borracha, implementada pelo migrante; o trabalho na lavoura como fruto do progresso. E por fim um outro elemento relevante, quando se fala da imigração que é o papel do poder público nesse processo. Na Folha do Norte, por exemplo, o Estado aparece como o redentor, capaz de solucionar alguns dos problemas destes cearenses. Afinal, no caso em questão, os filhos que restavam do que havia sido a "opulenta prole" de "José de Aracaty" pretendiam se encontrar com o governador Paes de Carvalho, para pedirem "a sua proteção" a fim de adquirirem um lote de terra onde pudessem trabalhar. ${ }^{7}$

Ao nos propormos analisar a produção historiográfica, bem como algumas observações de estudiosos variados acerca da migração nordestina para o estado do Pará, nos deteremos em entender alguns destes aspectos citados anteriormente, uma vez que eles traduzem mais claramente concepções e compreensões da emigração para o Pará. De maneira especial, daremos ênfase às seguintes questões: a migração de nordestinos para o Pará, dando maior destaque para a vinda dos cearenses; as relações estabelecidas entre os migrantes e a natureza amazônica; representações do migrante (essas noções, além da interação própria que carregam, no Pará de finais do século XIX e inicio do XX, são bastante específicas, devendo ser, ao longo do texto, melhor pensadas).

\footnotetext{
${ }^{7}$ Ibidem.
} 
Uma análise da historiografia sobre o tema remete também a entendermos o próprio contexto de produção desses textos. Assim, diante das questões a serem pensadas, selecionamos alguns trabalhos preocupados em entender a migração de cearenses para a Amazônia, e outros cuja preocupação seria o entendimento do processo de migração no Brasil, entre finais do século XIX e primeiras décadas do século XX. Nesse sentido, inicialmente, a ênfase é dada a esses trabalhos de cunho mais geral. Para tal, selecionamos trabalhos que têm influenciado na compreensão da história da imigração no Brasil.

Nesta primeira parte da discussão historiográfica, destacaremos os seguintes trabalhos: a coletânea Fazer a América, organizada por Boris Fausto; Evolução do povo brasileiro, de Oliveira Vianna; História Econômica do Brasil, de Caio Prado Junior; Formação Econômica do Brasil, de Celso Furtado; História do Brasil geral e regional -Amazônia, de Ernani Silva Bruno; o ensaio de Maria Ligia Prado e Maria Helena Capelato, na coleção História Geral da Civilização Brasileira; e alguns trabalhos da coleção História da Vida Privada no Brasil.

O critério para escolha desses textos é o grau de abrangência pretendido pelos mesmos, notadamente, organizados em coleções, ou coletâneas que objetivam entender, cada um ao seu tempo, com abordagem teórico-metodológica própria, muito do desenvolvimento do Brasil e igualmente de segmentos de sua população. No caso em questão, a ênfase aqui dada é em torno das visões que esses trabalhos ajudam a construir do papel dos migrantes nacionais na sociedade brasileira, mais especificamente na Amazônia, de finais do século XIX e inicio do século XX. Pode-se dizer, de uma maneira geral, que esses trabalhos, tinham por meta apresentar uma espécie de caracterização do Brasil, dando conta de sua população e das relações econômicas, culturais e sociais que iam se estabelecendo e entrelaçando.

$\mathrm{Na}$ verdade, nem todos eles foram feitos por historiadores e nem têm um caráter historiográfico, a exemplo de Imigração e colonização, publicado em 1916, pelo engenheiro Palma Muniz, mas que, por seu grau de abrangência, servindo de referência para muitas pesquisas sobre o Pará, não poderíamos nos furtar de discutir, o que faremos na segunda parte da análise historiográfica. Um segundo grupo de trabalhos a ser abordado é aquele que mais especificamente se refere à temática da migração nordestina no estado do Pará. Para tal, alguns desses textos aparecem aqui divididos de forma cronológica, sem se perder de vista, entretanto, as relações estabelecidas entre eles ao longo do tempo.

Ao analisarmos mais detidamente parte da produção historiográfica que se debruçou sobre a temática da migração nordestina para o estado do Pará, nos deparamos, mesmo que de 
forma isolada, com várias das questões que o caso narrado pelo jornal nos permite suscitar. Mas, ao mesmo tempo, percebemos também que para um grande número de trabalhos, a experiência da migração na Amazônia, na virada do século XIX para o XX, é praticamente nula. É que se prioriza a história de centros urbanos, como Rio de Janeiro, São Paulo, Recife, Porto Alegre. Aliado a esse fato, verifica-se igualmente que, quando se fala em migração nesse período, a ênfase maior, é dada às migrações externas, deixando-se quase de lado o desenvolvimento das migrações internas, notadamente de cearenses para a Amazônia, em fins do século XIX.

Ironicamente, o historiador Boris Fausto, na introdução do livro Fazer a América, que trata da imigração estrangeira para a América Latina entre as últimas décadas do século XIX e as três primeiras do século XX, referindo-se ao retardamento dos estudos brasileiros sobre a imigração, afirma que "a importância do tema parece ter sido obscurecida pelo impacto das migrações internas. Estas desempenharam um papel essencial em muitas das transformações históricas vividas nos últimos cem anos: a abolição da escravatura, a expansão da economia cafeeira, a urbanização, a industrialização, a formação da classe trabalhadora". ${ }^{8}$

Essa é uma justificativa bastante questionável, quando levamos em conta trabalhos historiográficos sobre imigração no Brasil desse mesmo período, em que o destaque é dado, em termos espaciais, para as regiões sul e sudeste do país, marcadamente constituídas pela presença de grande número de imigrantes estrangeiros, como portugueses, espanhóis, alemães, italianos, libaneses, etc. Indo por um caminho completamente oposto ao desse historiador, a análise da produção historiográfica, sobre a qual me deterei ainda neste capítulo, induz a pensar num tardio interesse justamente pelas migrações internas e não pelas externas, como afirma Boris Fausto. ${ }^{9}$

Embora esse autor reconheça "que os estudos sobre imigração, sob as mais diferentes formas e conteúdos, ganharam crescente impacto, nos últimos quinze anos”, não deixa também de apontar como já referi anteriormente, a importância das migrações internas, questão bastante discutível, conforme veremos ao analisarmos parte da historiografia

\footnotetext{
${ }^{8}$ FAUSTO, Boris. "Introdução". In: FAUSTO, Boris (org.). Fazer a América. A imigração em massa para a América Latina. São Paulo: EDUSP, 2000, p. 11.

${ }^{9}$ Ver por exemplo FAUSTO, Boris. "Imigração: cortes e continuidades". In: SCHWARCZ. Lília Moritz (org.). História da vida provada no Brasil: contrastes da intimidade contemporânea. São Paulo: Companhia das Letras, 1998, vol. 4, pp. 13-61.
} 
brasileira sobre imigração. Buscando fortalecer seus argumentos sobre o impacto que, segundo ele, tiveram na história do país as migrações internas, o autor cita como exemplo a sua própria experiência pessoal, lembrando que, em muitas palestras proferidas por ele sobre imigrações internacionais, muitas vezes pergunta-se, “em velado tom acusatório”, questões como "Por que o senhor não fala dos nordestinos?". 10

$\mathrm{Na}$ verdade, se de fato as migrações internas tiveram maior importância, isto não se refletiu em estudos sobre o tema, a julgar pelo quase esquecimento a que as regiões norte e nordeste do país - notadamente espaços bastante influenciados pelo processo de migrações internas - têm sido relegadas em muitos estudos sobre o período, considerando-se que o norte foi o espaço receptor destes migrantes e o nordeste o espaço irradiador. Vejamos então como essa questão tem sido apontada em trabalhos que buscaram entender a realidade brasileira entre finais do século XIX e início do século XX.

Um estudo importante neste sentido é Evolução do povo brasileiro, de Francisco José Oliveira Vianna, de 1923, editado pela primeira vez pelo Ministério da Agricultura, como um prefácio do recenseamento nacional de 1920, sendo portanto, de acordo com o próprio autor, um estudo limitado aos aspectos “econômicos e demográficos de nossa população", deixando-se assim de lado outros aspectos "interessantes de nossa evolução", como "a evolução da família, a evolução dos costumes e a evolução das classes sociais”. Oliveira Vianna justifica as lacunas de seu trabalho, lembrando ainda de outros elementos que limitaram seu estudo, como o fato de que o trabalho teria sido feito "em pouco mais de um mês”, de que o mesmo, de acordo com as normas habituais de publicação da Diretoria Geral de Estatística, não deveria “ultrapassar cem páginas”, o que ele apontava como uma grande dificuldade, considerando o encargo recebido de "sintetizar a nossa história nacional". 11

Aliado a tudo isto, o trabalho esbarrava ainda, como ele próprio afirmara, no fato de ser “publicado sob égide oficial”, o que o obrigava, no que dizia respeito ao período republicano, a deixar de "comentar certos lados obscuros e depressivos deste período, cuja crítica, para ser justa, não podia deixar de ser condenatória”. Apesar disso, o autor ainda dizia que, ao

\footnotetext{
${ }^{10}$ Ibidem. p. 12.

${ }^{11}$ VIANNA, Francisco José de Oliveira. Evolução do povo brasileiro. São Paulo: Monteiro Lobato e Cia Editores, [1923], pp. 36-37.
} 
escrever seu texto, esforçava-se para que no mesmo não se insinuasse "nenhum preconceito pessoal”. 12

Feita essas considerações, Oliveira Vianna entraria no foco principal de seu texto, " $a$ evolução do povo brasileiro", que passava pelo entendimento, da "Evolução da sociedade"; "Evolução da raça” e "Evolução das instituições políticas”, respectivamente, questões que dão título aos capítulos do autor. É justamente na primeira parte que vamos nos deparar com a visão do autor acerca dos movimentos populacionais na Amazônia. Para Oliveira Vianna, essa temática se justificava na medida em que ele criticava os "velhos historiadores”, que não aliavam em suas obras dois elementos que, naquele momento, lhe pareciam fundamentais: “ $O$ povo e o meio cósmico" ou, melhor dizendo, o "ambiente físico em que todos se movem, o povo e os seus dirigentes”. Como parte desse “meio cósmico” eram o ar, o relevo, o subsolo, a hidrografia, a flora, a fauna, o clima, tudo o que "determinava as ações dos homens na vida cotidiana”. ${ }^{13}$

Oliveira Vianna, no Brasil desse período, dois movimentos de deslocamento e entrada de populações de “orientação essencialmente sertaneja”, no sentido de uma penetração do interior do território brasileiro. Estes dois movimentos eram: no norte, “a colonização do Acre, pelos nossos caboclos do nordeste”, caracterizada por sua "rápida prolação”, iniciada no império; no sul, um "movimento de assalto à floresta tropical”, que se estendia desde o “'oeste’ paulista até à região serrana do Rio Grande”, referindo-se à colonização empreendida por imigrantes europeus nessa região. ${ }^{14} \mathrm{O}$ que chama a atenção, na análise de Oliveira Vianna, é o reconhecimento de frentes de expansão econômica que, naquele momento, se instauravam nesses dois extremos do Brasil.

Para o autor, desde o império, a Amazônia vivenciava em suas florestas a invasão dos "rudes vaqueiros do Ceará". Segundo ele, o afluxo migratório tinha nessa região "uma intensidade surpreendente"; comparando-o com outros estados de "imigração intensa", como São Paulo, Paraná e Rio Grande, afirmava que o "índice de crescimento demográfico é o maior do Brasil”. ${ }^{15}$ Oliveira Vianna, mostrava-se crítico nesse sentido, dando conta de que

\footnotetext{
${ }^{12}$ Idem, p. 37-40.

${ }^{13}$ Idem, pp. 38-39

${ }^{14}$ Idem, pp. 94-96.

${ }^{15}$ Idem, pp. 94-95.
} 
pouco se conhecia a este respeito. Assim, completava ele: "essa poderosa avançada sobre os sertões, esse deslocamento em massa da nossa população para o interior do planalto é um fenômeno geral que abrange a totalidade do país” Apesar disso, Vianna reconhecia que "só a indiscrição dos dados estatísticos" é que denunciava e revelava "aos nossos olhos surpreendidos” esses crescimentos populacionais. Além de reconhecer esse crescimento populacional, o autor enfatizava um deslocamento de nordestinos, que não se dava, nesse momento, somente para a Amazônia, mas também para outras áreas, como regiões de Goiás, de Minas, do Mato Grosso, do Rio Grande.

Apesar do reconhecimento desses fluxos migratórios intensos, o sertanejo na Amazônia, na visão do autor, é visto como rude e com "prodigiosa resistência física”, isto de acordo com as suas convicções, em função das próprias condições ambientais, pois com a seca, o sertanejo saía de um clima "ardente e sadio" para um viver em um clima "úmido e insalubre (...) para um mundo de florestas e águas em cujas vastidões o homem se perde e como que desaparece". Apesar disso, pelo menos "por um momento", esses migrantes "intrépidos caboclos", no dizer do autor, faziam da Amazônia "um centro de riqueza tão ativo e importante como os centros cafeeiros”. Esta visão momentânea da economia da região era avaliada pelo autor como resultado da própria instabilidade do extrativismo da borracha, pois o homem não está preso à terra, movimentando-se constantemente “como um explorador transitório (...) à medida que se cansam e se esgotam os seringais”. ${ }^{16}$

Percebe-se que Oliveira Vianna dá conta das diferenças regionais do Brasil, ao mesmo tempo que identifica também, na medida em que se utiliza de dados demográficos, um movimento interno populacional que não ocorria apenas em direção à Amazônia, mas em outros espaços. Por outro lado, a imagem que constrói do migrante, embora reconheça nele um certo caráter empreendedor, é de alguém que fica provisoriamente na região, que não tem interesse de fixação, uma vez que, para o autor, a presença do nordestino é circunscrita ao espaço da floresta (o que certamente limita a sua análise). Mas a despeito de todos os problemas de ordem ideológica que possa ter o autor, suas proposições não deixam de representar um certo avanço no entendimento dos fluxos migratórios internos do Brasil do inicio do século XX, considerando o momento em que o trabalho foi escrito, final da década de 1910 .

\footnotetext{
${ }^{16}$ Idem, p. 95.
} 
Um outro autor que se preocupou em entender a formação da sociedade brasileira e de sua economia foi Caio Prado Junior. Em um livro clássico História econômica do Brasil, publicado originalmente em 1945, referindo-se ao período republicano, em um item intitulado “Expansão e crise da produção agrária”, Caio Prado enfatiza o caráter de exportador de matérias primas, do Brasil, no cenário internacional. Isso seria a principal característica da economia brasileira. Nesse sentido, a "produção agrária” desenvolvida nas diferentes regiões do país, fosse ela o, café, a borracha, o cacau, ou o açúcar, estaria "voltada inteiramente para fora do país, isto é, para a exportação". ${ }^{17}$ É justamente fazendo parte desse contexto econômico que vamos encontrar a Amazônia, com a extração da borracha e, conseqüentemente, com os imigrantes nordestinos envolvidos neste processo.

Assim é que, para o autor, a vinda de nordestinos para a Amazônia, com a grande seca de 1877, influencia diretamente nos desdobramentos da economia da borracha. Essa "larga disponibilidade de mão-de-obra”, segundo Caio Prado Junior, seria a solução para os entraves desta produção, uma vez que esta era uma região "escassamente povoada da floresta amazônica”. O crescimento da economia da borracha no mercado internacional, dos finais do século XIX e inicio do século XX, se explica, para Caio Prado, por dois fatores: o primeiro seria "o consumo mundial e ascensão de preços"; o segundo o "afluxo constante de trabalhadores nordestinos impelidos pelas contingências naturais de sua região nativa, ou pelas precárias condições de vida de uma terra empobrecida e em decadência" ${ }^{18}$

Nesse contexto de produção, o emigrante nordestino descrito por Caio Prado é o seringueiro que, na floresta amazônica, trabalhando nos seringais, estava sujeito a um "sistema rudimentar de exploração econômica", que consistia no acúmulo de dívidas que esse trabalhador ia adquirindo desde a saída do nordeste, e depois com a compra de seus rudimentares utensílios de trabalho, de alimentação e de todo o necessário para a sua permanência no seringal. Isto, na visão do autor, era para "impedir que o trabalhador acumule reservas e faça economia que os tornem independente". ${ }^{19}$

\footnotetext{
${ }^{17}$ PRADO JÚNIOR, Caio. História econômica do Brasil [1945]. 35ª edição. São Paulo: Brasiliense, 1987, p. 225.

${ }^{18}$ Idem, p. 236.

${ }^{19}$ Idem, p. 238.
} 
Assim, o autor assevera o caráter provisório desse sistema econômico em que os proprietários e comerciantes "se rolavam nos prazeres fáceis das cidades (...)", e os trabalhadores dos seringais se "aniquilavam nas asperezas da selva e na dura tarefa de colher a goma”. Diante da exploração da floresta e dos trabalhadores, o autor descreve a Amazônia desses "anos de febre da borracha" não com o caráter de uma "sociedade organizada”, mas sim de um “acampamento”, em que, com o declínio da economia da borracha, “os aventureiros buscadores de fortuna fácil” iriam "procurar novas oportunidades em outro qualquer lugar", deixando para trás a "população miserável de trabalhadores". 20

Com este desfecho da trajetória da borracha na Amazônia, o autor não hesita em dizer que "O drama da borracha brasileira é mais assunto de novela romanesca que de história econômica". ${ }^{21}$ Diante dessas impressões que Caio Prado Junior deixa dos trabalhadores dos seringais da Amazônia quando do boom da borracha, não resta dúvida de que esse trabalho foi importante para consolidar na historiografia brasileira uma explicação clássica do emigrante nordestino, visto apenas como um seringueiro preso às dificuldades da floresta, sendo grandemente explorado pelos patrões.

Essa é a versão que, de certa forma, vamos também observar no livro de Celso Furtado, Formação econômica do Brasil, de 1959. Nesse sentido é que, ao discutir o Brasil do século XIX, um dos aspectos que chama a sua atenção é o que ele chama de "problema da mão-deobra” para o desenvolvimento do país. Assim, é que a imigração ganhará destaque, uma vez, que para o autor, "eliminada a única fonte de imigração que era a africana, a questão da mão-de-obra se agrava e passa a exigir urgente solução". ${ }^{22}$ A resolução desse problema estaria no fomento à imigração. Além da imigração européia, notadamente para a área dos cafezais, o autor identifica no século XIX também "grande movimento de população: da região nordestina para a Amazônia”. ${ }^{23}$

\footnotetext{
${ }^{20}$ Idem, p. 240.

${ }^{21}$ Idem, pp. 240.

${ }^{22}$ FURTADO, Celso. Formação econômica do Brasil [1959]. 22a edição. São Paulo: Companhia Editora Nacional, 1987, p. 119.

${ }^{23}$ Idem, p. 129.
} 
É assim que, evidenciando pontos semelhantes aos destacados por Caio Prado Junior, Celso Furtado, voltando-se para a Amazônia, afirma também, que em fins do século XIX, “crescia a procura de borracha nos países industrializados”. Entretanto, o crescimento dessa produção tinha como entrave a ausência de mão-de-obra, uma vez que, na visão do autor, "mais do que no caso do café, a expansão da produção da borracha na Amazônia era uma questão de suprimento de mão-de-obra". ${ }^{24}$

Essa mão-de-obra, segundo Celso Furtado, viria justamente do nordeste, com o deslocamento de grande número de migrantes. Para o autor, "essa enorme transumância indica claramente que a fins do século passado já existia no Brasil um reservatório substancial de mão-de-obra, e leva a crer que, se não tivesse sido possível solucionar o problema da lavoura cafeeira com imigrantes europeus, uma solução alternativa teria surgido dentro do próprio país”. Não se pode perder de vista o caráter especulativo dessa fala, na medida que jamais saberemos o que poderia acontecer diante de experiências sociais ainda não vividas. $^{25}$

Aqui, não se pode perder de vista, que o autor utiliza-se do termo "transumância" que não se aplica ao caso em questão. De fato, os grupos que deixavam o nordeste, muitas vezes o faziam movidos por problemas climáticos, notadamente as secas, e as muitas conseqüências desse fenômeno, como a fome e a falta de trabalho. Entretanto, essa situação de miséria nem sempre se revertia com o término das secas, permitindo o retorno do migrante à sua vida anterior. Além disso, muitos migrantes se dirigiam à Amazônia com a expectativa de uma vida melhor que lhes seria proporcionada com o trabalho nos seringais ou na agricultura.

Embora o retorno ao lugar de origem estivesse muitas vezes presente na vida do migrante já estabelecido no estado do Pará, por exemplo, este não estava ligado somente às secas. Do mesmo modo, a vinda para esta região não era pensada apenas a partir de um tempo específico condicionado por fatores climáticos, e de possibilidades de trabalho durante esse período específico, o que caracterizaria, num certo aspecto, a "transumância”, a exemplo de movimentos de trabalhadores evidenciados no nordeste entre o sertão e a zona da mata. Nesse sentido, a saída do nordeste e o seu retorno para esta região traziam no seu bojo uma maior complexidade, que implica entendermos os muitos sentidos que os migrantes estabeleceram

\footnotetext{
${ }^{24}$ Idem, pp. 130-131.

${ }^{25}$ Idem, p. 131.
} 
com o estado do Pará e com a sua experiência anterior, questões que a idéia de “transumância” por si só não consegue explicar.

Ora, na visão do autor, esse “reservatório de mão-de-obra”, no século XIX, estaria justamente no nordeste e seria resultado do "desequilíbrio estrutural da economia de subsistência”, deixando uma parte da população sem atividades produtiva. Somando-se a esse fator, estaria a prolongada seca de 1877-1880, quando desapareceu parte do rebanho, perecendo de “cem a duzentas mil pessoas”. Nesse cenário de dificuldades, pode-se dizer que, para Celso Furtado, estaria a base da emigração de nordestinos para a Amazônia. ${ }^{26}$

Assim, num quadro mais amplo, tomando como referência a visão do autor, a migração de nordestinos para a Amazônia pode ser sintetizada em 3 pontos principais: a demanda do mercado internacional por borracha, a reduzida mão-de-obra na Amazônia para atender a essa demanda, e por fim o nordeste, como "reservatório de mão-de-obra".

Para Celso Furtado, na Amazônia, o migrante, notadamente um seringueiro, era reduzido a um “regime de servidão", e continuando, acrescenta ainda que o seringueiro, em seu trabalho na floresta, na solidão de sua cabana, esgotava a sua vida "num isolamento que talvez nenhum outro sistema econômico haja imposto ao homem". ${ }^{27}$ Esta visão trágica, de exploração e submissão reforçada pelo autor em relação ao seringueiro, como veremos, estará presente em muitos outros trabalhos que buscaram compreender a Amazônia de finais do século XIX. “Judas-Asveros”, de Euclides da Cunha, não deixa de ser um bom exemplo disso com uma matriz literária de versão bastante trágica, em que o seringueiro no seu cotidiano na floresta tem seus dias descritos como em uma "mesmice torturante", diante de uma "existência imóvel feita de idênticos dias de penúrias”, como uma "interminável sexta-feira da Paixão”. A apoteose desses dias na visão do literato é mercada pela malhação de Judas, quando o seringueiro parece castigar a si mesmo diante do boneco de pano jogado na correnteza do rio. $^{28}$

Um outro trabalho de cunho mais geral, mas que deixa suas impressões sobre a Amazônia, é o de Ernani Silva Bruno. Se em estudos mais recentes, a exemplo de trabalhos dos quais falaremos a seguir, o tema da migração para a Amazônia é pouco recorrente, o mesmo não se

\footnotetext{
${ }^{26}$ Idem, p. 133.

${ }^{27}$ Idem, p. 134.

${ }^{28}$ CUNHA, Euclides da. “Judas-Asvero”.In: Um paraíso perdido, p. 76.
} 
pode dizer, da História do Brasil - Geral e Regional deste autor. Mesmo não sendo original em suas discussões, uma vez que se prende a estudos feitos acerca da região por outros autores, o mérito de seu trabalho, com todos os problemas que possa ter, repousa no fato de entender um Brasil, em suas diferenças. Este, aliás, é um contraponto importante, em relação a trabalhos, como a Coleção História da Vida Privada no Brasil, de que falaremos nas próximas páginas, uma vez que, no último caso, não há dúvida do extenso trabalho de pesquisa, que embasa os referidos textos, das preocupações teórico-metodológicas presentes nos trabalhos, e apesar disso apresentam uma história da imigração restrita a praticamente um único espaço - o sudeste e sul do Brasil.

Ernani Silva Bruno, preocupado em entender e caracterizar as regiões brasileiras, a partir da divisão feita pelo IBGE em 1941, dedica o volume I da sua História do Brasil - Geral e Regional, composta de 7 volumes e publicada em 1966, à Amazônia. Fazendo como que uma retrospectiva da história da região amazônica, através de marcos cronológicos, identifica os momentos de conquista, ocupação e desenvolvimento dessa parte do Brasil, ao mesmo tempo que a natureza amazônica, com o seu "rio-mar”, com os índios, missionários e seringueiros, castanheiros e vaqueiros, vai aparecendo. Dessa forma, busca falar de um período bastante longo, de 1494 a 1943, o que não seria de admirar, considerando o próprio título do livro. ${ }^{29}$

O autor acreditava que sua contribuição se inseria dentro de um conceito moderno de História, em que "não apenas a crônica política, o relato de guerras, de revoluções, de mudanças de forma de governo, mas também as etapas sucessivas da paisagem econômica, social ou cultural de um país ou de um povo" também podem ser alvo de estudos. Para Bruno, estes estudos seriam “oportunos e necessários”, uma vez que poderiam captar melhor, "através de minúcias significativas o processo histórico de um país de imensa área geográfica, cujo povo viveu e vive dentro de tão diversas condições econômicas, sociais e culturais". 30

\footnotetext{
${ }^{29}$ Cf. BRUNO, Ernani Silva. História do Brasil - Geral e Regional, 1. Amazônia. São Paulo: Cultrix, 1966. Os outros volumes da coleção estão assim distribuídos: 2 - Região Nordeste (Maranhão, Piauí, Ceará, Rio Grande do Norte, Paraíba, Pernambuco e Alagoas); 3 - Região Leste Setentrional (Sergipe e Bahia); 4 - Região Leste Meridional (Espírito Santo, Rio de Janeiro, Guanabara e Minas Gerais); 5 Região sul (São Paulo, Paraná, Santa Catarina e Rio Grande do Sul); 6 - Região Centro Oeste (Goiás e Mato Grosso); e 7 - História Geral.

${ }^{30}$ Idem, p. 9.
} 
Foi baseado nessa concepção que desenvolveu seu trabalho. Mesmo construindo uma história bastante linear, de fatos históricos que têm começo e fim, em que os chamados sujeitos históricos não têm ações próprias, baseado em vastos estudos sobre a Amazônia, como relatos de viajantes, produção historiográfica e também textos literários, Ernani Silva Bruno acaba por traçar uma espécie de perfil da região, que pode sugerir algumas pistas para o trabalho dos historiadores.

Nesse sentido é que, para o autor, a navegação a vapor e a economia da borracha foram fundamentais para o povoamento de áreas do Pará e do Amazonas, o que aconteceu pela presença dos nordestinos "empurrados de suas terras pela secas e atraídos para a Amazônia pela borracha”. ${ }^{31}$ Assim, Bruno aponta os vários espaços que foram ocupados pelos migrantes, notadamente espaços de extração do látex, como a região dos rios Purus e Juruá, no Amazonas. Descrevendo os seringueiros neste contexto, Ernani Silva Bruno toma para si as representações construídas por Euclides da Cunha. Desta forma, para Bruno, o seringueiro é visto então como sendo "um homem condenado ao mais terrível isolamento". 32

Assim, ao longo de todo o capítulo denominado "Ciclo do vapor e da borracha”, o autor vai se dedicar a falar do trabalho de extração do látex, da presença dos nordestinos, como trabalhadores desse processo, da decadência da atividade agrícola, das dificuldades desse homem sertanejo na floresta. Essa interpretação pode ser percebida até em trabalhos mais recentes e que têm uma visão crítica sobre a história da região. Este é o caso do trabalho de Pere Petit, Chão de promessas, que ao analisar o papel das elites políticas e das transformações econômicas no Pará, parte justamente de um panorama geral da região a partir

“de três principais períodos: a) ciclo da borracha (1850-1912); b) fase do declínio e posterior crescimento moderado da economia regional (1912-1965), e c) época das grandes transformações sócio-econômicas da Amazônia, a partir da segunda metade da década de 1960 até os dias de hoje”.

Embora o autor faça considerações sobre os problemas das influências dos "ciclos mundiais nas diferentes regiões”, na medida em que dificultam “a análise das estruturas sócioeconômicas regionais" acaba por não fugir de uma leitura da história regional, a partir dos

\footnotetext{
${ }^{31}$ Idem, p. 134.

${ }^{32}$ Idem, p. 135.
} 
chamados ciclos econômicos. ${ }^{33}$ Ainda sobre essa questão dos ciclos, João Pacheco de Oliveira, analisando modalidades de força de trabalho e constituição de fronteiras no século XIX, dando destaque aos seringais, faz uma breve análise da historiografia que se preocupou em entender a borracha nesta região. Enfatiza que "a noção de ciclos impôs-se como modelo de organização dos fatos históricos ligados à produção da borracha na Amazônia”, na medida que utilizada por "importantes historiadores do Brasil” acabou tendo "consagração científica”. Para o autor o uso de tais noções exclui "sistematicamente" outros aspectos importantes desse contexto. No caso da borracha, por exemplo, desvaloriza-se a produção que antecede o “apogeu do surto gomífero" além da "pouca atenção” que é dada aos "outros fenômenos que ocorreram na Amazônia contemporaneamente ao 'ciclo da borracha'”. ${ }^{34}$

Voltando à questão das migrações apontadas por Ernani Silva Bruno, vale lembrar que embora o autor faça referência a outros grupos de migrantes, e a outros espaços no qual desenvolveram suas atividades, como, por exemplo, a zona Bragantina, o que prevalece é um imigrante que é seringueiro, e que portanto está preso à solidão da floresta, longe da família, trabalhando em condições “de quase cativeiro". ${ }^{35}$ Na verdade, essa imagem do nordestino como sendo apenas seringueiro, não é exclusiva de Ernani Silva Bruno. Outros autores, quase sempre inspirados em Euclides da Cunha, reproduziram amplamente tal noção, que num certo sentido, acabou se tornando a explicação clássica sobre a presença de nordestinos na região, mesmo que as evidências apontem outras formas de sua interação no espaço amazônico.

Além dessa preocupação em destacar o trabalho dos seringueiros, o autor também se preocupa em fazer algumas comparações entre o nordestino e o caboclo da região. Essas descrições eram inspiradas em trabalhos como Terra imatura, de Alfredo Ladislau, texto de cunho literário, publicado em Belém do Pará, em 1923, em que se verifica claramente essas

\footnotetext{
${ }^{33}$ PETIT, Pere. Chão de promessas: elites políticas e transformações econômicas no estado do Pará pós-1964. Belém: Paka-Tatu, 2003, pp. 49-50.

${ }^{34}$ OLIVEIRA, João Pacheco de. "O caboclo e o Brabo. Notas sobre duas modalidades de força-detrabalho na expansão da fronteira amazônica no século XIX”. Encontros com a civilização brasileira, vol. 11 (1979), pp. 102-103.

${ }^{35}$ BRUNO, Ernani Silva. História do Brasil - Geral e Regional, 1. Amazônia, p. 136.
} 
comparações propostas por Silva Bruno. ${ }^{36}$ Traços semelhantes encontramos também em Arthur Cezar Ferreira Reis, O seringal e o seringueiro, de 1953, do qual falaremos adiante. ${ }^{37}$

Diante disso, Silva Bruno cria como que um perfil dos nordestinos e do nativo da região, em que este aparece como "desambicioso e indolente”, conseqüência de sua adaptação às “condições naturais e sociais dos vale amazônico", e aqueles figuram como trabalhadores com uma preocupação agrícola, enfrentando "as árvores gigantescas da selva”, com o objetivo de levar adiante o seu roçado, pois, de acordo com o autor "a lavoura do sertanejo conseguia ser considerada pelos governos, em suas mensagens, como sendo 'mais que uma esperança,", ${ }^{38}$ Ora, esta afirmação, quando tomamos como referência a imagem de um nordestino quase sempre como seringueiro, soa bastante contraditória, sugerindo outras referências para a investigação da migração de nordestinos para a Amazônia.

O exemplo de Silva Bruno serve para ilustrar a importância que o tema da economia da borracha teve na historiografia que investigou a Amazônia da virada do século XIX para o XX. Nesse sentido, falar da migração de nordestinos para a Amazônia, invariavelmente, é falar da importância da borracha nesta região. De maneira geral, é nesses trabalhos que encontramos algumas referências à imigração.

É o caso do texto de Maria Ligia Coelho Prado e Maria Helena Rolim Capelato, "A Borracha na Economia Brasileira da Primeira República", publicado em 1977, na parte referente à República da História Geral da Civilização Brasileira.

Nesse trabalho, baseado em bibliografia pertinente ao tema, e também em Euclides da Cunha, as autoras traçam como que um panorama da Amazônia na chamada Primeira República, dando destaque ao apogeu da goma elástica e sua crise e às tentativas de revitalização dessa economia. Dividindo a economia da Amazônia em "três fases”, acreditam que, para se entender a importância da borracha na economia brasileira, é necessário "não isolá-la de um contexto maior - o capitalismo -, no qual o Brasil se inseria como país periférico, fornecedor de produtos primários”. 39

\footnotetext{
${ }^{36}$ LADISLAU, Alfredo. Terra Imatura [1923]. Belém: Conselho Estadual de Cultura, 1971.

${ }^{37}$ REIS, Arthur César Ferreira. O seringal e o seringueiro [1953]. $2^{\text {a }}$ edição revista. Manaus: EdUA/Governo do Estado do Amazonas, 1997.

${ }^{38}$ Idem, p. 153.

${ }^{39}$ PRADO, Maria Ligia \& CAPELATO, Maria Helena Rolim. "A borracha na economia brasileira da Primeira República”. In: FAUSTO, Boris (org.). História Geral da Civilização Brasileira. São Paulo:
} 
A inserção da Amazônia no capitalismo internacional seria resultado das três fases pelas quais a economia da Amazônia teria passado, fases estas que tinham como característica principal a exploração das riquezas naturais da região, iniciada com as chamadas drogas do sertão e culminando com a extração do látex. Entre essas fases, em meados do século XVIII, as autoras entendem ter havido um certo incentivo à agricultura, mas o que de fato prevalecia por esta visão eram as atividades extrativistas.

É a partir dessa perspectiva que Prado e Capelato desenvolvem seus argumentos, e que nos deparamos com a figura dos nordestinos, dentro daquela visão clássica, da expulsão do sertão pela seca e da atração pela Amazônia como um espaço onde poderiam encontrar a sobrevivência, trabalhando como seringueiros. Assim, os migrantes são explorados pelos patrões, vivendo isolados e solitários, à mercê da floresta e de seus rios. A partir desta compreensão da Amazônia, como que reduzida a um centro fornecedor de matérias primas, quase sem produção agrícola, os imigrantes eram, no dizer das autoras, "uma multidão de que se esperava apenas o rendimento material de uma produção cada vez maior". ${ }^{40}$ Percebe-se assim, nesse trabalho de Prado e Capelato, as influências das idéias de Caio Prado Junior e Celso Furtado, quando de suas análises da Amazônia de finais do século XIX, conforme apontado anteriormente.

Com outras características, completamente diferenciadas dos trabalhos anteriores, uma vez que, representa claramente preocupações historiográficas contemporâneas, voltadas para o campo da história cultural e social, dando ênfase assim a uma variedade muito grande de fontes históricas, ironicamente, a Coleção História da Vida Privada no Brasil, de meados e final da década de 1990, volumes III e IV, é um trabalho em que praticamente não se faz referências à migração para a Amazônia, nem tão pouco às muitas experiências sociais decorrentes desse processo.

Difel, 1977, vol. 8, p. 287. Fazendo um breve comentário sobre a História Geral da Civilização Brasileira, Francisco Iglesias, em Historiadores do Brasil, alerta que "esta História é uma espécie de balanço do que se sabe da trajetória nacional. Evidentemente, em alguns capítulos está aquém do conhecido, pois outro mais habilitado poderia fazer melhor. O importante é dar uma visão abrangente, realçando o que há a ser pesquisado". IGLÉSIAS, Francisco. Historiadores do Brasil: capítulos de historiografia brasileira. Rio de Janeiro: Nova Fronteira; Belo Horizonte: UFMG/IPEA, 2000 , p. 237. As discussões anteriormente apontadas sobre os "ciclos", não deixam de ser pertinentes também para a divisão que as autoras fazem da economia da Amazônia em "3 fases".

${ }^{40}$ PRADO, Maria Ligia \& CAPELATO, Maria Helena Rolim. "A borracha na economia brasileira da Primeira República”, p. 291. 
Assim, é que em um texto intitulado "Imigração: cortes e continuidades", Boris Fausto, buscando compreender alguns aspectos da constituição da vida privada de imigrantes no Brasil no início do século XX, constrói sua análise a partir de duas questões importantes para esse processo, que são as rupturas com um passado anterior vivido pelos imigrantes, mas ao mesmo tempo, a manutenção de traços deste passado que são incorporados ao presente, e as visões que são estabelecidas do "imigrante para o nacional e do nacional para o imigrante". ${ }^{41}$ Não resta dúvida de que as questões levantadas pelo autor são de fato centrais para o entendimento das vivências dos imigrantes no espaço urbano. O que merece ser repensado, no entanto, é que tendo esse volume da História da vida privada, preocupações em discutir semelhanças e diferenças, simultaneidades entre passado e presente, moderno e arcaico, o autor acaba mais uma vez caindo na armadilha de pensar o Brasil apenas a partir da região sudeste, o que empobrece suas análises, uma vez que não faz referência, em nenhum momento, as migrações internas, muito menos, para a Amazônia, mesmo no que se refere à imigração européia, é como se ninguém fosse para esta região.

Aliás, quando o faz, é no sentido de sugerir a possibilidade de comparações entre os fluxos externos e internos das migrações, pois, para o autor, esses processos "têm pontos comuns", uma vez que, "cortes e continuidades, discriminação e preconceito, êxito, integração ou fracasso, integram a história de vida de muito nordestinos que migraram para o CentroSul". ${ }^{42}$ Sobre essa análise, pesa, na verdade, não a sua construção em si, que não deixa de ser bem pontuada, mas sim a ausência de um elemento importante que é justamente a referência à Amazônia. Deste modo, exclui-se da pauta de discussões um espaço que, entre finais do século XIX e início do século XX, em função da economia da borracha e da entrada de grande número de migrantes nacionais e de estrangeiros, passa por uma série de transformações, dentro dos padrões de modernização da época, tal qual o Rio de Janeiro, por exemplo.

Tomando como referência as afirmações de Fausto, há que se tomar cuidado para não esquecer essa experiência dos nordestinos, qual seja, a saída deste grupo para áreas do estado do Pará, do Amazonas, do Acre. De fato, muitas vezes, toma-se como exemplo da migração de nordestinos apenas a experiência mais contemporânea, como o processo migratório que se dá entre a décadas de 1950 e 1980 para São Paulo, trazido à tona naquele momento,

\footnotetext{
${ }^{41}$ FAUSTO, Boris. “Imigração: cortes e continuidades”, pp. 14-20.

${ }^{42}$ Ibidem, p. 61.
} 
principalmente pela mídia. Essa é uma questão bastante específica, com características certamente distintas da experimentada na Amazônia da virada do século XIX para o XX, embora os motivos que movessem o emigrante a sair do seu lugar de origem talvez fossem até muito semelhantes.

Ainda dentro dessa perspectiva, um outro trabalho da mesma série, que, mesmo tratando do tema da imigração, acaba circunscrito ao espaço das regiões sul e sudeste do Brasil, deixando de lado a experiência da imigração na Amazônia, é o de Zuleika Alvim, "Imigrantes: a vida privada dos pobres no campo". Tendo como eixo de suas análises imigrantes pobres que vieram para o Brasil entre meados do século XIX e início do século $\mathrm{XX}$, a autora busca entender o choque entre o público e o privado, verificando, para isto, os hábitos de morar, de higiene, de alimentação, práticas religiosas e educacionais nas fazendas de café e nos núcleos coloniais. Nesse sentido é que, entre 1830 e 1930, no Brasil, a autora identifica dois momentos deste processo: os primeiros cinqüenta anos, “calcados numa política de traslado de camponeses voltada para a ocupação e o povoamento de extensas regiões em particular no sul"; e os outros cinqüenta anos, "definidos por uma política imigratória clara, pautada pelos anseios dos cafeicultores paulistas por mão de obra farta e barata para as suas plantações". ${ }^{43}$

Há que se lembrar que a produção da borracha representou, durante muitos anos, uma exportação tão importante quanto a do café, o que contribuiu para a vinda de nordestinos, tanto como mão de obra para os seringais, como para serem povoadores de núcleos coloniais. Nelson Werneck Sodré, analisando a exportação no Brasil entre finais do século XIX e inicio do século XX, demonstra que dentre os produtos de exportação em ascensão, além do café, a borracha, alcançava "bons preços, em moeda nacional. (...) Em 1910, isoladamente, para os 385.000 contos de réis de café exportado, a borracha apresentaria 377.000 contos, e os dois produtos andavam por volta de $40 \%$ da exportação total cada um". ${ }^{44}$ Apesar da importância da borracha no cenário nacional, Zuleika Alvim acaba por se manter presa aos reducionismos de uma história, que considera como Brasil, quase sempre, a parte sudeste/sul do país,

\footnotetext{
${ }^{43}$ ALVIM, Zuleika. "Imigrantes: a vida privada dos pobres do campo". In: SEVCENKO, Nicolau (org.). História da vida privada no Brasil. República: da Belle-Époque à era do Rádio. São Paulo: Companhia das Letras, 1998, vol. 3, p. 250.

${ }^{44}$ SODRÉ, Nelson Werneck. Formação histórica do Brasil [1962]. 3a edição. São Paulo: Brasiliense, 1964, p. 310.
} 
deixando às margens desse processo outros espaços, como no caso aqui específico, a região norte. Desse modo, um outro exemplo de pesquisa que pretende discutir a imigração no Brasil, mas que desconsidera deste contexto a Amazônia, é o trabalho de Lúcia Lippi Oliveira, intitulado "O Brasil dos imigrantes". Fazendo parte da coleção Descobrindo o Brasil, que com textos curtos e gerais, objetiva trazer informações sobre vários temas de história e cultura brasileiras, neste número sobre imigração a autora acaba ficando praticamente restrita a São Paulo, Rio de Janeiro, Salvador Rio Grande do Sul e Santa Catarina, não fazendo referência a outros movimentos migratórios. É claro que pela própria natureza da coleção, os temas não poderiam ser aprofundados. ${ }^{45}$ De todo modo, o pensar o Brasil apenas tomando como referência o sul/sudeste é algo bastante questionável, conforme tratamos no corpo do texto.

$\mathrm{Na}$ verdade não se trata de negar as peculiaridades e especificidades de todos esses espaços, nem de negar que, nas regiões sul e sudeste do Brasil, a imigração estrangeira foi de fato muito maior do que nos estados da Amazônia. Entretanto, não deixa de causar estranheza, em uma coletânea que pretende analisar a chamada vida privada no Brasil, a ausência da experiência de trabalhadores pobres e imigrantes na região amazônica. Dessa forma, os migrantes nordestinos não aparecem, apesar de serem a principal mão de obra na extração do látex, tal qual muitos imigrantes estrangeiros nas fazendas de café; ao mesmo tempo, reduz-se a experiência imigrantista do Brasil a padrões homogeneizantes.

Ainda tomando como referência a coleção História da Vida Privada no Brasil, vale destacar o trabalho de Maria Cristina Cortez Wissenbach, que, buscando entender as muitas formas que integram os alforriados ao "universo dos homens livres", assinala que essa integração se dá de maneira variada, mesclando-se elementos da vida pública e privada, valores, tradições, fatores econômicos, a mobilidade dos homens pobres livres, o próprio espaço dessas experiências.

Nesse sentido, Wissenbach, observando dados censitários do final do século XIX, afirma que há “um movimento intenso de migrações internas ao longo dos anos de 1872 a 1900”, lembrando que “localizam-se na região nordeste as maiores perdas populacionais”, isto em função do comércio interno de escravos, e dos flagelos das grandes secas, fazendo com que muitos destes se dirigissem "para a Amazônia, para a florescente indústria da borracha e depois para o centro sul”. Além dessa movimentação populacional, que acaba aparecendo

\footnotetext{
${ }^{45}$ OLIVEIRA, Lúcia Lippi. O Brasil dos imigrantes. Rio de Janeiro: Jorge Zahar Editores, 2001.
} 
nos censos oficiais, a autora refere-se ainda aos grupos envolvidos em conflitos como a Guerra do Paraguai, Canudos, Contestado, Revolução Federalista do Sul, que "vagavam pelo país muitas vezes sem condição de se fixar”. Junto a isso, não se pode esquecer da própria Abolição. Desse modo, para a autora, a ampliação de redes ferroviárias, o crescimento das cidades, "serviram para incrementar este processo, uma vez que ofereciam facilidades de deslocamentos e pólos de atração". ${ }^{46}$

Ora, não resta dúvida de que a análise dessa autora avança, em relação às anteriores, na medida em que faz referência a outros espaços que não apenas o sul/sudeste e que se reporta às migrações internas, dando ênfase a essas questões, embora não as aprofunde pela própria natureza do texto, que tem um caráter mais geral e informativo, e sobretudo pelo próprio centro de suas análises, que são os ex-escravos, a outras vivências dos homens pobres, num Brasil que ainda tinha viva a memória da escravidão.

Voltando ainda para a História da Vida Privada, o texto de Luiz Felipe Alencastro e Maria Luiza Renaux, "Caras e modos dos migrantes e imigrantes", publicado no segundo volume da coleção, exceto por um breve comentário, acaba por se inserir na mesma linha dos demais que falam da imigração, ou seja, destaca o sul/sudeste e os imigrantes estrangeiros, apesar do sugestivo título. De todo modo, Renaux e Alencastro, analisando as afirmações de um membro do Instituto Histórico, acerca das observações de um viajante inglês, que em finais do século XIX, comparando a vida dos ingleses pobres com os brasileiros, dizia que estes viviam em melhores condições, lembraram que diante da "tragédia social e humana" que se desenrolava nos sertões do nordeste, este era um comentário bastante questionável. Assim, os autores não deixam de associar a seca à migração dos sertanejos para o Pará e Maranhão, afirmando que "a seca de 1877-8 causou, provavelmente, em termos relativos, o drama de maior custo humano jamais registrado no Brasil”. Mas os comentários não passam disso, mantendo-se no decorrer do texto circunscritos ao sul e sudeste do Brasil. ${ }^{47}$

\footnotetext{
${ }^{46}$ WISSENBACH, Maria Cristina Cortez. "Da escravidão à liberdade: dimensões de uma privacidade possível” In: SEVCENKO, Nicolau (org.). História da vida privada no Brasil. República: da BelleÉpoque à era do Rádio, vol. 3, pp. 58-59.

47 ALENCASTRO, Luiz Felipe \& RENAUX. Maria Luiza. "Caras e modos dos migrantes e imigrantes." In: ALENCASTRO, Luiz Felipe (org.). História da vida privada no Brasil, 2. São Paulo: Companhia da Letras, 1997, p. 312.
} 
Ao levantarmos esses questionamentos, não se pretende enveredar pelos caminhos de uma “História Regional”, cujo objetivo, no dizer crítico de Marcos Silva, seria “zelar pelas terras do rei”, mas justamente de refletirmos para o fato de que, se na produção historiográfica, “o dedutivismo regionalista é desastroso em sua ligeireza, isolando 'peculiaridades' pouco pensadas, o indutivismo urniversalizante oferece outra face da catástrofe ao fazer tábula rasa de qualquer diferença, perdendo experiências significativas dos grupos sociais”. 48

Se, em parte da produção historiográfica brasileira que se preocupou em entender a imigração, pouco se falou sobre a Amazônia de finais do século XIX e início do século seguinte, o mesmo não se pode dizer de uma produção feita por autores regionais, como evidenciou-se anteriormente, que muito se dedicou a esse período. É o caso das observações do intelectual paraense José Veríssimo sobre a Amazônia, publicadas em 1892, no Jornal do Brasil.

Na ocasião, Veríssimo lembrava aos seus leitores do quão pouco se conhecia sobre a região amazônica e que, justamente por isso, ela era "merecedora de atenção e estudo", sobretudo (argumentava Veríssimo, evocando certamente a nascente República Brasileira) nesse "momento histórico de reorganização da pátria". ${ }^{49}$ Preocupado que estava com o progresso da região, essa tarefa parecia ser uma grande obra a ser desempenhada pelo Estado, "visando orientar sua civilização no sentido nacional". 50

Assim, dentre as questões apontadas pelo autor, o povoamento da Amazônia lhe parecia um problema importante a ser resolvido. Desta forma, ao mesmo tempo que constatava que a população da região era bastante escassa, verificava também que pela "copiosa emigração cearense", a população regional vinha crescendo consideravelmente. Citava como exemplo disso o povoamento do rio Juruá: “há poucos anos quase deserto”, que tinha sua população aumentada "por cearenses e seus descendentes". 51

Apesar desse aumento de população, constatado pela presença de nordestinos, para Veríssimo, “o problema do desenvolvimento completo da Amazônia” concentrava-se no seu

\footnotetext{
${ }^{48}$ SILVA, Marcos Antônio da. "A História e seus limites". História \& Perspectivas, no 6 (janeirojunho 1992), pp. 64-65.

${ }^{49}$ VERÍSSIMO, José. “A Amazônia (aspectos econômicos)” [1892]. In: VERÍSSIMO, José. Estudos Amazônicos. Belém: Universidade Federal do Pará, 1970, p. 202.

${ }^{50}$ Idem, p. 171.

${ }^{51}$ Idem, p. 169.
} 
povoamento, constituídos por migrantes, mas também pelo "aproveitamento das populações indígenas”. Assim, o autor, quase em tom ufanista, exaltava as riquezas, e opulência da região, acreditando que maior "prosperidade e progresso" se teria "quando uma população mais numerosa vier aproveitar as suas prodigiosas riquezas naturais", 52

Ficava evidente, na fala de Veríssimo, uma preocupação com a integração da Amazônia ao restante do país, pois esse seria um caminho importante para o desenvolvimento e o progresso da região. Nesse contexto, a imigração seria um elemento fundamental por possibilitar o povoamento "a mais urgente necessidade da região", problema relevante para o "futuro" da Amazônia. ${ }^{53}$ A obra de Veríssimo vai ao encontro de uma boa parte dos pronunciamentos dos poderes públicos entre finais do século XIX e inicio do século XX, que expressavam a necessidade de se povoar e produzir a região com a presença de imigrantes. É justamente a “memória” dessas ações oficiais que foi trabalhada no texto de Palma Muniz.

O trabalho de João de Palma Muniz, Imigração e Colonização - História e Estatística 1616-1916, se inscreve neste mesmo contexto de interesses, na medida em que se trata de uma publicação oficial, solicitada em 1916, pelo Ministério da Agricultura Indústria e Comércio Diretoria do Serviço de Povoamento, encarregada, naquela ocasião, de “organizar o trabalho 'História da Colonização e Imigração do Brasil'”, constituído de "vinte memórias referentes a cada unidade da Federação”. O Ministério da Agricultura Indústria e Comércio entendia que essas memórias deveriam ser um "repositório de fatos notáveis” ligados á colonização e à imigração, contendo "informes e dados estatísticos sobre a população nacional $e$ estrangeira, produção, condições econômicas e quaisquer outras questões dignas de notas”. A Palma Muniz, Engenheiro Chefe da $3^{a}$ Secção da Secretária de Estado de Obras Públicas Terras e Viação do Estado do Pará, coube a tarefa de fazer a daquela memória oficial da imigração parte relativa a esse estado. ${ }^{54}$

Tal tarefa parecia ter sido recebida por ele com alguma reserva, pois em resposta a essa solicitação, afirmava que era "um estudo importante, a confiar antes a um mestre de história

\footnotetext{
${ }^{52}$ Idem, p. 190.

${ }^{53}$ Idem, pp. 202-203.

54 “Ofício $\mathrm{N}^{\mathrm{o}}$ 625, Ministério da Agricultura Indústria e Comércio - Diretoria do Serviço de Povoamento - Rio De Janeiro, 3 de abril de 1916”. In: MUNIZ, João de Palma. Estado do Grão-Pará. Immigração e Colonisação. História e Estatística. 1616-1916. Belém: Imprensa Oficial do Estado do Pará, 1616, p. 6.
} 
do que a um funcionário (...), que só dispõe, ao seu imediato alcance, documentos dos trabalhos de seu cargo dos quatro anos até a data do ano em decorrência”. De todo modo, Palma Muniz acaba por escrever seu trabalho, sem esquecer, no entanto, de desculpar-se, por não ser este um trabalho "completo nem perfeito", em função de ser ele "empregado público" e não dispor de "tempo e lazeres para pesquisar nos arquivos toda uma história". 55 Pode-se entrever por esta visão de Muniz, a concepção que ele tinha do trabalho de pesquisa, isto é, de uma atividade realizada em período de não trabalho, parecendo destinada a um período de lazer. A ida aos arquivos, soa em sua fala com um certo ar de diversão. Nesse sentido, o que ele considerava de fato como uma atividade profissional era o seu trabalho de funcionário público, encarando a pesquisa como um exercício de diletantismo intelectual, e não como uma atividade profissional. O certo é que Muniz, em outros momentos de sua carreira de funcionário público e engenheiro, acabou, a bem dos historiadores contemporâneos, se dedicando mais a este "lazer", como membro do Instituto Histórico e Geográfico do Pará, nos deixando outras importantes obras de referência sobre a história do Pará. Sobre João de Palma Muniz, Clóvis da Silva Rego, então presidente do Conselho Estadual de Cultura do Pará, afirmava em 1973, apresentando a reedição de uma revista do Instituto Histórico e Geográfico do Pará de 1922, “a intensa atividade espiritual de Palma Muniz esta substancialmente vinculada à vida do Instituto Histórico e Geográfico do Pará” do qual havia sido fundador. ${ }^{56}$

Em seu trabalho Imigração e colonização, o autor divide a história do "Grão Pará" em três períodos: Colonial (1616-1823); Imperial (1823-1889) e República (1889-1916). Palma Muniz busca entender a colonização e a imigração no Pará, a partir de uma variedade de fontes oficiais, como Relatórios, Falas, Mensagens, Leis. Ora, isso não seria de se admirar, pois sendo o autor ligado ao poder público paraense, a história escrita por ele é a história das ações do Estado, representado na figura dos Presidentes de Província e depois dos Governadores do Estado, para a implementação de uma política de imigração e colonização do Pará.

\footnotetext{
${ }^{55}$ Idem, p. 8.

${ }^{56}$ REGO, Clovis de Morais da Silva. "Apresentação". In: MUNIZ, João de Palma. Adesão do GrãoPará à independência e outros ensaios. 2a edição. Belém: Conselho Estadual de Cultura, 1973, p. 5.
} 
Palma Muniz, utilizando-se desses documentos produzidos pelo poder público paraense, ao longo de todo o seu texto, busca destacar as várias tentativas oficiais no sentido de se viabilizar a imigração para o estado. Vivendo na região e ligado aos homens públicos da Província, Muniz conhecia muito de seus problemas, apontando em todo o texto o interesse que o Estado tinha em levar adiante a imigração com grupos de estrangeiros instalados em núcleos coloniais, o que sempre fora muito difícil pois, segundo o autor, a imagem do Estado do Pará, construída no estrangeiro, era de uma região insalubre. Ao lado disso, o autor demonstra um descontentamento com o governo imperial, que segundo ele privilegiava a imigração de estrangeiros para os portos do sul, e não para o norte. Assim, referia-se ele ao assunto: "Dividiu-se o país em duas grandes secções, uma constituída pelas Províncias de São Paulo, Paraná, Santa Catarina e Rio Grande do Sul, e outra, pela parte restante do Império. Ao Sul todo o esforço, e ao Norte, o desinteresse e o abandono". 57

Embora o autor não deixe isso totalmente claro, ao longo do texto, vai-se percebendo que, com as dificuldades para a vinda de estrangeiros e com as facilidades para a entrada de nordestinos em função das secas que assolavam o sertão, como as de 1877 e de 1888-89, estes acabaram sendo o exemplo da experiência migratória que deu certo, diante dos muitos fracassos com os estrangeiros, destacados pelo escritor. De fato, Palma Muniz se refere aos entraves à imigração estrangeira. Entretanto, esses problemas são quase sempre exteriores ao poder estatal paraense, todas as dificuldades na vinda de estrangeiros para as terras paraenses, na visão do autor, "esbarraram no terreno prático, pela deficiência de interesse sempre demonstrado pelo governo geral”, pois, ainda segundo ele “os relatórios e falas dos presidentes que governaram o Grão-Pará são abundantes de vastas teorias sobre a imigração e seus efeitos, a sua necessidade para a Amazônia". 58

Pela ótica de Palma Muniz, o poder público paraense, provincial ou republicano, nutria um grande desejo de desenvolver a região, a partir de núcleos coloniais que pudessem ter uma produção agrícola. A ausência de braços para este trabalho é que acabava por gerar a imigração de estrangeiros e nacionais. A gênese da imigração, para Palma Muniz, concentrava-se no fato de que, tendo a Província do Pará a extensão de $2.046 .732 \mathrm{Km}$, “faltavam os habitantes para povoar o solo e os braços para cultivá-lo”, sendo assim

\footnotetext{
${ }^{57}$ MUNIZ, João de Palma. Estado do Grão-Pará. Immigração e Colonisação, p. 45.

${ }^{58}$ Idem, p. 45.
} 
“assunto de alta importância (...) o da imigração e da colonização”. Nesse sentido, a “vultosa extensão paraense", para desenvolver-se, exigia um "grande concurso imigratório". ${ }^{59} \mathrm{Na}$ medida em que o autor vai desenvolvendo tal idéia, destaca as ações do poder público visando à imigração. Assim, em seu texto, pode ser encontrado todo um conjunto da legislação oficial elaborada para esse fim, as despesas com a imigração, referências sobre a Hospedaria dos imigrantes, a Estrada de Ferro de Bragança, e sobre os núcleos coloniais, não esquecendo dos contratos firmados para a introdução de imigrantes, além de dados estatísticos sobre o número de imigrantes estrangeiros e nacionais aportados no Pará.

Ora, é óbvio que pela própria natureza de seu trabalho, o autor não faz mais que narrar esses acontecimentos. Entretanto, conforme evidenciamos, a história da migração escrita por Muniz é fundamental para o entendimento do processo no Pará. Pela leitura de Palma Muniz, a imigração ganha contornos diferentes dos trabalhos anteriormente discutidos, uma vez que em suas páginas, não vamos encontrar, por exemplo, um imigrante apenas sendo seringueiro, mas o encontramos, sobretudo, nos núcleos coloniais que iam se desenvolvendo e, muitas vezes, fracassando no esforço das autoridades paraenses de implementarem uma produção agrícola.

Essa é uma interpretação instigante, pois foge daquela explicação clássica de um emigrante que, expulso pela seca de seu lugar de origem, vem para a Amazônia exclusivamente para ser seringueiro. Uma leitura mais apurada das fontes permite pensar que, muitas vezes, o trabalho nos seringais poderia ser até uma outra alternativa, quando a lavoura acabava por fracassar nos núcleos coloniais. Para a historiografia paraense, o trabalho de Palma Muniz é fundamental, servindo de obra de referência para um grande número de estudiosos que buscaram entender a imigração para o Pará, pois ele teve a sutileza (mesmo sem ser historiador, ou um "mestre de história”, como ele mesmo disse) de escrever uma história da imigração utilizando uma variedade de documentos oficiais, fazendo referência a estes, aspecto muita vezes esquecido por historiadores desse inicio do século XX. Por isto, quase todos o trabalhos que pretendem estudar a economia da borracha, ou a cidade de Belém nesse período, por exemplo não deixam de se referir ao engenheiro Palma Muniz.

\footnotetext{
${ }^{59}$ Idem, pp. 21-22
} 
Se nesse inicio do século XX, o trabalho de maior fôlego é o de Palma Muniz, as décadas de 1920 e 1930 são marcadas por uma preocupação da literatura em representar a vida dos imigrantes nordestinos na Amazônia, marcadamente como seringueiros sempre lutando para sobreviver em um meio inóspito, construído por uma natureza bela e perversa. Mas esses trabalhos de cunho literário não serão analisados nesta parte do trabalho, pois o esforço aqui é uma leitura de textos de cunho mais diretamente historiográfico $\mathrm{Na}$ década de 1950, momento posterior às tentativas oficiais de retomada da economia da borracha, com os chamados “Soldados da borracha”, dos anos 40, encontramos alguns trabalhos que se voltam ao tema dos nordestinos na Amazônia. ${ }^{60}$

Se entre meados do século XIX e inicio do século XX, o chamado boom da borracha, o estudo do tema ficou restrito a mostrar as ações do Estado em prol da emigração e do desenvolvimento da região, ou mesmo em narrar a desventuras dos retirantes na floresta, a exemplo de textos como os de Euclides da Cunha, esse segundo momento da presença de emigrantes vindos de regiões do nordeste para a extração do látex na Amazônia traz à tona a memória de um passado de glórias e riquezas em conseqüência da economia da borracha e, ao mesmo tempo, uma espécie de rememoração do trabalho cotidiano dos seringueiros na floresta. Essa produção da década de 1950 aparece, às vezes, até com um caráter de denúncia da situação vivida pelos seringueiros. Nesse período, encontramos alguns trabalhos preocupados em reavivar uma memória da migração nos quais o migrante desde a saída do sertão é uma vítima. Invariavelmente, a figura do imigrante é ligada à do seringueiro, mesmo que nesses trabalhos se reconheça a presença de um seringueiro nativo, caboclo da região, acostumado com os rios e as matas.

Dentro dessas perspectivas, temos o trabalho do General Lobato Filho, A Borracha da Amazônia (sugestões para a solução prática de seus problemas), publicado no Rio de Janeiro em 1951. Lobato Filho, paraense, nascido na Ilha do Marajó, região em que viveu no inicio do século $\mathrm{XX}$, em áreas dos seringais, tinha nessa sua experiência, como ele próprio afirmara, “credenciais para meter-se em tal assunto". Assim, lamentando-se da decadência das

\footnotetext{
${ }^{60}$ Sendo contemporâneo à presença dos chamados "Soldados da borracha" na Amazônia, podemos citar o trabalho de BENCHIMOL, Samuel. "O cearense na Amazônia: inquérito antropológico sobre um tipo de imigrante”. In: Congresso de Geografia, 10, Rio de Janeiro: 1944. Boa parte deste trabalho se encontra em: BENCHIMOL, Samuel. Romanceiro da Batalha da Borracha. Manaus: Imprensa Oficial, 1992, pp. 7-62.
} 
exportações da borracha, em decorrência da chamada concorrência asiática, da primeira década do século XX, via essa situação como uma verdadeira "derrota”, como um desastre econômico e nesse seu trabalho, possibilidades de sugestões para a revitalização deste comércio exportador. ${ }^{61}$

Apesar dessa ser a principal preocupação do autor, o que nos interessa aqui não é o tema da borracha, mas o nordestino envolvido no processo, invariavelmente entendido apenas como seringueiro. Lobato Filho faz uma espécie de separação entre o "seringueiro regional”, isto é, o nativo da região, e o seringueiro de origem nordestina, o cearense. Comparando-os, considera o primeiro como "um arredio de qualquer convivência (...) quase um proscrito"; já os segundos são vistos como aqueles que têm um outro caráter, gente que "ama a conversa e procura relações". ${ }^{6}$

Essas comparações entre o caboclo da região e o nordestino são constantes em muitos trabalhos, conforme vimos, por exemplo, em Oliveira Vianna, ou em Arthur Cezar Ferreira Reis, do qual falaremos a seguir. Para Lobato Filho, tais diferenças decorrem do próprio ambiente em que ambos nasceram e se desenvolveram. Assim, o caboclo da região tem características indígenas, dentro de uma percepção do índio como um indolente, como isolado da sociedade. Por isso, afirma Lobato, referindo-se ao nativo regional, que "o índio com toda a sua alma de desconfiança, está metido dentro da carcaça do seringueiro natural da Amazônia”. Ao contrário, o nordestino é visto como alguém corajoso, forte, que mantém relações com a sociedade, uma vez que o ambiente em que nasceu é outro. Mesmo com essas diferenciações, ambos não deixam de ser vistos quase como vítimas, não dos patrões, que aqui, muitas vezes, são tidos como amigos dos seringueiros, mas da própria natureza. ${ }^{63}$

Apesar dessa vitimização do trabalhador pela própria natureza, em sua análise, o autor acrescenta um elemento importante, pouco recorrente nas discussões sobre os seringueiros, que é a presença da família. Em várias passagens do texto, Lobato Filho refere-se à mulher e aos filhos dos seringueiros, mesmo que estes também sejam vítimas do meio em que vivem. Convivendo com o medo da noite, dos animais, dos perigos sem fim da floresta amazônica,

\footnotetext{
${ }^{61}$ LOBATO FILHO (General). A Borracha da Amazônia (sugestões para a solução prática de seus problemas). Rio de Janeiro: Irmãos Pongetti, 1951, p. 10.

${ }^{62}$ Idem, pp. 30-31.

${ }^{63}$ Idem, pp. 30-31.
} 
sem saúde e instrução para os filhos, a família não deixa de fazer parte desse contexto de trabalho e sobrevivência, embora o experimente com passividade.

Diante disso, afirma o autor que "em tal regime, haverá quando muito, queixas $e$ lamentações na barraca, entre mulher, marido e filhos, pois o agrupamento não passa dessa simplicidade". ${ }^{64}$ Aliás, é justamente na organização familiar, com grupos de mais de uma família convivendo proximamente, com membros desse grupo trabalhando na extração da borracha, mas também na lavoura, que Lobato Filho, via possibilidades de se levar adiante, com maior produção e melhores condições de vida, a coleta do látex.

Assim, afirma ele que, “com trabalho de cooperação, desanalfabetização, pequena agricultura, criação, pequeno comércio de pequenas utilidades pelos membros das famílias que não trabalhassem na borracha”, isso poderia ser possível. ${ }^{65}$ Como podemos ver, essas são idéias bastante contemporâneas, a exemplo das cooperativas de seringueiros atuais do Acre. Apesar disso, Lobato Filho pouco avança nas suas falas sobre os nordestinos, estes continuam restritos à figura de seringueiros.

Trabalho clássico para a historiografia da Amazônia é o de Arthur Cezar Ferreira Reis, $O$ seringal e o seringueiro, editado pela primeira vez em 1953. O autor, que foi advogado, jornalista, membro do IHGB, Superintendente da SPVEA nomeado por Getúlio Vargas, sempre envolvido com a política da Amazônia, chegando até a governador do estado do Amazonas, ao longo de sua vida, demonstrou uma grande preocupação em entender a história da região, publicando vários textos e livros sobre uma variedade de temas, como a conquista e ocupação, as ordens religiosas, a demarcação do território.

Um de seus trabalhos mais conhecidos, entretanto, é esse, O seringal e o seringueiro, no qual ele investiga a sociedade da borracha, identificando alguns dos sujeitos sociais envolvidos nesse contexto histórico, dentre estes, o imigrante nordestino, que é apresentado como o seringueiro, ou seja, o trabalhador extrator do látex, mas também como o patrão, ou seja o dono do seringal, "geralmente nordestino (...) um explorador da selva que se impôs pela posse de virtudes e qualidades necessárias à vitória”. ${ }^{6}{ }^{6}$

\footnotetext{
${ }^{64}$ Idem, p. 31.

${ }^{65}$ Idem, p. 33.

${ }^{66}$ REIS, Arthur César Ferreira. O seringal e o seringueiro, p. 222.
} 
Embora, nesse trabalho de Ferreira Reis, prevaleça a imagem de um seringueiro extremamente explorado pelos patrões, preso à solidão da floresta, o autor, mesmo tratando dos seringais, observa que muitos nordestinos acabavam por ascender socialmente, chegando à condição de donos de seringal, revelando, portanto, outros papéis sociais por eles vividos.

Ironicamente, é a origem nordestina dos donos dos seringais (descritos como homens que não freqüentaram escola, que emergiram do "meio agreste na luta contra a natureza nordestina”) que é utilizada pelo autor para explicar as explorações sofridas pelos seringueiros. Era o meio social em que vivia na floresta, "lidando com homens, só com homens dominados pelas angústias do isolamento da floresta”, e os negócios do seringal que lhe exigiam "ação pronta, enérgica” explicando, no dizer do autor, a "aspereza” de suas ações, tendo de ser "dinâmico, rude, talvez tirânico". ${ }^{67}$ Por essa compreensão, as relações estabelecidas nos seringais entre os imigrantes parecem mediadas pelo meio em que vivem, e não pelas ações desses vários sujeitos sociais.

Deste modo, não é surpresa que em Ferreira Reis se reforcem, mais uma vez, as comparações entre os nordestinos e os caboclos amazônicos; estes entendidos como um “produto típico das forças telúricas (...) contentam-se com o pouco que obtêm”; aqueles na visão do autor "são de um temperamento vibrante, varonil. (...) Marcados pelas desventuras e pela impiedade do clima, mostram-se dotados de uma energia estuante”. Para Ferreira Reis, é essa força que o nordestino traz para a Amazônia, diante das dificuldades enfrentadas no seu lugar de origem, que lhe permite "enfrentar a vida" na floresta. ${ }^{68}$

Apesar dessa visão tipificadora, que num certo sentido, enquadra o nordestino e o caboclo da região em perfis pré-estabelecidos, que não permitem ver a complexidade das diferenças, os conflitos existentes entre esses dois grupos, e as relações sociais que foram se estabelecendo, Ferreira Reis, consegue perceber a manutenção de vínculos de identidade

\footnotetext{
${ }^{67}$ Idem, pp. 223-224.

${ }^{68}$ Idem, pp. 231-233. Esta tentativa de destacar adjetivos, de fazer comparações, também pode ser encontrada em Benchimol, em trabalho recente de 1999, quando afirma que: "A Amazônia os acolheu [nordestinos] e durante quase um século do ciclo da borracha, os nordestinos tornaram a Amazônia mais rica, melhor, maior e sobretudo,mais brasileira. Chegaram brabos e a Amazônia os domesticou, tornaram-se seringueiros mansos e experientes na linguagem regional. Enquanto eles passavam por este processo de amazonização, a região passou a cearensizar-se, assimilando os ímpetos de coragem, valentia, audácia e resistência dos homens do nordeste brasileiro". BENCHIMOL, Samuel. Amazônia - Formação Social e Cultural. Manaus: Valer, 1999, p. 14
} 
construídos pelos imigrantes nordestinos, mesmo que distante na floresta amazônica. Com a frase "Continuam nordestinos", o autor sintetiza muito das formas que esse imigrante tem de não se “despersonalizar pelo esquecimento da terra em que nasceram”. Era, por exemplo, o que acontecia quando esses imigrantes davam aos seringais que formavam o nome de lugares do nordeste, nomes que lhes "lembram o mundo distante de onde emigraram tangidos pelos horrores da seca ou seduzidos pela miragem da Amazônia”. 69

Ora, ao se reportar a esses elementos tradutores da identidade do imigrante na floresta, Ferreira Reis acaba por apontar uma questão importante para o entendimento da experiência da imigração nordestina na Amazônia que são algumas das formas de constituição de identidade desse grupo no estado do Pará, questão que deverá ser discutida na tese. Nesse sentido, é que, para esse autor, “a idéia de regresso à terra natal”, sempre presente na história de tais imigrantes na Amazônia, se explica pela relação que mantêm com a sua terra natal. $^{70}$

Mas se Ferreira Reis tem sensibilidade bastante para perceber esses elementos constituidores de identidade, e ainda de entender que o que movia a vinda dos nordestinos para a Amazônia não eram tão somente as secas, mas também a própria possibilidade de enriquecimento que a Amazônia representava naquele momento, no tocante à participação das mulheres no processo, o autor acaba por relegá-las ao abandono. Fontes de pesquisa, como processo criminais, demonstram que parte desses imigrantes não vinham sós, e que havia por parte de membros das famílias, dos que não estavam nos seringais, preocupações com o trabalho desses seringueiros, que se manifestavam através de cartas escritas de ambas as partes, por exemplo.

Assim, pode-se dizer, com certeza, que o trabalho de Arthur Cezar Ferreira Reis é um marco na historiografia que discute a presença dos nordestinos na Amazônia, por ter percebido, mesmo tendo com ponto de partida a vida nos seringais, questões importantes para o entendimento da história dessa emigração para a Amazônia, sendo amplamente utilizado em estudos que se preocupam com o entendimento da região nesse período da borracha. Muitas de suas idéias, como, por exemplo, o papel das mulheres e os "tipos sociais" que viviam nos

\footnotetext{
${ }^{69}$ REIS, Arthur César Ferreira. O seringal e o seringueiro, p. 236.

${ }^{70}$ Idem, p. 236.
} 
seringais, foram incorporadas na historiografia amazônica como explicações clássicas para a história da borracha na região.

Com perspectivas de entendimento, semelhantes às do General Lobato Filho, sendo que um trabalho de maior cunho investigativo, e tendo como centro das análises não o extrativismo da borracha, ou a urbanização, mas de fato os nordestinos, temos o trabalho de Alcino Teixeira de Melo, com o sugestivo título de Nordestinos na Amazônia, editado em 1956 pelo Instituto Nacional de Imigração e Colonização, onde o autor era chefe do Departamento de Migrações. Na verdade, o trabalho de Teixeira Mello é sobre os "soldados da borracha”, com os quais manteve contato na Hospedaria de Migrantes de Manaus durante o ano de 1945. Pode-se dizer que esse texto, baseado em entrevistas realizadas pelo autor com os seringueiros, aparece com um certo tom de denúncia da situação vivida pelos seringueiros na Amazônia.

Segundo o autor, com esse trabalho, ele pretendia "dar publicidade aos reclamos daqueles parias torturados, para que a Nação conheça o drama doloroso que se desenrola dia a dia no silêncio das florestas amazônicas". ${ }^{71}$ Embora o autor se preocupe com os "soldados da borracha”, ele não deixa de se reportar à experiência anterior da imigração de nordestinos para a Amazônia, em finais do século XIX, pois, segundo Teixeira Mello, os "soldados da borracha” eram seduzidos pela fortuna, que se poderia adquirir com a extração do látex, da mesma forma que "seus antepassados, que exploraram a borracha em épocas de seu fastígio". ${ }^{72}$ Assim é que, também para esse autor, a seca era o elemento gerador desta imigração, uma vez que os nordestinos saíam de seu lugar de origem "para não sucumbir à míngua em seu torrão natal (...). Emigraram para não se aniquilarem, para sobreviverem à calamidade telúrica" ${ }^{73}$

Rastreando a presença dos nordestinos na Amazônia, Teixeira de Mello enfatiza que estes, movidos pela "ilusão do ouro negro", deixam a sua terra natal, com "pesar e sentimento", para enfrentar "os percalços da vida na selva (...) lutando denodadamente contra as insídias da bravia natureza - guerreiro invicto na batalha da vida”. Como se vê, em Teixeira Mello,

\footnotetext{
${ }^{71}$ MELLO, Alcino Teixeira de. Nordestinos na Amazônia. Rio de Janeiro: Instituto Nacional de Imigração e Colonização/Departamento de Estudos e Planejamento, 1956, p. 10.

${ }^{72}$ Idem, p. 24.

${ }^{73}$ Idem, p. 42.
} 
reaparece, mais uma vez, o perfil de nordestino forte e valente, lutando contra a natureza, resistindo às "tristezas da vida solitária”, elementos recorrentes nos trabalhos anteriores citados. ${ }^{74}$ Mello, entretanto, acrescenta um outro aspecto que é o fato de que, no nordeste, o sertanejo vivia um estágio de civilização diferente do que experimentará na planície amazônica, uma vez que lá, ele tinha atividades na agricultura, nas usinas de açúcar, na criação de animais. Na Amazônia, entretanto, segundo o autor, o nordestino era obrigado a "entregar-se à atividade primitiva da indústria extrativa do látex, adotando, para isso, quase os mesmos rudimentares processos dos índios cambebas". 75

Assim, na visão do autor, dentre os elementos que contribuem para esse estado de primitivismo, ao qual o imigrante é lançado quando de sua presença na Amazônia, está o caráter de isolamento a que ele é relegado no seu trabalho solitário na floresta. Aqui se completa, então, o ciclo de desventuras vivido pelo nordestino: a saída do nordeste pela seca, as dificuldades enfrentadas no domínio da natureza, e por fim a solidão, que abatia e dominava o seringueiro, levando-o até mesmo a estados de perturbações mentais, diante da monotonia da selva, da "ausência do elemento feminino determinando a eclosão de vícios sexuais". 76

Como se pode perceber, nas análises de Alcino Teixeira Mello, é recorrente a imagem de um imigrante e da imigração que se constituem de forma muito trágica, espécie de luta constante entre o homem e a natureza, um homem que, lançado na floresta amazônica, na visão do autor, retrocede aos mais primitivos estágios de civilização. Essa interpretação, como temos evidenciado, parece ser a marca comum de boa parte dos estudos que se preocuparam em falar dos nordestinos na Amazônia.

Em boa parte dos autores, a agricultura (melhor dizendo: os problemas com a produção, a ausência de lavoura em virtude da valorização econômica da borracha em finais do século XIX) foi constante. Conforme demonstrou Palma Muniz, diante do extrativismo da borracha, os poderes públicos se preocupavam em implementar a agricultura. No Pará, essa tarefa foi

\footnotetext{
${ }^{74}$ Idem, pp. 13-15.

${ }^{75}$ Idem, p. 22.

${ }^{76}$ Idem, p. 44. Sobre esta questão da solidão na floresta, o autor dedica um item de seu trabalho específico sobre este aspecto denominado "Nostalgia e isolamento", ver pp. 44-46.
} 
levada adiante com a presença de imigrantes estrangeiros e nacionais. É isto que vai se vislumbrar nos trabalhos do historiador paraense Ernesto Cruz.

Baseado em pesquisas em jornais, e sobretudo no Arquivo Público do Estado do Pará, e também nos dados do trabalho anteriormente citado de Palma Muniz, esse historiador publica, a partir de meados da década de 1950 dois trabalhos que evocam o papel de imigrantes nacionais e estrangeiros no Pará de finais do século XIX e início do século XX. Assim, Estrada de Ferro de Bragança: visão, social, política e econômica, de 1950, e Colonização do Pará, de 1958, dão conta de demonstrar muito das ações dos poderes públicos paraenses em relação à imigração.

Em Estrada de Ferro de Bragança, o autor observa a constituição dessa via-férrea, dando destaque para a legislação, sua efetivação e a implementação dos núcleos coloniais em suas margens. Utilizando-se de farta documentação, o trabalho permite entender os objetivos que moveram o governo provincial a iniciar a construção de uma estrada de ferro em 1884, concluída em 1908, ligando a cidade de Belém à cidade de Bragança, acreditando que a produção agrícola dessa região serviria para o abastecimento da capital paraense. Esse trabalho acaba sendo mais um referencial de fatos, datas, legislação pois, sendo bastante descritivo, dada a própria abordagem teórico-metodológica do autor, não se preocupa com as chamadas ações dos sujeitos sociais.

Retomando questão semelhante em Colonização do Pará, trabalho menos conhecido que o anterior, Ernesto Cruz pretendeu, segundo suas próprias palavras "fixar os diferentes aspectos do que foi a colonização do Pará processada a partir do século XIX”. ${ }^{77}$ Assim é que, para o autor, a "falta de braços para o cultivo da terra e o conseqüente progresso da agricultura" desde as primeiras décadas do século XIX, constituíam um grande problema para as autoridades. A imigração seria a solução para esse problema. Diga-se imigração de estrangeiros, não de nacionais, pois os imigrantes estrangeiros seriam "ativos, inteligentes,

${ }^{77}$ CRUZ, Ernesto. Colonização do Pará. Belém: Conselho Nacional de Pesquisas/Instituto Nacional de Pesquisas da Amazônia, 1958, p. 5. Sobre colonização na zona bragantina do estado do Pará, área onde se fixaram muitos núcleos coloniais ler também: PENTEADO, Antônio Rocha. Problemas de colonização e de uso da terra na região Bragantina do Estado do Pará. Belém: Universidade Federal do Pará, 1967. Consultar ainda CONCEIÇÃO, Maria de Fátima Carneiro da. Políticas e Colonos na Bragantina, Estado do Pará: um trem, a terra e a mandioca. Campinas: Dissertação de Mestrado (Sociologia), Universidade Estadual de Campinas, 1991. 
moralizados”, sugeria Ernesto Cruz, observando um relatório do presidente da Província de 1867.

Assim, Ernesto Cruz traz à tona uma questão importante, o fato de que a colonização empreendida no Pará no século XIX é inicialmente pensada pelo poder público paraense com imigrantes estrangeiros. Na visão do autor, o fracasso dessa empreitada e as secas no nordeste é que favoreceram a vinda de "milhares de nordestinos para a Amazônia”. Estes "retirantes”, segundo Cruz, eram recebidos de "braços abertos pelo governo paraense”, que os amparava conforme a "situação econômica da Província autorizava" ${ }^{78}$ Ainda segundo ele, a experiência desses imigrantes não raro era de grande fracasso nos núcleos, o que se explicava pelo fato de que "os retirantes eram sem apego ao trabalho e sem conhecimentos". ${ }^{79}$ Dentro dessa perspectiva, o autor entendia que "o êxito das colônias dependia da sua administração e da capacidade de trabalho dos imigrantes”. ${ }^{80}$

Tais elementos não deixam de ser instigantes para entendermos algumas das compreensões acerca da vinda de nordestinos para o Pará, dentre elas, o fato de que o próprio Estado parecia acreditar de fato na ação caritativa empreendida para com os imigrantes. Além disso, um esforço para se investigar o perfil do imigrante pensado para o desenvolvimento da agricultura no Pará não pode ser deixado de lado quando se busca entender a imigração de nordestinos para o Pará. Se, nos autores anteriormente discutidos, fica evidente a comparação entre o caboclo da região e o nordestino, em Cruz, mesmo que minimamente, esboça-se uma comparação entre imigrantes nordestinos e estrangeiros. Essas são questões que, com base em variada documentação, merecem ser reinterpretadas.

Em suas análises, Ernesto Cruz privilegia as ações oficiais do poder público paraense, tendo o mérito de enveredar por outros aspectos da experiência dos nordestinos na Amazônia, mostrando a presença destes nos núcleos coloniais, espaço completamente diverso do mundo dos seringais, tão recorrente em quase todos os trabalhos anteriormente discutidos. Assim, com Ernesto Cruz e Palma Muniz, autores que por assim dizer traçam a crônica das tentativas de implementação dos núcleos coloniais no Pará, vemos que a imigração é entendida como a solução para o desenvolvimento da região. Com essa interpretação, a imagem do imigrante

\footnotetext{
${ }^{78}$ CRUZ, Ernesto. Colonização do Pará, p. 49.

${ }^{79}$ Idem, p. 53.

${ }^{80}$ Idem, p. 77.
} 
nordestino, que é apenas seringueiro, sai de foco, dando margem para a figura do agricultor, mesmo que este, pela fala do autor, fosse pouco afeito ao trabalho, tendo de aprender disciplina e determinação com o imigrante estrangeiro.

De 1960, o trabalho de Leandro Tocantins (paraense, posteriormente ligado ao Ministério da Cultura durante o regime militar), Amazônia - natureza, homem e tempo: uma planificação ecológica, mais uma vez, dá grande ênfase à importância da economia da borracha para a região amazônica. É nesse contexto que vamos encontrar os imigrantes nordestinos. Repetindo a explicação clássica, Tocantins entende o seringueiro como um homem subordinado à floresta, mas com um componente a mais, a reação. Assim, segundo o autor, esse "inter-relacionar-se com as plantas e animais, para conseguir o equilíbrio biótico (...) vencendo o meio ambiente e dele extraindo o fator econômico que o prendeu à terra”. Ora, por essa versão, tal homem age para sobreviver, não sendo dominado exclusivamente pela natureza. ${ }^{81}$

Se, no tocante à relação homem/natureza, o autor consegue, mesmo que minimante, perceber o homem como um "ser superior”, capaz, portanto, num certo sentido, de dominar as "influências do meio", no que diz respeito a sua relação de trabalho empreendida nos seringais, é um verdadeiro escravo. ${ }^{82}$ Assim, de acordo com Leandro Tocantins, "embora livre fisicamente, constituíra-se num escravo moral do patrão pela dependência econômica rígida, e às vezes, até mesmo, num genuíno escravo, vítima de castigos corporais, tolhido nas liberdades que fundamentam a existência livre”. Desse modo, descrevendo o seringal, o autor consegue vê-lo até com casa-grande e senzala: “O seringal, sede à beira-rio, possuía sua casa-grande - o barracão, mesmo tosco - e a senzala: toda a selva”. Dentro deste espaço, na visão do autor, abriu-se caminho para "implantar-se uma neo-escravidão" ${ }^{83}$

É nesse contexto que se fez presente a figura do imigrante nordestino, conseqüência, na visão do autor, do que ele chamou de "geografia do infortúnio" constituída dos seguintes elementos: "sol, terra, seca, retirante". Elementos que, como vimos, aparecem em

\footnotetext{
${ }^{81}$ TOCANTINS, Leandro. Amazônia. Natureza, homem e tempo: uma planificação ecológica [1960]. 2 edição. Rio de Janeiro: Civilização Brasileira, 1982, p. 101.

${ }^{82}$ Idem, p. 101.

${ }^{83}$ Idem, pp. 101-104.
} 
explicações anteriores acerca da imigração. ${ }^{84}$ Além disso, Leandro Tocantins entende que a borracha "provocou em seu habitat uma verdadeira revolução social", explicados pela adoção de novas técnicas de produção e de relações de trabalho, estando ai presentes os nordestinos. Assim, nos seringais, pela ótica do autor, percebe-se até uma organização patriarcal, "uma certa identidade que se explica pela procedência nordestina das populações seringueiras e a própria natureza do trabalho e da exploração econômica" ${ }^{85}$

Essa observação do autor, embora excessivamente presa à vida nos seringais, não deixa de ter certa pertinência na medida em que sugere uma reprodução ou recriação de relações de mandonismo e obediência na Amazônia, à semelhança do nordeste, considerando que muitas vezes tanto o dono dos seringais como os seringueiros eram de origem nordestina, e que de várias formas constituíam sua identidade. Embora as explicações do autor fiquem restritas ao universo da borracha, ao falar desse contexto, Leandro Tocantins procura mostrar as contradições da "civilização da borracha”, evidenciando que "não houve distribuição harmoniosa de riquezas por todo o território amazônico". ${ }^{86}$ Essa questão não pode ser desconsiderada, na medida em que remete a pensar as diferenças e contradições próprias da Amazônia de finais do século XIX e inicio do século XX.

Foi a busca do entendimento dessa distribuição de riquezas na Amazônia que, num certo sentido, moveu a pesquisa do economista Roberto Santos nos anos 70, tendo como resultado o livro História econômica da Amazônia, publicado em 1980. Trabalhando com cálculos para construir séries de população, renda e preço, em fontes pesquisadas no Arquivo Público do Pará e em acervos do Estado do Amazonas, o autor pretendeu, segundo suas próprias palavras, trazer "novas luzes à história econômica da região particularmente ao estudo da contribuição real da economia gomífera ao desenvolvimento do país". ${ }^{87}$

O trabalho de Santos acabou se tornando um referencial importante para o estudo da economia da região amazônica. Entretanto, suas análises, dada a própria natureza desse trabalho voltado para economia, estão muito presas à visão dos chamados "ciclos

\footnotetext{
${ }^{84}$ Idem, p. 105.

${ }^{85}$ Idem, p. 114.

${ }^{86}$ Idem, p. 133.

${ }^{87}$ SANTOS, Roberto Araújo de Oliveira. História econômica da Amazônia (1800-1920). São Paulo: T.A.Queiroz, 1980, p. 5.
} 
econômicos” experimentados na Amazônia, aos esquemas pré-estabelecidos que explicam as relações sociais através de fórmulas e cálculos econômicos. Tal abordagem torna o texto bastante esquemático. Fala da região amazônica sempre dentro de um esquema de causas e conseqüências. Além disso, alguns problemas apontados pelo autor necessitariam de maiores pesquisas que justifiquem as suas conclusões. Um exemplo disso é um item do capítulo 4, “Para a Amazônia: por quê?", ponto chave do capítulo, em que o autor enumera seis razões para a vinda dos nordestinos para a Amazônia: a) o preconceito do próprio trabalhador nordestino relativamente ao trabalho nos cafezais, que era tradicionalmente considerado como escravo; b) ilusões do enriquecimento rápido a que o boom da borracha expunha o nordestino; c) pela propaganda e arregimentação realizada por prepostos de seringalistas do Pará e do Amazonas em Fortaleza, Recife e Natal; d) subsídios que os governos do Pará e Amazonas concediam ao transporte de imigrantes em vista dos programas de colonização agrícola; e) proximidade e facilidade do transporte de cabotagem até o porto de Belém, nesse tempo maiores que para o sul; f) pela ruptura da resistência dos senhores de terra nordestinos à saída de homens. Apesar de destacar esses pontos o autor não deixa claro ao leitor as evidências que lhe permitiram tais constatações. ${ }^{88}$

Apesar disso, o texto é um dos mais utilizados para se explicar o contexto da economia da borracha no Pará, visto o autor ter-se utilizado de um bom número de trabalhos historiográficos que discutiram o tema na região. Assim, baseado em trabalhos como os de Palma Muniz, Antônio Rocha Penteado e José Veríssimo, entre outros, é que no capítulo intitulado "Superação escassez de mão-de-obra", o autor discute alguns aspectos da imigração na Amazônia. Nesse sentido, para Roberto Santos, sem a imigração proveniente do exterior, “mas sobretudo da região nordestina do país o estrangulamento da produção teria sido fatal”. Isto se justifica em função das preocupações do governo com a produção agrícola, levando a cabo variadas tentativas de "implantar núcleos agrícolas bem estruturados com colonos ligado à terra”. Entretanto, Santos avalia que esse “sonho” jamais se realizaria, pois, apesar dos esforços do poder público, “a grande imigração nordestina o movimento populacional mais saliente dessa fase, acabou tendo por destino final os seringais". ${ }^{9}$

\footnotetext{
${ }^{88}$ Idem, pp. 107-108.

${ }^{89}$ Idem, p. 87.
} 
Mesmo diante dessa constatação, uma questão importante salientada por Roberto Santos é o fato de que existem diferenças entre as atividades desenvolvidas pelos migrantes nordestinos no Pará e no Amazonas. Assim, para ele, “a principal função dos imigrantes no Pará, ao contrário do que ocorreu no Amazonas, foi a de preencher parte das vagas que os lavradores paraenses deixavam ao deslocar-se para as zonas produtoras de borracha do oeste. Graças a isso (...) pôde surgir a área agrícola da bragantina”. ${ }^{90}$

Essa diferenciação nos remete a um problema importante, que discutiremos adiante: não se pode pensar o processo de migração de nordestinos para a Amazônia de forma homogênea, mas dentro da sua pluralidade, percebendo-se, por exemplo, que tipo de atividade foi desenvolvida por este migrante, em função dos espaços que ele ia ocupando, seja nos seringais, na capital paraense os em núcleos coloniais. Nesse sentido, a história da família de “José de Aracaty”, narrada no início do texto, é modelar, uma vez que demonstra a mobilidade do imigrante em busca de um melhor lugar para se fixar. Pode-se dizer, assim, que as muitas causas e conseqüências apresentadas por Santos, ao longo de seu livro, sugerem problemas para maiores investigações sobre a migração de nordestinos para a Amazônia.

Discutindo também a economia da região, mas dentro de outras perspectivas diferenciadas das de Santos, e com extensa pesquisa sobre o tema, temos o trabalho de Barbara Weinstein, A borracha na Amazônia: expansão e decadência (1850-1920). Publicado inicialmente em 1983, pela Stanford University Press, esse livro, importante para a historiografia regional da Amazônia, só seria editado em português uma década depois, em 1993. Na época, ele foi bem recebido pelo público por representar uma releitura fundamentada da história da economia da borracha, em que a autora discute a expansão, o apogeu e decadência da borracha, visualizando os sujeitos históricos nesse processo, como o papel das elites locais, dos seringueiros, as ações políticas desse contexto, as transformações urbanísticas de Belém e Manaus, os problemas da produção agrícola.

$\mathrm{Na}$ introdução à edição brasileira, Bárbara Weinstein, referiu-se ao pequeno número de trabalhos de "estudos amazônicos" com "pesquisa histórica original". 91 De fato, essa preocupação apontada pela autora não seria descabida, considerando-se que um bom número

\footnotetext{
${ }^{90}$ Idem, p. 108.

${ }^{91}$ WEINSTEIN, Barbara. A Borracha na Amazônia: expansão e decadência (1850-1920). São Paulo: Hucitec/Edusp, 1993, p. 9,
} 
dos trabalhos sobre o período da borracha, a exemplo de alguns a que nos referimos anteriormente, acabam tendo muito mais um tom ensaístico, ou mesmo são trabalhos escritos por estudiosos ou observadores da região, sem grande preocupação com os rigores e a sistematização do trabalho historiográfico. Entretanto, cada um desses trabalhos tem sua importância para o entendimento da história da região, sendo, portanto, também passível de rigorosa crítica o menosprezo da autora à pesquisa pré-existente sobre a borracha na Amazônia. $^{92}$

Nesse sentido, vale lembrar que um artigo publicado em 2002, com o sugestivo título de "Experiência de pesquisa em uma região periférica: a Amazônia", no qual Barbara Weinstein narra o percurso de seu trabalho de pesquisa na Amazônia. Apesar da autocrítica a alguns aspectos de sua pesquisa, como por exemplo, a necessidade de utilização de outras fontes, para o entendimento da história social dos seringueiros, a autora reafirma a idéia de que, naquele momento de sua experiência (década de 1980), a Amazônia era, tomando como referência uma expressão de Euclides da Cunha, “região sem história”, também uma região "sem historiografia". ${ }^{93}$ Entretanto, trabalhos anteriormente citados como os de Palma Muniz, Lobato Filho, Ferreira Reis, Teixeira Mello, Ernesto Cruz, Leandro Tocantins, Roberto Santos demonstram justamente o contrário dessa visão da autora.

Desta forma, a autora afirma ainda que "havia naquela época, poucos estudos sérios sobre a Amazônia, justamente porque ela era tratada como uma região 'sem história': uma bela adormecida em quem a história deixava apenas pálidos traços”. Sua crítica também se estende a parte da comunidade acadêmica da época, que segundo ela, "compartilhavam da visão da Amazônia como uma região sem história (ou apenas com uma história que começara tardiamente)". ${ }^{94}$ Diante dessa percepção, seu trabalho, A borracha na Amazônia:expansão e decadência (1850-1920), seria justamente a resposta a essa região "sem historiografia”. Não resta dúvida de que, com este pensamento, Weinstein, mesmo fazendo

\footnotetext{
${ }^{92}$ Marcos Antônio da Silva, em "Notícias do Brasilianismo. Saudades da Historiografia Brasileira", apresenta pontuada crítica sobre um ensaio de Bárbara Weinstein, acerca de 4 livros de brasilianistas em que esta autora "quase não registra tradições brasileiras a respeito dos temas tratados". Cf. SILVA, Marcos Antônio da. "Noticias do Brasilianismo. Saudades da historiografia brasileira". Revista Brasileira de História, vol. 16, $\mathrm{n}^{\text {os }}$ 31-32 (1996), pp. 76-88.

${ }^{93}$ WEINSTEIN, Barbara. "Experiência de pesquisa em uma região periférica: a Amazônia". História, Ciência, Saúde. Manguinhos, vol. 9. n 2 (maio-agosto 2002), p. 263.

${ }^{94}$ Idem, pp. 263-264.
} 
um trabalho importante para a história da região, não deixa de demonstrar o seu preconceito em relação às pesquisas anteriores ao seu trabalho, além de desconsiderar a própria tradição historiográfica regional.

Assim, preocupada em entender o desenvolvimento da economia regional, a autora vai identificando os elementos constituidores desse processo e enfatiza que a exportação da borracha "gerou um crescimento comercial e demográfico sem precedentes na região e fez de uma área esquecida e muito atrasada um dos mais promissores centros de comércio do Brasil". Apesar disso, tal crescimento mostrou-se "efêmero e superficial" ${ }^{95}$ Ora, como nosso interesse é entendermos a maneira pela qual Weinstein se refere aos nordestinos, esse seu entendimento da economia da borracha é fundamental para compreendermos o processo de trabalho no qual estes foram inseridos, uma vez que a menção aos nordestinos aparece na medida em que a autora fala do trabalho nos seringais.

Nesse sentido é que Bárbara Weinstein, ainda na introdução de seu trabalho, chama atenção para os historiadores que “consideravam os seringueiros - pelo menos dos anos do boom econômico da borracha - como uma massa desumanizada, passiva, escravizada por dívidas e condições sub-humanas de trabalho”. Sua proposta é “enfatizar a imagem que os seringueiros faziam de si mesmos como 'produtores' e não como simples trabalhadores, assim como suas lutas para manter uma certa autonomia e auto-suficiência”. ${ }^{96}$ Embora esse entendimento não fique suficientemente apontado ao longo do texto, não resta dúvida de que a autora extrapola o entendimento simplista da exploração do seringueiro.

Para a autora, a economia da borracha representava "uma alternativa acessível de uma sobrevivência pobre", tanto para "os caboclos da região" e igualmente para "as desesperadas vítimas da seca do infeliz Nordeste”. É dentro dessa perspectiva que ela analisa as relações de trabalho dos seringueiros. ${ }^{97}$

Assim, Weinstein reporta-se às relações que se estabeleciam em função das dívidas adquiridas pelos seringueiros, entre estes e seus "patrões”. Segundo a autora, isso acontecia às vezes pelo fato de que a "maioria dos comerciantes carecia de liquidez, como também

\footnotetext{
${ }^{95}$ WEINSTEIN, Barbara. A Borracha na Amazônia: expansão e decadência (1850-1920), pp. 15-16.

${ }^{96}$ Idem, p. 10.

${ }^{97}$ Idem, p. 47.
} 
porque um seringueiro com dinheiro no bolso teria condições de comprar mercadorias de outros aviadores, sem estar violando seu 'acordo' comercial com o patrão”. 98

Essa abordagem da autora busca explicar o problema do endividamento dos seringueiros, não somente como um instrumento de coerção deste trabalhador por parte de seu patrão, mas também como uma conseqüência da própria estrutura econômica da região naquele momento, onde em muitas áreas, como a dos seringais, por exemplo, se experimentava uma economia baseada na troca. Aliás, essa é uma importante questão levantada pela autora, que referindo-se ao apogeu e declínio da economia gomífera, à efemeridade desse "ciclo", afirma que "ao invés de destruir as relações de produção existente, o negócio da borracha amazônica levantou-se sobre elas, consolidando modos tradicionais de extração e de troca". ${ }^{99}$

É nesse sentido que a exploração sofrida pelos seringueiros, na visão da autora, ganha também outra configuração, isto porque “com a simples caracterização dos seringueiros como trabalhadores escravizados pelas dívidas, tais observações contribuíram para dissimular o caráter complexo das relações entre seringueiro e comerciante" ${ }^{100}$

Pode-se dizer, num certo sentido, que o trabalho de Weinstein, apresenta um outro enfoque da economia da borracha na Amazônia, ao destacar nesse contexto, os seringueiros envolvidos em relações econômicas e sociais que se expressam de forma mais complexa do que os reducionismos da exploração por dívidas, que muitas vezes explicam a vida dos nordestinos seringueiros da Amazônia entre meados do século XIX e primeiras décadas do século XX.

Dentro desta perspectiva de destacar as ações dos seringueiros, temos o trabalho de Cristina Scheibe Wolff, Mulheres da Floresta: uma história: Alto Juruá, Acre (1890-1945). Utilizando-se de entrevistas realizadas com moradores da Reserva Extrativa do Alto Juruá e em Cruzeiro de Sul (Acre), de processos criminais e jornais, além de extensa bibliografia sobre o tema, a pesquisa tem como espaço de análise o Acre, mais precisamente no Alto Juruá. Nesse trabalho, Wolff enfatiza as muitas relações constituídas pelas mulheres na região, evidenciando as relações de gênero. Para a autora, "é importante pois analisar a constituição de um sistema de relações de gênero que se dá baseado nos estereótipos e

\footnotetext{
${ }^{98}$ Idem, p. 39.

${ }^{99}$ Idem, p. 30.

${ }^{100}$ Idem, p. 38.
} 
convicções vigentes na sociedade ocidental, mas também nas condições inusitadas impostas pela natureza da floresta e das condições de trabalho dos seringais”. 101

Assim, ganha destaque a participação das mulheres nesse espaço, talvez o aspecto mais importante levantado pela a autora, o fio condutor de sua pesquisa, ou seja, a participação feminina na empreitada dos seringais acreanos, tanto no boom da borracha, como no momento de sua revitalização na década de 1940, com os chamados "soldados da borracha”. Nesse sentido, Wolff foge completamente das abordagens tradicionais, dos homens sozinhos em meio à floresta na coleta do látex, e traz à tona variados papéis exercidos pelas mulheres nordestinas, índias, caboclas da região, na luta por sobrevivência, por preservar a floresta. Isto se justifica também a partir de um certo "sentido militante (...) que costuma ignorar quase por completo a experiência social das mulheres". ${ }^{102}$

Diante disso, recuperando a experiência social das mulheres no Acre de finais do século XIX e meados do século XX, a autora mostra compreensões acerca da família, das relações conjugais e do trabalho feminino, relações que se construíram com conflitos, solidariedade, violência, dominação e que tinham como agente dessas ações os seringueiros, mulheres nordestinas, grupos indígenas, apontando para uma história de homens e mulheres com ações próprias no contexto da economia da borracha no Acre, bem diferentes da imagem de vítimas da floresta, como muitas vezes os seringueiros e suas famílias são representados. Sobre essa questão, vale lembrar que não se trata de negar o grande número de homens envolvidos na coleta do látex no Acre, mas de demonstrar, também nesse contexto, a presença feminina.

As questões apontadas por Wolff, ao analisar a região do Acre, são sem dúvida importantes para se pensar o Pará, que mesmo fazendo parte da Amazônia, com florestas e rios, como o Acre, tem peculiaridades próprias e bastante específicas, nas quais os imigrantes nordestinos estavam envolvidos, e que precisam ser levadas em consideração como, por exemplo, a constituição de núcleos coloniais, as vivências urbanas experimentadas na capital paraense. Essas diferenças, evidenciadas na vinda dos nordestinos para a Amazônia, reforçam a questão, já enfatizada anteriormente, que busco identificar na tese, de que não se pode pensar na vinda

\footnotetext{
${ }^{101}$ WOLFF, Cristina Scheibe. Mulheres da Floresta: uma história: Alto Juruá, Acre (1890-1945). São Paulo: Hucitec, 1999, p. 14.

${ }^{102}$ Idem, p. 15.
} 
de nordestinos para a Amazônia como algo homogêneo, mas sim dentro de sua complexidade. $^{103}$

Dentro desse grupo de trabalhos mais contemporâneos, que apresentam uma abordagem teórico-metodológica mais voltada para a chamada história social, podemos citar alguns produzidos sobre o problema da seca no Ceará, que, de maneira geral, fazem referência à vinda de nordestinos para a Amazônia. Este é o caso do livro de Frederico de Castro Neves, $A$ multidão e a história: saques e outras ações de massa no Ceará, em que o autor investiga os muitos desdobramentos da seca no Ceará como a fome, as doenças, a saída do sertão para as zonas litorâneas, de maneira especial, Fortaleza. É nesse contexto que o autor destaca (embora não seja o objeto de suas análises, uma vez que estas se concentram na cidade de Fortaleza) a vinda de nordestinos para a Amazônia.

Assim, aponta Frederico Neves que, nos períodos de seca, a chegada dos retirantes à capital cearense era um “momento de preocupação", que abalava o "cotidiano dos moradores" na medida em que trazia uma série de problemas como: “criminalidade, mendicância, prostituição, doenças". ${ }^{104}$ Diante desses problemas de ordem urbana, além da

\footnotetext{
${ }^{103}$ Ver por exemplo: LENHARO, Alcir. Colonização e Trabalho no Brasil: Amazônia, Nordeste e Centro-Oeste. Campinas: Editora da UNICAMP, 1985; GUILLEN, Isabel Cristina Martins. Errantes da selva: histórias da migração nordestina para a Amazônia. Campinas: Tese de Doutorado (História Social), Universidade Estadual de Campinas, 1999; LACERDA, Franciane Gama. Em Busca dos campos perdidos: uma história de trem e cidade. São Paulo: Dissertação de mestrado (História), Pontifícia Universidade Católica de São Paulo, 1997; LACERDA, Franciane Gama. "Infância e Imigração no Estado do Pará (final do século XIX, início do século XX)". In: BEZERRA NETO José Maia \& GUZMÁN, Décio de Alencar (orgs.). Terra matura: historiografia e história social na Amazônia. Belém: Paka-Tatu, 2002, pp. 395-406; LACERDA, Franciane Gama. "História e memória de migrantes nordestinos no Estado do Pará". Anais do VI Encontro Nacional de História Oral (CD ROM). São Paulo: Associação Brasileira de História Oral, CNPq, Departamento de História da FFLCH/USP, 2002; LACERDA, Franciane Gama. "A vida e o trabalho nos seringais". In: FONTES, Edilza (org.). Contando a história do Pará: da Conquista à sociedade da borracha (sécs. XVI-XIX). Belém: E-Motion, 2003, vol. I, pp. 293-316. NUNES, Francivaldo Alves. A trajetória do imigrante nordestino na cidade de Belém (1877-1889). Belém: Monografia de Conclusão de Curso (História), Universidade Federal do Pará, 1999; AGUIAR, Keila de Sousa. Trabalho, Família e Habitação: cotidiano dos migrantes nordestinos na capital paraense (1898-1908). Belém: Monografia de Conclusão de Curso (História), Universidade Federal do Pará, 2001; CORPES, Raimundo Silva. Migrantes e Imigrantes no Pará da virada do século (1898-1908). Belém: Monografia de Conclusão de Curso (História), Universidade Federal do Pará, 2002.

${ }^{104}$ NEVES, Frederico de Castro. A multidão e a história: saques e outras ações de massas no Ceará. Rio de Janeiro: Relume Dumará, 2000, p. 30.
} 
disciplinarização, do assistencialismo estatal, da atividade caritativa, a vinda para a Amazônia, com passagens subsidiadas pelo Estado, era uma solução que se levava a cabo. Para o autor, "tudo parece fazer crer que a política de migração para o Norte foi uma estratégia governamental para desafogar os equipamentos urbanos da enorme pressão exercida pelos milhares de retirantes sem teto, sem alimento, sem saúde”. ${ }^{105}$

De fato, ao analisarmos o movimento dos vapores que seguiam de Fortaleza para a Amazônia, percebe-se o grande número de migrantes com extensas famílias se dirigindo para a região. Nesse contexto, o autor, utilizando-se de descrições de Rodolpho Theophilo, faz alguns comentários sobre os infortúnios dos migrantes a caminho da Amazônia. Mas se a principio parece evidente a ida dos migrantes para o Pará, o Amazonas ou o Acre, tomando como referência um outro trabalho de Neves, percebe-se que os debates em torno disso, a exemplo da seca de 1889, eram veiculados na imprensa local. Discutia-se então a ida dos migrantes para as Províncias do sul do império, ao mesmo tempo em que se questionava a saída destes do Ceará, uma vez que isto implicava em “despovoar a província, impedindo seu desenvolvimento econômico em períodos 'normais ", 106

Dentro destas perspectivas, apontadas por Neves, percebe-se uma certa complexidade estabelecida em torno da migração, que não se restringe apenas à idéia de certa forma simplista, de que os poderes públicos de Fortaleza, por exemplo, desejavam se livrar dos inconvenientes de grupos de famintos e desabrigados que, nos períodos de seca, chegavam à capital. Além disso, um outro elemento destacado pelo autor implica na própria decisão destes de escolherem o local para onde deveriam seguir quando da saída do Ceará. Nesse sentido, a vinda para a Amazônia aparecia como uma opção mais viável, considerando-se "uma extensa rede de conhecimentos” que, em 1889, por exemplo, já havia se estabelecido. ${ }^{107}$ Essa é uma questão importante para ser melhor investigada na tese. Aliás, as justificativas apresentadas pelos migrantes, no momento de solicitação de passagens ao governo - documentação utilizada neste trabalho - são bastante frutíferas nesse sentido.

\footnotetext{
${ }^{105}$ Idem, p. 32.

${ }^{106}$ NEVES, Frederico de Castro. "A seca e a cidade: a formação da pobreza urbana em Fortaleza (1880-1900)". In: SOUZA, Simone de \& NEVES, Frederico de Castro (orgs.). Seca. Fortaleza: Edições Demócrito Rocha, 2002, p. 79.

${ }^{107}$ Idem, p. 81.
} 
Não se pode esquecer que na recente produção historiográfica sobre as secas no nordeste, há um número expressivo de trabalhos que discutem o tema. Destacamos nesse sentido os trabalhos de Durval Albuquerque, que analisa os muitos discursos sobre a seca, ao mesmo tempo em que trata das condições históricas, que transformaram a seca 1877-1879 em um marco que permitiu significados novos ao problema da seca no nordeste. ${ }^{108}$ Desse modo, trabalho de Frederico Neves e de outros contemporâneos aparece como um contraponto em relação a uma historiografia tradicional sobre o Ceará, que ficou exclusivamente presa às dores de uma população de sertanejos empobrecidos e famintos. Não se trata, absolutamente, de negar os sofrimentos da fome, da migração forçada, mas de perceber também as muitas ações desses grupos populares em tempos difíceis. ${ }^{109}$

Um exemplo desta historiografia mais tradicional no trato com as questões da seca e da emigração encontramos na História do Ceará - resumo didático, de Cruz Filho. Baseado em trabalhos sobre o Ceará, como os de Tristão de Alencar Araripe, Capistrano de Abreu, Tomás Pompeu Sobrinho, Rodolpho Theophilo, Barão de Studart, além de revistas do Instituto Histórico do Ceará, o autor, numa “nota preliminar”, escrevia, em fevereiro de 1931, que existiam muitos livros sobre a história cearense, mas que estes, sem muitas pesquisas, firmavam-se “em tradições, muitas vezes lendárias, transmitidas pelos nossos maiores, as quais deram margem a inverosimilhanças (...)”. Assim, seu objetivo, ao redigir esse trabalho, seria o de "prestar um serviço útil à mocidade cearense que aprenderá a amar e venerar a nossa terra, tão grande e tão infortunada pelos flagelos das secas”. ${ }^{110}$

108 ALBUQUERQUE JÚNIOR, Durval. Falas de astúcia e de angústia: a seca no imaginário nordestino - de problema a solução. Campinas: Dissertação de Mestrado (História), Universidade Estadual de Campinas, 1988; ALBUQUERQUE JÚNIOR, Durval. "Palavras que calcinam, palavras que dominam: a invenção da seca no Nordeste". Revista Brasileira de História, vol. 14, nº 28 (1994), pp. 111-120. ALBUQUERQUE JÚNIOR, Durval. A invenção do nordeste e outras artes. Recife: Fundação Joaquim Nabuco/Editora Massangana, São Paulo: Cortez, 1999.

${ }^{109}$ RIOS, Kênia Sousa. Campos de concentração no Ceará: isolamento e poder na seca de 1932. Fortaleza: Museu do Ceará/Secretaria da Cultura e Desporto do Ceará, 2001; SOUZA Simone de \& NEVES, Frederico de Castro (orgs.). Seca; SOUZA. Simone de. (org.). Uma nova história do Ceará. $2^{\mathrm{a}}$ edição revista e atualizada. Fortaleza: Edições Demócrito Rocha, 2002.

${ }^{110}$ CRUZ FILHO. História do Ceará - Resumo Didático. São Paulo: Melhoramentos, s.d., pp. 3-4. Alguns dos trabalhos lidos por Cruz Filho foram os seguintes: Tristão de Alencar Araripe (História da Província do Ceará), Capistrano de Abreu (Capítulos de História Colonial), Barão de Studart (Datas e fatos para a história do Ceará, Notas para a história do Ceará e Dicionário bibliográfico cearense), 
Apesar dessa preocupação, Cruz Filho acabou por reproduzir o sertanejo, diante do flagelo da fome provocado pela seca, semelhante a muitos estudos feitos anteriormente. Assim, diante da seca, formavam-se, "tristíssimas caravanas de retirantes, sujos, andrajosos e esqueléticos, que demandam às cidades em busca de socorros”. Na ausência desses socorros, tais retirantes tornavam-se "emagrecidos, olhos assustadiços, chegando ao extremo de devorar cadáveres de animais pelos campos. A morte por inanição, afinal vem por termo ao suplicio dos desgraçados". 111

Com os graves problemas trazidos pela seca, a emigração para a Amazônia não deixa de ser lembrada pelo autor, que embora considere a Amazônia como uma "segunda pátria cearense”, enfatizando a "conquista e a colonização do longínquo território do Acre magnífico torrão de ouro com que o braço cearense presenteou o Brasil”, afirmava que a migração trazia "intenso dano ao progresso do Ceará”. ${ }^{112}$ Apesar disso, a conquista do Acre é descrita pelo autor com ufanismo, considerada até como "um prolongamento da história do Ceará". 113

É possível dizer que, diante das muitas dificuldades enfrentadas pelos sertanejos, expostos a toda a sorte de infortúnios, cabia ao autor, no seu desejo de legar à juventude cearense o amor a sua terra, aos seus heróis, destacar a conquista do Acre pelos cearenses que emigraram com a seca. $\mathrm{Na}$ fala do autor, essa façanha era motivo de muito orgulho, uma vez que se restituía à União Brasileira o “opulento território”. ${ }^{114}$ Com essa versão, Cruz Filho parecia querer criar um certo status de herói para os nordestinos que vieram para a Amazônia e conquistaram o Acre. Esse viés não deixa de ter sua originalidade.

Um outro trabalho que focaliza a migração de cearenses para a Amazônia é o de Raimundo Girão, História Econômica do Ceará, publicado em 1947. Referindo-se à seca de 1877 , descreve a cidade de Fortaleza naquele momento como "a metrópole da fome, capital dum pavoroso reino", e diante disso, a “oficialização", por parte do governo cearense, da

Thomas Pompeu Sobrinho (Problema das secas e esboço fisiográfico do Ceará), Rodolpho Theophilo (A Seca de 1915).

${ }^{111}$ Idem, p. 177.

${ }^{112}$ Idem, pp. 179-180.

${ }^{113}$ Idem, p. 186.

${ }^{114}$ Idem, p. 186. 
migração para as "florestas avernais do Amazonas", a fim de as desbravarem. Nessa condição, o nordestino aparecia nas palavras do autor "na posição de bandeirante de nova espécie”. ${ }^{115}$ Assim, Girão assevera que as muitas secas do Ceará, além da emigração, traziam sempre os mesmos problemas, como os "da fome, das doenças, da morte da pecuária e das lavouras". 116

Girão teve uma certa preocupação em mostrar as dificuldades que a lavoura e a pecuária nordestina experimentavam, com a chegada das secas. Como, por exemplo: a escassez de alimentos e a morte dos rebanhos, a própria diminuição da mão de obra para a produção em função da emigração, e também as soluções que os poderes públicos implementavam para esses problemas. $\mathrm{O}$ autor também procura mostrar o lado do sofrimento e das muitas dificuldades enfrentadas pelos moradores do sertão cearense atingidos pela seca. Diante da seca parcial de 1898 e da seca de 1900, por exemplo, afirma que "é inútil descrever a desgraça, que as cenas eram as mesmas, cruéis, humilhantes, as populações nuas, famintas, em retirada procurando o litoral e as serras, mal salvando-se da morte”. ${ }^{117}$ Assim, o trabalho de Raimundo Girão, é um bom referencial para entendermos alguns aspectos importantes da história e da economia do Ceará. No entanto, os sertanejos, os emigrantes aparecem fadados a uma vida de sofrimentos, vítimas da seca e da natureza amazônica.

Diante dessa discussão historiográfica, podemos dizer que, num certo sentido, encontramos dois elementos importantes que aparecem como definidores do nordestino. O primeiro a exemplo de trabalhos como os citados acima de Raimundo Girão e Cruz Filho, é uma espécie de quadro de horrores provocado pela seca levando os flagelados a uma vida de terríveis desgraças. O segundo elemento, muito presente na historiografia regional amazônica, é a figura desse flagelado que sai do nordeste para a Amazônia, um migrante quase sempre seringueiro, preso, como já evidenciamos, aos patrões e à floresta. Nessa linha de raciocínio desse primeiro ponto, temos por exemplo os trabalhos de Rodolpho Teophilo (1853-1932),

${ }^{115}$ GIRÃO, Raimundo. História econômica do Ceará. Fortaleza: Editora do Instituto do Ceará, 1947, pp. 390-392.

${ }^{116}$ Idem, p. 407.

${ }^{117}$ Idem, p. 415. Neste trecho do livro, o autor apóia-se em uma descrição de Rodolpho Teóphilo sobre o aparecimento de pombais no Ceará, e a caça desenfreada a estes animais por uma multidão de famintos. Com traços de romance naturalista, a descrição de Teóphilo, por vezes, coloca os homens e o animais numa mesma condição de brutalidade, diante de "nuvens de pombas", sendo perseguidas para saciar a fome. 
que além de suas ações ligadas à medicina, escreveu aproximadamente 28 livros dedicados aos mais diversos gêneros como poesia, romance, história. Seus livros de cunho naturalista, com traços escatológicos, traçam um verdadeiro quadro de horrores da seca no Ceará, da migração para a Amazônia. ${ }^{118}$ Com semelhante perspectiva, mas de cunho historiográfico, temos o recente trabalho de Antônio Marco Villa, publicado em 2000, baseado em farta documentação e em bibliografia sobre o tema e que também acaba por reproduzir a seca dentro desta perspectiva do horror, do descaso para com o problema por parte do poder público, sem evidenciar outros desdobramentos históricos deste processo. $\mathrm{Na}$ introdução do trabalho o autor explica que seu livro "narra o massacre de milhões de nordestinos, que acabou esquecido como se fosse uma lembrança incômoda aos brasileiros, especialmente aos donos do poder (...). É uma triste história que rondou diuturnamente a vida dos sertanejos". ${ }^{119}$ Essa pretensão inaugural de Villa no que se refere ao tema não pode passar desapercebida, diante da enorme bibliografia sobre o tema.

Buscar investigar a complexidade destas muitas relações sociais, que ultrapassam os horrores da seca e o trabalho dos seringais, enfatizando outras experiência que constroem este processo, é o interesse desta pesquisa.

\footnotetext{
118 TEOPHILO, Rodolpho. O Paraoara. Ceará: Typ. Moderna, 1899; e TEOPHILO, Rodolpho. A fome [1890]. Fortaleza: Edições Demócrito Rocha, 2002.

${ }^{119}$ VILLA, Marco Antônio. Vida e morte no sertão: história das secas no nordeste nos séculos XIX e XX. São Paulo: Ática, 2000, p. 2.
} 


\section{Natureza cearense e natureza amazônica}

Em maio de 1897, o vapor "S. Salvador", da Companhia de Navegação do Lloyd Brasileiro, chegava ao porto de Belém, vindo do Ceará. Trazia em sua carga uma encomenda, de certa forma incomum, considerando-se a imagem que se constrói do Ceará do século XIX, como um estado pobre, que necessitava da ajuda das outras unidades da federação. Tratava-se de "duas sacas com semente de café”, remetidas pelo governador do Ceará ao do Pará, e que depois foram entregues na Diretoria da Repartição de Obras Públicas, Terras e Colonização. ${ }^{1}$

Gesto irônico, considerando-se a História do próprio café, que depois de plantado no Pará, no século XVIII, acabou sendo levado e difundido para o resto do Brasil. Anos depois, no Ceará, no “Balancete da receita da despesa feita com os flagelados da seca de 1916”, em meio a uma lista de gastos oficiais com serviços de açudagem, transportes, aquisição de sementes, confecção de roupas, compras de tecidos, com auxílios ao asilo de alienados, à maternidade, à Associação de S. Vicente, à Santa Casa de Misericórdia, encontramos gastos no valor de seis contos de réis para a localização de flagelados em Estados vizinhos e também para a "aquisição de peixes, no Amazonas para o açude de Quixadá”. 2

Essas duas pequenas notas, que parecem desconexas, surgem aqui como exemplos das muitas relações que foram construídas entre os Estados do Ceará e do Pará, e que ultrapassam as imagens que nos acostumamos a ter desses dois espaços. Quem poderia acreditar que sementes da principal riqueza nacional, o café, teriam sido presenteadas ao governador do Pará, pelo do Ceará, em finais do século XIX? Quem poderia imaginar que peixes do Amazonas “migrassem” para viverem no açude de Quixadá? De fato, não sabemos o que foi feito das sementes, nem tão pouco se os peixes chegaram ao Ceará. Isso talvez seja o menos importante. É possível que o principal seja aqui a imbricada ligação que se estabelece entre esses dois estados, representada nas sementes de café destinadas à agricultura e nos peixes dos rios da floresta amazônica, enviados ao sertão de Quixadá. No cerne desses dois episódios,

\footnotetext{
${ }^{1}$ APEP, SPP - Códice 2124. Ofício n ${ }^{\circ} .1 .093$ de 22 de abril de 1897 e Ofício n ${ }^{\circ} .1244$ de 20 de maio de 1897.

${ }^{2}$ Mensagem dirigida à Assembléia Legislativa do Ceará em $1^{\circ}$ de julho de 1916 pelo Presidente do Estado Coronel Benjamin Liberato Barroso. Fortaleza, 1916, p. 35.
} 
estão a natureza do Ceará e do Pará, e o caminho percorrido por muitos sujeitos sociais e que vivenciaram variadas experiências nesses espaços.

O entendimento da História dos muitos migrantes cearenses que, entre 1889 e 1916, deixaram sua terra natal e aportaram em terras paraenses parece-nos indissociável de uma leitura das compreensões construídas sobre o Ceará e sobre a Amazônia, no caso aqui específico, o estado do Pará. Perceber o que significavam o Pará e o Ceará deste período é fundamental para entendermos os múltiplos sentidos presentes no ato de se migrar do Ceará, de se estabelecer no Pará, de depois retornar para o lugar de origem e até mesmo de voltar outra vez ao Pará, trajetória que parece ter sido feita por muitos migrantes. Um caminho profícuo para esse entendimento é o de entender os significados atribuídos aos elementos que compunham a natureza desses dois estados. A seca, o sertão, a chuva, a floresta e os rios são elementos intimamente ligados à História dos sujeitos sociais envolvidos no processo migratório.

Longe de ser tão somente uma questão contemporânea, em que o destino das riquezas naturais da Amazônia entra na pauta de discussão dos mais variados grupos sociais, a Amazônia das últimas décadas do século XIX e do início do século XX, conhecida pelos muitos negócios da borracha, era alvo constante de variadas percepções, que traziam a público a natureza desse espaço de florestas, rios, chuvas, clima quente e grandes extensões de terra a serem cultivadas. Do mesmo modo, embora diversa, a natureza cearense, com praias, coqueiros, e o sertão florido ou seco, e os muitos problemas decorrentes do fenômeno da seca, e até mesmo de invernos rigorosos, também não deixava de vir à tona.

No Pará, com a constante vinda de migrantes dos sertões cearenses refugiados das secas, em busca de uma vida melhor na região, é quase com um caráter complementar que a natureza cearense e a amazônica vão tomando corpo nos relatos dos poderes públicos e nos noticiários da imprensa, através de colunas diárias ou de quadros de poesias que enchiam os olhos dos leitores.

De fato, entre 1888 e 1915, a população do Ceará experimentou alguns períodos de seca, marcados, por um lado, pela busca de sobrevivência nos lugares do sertão atingidos por esse fenômeno, e ao mesmo tempo, pelo êxodo, rumo a Fortaleza, e muitas vezes de lá, para outros 
territórios, como o estado do Pará. ${ }^{3}$ Essa situação gerou uma variedade de explicações e interpretações, tanto a respeito da seca e do sertão, como também dos lugares distantes do Ceará, caso do Pará, para onde um grande número da população atingida pela seca se dirigia.

Assim, tanto nas falas do poder público, como nos relatos da tradição oral e nos textos literários, uma variedade de significados é atribuída à seca e ao sertão, e ao mesmo tempo, aos novos espaços que recebiam os retirantes cearenses. Não resta dúvida de que, para a construção dessas imagens sobre o Ceará ou a Amazônia, é fundamental entender a memória de um tempo narrado pelos antepassados, ou pelos que vivenciaram esses acontecimentos como observadores ou como participantes.

Nessas narrativas, mesmo que se tratem de registros indiretos das impressões dos migrantes, ou dos sertanejos, estão presentes as contradições próprias de quem é obrigado a partir para um lugar desconhecido, misto de Eldorado e de inferno e, ao mesmo tempo, as lembranças de um outro paraíso, o sertão cearense quando se tem chuva regularmente, momento em que a plantação floresce e o gado cresce.

Nessas imagens, entretanto, há uma espécie de convergência na representação do morador desses lugares. No Ceará, no embate cotidiano contra a seca, ou na Amazônia, lutando contra a floresta, o sertanejo é representado como um homem obstinado diante de tantos reveses da natureza. É dessas muitas representações da seca e dos sertões do Ceará e da Amazônia que pretendemos tratar aqui.

Textos jornalísticos e poesias veiculados em Belém levavam aos leitores diários uma visão trágica e exótica da natureza e do homem cearense, sempre ameaçado pelas secas. Ao mesmo tempo, esses textos revelam o embate travado na imprensa e na fala dos poderes públicos, visando a uma mudança na forma de se entender e de se pensar a própria Amazônia, compreendida como uma região de clima insalubre, propícia a muitas doenças. Na verdade,

\footnotetext{
${ }^{3}$ Raimundo Girão registra na História do Ceará "os efeitos horrendos de secas de larga duração, atingindo três anos consecutivos, dentre elas as verificadas em 1721/25, 1777/1778, 1790/93, 1824/25 e 1877/1879. Anotam-se também as de 1692, 1710/11, 1809/10, 1844/45, 1888/89, 1915 e 1932/33”. Cf. GIRÃO, Raimundo. "Panorama Econômico do Ceará". In: GIRÃO, Raimundo \& MARTINS FILHO, Antônio. O Ceará. Fortaleza: Editora Fortaleza, 1939, p. 165. Itamar de Souza e João Medeiros Filho identificaram no nordeste, ao longo de 5 séculos (entre o século XVI e o século XX), quarenta e uma secas com duração que variaram entre seis meses a 1 ano. As secas que aconteceram no período dessa pesquisa, isto é, entre 1888 e 1916 são as seguintes: 1888-1889; 1898; 1900; 19031904; 1915. Cf. SOUZA, Itamar \& MEDEIROS FILHO, João. Os degredados filhos da seca: uma análise sócio-política das secas no nordeste. $2^{\text {a }}$ edição. Rio de Janeiro/Petrópolis: 1983. pp. 38-39.
} 
como na história das sacas de café e dos peixes, nessas questões, rastreiam-se o entendimento e os significados atribuídos acerca da natureza cearense e amazônica, e das muitas relações travadas pelos habitantes desses espaços.

\section{A seca}

Câmara Cascudo, referindo-se aos contos populares, afirma que estes são como um “primeiro leite intelectual”, que suscitam sentimentos como amor, ódio, cisma, solidariedade, compaixão, e que nos chegam com as "Histórias fabulosas que ouvimos na infância". ${ }^{4} \mathrm{De}$ fato, muitas das explicações para as longas ausências de chuvas no Ceará e para as secas remetem a uma compreensão da natureza construída a partir da tradição oral. ${ }^{5}$ Dos contos recolhidos por este autor, "A causa da seca no Ceará" tem como cerne de explicação uma determinação divina, espécie de vingança do "Bom Jesus", contra os cearenses, que, em "priscas eras”, “malquistaram-se” com Ele e resolveram expulsá-Lo do Ceará. Conta a lenda que:

“prepararam uma jangada e nela puseram o Santo (...) rumo a Portugal, donde procedera (...) já muito distante das praias cearenses, 'entre o mar e o céu' sentiu sede. Por esquecimento, ou mui propositadamente, os seus perseguidores não haviam acondicionado água na jangada. Nem uma gota sequer existia do precioso líquido ... Nesse transe doloroso, sedento de sede, o Bom Jesus proferiu então essas palavras: 'Sim, cearenses ingratos e maus, vocês também não terão água quando tiverem sede'. O Vento Leste, que passava, acolheu as palavras do aflito Santo e varrendo do nosso céu todas as nuvens, trouxe para o Ceará a primeira seca". 6

Mesmo sendo uma lenda "popular”, que figura na tradição oral, o texto, segundo Câmara Cascudo, é "visivelmente de fundo literário e moderno relativamente". 7 Apesar disso, não deixa de ser exemplar na medida em que, ao explicar a seca no Ceará, destaca elementos como a fome, a sede com a falta de água, os ventos, as nuvens, o mar e as jangadas, tão presentes quando se evoca a natureza cearense.

\footnotetext{
${ }^{4}$ CASCUDO, Luis da Câmara. Contos tradicionais do Brasil (compilados por Câmara Cascudo). 12 edição. São Paulo: Global, 2003, p. III.

${ }^{5}$ Ver a tradição de "Santa Luzia", sobre a previsão de chuva, descrita por Euclides da Cunha. CUNHA, Euclides. Os sertões. Campanha de Canudos. 28 ${ }^{\mathrm{a}}$ edição. Rio de Janeiro/Brasília: Francisco Alves/INL, 1979, p. 93.

${ }^{6}$ Idem, p. 265.

${ }^{7}$ Idem. p. III.
} 
A "lenda" apresentada por Câmara Cascudo pode ser retomada à luz do trabalho de Natalie Zemon Davis, que analisa "coletâneas de provérbios comuns e as coletâneas de práticas e crenças populares a respeito da saúde e das curas médicas”, que circularam na França entre os séculos XV e XVIII. Essa autora acredita na possibilidade de que essas fontes históricas permitam "fazer ouvir as vozes do povo ali registradas". Apesar disso, suas conclusões apontam também para o fato de que os "compiladores tendiam a modificar seu material” no momento de organizar o texto para ser impresso, havendo, assim, “distorções e omissões” na sistematização escrita dessa cultura oral. Reconhecendo esses limites para o uso de tais fontes pelo historiador, a autora adverte que, mesmo assim, tem-se "oportunidade de voltar a trechos de conversas e a séries de atividades às quais os compiladores se referiam”. ${ }^{8}$

Embora discutindo um outro contexto histórico, esses questionamentos de Natalie Zemon Davis parecem bem apropriados quando pensamos nos significados atribuídos às secas no Ceará, tomando como exemplo a história coletada por Câmara Cascudo. Mesmo que o próprio folclorista afirme ser a lenda de fundo literário, possivelmente, na repetição própria da oralidade popular, talvez esteja um pouco da raiz, da origem lendária da seca, aqui destacada. James Obelkevich, também enfatizando as utilizações de provérbios, como fontes para o trabalho dos historiadores, refere-se a uma questão fundamental para muitas pesquisas de História, que é a tarefa de "ouvir a voz por trás do texto, invocando a oralidade que esta além da alfabetização”. Nesse sentido pergunta: "Em quais textos podemos ouvir as pessoas comuns conversando em épocas em que a maioria não sabia escrever?”. A alternativa para isso, como demonstra o autor, é apontada nos trabalhos de folcloristas e antropólogos que estudam a fala "por meio de suas formas e gêneros característicos - cumprimentos, charadas, maldições, piadas, lendas”. Para Obelkevich, esses registros podem fornecer muito do que as pessoas disseram em "inúmeras ocasiões da vida cotidiana". 9

Desse modo, nessa narrativa e, igualmente, em outras explicações sobre o Ceará, não resta dúvida de que o clima árido, com o sol que castiga e conseqüentemente com a ausência de chuvas, é uma questão central. Era nesse espaço que o sertanejo devia lutar por sua

\footnotetext{
${ }^{8}$ DAVIS, Natalie Zemon. "A Sabedoria proverbial e os erros populares". In: Culturas do povo: sociedade e cultura no início da França moderna: oito ensaios. [1975]. Rio de Janeiro: Paz e Terra, 1990, pp. 188-217.

${ }^{9}$ OBELKEVICH. James. "Provérbios e História social”. In: BURKE, Peter e PORTER, Roy. História social da linguagem. São Paulo: Fundação Editora da UNESP/Cambridge, 1997, pp. 41-42.
} 
sobrevivência nos períodos em que havia chuva e em que a plantação florescia, e nos períodos de estiagem, resistir enquanto lhe fosse possível.

Apesar dos estudos sobre climatologia da região, sobre as "manchas de sol” no Ceará, que buscavam uma compreensão científica do fenômeno das secas e de suas conseqüências, também é muito presente uma compreensão que remete a explicações místicas para o grave problema que aparece inseparavelmente ligado à história daquele Estado. ${ }^{10}$

Esse entendimento da seca como um fenômeno meio divino, meio natural, contra o qual o homem não tinha como lutar ou se precaver parecia ser compartilhado por muitos moradores do Ceará, mesmo os mais letrados. Assim, por ocasião das estiagens de 1889, o Presidente da Província do Ceará, o senador Henrique Francisco d' Ávila, diante dos muitos problemas enfrentados por ele no que se referia às “obras da regeneração do Ceará”, como o grande ônus dos cofres públicos com as secas, a construção de estradas de ferros e de reservatórios de água para a irrigação, chegou a afirmar que “(...) a experiência e os estudos, me demonstram a toda evidência, que esse terrível flagelo da seca nos visitaria mais vezes, pois depende ele de leis naturais independentes da vontade do homem". ${ }^{11}$

Quase dez anos depois, em 1898, quando o Ceará era assolado por uma "seca mais ou menos intensa em diversos pontos do Estado”, o governador de então, Antônio Accioly, fazia referência aos "presságios desanimadores sobre a estação invernosa do corrente ano", que deixaram a "população apreensiva desde os primeiros dias de janeiro". ${ }^{12}$

Utilizando-se, provavelmente, de interpretações que corriam por entre a população, o governador buscava explicar a seca daquele ano quase como um jogo de sorte, que atribuía a determinados anos o prenúncio de tempo de inverno ou de seca. A coincidência das secas de $1877 / 1878$ e de 1888 era bom argumento para a lembrança do governador de que " $a$

\footnotetext{
${ }^{10}$ Para um levantamento geral sobre manchas de sol e seca, ver: TEOPHILO, Rodolpho. "As manchas do sol e as secas. A causa destas e os meios de atenuar seus efeitos". In: Comemorando o Tricentenário da vinda dos primeiros portugueses ao Ceará. 1603-1903. Ceará, Typ. Minerva, 1903, pp. $421-431$.

${ }^{11}$ Os grandes reservatórios de que falava Henrique D’Avila eram os de: Quixadá, Itacolony e Lavras. As Estradas de ferro além da de Baturité, seriam as de Sobral, e a de Aracaty ao Crato. Fala com que o Exm. Sr. Senador Henrique Francisco d'Avila presidente da Província do Ceará, abriu a $2^{\text {a }}$ Sessão da Assembléia Legislativa Provincial no dia 15 de julho de 1889. [Ceará] Typ. da Gazeta do Norte, 1889, p. 3-4.

${ }^{12}$ Mensagem apresentada à Assembléia Legislativa do Ceará pelo presidente do Estado Dr. Antonio Pinto Nogueira Accioly em 4 de julho de 1898. Fortaleza: Typographia Econômica, 1898, p. 23.
} 
experiência dos últimos trinta a quarenta anos, mostrando com a periodicidade de uma lei cósmica a reprodução das secas nos anos terminados em 7 ou 8 ”. ${ }^{13}$

Embora Antonio Accioly tivesse conhecimento de pesquisas sobre a seca, como se percebe em sua Mensagem, ele próprio deixava entrever um entendimento desse fenômeno, construído muito mais a partir das vivências cotidianas dos moradores do sertão, do que em estudos mais apurados sobre o assunto. Nesse sentido, é que, para o governador Antonio Accioly, a seca se tornava um problema quase sem solução, uma vez que as populações atingidas por esse fenômeno, segundo ele, o entendiam a partir de uma espécie de "fatalismo" a que estavam condenados como castigo divino. Diante disso, sentenciava: "Não há como convencê-la de que aqueles fenômenos obedecem a marcha cíclica, e não ao alvedrio de um Deus caprichoso, sempre pronto a fulminar raios contra as classes desvalidas”. Frente a esse “fatalismo", o governador acreditava na improficuidade de se sugerir para a população o "precaver-se contra tais infortúnios (...) com o excedente dos anos fartos, trabalhar duplamente nas vésperas da calamidade". ${ }^{14}$

Para Accioly, a dimensão "fatalista” que a seca tomava era quase evidente, diante da situação de pobreza enfrentada pelo povo do sertão. E se perguntava o que se poderia esperar de uma população “cuja existência é uma luta sem tréguas contra elementos esmagadores, (...) a ardentia do sol, que estiola toda a vegetação, e as chuvas desordenadas que encharcam os campos putrefazendo as ervas dos prados?”. Pelas palavras do governador, os significados atribuídos à seca eram resultado da própria situação de enfrentamento da natureza construída pelos moradores do sertão, que os colocava quase impotentes face a uma natureza com características tão perversas.

No Pará, essa impotência do sertanejo diante da natureza era constantemente trazida ao público, através da imprensa, que se ocupou em construir uma imagem do Ceará e da seca. Se os documentos produzidos pelo poder público ficavam restritos a um grupo específico de pessoas, o noticiário jornalístico, mesmo considerando-se o grande número de pessoas que não tinham acesso aos jornais, acabou sendo um meio importante para se falar do Ceará.

Nesse sentido, alguns indícios extraídos de pequenas mensagens veiculadas na imprensa nos permitem afirmar que o jornal Folha do Norte circulava entre vários segmentos da

\footnotetext{
${ }^{13}$ Idem, p. 24.

${ }^{14}$ Ibidem.
} 
sociedade paraense, sendo muitas vezes um meio de comunicação entre os migrantes nordestinos. Um bom exemplo disso é o anúncio publicado, em 1900, pelo maranhense Joaquim Costa e Silva, que havia “chegado há pouco tempo” a Belém e desejava “conhecer alguns parentes", que moravam nessa cidade. Como ignorava a localização de "suas residências", pedia que esses, ao lerem o anúncio, o procurassem na "Farmácia César Santos". ${ }^{15}$ Semelhante teor se fazia presente no anúncio que procurava por Dona Joana Rodrigues Pacheco, ou sua mãe Joana Rodrigues dos Anjos, "senhoras naturais do Piauí". Quem desejava falar com elas era uma "pessoa chegada do Acre e residente no Hotel do Comércio", que terminava seu anúncio agradecendo a quem desse "notícias destas senhoras". ${ }^{16}$ Além disso, eram comuns propagandas de remédios para seringueiros, como o “Licor de Café Beirão”, muito bom para aqueles “cidadãos laboriosos, que, pelas ilhas e pelos sertões, vivem labutando na extração da borracha e em luta gigante com as terríveis sezões”. ${ }^{17}$

Esses poucos indícios revelam, como bem enfatiza Heloisa de Faria Cruz - referindo-se à cidade de São Paulo entre finais do século XIX e início do século XX -, uma espécie de transformação da "cultura impressa", que estabelece novas articulações na vida urbana. Ainda segundo essa autora - no que se aproxima muito da realidade vivida no estado do Pará, com a movimentação dos negócios da borracha —, observa-se que “a diversificação das atividades econômicas, a ampliação do mercado e o desenvolvimento da vida mundana são incorporados às formas e conteúdos dessas publicações”. ${ }^{18}$

Na Folha do Norte, por exemplo, em uma coluna intitulada "Jornal dos Estados", o leitor diariamente entrava em contato com um pouco do que acontecia em outros estados do Brasil,

\footnotetext{
${ }^{15}$ Folha do Norte. Belém, 3 de julho de 1900, p. 2.

${ }^{16}$ Folha do Norte. Belém, 13 de janeiro de 1915, p. 4.

${ }^{17}$ Folha do Norte. Belém, 19 de janeiro de 1896, p. 3. Uma boa leitura acerca de propagandas de remédios, é o texto de Denise de Sant'Anna, "Propaganda e História: antigos problemas, novas questões". A autora, pesquisando em jornais e revistas paulistas, busca rastrear variadas experiências históricas na constituição desses anúncios que trazem à tona significados atribuídos à saúde, à doença, ao próprio corpo, mas também referências à vida urbana e rural, ao desenvolvimento tecnológico. Cf. SANT'ANNA. Denise. Bernuzzi. "Propaganda e História: antigos problemas, novas questões". Projeto História, no 14 (fevereiro 1997), pp. 89-112.

${ }^{18}$ CRUZ, Heloísa de Faria. "A cidade do reclame: propaganda e periodismo em São Paulo". Revista Brasileira de História, vol. 9 (setembro 1989-fevereiro 1990), pp. 82-83.
} 
sobretudo nos do nordeste. Essas informações, muitas vezes, eram extraídas de jornais publicados em cidades do nordeste e que chegavam na mala dos vapores com aproximadamente dez dias entre o fato publicado no local de origem e a distribuição dos jornais ao Pará, para subsidiarem os redatores da Folha do Norte.

Pequenas e variadas notícias, como o lançamento de livros, a vida política local, posse de juízes, falecimento de algum político importante, casamentos de figuras ilustres da sociedade, questões sobre saúde e higiene pública, mas também casos "fantásticos”, como um menino “com voz de homem no Maranhão”, de violência, de roubos e até mesmo de chuva e de seca, davam aos leitores uma visão do que acontecia no nordeste. ${ }^{19}$

Noutras vezes, as notícias, de acordo com a importância conferida ao assunto, apresentavam-se ao público em artigos maiores e mais densos, que levavam vários dias ocupando páginas do jornal, quase sempre a primeira, até que o articulista os concluísse.

Este foi o caso das publicações sobre os conflitos políticos do Ceará em 1914, em que o leitor pode acompanhar o desenrolar dos acontecimentos diariamente. À medida que a seca ia se aguçando, por exemplo, as notícias iam ganhando mais destaque na Folha do Norte, deixando de figurarem somente na pequena coluna do "Jornal dos Estados". Ganhavam, assim, características de um artigo maior, que levava informações mais detalhadas ao leitor, que se deparava com os horrores da tragédia da seca e com as mobilizações da população para ajudar os “irmãos" do Norte.

Assim, quando da escassez de chuvas do ano de 1898, a Folha do Norte não deixou de fazer referências, baseada em informações do jornal cearense República, ao "grande pânico" que reinava na pequena vila de Santa Quitéria, “ante o medonho aspecto da seca”. Nesse ano, a imprensa local lembrava que no Ceará, “apenas pequenas e parciais chuvinhas caíram no fim de janeiro e princípios de fevereiro e nada mais”. Como última alternativa para que as plantações não se perdessem totalmente, esperava-se pelas chuvas do final de abril. ${ }^{20}$

Mas se, de um lado, o jornal narrava a tragédia da seca, parece-nos que de outro lado, o tempo da seca era marcado pelo aparecimento de Histórias sobre o sertão. Histórias que às vezes ganhavam um caráter místico, tal qual a explicação da seca registrada por Câmara Cascudo. Em 1898, por exemplo, surgia a notícia de uma "chuva de feijão, que deu tanto a

\footnotetext{
${ }^{19}$ Folha do Norte. Belém, 19 de janeiro de 1901, p. 2.

${ }^{20}$ Folha do Norte. Belém, 5 de abril de 1898, p. 1.
} 
falar na imprensa do norte”, mas que parecia ser conhecida de velhos moradores do sertão, conforme evidencia a Folha do Norte, ao contar a História de uma "grande chuva de feijão ao norte central do Ceará", que teria acontecido antes da "seca de 45". ${ }^{21}$

Dando conta da autenticidade do fenômeno tão inexplicável, o jornal República, do Ceará, lembrava que a informação chegara em sua redação através de um negociante, que escreveu ao periódico tão inusitada História, a qual lhe tinha sido narrada por uma senhora nascida em 1828 e que morava em sua casa. Das possíveis memórias narradas por dona Ignez da Conceição, surgiam os indícios da evocação de um sertão que se assemelhava ao deserto descrito na Bíblia, quando do envio do maná. Só que se o povo judeu pôde se alimentar desse "pão" enviado do céu, a sorte do sertanejo seria outra. Parecia que mesmo quando dos céus chovia feijão, o destino do sertanejo, ainda assim, seria o de passar fome, já que, segundo a narradora era impossível cozinhar este feijão.

"O feijão era bastante miúdo, de forma oval e de cor parda e vermelhada, que o vulgo chama rajado. Foi remetido do sertão uma porção dele a Joaquim Lopes, da Caminhadeira, que então morava na serra grande e este deu a diversas pessoas, dentre elas Domingos Cardoso, também morador na serra grande no sítio S. Miguel. Plantado este feijão, nasceu bem, porém produziu somente três folhas, a de mato-pasto em cada pé. Este feijão não cozinhava por mais que fosse ao fogo e o tempo que estivesse sob ele". ${ }^{22}$

Entendida como uma alusão à fome do sertanejo nos tempo das estiagens de chuva e à infertilidade do solo do sertão seco, a História da "chuva de feijão" parece reafirmar a peleja do sertanejo com a terra árida do sertão. Tal qual na lenda da seca, anotada por Câmara Cascudo, o sertanejo aparece como predestinado a sofrer nesse embate com uma natureza, que às vezes lhe permitia ver vingar, mas nem sempre colher e comer o fruto da sua plantação.

Essa referência a um cenário bíblico e à trajetória do povo judeu pelo deserto é uma metáfora recorrente na representação do sofrimento do sertanejo. Em 1916, a Folha do Norte, numa coluna intitulada "Ecos do Ceará", publicou um texto de Anna César, “distinta escritora patrícia”, que nesse ano havia presenciado um embarque de retirantes rumo a Belém. A figura de uma migrante no porto de Fortaleza aparecia no texto da escritora como

\footnotetext{
${ }^{21}$ Ibidem.

${ }^{22}$ Ibidem.
} 
uma "mulher bela e moça, olhos rasgados e chorosos, súplice implora clemência do alto, (...) Israelita infeliz, luta em vão para salvar o seu povo!”. ${ }^{23}$

Referências a elementos bíblicos também foram evocadas por Humberto de Campos, na crônica "Rosa de Jericó", em que narrou o envio, por Rodolpho Teophilo, ao Ministro da Viação de "um pequenino pedaço de planta seca, morta carbonizada”, a chamada "planta da Ressurreição". Esse nome derivava do poder de renascimento dessa planta, que logo que caía a primeira chuva, a "terra alcatifa-se de verde", como a Rosa de Jericó, flor que segundo o literato, depois da morte de Cristo, “desabrochou no instante mesmo da Ressurreição”. Depois da seca, verdadeiro calvário do sertanejo, a chuva chegava, trazendo a ressurreição da terra. Assim, em suas palavras, os fragmentos que faltavam para completar "a rosa encantada” apareciam em “outro deserto longínquo”, o Ceará. ${ }^{24}$

A luta do sertanejo para cuidar de sua família, levar adiante a sua plantação, sua espera pela chuva demarcavam a gravidade da seca, até esta parecer inevitável. Assim, por ocasião da seca de 1900, era na própria natureza do sertão que o governador Pedro Borges buscava caracterizar a seriedade da seca, dando conta de que, para o Estado, ela só se tornava evidente, e, portanto, um problema dos poderes públicos, quando no sertão se esgotavam todas as possibilidades de harmonia entre o homem e a natureza.

Essa desarmonia gerava uma série de problemas, que implicavam na ordem pública do próprio Estado. A “aglomeração dos retirantes”, que se deslocavam de seu lugar de origem rumo a Fortaleza; a ocupação no "campo do trabalho", o que concorreria, segundo Pedro Borges, para “o desenvolvimento da riqueza, do progresso e da civilização”; a preocupação com o estado sanitário da capital; os perigos de perturbação da saúde pública. Todas essas mazelas aliavam-se à tragédia da seca. ${ }^{25}$

\footnotetext{
${ }^{23}$ Folha do Norte. Belém, 28 de janeiro de 1916.

${ }^{24}$ CAMPOS, Humberto. "Rosa de Jericó”. In: Fatos e Feitos. Apresentação de Henrique de Campos. São Paulo: Gráfica Editora Brasileira LTDA, 1949. pp. 35-36.

${ }^{25}$ Mensagem apresentada à Assembléia Legislativa do Ceará em $1^{\circ}$ de julho de 1901 pelo Presidente do Estado Dr. Pedro Augusto Borges. Fortaleza: Typ. Econômica, 1901, p. 31. Sobre a seca e a cidade de Fortaleza, com problemas como higienização, saúde, disciplina ler: NEVES, Frederico de Castro. A multidão e a história: saques e outras ações de massas no Ceará; RIOS, Kênia Sousa. Campos de concentração no Ceará: isolamento e poder na seca de 1932; SOUZA, Simone de \& NEVES, Frederico de Castro (orgs.). Seca.
} 
Não sem razão, em 1900, o governador mostrava-se tão preocupado com o estado sanitário da capital, uma vez que a imprensa, entre os meses de agosto e setembro, dava conta da existência, na capital cearense, de casos suspeitos de peste bubônica, com o sugestivo título "A peste no Ceará". A cidade de Fortaleza é mostrada na Folha do Norte, em verdadeiro "pânico" diante do "desespero dos nossos irmãos do Ceará”, que além do flagelo da seca, pareciam ter que conviver com a ameaça dos ratos. ${ }^{26}$

Ao mesmo tempo em que publica a notícia da "peste" e da seca, a Folha do Norte descreve o Ceará como uma "grande terra, tão liberal e tão distinta pela sua História e pelos seus homens, quanto inditosa e desolada da Providência”. De outro lado, cria-se também, a imagem de um povo paraense solidário e preocupado com os destinos dos cearenses. Em agosto de 1900, “diante das tristes e alarmantes notícias que a imprensa publicou sobre a iminência da peste negra”, a Folha do Norte enaltecia "a alma paraense, tão ligada pelo sangue e pelos interesses recíprocos ao glorioso e infeliz Estado nortista”, a qual "não podia receber glacialmente a noticia de mais essa desventura que, à fome e à sede, se vem juntar". ${ }^{27}$

Em setembro de 1900, as notícias que chegavam dos jornais do Ceará, embora não confirmassem de fato a peste bubônica, "anunciavam ser o pior possível o estado sanitário de Fortaleza”. Na capital do Ceará, às epidemias, juntavam-se as vítimas da seca, "miseráveis retirantes esquálidos e andrajosos, famintos e sem abrigo, sem higiene e sem pão". 28

Numa cidade como Belém, que em 1900 vivia a efervescência dos negócios da borracha, além de se deparar constantemente com a chegada de grande número de cearenses para trabalharem nos seringais e na lavoura, essas impressões dão conta de criar uma imagem assustadora da cidade de Fortaleza, além, é claro, de manter no centro das discussões o grave problema da seca. A capital cearense era vista como um verdadeiro caos urbano, causado por problemas como as epidemias, “a falta de limpeza da cidade”, com os gêneros de primeira necessidade que "haviam subido excessivamente de preços", a exemplo do peixe. Segundo a imprensa, os problemas eram tantos que, em um pequeno texto intitulado "Os males do Ceará", descrevia-se, o estado sanitário do estado como "não menos terrível flagelo que a

\footnotetext{
${ }^{26}$ Folha do Norte. Belém, 30 de agosto de 1900, pp. 1-2.

${ }^{27}$ Folha do Norte. Belém, 31 de agosto de 1900, p. 1.

${ }^{28}$ Folha do Norte. Belém, 6 de setembro de 1900, p. 2.
} 
seca" ${ }^{29}$ Ao mesmo tempo que a imprensa paraense coloca em destaque os problemas urbanos de Fortaleza, em Belém, também a situação não é muito diferente, problemas de saneamento, de saúde pública são enfrentados diariamente pelos moradores dessa capital. As rimas de Telles de Meirelles, também publicadas na Folha do Norte expressavam um pouco disso:
"Higiene é letra morta;
limpeza pública ...um mito;
a peste bate à porta
e tudo corre bonito!
Quereis fortuna mais bela/
Temos tudo em profusão:
de um lado a febre amarela,
a bexiga, o sarampo;
doutro lado a falta d'água
para o consumo da gente,
que vê tristonha e com mágua,
as proezas do Intendente ...". ${ }^{30}$

Se essas imagens apresentadas na imprensa possivelmente deixavam os leitores da Folha do Norte perplexos, é possível também que permitissem a muitos segmentos da população paraense a representação do Pará como uma espécie de terra da promissão para os cearenses, que sofriam as agruras da seca, e até da peste bubônica. Exemplares nesse sentido foram as palavras do governador Paes de Carvalho, proferidas em sua Mensagem dirigida ao Congresso do Estado do Pará em fevereiro de 1901:

"Por uma coincidência feliz da natureza e como remédio ao devastador infortúnio, que aflige o Ceará, pôs a natureza em nossa região os grandes elementos que falham àquele populoso Estado nas suas tristes épocas de crises. Próximas uma da outra, as duas regiões se completam reciprocamente, dando, numa permuta generosa de vida e trabalho, de população e de riqueza". ${ }^{31}$

Voltando a 1900, no Ceará, aos poucos, ia-se desenhando o quadro da seca até sua concretização, sendo necessária, então, a ação do Estado. Dessa forma, em carta dirigida ao Presidente Campos Sales, visando à ajuda do governo federal para a crise que se instalava no Ceará com a seca, Pedro Borges assim descrevia de forma trágica o problema.

\footnotetext{
${ }^{29}$ Folha do Norte. Belém, 16 de outubro de 1900, p. 2.

${ }^{30}$ Folha do Norte. Belém, 5 de setembro de 1900, p. 2.

${ }^{31}$ Mensagem dirigida ao Congresso do Estado do Pará pelo Dr. José Paes de Carvalho Governador do Estado em 1 de fevereiro de 1901. Belém: Imprensa Oficial, 1901, p. 72.
} 
"Não tendo havido absolutamente inverno (apenas ligeiros aguaceiros) na estação de janeiro a
junho, perdida toda a esperança de colheita de cereais e legumes, não havendo depósitos
d'água no leito dos rios, secos ou pequenos açudes, cujo volume das águas desapareceu com
evaporação (...) esgotadas todas as reservas da provisão destinada à alimentação humana,
mormente de classes que vivem da pequena cultura, destruídos os recursos naturais e frutos
silvestres que na região sertaneja brotam do solo e servem como socorro de ocasião aos
desvalidos, falhando em suma tudo isso, o flagelo da seca não pode achar-se mais
caracterizado, ameaçando o Estado com perdas irreparáveis".

Semelhante era a descrição do jornal cearense República, transcrita pela Folha do Norte, em que a seca transforma a "natureza opulenta em queimada”, lugar de "pobreza farta" e onde “desalentados vão às profundezas das terras, aos 100 palmos arrancar água”. O sertão é visto como um "cemitério" de árvores, animais e "plantas a fenecer” e "o sol tinindo nas escarpas”. Apesar disso, um elemento, aqui, revela um outro lado do sertão, que também pode ter uma “natureza opulenta”. Essa expressão, aliada à informação de que até "remediados camponeses (...) que sempre tiveram cheios os celeiros" sofriam necessidades, num certo sentido, retira do sertão a noção de um espaço somente de morte e de desespero. Ao lado disso, na imprensa, também é possível captar o aspecto religioso que perpassa a experiência da seca, o que certamente dá ao flagelado uma condição mais humana, mais sensível.

Essa dimensão religiosa é recorrente na forma de se lidar com a seca, fosse acreditando nesse fenômeno como obra divina, fosse rogando aos céus para obter um alívio contra ela. Tal faceta religiosa não deixou de ser registrada pela imprensa: "Almas religiosas, cheias de unção e fé, voltam-se para Deus clamando remédio à nossa grande desgraça, tão grande que as nossas lágrimas secaram, como seca estão as correntes de nossos ribeirões". ${ }^{33}$ É um aspecto que, longe de ser entendido apenas como uma resignação diante do flagelo da seca, revela, também, uma sensibilidade dos grupos atingidos pela seca, que, comumente, apareciam reduzidos a uma imagem de "fome, sede e nudez".34

\footnotetext{
${ }^{32}$ Idem, p. 25.

${ }^{33}$ Folha do Norte. Belém, 18 de outubro de 1900, p. 1.

${ }^{34}$ Folha do Norte. Belém, 18 de novembro de 1900, p. 1. Críticas a essa imagem são pontuadas no trabalho de Marta Emisia Jacinto Barbosa, que partir de fotografias de "famintos do Ceará" busca entender os discursos na imprensa e a construção imagética dos flagelados pela seca, discutindo o modo homogenizante com que esses grupos são apresentados. BARBOSA, Marta Emísia Jacinto. Famintos do Ceará: imprensa e fotografia entre o final do século XIX e início do século XX. São Paulo: Tese de doutorado (História), Pontifícia Universidade Católica de São Paulo, 2004.
} 
Vários autores que se preocuparam em relatar práticas e costumes da população brasileira observaram muitas dessas práticas. Morais Filho (1843-1919) observou em alguns lugares da Província do Rio de Janeiro, no século XIX, “rogações para pedir chuva” Dessas procissões participavam as famílias do lugar com moças, meninas, velhos, crianças, escravos e livres, senhoras e "indivíduos votivamente maltrapilhos", que carregando "pequenas velas de cera", percorriam o caminhos cantando: "Rainha de eterna glória, Mãe de Deus, doce e clemente, Dai-nos água que nos molhe, Dai-nos pão que nos sustente”. ${ }^{35}$ Silvio Romero (1851-1914), que prefaciou o trabalho de Morais Filho, também não deixa de se referir no seu livro Cantos populares do Brasil, editado pela primeira vez em 1897, às procissões para pedir chuva. ${ }^{36}$ Do mesmo modo, Câmara Cascudo (1898-1986) no texto "Ad Petendam Pluviam" também faz referência a preces para pedir chuva, como os terços e as novenas, devoções muito praticadas por devotos “dispersos pelas fazendas e sítios” uma vez que não necessitam da presença de um padre para se realizarem. $\mathrm{O}$ autor apresenta como exemplo dessas práticas um canto ouvido em uma Fazenda no Rio Grande do Norte: "Maria, mãe dos que sofrem /Nosso clamor ouvi;/ À terra tão ressequida/ A chuva deixai cair!”.37

Vale lembrar que, de uma maneira geral, a própria historiografia também esquece de fazer referência a um sertão que não é só seca, às pessoas que não estão reduzidas somente à condição de famintos. Mas isto é assunto para mais adiante. Voltemos a falar da seca.

Não muito diferente, foram as percepções da seca de 1915. "Está no domínio de todos a desgraça que nos tocou este ano": com esta afirmação é que o governador do Ceará, Benjamin Liberato Barroso, iniciava sua descrição da seca. Tal qual o governador Pedro Borges, que insistia no significado "fatalista" que a seca tinha para a população do sertão, Liberato Barroso afirmava que, "avisado das secas e acostumado às suas agruras, o nosso povo não tem e não poderá ter tão cedo a previsão necessária para prevenir-se”. ${ }^{38}$

\footnotetext{
${ }^{35}$ MORAIS FILHO, Melo. Festas e Tradições Populares do Brasil. Brasília: Senado Federal, 2002.

${ }^{36}$ ROMERO, Sílvio. Folclore brasileiro: cantos populares do Brasil [1897]. Belo Horizonte: Itatiaia; São Paulo: EDUSP, 1985, p. 37.

${ }^{37}$ CASCUDO, Luis da Câmara. Superstição no Brasil. Belo Horizonte: Itatiaia; São Paulo: EDUSP, 1985, pp. 48-54.

${ }^{38}$ Mensagem dirigida à Assembléia Legislativa do Ceará em $1^{\circ}$ de julho de 1915 pelo Presidente do Estado Coronel Benjamin Liberato Barroso. Fortaleza: Typ. Moderna, 1915, p. 5.
} 
Por essa visão, era como se a seca fosse algo inerente à História do morador do sertão, que tinha como sina a ausência de água e as muitas conseqüências desse problema. Sendo assim, na visão do governador, a solução era bastante simples: “O mal está na falta d'água, façam grandes represas e tudo será sanado”. Essa solução tão simplista para tão grave problema também era fruto das críticas que o governador fazia ao que chamou de "teorismo sedutor $e$ fácil”, de “fantasia do domínio burocrático" de “teorismo doentio”, em detrimento de atitudes práticas, diante do problema da seca. Embora apresentando acirrada crítica às formas como no Ceará se conduzia o problema da seca, o próprio Liberato Barroso, como governador do estado, não deixava de fazer parte das práticas burocráticas que ele criticava. ${ }^{39}$

O coronel Benjamin Liberato Barroso foi o governador que sucedeu o interventor federal Setembrino de Carvalho em 1914, depois da grave crise política que levou em 1912 à renúncia do governador Antonio Accioly. ${ }^{40}$ Em função dos conflitos ocorridos em Fortaleza, que culminaram com aquela renúncia, Liberato Barroso demonstrava em seu relatório uma grande preocupação com a ordem pública na cidade, evocando os anos de Accioly no poder, quando, segundo sua visão "reinava o terror e paralisava-se o comércio". ${ }^{41}$ Assim, em sua mensagem de 1915, dirigida à Assembléia Legislativa do Ceará, em um item intitulado "Ordem Social", o governador enfatizava que o Estado ia atravessando um período de paz “altamente significativo". Afirmava ainda que "folgo de ver que a paz almejada se vai implantando, fundante, na consciência dos homens como uma necessidade essencial à ordem humana (...)" ${ }^{42}$ Como isto seria possível diante do quadro da seca, anteriormente descrito pelo próprio governador, considerando-se todos os problemas sociais decorrentes da fome e dos aglomerados de sertanejos na capital do Ceará?

\footnotetext{
${ }^{39}$ Mensagem dirigida à Assembléia Legislativa do Ceará em $1^{\circ}$ de julho de 1916 pelo Presidente do Estado Coronel Benjamin Liberato Barroso. Fortaleza, 1916, p. 11.

40 Sobre sedição de Juazeiro ler por exemplo: RAMOS, Francisco Régis Lopes. "Juazeiro e Caldeirão". In: SOUZA, Simone de (org.). Uma nova História do Ceará. $2^{\mathrm{a}}$ edição revista e atualizada. Fortaleza: Edições Demócrito Rocha, 2002. pp. 345-380; LOURENÇO FILHO, Joaseiro do Pe. Cícero. Scenas e quadros do fanatismo no nordeste. São Paulo: Melhoramentos, s/d.

${ }^{41}$ Mensagem dirigida à Assembléia Legislativa do Ceará em $1^{\circ}$ de julho de 1915 pelo Presidente do Estado Coronel Benjamin Liberato Barroso. Fortaleza: Typ. Moderna, 1915, p. 6.

${ }^{42}$ Mensagem dirigida à Assembléia Legislativa do Ceará em $1^{\circ}$ de julho de 1915 pelo Presidente do Estado Coronel Benjamin Liberato Barroso. Fortaleza: Typ. Moderna, 1915, p. 12.
} 
Significativamente, em um texto publicado na Folha do Norte em julho de 1915, Rodolpho Theophilo fazia uma análise bastante pessimista da crise que o Ceará atravessava com a seca, que, segundo ele, tinha "efeitos mais desastrados do que a de 1877”, visto que "naquele tempo a província tinha reservas acumuladas de trinta anos de invernos regulares”. Em 1915, o autor enfatizou uma série de problemas que tinham vindo piorar a situação do Estado. $^{43}$

Dentre esses problemas, citava as brigas políticas no Juazeiro, que não permitiram a plantação dos roçados, uma vez que "os lavradores abandonaram as suas lavras temendo o trabuco dos jagunços”. Ao lado disso, a "guerra da Europa”, impedindo o comércio de exportação. E, para completar esse quadro, um fato inusitado, o envolvimento da população com o jogo das "solidarísticas", sociedades mutuárias, em que "estelionatários ofereciam lucros fabulosos”. Nesse tipo de negócio, segundo Rodolpho Theophilo, uma “inscrição de dez mil réis dava quarenta mil réis no fim de trinta dias”. Essa possibilidade de lucro fácil gerou uma verdadeira "febre do jogo", fazendo com que as economias da população fossem empregadas nas “solidaristas”. Segundo Theophilo, “todos jogavam desde o proletário ao capitalista”. Para o autor, as dificuldades da seca de 1915 se concentravam na falta de reservas de produtos da lavoura e também numa escassez de dinheiro gerada pelas dificuldades de exportação, e até da perda do dinheiro da população envolvida em jogo. ${ }^{44}$

Nesse cenário de ausência de circulação de dinheiro, encontrava-se também o próprio Estado, que, pelo olhar de Rodolpho Theophilo, tinha "boas intenções” mas estava "sem um vintém nos cofres públicos”. Essa crise econômica, ainda segundo o artigo de Theophilo, se estendia ao governo da União, “tão pobre como o do Ceará”. Concordando com a idéia do "teorismo”, destacada pelo governador Liberato Barroso, Rodolpho Theophilo afirmava que o socorro da União só chegaria ao Ceará com “demora, como se a fome admitisse delongas

\footnotetext{
${ }^{43}$ Folha do Norte. Belém, 4 de julho de 1915, p. 1. Frederico de Castro Neves, analisando as origens da seca, mostra que com mudanças na estrutura produtiva cearense os problemas da seca se tornam maiores.As mudanças se tornam mais profundas por volta de 1877 com a importância comercial do algodão, que leva a uma utilização de grandes áreas de terra, fazendo com que "atividades de subsistência e de produção" cedessem lugar para uma "agricultura em grande escala, voltada para o mercado externo", modificando essa rede de dependência. Ao lado disso evidencia-se uma "mobilidade crescente da população camponesa em busca da proteção estatal nos espaço público da cidade, os períodos de escassez transformam-se em um problema social”. NEVES, Frederico de Castro. A multidão e a história: saques e outras ações de massas no Ceará, pp. 42-47.
}

${ }^{44}$ Folha do Norte. Belém, 4 de julho de 1915, p. 1. 
depois de muitas informações, muita papelada, depois que centenas de cearenses tiverem morrido de fome". 45

Com acirrada crítica à administração de Liberato Barroso, o literato Rocha Moreira, através da Folha do Norte, em Belém, escreveu alguns meses antes da análise de Rodolpho Theophilo, em fevereiro de 1915, pedindo ao governador que refletisse sobre o grave problema que "em futuro bem próximo" atingiria a "Terra das jandaias”. A seca dessa vez, como também viria a enfatizar Rodolpho Theophilo, encontraria "um povo faminto e os cofres vazios”. 46 Para Rocha Moreira, o que acontecia nesse momento, no Ceará, ainda era fruto da chamada sedição de Juazeiro, uma vez que quando a seca dava "trégua" para que o povo do sertão "progredisse e fosse venturoso", "veio a política", acabando com a "esperança de melhores dias". ${ }^{4}$

Rocha Moreira, escrevendo de Belém do Pará, mediante as notícias que recebia da "terra do sol”, cobrava os muitos gastos de Liberato Barroso. Como que antevendo o futuro, o literato lembrava que a "seca mirrará as árvores, sonegando aos retirantes a sombra”; mais grave que isso, porém, era o fato de que “a política devastou as searas, roubando ao homem o pão". 48

Dessa forma, Rocha Moreira era bastante enfático nas acusações que fazia ao governador, ao mesmo tempo em que construía dos retirantes cearenses a imagem de um grupo que poderia vir também a cobrar o descaso do Estado. Ao fazer isso, fica evidente que, como cearense que era, Rocha Moreira utilizava-se das páginas da Folha do Norte para manifestar sua melancolia em relação à população de sua terra natal, mas também para expor suas concepções políticas. Sua crônica, mesmo que nunca tenha deixado de expor uma imagem do cearense faminto, destacava a possibilidade dessa população pobre, atingida pela seca, vir a se rebelar, evidenciando assim a figura de um sertanejo que não era tão somente um resignado a sofrer.

"Não sabemos o que pensará ou fará um povo que tem fome, quando souber que os poderes públicos não têm dinheiro em custear o pão pedido por homens e crianças. Se tal acontecer, Oxalá que nenhum filho do povo se lembre de que a falta de pão e dinheiro, é o resultado da

\footnotetext{
${ }^{45}$ Ibidem.

${ }^{46}$ Folha do Norte. Belém, 24 de fevereiro de 1915, p. 1.

${ }^{47}$ Folha do Norte. Belém, 31 de janeiro de 1914, p. 1.

${ }^{48}$ Folha do Norte. Belém, 24 de fevereiro de 1915, p. 1.
} 
ganância de uma política bastarda que vem trabalhando para a infelicidade desse Estado de tradições gloriosas". ${ }^{49}$

Diante de todos esses problemas apontados por Rodolpho Theophilo e Rocha Moreira, voltemos ainda à Mensagem de Liberato Barroso, uma vez que sua fala, ironicamente, parece traduzir os anseios de muitos sertanejos atingidos pela ausência de chuva naquele fatídico 1915.

"Que importa, a nós, que a causa seja a vontade divina, as manchas do sol, o sopro constante dos Alísios, o paredão da Ibiapaba ou a abertura do canal do Panamá, desde que não dispomos de meios para evitá-los?". 50

Na medida em que a seca foi se intensificando em 1915, Rocha Moreira publicava, na Folha do Norte, crônicas e poesias cujo enfoque principal era a situação do Ceará e os sertanejos flagelados pela seca. $\mathrm{O}$ enredo desses seus textos era quase sempre o mesmo, como se essas partes fossem inseparáveis: o sertão; a seca; a migração; o descaso do governo; a saudade. Em uma dessas crônicas, por exemplo, como uma espécie de denúncia, ele afirmava: "Há uma raça que agoniza lá fora, sobre as estepes outrora verdes e hoje calcinadas do torrão natal: - é o povo cearense". 51

Considerando o cearense como uma "raça", o autor asseverava um caráter diferencial nessa população, demarcando a diferença sua e de seus conterrâneos, destacando uma identidade singular. Essa característica recorrente em suas crônicas e poesias era a obstinação desse povo de lutar para sobreviver, numa terra que muitas vezes se tornava infértil, e que, mesmo dali saindo, mantinha-se sempre ligado afetivamente a ela.

Empenhado em informar seus leitores, Rocha Moreira dizia ter entrevistado, em junho de 1915, um "paraense de 16 anos apenas" que chegara de Camocim, no vapor Paraíba. O rapaz, que era filho de cearenses e com parentes "remediados”, havia acompanhado a mãe em viagem ao Ceará e trazia de lá informações sobre a "miséria e a tristeza” que imperavam quando de sua partida. O moço relata a seu entrevistador as dificuldades enfrentadas "diante da falta d' água”, em que por volta de 3 e 4 horas da manhã, "mesmo os filhos de boas famílias partem comboiando jumentos, em busca d’água, num pequeno açude, a uma légua

\footnotetext{
${ }^{49}$ Idem.

${ }^{50}$ Mensagem dirigida à Assembléia Legislativa do Ceará em $1^{\circ}$ de julho de 1915 pelo Presidente do Estado Coronel Benjamin Liberato Barroso. Fortaleza: Typ. Moderna, 1915, p. 12.

${ }^{51}$ Folha do Norte. Belém, 6 de março de 1915, p. 1.
} 
de distância". ${ }^{52}$ Note-se que aqui percebemos um realce social marcado pela expressão filhos das “boas famílias”. Mesmo não sendo a intenção do entrevistado, ele acaba por evidenciar o fato de que os filhos das "más famílias", os grupos mais pobres que viviam no sertão já experimentavam habitualmente as agruras da busca de sobrevivência, até mesmo quando não tinha seca.

Apesar disso, o possível entrevistado do literato não deixava de apontar, para os leitores da Folha do Norte, as lembranças de sua chegada a Pedra Branca, quando no sertão "faziam-se roçados e árvores eram abatidas pelo machado”. Perguntado sobre as impressões que tinha da terra cearense, o rapaz respondeu com "as duas únicas que podia receber. Primeiro, a de encanto, depois a de desolação". 53

Ao manter contato com alguém que tinha vivido a tragédia da seca e publicar essas impressões naquele jornal, Rocha Moreira, como artifício da imprensa que se desenvolvia cada vez mais, dava ao fato apresentado status de veracidade por expor a opinião de quem tinha visto com seus próprios olhos a imagem da seca. Com a presença de muitos cearenses no Pará, com a chegada constante de flagelados ao porto da capital, trazendo informações sobre o sertão, não resta dúvida de que esse era um assunto que chamava atenção do público paraense.

\section{A chuva.}

Se na historiografia ou nos relatos sobre o Ceará o que prevalece é a representação de uma natureza castigada por constantes secas, um outro elemento importante nesse contexto, a antítese da seca, seria a chuva. Diante de uma História de secas, o fenômeno da chuva era tão importante para a vida da população cearense, a ponto de ser lembrado constantemente nas falas dos poderes públicos, que se preocupavam em demonstrar em seus relatórios anuais o "quadro das chuvas".

Ora, essa não era uma prática absurda, considerando que a ausência ou a presença de chuvas influenciava diretamente a produção agrícola e a pecuária do estado do Ceará e, conseqüentemente, a diminuição ou o aumento das rendas dos cofres públicos. Ao contrário

\footnotetext{
${ }^{52}$ Folha do Norte. Belém, 15 de junho de 1915, p. 1.

${ }^{53}$ Idem
} 
do Pará, em que muitas vezes, as chuvas eram associadas à insalubridade da região, no Ceará, ela era entendida como sinônimo de fartura e de possíveis progressos.

Dessa forma, no ano de 1893, em sua Mensagem, o governador fazia lembrar o fato de que o Ceará teve a "felicidade de ver caírem abundantes chuvas, indício certo de desenvolvimento e prosperidade da lavoura e poderosa indústria". 54

Dando continuidade à estação chuvosa, o ano de 1894 foi marcado, nas palavras do governador, pela "visita" de um "novo infortúnio": o inverno rigoroso. Diferentemente dos demais anos secos, a chuva em abundância, fenômeno pouco comum na região, causara severos problemas à lavoura e à criação de gado, arrastando inclusive casas e açudes. Afirmava o governador que "o mal que veio piorar as dificílimas condições de nosso viver, nasce de um excesso de chuvas do mais copioso inverno que talvez o Ceará tenha visto neste século". 55

Depois da grande estiagem dos anos de 1888 e 1889, vários anos da década de 1890, ao contrário de períodos de seca, foram marcados por invernos prolongados, a ponto de, em 1897, o Estado necessitar prestar auxílios para a cultura do algodão, prejudicada por

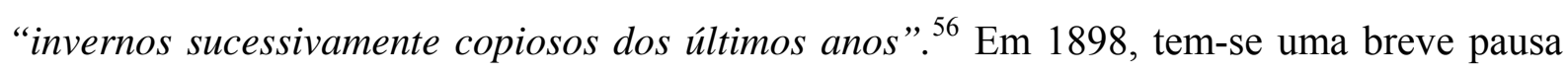
nas chuvas, o que logo se reflete na agricultura. Nesse ano, a estação invernosa durou "pouco mais de dois meses quando nos anos ordinários ela se dilata por cinco e seis”. Tal quadro de ausência de chuvas era apontado como a causa para a minguada produção de cereais daquele ano, que, segundo o governador, “apareceram nas feiras de maio, já em junho desaparecerá para dar lugar a importação de cereais de outros estados". ${ }^{57}$ A chuva, nesse contexto, acaba sendo um elemento fundamental tanto para a economia de subsistência como para a de maior escala.

\footnotetext{
${ }^{54}$ Mensagem do Presidente do Estado Tenente Coronel Dr. José Freire Bezerril Fontenelle à Assembléia Legislativa do Ceará em sua $2^{\mathrm{a}}$ sessão ordinária da $1^{\mathrm{a}}$ Legislatura. Fortaleza: Typ da República, 1893, p. 14.

${ }^{55}$ Mensagem do Presidente do Estado Coronel Dr. José Freire Bezerril Fontenelle à Assembléia Legislativa do Ceará em sua $3^{\mathrm{a}}$ sessão ordinária da $2^{\mathrm{a}}$ Legislatura. Fortaleza: Typ. d'A Republica, 1894, p. 6.

${ }^{56}$ Mensagem apresentada à Assembléia Legislativa do Ceará. Pelo Presidente do Estado Dr. Antonio Pinto Nogueira Accioly em $1^{\circ}$ de julho de 1897. Fortaleza: Typ. d'A República, 1897, p. 27.

${ }^{57}$ Mensagem apresentada à Assembléia Legislativa do Ceará pelo presidente do Estado Dr. Antonio Pinto Nogueira Accioly em 4 de julho de 1898. Fortaleza: Typographia Econômica, 1898, p. 28.
} 
Continuando uma incursão pelo “quadro das chuvas”, em 1899, tem-se no Ceará o que o governador chamou de "o inverno mais copioso que registra o século". Tão grandioso foi que seus efeitos tornaram-se prejudiciais à agricultura e à indústria pastoril. A lembrança desse inverno era bastante viva no ano de 1900, em que alimentava-se "a doce esperança de próxima manifestação de inverno”, o que não aconteceu, “perdendo-se por completo as plantações de cereais que iam sendo feitas ante aqueles animadores incentivos”. Assim, o ano de 1900, ao contrário do anterior, se caracterizou por uma falta de chuva geral em "todos os municípios". 58

Diante da seca de 1900, era com esperança que se aguardava o inverno de 1901. Essa espera da chuva se tornava maior à medida que a seca aguçava-se e que também a própria natureza dava sinais de possíveis chuvas. Em novembro de 1901, a Folha do Norte anunciava que "o povo cearense estava muito animado pela chuva de estrelas (...) por julgar ser sinal evidente de próximo inverno. Observam-se contínuos relâmpagos". 59

Evocando essas mesmas tradições populares, lembrava o governador Pedro Borges que “o equinócio de março [era] o prazo fatal, assinado, por decisiva experiência para a renovação do inverno". Por fim, "os primeiros albores de esperança” surgiram com as chuvas de dezembro, com escassas chuvas em janeiro, e finalmente com a "entrada franca" do inverno em fevereiro. ${ }^{60}$ Dentre a experiências para se saber sobre a chegada das chuvas, Silvio Romero refere-se à "prova de Santa Luzia, que consiste em colocar-se um bocado de sal em uma vasilha, na véspera do dia da santa, em lugar enxuto e coberto. Se o sal amanhecer molhado, choverá, ao contrário não" Ainda segundo esse autor, conta-se que no Ceará, o naturalista George Gardner, contrapondo suas observações meteorológicas às atestadas na tradição de Santa Luzia, “em português atravessado" teria dito: "Non, non, Luzi mentiu”. ${ }^{61}$ A essa experiência de Santa Luzia, Câmara Cascudo também dedica algumas páginas do seu

\footnotetext{
${ }^{58}$ Mensagem apresentada a Assembléia Legislativa do Ceará pelo Presidente do Estado Exmo. Sr. Dr. Antonio Pinto Nogueira Accioly em $1^{\circ}$ de julho de 1900. Fortaleza: Typ. D’A Republica, 1900, p. 18.

${ }^{59}$ Folha do Norte.Belém, 24 de novembro de 1900, p. 1.

${ }^{60}$ Mensagem apresentada à Assembléia Legislativa do Ceará em $1^{\circ}$ de julho de 1901 pelo Presidente do Estado Dr. Pedro Augusto Borges. Fortaleza: Typ. Econômica, 1901, p. 22.

${ }^{61}$ ROMERO. Sílvio. Folclore brasileiro: cantos populares do Brasil, p. 37.
} 
Superstições no Brasil, afirmando que “De Pernambuco ao Piauí, pelo interior a Experiência de Santa Luzia reaparece em dezembro em centenas e centenas de provas teimosas”. ${ }^{2}$

Se a chegada da seca muitas vezes era entendida como um desígnio de Deus, como espécie de "vingança" divina, o início da chuva também era visto como um presente de Deus, que se “apiedou” do sertanejo diante de tantos infortúnios. Em uma possível carta enviada do Ceará a um “cavalheiro residente em Manaus”, publicada nessa cidade e transcrita depois pela Folha do Norte, podemos perceber essa dimensão religiosa na maneira de se entender a chuva e a seca. Embora não fique claro quem escreveu tal carta, nem se de fato tratava-se de uma carta, podendo ser um artifício do próprio jornal para dar mais veracidade à notícia - como já se evidenciou anteriormente -, o texto aponta para o fato de que as relações que os moradores do sertão estabeleciam com a seca eram muito maiores do que apenas a idéia de um povo faminto, cuja única atenção estava voltada para a comida.

É óbvio, que diante da fome e da sede, a luta era pela sobrevivência e pela busca desses elementos vitais, mas isso não quer dizer que se perdia o sentimento de religiosidade. Pelo contrário, diante da fé cristã, em que o sofrimento leva à salvação, nos tempos de dificuldades, a religiosidade podia se mostrar até mais intensa. Vejamos trechos da carta publicada na Folha do Norte.

“O Deus de infinita bondade se apiedou, afinal de nossas desgraças. Graças a Ele tem chovido torrencialmente em todo Estado, segundo cartas e telegramas procedentes de todos os ângulos de nossa boa e infeliz terra.

Do Crato, Quixadá, Barbalha, Araripe, Assaré, Inhamuns, Carateú, Ipú, Sobral, Tamboril, Acaraú, Camocim, Itapipoca, Quixaramobim, Igatú, Jaguaribe Mirin, Icó, [Ramas], Aracaty, Cascavel, Aquiraz, Pacatuba, Maranguape, etc... vêm-nos notícias de chuvas torrenciais.

Nunca houve chuva tão a tempo, porque todas as vidas, desde a árvore ao homem estavam para morrer de uma só vez.

Só Deus nos podia acudir neste extremo desespero, pois o governo nos desprezou redondamente. (...)

A Caridade pública está esgotada, o comércio arrebentado, porém o Ceará, tendo chuva, jamais se aniquilará". ${ }^{63}$

${ }^{62}$ CASCUDO, Luis da Câmara. Superstição no Brasil, p. 55. Itamar de Souza e João Medeiros que entrevistaram "camponeses de várias regiões do sertão nordestino" também colheram várias experiências sobre previsões de chuva e da seca, que podem ser lidas no capítulo "A natureza e o saber popular". Cf. SOUZA, Itamar de \& MEDEIROS FILHO, João. Os degredados filhos da seca, pp. 4050.

${ }^{63}$ Folha do Norte. Belém, 10 de janeiro de 1901, p. 2. 
Mas não era só com orações pedindo e agradecendo a chuva que esse sentimento de religiosidade se mantinha em evidência. $\mathrm{O}$ batismo das crianças era algo que se preservava, apesar de todas as dificuldades. Em um trecho da referida carta, o escritor, ao criticar ações da Igreja, em 1901, no Ceará, revela, para o leitor de hoje, práticas da religiosidade popular. A Igreja "nem ao menos ordenou preces a Deus como era de costume fazê-lo em outros tempos flagelados. (...) Batizam um menino magro de fome, pelo mesmo preço que batizam os gordos em tempo de fartura". ${ }^{64} \mathrm{O}$ principal entendimento que temos dessas práticas é justamente essa dimensão de sensibilidade que, apesar da tragédia da seca, o sertanejo buscava manter, e a insistência no tema é fruto de uma historiografia, como evidenciamos no capítulo anterior, que, quase sempre, apresenta um sertanejo cuja vida se resume à busca por água e comida.

Nesse espaço de seca, que obrigava o sertanejo a sair do sertão e se refugiar em Fortaleza, em localidades do litoral ou em cidades mais importantes, as manifestações de chuva eram sinal de que o flagelo da seca estava terminando e que, portanto, para o sertanejo, era hora de retornar a seu lugar de origem. O governador Pedro Borges, afirmava que os flagelados haviam sido os primeiros a "mover-se no intuito de voltar a seus lares (...) em busca dos trabalhos da lavoura". ${ }^{65}$ Isto não significava, entretanto, que, imediatamente à chuva, a fome deixasse de existir e os problemas estivessem solucionados. Em janeiro de 1901, por exemplo, a Folha do Norte lembrava a seus leitores paraenses que "chuva, já há bastante no sertão, e a emigração paralisa um pouco. Entretanto a fome continuava a fazer vítimas, porque impossível era ainda obter meios de assistência". 66

Continuando suas informações sobre a chuva, o governador lembrava que, por volta de abril, em Fortaleza, “toda a população adventícia (...) já havia regressado aos seus lares”. ${ }^{67}$ Esse retorno do sertanejo a seu lugar de origem, quando da chegada da chuva, é recorrente nas narrativas sobre a seca. Pois se, de um lado, a fome e a sede obrigavam à saída do sertão, de outro, a chegada da chuva era fundamental para o retorno. Nesse sentido, ao se falar de seca e de saída do sertão, falava-se também na esperança de chuva e no retorno certo do sertanejo.

\footnotetext{
${ }^{64} \mathrm{Idem}$

${ }^{65}$ Idem, pp. 46-47.

${ }^{66}$ Folha do Norte. Belém, 19 de janeiro de 1901, p. 2.

${ }^{67}$ Idem, p. 47.
} 
Dada a sua importância, a chuva, sua ausência ou sua lembrança continuavam presentes nos registros do poder público. Em 1905, diante de chuvas muito espaçadas, entre março e junho, o governador Antônio Accyoli fazia um balanço das chuvas dos últimos anos, e trazia à memória o famoso inverno de 1899.

"Salvo a trégua de 1899, de inverno copioso não mais voltaram os anos de abundância pluvial, ficando os que decorrem de 1898 a 1902 aquém da média geral resultante dos 60 anos de observações pluviométricas". ${ }^{6}{ }^{8}$

Seguindo provavelmente a tradição dos agricultores do sertão, Antonio Accioly lembrava que, para serem proveitosos, os invernos "não devem vir depois do equinócio de março, nem se prolongar além de junho”. Enfatizava ainda que mudança nesse calendário de chuvas, “quando se frustram os prenúncios de janeiro ou os do equinócio de março”, já começavam a gerar desânimo no agricultor, dado o temor de uma nova seca. ${ }^{69}$

Entretanto, como os demais governadores e como, certamente, para boa parte da população, a presença da chuva vinha carregada da idéia de que se resolveriam todos os problemas, tanto de produção como até da ordem pública. A chuva, num certo sentido, era a presença certa do sertanejo em seu lugar de origem, e não nas ruas de Fortaleza, vivendo da esmola pública ou dos favores do Estado, e não vivendo como migrante em outros estados, diminuindo assim a mão de obra do Ceará. Por esse motivo, em 1906, Antonio Accioly afirmava que, quando chovia com "certa regularidade", permitindo a "fecundidade do solo", normalizava-se a "vida econômica", ao mesmo tempo em que se garantia a "subsistência dos que vão pedi-la às justas compensações do trabalho honesto e produtor". ${ }^{70}$

Por essa perspectiva, apontada por Antonio Accioly, bem como em outros pronunciamentos oficiais, parece-nos que, mais do que um fenômeno da natureza, inerente à vida dos moradores do sertão e de Fortaleza, a chuva passava a ser encarada como um elemento natural fundamental, também, para a manutenção da ordem, da disciplina, da saúde e da higiene, problemas tão caros aos administradores do início do século XX, empenhados na civilização dos trópicos.

\footnotetext{
${ }^{68}$ Mensagem dirigida à Assembléia Legislativa do Ceará em $1^{\circ}$ de julho de 1905 pelo Presidente do Estado Dr. Antonio Pinto Nogueira Accioly. Fortaleza: Typo - Litographia a Vapor, 1905, p. 42.

${ }^{69}$ Idem, p. 42.

${ }^{70}$ Mensagem dirigida à Assembléia Legislativa do Ceará em $1^{\circ}$ de julho de 1906 pelo Presidente do Estado Dr. Antonio Pinto Nogueira Accioly. Fortaleza: Typo - Litographia a Vapor, 1906, p. 22.
} 
Não sem razão, nas "Notícias cearenses", que a Folha do Norte publicava em 1910, ficava evidente a importância da chuva para a ordem social, para colocar em evidência (tal qual no tempo da seca) determinadas práticas religiosas, como as ofertas aos “santos”, o que ocorria provavelmente para agradecer o tempo de fartura. Aliada ao inverno, a circulação de dinheiro ganho com o trabalho na Amazônia parecia compor um cenário de certa estabilidade no Ceará, antes da grande crise política e econômica que viria a se instalar entre 1914 e 1915, tendo ao lado a seca. Em 1910, as notícias da chuva eram alvissareiras.

"O inverno tem sido esplêndido, quer no norte, quer no sul do Estado. Água muita por toda parte, desodeniando o velho Ceará. As esperanças cantam em todos os corações e o cobre que nos tem vindo da Amazônia, vai servindo largamente para auxiliar o contentamento. Os santos então, têm sido fartamente festejados e obsequiados e a padralhada vai enchendo o bandulho. (Ave, Inverno!)" ${ }^{71}$

1915, no entanto, foi um ano marcado por apenas alguns dias de esperança de chuva, que de acordo com o governador Benjamin Barroso - duraram "pouco tempo", desmoronando, assim, "tão caras ilusões”. Esse ano, para além de toda a tragédia da seca, trazia consigo, também, semelhante ao que acontecia nos demais anos secos, a certeza de que, com a chegada da chuva, os problemas seriam minorados, tanto no sertão como em Fortaleza.

Ora, se a ausência de chuva era motivo de desilusões para o sertanejo, além de significar problemas para ordem pública, por mais longa que fosse a sua ausência, sabia-se que ao primeiro sinal de inverno, o sertanejo começaria a pensar no caminho de volta para o sertão.

Assim, o governador Benjamin Barroso, em 1915, escrevia, num momento de intensa seca, que

"Expatriam-se uns, morrem outros de fome, de miséria e de peste, mas logo que se desata o inverno sobre o solo querido, os cearenses esquecem a inclemência do nosso céu, perdoam-lhe os seus procedimentos, enxugam as lágrimas, transformando-os em gotas de suor benfazejo do trabalho". ${ }^{72}$

Por essa compreensão de Barroso - também presente numa variedade de textos elaborados pelo poder público, a exemplo dos Relatórios e Mensagens, ou por literatos, como Rocha Moreira -, construía-se uma imagem do sertanejo como aquele que estava sempre disposto a recomeçar a vida no sertão, como aquele que se ufanava de sua terra com chuva, que lhe

\footnotetext{
${ }^{71}$ Folha do Norte. Belém, 6 de abril de 1910, p. 1.

${ }^{72}$ Mensagem dirigida à Assembléia Legislativa do Ceará em $1^{\circ}$ de julho de 1915 pelo Presidente do Estado Coronel Benjamin Liberato Barroso. Fortaleza: Typ. Moderna, 1915, p. 6.
} 
permitia trabalhar, divertir-se, cuidar da família. Essa idéia do retorno para o sertão, do retorno para a terra natal parece ser marcante na representação do migrante cearense, quando distante de seu mundo de origem. Nesse sentido, vale uma incursão pelas imagens construídas sobre o sertão em tempo de chuva.

\section{O sertão}

"Sou cearense e me ufano!

Pertenço a hoste aguerrida, Sempre em luta pela vida, Que não sabe recuar!

Minha terra, - é mãe fecunda, Que tem filhos por milhares, Que se espalham, n'outros lares, Num continuo viajar! Entretanto, quem não sabe? Possui montanhas verde rosas, Onde as plantas são viçosas, Onde o fruto alastra o chão;

(...)

Mas, o destino a persegue!

Quando chove, - é o paraíso (...)

(...)

Por todo o planeta vão!

Mas, lidando, em qualquer parte,

Seu ligeiro pensamento

Não abandona um momento o seu querido torrão!" ${ }^{73}$

Os versos acima, escritos por Juvenal Galeno em 1904, expressam o problema da saída dos cearenses nos períodos de seca, e ao mesmo tempo, a ligação afetiva que o sertanejo mantinha com "seu querido torrão". Esse aspecto, na verdade, está presente quando se fala do retirante da seca. Entretanto, dos versos de Galeno, surge a imagem de uma sertão que "quando chove é o paraíso". Essa sim é uma imagem pouco recorrente para representar o sertão, que quase sempre, na antítese do paraíso, é um inferno com sol escaldante.

\footnotetext{
${ }^{73}$ Almanach Administrativo, Estatístico, Industrial e Literário do Estado do Ceará para o ano de 1905, confeccionado por João da Camara. Ano 11․ Fortaleza: Empreza Tipographica, 1904, p. 140-141. O verso "sou cearense e me ufano" aparece em outro contexto também, em que Juvenal Galeno, não fala dos retirantes da seca, mas de acontecimentos e pessoas do Ceará, como o pioneirismo em libertar seus escravos, do orgulho dos romances de José de Alencar, por tudo isso afirma "Sou cearense, e a minha glória é sem par!”. GIRÃO Raimundo \& MARTINS FILHO, Antonio. O Ceará, p. 130.
} 
O sertão descrito por Galeno, além da seca, é também uma terra representada como "mãe fecunda”. Essa fertilidade da terra é descrita ainda a partir de uma natureza que, pelo olhar do poeta, tem até “montanhas verde rosas”. Embora o autor apresente como único problema do sertão a seca, construindo assim uma imagem idealizada desse espaço nos tempos de chuva, sua representação idílica e ufanista permite entrever um espaço cuja vida surge em profusão, através da natureza.

Semelhante idealização, encontramos também pela pena de Alípio Bandeira, poeta do Rio Grande do Norte, numa série de poesias publicadas em 1915, em plena seca, pela Folha do Norte. ${ }^{74}$ Ironicamente, as mesmas páginas da imprensa, que traziam o trágico episódio da seca, em que homens e animais morriam, revelavam também cenas de uma feliz vida campestre no sertão, que, pelo olhar do poeta, ganhava ares arcádicos.

A poesia "Na roça", escrita em primeira pessoa, como se o poeta, ou um sertanejo, experimentassem esse paraíso, é modelar nesse sentido. Belezas naturais, tranqüilidade, água para beber e comida completam o quadro da cena da poesia de Alípio Bandeira, que poderia até confundir um leitor desavisado, levando-o a pensar se tratar de outro espaço, e não do sertão do meio-norte, sempre tão decantado em suas misérias.

"Oh, que paz encontrei neste recanto!

Como agora os pulmões respiram bem

Nesta vida campestre cujo encanto

A cidade não tem!

(...)

Quanta força do sol a terra escalda

E a serra toma ao longe a cor do anil

(...)

Depois, fechada a noite, a sericóia

salta de vez em quando a voz loquaz,

Armo no alpendre, então, minha tipóia

Eis o silêncio e a paz.

Tenho em casa a borracha de água pura

Pederneira e farnel no matolão

Lá fora, a livre aragem da planura

E o cheiro do sertão" ${ }^{75}$

\footnotetext{
${ }^{74}$ Alípio Bandeira nasceu em Mossoró (Rio Grande do Norte), em 1873. Estudou na Escola Militar do Ceará em 1890. Em 1913, tornou-se "capitão graduado e depois efetivo". Foi agrimensor, trabalhou na "catequese dos índios como auxiliar do coronel Candido Mariano Rondon". WANDERLEY, Ezequiel. Poetas do Rio Grande do Norte. Recife: Imprensa Industrial, 1922, p. 99.

${ }^{75}$ Folha do Norte. Belém, 31 de janeiro de 1915, p. 1.
} 
Essa poesia também pode ser aproximada das análises de Raymond Williams, sobre o campo e a cidade. Dentre as interpretações desse autor, a idéia de que "o campo e a cidade são realidades históricas em transformação tanto entre si próprias quanto em suas interrelações” sugerem, no campo desta pesquisa, o constante dinamismo nas representações sobre o sertão em tempo de seca ou de inverno. Outra indicação importante desse autor, possível de ser percebida também em poesias sobre o sertão, é a questão da "inocência bucólica", que não pode ser apreendida apenas como formas que "representem meras ilusões”, sendo necessário ao historiador formular perguntas acerca do tipo de experiência que essas idéias parecem interpretar. Um bom caminho para isso seria o de se "levantar, histórica e criticamente, as diversas formas assumidas pelas idéias ". ${ }^{76}$

Trazendo essas reflexões para o entendimento do sertão, não há dúvida de que essa “inocência bucólica”, presente em algumas poesias, pode ser pensada como uma resposta aos sofrimentos da seca, inerentes à vida do sertão, ou, quem sabe até, à certeza do poeta de que o sertão era muito mais que secas.

Em outra poesia de Alípio Bandeira, intitulada "O vaqueiro", temos a figura destemida do sertanejo que, também na primeira pessoa, vai mostrando os seus atributos de coragem. Enfaticamente, o poeta afirma:
"Não tremo, não corro, da sorte que vem, de susto não morro nem vivo também; a vida mais forte fenece que é sorte, das malhas da morte não sobra ninguém”. ${ }^{77}$

O trecho evoca ritmos e rimas de Gonçalves Dias (I-Juca Pirama), e, através deles noções de heroísmo, grandiosidade. Além disso, desses versos, surgem elementos que revelam a importância da família, da casa, do trabalho na pecuária, e ao lado disso, do aconchego que tais elementos trazem, dando conta de um cotidiano com diversão, descanso e comida que são construídos pela determinação e coragem do sertanejo.

\footnotetext{
${ }^{76}$ WILLIAMS, Raymond. O campo e a cidade, pp. 387-388.

${ }^{77}$ Folha do Norte. Belém, 12 de fevereiro de 1915, p. 1.
} 
Por essa representação, fica muito presente a sensibilidade do homem do sertão. Ele, que se alegra com sua "choupana”, sua viola sua mulher e seus filhos. Diante de tudo isso, o poeta é enfático na síntese da felicidade, quando interroga: “Que mais quererei?”

"Na minha choupana

Que eu mesmo entaipei,

Meus filhos mais Anna

Contentes deixei,

Viola afinada.

Tipóia laçada,

Na ceia coalhada

Que mais quererei?”

Na poesia “A apartação”, mais uma vez, Alípio Bandeira recupera a temática do cotidiano do vaqueiro, quando se refere a um "pitoresco arraial” organizado para a troca, identificação e comercialização de gado. Segundo Câmara Cascudo, "criado em comum nos campos indivisos, o gado" nos anos de inverno em junho o gado era "tocado para grandes currais" das maiores fazendas onde era feita a "apartação", que consistia na identificação do gado de cada patrão dos vaqueiros presentes. Nesses momentos a “ausência de divertimentos”, segundo o autor era marcada por "um jantar sem fim, farto e pesado”, sempre com a presença de “um ou dois cantadores para 'divertir' (...) cantava-se a desafio até madrugada”. ${ }^{78}$ Nesse contexto, elementos semelhantes ao quadro anterior, descrito por Alípio Bandeira, completam a imagem do sertão e do sertanejo, que aqui surge quando pelo olhar do poeta "mal reina a luz do sol” em porte altivo, garboso, “lesto”, “destemido”, em seu traje de vaqueiro "de luvas de chapéu, gibão, perneiras, tudo de brando couro bem curtido”, muito diferente da imagem dos homens andrajosos, esqueléticos, famintos com que nos acostumamos a ver o sertanejo. Nessa “aldeia singular”, a noite não é marcada pela tristeza. Em seus versos, Alípio Bandeira vai revelando ao leitor toda a animação do que ele poeticamente chamou de "festa no trabalho":

\footnotetext{
${ }^{78}$ CASCUDO. Luis da Câmara. Vaqueiros e cantadores. Belo Horizonte: Itatiaia, São Paulo: EDUSP, 1984, pp. 106-107.
} 
"Em torno do curral que à revelia

O gado ajunta e prende,

A aldeia singular da Companhia

Pelo campo se estende

(...)

Pitoresco arraial que uma semana

O sertão, de alegria retempera

(...)

A noite é da folgança: os trovadores

$\mathrm{Na}$ viola sutil que geme e ofega

Cantam lendas, canções, trovas de amores

E o desafio sem demora pega.

Uns ao samba vão ter, outros preferem

Casos de assombração a [ouvir] atentos

Que os velhos de pavor nada referem

Baixando a voz, medindo os gestos lentos.

E a saudável coalhada que ao sereno

Melhor sabor alcança. (...)". ${ }^{79}$

A poesia de Alípio Bandeira destaca a figura de um sertanejo que tem uma experiência social bastante dinâmica, delineada num cotidiano do qual fazem parte as árvores, as novenas, as festas, os animais domésticos, a família, a alegria de viver, como já evidenciamos, bastante inversa, portanto, à imagem de um homem vencido pela seca. De qualquer modo, o poeta não deixou de asseverar em sua poesia a luta pela sobrevivência e as contradições desse processo, que é muito mais complexo do que a redução da vida do sertanejo à simples imagem de um pobre sofredor, lutando tão somente em busca de água e comida. Em versos do "Prelúdio", do seu "Sertaneja", descreve:

“(...) A gente rude e sã que canta e chora,

Mas nunca desespera;

a vida do sertão onde a tristeza

tantas vezes suplanta o doce encanto,

onde sofre onde luta a natureza ...”. ${ }^{80}$

Também publicados na Folha do Norte, entre 1914 e 1916, temos os textos de Rocha Moreira. Como vimos anteriormente, a prosa desse autor, além de representar o povo do

\footnotetext{
${ }^{79}$ Folha do Norte. Belém, 17 de fevereiro de 1915, p. 1.

${ }^{80}$ Folha do Norte. Belém, 16 de janeiro de 1915, p. 1.
} 
sertão no tempo da seca, empenha-se em traçar uma identidade do cearense, alguém que, mesmo distante, mantinha um "grande amor devotado a terra de seu berço" ${ }^{81}$

$\mathrm{Na}$ representação desse vínculo, temos uma natureza sertaneja que não é apenas seca e árida, mas que, com o trabalho, produz. Em 1914, com os muitos problemas da sedição de Juazeiro, o autor, que sempre se mostrou bastante crítico das ações que envolviam o padre Cícero, referia-se aos campos de Igatu, alertando que a "paz deve de novo voltar". Nesse seu alerta, evidencia-se um sertão de “dias venturosos”. Além disso, os conflitos deveriam terminar para que o "lavrador cearense" pudesse novamente "sachar as suas terras, para que a sementeira do Trabalho floresça e frutifique em vicejante eclosão”, ${ }^{82}$

O sertão descrito por Rocha Moreira, tal qual as imagens de Alípio Bandeira, traz à tona os dias de festa. Embora aqui não fique certo se o autor se refere a uma festa no sertão, sua sensibilidade em narrar o folguedo junino dá conta de expressar com sutileza o desenrolar de uma noite de festa. Aliás, os santos juninos, tão presentes na tradição nordestina, não deixam de ser festejados mesmo quando o cearense se encontra distante de seu lugar de origem.

Trata-se aqui de destacar uma representação do sertão, que quase sempre escapa à historiografia ocupada em estudar as migrações, ou seja, o sertão como um espaço de múltiplas experiências em função das relações estabelecidas entre essa natureza e seus moradores. Reforço, portanto, e mais uma vez, a visibilidade de uma variedade de práticas sociais, que, sem dúvida, acompanhavam os migrantes que aportavam em Belém. Assim, na véspera do dia de São João, do ano de 1914, a Folha do Norte trazia estampada, em sua primeira página, a poesia de Rocha Moreira, intitulada "São João", alvo da nostalgia do autor em relação a sua terra natal.

“Na noite de São João Baptista

Quem a que mudo resista

Ao prazer na minha aldeia?

(...)

Não há orquestra na sala,

O champagne não estala,

E etiqueta ali não há

Basta uma simples viola

(...)

\footnotetext{
${ }^{81}$ Folha do Norte. Belém, 31 de janeiro de 1914, p. 1.

${ }^{82}$ Folha do Norte. Belém, 27 de fevereiro de 1914, p. 1.
} 
E dois barris de aluá

(...)

Mas de repente, um matuto,

De modo gracioso e abrupto

Entra na sala a falar

E diz, num contentamento:

Seu major, traga o instrumento,

Que eu faço o povo dançar.

(...)

um velho sertanejo

Diz às moças um gracejo

(...)

De repente, resoluto

Para o instrumento o matuto,

Que muito cansado está:

E o velhote sertanejo,

Por entre um fino gracejo

Pede um copo de aluá". ${ }^{83}$

A partir de outra poesia de Rocha Moreira, "Vida sertaneja", de 1914, a natureza do sertão, mais uma vez, aparece grafada com um espaço de tranqüilidade. É como se o autor, diante da crise política experimentada naquele momento no Ceará, da qual ele foi grande crítico, quisesse reafirmar uma imagem positiva de sua terra natal. Nessa composição, as belezas naturais - com um sol que aqui não é visto como um castigo, mas como beleza, "que pela manhã desata", trazendo o canto arrebatador do "sonhassú", que enchia "de encanto a selva benfazeja” -, aliadas às noites de folguedo, ganhavam destaque, dando a tônica desse espaço:

"Quase ao sopé da serra, em meio à mata

Em que o vistoso jatobá verdeja

Esprende à frente da ideal cascata

Entre cabanas a pequena igreja

(...)

E assim o dia vai passando, passa

A tarde, e quando a noite vem chegando

$E$ no alto o vento as nuvens adelgaça

Surgem campônios de viola ao peito.

Um dançando o bahiano, outro cantando

E outro, falando e rindo satisfeito". ${ }^{84}$

\footnotetext{
${ }^{83}$ Folha do Norte. Belém, 23 de junho de 1914, p. 1.
} 
Alguns meses depois, diante da iminente seca de 1915, em fevereiro desse ano, a Folha do Norte trazia aos seus leitores a prosa de Rocha Moreira, "Miséria cearense". Embora ganhando outro tom, quando exclamava: "a desdita baixou, mais uma vez, sobre os sertões cearenses!", como antítese do que chamou "triste nova da seca", ainda deixava entrever memória de um sertão onde "fartura resplendia". ${ }^{85}$

Num certo sentido, parecia até que o autor como que entendia a presença da seca, pois afirmava que, embora sabendo que "os filhos do sol, não podem mais, por algum tempo alimentar a doce esperança de que os campos verdejem e as searas florescem”, a natureza nem sempre lhes tinha sido cruel. Evocava, assim, o fato de que "o sol impiedoso que ilumina os campos tabajaras, por muito tempo foi benigno, poupando ao lavrador um esforço improfícuo”. Diante disso, pela compreensão do poeta, passada essa espécie de trégua da natureza, era chegado o tempo da seca, e com ele o êxodo dos "filhos da terra do sol". ${ }^{86}$

Essa harmonia entre o homem e a natureza, que o autor asseverava na poesia "Sertanejas", era justamente quebrada com a seca, que, nas palavras de Rocha Moreira, tornava o Ceará uma "terra grandemente infeliz". Assim, à medida que o literato traduzia para os seus leitores o que significava a infelicidade de sua terra natal, é que se percebia também, a própria representação de uma terra que, quando regada pela chuva, revelava "canaviais extensos, cujas folhas se erguiam lindas, como estrias verdes desenhadas no ar”. A constatação da perda dessa harmonia, para o literato, era a hora difícil em que "os cearenses abandonam de novo, como aves de arribação, o ninho construído" ${ }^{87}$ Era a hora do êxodo, para Fortaleza, para o Pará, para o Amazonas, para o Acre, para o Rio de Janeiro... Aliás, essa metáfora das “aves de arribação" é recorrente em muitos textos escritos pelo autor. Desse modo, decifrar algumas das representações construídas sobre a Amazônia, diante do grande número de cearenses que para essa região se dirigiam, também faz parte das compreensões sobre a experiência da migração.

\footnotetext{
${ }^{84}$ Folha do Norte. Belém, 8 de julho de 1914, p. 1.

${ }^{85}$ Folha do Norte. Belém, 24 de fevereiro de 1914, p. 1.

${ }^{86}$ Folha do Norte. Belém, 24 de fevereiro de 1915, p. 1.

${ }^{87}$ Folha do Norte. Belém, 20 de junho de 1915, p. 1.
} 


\section{A Floresta}

Em 1893, o governador do Ceará, Tenente Coronel José Freire Bezerril Fontenelle, mostrava-se preocupado com o fato de que, apesar de “caírem abundantes chuvas” em todo Estado, a agricultura e a indústria pastoril estavam prejudicadas, muitas vezes deixando-se produtos "sem colheita", por uma crise gerada, segundo o governador, pela "falta absoluta de braços”. Em tom de reclamação, José Fontenelle afirmava o motivo do problema: “o cearense depois de ter sido acossado por duas secas tem abusado muito da liberdade de emigrar, pondo-se a correr mundo à procura d'um fantástico paraíso". ${ }^{88}$

As preocupações apresentadas pelo governador e que não foram só suas, mas também de outros governadores, refletiam na forma como o poder público lidava com a migração. Assim, se de um lado reclamava-se da falta de mão-de-obra, de outro, a saída para o Pará, por exemplo, era uma alternativa para o poder público, nos períodos da seca, pois permitia livrarse de uma parcela da população cearense que, sem ocupação, acarretava em gastos e em problemas de ordem social para o Estado.

Diante disso, o governador propunha que se criasse, no Ceará, "embaraços à emigração", visando ao "fim do êxodo". ${ }^{89}$ Apesar dessas preocupações, a migração para a Amazônia, entre finais do século XIX e no início do século XX, foi intensa, sobretudo nos períodos de seca. Essa constante ligação entre o Pará e o Ceará permitiu a construção de variadas impressões sobre a região. Tais impressões sintetizam-se em duas questões centrais: a primeira seria um olhar que se volta para a natureza, um espaço em que se destacam a floresta, as muitas águas dos rios, os animais e as doenças possíveis de se desenvolverem nesse meio ambiente, como o impaludismo; a segunda diz respeito à idéia do Pará como uma espécie de terra da fartura, onde o enriquecimento seria possível.

As impressões causadas pela Amazônia foram destacadas por muitos que por essa região passaram. Rios, florestas, animais, riquezas naturais enfim, que encantavam e que assustavam, são evocados nos relatos de viajantes, naturalistas, estudiosos e turistas, que na região viveram, muitas vezes por vários anos, e que, a princípio, viram com os próprios olhos o

\footnotetext{
${ }^{88}$ Mensagem do Presidente do Estado Tenente Coronel Dr. José Freire Bezerril Fontenelle à Assembléia Legislativa do Ceará em sua $2^{\mathrm{a}}$ sessão ordinária da $1^{\mathrm{a}}$ Legislatura. Fortaleza: Typ da República, 1893, p. 14.

${ }^{89}$ Ibidem.
} 
espaço que descreveram. ${ }^{90}$ Além dessas impressões, entretanto, existem outras grafadas por pessoas que não estiveram na região e que escreveram a partir das impressões de outros, ou de idéias que circulavam sobre a região.

Um bom exemplo disso são as muitas representações sobre a Amazônia encontradas nas Mensagens dos governadores do Ceará. Esse é o caso da fala de 1893 de José Fontenelle, que, em tom ufanista, saudava o clima cearense, ao mesmo tempo em que denunciava o fato de que “os igapós da Amazônia têm sido cemitérios, somente para o homem deste clima minimamente seco e sanificado pelos alísios. Ali o sacrifício de vidas excede de $50 \%$ dos números dos colonos". 91

Essas referências a um meio hostil ao homem foram constantes nas representações da região e alvo de preocupações no Pará também, quando se chegou a afirmar que a Amazônia tinha um "clima difamado". ${ }^{92}$ De fato, os problemas sanitários e as febres tropicais, que tanto assustavam os cearenses, não eram uma singularidade do Pará. Em 1895, o coronel José Fontenelle, ao falar das "manifestações palustres” em Fortaleza, associava a transmissão da doença ao "grande número de doentes" que vinham do Pará e do Amazonas, mas também ao fato de que a própria localização da capital cearense contribuía também para isso, uma vez que estava "edificada sobre terreno arenoso, cortada por dois córregos". 93

\footnotetext{
${ }^{90}$ Podemos citar, entre muitos, alguns dos observadores que passaram pela região e que deixaram suas impressões sobre este espaço: BATES, Henry Walter (1825-1892). Um naturalista no rio Amazonas. Belo Horizonte: Itatiaia; São Paulo: EDUSP, 1979. WALLACE, Alfred Russel (1823-1913). Viagem pelos rios Amazonas e Negro. Belo Horizonte: Itatiaia; São Paulo: EDUSP, 1979. Adalberto, Príncipe da Prússia (1811-1873). Brasil: Amazonas e Xingu. Belo Horizonte: Itatiaia; São Paulo: EDUSP,1977. KIDDER. Daniel P. (1815-1891). Reminiscências de Viagens e Permanência no Brasil (Província do Norte). Compreedendo notícias históricas e geográficas do Império e das diversas províncias. São Paulo: Livraria Martins, 1943. CUNHA, Euclides. Um paraíso perdido; GODINHO, Victor \& LINDENBERG, Adolpho. Norte do Brasil. Através do Amazonas, do Pará e do Maranhão. Rio de Janeiro/São Paulo: Laemmert \& C., 1906.

91 Mensagem do Presidente do Estado Tenente Coronel Dr. José Freire Bezerril Fontenelle à Assembléia Legislativa do Ceará em sua $2^{\mathrm{a}}$ sessão ordinária da $1^{\mathrm{a}}$ Legislatura. Fortaleza: Typ da República, 1893, p. 14.

${ }^{92}$ Folha do Norte. Belém, 21 de março de 1915, p. 1. Retirado de uma palestra proferida em Belém pelo Dr. Arthur França, que será analisada nas próximas páginas.

${ }^{93}$ Mensagem do Presidente do Estado do Ceará C.el dr. José Freire Bezerril Fontenelle À Respectiva Assembléia Legislativa em sua $4^{\mathrm{a}}$ sessão ordinária da $1^{\mathrm{a}}$ Legislatura. Fortaleza: Typ. d'A República, 1895 , p. 140.
} 
Três anos depois, Antonio Accioly descrevia a cidade de Fortaleza com "verdadeiros pântanos" que se formavam depois das chuvas, com "focos de miasmas paludosos que ceifavam grande número de vidas principalmente crianças”. Além de ruas alagadas, “o ar atmosférico de muitos quarteirões" vinha carregado de "exalações impuras do subsolo, úmido e carregado de materiais em decomposição (...)”. O aterramento desses "pântanos”, o prolongamento do calçamento eram medidas que o governador considerava importante para a solução do problema. ${ }^{94}$

Desse modo, o próprio espaço de Fortaleza não era dos mais salubres, como deixam entrever os gestores dos poderes públicos, imbuídos naquele momento das teorias higienistas. Não resta dúvida de que o imaginário da floresta e dos rios dava de fato a tônica da insalubridade da região norte, que realmente existia, mas que não pode ser entendida como uma característica somente da Amazônia. A malária, doença que atingia tantos cearenses seringueiros nos leitos dos rios, não deixa de ser referida em Fortaleza, mesmo quando o estado sanitário da capital era lisonjeiro. “Aparecem, é certo, febres de caráter grave devidas ao impaludismo", afirmava o governador cearense Pedro Borges, em 1902. ${ }^{95}$

A insalubridade da Amazônia também foi lembrada nos versos de Juvenal Galeno. No entanto, essa mesma natureza selvagem e hostil tem algo a oferecer ao cearense, pois "os rios lá não secam" e "o trabalho nunca falta”. Nesse meio, o cearense "audaz afronta todos os perigos”. E diante disso, com imaginação poética, como se ele próprio fosse o cearense, em meio à floresta amazônica, o poeta interroga: "Que importa a febre que assalta traiçoeira e pertinaz? Que importa a fera no bosque, nos rios o jacaré; as enguias no igarapé”. Na forma que representa a Amazônia, Galeno utiliza-se, provavelmente, do que se falava desse espaço, retratando assim uma natureza que é vencida pela coragem do cearense na selva que "labuta ao sol, à chuva”, sem esquecer da família que não "pode acompanhá-lo”. 96

Essa mesma hostilidade da floresta, a memória da terra natal e a Amazônia, como um castigo que o protagonista se impõe a viver, espécie de exílio forçado como seringueiro, é o

\footnotetext{
${ }^{94}$ Mensagem apresentada à Assembléia Legislativa do Ceará pelo presidente do Estado Dr. Antonio Pinto Nogueira Accioly em 4 de julho de 1898. Fortaleza: Typographia Econômica, 1898, p. 8.

${ }^{95}$ Mensagem apresentada a Assembléia Legislativa do Ceará em $1^{\circ}$ de julho de 1902 pelo Presidente do Estado Dr. Pedro Augusto Borges. Ceará - Fortaleza: Typ. Minerva, 1902, p. 16.

${ }^{96}$ Almanach Administrativo, Estatístico, Industrial e Literário do Estado do Ceará para o ano de 1905, confeccionado por João da Camara. Ano 11º. Fortaleza: Empreza Tipographica, 1904, p. 140
} 
foco da história intitulada um “Amor trágico", publicada em 1904 no Almanaque do Ceará. Essa pequena crônica descreve as últimas cenas da vida de Elvira e Flávio. Ela, num quarto de hospital em Fortaleza, “jovem louca (...) de cabelos em desalinho, semblante velado por uma nuvem de tristeza, olhar vago e indeciso (...) a imagem da dor”. Ele, no leito do rio Tocantins, no "interior de um barracão”, sofrendo com a febre, agarrado ao retrato de Elvira, imagem de quando ela ainda era bela, explicando a um cearense de regresso à terra natal que “este retrato tem uma História ... que é também a minha História, o resumo de minha vida...". 97

Depois de entrar em contato com a agonia de Elvira, que "há dois anos” isolava-se do “mundo e da felicidade”, o leitor vislumbrava o lugar que o cearense Flávio escolheu para o seu degredo voluntário: a Amazônia. Da barraca de seringueiro de Flávio, desvelava-se um mundo de encantos, medos e dores. Um mundo que, para quem vivia no Ceará e tinha um conhecido vivendo nessa região, parecia de fato assustador, diante do contato com o desconhecido. A natureza é descrita desse modo: "Corria mansamente o Tocantins, avolumado pelos degelos dos Andes. Silêncio nas águas povoadas de monstros, silêncio nas matas povoadas de mistérios". 98

$\mathrm{Na}$ crônica, ao conversar com um seringueiro que estava de volta para o Ceará, Flávio, sabendo que não voltaria à terra natal, identifica-se. Ao fazer isso, o texto deixa para os leitores a denúncia das dificuldades enfrentadas pelos seringueiros, além de reforçar o imaginário de uma terra distante e selvagem: “Eu também sou natural desse pobre Estado ... cujos filhos vêm aqui deixar a vida ..., supondo encontrá-la. — Sou natural do Ceará.” Nesse mesmo contexto, Flávio justifica a sua partida, que teria sido fruto de uma calúnia sobre a fidelidade de Elvira. Diante de tanta dor e vergonha, "sem que ninguém soubesse”, como um “miserável”, um "trânsfuga do amor”, ele resolve partir. O desfecho trágico para esse amor seria então o exílio voluntário de Flavio na Amazônia, aqui representada como uma terra que é "refúgio dos deserdados". 99

\footnotetext{
${ }^{97}$ Almanach Administrativo, Estatístico, Industrial e Literário do Estado do Ceará para o ano de 1905,

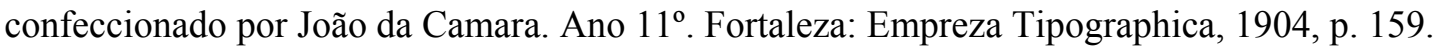

${ }^{98}$ Idem.

${ }^{99}$ Idem, p. 161.
} 
Não muito diferente da História de Flávio, mas dessa vez com final feliz, é outra crônica publicada, também no Almanaque do Ceará, escrita em 1917. O autor, que se identifica apenas como Yan, conta a seus leitores memórias de uma seca que ele não identifica, de quando residia em "uma cidade do interior". O texto, intitulado "Episódio da seca", além de demonstrar as relações do sertanejo com a natureza, também revela a imagem da Amazônia, lugar do qual não se volta, onde o sertanejo iria encontrar a morte. ${ }^{100}$

Assim, na crônica, o autor mostra a tristeza de um sertanejo, “um velho caboclo de tez amarelada (...) chefe de numerosa família de 16 filhos e quatro netos pequeninos. Vivia feliz em sua gleba”. As observações do sertanejo em relação à natureza se revelam na medida em que o autor destaca um diálogo em que este fala com tristeza, diante da não floração de um pau d'arco: "Vê aquele pau d'arco (...). Todos os anos a folha cai toda e se cobre de flores amarelas; no ano em que ele não fulora, triste do pobre a seca é certa (...)”. ${ }^{101}$

Diante da iminente seca, e da possibilidade de vir para a Amazônia trabalhar, o velho sertanejo afirma: "Não deixo meu rancho para ir morrer no Norte, não isto eu não faço, a gente deve ser enterrado onde nasceu - eu aqui nasci, aqui fico". ${ }^{102}$ Essa reposta, possivelmente dita por um sertanejo, reforça a idéia do amor por seu lugar de origem, além de uma imagem da Amazônia como um espaço insalubre onde a morte, mais que a possibilidade de prosperidade, era quase uma certeza. A parte final do texto é elucidativa nesse sentido, uma vez que o autor afirma que com o fim da seca "era o nascimento da terra querida, que tornava terra da luz que redime, (...) flagelada pela inconstância do tempo, mas que tem filhos como o velho caboclo, que não a abandonaram nunca”. ${ }^{103}$

Em outra descrição de um sertanejo, na Amazônia, dessa vez imaginada por Rocha Moreira, o cearense vê-se envolto nas águas do "rio-mar" que "corriam sobre o soalho de sua choupana rústica”. Diante das águas que cresciam, do "alto de uma árvore”, ele via, pela força da água, lhe "fugirem os objetos mais caros e as lembranças mais felizes da sua vida nômade”. Nessa cena, sobressai o "medo das águas”, a destruição provocada pela subida do

\footnotetext{
${ }^{100}$ Almanach Estatístico, Administrativo, Mercantil Industrial e Literário do Estado do Ceará para o ano de 1918 - Diretor e Oraganizador Sophocles Torres Câmara. Fortaleza: Typ. Moderna - Carneiro e C., 1918, p. 210.

${ }^{101}$ Idem

${ }^{102}$ Idem.

${ }^{103}$ Idem, p. 218.
} 
rio, que tudo derrubava, árvores, animais, casas, em contradição com o motivo que trouxe o sertanejo para aquela terra, a ausência de água. Para Rocha Moreira, a mesma destruição trazida pela seca parecia perseguir o sertanejo, na Amazônia, com as águas. ${ }^{104}$

Mais de um ano depois da publicação desse texto, em abril de 1916, em uma pequena secção da Folha do Norte, intitulada "Chroniqueta", Rocha Moreira reforçava essa sina do cearense em lutar com a natureza, dessa vez com a subida das águas que invadiam a cidade. Nas palavras do poeta, “a natureza é por vezes de uma ironia pungente”, em relação ao cearense, pois se quando ele está no sertão “maldiz o astro assassino que tudo destrói”, ele que “ama as águas”, na Amazônia, “ante ao volume de água doce”, sentia até "nostalgia do torrão distante”. Essa constante contradição experimentada pelo cearense - que luta para sobreviver quando não tem água, e igualmente quando a tem em abundância - é marcante na representação que Rocha Moreira faz, a ponto de ele afirmar que diante disso " $a$ via dolorosa do expatriado, porém, nunca termina”. ${ }^{105}$

Como cearense que era, o autor também não deixava de asseverar, em sua representação do sertanejo, os vínculos identitários que, mesmo na Amazônia, seus conterrâneos mantinham com o Ceará, representando-os, assim, como sujeitos sociais que buscavam construir o rumo de sua própria História. Apesar disso, não se pode perder de vista um certo olhar determinista nos personagens anônimos criados por Rocha Moreira, pois o cearense, na Amazônia ou no sertão, na visão do poeta, teria que lutar contra o meio em que vivia para sobreviver.

Em outros versos da poesia "Seca", também de Rocha Moreira, mais uma vez, o poeta evoca as águas e a floresta, imaginando um delírio de febre de um seringueiro na Amazônia. A febre do sertanejo fazia aflorar, pela imaginação do poeta, a lembrança da família que tinha ficado no Ceará. Nesses versos, as imagens da floresta se mesclam com a memória do sertão, com referências de uma outra natureza, a do Ceará, da qual o sertanejo sentia saudades. Apesar disso, a imagem da insalubridade da região amazônica não deixa de ser evidenciada com a febre que "devora” o cearense na floresta:

"Súbito lambe o vento a folhagem da selva!

Há sussurros na mata ... e estirado na relva

Ele tem sede, e sob a febre que o devora,

Julga ouvir um rumor, que igual ouvira

\footnotetext{
${ }^{104}$ Folha do Norte. Belém, 6 de março de 1915, p. 1.

${ }^{105}$ Folha do Norte. Belém, 4 de abril de 1916, p. 1.
} 
Em Maranguape, quando uma vez, assistira

Ao cantante rolar da água do Pirapora.

E ouvindo o vento e ouvindo as folhas que farfalham

Julga as águas do céu que na terra se espalham,

E delira e estremece e anseia e geme e sua ...

Pensa ver o seu lar ... a esposa e o filho a porta!

E na febre que aviva uma esperança morta,

Olhos abre ... vê ... nada ... Apenas a lua”. ${ }^{106}$

Se, nas representações sobre a Amazônia, sobressaem as agruras da vida na floresta, tão importante quanto essas imagens é a idéia de um verdadeiro "Eldorado" que se propaga sobre a região. Aliás, essa noção não é uma prerrogativa da Amazônia somente. Em outros espaços do Brasil, como Mato Grosso e Rondônia, por exemplo, o desconhecimento acerca desses lugares parece reforçar esse imaginário de uma região fabulosa e cheia de riquezas. Joaquim Ponce Leal falando sobre Mato Grosso dá indícios de que o isolamento de Cuiabá contribuiu para um imaginário do "país encantado" pois, segundo o autor "o Oeste é algo novo, infindável reino de fábula: são de ouro os brinquedos das crianças”. ${ }^{107}$ Igualmente, Maria de Fátima Costa, referindo-se ao Pantanal, demonstra que no período colonial o interesse por esse espaço é gerado em função de narrativas de viagem que o apresentavam como um lugar de "muitas riquezas", fazendo com que a bacia do rio Paraguai fizesse parte das "fabulosas histórias contadas sobre a América". Segundo a autora esse "era um mundo onde realidade e fantasia se imbricavam”. ${ }^{108}$ Também Laura Antunes Maciel, analisando as práticas da Comissão Rondon para a construção das linhas telegráficas no noroeste do estado de Mato Grosso, hoje estado de Rondônia, afirma que no início do século XX para a maioria dos brasileiros era um "imenso espaço vazio e impenetrável”. Essa noção de vazio se estendia, segundo a autora para outras partes do país como o Paraná o Mato Grosso, Goiás e Amazonas. Nesse sentido, para Laura Maciel é diante desse "mito da região deserta misteriosa e lendária" que vai se construindo essa visão do Eldorado, de uma terra "com

\footnotetext{
${ }^{106}$ Folha do Norte. Belém, 2 de maio de 1915, p. 1.

${ }^{107}$ LEAL, Joaquim Ponce. Os homens e as armas: o conflito campo-cidade no Brasil. Belo Horizonte: Itatiaia; Rio de Janeiro: Rio Arte, 1988, p. 292.

${ }^{108}$ COSTA, Maria de Fátima. A História de um país inexistente: Pantanal entre os séculos XVI e XVIII. São Paulo: Estação Liberdade: Kosmos, 1999, p. 17.
} 
metais, pedras preciosas e com 'ouro branco' da borracha” que atiçava a imaginação e atraia “um sem-número de aventureiros, curiosos e deserdados de todas as regiões do País”. 109

Em 1893, o governador Fontenelle, ao reclamar da falta de braços, não deixou de fazer referência a uma questão importante e pouco lembrada pela historiografia: o fato de que, do Ceará, nem sempre se emigrava por “motivo de fome, ou falta de trabalho", mas também, segundo o governador, "pela falsa idéia” que se tinha dos salários na Amazônia. Completando sua afirmação, argumentava ainda que essa “ilusão” também era resultado “da sedução empregada por ambiciosos, que vem recrutar as vítimas até os remotos sertões" ." 110

Esse pensamento sobre a atração causada pela Amazônia não era restrito apenas às autoridades cearenses. No Pará, também havia certa preocupação no mesmo sentido, sobretudo nos momentos de crise econômica, como em 1908. Nesse período, ocorreu uma queda de preços da borracha no mercado internacional, aliada à impossibilidade de os produtores cumprirem "os compromissos que tinham assumido", ao que se soma uma “diminuição da safra paraense”, em conseqüência das dificuldades no transporte ocasionada pela subida dos rios. ${ }^{111} \mathrm{O}$ comércio e os negócios locais foram atingidos. Nesse cenário, o aumento populacional acarretaria maiores gastos para os cofres públicos. Diante de tantos problemas, é que o governador Augusto Montenegro se manifestou, comparando a atração exercida pela borracha à corrida do ouro na Califórnia:

“(...) ainda corre a impressão quase lendária, de ser ele um negócio em demasia lucrativo, só lembrando o ouro californiano, quando se desconsidera que realmente constitui uma indústria excessivamente onerada, logo no ato da extração, graças às dificuldades e despesas do fabrico". ${ }^{112}$

As questões destacadas pelos governadores são importantes para entendermos a vinda de cearenses para a região. Com a efervescência da economia da borracha e também o

109 MACIEL, Laura Antunes. A nação por um fio. Caminhos, práticas e imagens da "Comissão Rondon”. São Paulo: EDUC, 1998, p. 96.

${ }^{110}$ Mensagem do Presidente do Estado Tenente Coronel Dr. José Freire Bezerril Fontenelle à Assembléia Legislativa do Ceará em sua $2^{\mathrm{a}}$ sessão ordinária da $1^{\mathrm{a}}$ Legislatura. Fortaleza: Typ da República, 1893, p. 15.

${ }^{111}$ Mensagem dirigida em 7 de setembro de 1908 ao Congresso Legislativo do Pará pelo Dr. Augusto Montenegro Governador do Estado. Belém: Imprensa Official do Estado do Pará, 1908, p. 7.

${ }^{112}$ Mensagem dirigida em 7 de setembro de 1908 ao Congresso Legislativo do Pará pelo Dr. Augusto Montenegro Governador do Estado. Belém: Imprensa Official do Estado do Pará, 1908, p. 11. 
desenvolvimento de projetos de colonização agrícola para o estado do Pará, com a noção da opulência dessa terra, entre finais do século XIX e início do século XX, propagava-se, tanto pelo poder público paraense, como por pessoas que pela região passavam e depois voltavam ao lugar de origem, a possibilidade de enriquecimento com o trabalho na lavoura, e também na coleta do látex.

Para uma população como a de muitas cidades cearenses, flagelada por secas periódicas, ou presa a proprietários de terras que não lhes permitiam prosperidade, não resta dúvida de que, nesse momento, a Amazônia aparecesse como um espaço de atração. É possível que a relativa proximidade dessa região em relação ao Ceará também contribuísse para isso. Em 1901, o governador do Ceará chegou até a afirmar que, para os cearenses, a emigração para o Pará e o Amazonas não se assemelhava a um “exílio”, não só pelas “estreitas relações comerciais e outras ordens de interesse", mas também pelo "pronto regresso à terra natal". ${ }^{113}$ Tudo leva a crer que a fala do governador foi um argumento utilizado por ele para justificar a saída de grande número de flagelados pela seca. Entretanto, as motivações evocadas pelos migrantes quando solicitam passagens ao governo para fazerem a viagem do Ceará para a Amazônia, ou por seus descendentes, quando se recordavam dos motivos da vinda da família ao Pará, nos aproximam um pouco dessa realidade social.

Em 1895, o governador Fontenelle recuperava os mesmos problemas do ano de 1893, referindo-se à “aflitiva situação da lavoura” no Ceará, tanto pelo falta de irrigação, como pelo fato de que, nas palavras do governador, a população rural continuava a "fugir, por essa espécie de mania à procura de um Eldorado inatingível na Amazônia”. ${ }^{114}$ Ora, esses indícios nos remetem à História de sujeitos sociais, que buscavam traçar os rumos de sua própria vida, mesmo que, nesse caso, muitas vezes fosse necessário deixar para trás a família e a terra natal. Pouco importa se o cearense, ao chegar na Amazônia, se deparasse com muitos obstáculos para o encontro da tão sonhada riqueza; menos ainda, que de fato se tratava de ilusões. O que interessa é o motivo que gerava a sua vinda, que nem sempre foi a seca, situação limite na qual, muitas vezes, o migrante se apresentava quase à beira da morte.

\footnotetext{
${ }^{113}$ Mensagem apresentada à Assembléia Legislativa do Ceará em $1^{\circ}$ de julho de 1901 pelo Presidente do Estado Dr. Pedro Augusto Borges. Fortaleza: Typ. Econômica, 1901, p. 29.

${ }^{114}$ Mensagem do Presidente do Estado do Ceará C.el dr. José Freire Bezerril Fontenelle À Respectiva Assembléia Legislativa em sua $4^{\mathrm{a}}$ sessão ordinária da $1^{\mathrm{a}}$ Legislatura. Fortaleza: Typ. d'A República, 1895, p. 5.
} 
Também através da Folha do Norte, é possível rastrear indícios dessa idéia da Amazônia como um lugar em que, com o trabalho, se poderia enriquecer. Em 1898, por exemplo, na coluna "Jornal dos Estados", apareceu uma pequena nota sobre o termo de Igatu, no Ceará, em que, dando conta da circulação de dinheiro falso, alertava-se para o fato de que tinha "chegado de regresso muita gente do Amazonas, trazendo notas". ${ }^{115} \mathrm{O}$ mesmo jornal, em 1910, anunciava a saída do porto de Camocim, no Ceará, do vapor "Sobral”, que conduzia ao Estado do Pará “mais de trezentos passageiros, gente em sua maioria destinada a trabalhar na 'árvore de ouro",. ${ }^{116}$ Por essas pequenas notícias, pode-se perceber um pouco desse imaginário que circulava sobre a Amazônia, entendida como uma região destinada ao enriquecimento; a metáfora da seringueira como "árvore de ouro" é significativa nesse sentido.

Fica evidente, também, uma troca de informações sobre o que acontecia no Ceará e no Pará, o que contribuía para a formação de um imaginário acerca desses dois estados. Em $1^{\circ}$ de janeiro de 1914, em tom jocoso, uma agência de loteria de Belém, a "Mão feliz”, em uma propaganda publicada na Folha do Norte, com o título "Revolução no Ceará", fazia uma alusão aos conflitos no Juazeiro, a partir de um telegrama ficcional enviado por Padre Cícero, direto do "Palácio governo revolucionário". 117

Em código Morse, padre Cícero dizia ser conhecedor da abertura da agência e, por isso, solicitava "depositar banco bilhete sorte grande", pois ele precisa desse dinheiro para “continuar movimento”. Em resposta ao telegrama, Carvalho, o proprietário da agência lotérica, dizia não poder atendê-lo "devido compromisso vender sorte Pará". ${ }^{118}$ Para além dos risos que a propaganda da "Mão feliz" venha a suscitar, delineia-se também a idéia do Pará como um lugar de riquezas e prosperidade, ao qual até Padre Cícero recorria. Além do mais, demonstra que os leitores conheciam os acontecimentos do Juazeiro, que davam o enredo ao anúncio; do contrário, a propaganda não teria sentido.

Fazendo parte desse mesmo contexto, também no ano de 1914, a Folha do Norte trouxe ao público uma suposta carta enviada do interior do Ceará, cujo destinatário morava em Belém.

\footnotetext{
${ }^{115}$ Folha do Norte. Belém, 5 de abril de 1898, p. 1.

${ }^{116}$ Folha do Norte. Belém, 6 de abril de 1910, p. 1.

${ }^{117}$ Folha do Norte. Belém, 1 de janeiro de 1914, p. 4.

${ }^{118}$ Folha do Norte. Belém, 1 de janeiro de 1914, p. 4.
} 
"Tópicos que por interessantes oferecemos aos nossos leitores", afirmava o redator. O autor da possível carta, cujo nome não foi divulgado, acreditava ser o Ceará, com os problemas de Juazeiro, um “novo e formidável Canudos”. Justificava seu pensamento afirmando que, no Ceará, “dantes o que metia medo era a falta ou dúvida do inverno, da chuva (...). Hoje o que mete medo a todos (...) é o medo jagunço, do romeiro, ou afilhado de Padre Cícero, o qual, de beato rezador, passou a político salteador". ${ }^{119}$

Diante dos conflitos de Juazeiro, o autor da tal carta como que pedia a um conhecido seu, no Pará, que lhe falasse da terra e de suas riquezas, pois tendo em vista o medo em que vivia no Ceará, pretendia se estabelecer no Pará, espaço entendido como uma "verdadeira Terra da Promissão”. Não é possível afirmar a autenticidade da carta, ou se não era uma estratégia utilizada pelo redator para conferir status de verdade ao texto publicado, dando assim liberdade ao articulista de expor seu pensamento político, por exemplo. Fica evidente o interesse de se passar aos leitores da Folha do Norte a idéia de um Pará que atraía pessoas de outros estados, justamente por ter terras que possibilitavam a prosperidade da lavoura.

Num Estado como o do Pará, onde, em função da economia da borracha, muito se valorizava o extrativismo, esse ufanismo em relação à fertilidade do solo era algo que também se buscava construir, até como um incentivo à produção agrícola. Por outro lado, mesmo que a carta tenha de fato existido, sua publicação na imprensa local não deixa de revelar ufanismo em relação ao Pará, assim como a crença de segmentos da sociedade paraense, como os intelectuais que escreviam na Folha do Norte, de que o Pará fosse para os cearenses uma “Terra da Promissão”. Vejamos um trecho da carta:

"Peço-te encarecidamente que me informes se sabes aí de terras boas e baratas que sirvam para a plantação de canas com resultados e de cereais e onde possa me estabelecer e tratar da nova vida. Comigo muitos querem ir, mas não quero e não devo me afoitar sem ter primeiro, informações seguras, por isso valho-me a ti. Irei trabalhar na agricultura: (dizem-me que a borracha nada vale agora). Irei também ao Pará ou Amazonas e não serei eu o primeiro e nem o último cearense que, não podendo viver no seu torrão natal tão bom e tão infeliz, vá procurar essa verdadeira Terra da Promissão. Estarei enganado?”. ${ }^{120}$

Com a crise da economia da borracha, assevera-se um discurso da prosperidade com o trabalho na agricultura, ao mesmo tempo em que também percebemos uma certa preocupação com a preservação dos recursos naturais, exemplo das solicitações da Comissão Permanente

\footnotetext{
${ }^{119}$ Folha do Norte. Belém, 29 de julho de 1914, p. 1.

${ }^{120}$ Folha do Norte. Belém, 29 de julho de 1914, p. 1.
} 
de Defesa Econômica da Amazônia para que se comemorasse o Dia da Árvore. Ao mesmo tempo em que se falava da Amazônia, construindo-se múltiplas imagens da natureza desse espaço, no Pará, também se buscava erigir uma imagem para a região. Dessa forma, contestando a imagem do clima inóspito ou valorizando as riquezas naturais da região, incentivando-se o trabalho na agricultura, festejando-se o Dia da Árvore, delineava-se, na imprensa e nas mensagens dos poderes públicos, uma imagem mais positiva desse espaço.

No caso da agricultura, recorria-se ao ideário de uma terra opulenta, fértil, e abundante, cujo florescimento dependia apenas do "lavrador operoso". Por essa perspectiva, Rocha Moreira, em tom ufanista, assim se reportava: "No Pará, os rios e os regatos são as veias que circulam por esse estranho e lindo corpo que é a terra”. Acreditava o literato - tal qual boa parte dos presidentes da Província e governadores paraenses de finais do século XIX e início do século XX - que o agricultor acostumado a "mandar na gleba, não pode chorar a falta de pão... só os inimigos das leiras e dos campos falam da penúria no riquíssimo vale da Amazônia”. ${ }^{121}$

Por esse pensamento, apostava-se, quase que exclusivamente, no trabalho do lavrador para a prosperidade da terra. ${ }^{122}$ Não se consideravam as dificuldades para a implementação dessa agricultura, como a derrubada da mata, a instalação dos lavradores nesse espaço, a efetivação das plantações e a espera da colheita e, por fim, os meios de transporte necessários para o escoamento dessa produção, que nem sempre estavam disponíveis. Portanto, um "lavrador operoso", por si só, não garantiria o sucesso da tão sonhada empresa agrícola.

Nesse entendimento da Amazônia como um espaço de natureza opulenta e terra fértil, espaço que, por essas qualidades, poderia garantir o sucesso do migrante que resolvesse instalar-se na região, temos a construção de uma imagem da Amazônia que correu pelo Ceará

\footnotetext{
${ }^{121}$ Folha do Norte. Belém, 20 de junho de 1915, p. 1.

${ }^{122}$ Fernando Antonio Lourenço, discutindo, o liberalismo e o escravismo nas origens da questão agrária brasileira afirma que "a História da agricultura no Brasil tem-se caracterizado por um estilo de desenvolvimento que instaura uma modernização sem modernidade, isto é, um incremento das forças produtivas sem a realização do tão prometido ingresso dos trabalhadores a cidadania. Alguns legados coloniais escravistas persistiram, renovados. A cultura extenuativa dos campos, as diversas formas de trabalho compulsório, a dominação pessoal, o favor, a violência e a ausência de uma profunda reforma agrária”. LOURENÇO. Fernando Antonio. Agricultura ilustrada: liberalismo e escravismo nas origens da questão agrária brasileira. Campinas: Editora da Unicamp, 2001, pp. 194195.
} 
e que, sem dúvida, influenciou na decisão de muitos cearenses deixarem ou não o seu lugar de origem.

Desse modo, em 1898, entre os dias 9 e 15 de março, a Folha do Norte publicou um conjunto de seis artigos, intitulados "Pelo futuro da Amazônia", em que um articulista anônimo buscava fazer uma reflexão sobre a Amazônia daquele momento. Nesses artigos, delineia-se uma compreensão da natureza da Amazônia e, ao mesmo tempo, do papel do homem em relação a essa natureza. No primeiro texto, as preocupações se voltavam para o Brasil, que, segundo o artigo, buscava sempre valorizar uma única atividade produtiva - no caso do norte, a borracha, e no sul, o café -, em detrimento de outras "fontes de riqueza". Nas palavras do articulista, abandonava-se e desprezava-se "tantas outras riquezas que o país encerra". Suas críticas se pautavam no fato de que se tinha "uma terra imensa a cultivar, um manancial enorme de riquezas a explorar". ${ }^{123}$

$\mathrm{Na}$ verdade, essa preocupação, que apontava uma falta de exploração da riqueza regional, não era nova. Em praticamente todos os discursos dos governadores do Estado do Pará, entre 1889 e 1916, ela se manifestou, mesmo nos momentos em que a extração da borracha era bastante lucrativa. A idéia de uma terra fértil, mas que precisava ser explorada e valorizada através da agricultura, aliada a uma crítica ao exclusivo extrativismo da borracha, sem dúvida, é a tônica dos muitos discursos sobre a Amazônia.

Já em 1877, observava-se essa preocupação quando o Presidente da Província, João Capistrano Bandeira de Melo e Filho, afirmava que boa parte dos habitantes de áreas do interior do Pará era "arrastada" para o trabalho de coleta do látex, abandonando "suas lavouras" e passando "quase metade do ano nos seringais". Diante disso, segundo o Presidente da Província, desapareciam culturas como de café, algodão, anil cacau, arroz, milho "e até mesmo da farinha de mandioca, importada do Maranhão". ${ }^{124}$

$\mathrm{Na}$ historiografia, esse "abandono" da agricultura em função de uma valorização do extrativismo da borracha é um tema sempre presente. ${ }^{125}$ De fato, a borracha foi durante um bom período o principal produto no quadro das exportações paraenses, o que, sem dúvida, em

\footnotetext{
${ }^{123}$ Folha do Norte. Belém, 9 de março de 1898, p. 1.

${ }^{124}$ Dr. João Capistrano Bandeira de Mello Filho abrio a $2^{\mathrm{a}}$ sessão da $20^{\circ}$ Legislatura da Província do Pará em 15 de fevereiro de 1877, p. 160.

${ }^{125}$ Ver por exemplo: SANTOS, Roberto. História econômica da Amazônia (1800-1920).
} 
termos econômicos, colocava em segundo plano outros itens, que, de qualquer modo, permaneciam, apesar da importância do látex. Ao lado disso, uma agricultura voltada para o consumo interno, além de uma produção vinda dos engenhos, sempre foram atividades presentes na economia paraense.

Desse modo, ao se falar do “abandono" da agricultura, é necessário definir de que região do Pará se está falando, entendendo esse espaço em suas diferenças. É possível que nas áreas dos seringais, na região das ilhas, tenha existido de fato esse "abandono”. Em outras áreas, como na chamada zona Bragantina do Pará, os núcleos coloniais que margeavam a Estrada de Ferro de Bragança são exemplo de produção agrícola, embora muitas vezes arcaica e em pequena quantidade, mas de forma alguma inexistente. Produzia-se nessa região tabaco, cacau, farinha de mandioca, aguardente de cana, milho, arroz, feijão, laranjas, limões, bananas e abacates. $^{126}$

Sendo o principal produto de exportação, a borracha estava na pauta de discussões Apesar disso, não se pode negar que as autoridades davam conta de demonstrar, em seus próprios pronunciamentos, a efemeridade da borracha. O governador Lauro Sodré, por exemplo, embora afirmasse em 1892 que a borracha, desde 1827, continuasse sendo para os paraenses a "sinfonia elástica a verdadeira árvore de ouro", compreendia que essa era uma riqueza natural que "poderia minguar, se medidas acertadas não [viessem] acudir aos danos da exploração desacautelada do futuro e unicamente arrastada pelo desejo de lucro". ${ }^{127}$ Paes de Carvalho também combatia a exclusividade da economia da borracha e, ao mesmo tempo, alertava para uma extração do látex feita por “imutáveis processos primitivos da preciosa seiva da seringueira". ${ }^{128}$

\footnotetext{
${ }^{126}$ Dr. João Capistrano Bandeira de Mello Filho abrio a $2^{\mathrm{a}}$ sessão da $20^{\circ}$ Legislatura da Província do Pará em 15 de fevereiro de 1877, p. 159. Mensagem dirigida ao Congresso do Estado do Pará pelo Dr. José Paes de Carvalho, Governador do Estado em 1 de fevereiro de 1901. Belém: Imprensa Oficial, 1901, pp. 73-74. Mensagem dirigida em 7 de setembro de 1908 ao Congresso Legislativo do Pará pelo Dr. Augusto Montenegro Governador do Estado. Belém: Imprensa Official do Estado do Pará, 1908, p. 219.

${ }^{127}$ Mensagem Dirigida pelo Senr. Goverandor Dr. Lauro Sodré ao Congresso do Estado do Pará em sua segunda reunião em $1^{\circ}$ de julho de 1892. Belém: Typ. do Diário Official, 1892, pp. 19-20.

${ }^{128}$ Mensagem dirigida ao Congresso Legislativo do Pará pelo Dr. José Paes de Carvalho, governador do Estado em 7 de abril de 1898. Belém: Diário Oficial, 1898, p. 7.
} 
Voltemos às impressões publicadas na Folha do Norte. Em outro artigo desse conjunto de textos, também intitulado "Pelo Futuro da Amazônia", a crítica à excessiva exploração da borracha ficava latente. Comparando o Pará com o Rio Grande do Sul, que, além do gado, tinha "quase todas as culturas compatíveis com o seu clima e natureza”, a borracha não era mais que uma "riqueza puramente fictícia”, talvez pela noção da fugacidade dessa economia. Além disso, era entendida como uma atividade que "menos inteligência e menos esforços exige do homem para a sua exploração". ${ }^{129}$ Pensamento semelhante era o do governador Paes de Carvalho, o qual também, em 1898, referia-se à borracha como uma atividade "facílima e vantajosa". ${ }^{130}$

A valorização da agricultura, que por essa ótica era fundamental para o desenvolvimento da Amazônia, colocava em plano secundário o difícil trabalho exercido pelo seringueiro, visto como inferior. No caso da região, esse era um pensamento bastante questionável, uma vez que, tradicionalmente, a produção extrativista sempre caminhava ao lado da lavoura.

O autor dos textos intitulados "Pelo futuro da Amazônia", como que antecipando o pensamento de Euclides da Cunha acerca das “aberrações” da natureza, acreditava que só com o "esforço e tenacidade" do homem, aliados aos "progressos das ciências agronômicas", se construiria um futuro de prosperidade para a região, com o surgimento de “uma nova era, verdadeira era de felicidade de emancipação”. Dentro dessa perspectiva, portanto, na Amazônia, tinha-se uma natureza com “aberrações”, que precisava ser modificada:

"A natureza, grande e virgem, sobretudo nesta futurosa América, carece de ser modificada na sua primitiva constituição, contrariada mesmo em muitas das suas aberrações. Se o entupir e desentupir rios, aplanar montanhas e rasgar ou fechar canais muitas vezes é privilégio da natureza, algumas vezes também é obra do homem. (...). A questão esta em corrigir, em modificar os excessos da natureza pelos meios que de fato estão ao nosso alcance, e que hoje, com os progressos das ciências agronômicas, são, quase todos, do domínio das construções rurais e processos da engenharia agrícola". ${ }^{131}$

O entendimento da natureza exposto pelo articulista da Folha do Norte, diante da semelhança de pensamento, remete a uma breve reflexão sobre algumas das considerações de

\footnotetext{
${ }^{129}$ Folha do Norte. Belém, 10 de março de 1898, p. 1.

${ }^{130}$ Mensagem dirigida ao Congresso Legislativo do Pará pelo Dr. José Paes de Carvalho, governador do Estado em 7 de abril de 1898. Belém: Diário Oficial, 1898, p. 7.

${ }^{131}$ Folha do Norte. Belém, 10 de março de 1898, p. 1.
} 
Euclides da Cunha, quando de sua passagem pela Amazônia. Noções como as de uma natureza "primitiva", com "aberrações", "cheia de excessos", presentes no texto da Folha do Norte, de 1898, são facilmente rastreadas nas observações que, anos depois, entre 1904 e 1905, Euclides da Cunha faria sobre a Amazônia. Analisando os principais elementos presentes nos textos que ele produziu sobre sua presença na Hilea, fica evidente, tomando aqui como exemplo "Terra sem História", uma interpretação da região pautada por noções da teoria evolucionista. Nesse sentido, o autor como que busca apontar na escala da evolução o grau de cada um dos elementos que formam o "vasto e luxuoso salão" da natureza. Uma natureza que, apesar de "portentosa", era "incompleta".

Uma rápida incursão ao quadro da natureza amazônica, descrito por Euclides da Cunha, aponta para o fato de que, para esse autor, os rios "ainda não se firmaram nos leitos; parecem tatear uma situação de equilíbrio". Igualmente, o caminho pela floresta parecia revelar para o literato uma flora de "imperfeita grandeza". Por esse motivo, escrevia: "quem segue pela mata tem a sensação angustiosa de um recuo às mais remotas idades, como se rompesse os recessos de uma daquelas mudas florestas carboníferas desvendadas pela visão retrospectiva dos geólogos". Como que completando este quadro da natureza, a fauna era "singular e monstruosa onde imperam, pela corpulência, os anfíbios, o que é ainda uma impressão paleozóica; (...) tipos abstratos ou simples elos da escala evolutiva". ${ }^{132}$

Nesse espaço, é travado um verdadeiro combate entre o homem e a natureza. Assim, ao mesmo tempo em que percebia as ações humanas para a conquista do Acre e para as invasões peruanas às terras brasileiras, preocupava-se com o que considerava o pouco domínio das técnicas de navegação moderna naquela região. Com seu olhar de engenheiro, o literato acabava por não perceber as peculiaridades próprias de se lidar com a navegação no Amazonas, insistindo numa espécie de atraso no trato com o rio.

Euclides da Cunha, em função de sua formação, e até mesmo de seus ideais republicanos, acreditava no domínio da técnica como forma de progresso. Ressentia-se do fato de que, ao seu olhar, peruanos e brasileiros pareciam não querer dominar o rio. Observando a navegação

\footnotetext{
${ }^{132}$ CUNHA, Euclides da. "Terra sem História”. In: Um paraíso perdido, pp. 25-26. Em suas Lições sobre a filosofia da história, Hegel comenta que os "imensos rios" Orinoco e Amazonas "formam grandes vales que não são apropriados para países civilizados”. HEGEL, Georg. W. F. Leçons sur la philosophie de l'histoire. Paris: Libraire Philosophique J. Vrin, 1979, p. 69.
} 
pelo Purus, afirmou, em tom semelhante ao do articulista da Folha do Norte, quando se referia às modificações dos "excessos da natureza":

"esbarram mil vezes a canoa num tronco caído há dez anos à beira de um canal (...) mas não despendem o mínimo esforço e não despendem um golpe único de facão ou de machado num só daqueles paus, para desafogar a travessia". ${ }^{133}$

Por essa declaração, evidencia-se, nesses últimos textos, um início de seu pensamento posterior, uma vez que, nesse cenário de “aberrações”, o homem, mesmo quando podia, parecia não querer modificar a natureza. Esse pensamento, carregado de preconceitos sobre a região e seus moradores, acabou imortalizado nos textos de Euclides da Cunha, um clássico da literatura brasileira, que raramente deixa de ser evocado quando se trata da Amazônia.

Passados alguns anos dessas observações, em 1907, o governador Augusto Montenegro, diante do evidente sucesso das plantações de seringueiras asiáticas, alertava para a necessidade de se "enveredar pelo caminho, por outros países abertos de transformação da indústria extrativa em uma verdadeira indústria agrícola”. Por essa perspectiva, havia o interesse de se plantar inclusive a seringueira. Se em outras falas, o discurso é de não se abandonar a agricultura, em função da extração do látex, valorizando outros produtos, aqui, até as seringueiras podem ser resultado de plantações feitas "de maneira racional $e$ metódica”. Por isso, o governador acreditava que diante das “condições especiais do Vale”, não deviam servir, "senão como lições" que convinham ser estudadas, "as plantações da preciosa árvore” que, naquela ocasião, se faziam na Ásia. ${ }^{134}$

À medida que os anos iam passando, modificava-se a forma como as autoridades lidavam com o extrativismo da borracha. Esse produto passou a ser entendido não somente como uma dádiva da natureza amazônica, como uma planta possível de florescer apenas na própria região, mas como um recurso natural que poderia ser produzido sistematicamente e que deveria ser, inclusive, preservado. A exemplo disso, Augusto Montenegro apresentou, em sua Mensagem, uma referência ao trabalho de Jacques Huber, diretor do museu Goeldi, que, em uma monografia sobre a borracha, buscava levar aos lavradores paraenses conhecimentos que

\footnotetext{
${ }^{133}$ CUNHA, Euclides da. "Rios em abandono". In: Um paraíso perdido, p. 48.

${ }^{134}$ Mensagem dirigida em 7 de setembro de 1907 ao Congresso Legislativo do Pará pelo Dr. Augusto Montenegro Governador do Estado. Belém: Imprensa Oficial, 1907, p. 5.
} 
lhes permitissem "aproveitarem e desenvolverem o precioso dom com que nos mimoseou a natureza". ${ }^{135}$

Dentro dessas preocupações sobre as transformações que deveriam ser processadas na natureza amazônica, em 1913, Severino Silva escreveu no Rio de Janeiro um texto, intitulado "Visão da Amazônia", publicado no ano seguinte pela Folha do Norte. Nesse trabalho, fica evidente a influência de Euclides da Cunha nas observações do autor sobre a Amazônia, quando se referiu à paisagem da região como um "imprevisto de anarquia e desordem geológica” e qualificou os rios como um “cosmos imperfeito e impreciso”, que parecia fugir à “sistematização regular das leis e postulados da hidrografia”. Do mesmo modo, quando concluiu, como Euclides da Cunha, que a Amazônia, com os seus rios, estava como a "desafiar a cultura dos eternos pesquisadores e oferecer espaço à criação de teorias e sistemas cientificamente reformadores (...), império tangível do infinito e do assombro". ${ }^{136}$

Apesar da pouca originalidade do pensamento de Severino Silva, num ponto, ele foi além de Euclides da Cunha; é numa espécie de certeza que teve de que seria possível transformar a região, a partir de seus recursos naturais, desde que para isso existisse ajuda dos administradores do Brasil. Das observações de Severino Silva, em contradição com sua própria fala anterior que evidenciava a monotonia da floresta, destacava-se uma Amazônia que, em suas palavras, era "maravilhosa, rica, generosa de mais para que morra à mingua sem o conforto dos atuais administradores do país”:

"Foi no entanto, a Amazônia com seu vale imenso, chato e ubertoso, a região farta e magnimamente galardoada em benesses pela prodigalidade da Natureza. No espaço, no solo desigual confuso e complexo, no subsolo abundante e inexplorado, enceleram se recursos, criminosamente deixados a um descaso impatriótico. Minguam iniciativas apreciáveis (...). A flora é a beleza majestosa, a desafiar o braço explorador, que a converta em ouro". ${ }^{137}$

Alguns meses depois, Severino Silva, em conferência proferida na sede da Associação do Comércio do Pará, diante da grave crise econômica, fruto do fim do monopólio da produção da borracha pela Amazônia, historiava os abusos, que os recursos naturais da floresta haviam sofrido na retirada desenfreada do látex.

\footnotetext{
${ }^{135}$ Mensagem dirigida em 7 de setembro de 1907 ao Congresso Legislativo do Pará pelo Dr. Augusto Montenegro Governador do Estado. Belém: Imprensa Oficial, 1907, p. 5.

${ }^{136}$ Folha do Norte. Belém, 6 de janeiro de 1914, p. 1.

${ }^{137}$ Idem.
} 
Afirmava que não havia "fenômeno isolado na Natureza" e que, portanto, se vivia naquele momento as conseqüências dessa "corrida cega e precipitada à selva guardadora de uma riqueza preciosa”. De acordo com Severino Silva, na visão de seringueiros e proprietários, a hévea era de "leite pródigo e eterno”, e por essa razão fazia parte da extração do látex o “cortar árvores brutalmente, arruiná-las, devastar estradas inteiras, arrancando o liquido generoso, esgotando”. Assim, “ninguém curou de estudar a atividade, os segredos biológicos da árvore de ouro, nem de protegê-la”. 138

Ao contrário do que pensava o conferencista, não se pode afirmar que não houve nenhum tipo de estudo sobre a seringueira, ou que não houve preocupação com o fim dessa riqueza natural, a julgar pelos pronunciamentos dos poderes públicos ou de trabalhos como os de Jacques Huber, acima mencionado. Ou ainda do trabalho de Theodoro Braga, de 1911, sobre o município de Breves, em que esse autor, a partir de documentos oficiais, dedicou uma parte de seu estudo às plantações de seringueiras. ${ }^{139}$

Apesar disso, não resta dúvida de que houve muita devastação na coleta do látex. A redenção para o Pará, diante da crise, era justamente, para Severino Silva, encontrada na implementação da agricultura e, igualmente, na valorização de recursos naturais que, ao lado da seringueira, poderiam ser utilizados, por exemplo, em manufaturas. Além disso, para o “futuro da Amazônia”, não deixava de fazer referência aos minérios, às pedras preciosas, à pecuária, atividades que poderiam gerar prosperidade.

Acostumados a vermos uma Amazônia que, em 1914, era ainda conhecida pela borracha, apesar da crise que cercava essa atividade, vale destacar os outros recursos naturais de que falava Severino Silva e que, em sua visão, deveriam ser melhor explorados. O articulista asseverava que "a flora paraense seria o bastante” para, através da exportação "enriquecer o estado empobrecido e quase esgotado". Os “representantes mais valiosos” dessa flora, além da seringueira, seriam:

\footnotetext{
${ }^{138}$ Folha do Norte. Belém, 8 de maio de 1914, p. 1.

${ }^{139}$ Cf. BRAGA, Theodoro. O município de Breves (1783-1910). Monografia organizada com o estudo feito sobre documentos oficiais e obras vulgarizadas. Belém: Livraria Gillet de Torres e Comp., 1911. Uma boa leitura sobre as tentativas de "domesticação" das seringueiras é o trabalho de Warren Dean. Ver: DEAN, Warren. A luta pela borracha no Brasil: um estudo de História ecológica. São Paulo: Nobel, 1989.
} 
“(...), o cacau, a castanha, o buriti, a oferecer, no caule fibras para a manufatura têxtil e nos frutos precioso marfim vegetal, (...) as plantas oleaginosas, a andiroba, a ucuúba, a copaíba, tão primitivamente exploradas. (...). As próprias aningas malditas, um depósito de fibras preciosas. (...) as madeiras preciosas e fortes (...), além de faixa vastíssima de solo incultivado". ${ }^{40}$

Vale lembrar que as preocupações e queixas do articulista não eram novas. O Barão de Maracaju, em um opúsculo, já apresentava sua crítica com teor semelhante ao que, anos depois Severino Silva traria aos leitores da Folha do Norte, o que nos induz a pensar que possivelmente ele teria lido tais observações. Assim, o Barão de Maracaju, falando das riquezas da região em 1883, afirmava que essas eram tantas que era "impossível numerá-las” sem transformar seu trabalho em uma "Flora Amazonense". Cita como produtos do "reino vegetal": algodão, anil, baunilha, cana-de-açúcar, castanha, óleo de copaíba, cravo, cumaru, óleo de rícino, salsaparrilha, guaraná, gergelim, tabaco, estopa, piassaba, a sumaúma, o puxuri, "fibras vegetais", “óleos como o de andiroba (...) e finalmente, goma elástica, que quase por si só constitui a riqueza do Pará, e é de origem de sua prosperidade”. ${ }^{141}$

Voltemos a Severino Silva. Suas perspectivas evidenciam o que poderíamos chamar - com as devidas proporções, para não incorrermos em anacronismos - certa preocupação ecológica. Melhor dizendo, compreensão de que a floresta, se bem aproveitada, poderia gerar outras fontes de riqueza além da exploração da seringueira. Embora pareça que essa compreensão da importância da flora da região tenha se intensificado com a crise da borracha, que levava à busca de alternativas de produção, mesmo antes disso, foi-se delineando um discurso que procurava descrever a região como um espaço de natureza bela e fértil, capaz de atrair visitantes, negociantes, imigrantes estrangeiros.

Essas preocupações se justificavam diante de uma imagem negativa, que - segundo alguns discursos dos poderes públicos paraenses - havia se criado da região. Em 1892, o governador do Pará, Lauro Sodré, lamentava uma imagem que se tinha do Pará, “fora do país e dentro dele nos estados do sul”, em que esse Estado figurava como "a região de todos os males, como a zona da terra eleita para morte". O principal elemento a gerar esses "falsos testemunhos" sobre o Pará, que tanto revoltavam o governador, era o clima. As preocupações com o clima da região eram bem presentes na imagem que se construía desse espaço. Antonio

\footnotetext{
${ }^{140}$ Folha do Norte. Belém, 12 de maio de 1914, p. 1.

${ }^{141}$ Barão de MARACAJU. A Amazônia. As províncias do Pará e Amazonas. Lisboa: Typographia Minerva, 1883, p. 20.
} 
Ladislau Monteiro Baena, por exemplo, já tratava de descrevê-lo nas primeiras décadas do século XIX, no seu Ensaio Corográfico sobre a Província do Pará. Para esse autor, os rios, os ventos, as chuvas, as selvas, contribuíam para que o clima da região fosse "não só apto para a vida, mais ainda propício à longevidade”, uma vez que muitos moradores em “diversos pontos da província” haviam "sucumbido ao peso da consumada velhice". ${ }^{142} \mathrm{Na}$ visão de Lauro Sodré, a solução para essa uma imagem destorcida da região estava no que ele chamava de "propaganda incansável e racional” e, por outro lado, no próprio "testemunho dos sábios e viajantes" que tinham passado pela região, prova de que o clima não era tão intolerável como se havia propagado. ${ }^{143}$

As mesmas queixas de Lauro Sodré são encontradas em Paes de Carvalho, que considerava uma “infundada opinião" a idéia divulgada sobre o clima do Pará como "insalubre e incompatível com as condições de vida do europeu”. Desse modo, em 1897, quando de sua posse ao governo do Pará, em um "Manifesto" encaminhado aos seus "concidadãos”, em meio ao seu programa de governo que constava de preocupações com a Educação, a produção, e a imigração, estava também a meta de se modificar a imagem do clima da região, entendida como um verdadeiro "empenho patriótico”, uma vez que, para Paes de Carvalho, essa imagem retardava "o progresso do Pará". ${ }^{44}$

Como governador empenhado na obra de consolidação da República no Pará, iniciada por Lauro Sodré, Paes de Carvalho acusava até o Império de ter contribuído para a imagem negativa do clima da região, repetindo, "sem protestos”, inverdades. Seja lá como fosse, tanto Sodré como Carvalho acreditavam no poder de instrumentos de divulgação como “publicações conscienciosamente feitas”, para o conhecimento da região, visando à mudança daquela imagem. ${ }^{145}$

${ }^{142}$ BAENA, Antonio Ladislau Monteiro (1782-1850). Ensaio corográfico sobre a Província do Pará. Brasília: Senado Federal, 2004, p. 30. Sobre o clima ler o terceiro capítulo, "A maldição dos trópicos", de GUILLEN, Isabel Cristina Martins. Errantes da selva.

${ }^{143}$ Mensagem Dirigida pelo Senr. Goverandor Dr. Lauro Sodré ao Congresso do Estado do Pará em sua segunda reunião em $1^{\circ}$ de julho de 1892. Belém: Typ. do Diário Official, 1892, p. 22.

${ }^{144}$ Manifesto ao Estado do Pará pelo governador Dr. José Paes de Carvalho. Belém: Typ. do Diário Oficial, 1897, p. 7.

${ }^{145} \mathrm{Na}$ sua Mensagem de abril 1899, Paes de Carvalho fazia referência aos "interessantes trabalhos que a aptidão devotada do ilustre Sr. Coudreau tem produzido (...). Ele como europeu, é um protesto irrespondível contra o falso juízo referente à insalubridade do nosso território". A Exposição Universal de 1900, também é lembrada pelo governador pela possibilidade de "exibição de espécies 
Em 1898, a Folha do Norte fazia referência às incursões do major Rocha dos Santos, em Portugal, na divulgação de mapas, impressos em "várias línguas”, com as observações meteorológicas feitas no observatório de Manaus. Ele, que era redator do Comércio do Amazonas e deputado ao Congresso do Amazonas, era lembrado no jornal português Diário da Manhã, em função de seu empenho em prestar informações, visando a tornar “conhecidas" na Europa "as riquezas e as condições climatéricas" da "vasta e opulentíssima” Amazônia. ${ }^{146}$

Reproduzindo um pequeno trecho do jornal português, a Folha do Norte mostrava um pouco do que se dizia sobre o clima da região amazônica: “- Mas são insalubres essas terras, o calor é insuportável por lá - diz-se vulgarmente na Europa”. A propaganda do major, objetivava demonstrar um progresso “assombroso” experimentado pela região. A Folha do Norte acreditava que com essa sua mensagem, o major prestaria tanto um serviço ao estado do Amazonas como também aos portugueses que desejassem emigrar para a região. Tratava-se, assim, tal qual buscavam fazer as autoridades paraenses, de se "desfazer", conforme assinalava a imprensa do estado, um "juízo errôneo”, uma “absoluta inexatidão” divulgada sobre a Amazônia. ${ }^{147}$ Diante dessas mesmas preocupações, o governo do Pará em 1900, em comemoração ao $4^{\circ}$ centenário dos descobrimentos publica um trabalho intitulado $O$ Pará em 1900, em que diversos intelectuais que viviam em Belém, escrevem suas impressões sobre doenças, população, aspectos geográficos da região, e também sobre o clima. Assim, em um texto intitulado "Notícia sobre a Meteorologia e Climatologia Médicas do Estado do Pará”, o Dr. Gonçalo Lagos buscou demonstrar que no Pará, alguns fatores como a topografia do terreno, as chuvas "quase cotidianas" e os ventos, contribuíam para “amenização, constância e salubridade do seu clima”. ${ }^{148}$ Não só ao estudioso do clima, mas também aos outros que escreveram no 'Pará em 1900', cabia a missão de se demonstrar para

de nossos produtos extrativos, agrícolas e manufatureiros". Mensagem dirigida ao Congresso do Estado pelo Dr. Paes de Carvalho governador do Estado em 7 de abril de 1899. Belém: Typ. do Diário Oficial, 1899, p. 50. A editora Itatiaia na coleção "Reconquista do Brasil" publicou as pesquisas de Henri Coudreau. Ver: COUDREAU, Henri (1859-1899). Viagem ao Xingu. Belo Horizonte: Itatiaia; São Paulo: EDUSP, 1977. COUDREAU, Henri (1859-1899). Viagem ao Tapajós. Belo Horizonte: Itatiaia; São Paulo: EDUSP, 1977.

${ }^{146}$ Folha do Norte. Belém, 15 de setembro de 1898, p. 1.

${ }^{147}$ Folha do Norte. Belém, 15 de setembro de 1898, p. 1.

${ }^{148}$ GOVERNO DO PARÁ. O Pará em 1900. Belém: Imprensa de Alfredo Augusto Silva, 1900. 
os brasileiros e também para outros países a imagem de um estado que progredia, que não era insalubre e que poderia caminhar nas sendas da civilização

O debate a respeito do clima não ficaria restrito, entretanto, ao século XIX, quando mais explicitamente o governo empreendia um projeto de colonização pensado com o trabalho de imigrantes estrangeiros, ou quando se buscava na nascente República combater a imagem de insalubridade da região, dando-lhe características mais modernas. Em 1915, o discurso era praticamente o mesmo, a ponto de se falar da imagem negativa do clima da região como " $A$ lenda perversa”. Assim, em março de 1915, a Folha do Norte trazia estampada em sua primeira página, em letras grandes, tomando quase todo o espaço, para chamar a atenção do leitor, a transcrição de uma conferência, proferida na Sociedade Médico Cirúrgica do Pará, pelo Dr. Arthur França, que visava a “restabelecer a verdade, tão impatrioticamente deturpada sobre as excelências do clima amazônico". ${ }^{149}$

O tempo havia passado, a borracha já não era um produto importante no mercado internacional e a Amazônia vivenciava os problemas decorrentes dessa perda, mas a descrição e o pensamento do Dr. Arthur França dão conta de expressar uma continuidade no olhar que se lançava sobre a região, descrevendo-a como de "mau clima":

“Não sei de clima mais difamado do que o desta esplêndida região amazônica: repudia-o o estrangeiro presumido desconhecedor da nossa terra, maldizem-no os nossos irmãos do Sul, muitos dos quais, por temor das viagens para estas bandas, o julgam através das narrativas apressadas e fantásticas dos que aqui chegam apavorados, ávidos da volta, cuja precipitação, não raro se justifica num surto de imaginação fabuladora". ${ }^{150}$

Visando a fortalecer seus argumentos contra essa "lenda perversa” sobre o clima, o Dr. Arthur França demonstrava, em sua fala, que na região norte do Brasil, "apenas a malária” tinha característica das “verdadeiras endemias". Mas o principal argumento eram as indagações que, na verdade, queriam afirmar que, em outros países, considerados civilizados, também existia uma variedade de doenças. Desse modo, assim perguntava o Dr. Arthur França, referindo-se à malária: “Não a tem mortífera a Itália, a Grécia e outros países? E por ventura é o nosso impaludismo mais terrível que a escarlet-fever na Inglaterra ou a febre tifóide na França?". ${ }^{151}$

\footnotetext{
${ }^{149}$ Folha do Norte. Belém, 21 de março de 1915, p. 1.

${ }^{150}$ Folha do Norte. Belém, 21 de março de 1915, p. 1.

${ }^{151}$ Folha do Norte. Belém, 21 de março de 1915, p. 2.
} 
A preocupação com o que se dizia da região era muito presente na Amazônia, pois acreditava-se que o progresso desse espaço se construiria também mudando-se a imagem da insalubridade que há muito tempo se tinha, dando destaque para outros características que compunham o espaço amazônico. Em 1899, por exemplo, Paes de Carvalho gostaria que o Pará fosse conhecido, de acordo com suas próprias palavras, como uma "região próspera, e futurosa, como povo civilizado, industrial e progressivo”. Em síntese, naquela ocasião, o governador concluía, que "era preciso tornar conhecido o maravilhoso solo do Pará". ${ }^{152}$ Anos mais tarde, em 1916, em meio a uma grave crise econômica, o governador Enéas Martins exaltava o Estado do Pará, e também como seus antecessores, buscava valorizar algumas de suas características, como a "vasta extensão territorial”, o "solo fértil adaptável a numerosas culturas”, o “clima dos mais propícios” e a "flora de inúmeros vegetais notáveis pelo seu valor econômico”. ${ }^{153}$

Essa visibilidade dos recursos naturais, em finais do século XIX, se tornava cada vez mais presente na construção da imagem positiva que se pretendia construir para a região, em resposta à idéia da insalubridade. Em "Fotografias do Pará", série de cinco textos publicados na Folha do Norte em 1898, quando Paes de Carvalho era o governador, Álvares da Costa buscava justamente demonstrar a viabilidade da exploração dos recursos naturais do Pará. Diante disso, fazia uma comparação entre o que existia na natureza de Paris, e que tanto deslumbrava os seus visitantes com "seus bosques parques e squares, em que a Arte supre a natureza”, e alertava que o Pará, que possui uma "flora invejável”, bem que poderia impressionar os estrangeiros que nos visitavam. ${ }^{154}$ Do mesmo modo, em um pequeno texto também publicado na Folha do Norte, encontramos uma exortação às utilidades do cacaueiro, chamado de "pau para várias obras", em virtude de sua utilidade na fabricação de chocolates, geléias, vinho, sabão medicinal, sabão comum, e que no Pará crescia, no dizer da Folha do Norte, “a barba longa e bons resultados”. 155

\footnotetext{
${ }^{152}$ Mensagem dirigida ao Congresso do Estado do Pará pelo Dr. José Paes de Carvalho Governador do Estado em 15 de Abril de 1899 apresentando a proposta de orçamento da receita e despesa para o exercício de 1899. Belém: Typ. do Diário Official, 1899, p. 50.

${ }^{153}$ Mensagem dirigida em 1 de agosto de 1916 ao Congresso Legislativo do Pará pelo Dr. Enéas Martins Governador do Estado. Belém: Imprensa Oficial do Estado do Pará, 1916, p. 93.

${ }^{154}$ Folha do Norte. Belém, 10 de março de 1898, p. 1.

${ }^{155}$ Folha do Norte. Belém, 9 de janeiro de 1901, p. 2.
} 
Dentre as ações voltadas para a valorização dos recursos naturais no Pará, temos ainda a instituição das festas do Dia da Árvore, em 1911, pelo governador João Coelho. As escolas seriam, então, o espaço propício para essa prática, que ia se consolidando, tomando o exemplo de outros países considerados modernos. O governador João Coelho argumentava que essas cerimônias faziam parte de uma "tradição honrosa nos grandes países cultos da atualidade". ${ }^{156}$

As idéias do governador João Coelho podem ser aproximadas dos estudos de Eric Hobsbawm sobre tradições inventadas, uma vez que no Pará, a festa era uma prática formalmente institucionalizada, que, como evidenciam as cerimônias, visava a "inculcar certos valores e normas de comportamento através da repetição”, elementos constituidores de uma tradição daquela natureza. Nesse sentido, o autor afirma que "provavelmente não há lugar nem tempo investigados pelos historiadores onde não haja ocorrido a invenção de tradições”. Entretanto, Hobsbawm lembra que essas invenções ocorrem com mais freqüência quando há uma transformação rápida na sociedade. ${ }^{157}$ No caso do Pará, as mudanças na Economia da borracha, aliadas à preocupação com a Agricultura e também a um ideal de modernidade para o Pará, levaram a essa “invenção" da Festa da Árvore.

Embora se demonstre uma preocupação com a flora paraense, a seringueira, na visão do governador, deveria se constituir em "verdadeiro culto nessas festas”, uma vez que a hévea era a "principal razão econômica, a primeira condição da nossa prosperidade material”. Apesar da importância da seringueira, João Coelho advertia que essa cultura não poderia “induzir a um fanatismo e exclusivismo absurdo". ${ }^{158}$ Em 1911, quando a Economia da borracha experimentava uma grave crise, as preocupações do governador eram pertinentes. Em seu Relatório, ele lembrava que o Pará tinha terra e clima propícios para produção de cacau, castanha, frutas e cereais. Além disso, buscava estimular o plantio até mesmo da

\footnotetext{
${ }^{156}$ Mensagem dirigida em 7 de setembro de 1911 ao Congresso Legislativo do Pará pelo Dr. João Antônio Luiz Coelho Governador do Estado. Belém: Imprensa Oficial do Estado do Pará, 1911. p. 134.

${ }^{157}$ HOBSBAWN, Eric "Introdução: A invenção das tradições". In: HOBSBAWN, Eric \& RANGER, Terence (orgs.). A invenção das tradições. Rio de Janeiro: Paz e Terra, 1984, pp. 9-12.

${ }^{158}$ Mensagem dirigida em 7 de setembro de 1911 ao Congresso Legislativo do Pará pelo Dr. João Antônio Luiz Coelho Governador do Estado. Belém: Imprensa Oficial do Estado do Pará, 1911, p. 134.
} 
própria seringueira. ${ }^{159}$ A prática já iniciada no governo de Augusto Montenegro, com a constituição de estações experimentais para a produção de mudas para serem plantadas, dão conta de expressar as preocupações nesse sentido.

Por ocasião da Festa da Árvore, em junho de 1914, realizava-se em Belém, no campo de cultura experimental, instalado ao lado do Instituto Lauro Sodré, uma grande festa que contava com a presença de alunos de escolas municipais, estaduais e particulares, além de um grande número de autoridades locais. Essa cerimônia, chamada pela Folha do Norte de “celebração oficial da festa da árvore”, revelava-se propícia para o fortalecimento do patriotismo, do amor ao Pará. Iniciada com o "Hino nacional em homenagem à felicidade do Brasil, sob os auspícios da agricultura", além dos discursos, da recitação de "várias poesias alusivas à árvore recitadas por alunos", e do "hino à árvore”, o ponto alto dessa solenidade seria a plantação de algumas árvores. Vinte coqueiros, quatro palmeiras jarinas e duas laranjeiras japonesas, que buscavam homenagear, entre outros, homens como o Dr. Jacques Huber, já falecido na ocasião, que, como diretor do Museu Goeldi, buscava estudar a fauna e a flora da região, dedicando parte desses seus estudos à seringueira. ${ }^{160}$

A festa, que era organizada pela "Comissão de Defesa Econômica da Amazônia", demonstrava claramente o interesse na valorização da flora paraense, mas, ao mesmo tempo, era o momento de se homenagear homens, instituições e acontecimentos considerados importantes para a História do desenvolvimento econômico do Pará. Num momento de crise, em que a economia da borracha entrava em decadência, as autoridades locais buscavam encontrar na natureza regional outros elementos capazes de despertarem na juventude o ufanismo pelo Pará, capazes de aguçarem o interesse pelas muitas riquezas naturais.

Nesse mesmo dia, como que tomando carona nas festividades do Dia da Árvore, outros escritos sobre o tema apareciam na imprensa, a exemplo da poesia "As Árvores” de Marques de Carvalho ${ }^{161}$ Um outro texto, com semelhante título era "A árvore”, de Remígio Fernandez, que lembrava que não era de "criação recente" o culto à árvore, mas uma prática presente na História da humanidade. Além disso, fazia referência, já em 1914, ao fato de que a demanda

\footnotetext{
${ }^{159}$ Mensagem dirigida em 7 de setembro de 1911 ao Congresso Legislativo do Pará pelo Dr. João Antônio Luiz Coelho Governador do Estado. Belém: Imprensa Oficial do Estado do Pará, 1911, p. 135.

${ }^{160}$ Folha do Norte. Belém, 7 de junho de 1914, p. 1.

${ }^{161}$ Folha do Norte. Belém, 7 de junho de 1914, p. 1.
} 
das indústrias levava a um "abatimento das árvores” em "progressão assustadora”, que impôs a criação de "leis proibitivas e penas para impedir devastações". ${ }^{162}$

Em 1915, as festividades da árvore se repetiam e o governador Enéas Martins, em seu Relatório anual, fazia referência às plantações feitas durante as solenidades. Dessa vez, as espécies da flora semeadas eram de árvores que já se plantavam havia muito tempo como o cacaueiro, de árvores como as seringueiras, ainda na busca por domesticar, mas também de “espécies jamais cultivadas”, que, segundo o governador, poderiam ser "fonte de produtos novos para a indústria" e que possuíam, de acordo com Enéas Martins, "todo o interesse da originalidade”. Para ele, a “policultura”, com produtos da “própria natureza silvestre”, poderia ser a chave para se colocar a Amazônia mais uma vez na concorrência dos mercados mundiais. $^{163}$

Se a mudança no mercado internacional da borracha acarretou grandes perdas para a economia local, ela também foi responsável pela busca de outras alternativas de produção. Além do mais, levou a uma compreensão de que os recursos naturais da floresta eram falíveis, e o que é mais importante, delineou uma preocupação com os perigos do desflorestamento. Essa compreensão não era compartilhada por todos os segmentos que compunham a sociedade paraense desse período, mas sobretudo por uma parcela mais letrada da população, como os governadores e intelectuais que escreviam na imprensa.

Os grupos preocupados em administrar essa terra, ou preocupados com o seu futuro, começavam a perceber - embora suas ações nem sempre correspondessem a suas falas que, para além da imagem de "Eldorado" ou de insalubridade, tão presentes nas formas de se entender a Amazônia, existia um espaço ainda desconhecido que precisava ser cultivado e explorado e que guardava bem mais riquezas do que a já saturada goma elástica.

Redescobrir essa terra era provavelmente o desafio a que esses homens se lançavam. Redescobrir também essa terra, e reconstruir sua vida, plantando, ou explorando recursos naturais da floresta, também foi o desafio imposto a um grande número de cearenses. Entendendo o Pará a partir de seus próprios interesses, sonhos e memórias, esses migrantes aportaram no Estado e nele construíram sua própria História.

\footnotetext{
${ }^{162}$ Folha do Norte. Belém, 7 de junho de 1914, p. 1.

${ }^{163}$ Mensagem dirigida em 1 de agosto de 1915 ao Congresso Legislativo do Pará pelo Dr. Enéas Martins Governador do Estado. Belém: Imprensa Oficial do Estado do Pará, 1915, p. 49.
} 


\section{A saída do Ceará e a chegada ao Pará}

\section{“Homem ao mar! Homem ao mar!”}

Foi com este brado, de acordo com a versão publicada na Folha do Norte, que por volta de 8 horas da noite de 18 de abril de 1898, alguns passageiros do vapor Brasil - que havia saído do porto do Ceará, e na ocasião parara em frente da povoação de Mosqueiro, bem próximo da cidade de Belém do Pará - se deram conta de que o cearense Mariano José de Sousa ("moço ainda”, contando com “cerca de trinta anos de idade”) havia se atirado na água.

Não do mar, como gritaram os companheiros de infortúnio de Mariano, mas do rio, de água meio doce e salobra, marcando o primeiro e o último contato dele com a Amazônia. Essa história, que no jornal Folha do Norte ganhou destaque por vários dias, foi narrada na redação desse periódico pela viúva de Mariano, Maria Izabel do Espírito Santo, “cujo aspecto compungia aos mais empedernidos", que antes de passar no escritório do jornal, "havia estado na polícia”, para registrar o que acontecera a bordo do vapor. ${ }^{1}$

A viúva Maria Isabel contou no escritório da Folha do Norte que ela e os filhos do casal (o mais velho, com cerca de 5 anos) acompanhavam Mariano, que havia sido “contatado” por Luiz Antonio Rodrigues, "negociante do rio Purus", para fazer "parte da turma de trabalhadores por este empregada ali, na extração da goma elástica”. Segundo o jornal, "animado pelas mais belas esperanças", Mariano deixou sua terra natal "quase sem saudades”, diante da possibilidade de uma vida melhor, que o trabalho na Amazônia poderia garantir para a família. Entretanto, o desfecho da história de Mariano foi outro, bem diferente daquele sonhado por ele. ${ }^{2}$

O vapor Brasil, quando saiu do Ceará, "trazia número de passageiros superior a sua lotação”, aportando em Belém com 1527 pessoas. Ao longo da viagem, conforme contaram vários passageiros, a comida foi "se tornando escassa (...) sobretudo para os passageiros de proa”, caso de Mariano e sua família. Diante disso, em pouco tempo "acampou a fome com todos os seus horrores”. Para minimizar a situação dos filhos e da mulher, "louco de desespero", Mariano, segundo a viúva Maria Izabel, foi até à cozinha do vapor e "pediu ao

\footnotetext{
${ }^{1}$ Folha do Norte. Belém, 19 de abril de 1898, p. 2.

${ }^{2}$ Folha do Norte. Belém, 19 de abril de 1898, p. 2.
} 
cozinheiro que lhe valesse, dando-lhe qualquer coisa para os seus”. O cozinheiro, por sua vez, "estava mal humorado", provavelmente em conseqüência dos tumultos e reclamações dos passageiros que estavam com fome, e até mesmo água “começou a faltar a bordo”, e ameaçou Mariano com uma “chaleira de água a ferver”. Mariano pensou em reagir à humilhação e aos insultos sofridos, chegou até a "lançar mão de uma faca, mas conteve-se". Segundo o jornal, a “idéia da família desarmou-lhe o braço”. Desde esse episódio, entretanto, pouco a pouco, Mariano foi vivendo num estado de "indiferença, profunda e gélida”. O desenlace foi o suicídio, antes de chegar ao porto de destino. ${ }^{3}$

Tomando o trágico fim de Mariano como exemplo, adentramos no universo das viagens dos migrantes para a Amazônia. Ao mesmo tempo, percebem-se os sentidos que estes davam a seu deslocamento do Ceará. No caso de Mariano e sua família, fica evidente que a seca de 1898 os trazia para região amazônica com a promessa de melhoria de vida proporcionada pelo trabalho na extração da borracha, como muitos dos passageiros da sinistra viagem do vapor Brasil. Sobre essa seca Rodolpho Theophilo lembra que "alguns mil retirantes mendigavam em Fortaleza", sem que o governo lhes prestasse assistência. Nesse contexto a migração para o Pará aparecia como a alternativa de sobrevivência. De acordo com o autor sem essa migração "teria morrido muito gente". Assim, se de um lado isso fica evidente, de outro, aspectos diferentes desse processo de migração também vão sendo apontados. É o caso da importância que a família tinha na vida de Mariano. Em toda a narrativa publicada na Folha do Norte, as ações de Mariano são destacadas, dando-se ênfase aos seus cuidados com mulher e filhos. Desde sua saída do Ceará, os desentendimentos com o cozinheiro em busca de comida e o próprio suicídio, coroamento do fracasso como chefe de seu grupo familiar, vemos Mariano no papel de provedor da família.

Ora, se na historiografia sobre o tema privilegiou-se a imagem do homem solitário, preso à floresta, as ações e significados dados pelos migrantes em seu processo de saída do Ceará, a exemplo do caso aqui citado, indicam que não só de homens que embarcaram sozinhos foi feita a migração para o Pará. Ao contrário disso, a família nuclear ou outros arranjos familiares sempre estiveram presente nos vapores que partiam do Ceará entre finais do século XIX e início do século XX. Além disso, a história de Mariano revela igualmente as redes de

\footnotetext{
${ }^{3}$ Folha do Norte. Belém, 19 de abril de 1898, p. 2.

${ }^{4}$ TEOPHILO, Rodolpho. A seca de 1915. Fortaleza: Moderna, 1919, pp. 11-12
} 
solidariedade que são construídas nesse contexto de migração, e até mesmo a atividade caritativa que se estabelece, diante da preocupação com um grande número de pessoas, que chegavam, nos períodos de seca intensa no Ceará, quase que diariamente ao porto de Belém. Passageiros em sua maioria como os de proa do vapor Brasil, descritos na Imprensa como de aparência "andrajosa, esquálida e faminta". 5

Essa realidade social, entre 1888 e 1916, fazia com que os próprios migrantes, a população paraense em geral e os poderes públicos se envolvessem nesse processo, buscando alternativas de ajuda para os recém-chegados. Doação de alimentos, de roupas, de remédios, de brinquedos, distribuição de esmolas, busca de trabalho nos núcleos coloniais, vacinação, internamento de doentes em hospitais são ações constantes em Belém, visando à manutenção da ordem e da disciplina, diante da chegada de tantas pessoas à capital paraense.

Além disso, as teorias higienistas, o medo dos miasmas, a constante ameaça de doenças como a febre amarela e a peste bubônica, na virada do século XIX, deixavam as autoridades locais e a população em alerta, quando no Pará corria a notícia de mais uma seca no Ceará. Nesse contexto, não resta dúvida, o medo dos aglomerados de uma multidão de desocupados, a necessidade de mão-obra e, aliada a tudo isso, uma obrigação da caridade cristã ou um sentimento caritativo humanitário - cultuado pelos grupos letrados como sinônimos de civilização - deram a tônica das ações dos poderes públicos paraenses, bem como da sociedade local, em relação aos migrantes cearenses quando de sua chegada a Belém.

$\mathrm{O}$ caso de Mariano parece ter de fato, mobilizado a população da capital, uma vez que segundo a Folha do Norte, esse homem suicidou-se, "enlouquecido de fome em meio de gente civilizada" ${ }^{6}$ Ora, não era novidade para os paraenses a notícia dos horrores da seca, de suas muitas mortes em decorrência da ausência de chuvas, dos atos de desespero dos famintos; o que chocou a população foi, provavelmente, o fato de o suicídio ter acontecido já em terras paraenses. Isto porque o Pará, desde a grande seca se 1877, era representado como um espaço onde os fugitivos da aridez do sertão encontrariam um alívio para seus males. Além disso, numa cidade como Belém, sem grandes atrativos, sem grandes novidades, essa morte era, de fato, um assunto para ser bem comentado, e a Imprensa local sabia disso.

\footnotetext{
${ }^{5}$ Folha do Norte. Belém, 19 de abril de 1898, p. 2.

${ }^{6}$ Folha do Norte. Belém, 19 de abril de 1898, p. 2.
} 
A primeira notícia que sai sobre o caso vem com o sugestivo título de "Um caso horroroso a bordo do vapor Brasil". ${ }^{7}$ Com essa chamada, não era de se admirar que "logo nas primeiras horas do dia”, estivesse "quase esgotada a edição da Folha”. Assim, de acordo com o jornal, a morte de Mariano "impressionou dolorosamente o espírito público despertando nele o sentimento da mais justa compaixão". ${ }^{8}$ Ainda no vapor, os passageiros de ré “abriram” uma "subscrição" em nome da viúva e dos órfãos, cujo valor obtido foi de 107\$000. ${ }^{9}$ A partir daí, a própria Folha do Norte inicia uma campanha, incentivando a população a prestar ajuda à família de Mariano. ${ }^{10}$

Diante disso, ao nos determos em analisar a saída dos migrantes do Ceará ao Pará, alguns pontos nos parecem fundamentais para o entendimento dessa questão. O primeiro deles é os motivos que levavam ao êxodo; se as conseqüências das secas que periodicamente assolaram o Ceará entre 1888 e 1916 podem ser entendidas como o principal fator para esse deslocamento de pessoas, outros elementos como o incentivo à agricultura pelo poder público paraense, aliado ao ideário das terras abundantes, representadas na extração do látex, também contribuíram para isso.

Nesse sentido, vale uma incursão pelas ações dos poderes públicos, do Ceará e do Pará, juntamente com uma análise dos sentidos que os migrantes davam a seu próprio deslocamento. Isso nos permite visualizá-los, indicar suas origens, os trâmites para adquirir a passagem, e a viagem propriamente dita, do Ceará ao Pará. Se muitas vezes essa passagem nos vapores foi dada pelo poderes públicos do Ceará, e até mesmo do Pará, não raro, eram os migrantes que, por conta própria, pagando com seus parcos proventos, embarcavam rumo ao seu destino; ou existiram também aqueles, como foi o caso de Mariano, que vinham com uma passagem financiada por um dono de seringal que o contratava.

Assim, decifrar o desenrolar dessas viagens permite igualmente falarmos dos homens, mulheres, velhos e crianças que desembarcavam no porto de Belém. Não se pode esquecer que o impacto da migração era tão grande na cidade de Belém a ponto de se criarem instituições de ajuda a esses recém chegados à cidade, como a “Associação Humanitária Liga

\footnotetext{
${ }^{7}$ Folha do Norte. Belém, 19 de abril de 1898, p. 2.

${ }^{8}$ Folha do Norte. Belém, 20 de abril de 1898, p. 2.

${ }^{9}$ Folha do Norte. Belém, 19 de abril de 1898, p. 2.

${ }^{10}$ Ver Folha do Norte, dos dias 20, 22, 23, 24 de abril de 1898, p. 2.
} 
Cearense”, criada em 1900, e a “Assistência aos flagelados da seca”, fundada em 1915. Trata-se de entender os muitos trâmites para a saída dos migrantes do Ceará, a viagem até Belém e, por fim, as ações construídas no Pará em função da chegada desses grupos.

\section{Poder público e migração}

Em 1904, João da Câmara, ao confeccionar o Almanach Administrativo Estatístico Industrial e Literário do Estado do Ceará para o ano de 1905, referiu-se à população desse estado afirmando que a inexatidão das estatísticas sobre o número de habitantes era decorrente da não regularização da lei que estabelecia o registro civil. Ao mesmo tempo, na tentativa de indicar um número aproximado dos moradores do Ceará, lembrava que, "apesar das consecutivas secas que determinaram o êxodo para o extremo norte", acreditava-se que essa população, nesses primeiros anos do século XX, não poderia "ser calculada em menos de um milhão". ${ }^{11}$

A contagem dos migrantes que saíram do Ceará e que aportaram em Belém entre 1888 e 1916 se torna difícil em função de os registros desses deslocamentos serem muito fragmentados. Um bom exemplo disso é o dos "Livros das Companhias de Vapores", que trazem as indicações dos embarques feitos no Ceará para os portos do Sul e do Norte, mas que dão conta apenas do final de 1888, e de alguns meses do primeiro semestre de 1889, quando, na verdade, ao longo de todo esse ano, registra-se a chegada de migrantes. O mesmo acontece com o livro da "Relação dos migrantes que se destinam aos portos do norte e sul em diversos vapores”, do ano de 1915, cujos registros circunscrevem-se aos meses de outubro, novembro e dezembro. $^{12}$

Note-se que estamos falando de registros dos períodos de seca. No entanto, há que considerar as saídas do Ceará nos períodos em que não ocorria a seca. Do mesmo modo, é preciso computar a vinda de pessoas que pagavam sua própria viagem, chegando muitas vezes a Belém, em períodos de seca, sem fazer parte dos grupos que tinham a passagem subsidiada e que eram esperados oficialmente pelas autoridades locais. Por ocasião da seca de 1889, o Ministério dos Negócios do Império enviou ao Presidente da Província do Ceará um ofício,

\footnotetext{
${ }^{11}$ Almanach Administrativo, Estatístico, Mercantil Industrial e Literário do Estado do Ceará para o

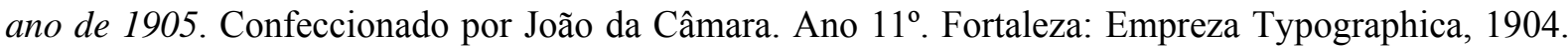
p.VIII.

${ }^{12}$ APEC - Livro da Companhia de Vapores 1888-1889; Caixa Relação dos emigrantes 1915 - Livro Relação dos emigrantes que se destinam aos portos do norte e sul em diversos vapores - 1915.
} 
solicitando providências relativas "à situação dos emigrantes” transportados para a Província do Pará em paquetes "nacionais s estrangeiros". 13

O que gerara tal solicitação teria sido um telegrama enviado ao Rio de Janeiro, pelo Presidente da Província do Pará, Miguel José de Almeida Pernambuco, que se via pressionado, em 1889, com “reclamações” publicadas na Imprensa local, pedindo providências quanto aos migrantes que chegavam ao porto de Belém. Nesse telegrama, Miguel de Almeida Pernambuco ressentia-se de que chegavam de surpresa em Belém flagelados cearenses, em "grandes levas (...) implorando a proteção e socorros do governo". Além disso, o Presidente da Província do Pará pedia que não viessem mais para esta Província “cearenses (...) em vapores estrangeiros”, uma vez que estes "desembarcavam inesperadamente”, não sendo possível lhes prestar socorros. ${ }^{14}$

Do mesmo modo, em julho de 1900, na coluna “Ecos e Notícias”, o jornal Folha do Norte fazia referência a algumas famílias de migrantes que haviam sido localizadas na Colônia Anita Garibaldi. Eram "37 famílias cearenses que se achavam no Castanhal sem meios de trabalhar". O motivo disso, segundo a Folha do Norte, era o fato de que esses flagelados pela seca tinham saído do Ceará “por conta própria”, sendo portanto ignorados pelo Inspetor de Terras. ${ }^{15}$ Alguns dias depois, a Folha do Norte tornava a anunciar cena semelhante com que se deparou mais uma vez o Inspetor de Terras, dessa vez no Largo do Palácio, em Belém. Tratava-se de "grande número de imigrantes, na sua maioria mulheres e crianças", que, sem o “conhecimento do governo", havia chegado a bordo do vapor "Belém”. Para espanto do Inspetor, os migrantes, "não tendo onde se recolher, ali acamparam”. Na ocasião, foi determinado pelo governador do Estado, Paes de Carvalho, que se lhes desse alimentação e, no outro dia, seguissem na "lancha Altiva”, especialmente para esse "fim fretada”, para o núcleo do Acará. ${ }^{16}$

Exemplos demonstram que mesmo nas situações mais adversas, os flagelados pela seca buscavam gerir seu próprio destino, pagando a própria passagem e deslocando-se do Ceará sem auxílio do Estado. No porto de destino, não ficavam igualmente passivos diante da

\footnotetext{
${ }^{13}$ APEC Ala 19, Estante, 407, $\mathrm{n}^{\circ} 11$ - Ministério do Império ao Presidente da Província do Ceará, avisos. 1889. Ministério dos Negócios do Império, $1^{\text {a }}$ Diretoria, $\mathrm{n}^{\mathrm{o}} 1307$ - Rio de Janeiro, 29 de março de 1889

${ }^{14}$ Idem.

${ }^{15}$ Folha do Norte. Belém, 23 de julho de 1900, p. 2.

${ }^{16}$ Folha do Norte. Belém, 27 de julho de 1900, p. 2.
} 
miséria. Note-se que os migrantes que estavam no núcleo de Castanhal, distante aproximadamente 75 quilômetros da capital paraense, depois de aportados em Belém, de algum modo, conseguiram uma passagem para chegar de trem até esse núcleo, seguindo um caminho que não era o dos seringais. O outro grupo, com as mulheres e as crianças, acampou num lugar bastante estratégico, por onde passavam muitas pessoas, a fim de serem vistos, sensibilizando os transeuntes e o próprio poder público paraense para suas necessidades. Em ambos os casos, mesmo considerando-se as dificuldades de se adaptar e viver em um núcleo colonial, e igualmente o que movia as ações dos poderes públicos, ou seja, a preocupação de logo encontrar trabalho para esses grupos, visando a ordem e disciplina, evitando os aglomerados na cidade, parece-nos que os migrantes atingiram seus objetivos. ${ }^{17}$

Deslocar-se do Ceará até Belém do Pará, entretanto, não era uma tarefa das mais fáceis, considerando-se que a viagem teria que ser feita de navio e implicava em muitos custos, que nem sempre eram viáveis para pessoas que saíam do Ceará em situação de extrema miséria. Aqueles que, atingidos pela seca, resolviam migrar juntamente com toda a família, às vezes até com agregados, tinham que enfrentar grandes gastos. A leitura atenta do "Livro da Companhia de Vapores" do ano de 1889 do Ceará, e da "Relação dos migrantes que se destinam aos portos do norte e do sul em diversos vapores" do ano de 1915 permite perceber a presença de grande número de famílias nucleares entre os grupos de migrantes. Buscando “fornecer alguns subsídios ao estudo da mobilidade espacial no Brasil do século XIX”, Maria Silvia C. Beozzo Bassanezi, no trabalho "Migrantes não Brasil da segunda metade do século XIX", utilizando-se de dados do "Livro da Companhia de Vapores" do Ceará, identifica que de “5.795 autorizações para a emissão de passagem marítima emitida pelas autoridades cearenses entre 1888-1889 (...) 91,6\% foram concedidas para grupos de duas ou mais pessoas, na sua grande maioria aparentados entre si”. ${ }^{18}$

\footnotetext{
${ }^{17}$ Analisando a imigração de italianos para São Paulo nas últimas décadas do século XIX, Esmeralda Bolsonaro adverte que, embora seja difícil deslocar a miséria das causas do êxodo, é importante que se focalize também esses deslocamentos num "ato que se inscreve também no processo de escolha de cada indivíduo"; essa questão destacada pela autora é importante como ponto de reflexão sobre a vinda de cearenses para o Pará. MOURA, Esmerada Blanco Bolsonaro de. "Imigrantes italianos em São Paulo na passagem para o século XX”. In: DEL PRIORE, Mary (org.). Revisão do Paraíso: os brasileiros e o estado em 500 anos de história. Rio de Janeiro: Campus, 2000, p. 238.

${ }^{18}$ BASSANEZI, Maria Silvia C. Beozzo. "Migrantes no Brasil na segunda metade do século XIX". Anais do XII Encontro Nacional de Estudos Populacionais da ABEP, Caxambu: ABEP, 2000, vol. 1, p. 15.
} 
Sem as passagens subsidiadas pelo governo do Ceará ou pelos poderes públicos dos portos de destino dos migrantes, ou até mesmo por agenciadores que buscavam trabalhadores para os seringais, como foi o caso de Mariano, essa viagem era praticamente impossível. As companhias de vapores só não cobravam passagens das crianças muito pequenas. Por ocasião da seca de 1888, por exemplo, a Companhia Brasileira de Navegação a Vapor, que fazia viagens entre portos do sul e do norte, chegava a cobrar a "passagem por inteiro de crianças de um ano para cima". ${ }^{19}$

Assim, "achar-se em estado de não poder pagá-las [as passagens]" é o que declararam alguns flagelados pela seca de 1889, a fim de conseguirem embarcar para a Província do Pará. Essa foi a justificativa apresentada pela Sra. Maria Xavier, de 50 anos, natural de Baturité, que, com seus filhos e netos, desejava encontrar seu marido, Manuel Soares, que já estava no Pará. Não ter "absolutamente meios" para fazer a viagem ao Pará "a sua custa” foi a declaração dada por Manuel Pereira de Melo, solteiro de 50 anos, que morava em Acarapé. Manuel, que era responsável por um grupo familiar formado por sua irmã e quatro sobrinhos e inclusive com sua mãe, que tinha 70 anos de idade, queria migrar para o Pará, mas não tinha meios para pagar sua passagem. ${ }^{20}$ Essa justificativa - embora bastante evidente, considerando a pobreza experimentada por esses grupos em tempo de seca - revela, entretanto, a idéia de que o retirante, se tivesse meios, pagaria sua própria passagem, não dependendo assim dos favores do Estado, que sempre considerava os gastos com passagens onerosos para os cofres públicos.

Os governantes cearenses, muitas vezes pressionados por produtores locais, não se mostravam favoráveis à saída de grande número de pessoas, uma vez que esse deslocamento implicava em retirar do Ceará parte da mão-de-obra que deveria ser empregada ali nos trabalhos da lavoura. Nesse sentido, em 1889, é enviada ao "Ministério dos Negócios do Império" uma "representação", assinada por diversos comerciantes da praça de Fortaleza, em que estes se mostravam "receosos" de que, com a seca, se promovesse a "emigração em massa como socorro definitivo à população indigente da província”. Desse modo, solicitavam providências ao governo para que os flagelados pela seca fossem admitidos em

\footnotetext{
${ }^{19}$ APEC - Ala 19, Estante 407, $\mathrm{n}^{\mathrm{o}} 35$ - Ministro dos Negócios da Agricultura, Comércio e Obras Públicas ao presidente da Província do Ceará, avisos. 1886 -1888 - Repartição Geral de Telégrafos. 5 de outubro de 1888. Telegrama $\mathrm{n}^{\circ} 685$.
}

${ }^{20}$ APEC - Caixa Governo da Província do Ceará. Ofícios - emigração. 1889. 
“trabalhos de utilidade pública”. No mesmo ofício em que comentava tal solicitação, o Ministério dos Negócios do Império pedia ao governo do Ceará que informasse àqueles que assinaram a "representação" que esse Ministério recomendava aos "presidentes das províncias flageladas" que não prestassem socorro em "esmolas", mas que inserissem os flagelados em atividades úteis à população, recebendo "salários". Somente em "último caso" é que as passagens deveriam ser fornecidas. ${ }^{21}$

Diante das muitas secas, o Ceará constantemente experimentava problemas com a mão-deobra para o trabalho na lavoura. Nos períodos de chuva, com a possibilidade de se levar a produção adiante, os governadores expressavam seu descontentamento com a saída da população. Foi o que aconteceu em 1893, quando o Coronel José Freire Bezerril Fontenelle, governador do Ceará, dirigindo-se à Assembléia Legislativa do Estado, sugeriu que diante das dificuldades de mão-de-obra, o “Ceará poderia mandar vir colonos”. Entretanto, o governador acreditava que primeiramente se devia “criar embaraços à emigração”, pondo-se assim, na visão de Fontenelle, "fim ao êxodo". ${ }^{22}$ Um ano depois, o mesmo governador reclamava de que uma "boa parte da população rural", diante das incertezas de "bons ou maus invernos", deixava os trabalhos na lavoura e na indústria pastoril se entregando a uma "vida nômade". As preocupações do governador se estendiam igualmente aos "agenciantes de gente para o Amazonas", atividade considerada pelo governador como uma "indústria explorada por ambiciosos", que recrutavam "vítimas" nos mais "remotos sertões". É possível que Mariano tenha sido contratado para trabalhar num seringal do rio Purus por um desses “agenciantes". 23

Nos períodos de seca, essa foi uma questão que se colocava para os poderes públicos do Ceará. O que se explica pelo fato de que, ao mesmo tempo em que buscavam não incentivar a

\footnotetext{
${ }^{21}$ APEC - Ala 19, Estante 407, no 11 - Ministério do Império aos presidente da Província do Ceará, avisos 1889. Ministério dos Negócios do Império. $1^{\text {a }}$ Diretoria, $\mathrm{n}^{\circ} 1110$. Rio de Janeiro, 19 de março de 1889.

${ }^{22}$ Mensagem do Presidente do Estado Tenente Coronel Dr. José Freire Bezerril Fontenelle à Assembléia Legislativa do Ceará em sua $2^{\mathrm{a}}$ sessão ordinária da $1^{\mathrm{a}}$ Legislatura. Fortaleza: Typ da República, 1893, p. 16. Em 1892, analisando a economia da Amazônia, José Veríssimo referindo-se aos seringueiros, não deixa de fazer referência ao fato de que na estruturação dos seringais existiam aqueles que recebiam dinheiro "para irem buscar gente no Ceará" para trabalharem em seringais já conhecidos, visando aumentar a produção ou para trabalharem em novos seringais.

${ }^{23}$ Mensagem do Presidente do Estado Coronel Dr. José Freire Bezerril Fontenelle à Assembléia Legislativa do Ceará em sua $3^{\mathrm{a}}$ sessão ordinária da $2^{\mathrm{a}}$ Legislatura. Fortaleza: Typ. d'A Republica, 1894, p. 7.
} 
saída de cearenses, tinham que resolver os muitos problemas decorrentes dos aglomerados de flagelados na cidade de Fortaleza. Estes, em grande número, famintos e doentes, chegavam diariamente do sertão. ${ }^{24}$ Henrique D’Ávila, Presidente da Província do Ceará em 1889, era ferrenho crítico de tais aglomerados de retirantes da seca. Afirmava que esses espaços eram como que uma "escola de todos os vícios imagináveis" e completando, acreditava ainda que eram "antros do vício e da perdição da família cearense". 25

Diante disso, dentre suas preocupações de manter o sertanejo em seu lugar de origem, Henrique D’Ávila, no relatório de 1889, não se descuidou ainda de afirmar, até como uma forma de louvar suas próprias iniciativas, que o serviço de socorro prestado na Província do Ceará, por ocasião da seca de 1889, segundo suas palavras, estava "inteiramente desorganizado e anarquizado", o que fazia com que migrasse "para fora da província o maior número de retirantes”. Desse modo, dentre suas tarefas, estava a de reorganizar esse serviço. Assim, afirmava que trabalhava na "grande obra de localização" dos retirantes em "terras de cultura". Para o governador, esse seu trabalho era fundamental para ocupar "milhares de cearenses" que viviam "na vida ociosa e pervertida dessas grandes aglomerações”, organizadas, segundo Henrique D’Ávila, a “título de obra de socorro" ${ }^{26}$

Se para o Presidente Henrique D’Ávila, nos aglomerados na cidade, os flagelados pela seca tinham uma vida ociosa, uma vida pervertida, às custas do Estado, da qual pareciam até

${ }^{24}$ Embora detendo-se mais especificamente na seca de 1932, a leitura do trabalho de Frederico de Castro Neves, permite entender muitas das ações das multidões de flagelados pela seca no Ceará. NEVES, Frederico de Castro. A multidão e a história: saques e outras ações de massas no Ceará.

${ }^{25}$ Relatório com que o Exm. Snr. Conselheiro Henrique D’Avila senador do Império e Presidente do Ceará passou a administração desta Província ao Exm. Sr. Fortaleza: Typographia Econômica, 1889, p. 6. Sidney Chalhoub, analisando epidemias e ações de higiene no Rio de Janeiro imperial lembra que pelo saber médico da época "as classes pobres não passaram a ser vistas como classes perigosas apenas porque poderiam oferecer problemas para a organização do trabalho e a manutenção da ordem pública. Os pobres ofereciam também perigo de contágio”. Isso se dava na medida que seus hábitos eram reproduzidos por seus filhos, para combater tal problema seria necessário uma "repressão à ociosidade" e inclusive cuidar da "educação dos menores". Essas ações passavam por preocupações com os espaços ocupados pelos mais pobres, considerados "nocivos à sociedade", uma vez que nesse sentido, eram foco de epidemias e de propagação de vícios. No caso dos aglomerados de flagelados pela seca em Fortaleza e igualmente dos migrantes cearenses que chegavam a Belém, não resta dúvida de que esse pensamento dará também a tônica de muitas das ações voltadas para esse grupo. CHALHOUB, Sidney. Cidade febril: cortiços e epidemias na corte imperial, p. 29.

${ }^{26}$ Relatório com que o Exm. Snr. Conselheiro Henrique D’Avila senador do Império e Presidente do Ceará passou a administração desta Província ao Exm. Sr. Fortaleza: Typographia Econômica, 1889, pp. 4-6. 
gostar, essa não era a visão compartilhada pelos retirantes, que eram obrigados a sair de seu lugar de origem e se instalar improvisadamente em Fortaleza. Tomando como referência as análises de Bronislaw Geremek, ao estudar a história da miséria e da caridade na Europa, percebemos que o pensamento do governador do Ceará se inscreve na concepção de que a "degradação moral causada pela pobreza anda a par com a depravação nascida de uma vida ociosa às custas da sociedade”. Daí, porque se verificará uma constante preocupação em inserir o indivíduo considerado ocioso em atividades produtivas. ${ }^{27}$

Desse modo, relendo as justificativas de alguns flagelados para obter passagens financiadas pelo governo para o porto de Belém, no ano 1889, é possível perceber o que eles pensavam de sua condição. De 75 dessas justificativas, aproximadamente 13 solicitantes de passagens alegavam querer sair do Ceará por não poderem mais subsistir na capital, diante de tanta miséria. ${ }^{28}$ Nesse sentido, não poder "continuar a residir nesta capital”, referindo-se a Fortaleza, devido à "falta de recursos", era o que dizia a viúva Juvínia Mendes da Costa ${ }^{29}$, que desejava passagens para ela e para um casal de filhos solteiros. $\mathrm{O}$ mesmo argumento era invocado por Lucio Francisco da Frota, que assinava o seu pedido de passagem para um grupo familiar formado por nove pessoas, incluindo uma outra família que se juntava à dele. ${ }^{30}$ Esse também era o caso de Vitor Francisco das Chagas, que havia saído do povoado de Maria Pereira, e que pedia passagem "para si e sua mulher". Alegava que era "pobre” e que tinha migrado com "sua mulher em conseqüência da seca" que grassava em "toda a província” e que não podia permanecer em Fortaleza "por mais tempo, em vista de seu estado de miséria”. 31

Semelhante foi a alegação dada pelo lavrador Manuel Caetano Pereira, de 28 anos, natural de Uruburetama, que também solicitava passagens para a mulher, dois filhos crianças e para um agregado. Manuel havia deixado o lugar de "sua residência” e, estando em Fortaleza, não podia "conseguir trabalho na agricultura de que sempre se ocupou”. ${ }^{32}$

\footnotetext{
Terramar, 1986, p. 276.

${ }^{28}$ APEC - Caixa: Governo do Ceará. Ofícios emigração 1889.

${ }^{29}$ APEC - Caixa: Governo do Ceará. Ofícios emigração 1889

${ }^{30}$ APEC - Caixa: Governo do Ceará. Ofícios emigração 1889

${ }^{31}$ APEC - Caixa: Governo do Ceará. Ofícios emigração 1889

${ }^{32}$ APEC - Caixa: Governo do Ceará. Ofícios emigração 1889.
}

${ }^{27}$ GEREMEK, Bronislaw. A piedade e a forca. História da miséria e da caridade na Europa. Lisboa: 
É provável que todos esses solicitantes tenham conseguido a passagem, pois seus pedidos traziam o "atestado de pobreza", indicando sua condição de necessitados. Desses, sabemos apenas que Manuel e a família conseguiram embarcar. Assim, apesar de todas as restrições impostas à saída dos flagelados, folheando o livro da "Companhia de Vapores”, encontramos Manuel e seus parentes seguindo para Belém a bordo do Vapor "Pará". 33

Esses exemplos revelam que, para os flagelados pela seca, a permanência na cidade de Fortaleza, diante da miséria em que viviam, e apesar de receberem os socorros do Estado, era uma condição não desejada. Muitos deles preferiam inclusive deixar a capital, lugar próximo do seu lugar de origem, e se lançarem a caminho do Pará, a viverem em Fortaleza sem trabalho, dependendo de favores do Estado ou da população. Sem dúvida nenhuma, muito ao contrário da idéia da ociosidade, para muitos flagelados, essa falta de ocupação na cidade e a impossibilidade de regressar ao lugar de origem é que levavam à decisão de sair do Ceará.

As reflexões destacadas por Herbert S. Klein, ao analisar as migrações internacionais na história das Américas, vão ao encontro também do processo de deslocamento dos cearenses. Esse autor, partindo da pergunta "Por que as pessoas migram?", acredita que, "com exceção dos poucos que anseiam por mudanças e aventuras", os migrantes em sua maioria "não desejam abandonar suas casas nem suas comunidades”. Para Klein, a migração não começa "até que as pessoas descobrem que não conseguirão sobreviver com seus meios tradicionais em suas comunidades de origem". Sem esquecer a questão das pessoas perseguidas por questões de nacionalidade ou de religião, o autor lembra que "na grande maioria dos casos não logram permanecer no local porque não têm como alimentar-se nem a si próprias nem a seus filhos". ${ }^{34}$

As falas dos poderes públicos cearenses sobre a falta de braços para o trabalho e a ociosidade revelam duas formas de se pensar nos flagelados pela seca. Na primeira delas, o sertanejo é visto com mão-de-obra que deverá ser ocupada no Ceará, e, portanto, sua saída implica problemas ao desenvolvimento da produção. Na segunda, um olhar disciplinador e higienista parece culpar o próprio migrante por sua situação de miséria, quando ele é obrigado a deixar seu lugar de origem e seguir com a família para Fortaleza, construindo muitas vezes outros arranjos familiares, que se tecem, em função da perda da casa e do trabalho que a seca

\footnotetext{
${ }^{33}$ APEC - Livro da Companhia de Vapores 1888-1889.

${ }^{34}$ KLEIN, Herbert S. "Migração internacional na história das Américas". In: FAUSTO, Boris (org.). Fazer a América, 2000, p. 13.
} 
impõe ao sertanejo, obrigando-o a viver na capital cearense dependente dos socorros públicos e da caridade da população.

Diante desses graves problemas e até de protestos, a exemplo da "representação" dos comerciantes da praça de Fortaleza e, igualmente, da crise de mão-de-obra que esses deslocamentos causavam, não resta dúvida de que a migração acabava sendo uma boa saída para os poderes públicos do Ceará. Ao fornecer passagens para portos do sul e do norte, livravam-se de um grave problema social ocasionado pelas multidões de flagelados circulando pelas ruas daquela capital.

Mesmo assim, conseguir uma passagem não era algo tão fácil. Quando da escassez de chuvas em setembro de 1888, o Ministério dos Negócios da Agricultura Comércio e Obras Públicas enviou a Fortaleza uma autorização para que as passagens, nos vapores da Companhia Brasileira de Navegação, fossem dadas somente para "famílias de retirantes" que as solicitassem por "motivos da seca reinante". ${ }^{35}$ Através desse procedimento, é possível deduzir que existissem pedidos de passagem por outros motivos que não a seca. Talvez, até mesmo pessoas que tinham condições de pagar acabassem recorrendo aos favores do Estado. Além disso, diante da crise de mão-de-obra, o governo pretendia dificultar a saída do Ceará. Alguns dias antes, em telegrama enviado pelo mesmo Ministério ao Presidente da Província do Ceará, alertava-se que, para receberem as passagens, as famílias deveriam provar que necessitavam desse auxílio em função da seca. ${ }^{36}$ Seguindo essa regulamentação de 1888 , as famílias de Vitor Francisco, de Manuel Caetano, de Juvínia Mendes e de Lucio Francisco, em 1889, receberam atestado de pobreza de autoridades como o juiz de paz, o delegado de polícia e o vigário da localidade onde residiam.

Ao final do ano de 1888, o Ministério dos Negócios da Agricultura Comércio e Obras Públicas, mesmo julgando conveniente “outras medidas”37 que não a concessão de

\footnotetext{
${ }^{35}$ APEC - Ala 19, Estante 407, no 35 - Ministro dos Negócios da Agricultura, Comércio e Obras Públicas ao presidente da Província do Ceará, avisos. $1886-1888-3^{\mathrm{a}}$ secção, $\mathrm{n}^{\circ} 1$. Rio de Janeiro, 14 de setembro de 1888 .

${ }^{36}$ APEC - Ala 19, Estante 407, no 35 - Ministro dos Negócios da Agricultura, Comércio e Obras Públicas ao presidente da Província do Ceará, avisos. 1886 -1888 - Repartição Geral de Telégrafos. 6 de setembro de 1888. Telegrama $\mathrm{n}^{\circ} 697$.

${ }^{37}$ APEC - Ala 19, Estante 407, no 35 - Ministro dos Negócios da Agricultura, Comércio e Obras Públicas ao presidente da Província do Ceará, avisos. 1886 -1888 - Repartição Geral de Telégrafos. 14 de novembro de 1888 . Telegrama $\mathrm{n}^{\circ} 387$.
} 
passagens, diante do receio do prolongamento da seca e da "impossibilidade de socorros ou obras para acudir a população”, acabou autorizando passagens gratuitas para os retirantes. ${ }^{38}$ 1889 seria um ano marcado por grandes deslocamentos, que se intensificaram no primeiro semestre desse ano à medida que a chuva não chegava.

Apesar disso, o Presidente da Província do Ceará, Senador Henrique D’Ávila, afirmava, ainda no primeiro semestre de 1889, que havia deliberado "não conceder passagens por conta do Estado aos retirantes para saírem da Província”. Para acabar com deslocamentos, ele acreditava que se deveria manter a população no lugar em que esta residia. As preocupações com a saída de pessoas eram tantas que o Presidente, em sua Fala à Assembléia Provincial, afirmou que havia feito "parar completamente a saída dos retirantes para fora da Província, o que atraía sempre a esta capital um grande número de indigentes”.

Apesar das tentativas de se manter a população atingida pela seca empregada em serviços de utilidade pública, ou mesmo recebendo alimentos fornecidos por armazéns administrados pelo Estado, isto de fato não acontecia, pois pelo menos três vezes por mês os vapores saíam do porto de Fortaleza, conduzindo passageiros para os portos do sul e do norte. Nesses vapores, sem dúvida, seguiam para outras províncias muitos flagelados pela seca.

A partir de alguns dados da Inspetoria Geral de Emigração do ano de 1889, pode-se visualizar no quadro abaixo parte do movimento de migrantes que saíram do Ceará com destino a Maranhão, Pará e Amazonas. Embora, não sejam possíveis maiores análises desses dados, considerando-se que se tratam de registros muito fragmentados, um aspecto deles chama a atenção. Mesmo no momento de grande crescimento da economia da borracha, entendido pela historiografia como um período em que muito se utilizou o trabalho de cearenses na extração do látex, a família é muito presente, inclusive na própria maneira de se organizar, naquele momento, os dados sobre a saída dos migrantes. ${ }^{39}$

\footnotetext{
${ }^{38}$ APEC - Ala 19, Estante 407, $\mathrm{n}^{\mathrm{o}} 35$ - Ministro dos Negócios da Agricultura, Comércio e Obras Públicas ao presidente da Província do Ceará, avisos. 1886 -1888 - Repartição Geral de Telégrafos. 23 de novembro de 1888 . Telegrama $\mathrm{n}^{\mathrm{o}} 2659$.
}

${ }^{39}$ APEC - Caixa Inspetoria Geral de Emigração. Relação de Emigrantes norte-sul. 1888-1889 


\begin{tabular}{|l|c|c|c|c|c|c|c|}
\hline \multirow{2}{*}{ Vapor } & \multirow{2}{*}{ Data de saída } & \multicolumn{2}{c|}{ Maranhão } & \multicolumn{2}{c|}{ Pará } & \multicolumn{2}{c|}{ Amazonas } \\
\cline { 3 - 8 } & & Famílias & Pessoas & Famílias & Pessoas & Famílias & Pessoas \\
\hline Pernambuco & $11 / 1 / 1889$ & 42 & 203 & 30 & 127 & 32 & 217 \\
\hline Pará & $21 / 1 / 1889$ & - & - & 5 & 40 & 6 & 50 \\
\hline Argentina & $16 / 2 / 1889$ & - & 7 & - & 554 & - & - \\
\hline Pernambuco & $4 / 3 / 1889$ & 17 & 78 & 18 & 158 & 90 & 553 \\
\hline Alagoas & $22 / 3 / 1889$ & - & - & 1 & 7 & 212 & 1260 \\
\hline Manaus & $22 / 3 / 1889$ & 24 & 159 & 93 & 515 & 105 & 667 \\
\hline Cearense (UK) & $28 / 2 / 1889$ & - & - & 51 & 261 & 59 & 331 \\
\hline Teresina (UK) & $2 / 3 / 1889$ & - & - & 24 & 137 & 141 & 749 \\
\hline Pará & $13 / 3 / 1889$ & 11 & 66 & 49 & 268 & 83 & 413 \\
\hline Cyril (UK) & $15 / 3 / 1889$ & - & - & 6 & 63 & 135 & 804 \\
\hline Colombo & $20 / 3 / 1889$ & - & - & - & - & 145 & 847 \\
\hline Ambrose (UK) & $28 / 3 / 1889$ & - & - & 75 & 480 & - & - \\
\hline Maranhão & $2 / 4 / 1889$ & 6 & 35 & 20 & 162 & 144 & 962 \\
\hline Clement (UK?) & $6 / 4 / 1889$ & - & - & 37 & 408 & - & - \\
\hline Alagoas & $12 / 4 / 1889$ & 8 & 30 & 29 & 204 & 45 & 373 \\
\hline & & - & - & $11(\mathrm{RN})$ & 27 & $28(\mathrm{RN})$ & 113 \\
\hline Pernambuco & $22 / 4 / 1889$ & $1(\mathrm{Hosp})$. & 3 & $4(\mathrm{Hosp})$. & 31 & $6(\mathrm{Hosp})$. & 38 \\
\cline { 3 - 9 } & & - & - & $1 *$ & 1 & $6 *$ & 38 \\
\hline Pará & $15 / 1889$ & - & - & $8(\mathrm{CE})$ & 46 & $8(\mathrm{CE})$ & 46 \\
\cline { 3 - 9 } & $21 / 5 / 1889$ & 3 & 31 & 42 & 235 & 104 & 570 \\
\hline Maranhão & $22 / 5 / 1889$ & 2 & 5 & 35 & 247 & 49 & 417 \\
\hline Manaus & $2 / 6 / 1889$ & 7 & 34 & 48 & 338 & 46 & 259 \\
\hline Espírito Santo & $12 / 6 / 1889$ & 1 & 1 & 46 & 278 & 84 & 452 \\
\hline Pernambuco & & - & 11 & 44 & 238 & 74 & 438 \\
\hline Pará & & & & $11(\mathrm{RN})$ & 40 & $17(\mathrm{RN})$ & 79 \\
\hline
\end{tabular}

No quadro abaixo, de dados enviados pelo Governo do Ceará ao Secretário dos Negócios do Império e à Secretaria de Agricultura, Comércio e Obras Públicas, temos uma visão das saídas mensais de alguns vapores do Ceará com destino aos portos do sul e do norte ${ }^{40}$ :

\footnotetext{
${ }^{40} \mathrm{~N}^{\mathrm{o}} 347$ B. Minutas dos Ofícios da Secretaria do Governo da Província do Ceará, dirigidos ao secretário dos Negócios do Império; à Secretaria de Agricultura, Comércio e Obras Públicas 1887- 1889. Ofícios da $1^{\text {a }}$ (*2a Seção) Secção destinados à Secretaria da Agricultura, Comércio e Obras Públicas.
} 


\begin{tabular}{|c|c|c|c|c|c|}
\hline Data & Vapor & Chegada do Sul & Partida para o Norte & Regresso do Norte & Partida para o Sul \\
\hline $3 / 11 / 88$ & Manaus & $11 / 10 / 88$ & $12 / 11 / 88$ & $2 / 11 / 88$ & $3 / 11 / 88$ \\
\hline $14 / 11 / / 88$ & Espírito Santo & $22 / 10 / 88$ & $23 / 11 / 88$ & $13 / 11 / 88$ & $14 / 11 / 88$ \\
\hline $20 / 11 / 88$ & Maranhão & $30 / 10 / 88$ & $30 / 10 / 88$ & $19 / 11 / 88$ & $20 / 11 / 88$ \\
\hline $11 / 12 / 88$ & Alagoas & $10 / 11 / 88$ & $10 / 11 / 88$ & $30 / 11 / 88$ & $1 / 12 / 88$ \\
\hline $13 / 12 / 88$ & Pernambuco & $21 / 11 / 88$ & $21 / 11 / 88$ & $12 / 12 / 88$ & $13 / 12 / 88$ \\
\hline $23 / 12 / 88$ & Pará & $1 / 12 / 88$ & $1 / 12 / 88$ & $22 / 12 / 88$ & $23 / 12 / 88$ \\
\hline $30 / 12 / 88$ & Manaus & $11 / 12 / 88$ & $11 / 12 / 88$ & $30 / 12 / 88$ & $30 / 12 / 88$ \\
\hline $12 / 1 / 89$ & Maranhão & $21 / 12 / 88$ & $21 / 12 / 88$ & $11 / 1 / 89$ & $12 / 1 / 89$ \\
\hline $21 / 1 / 89$ & Alagoas & $21 / 12 / 88$ & $21 / 12 / 88$ & $20 / 1 / 90$ & $21 / 1 / 89$ \\
\hline $31 / 1 / 89$ & Pernambuco & $10 / 1 / 89$ & $11 / 1 / 89$ & $30 / 1 / 89$ & $31 / 1 / 89$ \\
\hline $12 / 2 / 89$ & Pará & $21 / 1 / 89$ & $21 / 1 / 89$ & $10 / 2 / 89$ & $12 / 2 / 89$ \\
\hline $22 / 2 / 89$ & Manaus & $31 / 1 / 89$ & $1 / 2 / 89$ & $21 / 2 / 89$ & $22 / 2 / 89$ \\
\hline $3 / 3 / 89$ & Maranhão & $10 / 2 / 89$ & $11 / 2 / 89$ & $3 / 3 / 89$ & $3 / 3 / 89$ \\
\hline $14 / 3 / 89$ & Alagoas & $21 / 2 / 89$ & $22 / 2 / 89$ & $13 / 3 / 89$ & $14 / 3 / 89$ \\
\hline $23 / 3 / 89$ & Pernambuco & $3 / 3 / 89$ & $3 / 3 / 89$ & $22 / 3 / 89$ & $23 / 3 / 89$ \\
\hline $2 / 4 / 89$ & Pará & $12 / 3 / 89$ & $13 / 3 / 89$ & $1 / 4 / 89$ & $2 / 4 / 89$ \\
\hline $13 / 4 / 89$ & Manaus & $21 / 3 / 89$ & $22 / 3 / 89$ & $12 / 4 / 89$ & $13 / 4 / 89$ \\
\hline $22 / 4 / 89$ & Maranhão & $1 / 4 / 89$ & $2 / 4 / 89$ & $21 / 4 / 89$ & $22 / 4 / 89$ \\
\hline $3 / 5 / 89$ & Alagoas & $11 / 4 / 89$ & $12 / 4 / 89$ & $2 / 5 / 89$ & $3 / 5 / 89$ \\
\hline $12 / 5 / 89$ & Pernambuco & $21 / 4 / 89$ & $22 / 4 / 89$ & $11 / 5 / 89$ & $12 / 5 / 89$ \\
\hline $23 / 5 / 89$ & Pará & $1 / 5 / 89$ & $1 / 5 / 89$ & $22 / 5 / 89$ & $23 / 5 / 89$ \\
\hline $3 / 6 / 89$ & Manaus & $11 / 5 / 89$ & $12 / 5 / 89$ & $2 / 6 / 89$ & $3 / 6 / 89$ \\
\hline $12 / 6 / 89$ & Maranhão & $20 / 5 / 89$ & $21 / 5 / 89$ & $10 / 6 / 89$ & $12 / 6 / 89$ \\
\hline $22 / 6 / 89$ & Espírito Santo & $31 / 5 / 89$ & $2 / 6 / 89$ & $22 / 6 / 89$ & $23 / 6 / 89$ \\
\hline $3 / 7 / 89$ & Pernambuco & $11 / 6 / 89$ & $12 / 6 / 89$ & $2 / 7 / 89$ & $3 / 7 / 89$ \\
\hline$[13] / 7 / 89$ & Alagoas & $22 / 6 / 89$ & $23 / 6 / 89$ & {$[12] / 7 / 89$} & {$[13] / 7 / 89$} \\
\hline $22 / 7 / 89$ & Pará & $30 / 6 / 98$ & $1 / 7 / 89$ & $21 / 7 / 89$ & $22 / 7 / 89$ \\
\hline $30 / 7 / 89$ & Manaus & $10 / 7 / 89$ & $10 / 7 / 89$ & 29/7/89 & $30 / 7 / 89$ \\
\hline $10 / 8 / 89$ & Maranhão & $20 / 7 / 89$ & 20/7/89 & $9 / 7 / 89$ & $10 / 7 / 89$ \\
\hline $21 / 8 / 89$ & Espírito Santo & $31 / 7 / 89$ & $31 / 7 / 89$ & $20 / 8 / 89$ & $21 / 8 / 89$ \\
\hline $13 / 9 / 89$ & Pernambuco & $10 / 8 / 89$ & $10 / 8 / 89$ & $11 / 9 / 89$ & $13 / 9 / 89$ \\
\hline $21 / 9 / 89$ & Pará & $31 / 8 / 89$ & $31 / 8 / 89$ & $21 / 9 / 89$ & $22 / 9 / 89$ \\
\hline $2 / 10 / 89$ & Manaus & $10 / 9 / 89$ & $12 / 9 / 89$ & $1 / 10 / 89$ & $2 / 10 / 89$ \\
\hline $23 / 10 / 89$ & Alagoas & $11 / 10 / 89$ & $11 / 10 / 89$ & $23 / 10 / 89$ & $23 / 10 / 89$ \\
\hline $12 / 11 / 89$ & Pernambuco & $21 / 10 / 89$ & $21 / 10 / 89$ & $11 / 11 / 89$ & $12 / 11 / 89$ \\
\hline
\end{tabular}


Note-se que nesse período de transição entre o Império e a República, os gestores públicos, na capital do Império e depois da República, eram informados do movimento de saída do Ceará, dos problemas que esses deslocamentos de pessoas causavam ao Ceará e aos portos receptores desses migrantes, sem que, entretanto, se buscassem outras alternativas para o problema. Essa fala, sem dúvida, já se tornou um lugar comum, baseada na idéia de um descaso histórico para com as populações menos favorecidas do que hoje chamamos de Nordeste. Alimenta-se, nesse sentido, um pensamento em que os grupos pobres parecem não só desprovidos de bens materiais, mas também de vontade própria e de anseios pessoais que lhes permitam tomar decisões sobre o seu próprio destino.

Assim, deve-se atentar para o fato de que no meio dessas muitas viagens, desses tantos pronunciamentos dos poderes públicos, e dos dados produzidos sobre esses deslocamentos, enfim, os principais envolvidos nessa história os migrantes, em todas as situações em que se acharam envolvidos, lutavam por aquilo que consideravam fundamental para a sua sobrevivência. A julgar pelos pronunciamentos de Henrique D’Ávila, um número médio de 3 viagens mensais, em vapores nem sempre velozes, entre o Ceará e outras províncias, segundo dados do próprio poder público, indicam que para além dos dados oficiais, nos períodos de grave seca, como a dos anos de 1888 e 1889, os atingidos por esse fenômeno elaboravam suas estratégias de sobrevivência.

Em março de 1889, o jornal paraense O Liberal do Pará anunciava a entrada do vapor costeiro Cabral "conduzindo 841 imigrantes cearenses". ${ }^{41}$ Note-se que, nos dados anteriores não se faz nenhuma referência a esse vapor, o que nos indica um dinamismo maior dessas viagens em relação aos dados produzidos pelos poderes públicos. Dois dias depois da chegada do Cabral ao porto de Belém do Pará, um articulista desse mesmo jornal alertava para a “triste sorte dos cearenses atirados para nós”. Tal preocupação não se dava por acaso, e o próprio texto d' "O Liberal do Pará" dava conta de explicar isso. Para o articulista, os migrantes deveriam ser recebidos e localizados no Pará com “cuidados e desvelos”. Através de um cálculo, o leitor compreendia que isso não significava um pensamento altruístico diante do êxodo imposto pela seca, mas sim, uma preocupação que entendia o cearense como mãode-obra, importante para a produção paraense: "Calculando-se que vale um conto de réis

\footnotetext{
${ }^{41}$ O Liberal do Pará. Belém, 27 de março de 1889, p. 2.
} 
cada braço válido, que nos chega é fácil calcular também o enorme capital que o êxodo cearense traz para o vale do Amazonas". 42

Ora, esse pensamento que se assemelha ao do governo cearense, só que no sentido oposto, da permanência dessa mão-de-obra no Pará, revela que muitas vezes as ações para com esses grupos de desfavorecidos se dava muito mais no sentido de preservação e manutenção de trabalhadores necessários para a produção paraense, fosse agrícola ou extrativa na coleta do látex. Em um outro episódio da história da Amazônia, quando da construção da Estrada de Ferro Madeira-Mamoré, diante de grande número de mortes de trabalhadores, o médicosanitarista Oswaldo Cruz, que visitou a região a pedido da companhia construtora, incorporou nessa frente de trabalho medidas profiláticas contra a malária, a partir de uma "uma campanha ampla e intensiva de quinização”. Segundo Foot Hardman essas medidas eram fundadas "numa ordem do tipo militar", tal sua rigidez. O objetivo final inseria-se num ideário como lembra Hardman, de "sanear para produzir". ${ }^{43}$ No caso da vinda dos migrantes cearenses para o Pará, entendemos que apesar dos muitos problemas que a chegada desses grupos acarretava aos poderes públicos, se bem aproveitada em diversas modalidades de atividade produtiva, poderia ser bem vantajosa.

Passada a crise das estiagens do ano de 1889, por ocasião de nova seca em 1898, o governador do Ceará, Antonio Accioly, mostrava-se tão preocupado como Henrique D’Ávila, com o crescimento da "massa da população indigente". ${ }^{44}$ Alguns anos depois, em 1901, o governador Pedro Borges assegurava que a saída de grupos de sertanejos era muito grande, o problema era tão grave que, segundo ele, “dia a dia” entravam em Fortaleza "caravanas de retirantes em busca de socorros junto ao governo ou de passagens para fora do Estado" 45 Como em anos anteriores, buscava-se manter a população flagelada no Ceará. O governador Pedro Borges acreditava que as estradas de ferro, como as de Sobral e Baturité, seriam importantes para evitar a migração, inclusive para Fortaleza, uma vez que "diminuindo distâncias e facilitando comunicações”, seria possível levar com mais rapidez socorros aos

\footnotetext{
${ }^{42}$ O Liberal do Pará. Belém, 29 de março de 1889, p. 1.

${ }^{43}$ HARDMAN, Francisco Foot. Trem fantasma, p. 151.

${ }^{44}$ Mensagem apresentada à Assembléia Legislativa do Ceará pelo presidente do Estado Dr. Antonio Pinto Nogueira Accioly em 4 de julho de 1898. Fortaleza: Typographia Econômica, 1898, p. 25.

${ }^{45}$ Mensagem apresentada à Assembléia Legislativa do Ceará em $1^{\circ}$ de julho de 1901 pelo Presidente do Estado Dr. Pedro Augusto Borges. Fortaleza: Typ. Econômica, 1901, p. 25.
} 
flagelados. ${ }^{46} \mathrm{Na}$ verdade, a facilidade de transporte acabou sendo uma via de mão dupla, uma vez que ao mesmo tempo que serviam para a chegada dos parcos socorros do Estado, eram usadas sobretudo para a saída do sertanejo rumo ao litoral.

A cada seca, os mesmos problemas e as mesmas discussões vinham à tona. Vinte e seis anos depois da seca de 1889, as preocupações não eram diferentes e o governador do Ceará, Benjamin Barroso, referia-se aos prejuízos que sofriam a lavoura e a pecuária do estado, com a diminuição da população, que “desaparece do Estado, uma grande parte por morte e outra por emigração". ${ }^{47}$ Apesar disso, um ano depois desse pronunciamento, em julho de 1916, Benjamin Barroso, justificando à Assembléia Legislativa do Ceará a saída de grande número de flagelados pela seca, afirmava que "à falta de meios" que permitissem "manter dentro do Estado o povo faminto e nu” preferiu, segundo ele, “com grande tristeza” e também contra todos os “princípios econômicos”, facilitar a saída dos flagelados, “expatriá-los”, a "deixálos morrer de fome". ${ }^{48}$

A análise da fala de todos dos presidentes da província e depois governadores do Ceará, nos períodos de seca entre 1888 e 1916, revela um único discurso concentrado em duas idéias centrais. Primeiro, pretende-se, manter a todo custo as populações atingidas pela seca no próprio Ceará; na impossibilidade disso, diante da pressão dos próprios flagelados, que não ficavam no seu lugar de origem e que seguiam para Fortaleza em busca de socorro do Estado ou da caridade pública, diante de grande número de mortos, acaba-se liberando a saída dos sertanejos. Desse modo, tomando como referência os discursos oficiais, a migração para o norte ou para o sul nos períodos de seca, pelo menos nos pronunciamentos dos poderes públicos, aparece como uma alternativa para o Estado, não como a solução para o problema.

Nesse sentido, o pronunciamento do governador Antonio Accioly poderia ser atribuído aos demais governadores, mudando talvez a forma de se dizer mas mantendo o mesmo conteúdo

\footnotetext{
${ }^{46}$ Mensagem apresentada à Assembléia Legislativa do Ceará em $1^{\circ}$ de julho de 1901 pelo Presidente do Estado Dr. Pedro Augusto Borges. Fortaleza: Typ. Econômica, 1901, p. 26.

${ }^{47}$ Mensagem dirigida à Assembléia Legislativa do Ceará em $1^{\circ}$ de julho de 1915 pelo Presidente do Estado Coronel Benjamin Liberato Barroso. Fortaleza: Typ. Moderna, 1915, 8.

${ }^{48}$ Mensagem dirigida à Assembléia Legislativa do Ceará em $1^{\circ}$ de julho de 1916 pelo Presidente do Estado Coronel Benjamin Liberato Barroso. Fortaleza, 1916, p. 6. De acordo com Rodolpho Theophilo, "O Ceará perdeu pela emigração de julho de 1915 a abril a abril de 1916 - 39.313 pessoas. Para o Norte embarcaram - 30.802 e para o sul 8511”. TEOPHILO, Rodolpho. A seca de 1915, 1919, p. 134.
} 
do discurso. Assim, descrevendo aos representantes do Ceará no Congresso Federal, em 28 de maio de 1900, a situação vivida pelo estado, em decorrência da seca afirmou: "não dispomos de recursos para enfrentar a crise”. Diante disso, tal qual seus antecessores e aqueles que viriam depois dele, declarava: “é absoluta a necessidade de facilitar transportes para franca emigração" ${ }^{49}$ O governador Pedro Borges, que o precedeu, também acreditava assim. Para ele, a fase mais "aguda da seca" era medida pela "emigração sempre crescente e ruinosa", uma vez que "ninguém expõe sua família a longas e penosas jornadas, em busca de um refúgio desconhecido, senão na última extremidade”. 50

Tomando as palavras de Pedro Borges como ponto de partida, pode-se investigar acerca do que muitos cearenses pensavam como "última extremidade”. Seria um engano acreditar, como o governador, que a "última extremidade" seria a seca, ou que se saia do Ceará somente em períodos de seca. Embora não se tenha dados significativos a esse respeito, é possível perceber que a saída do Ceará para o Pará não pode ser associada somente à seca, como já afirmamos. Em 1894, por exemplo, o governador do Ceará, José Freire Bezerril Fontenelle, afirmava que os invernos tinham sido "mais que regulares" nos últimos dois anos, mas mesmo assim não tinha "diminuído o êxodo". 51

Em 1897, o governador do estado do Pará, Lauro Sodré, também preocupado com o problema de mão-de-obra para os trabalhos na lavoura, em função dos fracassos com a vinda de estrangeiros, considerava uma "obra impatriótica" o incentivo à vinda de migrantes nacionais, pois, segundo ele, os estados da União lutavam com a "escassez de população”. Entretanto, o governador reconhecia a vinda de trabalhadores de "alguns estados do Norte", que se empregavam "principalmente para os serviços da indústria extrativa”. A conclusão que Lauro Sodré tirava dessa migração é que ela se dava "espontaneamente”. Chamando os migrantes de "ajudadores do nosso progresso", o governador considerava que esses deslocamentos espontâneos eram, na verdade, fruto de um "natural desejo, que leva a todos

\footnotetext{
${ }^{49}$ Mensagem apresentada a Assembléia Legislativa do Ceará pelo Presidente do Estado Exmo. Sr. Dr. Antonio Pinto Nogueira Accioly em 1º de julho de 1900. Fortaleza: Typ. D'A Republica, 1900, p. 19.

${ }^{50}$ Mensagem apresentada à Assembléia Legislativa do Ceará em $1^{\circ}$ de julho de 1901 pelo Presidente do Estado Dr. Pedro Augusto Borges. Fortaleza: Typ. Econômica, 1901, p. 25.

${ }^{51}$ Mensagem do Presidente do Estado Coronel Dr. José Freire Bezerril Fontenelle à Assembléia Legislativa do Ceará em sua $3^{a}$ sessão ordinária da $2^{a}$ Legislatura. Fortaleza: Typ. d'A Republica, 1894, p. 5.
} 
os homens a procurar o seu bem estar dependendo o menor esforço”. Lauro Sodré, pouco sensível às múltiplas experiências sociais presentes nos ato de se aventurar em terras distantes, via a migração para o Pará não como um último recurso, ou como disse o governador Pedro Borges, como a "última extremidade"; bem ao contrário disso, a via como a procura de uma vida melhor, baseada no "menor esforço". 52

Em dados transcritos pela Folha do Norte do jornal A República do Ceará, sobre o número de pessoas que migraram pelo porto de Fortaleza entre janeiro e junho de 1900, evidencia-se também uma vinda para Amazônia desvinculada da seca, quando se destaca a grande quantidade de migrantes para a Amazônia em $1899 .{ }^{53}$ Mesmo levando em consideração as possíveis falhas desses dados, decorrentes da própria feitura dos registros, feitos muitas vezes apressadamente em meio à movimentação do porto e ao grande número de passageiros que embarcavam nos vapores, pode-se ter uma visão aproximada do número de pessoas que se deslocaram do Ceará.

Assim, segundo o jornal, no primeiro semestre de 1900, teve-se um movimento populacional de cerca de 15.482 pessoas. Entretanto, referindo-se ao ano de 1899, o articulista afirmava que "em igual período do ano passado emigraram para as regiões amazônicas 17.045 mais do que este ano 2.563”. Ironicamente, como lembrava o jornal República, o ano de 1899 teria tido "o maior inverno daquele século" 54 Portanto, resumir o processo de migração para o norte tão somente no drama da seca é tornar essa questão muito elementar, não necessitando até de maiores interpretações. Buscar entender a migração em seus vários significados é sem dúvida investigar as ações de variados sujeitos sociais envolvidos nesse processo.

Mesmo nos períodos de seca, a exemplo do ano de 1889, os flagelados, ao solicitarem passagens à Província do Pará, não falam necessariamente da seca, mas de suas conseqüências. Isto permite dizer que o sertanejo convivia bem com a aridez do sertão, com os períodos de ausência de chuva, que já faziam parte do seu cotidiano. Nas justificativas para os pedidos de passagem, não se dizia somente "quero ir embora pela seca", mas iam-se

\footnotetext{
${ }^{52}$ Mensagem dirigida ao Congresso do Estado do Pará pelo Dr. Lauro Sodré Governador do Estado ao expirar o seu mandato, no dia $1^{\circ}$ de fevereiro de 1897. Pará: Diário Oficial, 1897, pp. 26-27.

${ }^{53}$ Folha do Norte. Belém, 24 de junho de 1900, p. 1.

${ }^{54}$ Folha do Norte. Belém, 24 de julho de 1900, p. 1.
} 
enumerando suas muitas conseqüências. Assim, a seca por si só não pode ser qualificada com o motivo da saída. Além disso, o sertanejo, nos períodos de estiagem, parecia resistir o quanto podia, indo do sertão para capital, buscando meios para não sair, até que sua situação ficava tão desastrosa que chegava a hora de partir. Seria isso a "ultima extremidade?”

Assim, um número significativo das solicitações de passagens do ano de 1889, traz como justificativa para o interesse de sair do Ceará a impossibilidade de se "obter meios para a subsistência". Esse foi o caso de João Antonio Fernandes, solteiro de 32 anos, natural de Baturité, que pedia passagem para ele e para um sobrinho. Outros flagelados pela seca, como Francisco de Sousa, de 59 anos, casado, também natural e morador de Baturité, desejavam sair do Ceará em conseqüência da "falta de recursos" para a sobrevivência do grupo familiar. O grupo de Francisco era composto por sua família e pelas famílias de dois filhos casados. Essas justificativas sugerem que o flagelado pela seca busca encontrar meios para manter a si e a sua família. Parece-nos, que longe de querer sobreviver às custas do poder público, esses homens buscavam um trabalho; a falta dessa ocupação é o que justamente lhes movia a solicitar a passagem. Luis Pereira de Araújo, por exemplo, residente em Baturité, afirmava não poder "continuar a residir no lugar de sua naturalidade, por causa da seca que o reduziu à última miséria". ${ }^{55}$ Essa afirmação parece carregada de um sentimento de perda diante da terra em que se vive, sugere um apego do sertanejo ao seu lugar de origem.

Outros alegavam para a saída - como Miguel Alves Maia, de 32 anos, casado, natural de União, que pedia passagem para ele seus sei irmãos solteiros - "achar-se em indigência". ${ }^{56}$ Miguel pode ser tomado, como um caso clássico, do que a historiografia consagrou e tomou como padrão do migrante cearense, isto porque, embora casado, pretendia vir só, acompanhado de seus irmãos.

Aliás, de 75 justificativas de pedidos de passagens, encontramos somente 16 que são de homens que pretendiam viajar sozinhos, ou acompanhados de outros parentes, como sobrinhos, cunhados, irmãos. Desse grupo de justificativas, a maioria é de homens que pretendem emigrar junto com a família, ou de mulheres que seguiam sozinhas ou como chefes de família. Sabe-se que o número de pedidos de passagens disponíveis no Arquivo Público de Fortaleza é muito pequeno, diante do grande número de pessoas que saíram do Ceará com

\footnotetext{
${ }^{55}$ APEC - Caixa: Governo do Ceará. Ofícios emigração 1889.

${ }^{56}$ APEC - Caixa: Governo do Ceará. Ofícios emigração 1889.
} 
destino ao Pará. Entretanto, essa pequena amostra serve pelo menos para se repensar a noção tão arraigada da ausência da família entre os migrantes, além de demonstrar um pouco do que esses grupos pensavam sobre a sua saída do Ceará.

Por isso, nas justificativas, também se evocava o papel de chefe de família, requerendo passagens. Isto foi o que possivelmente disse João Rodrigues de Lima Roque, casado, de 35 anos, que pedia passagem por ser “chefe de numerosa família”, que, aliás, nem era tão grande assim, para os padrões da época, formada por seis pessoas, João, sua esposa Maria da Conceição, seus dois filhos, e mais dois irmãos de João. O mesmo alegava Luisa Francisca do Espírito Santo, que cuidava de sua família e da de sua cunhada, como veremos a seguir. ${ }^{57}$ Essa constante evocação de papéis familiares indica que, embora a seca modificasse os comportamentos, criando muitas vezes outros valores, a exemplo de mulheres que saíram sozinhas ou como chefes de grupos familiares do Ceará, os laços de afetividade, de proteção e a função de provedor do grupo familiar poderiam até sofrer outros engendramentos, mas não se perdiam, nem tão pouco se rompiam com a migração, como pareciam acreditar os gestores públicos.

No caso das mulheres, assim como os homens, elas se integram aos trâmites da migração, indicando que em seu lugar de origem ou em Fortaleza - da mesma maneira que outros chefes de família - buscavam prover o seu grupo. Assim é que, em meio às justificativas e aos pedidos de passagem feitos por muitos homens para migrarem ao Pará, encontramos também, os de muitas mulheres. É o caso de Maria Thereza de Jesus, solteira, de 28 anos de idade; de Maria de Hollanda, natural de Limoeiro, casada, de 18 anos de idade, que seguia para a Amazônia em "procura de seu marido"; de Luisa Francisca do Espírito Santo, natural e moradora de Acarapé, de 25 anos de idade, também casada, "vivendo em extrema pobreza com a [onerada] família de 7 pessoas, inclusive a sua, isto devido à ausência de seu marido"; da viúva Francisca Gonçalves de Moura, de 69 anos de idade e sua extensa família de 37 pessoas.

Da primeira mulher, Maria Thereza, pouco é possível saber, uma vez que ela, em 1889, declarando-se solteira, parece ter embarcado desacompanhada, em meio a numerosas famílias que também fugiam da seca, no Vapor Pernambuco. ${ }^{58}$ Sua atitude pode ser vista como uma

\footnotetext{
${ }^{57}$ APEC - Caixa: Governo do Ceará. Ofícios emigração 1889.

${ }^{58}$ APEC - Caixa: Governo da Província do Ceará. Ofícios emigração 1889.
} 
certa ousadia, considerando-se os valores que norteavam os comportamentos femininos naquele momento, e ao mesmo tempo, como indicador de valores morais e regras de comportamento bastante específicos diante da calamidade da seca. Maria Clementina Pereira Cunha, referindo-se à presença feminina no asilo do Juquery em São Paulo, relata o caso de várias mulheres que eram consideradas alienadas por apresentarem comportamentos independentes em relação à família. Dentre os elementos que compunham a imagem da mulher degenerada, o viajar só apresentava-se como algo completamente incompatível com a própria natureza feminina. Afirma a autora que "vestir-se de homem, viajar só. Recusar o casamento, a maternidade, a família. Manifestar uma independência essencialmente estranha àquela sociedade” aparecem com elementos da degeneração feminina. Isso implica no fato de que "no caso da loucura feminina, a transgressão não atinge apenas as normas sociais, senão à própria natureza que a destinará ao papel de mãe e esposa", 59

Mas se Maria Thereza viajou só, não muito diferente foi a atitude da jovem senhora Maria de Hollanda, que solicitou passagem para os portos do norte, "forçada pela seca, não podendo mais subsistir", mas também “em procura” de seu marido, que há “cerca de 3 anos" havia se retirado para a província do Amazonas, para "trabalhar no serviço da borracha”. Para conseguir um atestado de sua pobreza, Maria recorreu ao vigário da matriz da Freguesia de Nossa Senhora da Conceição do Limoeiro, onde ela havia casado em 1886, solicitando-lhe "por certidão o termo de seu casamento", a fim de que ela pudesse seguir para o Amazonas “em conseqüência da pobreza e do desamparo em que se achava”. 60

Ao que tudo indica, o marido de Maria de Hollanda havia se retirado para o Amazonas logo após o casamento, e ao longo desses três anos, ela parecia ter mantido seus vínculos matrimoniais apesar da distância, vendo no encontro com o esposo a possibilidade de "salvarse da tremenda calamidade da qual ela já se sentia vítima”. Não fica claro se ela tinha notícias de seu marido ao longo desse tempo, mas isso não seria muito difícil, levando em conta as muitas redes de ligação que se formavam entre os migrantes e conhecidos que ficavam no sertão. Seja lá como for, ela acabou se lançando no desafio dessa difícil e longa viagem. Apesar de, segundo ela, seu marido se encontrar na província do Amazonas, Maria

\footnotetext{
${ }^{59}$ CUNHA, Maria Clementina Pereira. O espelho do mundo. Juquery, a história de um asilo. Rio de Janeiro: Paz e Terra, 1986, p. 144.

${ }^{60}$ APEC, Caixa: Governo da Província do Ceará - Ofícios emigração 1889.
} 
solicitava passagem ou para o Pará ou para o Amazonas. Embora os documentos não indiquem claramente para onde ela seguiu, num certo sentido, é possível até dizer que o encontro com seu marido não era o principal fator de sua saída do Ceará, que, quem sabe, fosse sua própria sobrevivência. ${ }^{61}$

Da mesma forma que Maria de Hollanda, que alegava ir à procura de seu marido, a senhora Luísa Francisca também precisava seguir para a província do Pará, onde esperava "ser socorrida pelo referido marido”. Um aspecto, entretanto, diferencia a partida de Luisa Francisca da de Maria de Hollanda. A segunda, apesar de sua condição de pobreza, viajava sozinha, ou pelo menos não declarara outros familiares. Luisa Francisca, entretanto, já na justificativa de seu pedido de passagem, indicava sua grande responsabilidade, que era a de sustentar uma “[onerada] família”. Tratava-se da família de sua cunhada, Teresa Maria de Jesus, de 24 anos de idade, que havia ficado viúva, com três crianças pequenas. Além dessas crianças, Luisa Francisca ainda tinha duas filhas, com 18 meses e com 2 anos de idade. Esse grupo familiar, composto por sete pessoas (duas mulheres e cinco crianças), tinha claramente como provedora Luisa Francisca, que, na ausência de seu marido, assumia tanto os seus filhos como os de sua cunhada. Se a atitude dessa jovem senhora indica solidariedade familiar, por outro lado, expressa ainda a decisão de não assumir sozinha essas responsabilidades, buscando "unir-se ao seu marido emigrando para o Pará". ${ }^{62}$

Se Maria Luisa tinha uma pequena família que a acompanhava na empreitada de emigrar para o Pará, a viúva Francisca Gonçalves de Moura, com 69 anos de idade, tinha sob sua responsabilidade um extenso grupo familiar, composto provavelmente por mais cinco famílias nucleares, que eram constituídas por seus filhos. Sua ida para o Pará se justificava por ser esse o lugar, conforme declarou, “onde tem parentes”. Diante disso, é que pedia ao vigário Luis de Sousa Leitão para que atestasse que sua família era, de fato, composta pelas pessoas por ela indicada. ${ }^{63}$ A extensa família de Francisca, emigrando junto com ela para a província do Pará,

\footnotetext{
${ }^{61}$ APEC, Caixa: Governo da Província do Ceará - Ofícios emigração 1889

${ }^{62}$ APEC, Caixa: Governo da Província do Ceará - Ofícios emigração 1889

${ }^{63}$ APEC, Caixa: Governo da Província do Ceará - Ofícios emigração 1889. Esse extenso grupo familiar era assim constituído: Francisca Gonçalves de Moura, 69; Maria Gonçalves de Moura, 25; Manuel Feliz, 16; Joana Gonçalves de Moura, 17; Francisco Ângelo Ribeiro, 46; Raimunda Francisca Moreira, 43; Francisco Jerônimo Ribeiro, 23; Miurinha Isadora Ribeiro, 16; Maria da Paz Ribeiro, 11; [Firmina], 6; Cândido, 3; Arcênia, 2; Manuel Severino, 17; Cândido Severino, 16; Manuel [...] dos Reis, 25; Idalina [...] do Nascimento, 20; Virgínia, 7; Antônia, 5; Francisca, 3; Maria, 2; Serafim da
} 
pode até sugerir um certo poder matriarcal, exercido por ela em relação a seu grupo familiar, uma vez que, mesmo havendo homens que faziam parte desse grupo, como era o caso de Francisco Ângelo Ribeiro, com 46 anos de idade, era em seu nome que aparecia o pedido de passagem feito ao governador da província do Ceará. ${ }^{64}$

$\mathrm{Na}$ medida em que revelam o que levava homens e mulheres a pedirem passagem para o Pará, as justificativas apresentadas indicam igualmente suas expectativas em relação a esse espaço. Por outro lado, longe da idéia de que, distante do Ceará, o migrante perdia seus vínculos com os parentes que haviam ficado, as justificativas revelam, pelo contrário, uma vasta teia de relações. Bom exemplo disso é o caso de Silvestre Amaral Lima, viúvo de 74 anos, natural e morador da vila de União, que viria ao encontro de seus dois filhos, que lhe garantiriam "os meios necessários para a sua subsistência e de sua família”. ${ }^{65}$ Num tempo em que a expectativa de vida era muito pequena, o velho Silvestre se propunha fazer essa longa viagem, mesmo que na companhia de seus outros três filhos, por acreditar no amparo que teria dos filhos já residentes no Pará. Nesse sentido, já ter vínculos familiares para o porto de destino foi, sem dúvida, um elemento importante que pesou na decisão de migrar para a Província do Pará

Desse modo, das 75 justificativas analisadas, somente 17 não fazem referência a parentes que já estão morando no Pará. A maioria explica sua saída alegando contar “com parentes que o podem amparar”; ter "pessoas da família bem colocadas que o convidam”, ou mesmo "sofrivelmente colocados"; ter "parentes que o chamam”; já ter no Pará “a maior parte da família"; ir "para a companhia de um filho e irmãos empregados na capital”, ou para a

Silva Santiago, 30; Adelina Gonçalves de Moura, 25; Antônio Sérgio da Silva, 16; Antônio, 7; Ildefonso, 6; Francisco, 5; Maria, 3; Carolina, 1; João Furtado, 35; Maria Gonçalves de Moura, 24; Francisco, 4; Raimundo, 5; Antônia Gonçalves de Moura, 38; Francisco Gonçalves de Moura, 24; Maria Gonçalves de Moura, 18; Maria, 7; [Antônia], 6.

${ }^{64}$ Partes dessas questões foram por nós discutidas em texto em que analisou-se justificativas de algumas mulheres ao solicitarem passagem do Ceará para a Província do Pará, bem como a experiência social de mulheres migrantes em Belém. LACERDA. Franciane Gama. "Requerendo passagem para si e sua família: mulheres migrantes no Para da virada do século XIX". Projeto História, $\mathrm{n}^{\mathrm{o}} 27$ (dezembro 2003), pp. 305-320.

${ }^{65}$ APEC, Caixa: Governo da Província do Ceará - Ofícios emigração 1889. 
“companhia de um genro”; ir para o Pará “onde existe mulher e sogro”, ou “onde moram os pais”, ou até “achar o marido". 66

Além dos vínculos familiares, a escolha também se dava pela crença de se encontrar trabalho em terras paraenses. Foi o que declarou, em junho de 1889, Libania Maria do C. [Santos], que pretendia viajar, ao que tudo indica sozinha, e que parecia muito cansada da vida no Ceará. Disse na ocasião que tinha “como certo” encontrar na Província do Pará “um trabalho decente", do qual pudesse "viver com menos sacrifício". Se de fato, essa foi a declaração de Libania, vemos que ela, no momento de pedir sua passagem, reafirmava os seus valores, ou os valores do que socialmente se esperava de uma mulher, pois desejava não qualquer trabalho, mas um que ela qualificava como "decente”. Outros flagelados pela seca, de forma semelhante a Libania, acreditavam que a Província do Pará lhes oferecia "meios de subsistência”, ou como disse Antonio Alves da França, tinham "certeza de encontrar meios para poder escapar das terríveis conseqüências da seca" ${ }^{67}$

Essas noções acerca do Pará indicam que muitos migrantes já tinham conhecimento da terra para onde pretendiam seguir. Laços de parentesco ou de amizade, relações variadas de

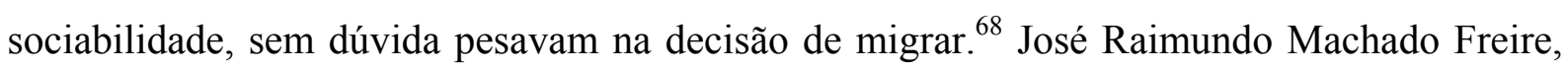
que morava em Baturité, em outubro de 1889, alegando viver com a mulher e mais seis filhos crianças, o mais velho com sete anos de idade, em verdadeiro “estado de penúria”, já indicava o lugar para onde desejava seguir na Província do Pará, a cidade de Santarém. O mesmo aconteceu com Jacinto Gonçalves da Silva, solteiro, de 23 anos, e seus três irmãos, que argumentava para o seu pedido de passagem o fato de não ter "alcançado meios para subsistir", sendo, por isso, "convidados por um outro irmão" que se achava "residindo na colônia Benevides do Pará”. Outros, como o viúvo Martinho Dias Pinto, expunham como razão para a saída a experiência anterior de já ter vivido no Pará. Alegou "seu estado de

\footnotetext{
${ }^{66}$ APEC, Caixa: Governo da Província do Ceará - Ofícios emigração 1889.

${ }^{67}$ APEC, Caixa: Governo da Província do Ceará - Ofícios emigração 1889.

${ }^{68}$ Denise Aparecida Soares de Moura, referindo-se à migração de cearenses para fazendas de café em São Paulo em 1878, afirma que a migração para São Paulo "longe de restringir-se às negociações e interesses das elites e autoridade das duas províncias, fez-se através de ajustes ligados a solidariedades vicinais, às formas de sociabilidade na terra natal, à afetividade e vínculo familiar e às relações de dependência". MOURA, Denise Aparecida Soares de. "Andantes de Novos Rumos: a vinda de migrantes cearenses para fazendas de café paulistas em 1878”. Revista Brasileira de História, vol. 17, no 34 (1997), p. 124.
} 
pobreza” que não lhe permitia "atravessar a crise dolorosa da seca em sua província natal”. Não podendo, dessa forma, junto com a família "regressar a sua custa”. 69

Indicativa de que conhecia o Pará é a solicitação do também viúvo Manuel Joaquim de Lima, que, diante da seca, "preferia a província indicada a qualquer outra”, apesar de se dizer, "bem informado do seu mau estado sanitário”. Mesmo assim, gostaria de emigrar, uma vez que na Província do Pará, tinha “muitos parentes” com os quais pretendia “ajuntar-se”. Pelas afirmações do viúvo Manuel, vê-se claramente que ele tinha informações prévias do porto de destino desejado, mas a possibilidade de reencontrar parte de sua parentela é o que lhe permitia solicitar a passagem. ${ }^{70}$

Aliás, seguir para o porto que o solicitante da passagem preferia foi uma questão que se colocou como ponto de discussão tanto para o Ministério dos Negócios do Império, como para o governo do Ceará, em 1889. De fato, a preferência pela Província do Pará, como afirmou ter o viúvo Manuel Joaquim de Lima, nem sempre foi vista com bons olhos, na medida em se pretendia incentivar uma corrente migratória de cearenses para o sul.

Essa questão trazia à tona um outro problema que também era fundamental: "o direito de locomoção". ${ }^{71}$ Assim, em ofício enviado ao presidente da Província do Ceará, o Ministério dos Negócios do Império enfatizava que sempre havia opinado no sentido de que "seria preferível que os retirantes buscassem trabalho no sul a buscá-lo no norte”. Entretanto, ainda segundo o mesmo ofício, diante do que se chamou de um "clamor injustamente levantado" de que se pretendia "tolher o direito de locomoção", afirmava que se deveria respeitar "a

\footnotetext{
${ }^{69}$ APEC, Caixa: Governo da Província do Ceará - Ofícios emigração 1889.

${ }^{70}$ APEC, Caixa: Governo da Província do Ceará - Ofícios emigração 1889.

${ }^{71}$ Por ocasião da seca de 1889, o Ministério dos Negócios do Império em ofício encaminhado ao Presidente da Província do Ceará, recomendava a expedição de algumas ordens aos comandantes de vapores no sentido de que estes nos portos que existissem "indigentes flagelados pela seca", não excedessem a lotação dos vapores e que recebessem e conduzissem "sem constrangimento para os portos preferidos as pessoas que quisessem utilizar desse serviço". APEC - Ala 19, Estante 407, no 11 - Ministério do Império ao presidente da Província do Ceará, avisos. 1889. Ministério dos Negócios do Império. $1^{\text {a }}$ Diretoria, $n^{\circ} 430$. Rio de Janeiro, 30 de janeiro de 1889. Em outro ofício também do ano de 1889, o Ministério dos Negócios do Império, sugeria ao Presidente da Província do Ceará, que só em último caso se dessem passagens para os flagelados pela seca, mas que quando se tomasse tal providência que se respeitasse o "princípio da locomoção, deixando-se ao arbítrio de cada um tomar a direção mais conveniente para os seus interesses". APEC - Ala 19, Estante 407, nº 11 - Ministério do Império ao presidente da Província do Ceará, avisos. 1889. Ministério dos Negócios do Império $1^{\text {a }}$ Diretoria, $\mathrm{n}^{\mathrm{o}}$ 1110. Rio de Janeiro, 19 de março de 1889.
} 
livre escolha do porto de destino". Nesse sentido, visando a esclarecer os "próprios retirantes" das vantagens que as regiões do sul do império ofereciam, propunha-se a “conveniência” de uma "propaganda”. Essa propaganda deveria enfatizar o "trabalho" e "remuneração" que os retirantes teriam no sul do país. ${ }^{72}$

Em outro ofício, datado de 10 de março de 1889, o Ministério do Império referia-se ao fato de que o estado sanitário do Rio de Janeiro não tinha "melhorado", e que em São Paulo, Santa Catarina, e Rio Grande do Sul tinham “aparecido alguns casos de febre amarela”. A circulação de notícias sobre esses fatos, bem como a "exageração" dos mesmos, segundo o ofício enviado, concorria para que as "populações retirantes do Ceará” se desviassem da intenção de "emigrarem para o sul”. Embora o Ministério do Império afirmasse ter adquirido uma "vasta e fértil propriedade rural" na província do Rio de Janeiro, mesmo assim, a migração para o norte continuou sendo mais intensa. ${ }^{73}$

Além da importância de se ter parentes no Pará, outros elementos que pesavam na escolha do norte era a proximidade com o Ceará, as notícias do enriquecimento com a borracha, o

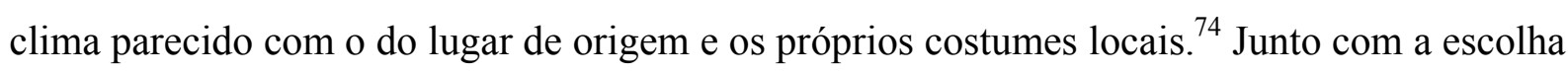
do porto de preferência, temos aqui mais um argumento para fortalecer a idéia de que os flagelados pela seca indicavam os caminhos que consideravam importantes para a sua vida, mesmo que isso não correspondesse aos anseios daqueles que, por exemplo, financiavam a passagem quando eles decidiam migrar.

A questão da locomoção dos migrantes também entra em evidência quando da seca de 1900. Através das memórias do Cônego Luiz Leitão, anotadas no livro de tombo da Freguesia de São de José de Castanhal, escritas entre 1911 e 1921, é possível perceber um pouco disso. O padre Luiz Leitão, que também era um migrante cearense, ao narrar sua saída do sertão de

${ }^{72}$ Ala 19, Estante 407, no 11 - Ministério do Império ao presidente da Província do Ceará, avisos. 1889. Ministério dos Negócios do Império. $1^{\mathrm{a}}$ Diretoria, $\mathrm{n}^{\circ}$ 908. Rio de Janeiro 2 de março de 1889.

${ }^{73}$ Ala 19, Estante 407, no 11 - Ministério do Império ao presidente da Província do Ceará, avisos. 1889. Ministério dos Negócios do Império. Gabinete, $\mathrm{n}^{\circ} 1112$ - Rio de Janeiro, 10 de março de 1889

${ }^{74}$ Rodolpho Theophilo, referindo-se a essa questão, afirma que "O cearense emigra para o sul porém contra vontade. A emigração que lhe agrada é para a Amazônia”. Exagerando afirma até que "o cearense considera aquela região como um prolongamento da sua terra. (...) Lá ele vai encontrar irmãos vai conviver com os seus, com quem passa relembrar o seu Ceará (...). No sul não encontrará quem fale no Ceará. Lá são outras gentes e outros os ares. Tudo é diferente. Ou há de ser o frio que gela ou o calor que insola. (...) É tão outra a sua vida nas regiões do sul! Dizem que lá acabarão que nunca mais voltarão a ver as belezas da sua amada terra". TEOPHILO, Rodolpho. A seca de 1915. 
Canindé para Fortaleza, conta que “depois de três meses”, morando com um cunhado em uma “chácara”, sem adquirir “o necessário para o sustento de numerosa família”, tomou a resolução de "emigrar para o Pará”. Como outros migrantes, o padre afirma que já tinha indicações do lugar onde pretendia viver: “ocupava já meu espírito a vila de Castanhal, que conhecia por informações". 75

Luiz Leitão, acompanhado de um "bom amigo e chefe político”, chega a Belém em junho de 1900, indo ao encontro do governador Paes de Carvalho, para falar acerca do "flagelo que assolava o Ceará" e também da “necessidade de se acolher neste rico Pará os emigrantes”. Antes disso, entretanto, ainda em Fortaleza, ele disse que se colocou "ao lado dos flagelados", buscando "defender-lhes o direito de transporte para qualquer porto que entendessem”. Ao tomar essa atitude, declarava que havia se oposto à "vontade do governo do Estado do Ceará", que "dificultava” a posse de passagens daqueles "sem recursos". 76

A trajetória de vida do padre Luiz Leitão em Castanhal demonstra que ele tinha claros interesses políticos, buscando manter amizades com personagens influentes como os governadores Paes de Carvalho e Augusto Montenegro, ou vivendo em conflito com outros grupos políticos daquela vila. Sua vinda para a região permite visualizar, ainda, as dificuldades de se obter passagens, bem como as preocupações que os governos cearenses sempre assinalaram em relação à saída de trabalhadores do Ceará. Por outro lado, demonstrando oposição ao governo do Ceará e buscando no Pará bases para a influência política que pretendia construir na região de Castanhal, o padre se descreveu no livro de tombo como um dos incentivadores para que o governador Paes de Carvalho "resolvesse custear o transporte de emigrantes cearenses". ${ }^{77}$

Tudo indica que Luis Leitão não era um retirante da seca de 1900, como muitos que chegaram ao Pará. Sendo padre, tinha estudado e provavelmente pagou a própria passagem, não vindo na condição de um faminto, mas de alguém que se colocava no papel de requerer auxílio junto ao governo do estado do Pará pelos flagelados da seca. Sua ida, logo na chegada

\footnotetext{
${ }^{75}$ Cônego Luis Leitão - Livro de Tombo da Freguesia de São José de Castanhal, p. 2.

${ }^{76}$ Cônego Luis Leitão - Livro de Tombo da Freguesia de São José de Castanhal, p. 2.

${ }^{77}$ Cônego Luis Leitão - Livro de Tombo da Freguesia de São José de Castanhal, p. 3.
} 
a Belém, ao "Palácio de Dr. Paes", que o recebeu “fidalgamente”, convidando-o inclusive para "almoçar em sua residência”, é elucidativa nesse sentido. ${ }^{78}$

Conceder passagens para os retirantes da seca se transportarem do Ceará ao porto de Belém, como registrou o Cônego Leitão, foi sem dúvida uma das ações empreendidas pelos poderes públicos paraenses. Embora o governo reclamasse, como se viu anteriormente, da constante chegada de cearenses ao Pará, também se colocava à disposição para o transporte de migrantes. Em 1889, por exemplo, o Ministério dos Negócios do Império comunicava ao Presidente da Província do Ceará que o Dr. Antonio José Ferreira Braga, Presidente da Província do Pará, concedia passagens até Belém num "vapor da Companhia Brasileira” a "22 imigrantes cearenses, sendo 15 adultos e 7 menores". ${ }^{79}$

Do mesmo modo, bem antes da chegada do padre Luis Leitão ao Pará, o governador do Ceará, Antonio Accioly, em Mensagem de 4 de julho de 1898, lembrava que com as notícias da seca, os governadores do Pará e do Amazonas “apressaram-se” em manifestar os seus "sentimentos fraternais", diante do problema vivido pelo Ceará. Na ocasião, mostraram-se dispostos a "facilitar meios de transporte" para "todas as pessoas" que tivessem necessidade de "emigrar para aqueles estados do extremo norte”. Segundo Accioly, garantia-se a esses migrantes "ocupações na lavoura e na indústria extrátil”" ${ }^{80}$

Em 1900, a situação não foi diferente, e o governador do Ceará, Pedro Borges, referia-se mais uma vez à "simpática solidariedade” dos governadores do Pará e do Amazonas. ${ }^{81}$ Ao contrário do que poderia parecer pela descrição do Padre Luiz Leitão, na Mensagem de 1901, o Governador do Ceará, Pedro Borges, mostrava-se bastante satisfeito com a atitude de Paes de Carvalho em proporcionar "transporte às expensas” do Estado do Pará “aos cearenses que quisessem emigrar". 82

\footnotetext{
${ }^{78}$ Cônego Luis Leitão - Livro de Tombo da Freguesia de São José de Castanhal, p. 4.

${ }^{79}$ APEC - Ala 19, Estante 407, no 11 - Ministério do Império ao presidente da Província do Ceará, avisos. 1889. Ministério dos Negócios do Império. $1^{\text {a }}$ Diretoria, $\mathrm{n}^{\circ}$ 4277. Rio de Janeiro, 28 de setembro de 1889.

${ }^{80}$ Mensagem apresentada à Assembléia Legislativa do Ceará pelo presidente do Estado Dr. Antonio Pinto Nogueira Accioly em 4 de julho de 1898. Fortaleza: Typographia Econômica, 1898, p. 35.

${ }^{81}$ Mensagem apresentada à Assembléia Legislativa do Ceará em $1^{\circ}$ de julho de 1901 pelo Presidente do Estado Dr. Pedro Augusto Borges. Fortaleza: Typ. Econômica, 1901, p. 29.

${ }^{82}$ Mensagem apresentada à Assembléia Legislativa do Ceará em $1^{\circ}$ de julho de 1901 pelo Presidente do Estado Dr. Pedro Augusto Borges. Fortaleza: Typ. Econômica, 1901, p. 44.
} 
Por ocasião da seca de 1915, o governador do Pará, Enéas Martins, também não deixou de fazer referência ao tema em sua Mensagem, dirigida ao Congresso Legislativo do Pará, afirmando que a seca havia determinado "emigração em massa", uma vez que esses flagelados faziam o que ele chamava de um "êxodo forçado" em "fuga de uma natureza hostil”. Segundo Enéas Martins, dentre os estados que receberam migrantes, o Pará foi o destino de maior número deles. Os governadores anteriores a Enéas Martins e que também receberam flagelados pela seca viviam as muitas vantagens da economia da borracha. Esse governador, entretanto, experimentava uma crise econômica de grandes proporções em função das mudanças no mercado internacional da goma elástica. Mesmo assim, diante da seca, afirmou que “o sacrifício” de acudir os migrantes “impôs-se inevitável” ${ }^{83}$

Entre agosto de 1915 e junho de 1916, segundo a Mensagem do Dr. Enéas Martins, chegam ao estado do Pará, de diversas partes do nordeste, aproximadamente 18. 255 migrantes. Um número bastante elevado, sobretudo de pessoas vindas do Ceará - 16.068. Os demais migrantes eram de Rio Grande do Norte (1.694), Pernambuco (262), Maranhão (95), Paraíba (26), Piauí (14) e Bahia (12). ${ }^{84}$ A chegada desses muitos migrantes em Belém, em tempos de crise econômica, gerou uma série de ações de ajuda humanitária, organizadas pela sociedade local, a exemplo das campanhas da "Assistência aos flagelados pela seca", empreendidas com fins altruísticos, mas também com claros fins civilizatórios e disciplinatórios. Antes de serem alvos dessas medidas, entretanto, os migrantes cearenses teriam uma árdua viagem a enfrentar, a exemplo da história de Mariano e sua família. Se a viagem em vapores, quase sempre com muitos passageiros, sobretudo nos períodos de seca, foi marcada pelos medos e incertezas do futuro, pela saudade da terra natal, essa mesma experiência também refletia solidariedade, construção de identidade do grupo e sobretudo a tentativa de ir ao encontro de uma vida melhor.

\footnotetext{
${ }^{83}$ Mensagem dirigida em 1 de agosto de 1916 ao Congresso Legislativo do Pará pelo Dr. Enéas Martins Governador do Estado. Belém: Imprensa Oficial do Estado do Pará, 1916, p. 85

${ }^{84}$ Mensagem dirigida em 1 de agosto de 1916 ao Congresso Legislativo do Pará pelo Dr. Enéas Martins Governador do Estado. Belém: Imprensa Oficial do Estado do Pará, 1916, p. 85.
} 


\section{A viagem}

Depois da passagem adquirida - por meios próprios, financiada pala União, pelos governos do Ceará, ou pelo dos lugares para onde os migrantes pretendiam seguir -, os problemas do retirante da seca não haviam terminado. A hora do embarque, que era sempre muito difícil, pela própria natureza da situação de quem deixava sua terra, nem sempre por vontade própria, mas pela necessidade de sobreviver, foi alvo de críticas, diante da forma desrespeitosa com que muitas vezes os migrantes foram tratados. Buscando rastrear a experiência social das mulheres nos seringais do Acre, Cristina Wolff, faz referência a esses deslocamentos populacionais enfatizando as dificuldades que os migrantes enfrentavam nessas viagens do nordeste para a Amazônia. ${ }^{85}$ Do mesmo modo, Frederico de Castro Neve, referindo-se aos deslocamentos para a Amazônia afirma que no embarque "os retirantes enfrentavam os mais inusitados desafios, com os desmandos dos responsáveis pelo alistamento e alojamento das famílias". ${ }^{86}$

Em 1894, preocupado coma a constante saída de cearenses para a Amazônia, o governador do Ceará afirmava que seguiam para essa região "magotes de emigrantes”. Dentre esses, lembrava que não vinham apenas "criminosos e desertores", que fugiam de punições, mas igualmente "órfãos", além de "infelizes mulheres", que eram "arrastadas pela sedução", muitas vezes se prestando a serem "vendidas por um certo número de quilos de borracha". ${ }^{87}$

A vinda de mulheres para a região foi uma prática bastante comum, e que como também evidenciou-se, não pode ser entendida apenas dentro da perspectiva de se prostituir. Mesmo que de fato viesse com esse objetivo, ou que muitas mulheres fossem seduzidas pelas possíveis riquezas da economia da borracha, não resta dúvida de que esse embarque para o Vale Amazônico se dava em nome de uma vida melhor, que no Ceará não se tinha esperança de ter.

85 "De primeiro ... As mulheres na constituição dos seringais (1870-1912)". WOLFF, Cristina Scheibe. Mulheres da Floresta: uma história: Alto Juruá, Acre (1890-1945), pp. 41-91.

${ }^{86}$ NEVES, Frederico de Castro. A multidão e a história: saques e outras ações de massas no Ceará, p. 33.

${ }^{87}$ Mensagem do Presidente do Estado Coronel Dr. José Freire Bezerril Fontenelle à Assembléia Legislativa do Ceará em sua $3^{a}$ sessão ordinária da $2^{a}$ Legislatura. Fortaleza: Typ. d'A Republica, 1894, p. 7. 
Assim, um funcionário do governo federal, do qual o governador do Ceará José Freire Bezerril Fontenelle não dizia o nome, referindo-se na Mensagem que esse governador dirigiu à Assembléia Legislativa ao embarque de cearenses, afirmou ser "doloroso assistir ao espetáculo" que era "oferecido 6 ou 7 vezes por mês” aos moradores de Fortaleza. Tratava-se das saídas dos paquetes do Lloyd Brasileiro para a região amazônica. Aquele narrador dizia que se via uma "leva de 700 a 800 pessoas", descritas como "válidas e na flor da vida". Segundo ele, dias depois, assistia-se a um outro movimento no porto, o de desembarque de cearenses que retornavam da Amazônia e vinham "envelhecidos pelas moléstias descrentes", traziam como bagagem "um futuro de dores" e - o que é mais importante - como mão de obra inapta para "qualquer dos trabalhos que se entregavam em sua mocidade". ${ }^{88}$ Mais do que uma preocupação com o futuro de cearenses pobres, a crítica aqui é voltada para a possível perda dessa mão-de-obra.

Nessa abordagem, em sua partida do Ceará ou no retorno, o cearense era visto não como alguém que buscou melhorar a sua condição, arriscando muitas vezes para isso a própria vida, mas como uma perda de braços para o trabalho. Apesar disso, um aspecto apontado nessa descrição é a saída não de famintos andrajosos, mas de homens sadios e fortes, o que é incomum nos registros de migrantes cearenses embarcando em paquetes para a Amazônia.

Embora a saída de cearenses não fosse muito bem vista, esse deslocamento, não só pela seca mas também pelas possibilidades de trabalho oferecidas no estado do Pará, era bastante dinâmico. Não sem razão, nesse mesmo ano de 1894, o Ministério da Indústria, Viação e Obras Públicas remetia, do Rio de Janeiro, ao governador do Ceará, um "exemplar do Diário oficial”, em que se achava publicado um “edital”, que visava à “concorrência” para uma empresa que se interessasse por fazer "serviço de navegação" entre os estados do Ceará e do Pará. Segundo o edital, a empresa deveria realizar "pelos menos duas viagens mensais" em vapores que pudessem acomodar "30 passageiros de ré e 50 de proa debaixo de coberta". ${ }^{89}$ Considerando que outras companhias de vapores vinham do sul ou da Europa, e também

\footnotetext{
${ }^{88}$ Mensagem do Presidente do Estado Coronel Dr. José Freire Bezerril Fontenelle à Assembléia Legislativa do Ceará em sua $3^{a}$ sessão ordinária da $2^{a}$ Legislatura. Fortaleza: Typ. d'A Republica, 1894, p. 8.

${ }^{89}$ APEC - Ala 19, Estante 407, no 45 - Diversos Ministérios ao presidente da Província do Ceará, avisos 1890-1893. Ministério da Indústria, Viação e Obras Públicas. Diretoria Geral da Indústria, $1^{a}$ secção, n 102. Rio de Janeiro, 31 de agosto de 1894.
} 
faziam escala no porto de Fortaleza, mesmo em períodos que não eram de seca, isso significava que um número representativo de cearenses poderia desembarcar no Pará.

Nos períodos de seca, como em 1900, o desembarque no porto de Fortaleza causava grande surpresa ao viajante. O governador Pedro Borges conta que, ao chegar ao porto de Fortaleza, se "deparou com o mais vivo testemunho da infeliz situação dos retirantes”. Era possível vêlos segundo o governador “aglomerados na praia”, nas “praças” e “sob as árvores”, angustiando a todos que presenciavam essa cena. ${ }^{90}$ Semelhante impressão foi a que teve a escritora Anna César, que, em janeiro de 1916, acompanhou no porto de Fortaleza o "penoso êxodo do sertanejo". No vapor que a escritora tomou para Belém, viajaram na proa “seiscentos retirantes", que, por seu olhar, que enxergava apenas a migração dentro de um contexto extremamente trágico, vinham "a mercê da sorte, saudosos dos seus lares" $e$ igualmente "chorando a terra infeliz e amada". 91

Mas o porto do Ceará não pode ser visto somente de forma trágica, mesmo nos anos em que se sofriam os efeitos da seca. Apesar da pobreza enfrentada pela cidade, outras atividades se mantinham. Da série de crônicas publicadas na Folha do Norte, intitulada acertadamente "Bilhetes postais - impressões de viagem”, podem-se perceber outros contornos do porto, que não apenas a imagem do embarque de famintos. O cronista que assinava apenas como Ignotus, nesse mesmo ano de 1916, a bordo do vapor Ceará, da empresa Lloyd Brasileiro, descreveu a movimentação do porto de Fortaleza quando da chegada de um vapor. Assim, depois das "visitas de praxe” que os fiscais da saúde pública, da alfândega e da polícia faziam aos paquetes, “uma aluvião de mercadores de ambos os sexos” apareciam, vendendo uma variedade de produtos. ${ }^{92}$

Dos “samburás”, os fruteiros “exibiam” frutas, como "as belas e saborosas pinhas”; um outro homem procurava vender aos passageiros que chegavam "bengalas, argolas para guardanapo, copos e muitos outros objetos, (...) pacientemente trabalhados com chifre pelos presos da cadeia”. Além desses produtos, “um mundo de coisas” saía de "pequenos baús de madeira ou de folha de flandres" apresentados pelas mulheres cearenses aos recém-chegados

\footnotetext{
${ }^{90}$ Mensagem apresentada à Assembléia Legislativa do Ceará em $1^{\circ}$ de julho de 1901 pelo Presidente do Estado Dr. Pedro Augusto Borges. Fortaleza: Typ. Econômica, 1901, p. 24.

${ }^{91}$ Folha do Norte. Belém, 19 de janeiro de 1916, p. 1.

${ }^{92}$ Folha do Norte. Belém, 7 de setembro de 1916, p. 1.
} 
à cidade. Eram "delicados trabalhos de crochet, de bordados e de rendas", feitos por mulheres que, como ninguém, exploravam essa indústria, da qual viviam "exclusivamente" muitas famílias pobres. "Nha Raymunda” era uma dessas mulheres que, "como os caixeiros viajantes", todos os anos, saía de Fortaleza para "fazer as praças do norte e sul da República”. ${ }^{93}$

Ao lado dessa legião de mercadores, estavam presentes também, na hora do desembarque, os catraieiros, que "convidavam os passageiros a saltar” e, igualmente, "caixeiros de hotéis e pensões", dando conta das hospedagens ou mesmo apregoando os "menus" que se podia experimentar em Fortaleza. ${ }^{94}$ Nesse movimentado espaço de chegada dos paquetes, é que também se concentravam os migrantes que seguiam para a Amazônia.

A saída de cearenses para a região norte tornou-se um problema tão importante, a ponto de, nos pronunciamentos oficiais, se fazerem referências a esses deslocamentos. Na Mensagem que Benjamin Barroso, governador do Ceará, dirigiu à Assembléia Legislativa, aparecem igualmente menções a embarques da seca de 1915. Segundo o governador, diante das exigências dos portos de destino dos migrantes de que não "emigrassem os afetados por tracoma” e, também, para que não embarcassem "os inválidos”, em muitos paquetes do Lloyde, os comandantes e médicos eram bastante arbitrários e buscavam a todo custo impedir a entrada de passageiros com tais características: “à menor vermelhidão de olhos os faziam voltar para terra". 95

Essa atitude do não embarque de passageiros suspeitos de tracoma tinha outro desdobramento mais grave. Muitos deles ficavam, nas palavras do governador, "desgarrados do resto da família” que por vezes já havia se “alojado na proa e seguia destino incerto”. Além desta separação da família, em "que filhos pequenos ficavam privados do conforto materno", sem saberem o rumo que os pais haviam tomado, o governador citava um outro problema decorrente das muitas exigências na hora do embarque: o extravio de bagagens ou,

\footnotetext{
${ }^{93}$ Folha do Norte. Belém, 7 de setembro de 1916, p. 1.

${ }^{94}$ Folha do Norte. Belém, 7 de setembro de 1916, p. 1.

${ }^{95}$ Mensagem dirigida à Assembléia Legislativa do Ceará em $1^{\circ}$ de julho de 1916 pelo Presidente do Estado Coronel Benjamin Liberato Barroso. Fortaleza, 1916, p. 12
} 
como ele mesmo disse, dos "cacarecos que ficavam abandonados nos escaleres e ainda nas praias". 96

Benjamin Barroso afirmou que isso gerava grandes custos em telegramas para "todos os portos de destino dos retirantes", a fim de que eles pudessem reaver as "suas miseráveis bagagens". ${ }^{97}$ Essas considerações do governador sugerem dois pontos de reflexão. O mais importante talvez seja o fato de que ele buscava, em sua Mensagem, construir sua imagem como o protetor dos cearenses. Entretanto, considerando-se a crise econômica vivida pelo Ceará, agravada pela seca, e as críticas aos muitos gastos inúteis na administração de Barroso e ainda, às dificuldades desse mesmo Estado em alimentar milhares de sertanejos expulsos de seu lugar de origem pela seca, o gasto com o envio dessas bagagens de pouco valor, importantes apenas para o próprio dono que as tinha perdido, talvez tenha sido uma prática não tão comum quanto o governador parecia querer demonstrar. Por outro lado, o fato de se ter bagagens, mesmo que fossem poucas e miseráveis, não reduz o migrante da seca apenas a um faminto vestido em andrajos, que não guardava absolutamente nada do sertão, de sua vida antes da seca, que havia perdido a condição humana.

Um outro aspecto importante que Benjamin Barroso apontou em sua Mensagem diz respeito à forma desigual como, segundo ele, eram "tratados” os imigrantes estrangeiros no Brasil, pois que "não lhes tomam conta da sua capacidade de trabalho, de sua saúde e robustez”. Para o governador, as imposições para o embarque de cearenses davam conta de grande "desigualdade" para com os migrantes nacionais. Citava como exemplo o não embarque de passageiros com suspeita de tracoma, argumentando que os atestados dados por oculistas declarando a inexistência da moléstia, muitas vezes, não eram aceitos. A crítica do governador se estendia sobretudo ao incentivo à vinda de imigrantes estrangeiros ao país, vistos como “irmãos na obra do desenvolvimento”, quando no próprio Brasil se criavam embaraços aos deslocamentos de migrantes nacionais. ${ }^{98}$

\footnotetext{
${ }^{96}$ Mensagem dirigida à Assembléia Legislativa do Ceará em $1^{\text {o }}$ de julho de 1916 pelo Presidente do Estado Coronel Benjamin Liberato Barroso. Fortaleza, 1916, p. 12

${ }^{97}$ Mensagem dirigida à Assembléia Legislativa do Ceará em $1^{\circ}$ de julho de 1916 pelo Presidente do Estado Coronel Benjamin Liberato Barroso. Fortaleza, 1916, p. 12

${ }^{98}$ Mensagem dirigida à Assembléia Legislativa do Ceará em $1^{\circ}$ de julho de 1916 pelo Presidente do Estado Coronel Benjamin Liberato Barroso. Fortaleza, 1916, p. 12
} 
Em reposta a esse problema, Benjamin Barroso lembrou que Gustavo Barroso, "representante do Ceará" no Congresso, havia proposto uma medida no sentido de também se impedir, no Brasil, a entrada de "emigrantes inúteis de mutilados pela guerra”. Acreditava o governador que essa medida poderia ser o "começo" de uma "assistência aos trabalhadores nacionais". ${ }^{99}$ Essa valorização de trabalhadores estrangeiros, e até mesmo de ajuda humanitária enviada ao estrangeiro, a exemplo de doações à Bélgica e à Cruz Vermelha Portuguesa, também foi alvo de críticas na Imprensa local. ${ }^{100}$ Em 1916, por exemplo, um articulista com o pseudônimo de "Pan Demônio" afirmava que "o brasileiro esquece a miséria que reina em casa", referindo-se à seca de 1915, enviando donativos para outros países. ${ }^{101}$ Não se pode afirmar exatamente isso, a julgar uma mobilização caritativa em relação aos cearenses. No entanto, em alguns momentos, os argumentos de "Pan Demônio" têm sentido, diante de um ideal de civilidade que tinha a Europa como modelo, valorizando-se sobremaneira os padrões e costumes europeus.

As críticas em relação aos embarques e à maneira como as companhias de vapores se portavam com seus passageiros não se faziam sem razão. Um bom exemplo disso são os problemas que a população enfrentava com vapores da companhia Lloyde Brasileiro, que, vindos do Rio de Janeiro, paravam em portos do nordeste, seguindo para a Amazônia. Especulação na venda das passagens, atraso ou mudança de data das viagens sem aviso prévio aos usuários e falta de alimentação são denúncias que aparecem na Imprensa local.

Em 1892, a partir de uma denúncia publicada no jornal “A República”, o Ministério dos Negócios do Império da Agricultura, Comércio e Obras Públicas pediu ao governador do Ceará informações detalhadas sobre a "grave infração do contrato celebrado com o Lloyde Brasileiro". A denúncia era de que essa agência "entregava todos os bilhetes de passagens

\footnotetext{
${ }^{99}$ Mensagem dirigida à Assembléia Legislativa do Ceará em $1^{\circ}$ de julho de 1916 pelo Presidente do Estado Coronel Benjamin Liberato Barroso. Fortaleza, 1916, p. 12.

${ }^{100}$ Do mesmo modo que a Folha do Norte, anunciava campanhas em prol dos flagelados pela seca, também anunciava eventos de ajuda à Cruz Vermelha Portuguesa e à Cruz Vermelha Belga.

Folha do Norte. Belém, 7 de janeiro de 1915, p. 2; Folha do Norte. Belém, 12 de janeiro de 1915, p. 2; Folha do Norte. Belém, 16 de janeiro de 1915, p. 2.

${ }^{101}$ Folha do Norte. Belém, 2 de fevereiro de 1916.
} 
para o norte” para alguns "cambistas protegidos”. Esses bilhetes eram então vendidos com “grande ágio” para os "infelizes” que pretendiam emigrar. ${ }^{102}$

Anos mais tarde, por ocasião da seca de 1900, o mesmo tipo de denúncia é publicado na Folha do Norte, a partir do que esse jornal chamou de "nota de torpeza que constrange", que havia circulado no jornal carioca "O Comércio”. As denúncias, com o mesmo teor do ano de 1892, afirmavam, a partir de um “documento" que os redatores de “O Comércio” possuíam, que as passagens para os estados do Pará e do Amazonas, nos vapores do "Lloyde Brasileiro", eram vendidas a um "sindicato", que as "revendia com um aumento de cento por cento". Para se ter uma idéia, pela tabela dos vapores do Lloyde, as passagens de terceira classe de Fortaleza para Belém, que custavam "vinte mil e seiscentos réis”, eram vendidas pelos cambistas "a razão de quarenta e cinco e cinqüenta reis cada". ${ }^{103}$

Segundo a declaração de uma testemunha, que viu por “diversas vezes” o proprietário de uma hospedaria "vender" passagens a "diversas pessoas que se destinavam aos portos do Pará e do Amazonas", o lucrativo negócio se dava na medida em que um agente de nome Newton Burlamaqui entregava “com antecedência grandes quantidades” de passagens aos cambistas que, depois de vendidas, tinham os "lucros repartidos" inclusive com o próprio agente. O que chamava a atenção da Imprensa era o fato de que as vendas de passagem se davam num momento de grandes dificuldades com a seca, em que se utilizava dos sacrifícios de "pobres emigrantes, que precisavam fugir dos arrasos da miséria". ${ }^{104}$

Por mais constrangedora que a notícia do ágio das passagens possa nos parecer, por mais que muitos agenciadores de trabalhadores para os seringais tenham se envolvido nesse esquema de compra e venda das passagens, tais episódios também revelam o empenho do próprio migrante em se deslocar para o norte, mesmo que para isso tivesse que pagar preços exorbitantes. Embora sendo explorado pela ma fé dos cambistas, o migrante aqui se apresenta como o responsável por suas próprias ações.

Viajar para o norte não era, de fato, nada fácil. No ano de 1898, por exemplo, além do caso de Mariano e dos demais passageiros do vapor Brasil, outro grupo de migrantes reclamou de

\footnotetext{
102 APEC - Ala 19, Estante 407, no 45 - Diversos ministérios ao presidente da Província do Ceará, avisos 1890-1893. Ministério dos Negócios da Agricultura, Comércio e Obras Públicas. Diretoria de Comércio, $1^{\text {a }}$ seção, $n^{\circ}$ 9. Rio de Janeiro, 26 de maio de 1892.

${ }^{103}$ Folha do Norte. Belém, 27 de julho de 1900, p. 1.

${ }^{104}$ Folha do Norte. Belém, 27 de julho de 1900, p. 1.
} 
fome, desta vez, no vapor Paraíba, da agência Lloyde Brasileiro. O comandante do vapor, José Freire de Albuquerque, depois das denúncias, tal qual a viúva de Mariano, também foi ao escritório do jornal Folha do Norte a fim de explicar o que acontecera. A explicação dada era simples: "logo que qualquer passageiro chega ao porto a que se destina, tem o dever de desembarcar". Os passageiros do Paraíba deveriam seguir para o interior. A pedido do contratante desses migrantes, os mesmos se mantiveram a bordo do vapor, uma vez que "vindo a terra poderiam extraviar-se", o que daria muito trabalho para "reuni-los na hora da partida”. 105

No porto de destino, o comandante estava "desobrigado do compromisso de dar-lhes alimentação", que passaria para a responsabilidade do "contratante” dos mesmos, o que, ao que tudo indica, não aconteceu. Para demonstrar o quão infundados eram os boatos da fome no vapor, o comandante declarou que "ainda fez matar um boi para a alimentação dos passageiros". ${ }^{106}$ A prática de que, chegando ao porto de destino, a empresa estava desobrigada de auxílio aos migrantes não era uma regulamentação apenas para aqueles que viajavam com passagem financiadas pelo contratante. Mesmo no caso de passagens subsidiadas pelo Estado, isso também poderia acontecer. Por ocasião da seca de 1889, o Ministério dos Negócios do Império recomendava que nos "vapores fretados para transporte dos retirantes", os passageiros embarcassem "na certeza” de que não poderiam "contar com outro auxílio além da passagem”, e que chegando ao porto de destino, deveriam "procurar por si” a colocação que mais lhes conviesse. ${ }^{107}$

O caso do vapor Paraíba revela a situação em que muitos migrantes chegavam ao Pará. Esses passageiros, que "não foram contratados pelo delegado especial do governo em nenhum dos estados próximos”, vinham para o estado do Pará, como era comum, em virtude de "contrato particular", para trabalharem na "indústria extrativa”. ${ }^{108}$ Isso sugere que o contrato com particulares colocava o migrante em uma situação de maior exploração, uma vez que esse trabalhador chegava à região pago para atuar na extração do látex. Nesse contexto, o

\footnotetext{
${ }^{105}$ Folha do Norte. Belém, 6 de dezembro de 1898, p. 1.

${ }^{106}$ Folha do Norte. Belém, 6 de dezembro de 1898, p. 1.

${ }^{107}$ APEC - Ala 19, Estante 407, no 11 - Ministério do Império ao presidente da Província do Ceará, avisos. 1889. Ministério dos Negócios do Império. $1^{\mathrm{a}}$ Diretoria, $\mathrm{n}^{\mathrm{o}} 430$. Rio de Janeiro, 30 de janeiro de 1889 .

${ }^{108}$ Folha do Norte. Belém, 6 de dezembro de 1898, p. 1.
} 
migrante, que seria um seringueiro, reproduziria a experiência que a historiografia consagrou como a única do cearense na Amazônia.

Mesmo nessa situação, eles não eram tão passivos assim. O confinamento a que foram obrigados os passageiros do vapor Paraíba é revelador nesse sentido, diante do medo de que - como teria dito o comandante - pudessem "extraviar-se” ao desembarcarem em Belém. Por outro lado, na memória da população paraense, talvez ainda estivesse viva a lembrança da triste história da fome, seguida de suicídio, de Mariano, em abril desse mesmo ano, levando a um olhar mais atento às histórias dos vapores que aportavam em Belém. Do contrário, esse caso, que de fato não ficou muito esclarecido, não teria chegado aos ouvidos da Imprensa. Seja lá como for, o principal é que o comandante do vapor Paraíba acabou tendo que ir se explicar na redação da Folha do Norte.

No ano de 1900, os problemas com os vapores do Lloyde continuavam a ser noticiados. Além do preço das passagens, a Imprensa reclamava da "freqüente irregularidade" nas viagens desses paquetes, causadora de "transtornos e prejuízos" ao comércio e aos passageiros que utilizavam desse serviço. Um bom exemplo disso foi o de um negociante, que embarcou no porto do Rio de Janeiro, no paquete Maranhão, um "carregamento de charque para o Pará”. Com as mudanças na data de saída do paquete, o produto chegou ao porto de Belém “imprestável”. ${ }^{109}$ Nesse ano, a mesma agência fazia muitas viagens para o extremo norte, uma vez que, diante da seca, o próprio governo do Ceará solicitava a ajuda da União, para auxiliar na concessão de passagens nos vapores do Lloyde Brasileiro, “ou em quaisquer outros que fizessem escala" em Fortaleza e fossem em "direção ao Pará e Amazonas". 110

Se o embarque por vezes era complicado, não menos o era a vida a bordo, com vapores sempre abarrotados de pessoas. Nem sempre, os flagelados pela seca seguiam sozinhos nos vapores. No ano 1889, era comum encontrar solicitações de passagens às agencias de navegação para funcionários do poder público, que acompanhariam grupos de retirantes da seca, até ao porto de destino.

Nesses vapores, existiam dois tipos de passagem: de ré e de proa. As passagens de proa, notadamente financiadas pela verba dos "Socorros Públicos", eram destinadas aos mais

\footnotetext{
${ }^{109}$ Folha do Norte. Belém, 13 de julho de 1900, p. 1.

${ }^{110}$ Mensagem apresentada à Assembléia Legislativa do Ceará em $1^{\circ}$ de julho de 1901 pelo Presidente do Estado Dr. Pedro Augusto Borges. Fortaleza: Typ. Econômica, 1901, p. 28.
} 
pobres, a exemplo dos flagelados pela seca. As de ré eram de passageiros com maior poder aquisitivo. Em fevereiro de 1889, por exemplo, o governo da Província do Ceará pedia à Red Cross Lines of Mail Steamers passagem de ré na linha Fortaleza-Manaus-Fortaleza para o Dr. Eduardo Salgado, que viajava em comissão pela província, “acompanhando as famílias” que, no vapor "Cearense”, emigrariam para as províncias do Pará e do Amazonas. ${ }^{111} \mathrm{O}$ mesmo acontecia com o conferente da Alfândega Norberto de Azeredo Coutinho, que também acompanhava famílias de migrantes. ${ }^{112}$ Por ocasião da seca de 1915, o governador do Ceará, Benjamin Barroso, fazia referência à “assistência espiritual” que o Arcebispo Frei Ignácio promovia entre os flagelados pela seca, lembrando que dentre as ações do religioso, estava a de ter acompanhado até Belém "uma turma de cerca de dois mil retirantes". 113

Além de religiosos ou de funcionários do governo que, vez por outra, acompanhavam grupos de migrantes, também deveriam fazer parte da tripulação dos vapores os médicos de bordo, o que nem sempre acontecia. Em 1901, na Folha do Norte, destacava-se a polêmica acerca da obrigatoriedade ou não da presença de médicos. A questão se colocava na Imprensa porque "vários comandantes da marinha mercantil" protestavam contra uma resolução da Diretoria da Saúde Marítima de cobrar multa aos vapores que circulassem sem médicos ou farmácia. Na verdade, os comandantes não discordavam da obrigatoriedade dos médicos e da farmácia, mas afirmavam que esse era um problema da "alçada exclusiva dos proprietários de vapores", e não dos comandantes, que pela resolução deveriam arcar com a multa. ${ }^{114} \mathrm{O}$ que fica bastante evidente aqui é o fato de que muitos vapores seguiam viagem sem condições mínimas para o atendimento dos passageiros. Em tempos de seca, com vapores com grande número de passageiros, quase sempre mal alimentados, e muitas vezes doentes, aliado às precárias práticas médicas, não raro eram os passageiros que acabavam morrendo, mesmo quando os médicos estavam a bordo.

\footnotetext{
${ }^{111}$ APEC - No 389 - B, Minutas de Ofícios da Secretaria do Governo da província do Ceará, dirigidos ao diretor da Estrada de Ferro de Baturité, aos agentes da Companhia Brasileira de Navegação a Vapor. 1889. $1^{\text {a }}$ Secção, 28 de fevereiro de 1889 à Red Cross Lines of Mail Steamers.

${ }^{112}$ APEC - No 389 - B, Minutas de Ofícios da Secretaria do Governo da província do Ceará, dirigidos ao diretor da Estrada de Ferro de Baturité, aos agentes da Companhia Brasileira de Navegação a Vapor. 1889. $1^{\text {a }}$ Secção, 15 de março de 1889 à Red Cross Lines of Mail Steamers.

${ }^{113}$ Mensagem dirigida à Assembléia Legislativa do Ceará em $1^{\text {o }}$ de julho de 1916 pelo Presidente do Estado Coronel Benjamin Liberato Barroso. Fortaleza, 1916, p. 8.

${ }^{114}$ Folha do Norte. Belém, 5 de janeiro de 1901, p. 4.
} 
A bordo de um vapor repleto de pessoas, como o "Maranhão”, que saiu de Fortaleza em novembro de 1915, conduzindo "1600 flagelados", era comum acontecerem casos de mortes, mas também de nascimentos. Se, pela ótica dos médicos ou comandantes dos vapores, esses casos pareciam naturais, não representando anormalidade no transcurso da viagem, o fato de se lançar ao mar o corpo de uma criança falecida a bordo, por exemplo, ganhava outros significados para os migrantes. Como evidenciado anteriormente no caso de Mariano, morte e nascimento acabavam sendo alvo da solidariedade.

Afirmações como a viagem "se fez sem nenhum incidente"115 ou "apenas faleceram duas crianças"116 ou até mesmo, “a não ser óbitos, nada mais de anormal ocorreu” "117 expressam que as mortes que se davam a bordo não representavam um problema para as autoridades. ${ }^{118}$ Diante “do elevado número de flagelados”, que se recebia no porto de Fortaleza, essas mortes isoladas eram parte da viagem. Só existia preocupação por parte das autoridades diante da possibilidade de doenças contagiosas nos vapores. O vapor Maranhão atracou em Belém em 1915, apesar de algumas mortes que ocorreram a bordo, e ainda da passageira de $3^{\text {a }}$ classe Maria Laurinda de Jesus ter falecido logo que desembarcou no "cais da port of Pará". Mais ainda: o Maranhão teve, por parte da Higiene do Estado, louvado "o cuidado do médico de bordo em zelar pelo estado sanitário do navio". ${ }^{119}$ O mesmo aconteceu com o vapor Sergipe, que “mereceu elogio por parte dos médicos que lhe fizeram a visita”. O irônico nessa história do vapor Sergipe é o fato de a Imprensa anunciar a morte de quatro crianças de gastrenterite, “cujos cadáveres foram lançados ao mar”, além da morte de mais várias outras, também passageiras do vapor, depois de alojadas na hospedaria dos imigrantes. ${ }^{120}$

\footnotetext{
${ }^{115}$ Folha do Norte. Belém, 24 de novembro de 1915, p. 2.

${ }^{116}$ Folha do Norte. Belém, 14 de dezembro de 1915, p. 2.

${ }^{117}$ Folha do Norte. Belém, 16 de março de 1916, p. 2.

${ }^{118}$ As reflexões de Philippe Ariès sobre a morte no ocidente, embora não se refiram ao tema em questão, nos levam a pensar que considerando um sentimento de valorização do túmulo como um espaço de recordação que "confere ao morto uma espécie de imortalidade" e até mesmo de "exagero do luto", que no século XIX vai se solidificando cada vez mais, nos levam a pensar o quão doloroso era para os familiares ou conhecidos, a morte em um vapor, uma vez que o corpo era lançado ao mar, modificando-se assim completamente as cerimônias em relação ao morto. ARIÈS, Philippe. História da morte no Ocidente: da idade média aos nossos dias. Rio de Janeiro: Franciso Alves, 1977, p. 47.

${ }^{119}$ Folha do Norte. Belém, 24 de novembro de 1915, p. 2.

${ }^{120}$ Folha do Norte. Belém, 24 de dezembro de 1915, p. 3.
} 
Algumas questões importantes se colocam aqui. Uma delas é o fato de que mortes isoladas, de moléstias que a princípio não eram contagiosas, não representando portanto maiores perigos, eram vistas como um fenômeno natural. As preocupações começavam diante do medo das epidemias que pudessem chegar com os passageiros dos vapores, expressando muito bem o medo das multidões, dos miasmas, a própria relevância que os médicos sanitaristas ganhavam nesse contexto, indicando quando os vapores poderiam atracar no porto. O ano de 1900, como veremos a seguir, é exemplar nesse sentido.

Diante da tragédia da seca, a morte, sobretudo para as autoridades sanitárias, acabava sendo algo comum, que não causava espanto, pois num universo de 1600 flagelados vivendo em um vapor, pouca importância teria a perda de algumas crianças. Por outro lado, mesmo que o século XX seja marcado por uma maior valorização da infância, sobretudo pelos grupos burgueses, que passam a investir mais nelas, também fica evidente que frente à miséria, à fome e aos poucos avanços da medicina, a morte na primeira infância também era algo que fazia parte da vida das famílias, sobretudo nos momentos de tragédia, como era o caso da seca. ${ }^{121}$ Isso entretanto, de forma alguma, pode significar um abandono ou desvalorização das crianças filhas de migrantes.

Não era à toa que os nascimentos a bordo de um vapor eram festejados pelos passageiros, que, em muitos desses momentos, embora também fossem pobres retirantes da seca, não deixavam de ser solidários, fazendo uma subscrição para angariar algum dinheiro, como ajuda à família do recém-nascido. Esse foi o caso registrado no vapor Maranhão, que "trouxe para Belém muitos flagelados”, em outubro de 1915. Quando a retirante Maria Ribeiro da Silva deu “à luz uma criança do sexo masculino", recebeu dos companheiros de viagem "a importância de 57\$000”, resultado de uma subscrição. ${ }^{122}$ Um nascimento a bordo também podia representar um marco na identidade daquela família de migrantes, que, ao dar o nome à criança, às vezes até fazia referência ao mar, ou ao nome do vapor onde ela veio ao mundo.

Desse modo, o menino filho de Maria Ribeiro, por exemplo, recebeu o nome de “Raymundo Maranhão”, provavelmente numa alusão a São Raimundo Nonato, venerado

\footnotetext{
${ }^{121}$ Sobre história da criança no Brasil ver: DEL PRIORE, Mary (org.). História da criança no Brasil. São Paulo: Contexto, 1991. DEL PRIORE, Mary (org.). História das crianças no Brasil. São Paulo: Contexto, 1999. FREITAS, Marcos Cezar (org.). História social da infância no Brasil $3^{\text {a }}$ edição revista e ampliada. São Paulo: Cortez, Universidade São Francisco, 2001.
}

${ }^{122}$ A Tarde. Belém, 5 de outubro de 1915, p. 2. 
como protetor das parturientes, e também ao nome do vapor onde a criança nasceu, assistida pelo médico de bordo. ${ }^{123}$ Pouco mais de um mês depois, um outro menino, filho do casal de cearenses Maria Joaquina e Antonio Ricardo, que coincidentemente também nasceu no mesmo vapor, "tomou o nome de Manoel Maranhão da Silva”, igualmente em uma referência ao nome do vapor. Essa segunda criança, entretanto, veio a falecer dois dias depois de seu nascimento de "fraqueza congênita", segundo o atestado do médico de bordo. ${ }^{124}$ Também nos dias que antecediam ao Natal de 1915, uma outra criança nascia no vapor Sergipe, e recebia o nome de "Marina". ${ }^{125}$ Seria o nome da menina também uma alusão ao mar, que cada vez mais os distanciava do Ceará e os aproximava dos rios da Amazônia?

Se a saída do Ceará e a viagem ao bordo de um vapor podiam ser cheias de acontecimentos inusitados, o desembarcar no porto de destino não era mais tranqüilo. O medo de doenças contagiosas que pudessem ser trazidas nos vapores foi alvo constante da Inspetoria de Higiene do porto, sobretudo no ano de 1900, com as notícias da peste bubônica no Ceará. Antes de descer em terras paraenses, os passageiros dos vapores passavam muitas vezes por demoradas fiscalizações sanitárias, que os expunham às longas esperas, ao medo e à discriminação da população.

Em setembro de 1900, a Folha do Norte trazia a seu público uma bem humorada crítica a respeito de algumas medidas de desinfecção que a Saúde Pública propunha em casas de cearenses. As diligências da saúde se davam em decorrência das notícias divulgadas na Imprensa sobre a peste bubônica no Ceará. As notícias colocavam em alerta a Saúde Pública e igualmente a população, pelo medo de que, de fato, uma epidemia ocorresse em Belém.

Diante da chegada de vapores que haviam feito escala no porto de Fortaleza, e também do grande número de migrantes que saíam do Ceará em virtude da seca, os cearenses eram vistos como principais suspeitos da peste. ${ }^{126}$ A crítica que a Folha do Norte lançava se concentrava

\footnotetext{
${ }^{123}$ A Tarde. Belém, 5 de outubro de 1915, p. 2

${ }^{124}$ Folha do Norte. Belém, 24 de novembro de 1915, p. 2.

${ }^{125}$ Folha do Norte. Belém, 24 de dezembro de 1915, p. 3.

${ }^{126}$ A idéia de que os cearenses eram portadores das epidemias não foi um pensamento recorrente apenas em 1900. Em 1975, Carlos Alberto Amaral Costa ao fazer uma introdução à $2^{\mathrm{a}}$ edição do livro de Arthur Vianna publicado pela primeira vez em 1908, ainda afirma que "as correntes migratórias procedentes do nordeste, sob o ponto de vista sanitário, foram prejudiciais à Amazônia”. COSTA, Carlos Alberto Amaral. "Introdução". In: VIANNA, Arthur. As epidemias no Pará [1908] 2a edição. Belém: Universidade Federal do Pará, 1975, p. 13.
} 
no fato de que visitas sanitárias, sem um controle maior da chegada de passageiros nos vapores pouco adiantariam, uma vez que, com a entrada constante de cearenses, depois que esses se alojavam na cidade, era muito difícil encontrá-los. Além disso, a própria Folha do Norte lembrava, na ocasião, que "a peste se cá estivesse, já tinha tido tempo de irromper se fôssemos a esperar por essas desinfecções”, levando o leitor a desconfiar das intenções de se proceder “diariamente visitas nos domicílios” de pessoas que, na ocasião, estivessem recentemente "chegadas do Ceará”. 127

Diante disso, a Folha do Norte criava vários diálogos com a figura de um personagem chamado de "O novo Colombo, descobridor de casas de cearenses 'chegados há pouco"”. Nesses diálogos, na verdade, o articulista procurava demonstrar o quão falhas eram as ações da Saúde Pública em Belém. Tomando como exemplo as medidas de se procurar pelos cearenses, aponta o quanto improfícua seria essa tarefa, tomada como uma das medidas de profilaxia à peste bubônica:

“- Não mora aqui nenhum dos cearenses chegados há pouco?

A pessoa interrogada não compreendeu (...). Não senhor (...)

- Mas olhe, venha cá. Sinceramente: não há mesmo nenhum cearense?

- Não lhe disse que não. - Mas, eu me engano muito, o sr. é.

— Eu!?(...) Ora vá daí. Eu sou paraibano (...)

Retira-se para entrar na porta junto (...)

- O sr. é cearense? - Adivinhou.

- Há quantos anos está? - Há um bom par deles

- Mas preciso a data. - Essa agora é boa! Se não me lembro do que comi ontem como hei de lembrar do número de anos que estou aqui?

- Então não é dos chegados no 'Gram -Pará'? — Que 'Gram-Pará'? - No vapor 'GramPará’? (...). O sujeito atira a porta à cara do Cristóvão Colombo. (...). - Não me encrespa. Já te conheço. Amanhã serás desinfectado. Puxa uma carteira toma nota: Alto gordo, baixo, pouca barba; nem moreno nem claro; cara como a minha, cabeça chata. Rua tal, $n^{\circ}$ tanto. E lá foi o descobridor ...". ${ }^{128}$

Não resta dúvida de que o diálogo construído pela Folha do Norte revela a crítica política desse jornal em relação às ações do poder público, considerando a próprio papel de oposição que esse periódico tinha em relação, por exemplo, ao intendente de Belém. Por outro lado, mesmo não sendo o objetivo do redator, o migrante acaba sendo visualizado não somente

\footnotetext{
${ }^{127}$ Folha do Norte. Belém, 2 de setembro de 1915, p. 2.

${ }^{128}$ Folha do Norte. Belém, 2 de setembro de 1900, p. 2.
} 
como grupo homogêneo, em que todos são chamados de cearenses, mas também em sua diversidade, a julgar pelo trecho em que o morador de uma casa lembra que não é cearense, mas sim paraibano.

O ano de 1900 foi marcado pelas notícias da peste bubônica no Ceará. Segundo a Imprensa, aumentavam-se, no porto de Belém, os cuidados do Serviço Sanitário Marítimo, que providenciava "fiscalizações do ancoradouro" e também ordenava a "paralisação das descargas” de vapores que passavam pelo Ceará. No final de setembro, com o agravamento da situação, anunciava-se que estavam suspensas “as escalas pelos portos do Ceará”. Além disso, o governador do Pará, Paes de Carvalho, por medida de segurança, resolveu que "246 imigrantes cearenses”, que haviam chegado no vapor Gram-Pará, ficassem em observação na hospedaria de Outeiro "por espaço de 10 dias". ${ }^{29}$

Os vapores que transportavam passageiros para o Pará não vinham apenas com portadores de bilhetes de $3^{\mathrm{a}}$ classe, mas também com passageiros de maior poder aquisitivo. Quando se instituiu a obrigatoriedade da observação dos passageiros, por medo da peste, essa observação recaiu apenas para os passageiros de terceira classe que vinham do Ceará. Desse modo, em outubro de 1900, a Folha do Norte anunciava que os passageiros de terceira classe purgariam “quarentena no Outeiro". 130

Em 1901, por exemplo, quando houve suspeita de que no vapor Alagoas ocorrera um caso de peste bubônica, informava-se, a partir do que dizia a Inspetoria Sanitária, que seriam tomadas providências "sérias e enérgicas", para que o "fisco sanitário" fosse feito com o “mais severo escrúpulo”. Diante de medidas como a de se receber, na Repartição da Saúde do Porto, “correspondências” para passageiros do vapor, a Imprensa especulava que a "retenção do Alagoas” não seria curta. De fato, quando esse vapor chegou, acabou retido na estação de Tatuoca, "por determinação do diretor de saúde marítima”. ${ }^{131}$ Segundo Arthur Vianna, essa estação, instalada na ilha de Tatuoca, próximo a Belém, foi inaugurada em 28 de dezembro de 1899 e "compreendia alojamentos para passageiros de primeira e terceira classes, um armazém para alfandegar mercadorias suscetíveis de transmitir o vírus epidêmico, um desinfectório para saneamento de bagagens, malas postais e outros objetos, uma farmácia,

\footnotetext{
${ }^{129}$ Folha do Norte. Belém, 30 de setembro de 1900, p. 2.

${ }^{130}$ Folha do Norte. Belém, 2 de outubro de 1900, p. 2.

${ }^{131}$ Folha do Norte. Belém, 18 de janeiro de 1901, p. 2.
} 
almoxarifado e outras dependências necessárias”. Esse aparelhamento ainda segundo Vianna, não bastava uma vez que o serviço ressentia-se de "ordem e eficácia". ${ }^{132}$ Diante disso, a Folha do Norte informava que havia sido solicitado um outro vapor para transportar os passageiros de primeira classe que vieram no Alagoas, "ficando os de $3^{a}$ em observação". ${ }^{133}$ Como se vê, bem dentro das teorias higienistas da época, a pobreza é associada às doenças, levando a uma discriminação. ${ }^{134}$

Aliás, a permanência de migrantes cearenses na hospedaria de Outeiro nem sempre foi vista com bons olhos pela população local. De acordo com a Folha do Norte, o vapor destinado à condução dos moradores da Vila de Pinheiro (onde ficava a hospedaria) a Belém estava sendo "desviado do seu mister", com a condução de migrantes. Reclamava-se ainda desse vapor passar pela vila "sem dar os avisos de costume". No entanto, a maior reclamação era direcionada ao que a Folha do Norte qualificou de "promiscuidade forçada", dada a convivência a bordo entre "passageiros e imigrantes". ${ }^{135}$ Pelas palavras do jornal, percebe-se claro antagonismo entre esses dois grupos de pessoas, que serve para indicar diferenças sociais. Os imigrantes eram pensados como intrusos, que causavam problemas para os moradores locais. Além disso, um outro foco de atritos entre moradores e migrantes dizia respeito ao medo das doenças que esses forasteiros podiam trazer.

A Folha do Norte, tomando como referência as reclamações dos moradores da Vila de Pinheiros, registrou ainda que muitos migrantes que viajavam no vapor dessa linha constituíam "perigo irreparável para a saúde e a higiene”, pois se apresentavam "sem asseio compatível com a embarcação e seus habituais passageiros". O redator do jornal dizia que estava “clamando por providências”, sugerindo como solução para o conflito a utilização de “embarcação própria” que o Estado possuía para o transporte de imigrantes. ${ }^{136}$ Evidencia-se aqui discriminação em relação aos migrantes cearenses, não só pelos boatos da peste

\footnotetext{
132 VIANNA, Arthur. As epidemias no Pará, p. 179.

${ }^{133}$ Folha do Norte. Belém, 21 de janeiro de 1901, p. 1.

${ }^{134}$ George Vigarello referindo-se a epidemia de cólera em Paris no século XIX, adverte que "existe uma racionalização, muito mais aguda do que no tempo das grandes pestes: a morte seria veiculada pelas classes pobres. São elas que intensificam os focos de epidemia”. VIGARELLO. Georges. "O trabalho dos corpos e do espaço". Projeto História, no 13 (junho 1996), p. 9.

${ }^{135}$ Folha do Norte. Belém, 23 de novembro de 1900, p. 1.

${ }^{136}$ Folha do Norte. Belém, 23 de novembro de 1900, p. 1.
} 
bubônica, mas também, pela própria aparência e igualmente pelos transtornos causados pelo aumento populacional gerado pela migração.

No final de 1900, o medo da peste e de outras doenças contagiosas ainda era bastante presente. Através de uma série de crônicas intituladas “Dez dias em Manaus”, publicadas na Folha do Norte em 1901, a partir de uma viagem de Belém àquela cidade, o italiano Mario Cataruzza, faz referência a uma "longa espera a bordo", que chegava a constranger os passageiros, pela “demora da visita sanitária”. Essa espera, no porto de Manaus, somente ia se dissipando diante da "paisagem solene e poética”, que Cataruzza descrevia como uma “maravilha verde, de azul, de luz e de vida”, permitindo que, mesmo diante das maçantes visitas sanitárias, o “desembarque se efetuasse num sonho", do qual o recém- chegado à capital do Amazonas despertava, quando, na entrada do hotel o catraieiro "exigia os seus cinco mil réis". ${ }^{137}$ Ora, se para Mario Cataruzza - que viajava com conforto, como uma espécie de turista - o desembarque não deixou de ser um transtorno enfadonho, façamos uma idéia do que não sofriam os migrantes cearenses, que desembarcavam com uma aparência desagradável, além do medo que, em alguns momentos, se teve de que os vapores fossem portadores de moléstias contagiosas.

Em 1904, diante de casos de peste bubônica, o governador Augusto Montenegro afirmava que o Estado custeava os expurgos dos vapores que vinham de portos infeccionados. Informava também que era "insuficiente a defesa sanitária marítima”, que contava segundo ele, apenas com os recursos do próprio estado do Pará, visto que o Governo Federal se mantinha "silencioso", não fornecendo "nada absolutamente apesar dos instantes reclamos". Montenegro ressentia-se das dificuldades enfrentadas "diante da impotência material”. ${ }^{138}$ Em 1910, a situação não era muito diferente, inclusive com o fornecimento de laudo incorreto sobre o estado sanitário de vapores.

Alguns anos depois do medo da peste bubônica, o pavor das moléstias contagiosas não havia se dissipado. Que o diga o episódio que, em novembro de 1910, a Folha do Norte chamou de "A Odisséia de quinhentos passageiros”. O caso deu-se com o vapor nacional “Manaus”, da empresa Lloyde Brasileiro, que, chegando ao porto de Belém, foi impedido de

\footnotetext{
${ }^{137}$ Folha do Norte. Belém, 9 de janeiro de 1901, p. 1.

${ }^{138}$ Mensagem dirigida em 7 de setembro de 1904 ao Congresso Legislativo do Pará pelo Dr. Augusto Montenegro Governador do Estado. Belém: Imprensa Oficial, 1904, p. 39.
} 
ancorar por suspeita de cólera, sendo obrigado a retornar para "expurgo" no "Lazareto de Tamandaré”, em Pernambuco. Lá, foi constatado que não se tratava de cólera o mal que atacara alguns passageiros, mas sim sarampo, que se complicou "em conseqüência da aglomeração de passageiros de $3^{a}$ classe”. O parecer dos médicos fora de que, apesar disso, o navio estava “em condições de ser recebido em qualquer porto da República”. Para os passageiros do vapor Manaus, os transtornos da viagem eram grandes em virtude do retorno que foram obrigados a fazer, aumentando inclusive os casos de sarampo, além da morte por tuberculose de um cearense de 26 anos de idade. ${ }^{139}$

A chegada a Belém, depois de alguns protestos, foi comemorada com manifestações de “apreço ao comandante”, e, posteriormente, por “um banquete oferecido pelos passageiros”, onde foi servido um elegante menu constituído de: "sopa de legumes, pasteis de lagosta, frango sauté com batatas, lombo e arroz, aspargos de molho branco, peru assado à brasileira. Sobremesa: Sonhos, queijo do reino e prato, frutas sortidas em calda, café e chá”. Segundo a Folha do Norte, depois de brindes e saudações "no tombadilho do Manaus, iluminado e ornamentado, dançou-se animadamente até à meia noite”. Sem dúvida, o modo encontrado pelos passageiros de primeira classe para comemorarem sua chegada à cidade de Belém, depois de perambularem por vários dias "Atlântico abaixo e acima”, foi bastante atraente. ${ }^{140}$ A comemoração feita no Manaus, entretanto, em nada se parecia com a entrada, no porto de Belém, dos passageiros de terceira classe, sobretudo, nos períodos de seca no Ceará.

O migrante, depois de enfrentar os rígidos trâmites da saúde pública, ao descer no porto de Belém, quando viajava por meios próprios, se dirigia à casa de algum parente, ou para um dos muitos hotéis ou casas de pensão, espalhados pela cidade, ávidos para encontrarem clientes. Quando vinha oficialmente, era conduzido para a Hospedaria dos Imigrantes, ou até mesmo para um núcleo colonial.

Em 1889, o Presidente da Província do Pará, José de Araújo Roso Danin, afirmava que, buscando localizar migrantes da seca às margens da Estrada de Ferro de Bragança, ficou com uma “impressão bem desagradável”, uma vez que não haviam sido tomadas as providências para "recebimento e colocação das famílias". Danin revelava que, com essa falta de infra-

\footnotetext{
${ }^{139}$ Folha do Norte. Belém, 10 de novembro de 1910, p. 2.

${ }^{140}$ Folha do Norte. Belém, 10 de novembro de 1910, p. 2.
} 
estrutura, "encheram-se os alojamentos" e os migrantes viviam numa "aglomeração inconveniente”. $\mathrm{Na}$ visão do Presidente, os migrantes, nessas condições, estavam na "ociosidade”, e - o que é pior - acreditavam que "tão cedo não seriam privados dos socorros públicos”. ${ }^{141}$ Por essa fala, percebe-se que o próprio Estado reconhecia a ineficácia das ações para o recebimento dos migrantes cearenses.

Além disso, no Pará, também a falta de uma ocupação, tal qual no Ceará, colocava, pelo menos para os poderes públicos, o migrante na condição de vadio, de desocupado, sendo alvo certo, portanto, de ações disciplinatórias. Se por um lado, como veremos, o migrante era alvo da caridade pública, por outro, dele se cobrava um enquadramento, o mais breve possível, nas relações de produção.

Em 1898, as ações do governador Paes de Carvalho não foram diferentes. Considerado um grande incentivador da migração e da localização de cearenses em núcleos coloniais, esse governador, que chamou os cearenses de “laboriosa, sofredora e inteligente população”, “população irmã”, “compatriotas”, afirmava, por ocasião da seca de 1898, que o Pará já estava aparelhado "para oferecer o conforto afetuoso e o domicílio tranqüilo" ${ }^{142}$ No entanto, quando de fato começaram a se encaminhar para a região muitos retirantes da seca, no mesmo ano de 1899, o discurso foi outro, e o governador afirmou que, apesar de não poupar "sacrifícios" para que os migrantes estivessem "satisfeitos", o Estado não estava inteiramente preparado para "receber e agasalhar esses infortunados compatriotas". ${ }^{143}$ Seja lá como for, Paes de Carvalho, preocupado com a produção agrícola e diante de tentativas não tão frutíferas com a imigração estrangeira, acabou sendo um grande incentivador para que os cearenses ocupassem os núcleos coloniais. Mesmo assim, o momento da chegada ao Pará parecia ser bastante complicado, pois mesmo sabendo da vinda dos retirantes, o governo paraense nem sempre tinha a infra-estrutura necessária.

\footnotetext{
${ }^{141}$ Fala com que José de Araujo Roso Danin - $1^{\circ}$ Vice- presidente da Província do Pará passou a administração da mesma ao Exm. Sr. Dr. Antonio José Ferreira Braga, presidente nomeado por Dec. De 22 de julho de 1889. Pará: Typ. de A. Fructuoso Costa, 1889, pp. 27-28.

${ }^{142}$ Mensagem enviada à Praça do Comércio do Pará pelo Governador Dr. José Paes de Carvalho em $1^{\circ}$ de fevereiro de 1899. Pará: Imprensa Oficial, 1899, p. 49.

${ }^{143}$ Mensagem dirigida ao Congresso do Estado pelo Dr. Paes de Carvalho governador do Estado em 7 de abril de 1899. Belém: Typ. do Diário Oficial, 1899, p. 25.
} 
Em 1900, quando começavam a chegar novamente flagelados pela seca, o mesmo Paes de Carvalho, em Mensagem dirigida ao Congresso Legislativo do Estado, asseverava que tinham sido "extraordinárias" as despesas feitas para a "preparação de lotes, abertura de estradas, construção de casas e localização de colonos nacionais". ${ }^{144} \mathrm{Na}$ verdade, Paes de Carvalho, como ardoroso defensor da República que era, acreditava que a localização de migrantes nacionais no Pará era uma "obra de humanidade e patriotismo". ${ }^{145}$ Mais uma vez, como fica claro pelas palavras do próprio Paes de Carvalho, entendia-se a migração como um dever patriótico a que o Pará se impunha, mesmo que em alguns momentos reconhecesse a importância que os migrantes cearenses tinham na produção paraense, quando assegurava que o colono nacional contribuía "patrioticamente para o progresso e prosperidade". 146

No ano de 1904, com mais uma estiagem no Ceará, o governador Augusto Montenegro, em sua Mensagem anual de 7 de setembro, dentre os assuntos tratados, dedicava uma parte ao que chamou de "Socorros aos famintos", em que dava conta de suas ações para com os cearenses flagelados pela seca. Declarava-se "fiel às generosas e altruísticas tradições de seu antecessor", uma vez que não se podia ser "insensível” diante das condições "tristes e lastimáveis em que aqui aportavam os nossos infelizes patrícios”. 147

As figuras “lastimáveis” dos migrantes empobrecidos que aportavam em Belém causavam medo à população. Por outro lado, essa mesma imagem, diante de um ideal de civilização e progresso, também levou a ações filantrópicas, tanto do Estado como da população, que, isoladamente ou em organizações, buscava prestar auxílio aos migrantes. Através da imprensa, é possível perceber claramente que a chegada dos cearenses, em nenhum momento, passou desapercebida da população. Frente à miséria dos flagelados que aportavam em Belém, por piedade cristã e igualmente por valores de civilidade, muitos foram aqueles que participavam ativamente de campanhas em prol dos recém-chegados.

\footnotetext{
${ }^{144}$ Mensagem dirigida ao Congresso do Estado do Pará pelo Dr. José Paes de Carvalho governador do Estado em 1 de fevereiro de 1900. Belém: Typ do Diário Official, 1900, p. 70.

${ }^{145}$ Mensagem dirigida ao Congresso do Estado do Pará pelo Dr. José Paes de Carvalho, Governador do Estado em 1 de fevereiro de 1901. Belém: Imprensa Oficial, 1901, p. 72.

${ }^{146}$ Mensagem dirigida ao Congresso do Estado do Pará pelo Dr. José Paes de Carvalho governador do Estado em 1 de fevereiro de 1900. Belém: Typ do Diário Official, 1900, p. 70.

${ }^{147}$ Mensagem dirigida em 7 de setembro de 1904 ao Congresso Legislativo do Pará pelo Dr. Augusto Montenegro Governador do Estado. Belém: Imprensa Oficial, 1904, p. 40.
} 


\section{A caridade}

No ano de 1898, depois das notícias do suicídio de Mariano e do desamparo em que sua família ficou, ocorreram várias manifestações de ajuda aos migrantes nordestinos. Nos dias que se seguiram ao trágico fim desse cearense, foram entregues à redação da Folha do Norte doações em dinheiro, que o jornal fazia questão de mostrar aos seus leitores, certamente no intuito de angariar mais fundos para a causa da pobre viúva, que o periódico parecia tomar como sua protegida. Na verdade, o caso de Mariano não foi o único a sensibilizar a população de Belém. Nos períodos de seca no Ceará, com a chegada de muitos cearenses, é comum encontrarmos referências a auxílio prestado pela população. Nesse contexto, percebe-se que as manifestações de filantropia se davam de duas maneiras. A primeira delas, através de doações individuais, em que alguém, sensibilizado com o caso, resolvia por conta própria enviar seu óbolo à Folha do Norte. A segunda, através de grupos organizados, como a Sociedade Beneficente e Literária José de Alencar, a Associação Humanitária Liga Cearense, a Associação de Assistência aos flagelados pela seca, cujas ações eram pautadas por uma abrangência maior, mobilizando a própria população a colaborar com a causa dos cearenses flagelados pela seca. Além, é claro, de expressarem a sua postura política.

Assim, de forma individual, prestaram auxílio à família do cearense Mariano “distintos moços”, que pretendiam fazer uma "manifestação simpática a um amigo”, mas que diante das dificuldades enfrentadas pela viúva, enviaram à Folha do Norte, a quantia de 10\$000, "saldo das despesas da festa”. Do mesmo modo, "um cidadão”, que assinava apenas como "Um Cearense”, enviou sua contribuição. Além dessas doações, alguns negociantes locais, como foi o caso do grupo Velhote, Silva \& Comp., comerciantes e proprietários do vapor Mapuá, que fazia linha para as ilhas, promoveram uma subscrição cujo valor foi de $200 \$ 000$ em prol da família de Mariano. ${ }^{148}$ Um outro comerciante, o Sr. Luiz França, sensibilizado com a situação, abriu uma subscrição, cujo valor foi de $100 \$ 000$, e muitas outras pessoas também contribuíram. ${ }^{149}$ Alguns dias depois da primeira notícia ter sido publicada, a Folha do Norte afirmava que continuavam os "confortos à desventura que punge a viúva e filhos de Mariano". Com pequenas quantias ou com maiores, só ou mobilizando outras pessoas, a exemplo das subscrições abertas por comerciantes de Belém, ao longo de uma semana,

\footnotetext{
${ }^{148}$ Folha do Norte. Belém, 20 de abril de 1898, p. 2.

${ }^{149}$ Folha do Norte. Belém, 22 de abril de 1898, p. 2.
} 
chegavam à Folha do Norte contribuições para a viúva e os filhos de Mariano, o que a Imprensa qualificava de "caridade pública”. ${ }^{150}$

Diante de tantos pobres e de tantos cearenses vivendo em dificuldade, o que movia a população a se manifestar, buscando prestar socorro à família enlutada, era também a publicidade que o caso tomou. Não resta dúvida de que a Imprensa teve papel importante na publicização do fato ocorrido no vapor Brasil e nos desdobramentos desse episódio. Mas, além disso, não se pode perder de vista um sentimento caritativo que se impunha à população diante da desgraça do outro, e que passava por uma dimensão religiosa baseada na máxima cristã de se amar ao próximo. A carta, possivelmente escrita por um hispano-parlante ao diretor da Folha do Norte, no momento em que enviava seu óbolo a "infortunada viúva", revela um pouco disso, na medida em que o desconhecido, que assina apenas como $\mathrm{P}$. $\mathrm{CH}$. DE S., escreve que "El alivio de un dolor es siempre obligación sagrada de todos los que pueden hacerlo". 151

Entretanto, longe de revelar apenas o amor ao próximo, as ações de filantropia expressam também os significados que os envolvidos com as manifestações de caridade davam à pobreza, além de revelarem o grau de importância social que esses filantropos tinham na sociedade paraense. Ao abrir, por exemplo, uma subscrição entre os amigos ou clientes, o comerciante não deixava de ligar seu nome ao socorro aos necessitados, ao mesmo tempo que poderia medir sua influência na sociedade diante do atendimento ou não de sua solicitação.

Natalie Zemon Davis, mesmo estudando um outro tempo e espaço completamente diverso, ao examinar a pobreza em Lyon, em meados do século XVI, destaca algumas questões importantes para a reflexão que ora tratamos. Assim, segundo a autora, a pobreza nessa região também era resultado de um crescimento populacional "graças à imigração”. Ao lado disso, nessa sociedade pré-industrial, a fome era uma "grande aflição", tendo como resultado um grande número de mendigos e de vagabundos pelas ruas de Lyon no período indicado. Esses grupos eram vistos como uma ameaça tanto para a "saúde física e espiritual quanto à propriedade e o poder”. É justamente nesse espaço que apareceu o que essa autora chamou de “caridade organizada”, caracterizada por uma organização empenhada em distribuir comida para os famintos, modificando assim os atos de caridade, que saía das "mãos

\footnotetext{
${ }^{150}$ Folha do Norte. Belém, 23 de abril de 1898, p. 2.

${ }^{151}$ Folha do Norte. Belém, 24 de abril de 1898, p. 2.
} 
eclesiásticas para as leigas". Nesse contexto, a autora conclui algo bastante inspirador para se pensar a atividade de filantropia que se institui em Belém entre 1900 e 1915: o fato de que os humanistas lionenses, "inspirados por amor e pelo medo", construíram ações visando a minimizar os problemas da pobreza. ${ }^{152}$

Os momentos em que a vinda de cearenses era mais intensa foram marcados pelas manifestações de sociedades locais, organizadas em nome de um interesse comum, a ajuda aos flagelados pela seca que aportavam em Belém, ou mesmo para aqueles que permaneciam no Ceará. Em 1898, dentre os auxílios que a família de Mariano recebeu, constavam as manifestações de apoio prestadas pela Sociedade Cearense Beneficente José de Alencar, que, segundo a Folha do Norte, havia sido "recentemente instalada". Em nome da associação, foram visitar a viúva de Mariano alguns membros desse grupo, a fim de saberem se ela gostaria de "regressar com seus filhos para o Ceará", pois se assim o fosse, pretendia-se fornecer à família as passagens e "outros auxílios para a viagem". Como a viúva decidira ficar no Pará, seguindo para a "ilha do Jacaré", onde pretendia "viver do seu trabalho e sob um amparo de um irmão", os membros dessa sociedade deixaram para a família a quantia de "cem mil réis". 153

Dentro desse trabalho assistencialista, em 1900, com as notícias da "peste negra", no Ceará, vemos a "Sociedade Beneficente Literária José de Alencar" empenhada no que a Folha de Norte chamou de "corrente de piedade", que "impulsionou a família paraense". Essa Sociedade, através da Imprensa, convocava a "colônia cearense" e pedia a ajuda do "povo paraense". Previa-se com essas convocações a criação da Liga cearense. A Folha do Norte informava aos seus leitores que a Liga Cearense tinha por finalidade "proteger por todos os meios ao seu alcance, aquele povo infeliz nessa cruel emergência”. O momento da seca levou a uma mobilização de alguns intelectuais, a exemplo dos advogados Justiano de Serpa e Mello Filho, que faziam parte do grupo interessado em criar a Liga Cearense. A situação vivida pelo Ceará impunha ações filantrópicas no Pará, diante da chegada de migrantes. Por outro lado, no Pará já viviam muitos cearenses, que, nesses momentos, se mostravam sensíveis à situação de seus conterrâneos. Note-se que, ao pedir ajuda à

\footnotetext{
${ }^{152}$ DAVIS, Natalie Zemon. "Ajuda aos pobres, humanismo e heresia”. In: Culturas do povo, pp. 2358.

${ }^{153}$ Folha do Norte. Belém, 20 de abril de 1898, p. 2.
} 
população, a Sociedade Beneficente Literária José de Alencar se dirigia aos paraenses e aos cearenses. ${ }^{154}$

No início de setembro de 1900, foi instituída a Liga Cearense. Com estatutos próprios e diversos cargos, como presidente, secretário, tesoureiro, conselheiros, ocupados por pessoas influentes em Belém. A Liga também mantinha alguns delegados no Estado do Ceará, como o Barão Studart, os desembargadores Paulino Nogueira Borges da Fonseca e Joaquim Bastos de Oliveira, coronel Deodato Martins, coronel Hermelindo Macahyba, José Meneleu de Pontes, cônego Bruno Rodrigues de Figueiredo, doutor Farias Brito e coronel João da Costa Bastos, revelando uma ligação entre intelectuais cearenses e paraenses. Por outro lado, a Liga Cearense, além de empreender ações para os migrantes que chegavam ao Para, também se propunha a enviar auxílios ao estado do Ceará, que seriam distribuídos pelos delegados que a Liga mantinha nesse Estado. ${ }^{155}$

A abrangência da Liga Cearense talvez tenha sido uma de suas marcas, uma vez que seus dirigentes, empenhados em angariar fundos para a causa dos flagelados da seca, mantinham em todo o Estado cinco "comissões distritais", que enquadravam lugares como Pinheiro, Mosqueiro, Santa Izabel, Castanhal, e até mesmo na região do Purus. As doações nesses lugares eram recolhidas através de subscrições abertas, para quem desejasse contribuir, onde se buscava "angariar donativos em favor dos socorridos da Liga". ${ }^{156} \mathrm{Na}$ verdade, essas associações não ficavam restritas somente à cidade de Belém. Em 1915, por exemplo, a Assistência aos Flagelados pela seca também parecia manter contato com outras localidades do Estado, no sentido de que se prestasse auxílio aos retirantes. Esse foi o caso do vigário Arão Andrade, da cidade de Bragança, que convidou algumas pessoas da elite local, como o intendente, o juiz de direito e o promotor público, a fim de se integrarem na obra filantrópica proposta pela associação. ${ }^{157}$

Uma questão importante sugerida por essa abrangência da Liga diz respeito à participação também de muitos migrantes cearenses, que moravam nessas localidades. Castanhal e Santa Isabel, por exemplo, foram vilas fundadas em finais do século XIX, que tinham em sua

\footnotetext{
${ }^{154}$ Folha do Norte. Belém, 31 de agosto de 1900, p. 2.

${ }^{155}$ Folha do Norte. Belém, 3 de setembro de 1900, p. 3.

${ }^{156}$ Folha do Norte. Belém, 14 de setembro de 1900, p. 2.

${ }^{157}$ Folha do Norte. Belém, 8 de setembro de 1915, p. 3.
} 
maioria como moradores migrantes nordestinos, vindos para a região para trabalharem na lavoura. A região do Purus se caracterizava pela muitos seringais que possuía, notadamente com trabalhadores nordestinos. Assim, pode-se dizer que as contribuições angariadas nesses lugares eram frutos do trabalho de muitos cearenses, que, tal qual os que estavam ajudando, entre 1889 e 1898, considerando-se que esse foi um período de colonização na zona bragantina e de crescimento da economia da borracha, também haviam chegado a essa região, não raro, como migrantes da seca e, portanto, eram conhecedores dessa mesma experiência. Esse é um aspecto que não pode ser desconsiderado, por remeter a uma questão da identidade entre os cearenses.

O auxílio prestado pelos próprios cearenses que já estavam no Pará aos flagelados pela seca é revelador, no sentido de marcar a experiência social desse grupo por relações de identidade e por laços de solidariedade. Por outro lado, para os organizadores da Associação Humanitária Liga Cearense, a beneficência empreendida pelo grupo era entendida como um esforço de "valor patriótico e humanitário". Sendo apoiada (como afirmou a Folha do Norte, referindo-se à elite paraense) por pessoas da "nossa melhor sociedade", a Liga não deixou de envidar esforços, visando a demonstrar seu caráter patriótico. Esse caráter era manifestado no auxílio que se pretendia prestar "não só ao povo cearense", que padecia com a seca, mas também, como lembrava a Folha do Norte, aos "irmãos do Piauí e do Rio Grande do Norte". Nesse contexto, pela compreensão de que as ações da Liga eram também patrióticas, a Amazônia era representada como uma terra "generosa", que oferecia "a mão de sua caridade aos que quisessem", a partir da "filantropia pública", a que a Liga cearense tanto se empenhava, e igualmente por meio dos "frutos abençoados" do trabalho daqueles que quisessem "desentranhar as riquezas de seu solo opulento". ${ }^{158}$

Embora não seja evidente, entre os objetivos da Liga, o fato dessa associação pretender conduzir os migrantes para o trabalho na lavoura, incentivando proprietários rurais e donos de seringais a se utilizarem dessa mão-de-obra, nas propostas da Assistência aos Flagelados pela Seca, percebe-se que o discurso humanitário da Liga vai ao encontro do ideário republicano, apregoado por governantes do Pará desse período. Governadores como Paes de Carvalho, por exemplo, visando a ordem, disciplina e produção agrícola no Pará, pretendiam inserir os migrantes cearenses no sistema de produção dos núcleos coloniais.

\footnotetext{
${ }^{158}$ Folha do Norte. Belém, 8 de setembro de 1900, p. 2.
} 
Assim, logo depois da fundação da Liga Cearense, visando também a mobilizar a população, o jornal Folha do Norte conclamava seus leitores a se congregarem em prol da "vasta obra de altruísmo" proposta por essa "nova associação de caridade”. Para isso, chamava atenção para duas características que marcavam o Ceará. A primeira seria a situação aflitiva em que se debatiam, no dizer da Imprensa, "os nossos irmãos do Ceará”, e a segunda evocava uma tradição em que esse estado é representado como uma terra que sempre buscou minorar o sofrimento do seu povo, a exemplo da abolição da escravidão que, nesse "recanto glorioso do norte", teve o "grito primeiro do escravo libertado". 159

Evocando um passado glorioso do Ceará e, ao mesmo tempo, as agruras da seca, buscavase sensibilizar o público para que contribuísse com a obra de caridade que a Liga Cearense visava a implementar. ${ }^{160} \mathrm{O}$ pedido da Folha do Norte parecia sensibilizar a população, uma vez que aproximadamente 15 dias depois de fundada a Liga Cearense, já contava com "perto de quinhentos sócios”. Nas reuniões dessa Associação, periodicamente anunciadas pela Imprensa, era comum a proposta de adesão de novos sócios. ${ }^{161}$

A Liga Cearense e a Assistência aos Flagelados pela seca buscaram mobilizar a população e angariar fundos para sua obra filantrópica de diversas formas, como as listas de subscrições e os chamados bandos precatórios que percorriam as ruas da cidade "esmolando" em nome de alguma causa considerada nobre. Em setembro de 1900, por exemplo, a Associação Humanitária de Bombeiros Voluntários do Pará, aliada a outros grupos como, Comissões das Sociedades Santa Rosa, Empregados do Comércio, Trabalhadores do Mar e Terra da Amazônia, Liga Cearense, Nossa Senhora da Batalha, Santa Rita dos Impossíveis, Santa Cecília, Liga dos Socorros Mútuos, União Vigiense, "e muitas outras além de uma comissão de gentis senhoras”, saiu por algumas ruas de Belém, em causa própria e também pelas

\footnotetext{
${ }^{159}$ Folha do Norte. Belém, 8 de setembro de 1900, p. 2. Arthur César Ferreira Reis, ao falar das secas que assolaram o Ceará, também não deixa de fazer referência a um passado glorioso desse estado que com a seca cedia lugar para notícias sobre calamidade, afirma assim que: "o Nordeste, que enchera as páginas da história nacional pelo heroísmo de seus soldados nas guerras contra o holandês, nas jornadas cívicas pela liberdade, pelos princípios democráticos ou ainda no feito memorável da organização do empreendimento econômico do ciclo do açúcar e do ciclo do gado, era agora assunto para capítulos da geografia das calamidades". REIS, Arthur Cezar Ferreira. "O flagelo das secas através dos tempos". In: Épocas e visões regionais do Brasil. Manaus: Governo do Estado do Amazonas, 1966, p. 492.

${ }^{160}$ Folha do Norte. Belém, 8 de setembro de 1900, p. 2.

${ }^{161}$ Folha do Norte. Belém, 14 de setembro de 1900, p. 2.
} 
"vítimas da seca do Ceará" 162 Alguns dias depois, os membros da Liga desdobravam-se na venda de "bilhetes" premiados, em lugares movimentados da cidade ${ }^{163}$; de "pequenos folhetos", de produções literárias de Maria Valmont, Álvaro Bomilcar, Theodoro Rodrigues e Hermeto Lima ${ }^{164}$; com a cobrança de "jóias, mensalidades"165; recebendo doações e promovendo bandos precatórios. As mensalidades dos sócios permitiram, por exemplo, "uma pensão de 30\$000 a uma infeliz família". Essa foi uma das primeiras ações que a Liga teve em Belém. Segundo a Folha do Norte, a família auxiliada vivia "sob completa miséria" em uma "palhoça à entrada do Marco". 166

A "palhoça", da família auxiliada pela Liga ficava em uma área bastante insalubre da cidade, em virtude da obstrução de vários igarapés, que geraram água estagnada propícia para proliferação de mosquitos. Em 1909, o governador do estado João Antonio Luiz Coelho, referia-se a "formação de extensos brejos", nessa área da cidade. Além disso, a chegada de migrantes da região da Madeira-Mamoré, acometidos de impaludismo, contribuía para o alastramento dessa moléstia entre os moradores de bairros como Marco, Pedreira e Canudos, redutos, como veremos adiante, de moradias de nordestinos em Belém. Em 1900, quando a Liga ajuda essa família de cearenses, a situação não era tão diferente assim. ${ }^{167}$

Além da ajuda que a Liga Cearense efetuava no Pará, o envio de dinheiro arrecadado, para os flagelados que estavam no Ceará, tornou-se uma prática importante nas ações dessa associação. Quando, em setembro de 1900, a seca se tornava intensa, a Liga convocou uma reunião com seus associados, a fim de "remeter com urgência toda a quantia arrecadada" para o Ceará. Objetivava-se, de acordo com as palavras da Folha do Norte, "socorrer os

\footnotetext{
162. Folha do Norte. Belém, 25 de setembro de 1900, p. 1

${ }^{163}$ Folha do Norte. Belém, 16 de outubro de 1900, p. 2

${ }^{164}$ Folha do Norte. Belém, 27 de outubro de 1900, p. 2.

${ }^{165}$ Folha do Norte. Belém, 11 de novembro de 1900, p. 2.

${ }^{166}$ Folha do Norte. Belém, 14 de setembro de 1900, p. 2.

${ }^{167}$ Mensagem dirigida em 7 de setembro de 1909 ao Congresso Legislativo do Pará pelo Dr. João Antônio Luiz Coelho Governador do Estado. Belém: Imprensa Oficial do Estado do Pará, 1909, pp. 33-34
} 
necessitados". ${ }^{168} \mathrm{Em} 1^{\circ}$ de outubro, com a “presença de muitos sócios”, tratou-se de enviar pelo paquete $S$. Salvador o tão propagado dinheiro para as vítimas da seca. ${ }^{169}$

Menos de um mês depois dessa nota da Imprensa, o leitor da Folha do Norte, que acompanhava o desenrolar das ações da Liga Cearense, sabia, através das páginas desse periódico, que publicou um ofício enviado pelos delegados da Liga no Ceará, o que acontecera com remessa de 20 contos de réis destinados às vítimas da seca. Em "benefício dos patrícios indigentes”, informou-se que Monsenhor Bruno, representante da Liga no Ceará, deliberou que fosse remetido uma parte para os municípios “mais flagelados”, e que a outra parte do "óbolo de caridade" fosse empregada na "construção de casinhas para abrigos de emigrantes”, que estavam "expostos ao relento” em Fortaleza. Além disso, se construiriam poços para "o abastecimento de água” em municípios circunvizinhos. ${ }^{170}$

A ajuda aos atingidos pelas secas revela uma preocupação com a ordem, com a disciplinarização, com o próprio medo em relação às ações de grupos de famintos e desocupados. Por outro lado, a mobilização da sociedade, em prol dos flagelados da seca, indica igualmente a importância que esse problema tinha para os moradores de Belém. Além disso, expressa valores caritativos e identitários que moviam a população a sair pelas ruas "esmolando", em nome dos cearenses. Não resta dúvida, por exemplo, de que os bandos precatórios se formavam em função de alguma causa que se considerava nobre, dando conta, assim, de valores morais, religiosos e humanitários que norteavam a conduta da sociedade paraense. Um bom exemplo disso ocorreu em 1900, quando Severa Romana, uma migrante

\footnotetext{
${ }^{168}$ Folha do Norte. Belém, 28 de setembro de 1900, p. 3.

${ }^{169}$ Folha do Norte. Belém, 3 de outubro de 1900, p. 1 . O envio de auxílio ao Ceará não deixou de ser registrado pelos governantes cearenses, que nos períodos de seca recebiam ajuda encaminhada de várias cidades brasileiras. Arthur Cezar Ferreira Reis lembra que "Em 1903/04, 1908/09 e 1914/15, repetiram-se as faltas de chuvas, as retiradas da população sertaneja, as perdas de vidas humanas, de gado e das lavouras. Como se repetiram as ajudas em dinheiro, roupas, remédios e alimentos remetidos pelo governo central, pelos governos e populações dos Estados não alcançados pelas crises. (...) no Rio de Janeiro, no Teatro Municipal realizou-se um ato cívico (...) para angariar donativos destinados aos flagelados. Artistas do pincel e da música, do canto, poetas, conferencistas, deram a sua contribuição, alcançando particular sucesso o número em que tomaram parte Raul Pederneiras e mais dois dominadores do pincel. Trabalhando em conjunto sobre um grande quadro, os três, após alguns minutos, davam por terminado, sob ruidosos aplauso a obra, que representava a peste, a fome e a guerra". REIS, Arthur Cezar Ferreira. "O flagelo das secas através dos tempos", pp. 492-493.
}

${ }^{170}$ Folha do Norte. Belém, 11 de novembro de 1900, p. 2. 
maranhense que estava grávida de quase nove meses, foi brutalmente assassinada a navalhadas, por se negar a manter relações com um amigo de seu marido. A população de Belém, considerando-a "uma vítima do amor conjugal” se mobiliza para lhe prestar homenagens. Dentre os grupos que participaram dessas homenagens, encontramos a Associação Humanitária de Bombeiros Voluntários do Pará, correndo a cidade com um bando precatório, para a construção do túmulo de Severa Romana. ${ }^{171}$

Ao longo dos anos, a Liga Cearense foi se fortalecendo e igualmente sendo ponto de referência para cearenses que viviam em Belém. Encontramos referências à Liga Cearense também em 1915. Desse modo, quando começam as reuniões para a organização das ações da Assistência aos Flagelados pela Seca, aparecem referências à Liga Cearense. ${ }^{172}$ Também, dentre os donativos recebidos pela Assistência aos Flagelados pela Seca, registram-se $150 \$ 000$ réis adquiridos através de uma subscrição feita pela Liga Cearense. ${ }^{173}$ Em 1915 , também, o jornal paraense A Tarde informava os seus leitores acerca de uma assembléia geral em que havia sido escolhida uma nova diretoria da Liga Cearense, demonstrando que 15 anos depois de sua fundação, a Liga ainda era uma associação importante. ${ }^{174}$

Exemplo modelar da importância dessa organização é o fato de que quase dez anos depois de sua criação, em abril de 1910, encontramos, na Folha do Norte, o estranho caso do suicídio de uma mulher. O cearense Luiz Martiniano Barbosa, “tendo enviuvado”, deixou sua filha na casa de uma mulher, que "vivia honestamente em companhia do esposo". O término do casamento da senhora com a qual a menina morava, tendo sido interpretado por Luiz Martiniano como um mau procedimento, leva-o a querer tirar a filha da casa da referida mulher. Como essa se negou a "entregar a menina”, Luiz Martiniano, que segundo a Folha do Norte, pertencia à Liga Cearense, "solicitou a intervenção" dessa associação a fim de que esta, “por intermédio da polícia”, lhe permitisse "reaver" sua filha Luiza da França Barbosa. $^{175}$

\footnotetext{
${ }^{171}$ Folha do Norte. Belém, 8 de julho de 1900, p. 1; Folha do Norte. Belém, 9 de julho de 1900, p. 2.

${ }^{172}$ Folha do Norte. Belém, 19 de julho de 1915, p. 1.

${ }^{173}$ Folha do Norte. Belém, 3 de setembro de 1915, p. 3.

${ }^{174}$ A Tarde. Belém, 15 de outubro de 1915, p. 1.

${ }^{175}$ Folha do Norte. Belém, 13 de abril de 1910, p. 1.
} 
Diante do pedido de seu sócio, a Liga Cearense acabou por oficiar ao Chefe de Segurança, "expondo o que havia e requerendo as providências necessárias". Ao ser intimada pela polícia, Maria Ferreira Barbosa desesperou-se e ingeriu "terrível corrosivo”, falecendo horas depois. $^{176}$

Algumas questões relevantes são expressadas aqui, como a preocupação que Luiz Martiniano tinha com a sua filha, levando-o a tirá-la da companhia de Maria Barbosa, quando passou a acreditar que essa não seria uma boa influência para a menina. E o mais central para nossa discussão, a importância que a Liga Cearense demonstra ter nesse contexto.

Ao que tudo indica, Luiz Martiniano não parecia ser um homem de grandes posses, tanto que sua filha não morava com ele - mesmo sendo viúvo, se tivesse maiores recursos, poderia contratar uma preceptora ou governanta, que o ajudariam na educação da filha. Mesmo assim, pertencia à Liga e, num momento de dificuldade, pedira ajuda a essa instituição, indicando que ela foi um espaço de identidade para os cearenses que viviam em Belém. Pelo texto da Folha do Norte, entende-se que antes de recorrer à Liga, Luiz Martiniano, por conta própria, fez algumas tentativas frustradas de reclamar o direito sobre sua filha. Somente depois de frustrados os seus intentos é que ele acionou a Liga, que passou a representá-lo. Revela-se assim que, para os cearenses que estavam no Pará, essa instituição podia ser pensada como um espaço de construção da sua identidade, mas também como uma instituição de caráter corporativo, congregando interesses variados dos cearenses, que iam desde a ajuda aos flagelados pela seca que aportavam no Pará, passando pelos que estavam no Ceará, e até mesmo intervindo em casos, como o de Luiz Martiniano.

Passaram-se alguns anos e em 1915, por ocasião das estiagens no Ceará, a Folha do Norte, tal qual em outras secas, passou a se manifestar em busca de auxílio ao "flagelados do norte". A Associação de Imprensa, um grêmio formado por jornalistas, afirmava, do mesmo modo que fazia em 1900 a Liga Cearense, ao conclamar a população para socorrer os cearenses, que essa ajuda a uma "legião de patrícios famintos e maltrapilhos”, que naquele ano sofriam "os horrores de um clima ingrato”, não era “dever só de humanidade, mas também de patriotismo". 177

\footnotetext{
${ }^{176}$ Folha do Norte. Belém, 13 de abril de 1910, p. 1

${ }^{177}$ Folha do Norte. Belém, 14 de julho de 1900, p. 1.
} 
Evocando o amor à pátria e lembrando igualmente as virtudes do "povo paraense” em cultuar "sentimentos de fraternidade" anunciava-se um bando precatório que, "composto de várias carruagens”, sairia da Associação de Imprensa. ${ }^{178}$ Embora no Ceará a seca já fosse bastante intensa ao longo do primeiro semestre de 1915, foi sobretudo a partir de julho de 1915, com a chegada constante de vapores trazendo cearenses, que se divulgou com mais expressividade "um movimento de socorro" aos flagelados, que se estendeu até 1916. Segundo a Folha do Norte, "o momento de angústia” atravessado pelo nordeste levava a essas manifestações filantrópicas. ${ }^{179}$

Esse tipo de atitude não era nenhuma novidade para a população que vivia no Pará, uma vez que em secas anteriores, através dos poderes públicos ou de associações locais, os atingidos pela seca não deixaram de receber alguma ajuda do Estado do Pará. O que diferenciava as campanhas humanitárias que se construíram com a seca de 1915 é que, além desse caráter assistencialista, caritativo, um grupo em especial, a Assistência aos Flagelados pela seca, fundada em 17 de julho de 1915, deixava bastante evidente que suas intenções altruísticas passavam também por uma integração do cearense que aportava ao Pará em atividades produtivas, além de revelar certa consciência política, em relação ao descaso a que muitas vezes eram relegadas as populações nordestinas atingidas pelo fenômeno da seca. Desse modo, quando "vários cavalheiros" aliaram-se à Associação de Imprensa, a fim de fundarem essa associação, segundo a Folha do Norte, pretendiam:

“dar abrigo e alimentação aos retirantes que aqui continuam a aportar; cercá-los de cuidados médicos e farmacêuticos; encaminhá-los de preferência para a nascente agricultura do Estado, evitar enfim que o infortúnio que os impele a fugirem do torrão nativo, aqui se avolume com o abandono a que estão votados pelos poderes públicos do país". ${ }^{180}$

Isso não quer dizer que a ajuda aos cearenses não fosse entendida como um ato de caridade, dentro das perspectivas cristãs da importância de se dar esmolas aos pobres e necessitados - embora a Assistência aos Flagelados pela seca não destacasse essa nuance da filantropia. Essa era uma prática comum em Belém, porto de chegada de muitos migrantes, em tempo de seca. Em julho de 1915, quando a cidade se preparava para a comemoração dos 300 anos de sua fundação, ao lado da publicação do "Canto do centenário”, a Folha do

\footnotetext{
${ }^{178}$ Folha do Norte. Belém, 14 de julho de 1900, p. 1.

${ }^{179}$ Folha do Norte. Belém, 17 de julho de 1900, p. 1.

${ }^{180}$ Folha do Norte. Belém, 17 de julho de 1900, p. 1.
} 
Norte, trazia uma pequena nota intitulada "Esmola aos imigrantes cearenses”. Informava assim aos seus leitores, que um "distinto cavalheiro", distribuiria na manhã do dia 20 de julho, no Largo de Nazaré esmolas "aos imigrantes cearenses” recentemente "chegados a capital paraense". ${ }^{181}$

Aliás, ao pedir ajuda aos flagelados pela seca, quase como um slogan, a Folha do Norte referia-se à Assistência aos Flagelados pela seca como a instituição que dava o "pão" e procurava o "trabalho" para os recém-chegados a Belém. ${ }^{182}$ Pão e trabalho foram as duas vertentes de ação dessa associação, que, de maneiras variadas, buscava fornecer ajuda aos flagelados pela seca. Em um "velho casarão", no Largo da Sé, onde outrora havia funcionado o hospital militar, eram acolhidos os migrantes recém-chegados à cidade de Belém. O fluxo de migrantes era tanto que, por "ordem do governador", para suportar o grande número de pessoas, - que em alguns momentos chegou a ser mais de quinhentos indivíduos —, em 1915, a Imprensa anunciava "vários reparos” no prédio. ${ }^{183}$

Dentro dos princípios higienistas, nos primeiros dias de chegada do migrante à improvisada hospedaria, o serviço sanitário procedia à vacinação do grupo, seguida de visita médica. ${ }^{184}$ Além desses serviços, na "hospedaria cedida pelo governo", os migrantes recebiam alimentação. Dentre os gastos que a Assistência, tinha com alimentos, a Folha do Norte assegurava que, nos momentos de grande fluxo de pessoas, como em agosto de 1915, quando alimentavam-se "para mais de 500 emigrantes", gastava-se "diariamente a importância de duzentos e tanto mil réis”, em carne, feijão, arroz, leite e outros alimentos. ${ }^{185}$ Isso indica, talvez, que a permanência do migrante na hospedaria não fosse muito prolongada, pois a própria Assistência buscava inserir o recém-chegado em atividades produtivas, como o trabalho na agricultura e nos seringais. Assim, nem sempre eram alimentados um número tão elevado de migrantes na hospedaria.

A alimentação fornecida pela Assistência aos Flagelados pela seca, de acordo com dados divulgados pelo jornal Folha do Norte, parecia ser variada, além de não ser dada em porções

\footnotetext{
${ }^{181}$ Folha do Norte. Belém, 18 de julho de 1915, p. 1.

${ }^{182}$ Folha do Norte. Belém, 9 de setembro de 1915, p. 2.

${ }^{183}$ Folha do Norte. Belém, 24 de agosto de 1915, p. 2.

${ }^{184}$ Folha do Norte. Belém, 24 de agosto, de 1915, p. 2

${ }^{185}$ Folha do Norte. Belém, 27 de agosto de 1915, p. 2.
} 
muito pequenas. Em 11 de setembro de 1915, por exemplo, dia em que a hospedaria contava com aproximadamente 50 pessoas, saíram da dispensa, para o preparo de 43 "rações para adultos" e 5 "para menores":

“arroz, gramas 3.440; açúcar, idem 2150; café, idem 1750; carne seca, idem 6450; farinha seca, idem 4300; dita para papa, idem 150; feijão, idem 2580; frutas unidades 43; leite gramas 300; pães de 110 gramas, unidade 86; temperos, reis 860, verduras, idem 430". ${ }^{186}$

Considerando-se a situação em que se encontravam os flagelados pela seca, a crise econômica vivida no Pará, as instalações improvisadas em que se abrigavam os migrantes, os próprios hábitos alimentares da época, aliados muitas vezes à escassez de gêneros alimentícios em Belém, a alimentação dada ao longo de um dia pretendia atender às necessidades básicas de alimentos de homens, mulheres e crianças.

Observando a lista da dispensa da hospedaria, é possível perceber alguns aspectos da experiência social dos migrantes em Belém. Essa lista de ingredientes para o preparo das refeições sugere a presença de pelo menos três refeições diárias, o café da manhã, o almoço e o jantar, revelando também o consumo muito grande de carne seca e farinha, em relação aos outros alimentos. Até na "papa” das crianças, a farinha é um alimento muito presente. Já conhecido e consumido, pelo migrante em seu lugar de origem, a farinha ganhou importância fundamental na alimentação do migrante no Pará, a ponto de José Veríssimo considerar a mandioca como um verdadeiro trigo para o seringueiro, numa possível alusão ao pão como um alimento básico. ${ }^{187}$ Fazendo parte da alimentação dos moradores locais, a farinha se incorporou, cada vez mais, à alimentação do nordestino. A ausência de outros alimentos não deixou de colocar em evidência o consumo de farinha, cuja produção era permanente nos núcleos coloniais.

Fazendo parte das ações desenvolvidas pela “Assistência aos flagelados pela seca”, vemos muito presente um projeto de incorporação do trabalhador às atividades produtivas na agricultura ou na extração do látex, que mesmo em menor escala, ainda representava uma parte significativa das exportações paraenses. Essa ação se inseria num ideário de produção agrícola, que sempre foi alvo de grupos letrados paraenses, os quais, nas últimas décadas do século XIX, mas sobretudo com a crise da economia da borracha, colocavam na lavoura o

\footnotetext{
${ }^{186}$ Folha do Norte. Belém, 11 de setembro de 1915, p. 2.

187 VERISSIMO, José. “A Amazônia (aspectos econômicos)”. In: Estudos Amazônicos. Belém: Universidade Federal do Pará, 1970, p. 180.
} 
ideal de uma sociedade moderna e progressista. Também não se pode perder de vista o fato de que, ao se buscar ocupação para os migrantes, procurava-se também manter a ordem e a disciplina na cidade. ${ }^{188}$ Nesse contexto, entretanto, os migrantes não podem ser pensados como sujeitos passivos, como que obrigados a trabalhar, uma vez que, ao se deslocarem de seu lugar de origem, também vinham para o Pará em busca de trabalho, também acreditavam que sua inserção em atividades produtivas é que os levaria à prosperidade na Amazônia.

Algumas das ações da Assistência revelam indícios dessa preocupação com a produção. Nos planos dessa "altruística obra", estava o de encaminhar o retirante da seca, “de preferência" para a agricultura. ${ }^{189}$ Para isso, dentre as atribuições a que se propunha a Assistência, como, por exemplo, a de publicar balancetes do "movimento financeiro", dos “donativos recebidos", dos "gêneros entrados e saídos do almoxarifado" do "movimento da enfermaria e do serviço sanitário", estava a de publicar também o nome dos proprietários e dos "estabelecimentos rurais" que dessem "colocação aos emigrantes". Em tom de propaganda, a Folha do Norte assegurava que essa associação oferecia serviços para a “colocação de bons trabalhadores", aceitando pedidos de "particulares" ou de "governos municipais" que desejassem "fomentar o povoamento e a lavoura de seu território". ${ }^{190}$ Como veremos adiante, ao discutirmos colonização, esse foi um discurso muito presente, como uma meta a ser atingida para o desenvolvimento do Pará.

Através da Folha do Norte, a Assistência aos Flagelados pela seca ia informando ao público as suas atividades com os migrantes. Em julho de 1915, por exemplo, embora não fique muito claro se foi a Assistência a mediadora para a localização na zona Bragantina de um bom número de migrantes, observa-se uma lista de mais de 130 nomes de adultos, sempre acompanhados de grande número de crianças, que a Secretaria de Estado de obras Públicas Terra e Viação enviara à Folha do Norte. Esse grupo de "flagelados do norte", como foram chamados, havia sido encaminhado para a colônia São Luiz, a vila de Santa Izabel, a colônia

\footnotetext{
${ }^{188}$ Bronislaw Geremek, lembra que "o trabalho como dever dos pobres e fundamento do seu estatuto. A criação de possibilidades de trabalho constitui uma forma de assistência social e, ao mesmo tempo, de luta contra a decadência da moral social, (...) o trabalho aparece como uma panacéia quer contra a miséria quer contra a delinqüência”. GEREMEK, Bronislaw. A piedade e a forca, p. 276.

${ }^{189}$ Folha do Norte. Belém, 17 de julho de 1915, p. 1.

${ }^{190}$ Folha do Norte. Belém, 19 de julho de 1915, p. 1.
} 
de Marapanim, a vila de Castanhal, a colônia do Prata, a colônia de Capanema, a cidade de Bragança, ao longo da Estrada de Ferro de Bragança, área de colonização. ${ }^{191}$

Algum tempo depois, parece que as propagandas dos "bons trabalhadores" davam algum resultado. Em uma reunião da Assistência, informava-se aos presentes o envio de um telegrama da localidade de Quatipuru, na zona Bragantina, em que o grupo Commeto \& $C^{a}$, pedia a "remessa de algumas famílias". ${ }^{192}$ Do mesmo modo, em setembro de 1915, era com certo orgulho que a Folha do Norte lembrava a seu público que a Assistência já tinha “socorrido mais de 300 famílias emigrantes”, a quem fornecia alimentos e roupas, além de tê-los colocados “em diversos municípios do Estado nos trabalhos da lavoura”. ${ }^{193}$

Ao mesmo tempo, falava-se na Imprensa das vantagens de se ter como trabalhadores "os sertanejos imigrantes”, que enriqueceriam o Estado do Pará, “como produtores e consumidores de nossas riquezas”. Pensamento, raro aliás, no que se refere aos retirantes da seca, vistos quase sempre somente como trabalhadores explorados. Por essa perspectiva, entretanto, o migrante não era encarado exclusivamente como força de trabalho, mas como alguém que também era um consumidor. Sua importância nesse contexto era justamente a de contribuir para a economia local. Nesse sentido, a Assistência informava ao público as diversas atividades em que os migrantes poderiam se empregar: "seringais, cacauais, estabelecimentos de lavoura, fazendas de criação, serrarias, olarias”. ${ }^{194}$

Para levar adiante essas suas atividades, os membros da Assistência aos Flagelados pela Seca, entre 1915 e 1916, se esmeravam em programações que visavam a angariar fundos. A Assistência, não estava só nessa empreitada. Ela também congregava grupos bastante heterogêneos, simpatizantes dos objetivos que essa associação propunha. A título de exemplo, podem ser citados os maçons, que, através da Loja Maçônica Padre Eutíquio, promoveram um bando precatório ${ }^{195}$; a Igreja Católica, através de doações de roupas e dinheiro do arcebispo, Dom Santino Coutinho ${ }^{196}$, e do trabalho das Filhas de Maria, envolvidas na

\footnotetext{
${ }^{191}$ Folha do Norte. Belém, 7 de agosto de 1915, p. 2.

${ }^{192}$ Folha do Norte. Belém, 11 de agosto de 1915, p. 3.

${ }^{193}$ Folha do Norte. Belém 8 de setembro de 1915, p. 3.

${ }^{194}$ Folha do Norte. Belém, 24 de agosto de 1915, p. 2.

${ }^{195}$ Folha do Norte. Belém, 24 de agosto de 1915, p. 2.

${ }^{196}$ Folha do Norte. Belém, 9 de setembro de 1915, p. 2
} 
preparação do natal das crianças $^{197}$; a Associação de Imprensa, que foi um dos grupos articuladores dessa instituição ${ }^{198}$; a União Síria, que mobilizou membros importantes de sua colônia a fim de contribuírem com doações ${ }^{199}$; vários comerciantes estrangeiros, como os alemães $^{200}$, entre outros.

Uma prática importante para angariar fundos para a obra da Assistência foi voltada para o lazer da população, em que se vendiam ingressos para os chamados festivais realizados no campo de foot-ball, no Sport Clube e no Teatro da Paz, e até mesmo para sessão no Cinema Olympia. ${ }^{201}$ Esses eventos davam a tônica de uma animada programação, que contava com o trabalho de vários intelectuais, como a poetisa Elmira Lima. ${ }^{202}$ As atividades propostas pela Assistência em 1915 ou pelas associações que a auxiliavam, expressam hábitos mais urbanos da população, que incorporava a seu lazer idas ao cinema e partidas de futebol. Nesses momentos, a Imprensa foi parceira importante na divulgação das atividades. O público leitor

${ }^{197}$ Folha do Norte. Belém, 9 de dezembro de 1915, p. 1; Folha do Norte. Belém, 14 de dezembro de 1915, p. 2; A Tarde. Belém, 17 de dezembro de 1915, p. 1; A Tarde. Belém, 21 de dezembro de 1915, p. 1. Em suas andanças pelas ruas de Belém as Filhas de Maria recolheram uma variedade muito grande de produtos como: cortes, vestidinhos, paneiros de farinha, caixinha com brinquedos, dinheiro, manta de pirarucu, pares de meia, seis pires, sapatos, bonés, café, camisas, latas de goiabada, de marmelada, copos, bacias, caixas de figo, touquinhas, retalhos de fazenda, babadouros, fatinhos, leite condensado, latas de biscoitos, maisena, cadernos, chapéu. Estes produtos são encontrados ao longo do mês de dezembro de 1915 no jornal A Tarde.

${ }^{198}$ Folha do Norte. Belém, 17 de julho de 1915, p. 1; Folha do Norte. Belém, 22 de fevereiro de 1916, p. 3 .

${ }^{199}$ Folha do Norte. Belém 27 de julho de 1915, p. 2.

${ }^{200}$ As empresas que contribuíram com o envio da importância de $400 \$ 000$ foram: Berringwer \& C. , Gustava Graeff, Richard Lang, (relojoaria alemã), B. Max Burckhart (fotografia alemã); Seligmann \& C. ${ }^{a}$, H. Schoeneaberg (fotografia Fidanza), P. Steiner (vice-cônsul da Áustria-Hungria), E. Hoeting (comandante do Vapor Rio Grande), Membros da fábrica Titânia, Carl Ludwig (diretor da fábrica de cerveja Paraense). Essa doação foi comentada com louvor pela Imprensa local, em virtude de um episódio em que um comerciante inglês "repeliu grosseiramente", uma comissão de senhoras das Filhas de Maria, que passavam por lojas a da capital recolhendo donativos. Folha do Norte. Belém, 18 de dezembro de 1915, p. 2; A Tarde. Belém, 17 de dezembro de 1915.

${ }^{201}$ Os proprietários do Cinema Olympia exibiram o filme "O rei do diamante” em prol dos flagelados. Folha do Norte. Belém, 21 de julho de 1915. O Festival "Sport-Club" foi organizado por um grupo de profissionais liberais como médicos, jornalistas e advogados. Folha do Norte. Belém, 14 de agosto de 1915, p. 1. Dentre as atividades propostas o "Festival no Teatro da Paz" ganhou destaque na Imprensa local.

${ }^{202}$ Folha do Norte. Belém, 11 de agosto de 1915, p. 3. 
da Folha do Norte, por exemplo, pôde acompanhar diariamente a preparação do "festival" no teatro da Paz. ${ }^{203}$

As ações de filantropia da Assistência não deixaram de atenuar de alguma maneira as necessidades de muitos flagelados pela seca e de expressar compreensões de República e de cidadania. Entretanto, tomando aqui as reflexões de Bronislaw Geremek sobre a miséria no mundo contemporâneo como referência, essas iniciativas não passaram de "meros paliativos". 204

Essas muitas ações em relação aos migrantes indicam claramente que os cearenses e outros nordestinos que chegaram ao Pará não deixaram de ser percebidos pelos paraenses, pelos imigrantes estrangeiros e nem muito menos por seus conterrâneos. De maneira alguma, foram anônimos. A chegada desses grupos ao Pará revela que, por um lado, sua permanência nesse estado foi marcada por muito trabalho, por discriminações, por saudades de sua terra natal; por outro, as muitas ações dos migrantes e em torno deles atestam igualmente uma experiência social bastante dinâmica. Nesse contexto, encerrou-se uma multiplicidade de relações sociais gestadas na vivência dos migrantes entre os seringais, nos núcleos coloniais e na cidade de Belém.

Assim, ao rastrearmos as saídas do Ceará para o Pará, mesmo que essas tenham sido repletas de variados problemas, fica muito evidente que longe de serem tão somente os pobres flagelados pela seca, que para sobreviver precisavam da ajuda do Estado, os migrantes não se viam nessa condição, expressando seus anseios em relação à migração.

Além disso, em registros dispersos, é possível vermos que esses grupos sabiam por que queriam vir ao Pará. Mesmo nos momentos em que estavam morrendo de fome, foram solidários e igualmente alvo de solidariedade. Nas situações mais adversas, buscaram construir a sua identidade até quando estavam dentro de um vapor no meio do mar. Resistiram

\footnotetext{
${ }^{203}$ O programa do espetáculo divulgado pela Folha do Norte era o seguinte: 'Um eco dos sertões flagelados', palestra pelo Dr. Almeida Genú,, valsa por mlle. Helena Nobre, 'Monólogo', por Octavio Pires Junior; 'Poesias' de Dona Elmira Lima, de Nicolino Milano, solo ao violino, por Alberto Falcão, 'Canção do Toureador', Bizet; 'Carmem', por Ulisses Nobre, 'Salada de frutas', opereta pelas meninas Pombo, 'Prosa', de Hamilton Barata 'Concerto' pela Tuna Luso Caixeral; 'Assalto d'armas' por uma turma de alunos da Escola de Aprendizes de Marinheiro, e 'Breves Palavras', pelo orador da Assistência ao estudante de direito, sr. Genaro Ponte Sousa. O acompanhamento ao piano será feito pelo professor Manoel Paiva”. Folha do Norte. Belém, 11 de setembro de 1915, p. 2. Folha do Norte. Belém, 11 de setembro de 1915, p. 2.
}

${ }^{204}$ GEREMEK, Bronislaw. A piedade e a forca, p. 280. 
igualmente à exploração sofrida, mesmo que para isso fosse preciso morrer. Enfim, os migrantes cearenses, quando resolviam deixar sua terra natal, acreditavam que no Pará encontrariam trabalho que, quem sabe, até poderia deixá-los ricos, seriam acolhidos por parentes e amigos, e teriam condições de sobreviver de maneira mais digna. 


\section{Migrantes cearenses na cidade de Belém}

Uma primeira história. O ano é 1889. Era a hora de descer do vapor, parar por uns dias na capital do Pará e, com ou sem ajuda das autoridades locais, buscar sobreviver nessa nova terra.

Foi assim que, nesse ano, os “imigrantes cearenses” Antonio Soares de Souza, sua mulher, Edviges Maria de Jesus, e seus filhos, Maria, de 4 anos, Joana, de 2, e uma "recémnascida de 2 meses", preparavam-se para enfrentar, num dos vapores da "Companhia do Amazonas", uma viagem de Belém até Monte Alegre (Pará). Do mesmo modo, Tomé de Souza, um viúvo que havia saído do Ceará com suas 3 filhas e um filho de 10 anos de idade, seguiam num barco da "Navegação Costeira do Maranhão", financiados, ou melhor dizendo, “por conta do Ministério do Império”, para a região de Viseu (Pará). Nesse mesmo ano, é a vez de Manoel Dantas seguir para Souzel (Pará), junto com "sua família composta de 6 pessoas”. Também seguia viagem para Santa Maria do rio Anajás (Pará) o cearense Firmino Ferreira de Matos. Esses trajetos, feitos por esses, e por muitos outros, eram a segunda parte da viagem que empreendiam depois da saída do Ceará. ${ }^{1}$

É difícil saber quantos aportaram no Pará e para onde esses migrantes se direcionaram, já que os registros a respeito são muito fragmentados e incompletos. Entretanto, a partir de "Minutas de ofício" da Presidência da Província do Pará a diversas companhias de navegação, do ano de 1889, podemos rastrear alguns dos caminhos percorridos pelos migrantes e suas famílias depois que chegavam em Belém. De uma maneira geral, tomavamse três rotas. Seguir para áreas voltadas para a agricultura, seguir para os seringais ou permanecer em Belém.

Desse modo, a partir de ofícios enviados às companhias de navegação, pela presidência da província, solicitando passagens para migrantes cearenses, podemos identificar os seguintes lugares, notadamente espaços voltados para agricultura ou áreas de seringais. São Miguel do Guamá, Bragança e Caraú, Turiassu (Bragança), Ourém, Viseu, Souzel, Santarém, Monte Alegre, Alenquer, Óbidos, Ilhas, Anajás, Santa Maria do Rio Anajás, Laguna (no Alto

\footnotetext{
${ }^{1}$ APEP - Secretária da Presidência da Província Códice 1963. Minutas de Ofício da Presidência às Companhias de Navegação 1/6/1889 a 15/11/1889. Ofícios das Companhias de Navegação - $2^{\circ}$ semestre de 1889 .
} 
Anajás), Povoação Bom Jesus do Moura, Rio Piriá, Rio Jary, Bom Jardim do Jary Gurupá, Vila do Roberto (município de Gurupá), Cruzeiro do Moju (Distrito de Gurupá), Mapary, Porto de Ceretama, Alto Mapuá, Repartição no Alto Mapuá, Rio Javary, Rio Madeira, Juruá, Rio Tajapurú, Mazagão, lugar Maria do Milagres em D. Pedro II (Mazagão), Porto de Moz. ${ }^{2}$

Mesmo se tratando de um número reduzido de registros do segundo semestre do ano de 1889, é possível apontarmos algumas questões. Trata-se de 161 pedidos de passagens de migrantes cearenses que, estando em Belém, desejavam seguir para outros lugares. Desses, 60 são para áreas do interior do Pará ou outras áreas da Amazônia. Os demais são para Manaus e inclusive para o Ceará. Dos registros para o interior e demais áreas da Amazônia, apenas 13 são de homens cearenses que partem dessa cidade sozinhos. Os outros registros são de grupos de famílias. ${ }^{3}$

Nesse capítulo, falaremos das experiências dos migrantes que ficaram na capital paraense, e dos seringueiros que periodicamente desciam dos seringais para Belém. Se, na Amazônia, as fronteiras entre a cidade e a floresta parecem distantes, espécie de antítese, de negação de uma, para que a outra sobreviva, na vida cotidiana, esses dois mundos aparecerão na virada do século XIX para o XX, em constantes imbricações. Ora, é a economia do látex, extraído na floresta, que possibilita riquezas para implementação de uma nova estética urbana. Ao lado disso, os trabalhadores dessa floresta, não raro, transitam entre esses dois espaços. Sem dúvida, as reflexões de Raymond Williams, ao apontarem uma estreita relação entre o campo e a cidade, a partir da experiência inglesa, mesmo se tratando de um espaço completamente diverso do aqui apresentado, são importantes para pensarmos as muitas relações estabelecidas entre a cidade de Belém e a floresta amazônica no contexto da valorização econômica da borracha.

Embora aqui nos referindo à floresta e à cidade, as reflexões de Raymond Williams, que se deteve em uma análise acerca da experiência inglesa do Campo e da Cidade, acabam por nos indicar boas pistas para se pensar essa questão. O autor lembra que, historicamente,

\footnotetext{
${ }^{2}$ APEP - Secretária da Presidência da Província Códice 1963. Minutas de Ofício da Presidência às Companhias de Navegação 1/6/1889 a 15/11/1889. Ofícios das Companhias de Navegação - $2^{\circ}$ semestre de 1889.

${ }^{3}$ APEP - Secretária da Presidência da Província Códice 1963. Minutas de Ofício da Presidência às Companhias de Navegação 1/6/1889 a 15/11/1889. Ofícios das Companhias de Navegação - $2^{\circ}$ semestre de 1889.
} 
“cristalizaram-se e generalizaram-se” compreensões acerca desses espaços. Nesse sentido, o “campo passou a ser associado a uma forma natural de vida - de paz, inocência e virtudes simples. À cidade associou-se a idéia de centro de realizações - de saber de comunicações, luz". Diante disso, o autor enfatiza que a "realidade histórica, porém, é surpreendentemente variada". Tomando a experiência inglesa como exemplo, Williams assevera que "mesmo depois de a sociedade tornar-se predominantemente urbana, a literatura, durante uma geração continua basicamente rural, e mesmo no século $X X$, numa terra urbana $e$ industrializada, é extraordinário como persistem formas de antigas idéias e experiências”. Raymond Williams, logo no seu primeiro capítulo, adverte que "a relação entre campo e cidade é não apenas um problema objetivo e matéria de história como também, para milhões de pessoas hoje e no passado, uma vivência direta e intensa". ${ }^{4}$

Uma segunda história. O ano é 1910. Ano em que não se fala de seca, muitos dos migrantes que haviam chegado em 1889 já haviam falecido, outros regressado para o Ceará, muitos ficado, e outros continuavam a chegar. Em outubro de 1910, depois da animação das festas do Círio de Nossa Senhora de Nazaré, um outro acontecimento veio movimentar a cidade de Belém. Através de um leiteiro, que tinha "ido cortar capim”, nas matas da Rua Mundurucus, próxima ao rio Guamá, lugar conhecido como “cacaualinho”, espalhou-se a notícia de que nesse local, um homem vestindo roupas de algodão "bastante sujas e rotas” e tendo "cabelos crescidos barbas e unhas compridas", morava "numa miserável choça de um metro e quarenta de altura e outro de comprimento". Além de seu aspecto físico, que o colocava na categoria de um "selvagem", o que despertou o interesse de muitos moradores de Belém pela história do "ermitão do cacaualinho", como o homem ficou conhecido, era o fato de que ele havia afirmado que estava ali "cumprindo uma expiação" que lhe impusera "sua mãe”. A origem daquele homem de aspecto "selvagem e miserável ao mesmo tempo", conforme a descrição da Folha do Norte, dava a esse episódio um tom de mistério, que impressionou aos leitores do jornal, que deu destaque em primeira página ao caso, por três dias seguidos. ${ }^{5}$

De fato, mesmo depois de ter falado à reportagem da Folha do Norte que estava nessa capital desde o dia 2 de setembro, o mistério sobre a origem de Francisco Xavier de Souza, “o

\footnotetext{
${ }^{4}$ WILLIAMS, Raymond. O campo e a cidade, pp. 11-13.

${ }^{5}$ Folha do Norte. Belém, 26 de outubro de 1910, p. 1.
} 
ermitão do cacaualinho", permanecia. Desse modo, ora dizia ser "fluminense, ora cearense, ora mineiro". Ao mesmo tempo, declarava ter "deixado a família na terra”, terra essa que o jornal especulava ser Fortaleza, uma vez que o “ermitão” chegou mesmo a falar "na Fortaleza". 6

Diante de tão inusitado episódio, não tardou para que também corresse a notícia de que o homem, que dizia cumprir uma "penitência”, poderia até mesmo ser um “santo", um “escolhido por Deus”, uma vez que Francisco Xavier teria dado indícios de que "passava sem comer", não precisando de "coisa alguma" até que terminasse a sua expiação. ${ }^{7} \mathrm{O}$ mistério do homem meio "santo", meio "selvagem", meio "macabro", como o definia a imprensa, correu a cidade de Belém, e “de todos os ângulos da capital”, desde as "primeiras horas do dia”, seguiam para a Mundurucus “magotes de gente”, até mesmo de famílias da “melhor sociedade”, de carro ou a pé, em “ondas rumorejantes”, em busca do "ermitão". 8

Apesar de toda a movimentação em torno desse episódio, e até mesmo da possibilidade levantada pelo proprietário do teatro Avenida de "pedir permissão à policia" para exibir Francisco Xavier "nas noites de sábado e domingo", revertendo parte do dinheiro do "espetáculo" a ele, da mesma forma inusitada com que passou a fazer parte da crônica urbana de Belém, o "ermitão do cacaualinho" desapareceu. Para os leitores da Folha do Norte, no descerramento de mais uma parte desse mistério, ficava o registro de que "há tempos" Francisco tinha sido “carregador ambulante”, que era natural do Ceará e que a esse estado regressaria assim que arranjasse meios para o seu transporte. ${ }^{9}$

Se não fosse por seu aspecto assustador e seu modo de vida que causava espanto e admiração, provavelmente Francisco Xavier teria sido mais um morador anônimo da cidade de Belém, diante de tantos migrantes que viviam nesse espaço entre finais do século XIX e início do século XX. A visibilidade de Francisco, que chega à imprensa, se dá na medida em que sua vida toma um rumo diferente dos padrões de comportamento pensados como normais nesse contexto.

\footnotetext{
${ }^{6}$ Ibidem

${ }^{7}$ Ibidem.

${ }^{8}$ Folha do Norte. Belém, 27 de outubro de 1910, p. 1.

${ }^{9}$ Folha do Norte. Belém, 28 de outubro de 1910, p. 1.
} 
Isso não quer dizer que os migrantes cearenses não fossem percebidos na cidade de Belém. As ações caritativas de variadas associações, das quais esses migrantes foram alvos, como vimos anteriormente, são exemplares nesse sentido. Acontece que, muitas vezes, a visibilidade deles em Belém é demarcada por situações limites, em que as suas histórias de vida acabam perdendo uma dimensão privada, e ganham a esfera pública, chegando às páginas dos jornais ou à chefatura de polícia, por exemplo. ${ }^{10}$

Assim, se, de um lado, a história do “ermitão do cacaualinho" permite essa reflexão, de outro, expressa também um mundo urbano que em 1910, apesar das pretensões cosmopolitas dos poderes públicos (que desde finais do século XIX, buscavam imprimir na cidade, características urbanas mais modernas, gerando conseqüentemente um processo de remodelação urbana), guardava muito de uma vida provinciana e acanhada. ${ }^{11} \mathrm{Na}$ verdade, Belém, nesse momento, tinha ainda uma área muito grande cercada por matas, próximas ou não ao rio, era uma cidade que ainda tinha igarapés e onde muitas casas eram inclusive cobertas de palha, as chamadas "barracas", em ruas de chão batido, ou alagadiças, sem nenhuma infra-estrutura.

Esse processo de remodelação gerou na cidade problemas como os chamados pântanos, que tantos danos causaram à população na transmissão de doenças como a malária, sem contar os problemas de saúde causados pelo grande número de ratos. Além disso, a falta de calçamento das ruas, as paralisações de energia elétrica ou as dificuldades para o abastecimento de água, e ao lado de tudo isso, o aumento do preço de produtos consumidos pela população, como a carne verde (carne fresca), davam bem a tônica do que era se viver em Belém na virada do século XIX para o XX. Os moradores de Belém mantinham-se, assim, numa estreita fronteira, convivendo em espaços que representavam a civilização moderna, e em outros, onde as ações de desenvolvimento urbano passavam ao largo.

Ainda em 1897, essas contradições, que têm seu ápice com o advento da República, não deixaram de ser alvo da imprensa local. O jornal paraense $O$ Holophote soube, com maestria e em tom chistoso, expressá-las através de um diálogo intitulado “O Matuto”, entre um

\footnotetext{
${ }^{10} \mathrm{Na}$ historiografia brasileira o trabalho de Maria Odila Silva Dias é modelar nesses sentido. DIAS, Maria Odila Leite da Silva. Quotidiano e poder em São Paulo no século XIX. São Paulo: Brasiliense, 1984.

${ }^{11}$ Sobre o processo de remodelação urbana de Belém ler o trabalho pioneiro de SARGES, Maria de Nazaré. Belém: Riquezas produzindo a Belle-Époque (1870-1912).
} 
jornalista, a quem se chama de "compadre" e o "velho Pereira". ${ }^{12}$ Ao se encontrarem, diante da surpresa de rever Pereira, o compadre afirma que é uma "novidade” vê-lo por ali. Ao que o "velho Pereira" responde:

“- minha vinda aqui deve mesmo causar espanto, pois desde que apareceu a República e que vi os home que ela trouxe, que eu me arrecolhi a vida privada, com medo de ir ao embrulho com o progresso da mesma”.

Dando continuidade ao diálogo, o compadre pergunta:

“- Então seu Pereira, o que nesta forma de governo patriótico e quase universal tanto incômodo provocou amigo! Ora! Ora.”

Seu Pereira, com rapidez, passa a enumerar os muitos problemas que a República lhe trouxe:

"- tudo que se comia era mais barato, pão, café, açúcar, manteiga, carne verde, querosene, carne-seca, chita, finalmente tudo, e agora o que vunce vê? Tudo caro, até a gurijuba (...) Olhe eu cá não sou vadio, porém vunce esta vendo chinela não há, paletó foi-se, manteiga era uma vez, pão nem duro, dinheiro fiote ...”

No diálogo, o compadre busca argumentar com “seu Pereira” sobre os progressos que a República trouxe ao Pará:

"Porém seu compadre também em comparação o progresso material e industrial de nossa terra caminha a passos agigantados. Temos luz elétrica, bonde de tração idem, carro de praça com tabela de preços fixos, água barata, espetáculos gratuitos e ...”

Ao ouvir todas as benesses da República, o velho Pereira não se esquece de lembrar ao seu compadre:

"Sim cumpadre tudo isso é de grande utilidade para a República e não para o Povo, pois tudo foi feito para o seu mal, a elétrica luz em vez de alumia é assassina, os bondes idem, tabela de carros para inglês ver (...) água com cobra, espetáculo gratuito babau (...)”. ${ }^{13}$

O diálogo entre o jornalista e o matuto sugere alguns dos possíveis anseios dos grupos populares em relação à República, apontando suas desilusões e destacando uma série de problemas enfrentados, sobretudo pelos grupos mais pobres em Belém. Na verdade, na fala do "velho Pereira" se configuram as contradições do ideário republicano, traduzidas, por exemplo, na modernização do espaço de Belém com a introdução de variados equipamentos

\footnotetext{
${ }^{12}$ O Holophote. Belém, 29 de abril de 1897, p. 1. Sobre o humor nos primeiros tempos da República, ver: SILVA, Marcos Antônio da. Caricata República: Zé Povo e o Brasil. São Paulo: Marco Zero/ CNPQ, 1990.

${ }^{13}$ O Holophote. Belém, 29 de abril de 1897, p. 1.
} 
urbanos, ao mesmo tempo em que a população convivia com graves problemas como a carestia, o abastecimento de água, a iluminação pública, a ausência de saneamento básico. ${ }^{14}$

De fato, no Pará, o advento da República, no final de 1889, coincide com a valorização do látex no mercado internacional e o conseqüente aumento da exportação desse produto, gerando riquezas para os cofres públicos paraenses investirem em infra-estrutura para uma parte da cidade. É justamente nesse contexto que, sobretudo com a seca de 1889 que assolou o Ceará, começa a passar pela capital paraense grande número de cearenses, que, dessa cidade, seguiam muitas vezes para os seringais, para as áreas de produção agrícola ou mesmo permaneciam em Belém. Desse modo, Maria de Nazaré Sarges considera que a "preocupação com a ordenação do espaço público se intensificou com o fluxo de imigrantes nordestinos que se dirigiu ao Pará". A autora enfatiza ainda que muitos nordestinos que por razões diversas não seguiam para os seringais concorreram "para um elevado número de subempregados $e$ também desempregados na capital do Pará". ${ }^{15}$

Nesse sentido, falar da cidade de Belém, entre finais do século XIX e primeiras décadas do século XX, é adentrar na história de um espaço que sofreu grandes intervenções urbanas idealizadas pelos poderes públicos. Vários segmentos sociais da população belenense passam ao largo desse processo e, à sua maneira, também disputavam e demarcavam seu território. Imprimiram suas marcas das mais variadas formas, através de práticas culturais, do trabalho cotidiano, de seus valores, enfim. ${ }^{16}$ Desse modo, construíam também essa cidade, sempre tão evidenciada na historiografia muito mais pelas ações dos poderes públicos e menos pela experiência social de outros sujeitos igualmente constituidores desse espaço.

\footnotetext{
${ }^{14}$ Ver por exemplo: SEVCENKO, Nicolau. A introdução ao terceiro volume da coleção História da vida privada no Brasil, "O prelúdio republicano, astúcias da ordem e ilusões do progresso". In: SEVCENKO, Nicolau (org.): História da vida privada no Brasil. República: da Belle-Époque à era do Rádio, vol. 3, pp. 7-48. Ver ainda: SEVCENKO, Nicolau. "A capital irradiante: técnica, ritmos, e ritos do Rio". In: SEVCENKO, Nicolau (org.): História da vida privada no Brasil. República: da Belle-Époque à era do Rádio, vol. 3, pp. 513-619.

${ }^{15}$ SARGES, Maria de Nazaré. Belém: riquezas produzindo a Belle-Époque (1870-1912), p. 89.

${ }^{16}$ Sobre essa questão dos conflitos em relação à praticas culturais de grupos populares no Pará ler por exemplo: FIGUEIREDO, Aldrin Moura de. A cidade dos encantados: pajelanças, feitiçarias $e$ religiões afro-brasileiras na Amazônia. A constituição de um campo de estudo, 1870-1950. Campinas: Dissertação de mestrado (História Social), Universidade Estadual de Campinas, 1996. MAUÉS, Raymundo Heraldo. Padres, pajés, santos e festas: catolicismo popular e controle eclesiástico. Belém: Cejup, 1995.
} 
À luz das reflexões de Deá Ribeiro Fenelon quando adverte que o entendimento da cidade passa por se "captar e investigar", "os modos de viver, de morar, de lutar, de trabalhar e de se divertir dos moradores” na construção da “cultura urbana”, neste capítulo, as atenções se voltam para essas muitas experiências sociais dos migrantes cearenses na cidade de Belém, a partir das vivências dos seringueiros e igualmente de outros grupos de cearenses que viviam em Belém. Nesse sentido, como lembra a autora "são as relações sociais constituídas na cidade que, em última análise, acabam por definir e delinear a paisagem urbana, a imagem da cidade (...)”. ${ }^{17}$

\section{1. Águas, noites}

À época da aparição do "ermitão do cacaualinho", a área conhecida como Marco da Légua, a área do Souza à Bandeira Branca, o ramal do Utinga e da Travessa Lomas Valentina, Pedreira, Canudos, Jurunas, eram lugares da cidade de Belém considerados insalubres e focos de impaludismo. Além disso, alguns igarapés, como Pedreira, Engenho, São Joaquim, Jary, Utinga e Tucunduba, haviam sido obstruídos, gerando, segundo o governador João Coelho, verdadeiros "pântanos". ${ }^{18}$ Aliás, as preocupações com áreas pantanosas em Belém não eram novas; em 1894; por exemplo, o governador do estado, Lauro Sodré, alertava para a necessidade de se fazer um "plano" que, além da abrangência dos "esgotos de materiais fecais e de águas”, também produzisse o “dessecamento de pântanos”. ${ }^{19}$

Do mesmo modo, em 1898, Álvares da Costa, ao fazer como que um retrato de Belém, numa série de textos intitulados "Fotografias do Pará", apesar de sua visão ufanista da cidade - a ponto de exagerar no que chamou de "progredimento rápido, surpreendente da

\footnotetext{
${ }^{17}$ Sobre o estudo da cidade, Déa Ribeiro Fenelon na introdução da coletânea de textos Cidades, chama atenção para o fato de que Por outro lado, ainda segundo essa autora "a cidade e suas instituições devem ser vistas como espaços de produção de conflituosas relações que historicamente podem exprimir-se em dominação, cooptação ou consenso, mas também em insubordinação e resistência”. FENELON, Déa Ribeiro (org). Cidades, pp. 6-7.

${ }^{18}$ Mensagem dirigida em 7 de setembro de 1909 ao Congresso Legislativo do Pará pelo Dr. João Antônio Luiz Coelho Governador do Estado. Belém: Imprensa Oficial do Estado do Pará, 1909, pp. 32-34. Vale lembrar que em 1915 o jornal paraense, "A Tarde", informava aos seus leitores um surto de malária na região do bairro do Marco. A Tarde. Belém, 18 de dezembro de 1915, p. 1.

${ }^{19}$ Mensagem dirigida pelo Sr. Governador Dr. Lauro Sodré ao Congresso do Estado do Pará em 7 de abril de 1894. Belém: Typ. do Diário Oficial, 1894, p. 31.
} 
formosa capital do Gram-Pará" ${ }^{20}$-, não deixou de observar que ainda existiam "muitas ruas por calçar", e igualmente que a cidade deveria "ser saneada por meio da dissecação dos pântanos" que crivavam suas ruas, constituindo, assim, "verdadeiras fontes de infecção". ${ }^{21}$

Nos primeiros anos do século XX, ao lado dos "pântanos", um número muito grande de ratos assustou a população pelo medo da peste bubônica. Na ocasião, o governador Augusto Montenegro chegou mesmo a afirmar, em sua Mensagem do ano de 1904, em relação ao problema que "não se tratou de casos esporádicos, mas de uma verdadeira epidemia". O que levou o governador a fazer tal afirmação foi a intensidade de casos que se desenvolveram em boa parte dos bairros da capital do Pará. Segundo Augusto Montenegro, em "quase todas as ruas do bairro Comercial", nas ruas Dr. Malcher e Dr. Assis (Cidade Velha), na Estrada de São Jerônimo, na Estrada da Independência, na Travessa do Jurunas com a Mundurucus e em "quase todas as casas do Largo da Independência", aconteceram casos da peste. Para se ter uma idéia da situação, de 446 ratos examinados no laboratório de higiene, 113 estavam "pestosos". 22 Nesse contexto de medidas higienistas Maria de Nazaré Sarges demonstra que diante das preocupações com ao processo de civilização da cidade, o Intendente Antonio Lemos, que a administrou entre 1897 e 1910, buscou adotar "uma política saneadora preventiva" que não passava somente pelo 'bem estar social', como também "cuidar de certos aspectos da vida urbana como saneamento, saúde pública, estética da cidade etc.”, que não poderiam ser prejudicados pelos "maus hábitos", de uma população considerada pelas autoridades como "indisciplinada e fétida". 23

Passaram-se os anos, a cidade se remodelava, mas seus problemas de infra-estrutura pareciam ser os mesmos de anos antes. Em 1910, por ocasião das muitas chuvas que assolaram a cidade no mês de abril, a Folha do Norte, sob o título de "As grandes enchentes em Belém", descrevia para os seus leitores o espaço urbano invadido pelas águas, tanto do rio como de igarapés que transbordaram, despejando água pelas ruas. $\mathrm{O}$ volume das águas foi tanto que, na ocasião, transpuseram "o cais e a rampa do Ver-o-peso" e se "derramaram"

\footnotetext{
${ }^{20}$ Folha do Norte. Belém, 28 de fevereiro de 1898, p. 1.

${ }^{21}$ Folha do Norte. Belém, 3 de março de 1898, p. 1.

${ }^{22}$ Mensagem dirigida em 7 de setembro de 1904 ao Congresso Legislativo do Pará pelo Dr. Augusto Montenegro Governador do Estado. Belém: Imprensa Oficial, 1904, pp. 36-37.

${ }^{23}$ SARGES, Maria de Nazaré. Belém: riquezas produzindo a Belle-Époque (1870-1912), p. 97.
} 
pelo mercado de ferro, pelo boulevard da República, pela Rua 15 de novembro e também pela Rua João Alfredo. A doca do Reduto, segundo a Folha do Norte, “dava a impressão de um rio com casa à borda d'água”. E a Avenida Tamandaré ficou também inundada pela "maré que entrou pela vala”. ${ }^{24}$

A cidade de Belém, debaixo da chuva, de forma poética, foi também traduzida por Rocha Moreira numa louvação às mangueiras de seu quintal. Pelo olhar do literato, eram as únicas a permanecerem bonitas, com ou sem a chuva, sugerindo as mudanças que a cidade sofria na temporada mais chuvosa. Desse modo, mesmo lembrando que a chuva fazia florirem fruteiras e crescerem as plantações, o autor também não deixou de se referir aos pântanos vizinhos a sua casa. Com as chuvas, certamente, essas áreas alagadiças onde proliferavam insetos e sapos se tornavam mais problemáticas para a população. Ao ler “Mangueiras”, junto com a singeleza da chuva vista da janela do literato, pode-se ver também a imagem de uma cidade com pântanos e sapos coaxar:

Sede benditas, trêmulas mangueiras Do formoso quintal do meu abrigo; Com os aguaceiros, velho tronco amigo $O$ inverno vem amamentando as jeiras

Já se anunciam, lindas cantadeiras, As cigarras das selvas a que ligo Empenho, pois se em meio à mata sigo, Dizem da chuva a reflorir fruteiras

Ontem coaxou nos pântanos vizinhos Um sapo-boi, que a soluçar, sombrio, A noite encheu de gritos escarninhos ...

Só vós, mangueiras do meu pobre lar Se chora o inverno, ou canta a luz do estio, Sois sempre belas, não sabeis mudar. ${ }^{25}$

A sensibilidade do literato aflora ainda mais quando das muitas chuvas que em abril de 1916, no chamado inverno paraense, cobriram a cidade, Rocha Moreira, que tanto já havia escrito sobre os sofrimentos dos cearenses causado pela seca, imagina a figura de um

\footnotetext{
${ }^{24}$ Folha do Norte. Belém, 12 de abril de 1910, p. 1.

${ }^{25}$ Folha do Norte. Belém, 11 de janeiro de 1915, p. 1.
} 
migrante "estarrecido" diante da água doce que "banha a urbs". ${ }^{26}$ A reflexão do literato não deixa de ser instigante, considerando o sentimento de muitos migrantes cearenses, que deixaram sua terra justamente pela ausência da chuva, ao se depararem em Belém com uma cidade debaixo de chuvas torrenciais.

Se a água da chuva, esparramando-se pela cidade e invadindo comércios, ruas e casas foi alvo de atenção de vários moradores de Belém que eram atingidos por esse fenômeno, não menos preocupante foi o problema da água para o abastecimento diário. Em 1900, por exemplo, em função do crescimento da cidade, os poderes públicos faziam experiências com “novas máquinas do Utinga”, visando a um melhor fornecimento de água para a população. $\mathrm{Na}$ ocasião, a crítica que se fazia voltava-se para o fato de que iniciava-se um trabalho de "ligação das bombas novas com encanamento antigo. ${ }^{27}$ Por esse motivo, o medo de que o "precioso liquido" não chegasse às torneiras inquietava os segmentos sociais mais privilegiados, que tinham acesso a esse tipo de conforto. Assim, a imprensa, ironicamente, lembrava que, diante da dúvida quanto ao abastecimento da água, melhor seria que os usuários desse serviço não se descuidassem de "quando chover pôr os barris e latas às bicas dos telhados" 28

A ansiedade para com a chegada da água às torneiras das casas, sem dúvida, era um problema que atingia apenas a uma parte da população. Para muitos, a utilização de poços ou as idas às fontes públicas, nesse mesmo ano de 1900, era o recurso mais comum para o consumo da água. ${ }^{29}$ Não raro, esses espaços que juntavam muita gente foram ponto de conflitos. Desse modo, a Folha do Norte, diante de reclamações que chegavam sobre desordens nas fontes públicas as classificou como um espaço “indecente, abusivo e punível”,

\footnotetext{
${ }^{26}$ Folha do Norte. Belém, 4 de abril de 1916, p. 1.

${ }^{27}$ Folha do Norte. Belém, 14 de setembro de 1900, p. 2.

${ }^{28}$ Folha do Norte. Belém, 16 de setembro de 1900, p. 2.

${ }^{29}$ Ernesto Cruz, referindo-se ao abastecimento de água na capital paraense no século XIX, mais precisamente nas primeiras décadas desse século, afirma que "a água era fornecida à população por meio de poços e por uma bica - 'enterrada de dois canos de pedra, para a qual se descia por duas escadas laterais (...) Afora os poços de serventia pública, havia os particulares nos domicílios". CRUZ, Ernesto. "Na estrada do tempo". pp. 157-158. Em outro trecho do autor intitulado "A fonte das Pepes" é possível visualizarmos um pouco do abastecimento de água em Belém entre o século XVII e XIX. pp. 52-54. Os referidos textos podem ser consultados em CRUZ, Ernesto. Procissão dos Séculos: Vultos e Episódios da História do Pará [1952]. Belém: Imprensa Oficial do Estado, 1999.
} 
que carecia de presença da "vigilância policial". ${ }^{30}$ Dias depois, com o título "Por causa D’água”, a Folha do Norte, fazendo lembrar sua reportagem anterior, noticiava um desentendimento ocorrido entre dois homens numa fonte pública que ficava na Travessa do Príncipe, canto da Dr. Moraes. O motivo da contenda era o fato de "quererem ambos encher as latas ao mesmo tempo". 31

Como espaço propício à socialização onde circulavam, por exemplo, serviçais de casas de família, lavadeiras, donas de casas, tipos populares que viviam pela redondeza, as fontes públicas foram alvo constante da imprensa, com seu olhar disciplinador. ${ }^{32}$ Além disso, tais espaços revelam igualmente a faina cotidiana de muitos moradores da cidade em busca da água, indicando que nem sempre o ato de abastecer-se de água numa terra cercada de rios era algo tão fácil. Diante dos conflitos em torno das fontes públicas, o que teriam os cearenses que viviam em Belém pensado?

Mas nem só com problemas de chuva e água conviviam os moradores de Belém. Em 1914, com a crônica "As fealdades da formosa Belém”, trazia-se a denúncia de um articulista da Folha do Norte, que assinava sob o pseudônimo de Joafnas, acerca da Estrada do Marco, a única via terrestre de saída da cidade. O articulista pedia que se fizesse "qualquer coisa, mesmo ligeira” para que o trânsito de veículos que passavam por esse local, como "carros hipo, automóveis, bicicletas e motociclos”, e até mesmo de 'cavaleiros e peões”, pudesse ser feito de forma mais “suave”. Pelo olhar de Joafnas, não só o “Marco” precisava de reparos urgentes, mas também outros trechos da capital, que tinham um aspecto "desolador", como se fossem "lastimáveis ruínas”. Eram avenidas começadas e que, desordenadas, pareciam “desalinhados arraiais do sertão, com seus casebres, palhoças, cercas podres e chão vazios". No seu passeio por Belém, Joafnas era taxativo ao indicar as feiúras da cidade.

\footnotetext{
${ }^{30}$ Folha do Norte. Belém, 25 de agosto de 1900, p. 1.

${ }^{31}$ Folha do Norte. Belém, 14 de setembro de 1900, p. 1.

${ }^{32}$ Michelle Perrot, na segunda parte do seu trabalho Os excluídos da História, ao se dedicar a falar das mulheres não deixa de fazer referência no trecho "Mulheres no lavadouro", à sociabilidade construída nesses espaços, que como lembra a autora são "cadinhos do empirismo popular". PERROT, Michelle. Os excluídos da História: operários, mulheres e prisioneiros. Rio de Janeiro: Paz e Terra, 1992, pp. 202-204. José Carlos Barreiro menciona as fontes públicas no século XIX como pontos de encontro de escravos e de troca de informações. BARREIRO, José Carlos. Imaginário e viajantes no Brasil do século XIX: cultura e cotidiano, tradição e resistência. São Paulo: UNESP, 2002. Do mesmo autor ver também: "O materialismo histórico e a questão da cultura". Revista Brasileira de História, vol. 9 (setembro 1989-fevereiro 1990), pp. 209-218.
} 
Assim, afirmava que não havia "uma única rua, mesmo de mais luxo e aparato onde não se depare o viandante um terreno vago, não amurado, cheio de matagal servindo de depósito de lixo”. Diante de tudo isso, o articulista concluía que não era preciso “citar os lugares”, posto que "um passeio por vários bairros" comprovaria o que estava sendo dito. ${ }^{33}$

A denúncia de Joafnas faz parte de um período em que Belém vive uma grave crise econômica pelo declínio da borracha, o que certamente influenciou em menores gastos dos poderes públicos com a urbanização da capital, deixando-se inclusive, como destaca o articulista, obras incompletas. No entanto, mesmo nos momentos de crescimento econômico e de intensa urbanização, a cidade nunca deixou de ter espaços ainda muito pouco cuidados, que se aproximavam de um mundo muito mais rural que urbano. Essa é uma das contradições do processo de crescimento das cidades no século XIX. Guardando as devidas proporções entre Belém e Londres, a movimentação da capital inglesa na era vitoriana, entre 1851 e 1901, é um bom exemplo desses contrastes entre a exibição de riquezas, o mau cheiro dos excrementos de cavalos, porcos, aves, os canteiros de obras, os pobres e operários a circularem pelas ruas, os bairros populares. ${ }^{34}$

Um bom exemplo disso é a história que chegou à Chefatura de Polícia em 1902, envolvendo um pedreiro cearense de 33 anos de idade, chamado Alberto de Souza, que havia recebido um "golpe de navalha no rosto". Do depoimento prestado por Alberto, que era "residente no lugar Canudos”, surge um espaço na cidade de Belém bem pouco “civilizado", se tomarmos como referência os modelos burgueses de moradia e de práticas de higiene. Ora, Alberto teria sido preso quando, por volta de 8 horas da noite, foi com a mulher ao fundo do quintal de sua casa porque teve "precisão de ir for (...) onde estava defecando", quando foi “asperamente agredido". Segundo declarou, tentando livrar-se de seus agressores, "correu escondendo-se entre uma roça que ficava por trás da casa". 35

Não ficam claros os motivos que levaram à agressão sofrida por Alberto, nem se ele de fato não tinha problemas com seus agressores, considerando que declarou conhecer seus

\footnotetext{
${ }^{33}$ Folha do Norte. Belém, 4 de outubro de 1914, p. 1.

${ }^{34}$ CHARLOT, Monica \& MARX, Roland. Londres, 1851-1901: a era vitoriana ou o triunfo das desigualdades. Rio de Janeiro: Jorge Zahar, 1993.

${ }^{35}$ APEP - Chefatura de Policia - Autos Crimes, 1902. Diligências policiais acerca de um ferimento que sofreu Alberto de Souza.
} 
desafetos, uma vez que tinham sido "companheiros de farda". ${ }^{36}$ Pode-se até especular que tivessem conflitos anteriores, que tivessem um acerto de contas. Se era comum a ausência de banheiros dentro das casas mais modestas, o que estariam fazendo os agressores de Alberto no fundo do quintal de sua casa, um lugar certamente sem iluminação e à noite? Os motivos da contenda aqui nos interessam pouco, prendendo-nos muito mais a atenção o espaço em que Alberto vivia.

Na verdade, da história de Alberto, fica muito mais o próprio espaço de sua moradia que, ao que tudo indica, seguia o padrão das casas dos bairros mais populares, onde muitas vezes nem mesmo fora da casa existiam banheiros. A expressão "ir fora”, colhida no depoimento de Alberto, é elucidativa nesse sentido, pois servia para indicar que o banheiro ou espaço semelhante ficava fora da casa. De fato, no Pará, algumas pessoas mais velhas ainda utilizamse dessa expressão, quando se referem às idas ao banheiro, mesmo quando esses ficam dentro das casas. Além disso, a roça por trás da casa revela essa proximidade com um mundo rural, num bairro muito próximo ao da estação central da Estrada de Ferro de Bragança, tida também como um dos símbolos de modernidade da época. Note-se que Alberto morava em Canudos e que a estação ferroviária ficava em São Braz, sendo esses espaços fronteiriços. ${ }^{37}$

A imagem de Belém como uma "cidade feia" vai sendo tecida na imprensa à medida que se assevera a crise da economia da borracha, ou também à medida que muitos jornalistas se dão conta das muitas contradições desse espaço. Nesse sentido, em 1916, evocando um artigo que possivelmente teria sido publicado "há trinta anos no Diário do Gram-Pará", Angyone Costa, em seu “Comentário do dia”, como que pega carona no artigo que descrevia Belém como uma "cidade porca como Constantinopla”, para dizer que, em 1916, "mais do que nunca”, essas palavras tinham razão de ser. Para fortalecer seus argumentos, o cronista lembrava a seus leitores as muitas "feiúras" que a cidade tinha, tanto em sua parte mais antiga quanto na parte que crescia em direção ao que é hoje o bairro de São Braz:

\footnotetext{
${ }^{36}$ APEP - Chefatura de Policia - Autos Crimes, 1902. Diligências policiais acerca de um ferimento que sofreu Alberto de Souza.

${ }^{37}$ Chamada de "rua dos Cearenses", a atual "Avenida Ceará", que fica no bairro de Canudos, na virada do século XIX para o XX, era um espaço constituído por casas de taipa cobertas de palhas e ruas de chão batido, sem nenhum tipo de calçamento. Uma boa imagem disso pode ser vista no álbum de cartões postais. GOVERNO DO PARÁ. Belém da Saudade: A memória de Belém do início do século em Cartões-Postais. 2a edição revista e aumentada. Belém: Secult, 1998, p. 131.
} 
“Junto ao largo da Pólvora, depara-se-nos a Serzedelo Correa; um pouco mais além estão os capinzais, as valas de água parada, da baixada que vai da travessa da Piedade à Rui Barbosa. E mais adiante? E a Cidade Velha? E a nova, que se espraia por de traz da futura basílica de Nazareth até São Braz? Paremos no limiar de tantas feiúras". 38

As críticas de Angyone se dirigiam aos administradores da capital paraense que, a seu ver, não geriram de maneira correta os cofres públicos. Assim, exclamava em tom de denúncia: “Tanto dinheiro que passou pela municipalidade!”. Numa rara crítica ao processo de remodelação de Belém, o cronista afirmara que o dinheiro "chegava de sobra para o pouco que se fazia”. Diante disso, ao comparar o crescimento de cidades como Salvador e Recife com o de Belém, ressentia-se do fato de que essas cidades, a exemplo da "velha São Salvador", haviam perdido a "sua antiga feição de burgo colonial”, enquanto que Belém, diante da receita que tinha, deixava muito a desejar. ${ }^{39}$

A originalidade do pensamento de Angyone Costa se concentra justamente no fato de que, ao ser contemporâneo das transformações da urbs paraense, ele se dá conta de que essa cidade, em comparação com outras, não era motivo de tanta "vaidade", 40 como os poderes públicos buscaram divulgar e como anos mais tarde a própria historiografia local se encarregaria de consagrar. Não resta dúvida de que os impostos da borracha contribuíram para o embelezamento de Belém, mas não se pode pensar essa cidade como um espaço unívoco, e sim dentro da sua diversidade, que passa justamente pelas práticas de seus moradores, sejam eles os gestores públicos, as elites ou os grupos populares, e igualmente pelas representações, por exemplo escritas, que esses grupos fizeram desse espaço social.

Aproximadamente dez anos depois do texto publicado no "Diário do Gram-Pará", e que serviu de ponto de partida para a reflexão de Angyone Costa, um outro cronista da cidade ao qual já nos referimos anteriormente - Álvares da Costa -, em 1898, descreve Belém como uma capital em "galopante progresso", que crescia em sua "vida material” na medida em que desenvolvia-se no "comércio, nas indústrias e na lavoura”, a ponto de assombrar os estrangeiros e “compatriotas dos outros estados". Para Álvares da Costa, a medida do

\footnotetext{
${ }^{38}$ Folha do Norte. Belém, 18 de junho de 1916, p. 1. Vale lembrar que não foi possível consultar esse periódico "Diário do Gram Pará", pois o mesmo não estava disponível ao público no momento da pesquisa.

${ }^{39}$ Folha do Norte. Belém, 18 de junho de 1916, p. 1.

${ }^{40}$ Folha do Norte. Belém, 18 de junho de 1916, p. 1.
} 
progresso da capital paraense não era apenas seu crescimento econômico, mas também o que ele chamou de "domínio intelectual”, caracterizado pela "fundação de estabelecimentos $e$ associações científicas literárias e artísticas”. Citava como exemplo:

“a Escola Normal, O Lyceu Paraense, (...) tendo além do curso integral de Ciências e Letras, o Comercial e o de Agrimensura, a Escola de Belas Artes, o Conservatório de Música, O Lyceu Benjamin Constant; o Colégio do Amparo, o Instituto de Educandos e Orfelinato Paraense. Há além disso um avultado número de casas particulares de instrução primária e secundária entre as quais salientam-se no sexo masculino o Atheneu Paraense, o Colégio Minerva, o Colégio Pará e Amazonas, o Seminário do Carmo e o Colégio da Imaculada Conceição; e no sexo feminino o Colégio e Asilo e Santo Antonio, e os colégios de Santa Luzia, o Antunes e o Progresso. Na arena literária: (...) a Mina Literária (...) Acabam de fundar-se o Grêmio Paraense e a Sociedade Médico-Farmacêutica Paraense". ${ }^{41}$

Ora, o período descrito pelo autor não necessariamente reflete essa realidade. Se, de um lado, em seu aspecto humanista, em práticas de civilidade moderna, com a criação de escolas e de associações literárias, a cidade de Belém crescia, pelo menos para os grupos mais privilegiados, o mesmo não se pode dizer do desenvolvimento da agricultura. Uma rápida leitura de Mensagens como as do governador Paes de Carvalho (como veremos no próximo capítulo) demonstram o quão ufanista era o escritor, considerando-se, por exemplo, as muitas dificuldades da lavoura e a pequena produção manufatureira que se tinha. ${ }^{42}$

A cidade descrita pelo cronista, ao contrário do olhar severo de Angyone Costa, é uma capital comparável aos grandes centros europeus da época, como Paris, Londres, Bruxelas, Barcelona, Madrid, Lisboa. ${ }^{43}$ Isso nos permite refletir que muitas vezes a historiografia, tomando como ponto de referência as ações dos poderes públicos ou as representações de visitantes que passaram pela cidade, acabou por idealizar Belém, com um olhar muito semelhante ao de Álvares da Costa. ${ }^{44}$ Entende-se que, em sua diversidade, construída por seus moradores, a capital paraense, entre os finais do século XIX e os primeiros anos do século XX, não era apenas a cidade feia descrita por Angyone Costa, nem muito menos, o mundo

\footnotetext{
${ }^{41}$ Folha do Norte. Belém, 28 de fevereiro de 1898, p.1.

${ }^{42}$ Mensagem dirigida ao Congresso Republicano paraense pelo Governador do Estado do Pará Dr. José Paes de Carvalho. Pará: Diário Official, 1897; Mensagem dirigida ao Congresso do Estado do Pará pelo Dr. José Paes de Carvalho. Governador do Estado em 7 de Abril de 1898. Belém: Diário Oficial, 1898.

${ }^{43}$ Folha do Norte. Belém, 3 de março de 1898, p. 1.

${ }^{44}$ ver por exemplo CRUZ, Ernesto. História de Belém. Belém: UFPa, 1973, vol. II.
} 
europeizado e urbano, grafado por Álvares da Costa. Seus muitos moradores sabiam bem disso.

Nesse sentido, de diversas maneiras, a cidade de Belém foi sendo descrita e entendida por seus moradores, ou por pessoas que por ela passaram. Assim, escreveu-se sobre a cidade a partir de várias perspectivas, criticando sua infra-estrutura ou mesmo exaltando seus progressos. Mas não somente os grupos intelectualizados utilizaram-se da imprensa para deixarem suas impressões sobre a capital do Pará.

Uma outra perspectiva de se falar de Belém na virada do século XIX para o XX é a partir de problemas cotidianos que diretamente atingiram sua população. O jornal Folha do Norte, por exemplo, através de uma coluna diária intitulada "Reclamações do Povo", caracterizada por pequenas queixas enviadas à redação do periódico, trazia ao conhecimento de seus leitores uma série de problemas enfrentados pelos moradores de Belém, sobretudo pelos mais pobres. $^{45}$

As reivindicações ou denúncias - que poderiam vir ou não na coluna, "Reclamações do Povo”, apareciam algumas vezes como que soltas em meio a outras notícias, uma vez que nem sempre o jornal seguia o mesmo padrão - podiam ser solicitando providências contra abusos cometidos, por exemplo, por vizinhos e que causavam problemas para os moradores mais próximos ou, em outras circunstâncias, se dirigiam aos poderes públicos quando estes não cumpriam com suas obrigações.

Desse modo, em janeiro de 1899, os moradores do Reduto reclamavam contra o "desleixo municipal”, uma vez que os trabalhos de calçamento da Rua 28 de setembro tinham piorado a situação daquelas pessoas, fazendo com que muitos, "a conselho médico”, retirassem seus filhos do local para que não “apanhassem alguma doença séria”. Além disso, afirmava-se nesse momento que a cidade era um "chiqueiro". ${ }^{46}$ Exageros à parte, considerando-se a própria postura política da "Folha do Norte", não se pode perder de vista que as atenções dos poderes públicos, sobretudo da Intendência Municipal, se deram muito mais no sentido de

\footnotetext{
${ }^{45}$ Essa era uma prática comum em jornais de todo o Brasil, trabalho de Eduardo Silva, que analisou uma coluna de jornal intitulada "Queixas do povo", é possível vermos um pouco disso no Rio de Janeiro. SILVA, Eduardo. As queixas do povo. Rio de Janeiro: Paz e Terra, 1988. Ver também: BALCÃO, Lier Ferreira. "A cidade das reclamações: moradores e experiência urbana na imprensa paulista (1900-1913)”. In: FENELON, Déa Ribeiro (org.). Cidades, pp. 225-256.
}

${ }^{46}$ Folha do Norte. Belém, 27 de janeiro de 1899, p. 1. 
obras de destaque na cidade, e não em investimentos de infra-estrutura mais básicos. Note-se, entretanto, que os moradores do Reduto, ao reclamarem de sua situação e exigirem providências, se davam conta de que não recebiam dos poderes públicos a atenção de que necessitavam.

Igualmente, em 1900, através das "Reclamações do Povo”, cobrava-se uma solução para o “estado de lastimável imundice” em que se encontrava a Estrada de São José, desde a rua Doca de Souza Franco até à rua Almirante Wandekolk. Esse trecho da cidade havia se tornado um "vasto lamaçal", por onde o trânsito se fazia "quase que a nado". ${ }^{47}$ Não muito diferente é o que pediam, nesse mesmo ano, os moradores das Ruas Riachuelo, Rosário e Travessa Piedade, que enviaram um "abaixo assinado" contra uma cocheira que era um "foco de miasmas na vizinhança”. Ironicamente, a cocheira pertencia ao "diretor de saúde do porto". 48

Se, de fato, procede essa informação da Folha do Norte, ela é modelar para pensarmos nas contradições das autoridades públicas, a exemplo da Saúde do Porto, que como vimos, tantas exigências faziam, nesse mesmo ano, para o desembarque de migrantes vindos em vapores do Ceará, por medo da peste bubônica. As cocheiras, sem grande higiene, parecem ter sido um problema que perturbava muitos moradores de Belém que viviam nas adjacências desses espaços. Naquele mesmo ano, do outro lado da cidade, alguns moradores do Largo de São José também reclamavam contra uma cocheira na Rua Cezario Alvim, cuja limpeza rareava e, quando era feita, a "água imunda e fétida” era "varrida para a rua”. 49

Além das cocheiras, os galinheiros, sempre alvo de ladrões, também eram foco de conflitos, chegando essas queixas às páginas dos jornais e até mesmo à Chefatura de Policia. Esse foi o caso de um dono de galinheiro, que, através das "Reclamações do Povo", queixava-se dos moradores de um “cortiço" na "Travessa da Alenquer” que, segundo noticiou a Folha do Norte, eram "um perigo para os galinheiros da vizinhança". 50 Justamente no afã de proteger suas galinhas, dois “árabes”, negociantes dessa mesma “mercadoria”, também foram alvo das "Reclamações do Povo”. Os mesmos, "seguramente

\footnotetext{
${ }^{47}$ Folha do Norte. Belém, 21 de julho de 1900, p. 1.

${ }^{48}$ Folha do Norte. Belém, 30 de agosto de 1900, p. 1.

${ }^{49}$ Folha do Norte. Belém, 13 de julho de 1900, p. 2.

${ }^{50}$ Folha do Norte. Belém, 30 de agosto de 1900, p. 1.
} 
para afugentar os gatunos", eram acusados de dispararem "revólveres toda a noite”, perturbando e assustando a vizinhança com um tiroteio no qual se revezavam noite adentro, numa casa na Rua de Santo Amaro, entre Bom Jardim e Monte Alegre. ${ }^{51}$

Em circunstâncias semelhantes, foi também alvo de briga entre vizinhos um possível roubo de ovos, de "criações que passavam para a casa” de Francisco Pinto, agente de segurança. As ditas galinhas acabaram se tornando motivo de conflitos entre ele e um soldado paraibano chamado Felippe Nery, do Corpo de Infantaria do Regimento Militar do Estado. No Inquérito Policial que foi aberto sobre o caso da desavença entre os dois praças, Felippe Nery apresenta contra o agente de segurança, Francisco Pinto, entre outras acusações - como a de "tocatas de violão e algazarras incomodativas" em frente a sua casa -, o fato de que ele servia-se dos ovos das suas criações. Entre as testemunhas desse caso, o cearense Guilherme [Quindiri], quando perguntado sobre se as galinhas passavam para a casa do agente de segurança, respondeu que "viu essa notícia na Folha do Norte”, e que não sabia quem havia publicado aquilo. $^{52}$

Essas situações não são absurdas se considerarmos o grau de pobreza em que viviam muitos moradores de Belém, e que, não raro, utilizavam-se das “criações” alheias, tanto para alimentar-se como para ganhar algum dinheiro com a venda das galinhas. O período do crescimento econômico da borracha também é marcado por problemas com a carestia de alimentos que fazem parte da vida cotidiana da população. Os gestores públicos sabiam desse problema. Em sua Mensagem de 1893, o governador Lauro Sodré afirmava que se tinha "uma vida precária pela elevação dos preços dos gêneros de primeira necessidade”, que se

${ }^{51}$ Folha do Norte. Belém, 21 de julho de 1900, p. 1. O episódio lembra um outro narrado por Lima Barreto, no qual duas vizinhas foram parar na delegacia em razão de uma briga envolvendo o roubo de ovos de galinha. Ver: BARRETO, Lima. Recordações do escrivão Isaías Caminha. Lisboa: Livraria Clássica Editora, 1909, pp. 94-97. Maria de Nazaré Sarges lembra que o "projeto de urbanização da cidade com a construção de praças jardins, quiosques, belos palacetes, largas avenidas, emaranhavase com o cotidiano do bota-abaixo de cortiços, da proibição de ambulantes em determinadas vias da cidade, do controle de trabalhadores através da obrigatoriedade de matrículas e da multa ao carroceiro que conduzia mal a sua carroça; enfim, era uma série de medidas que marcavam esse diaa-dia com confrontos entre a população e representantes da Municipalidade”. SARGES, Maria de Nazaré. Memórias do Velho Intendente (1869-1973). Belém: Paka-Tatu, 2002, p. 147.

${ }^{52}$ APEP - Chefatura de Policia - Autos Crimes -1901. Inquérito Policial Militar - Capital do Estado do Pará - Belém, 27 de setembro de 1901. 
complicavam sobretudo pela "escassez de carne verde e natural subida dessa mercadoria”. ${ }^{53}$ $\mathrm{O}$ registro do problema existe e se pode até falar em tentativas de solução do problema, como o incentivo à pecuária, mas no geral, essas ações ficavam muito restritas a pequenos grupos e a maioria da população tinha dificuldades para a compra de alimentos. ${ }^{54}$

Em 1898, por exemplo, os jornais noticiavam o aumento do preço da carne verde "nos talhos do mercado", que passava de $1 \$ 300$ para $2 \$ 000$ o quilo. ${ }^{55}$ No final desse mesmo ano, os problemas com a carne continuavam, dessa vez com a falta do produto. Especulava-se na imprensa que se não chegasse o "gado do Maranhão”, a população não teria como consumir carne. ${ }^{56}$ No ano seguinte, 1899 , com o sugestivo título "A fome", noticiava-se que se tinha "mais um dia de carne escassa no mercado". 57

Passaram-se os anos e os problemas com a carestia permaneciam, aguçando-se com a crise da economia da borracha, que atingiu diretamente o comércio local. Para se ter uma idéia, em texto publicado na Folha do Norte, em 1914, afirma-se que tanto a Intendência Municipal como o Estado levaram à "impontualidade" dos vencimentos do "funcionalismo" e dos “fornecedores”, que passavam “longos meses” sem receberem seus salários. A situação tornou-se tão grave que muitas vezes os comerciantes locais pediam "moratória" ou requeriam "falência". 58

Segundo a Folha do Norte, muitos comerciantes que não se utilizavam desses recursos arrastavam uma "vida de premente dificuldades", despediam o seus empregados e muitas vezes os mantinham "sob condições de não lhes pagar o ordenado", recebendo assim pelo seu trabalho "um armador de rede" e "seu talher à mesa redonda de um hotel de segunda ordem”. Nesse contexto econômico, não resta dúvida de que a sobrevivência para os

\footnotetext{
${ }^{53}$ Mensagem dirigida pelo Senr. Governador Dr. Lauro Sodré ao Congresso do Estado do Pará em $1^{\circ}$ de fevereiro de 1893. Belém: Typ. do Diário Oficial, 1893, p. 28.

${ }^{54}$ O desenvolvimento da indústria pastoril, para o governador Paes de Carvalho era importante por dizer respeito à solução de um grave problema que era o da "alimentação pública". Para isso seria necessário "desenvolver e animar a criação, ampará-la contra os seus inimigos naturais (...), contra os ataque criminosos". Mensagem dirigida ao Congresso Legislativo pelo Governador do Estado do Pará Dr. José Paes de Carvalho. Belém: Typ. do Diário Official, 1897, p. 23.

${ }^{55}$ Folha do Norte. Belém, 6 de maio de 1898, p. 1.

${ }^{56}$ Folha do Norte. Belém, 11 de dezembro de 1898, p. 1.

${ }^{57}$ Folha do Norte. Belém, 10 de fevereiro de 1899, p. 2.

${ }^{58}$ Folha do Norte. Belém, 15 de janeiro de 1914, p. 1
} 
moradores mais pobres da capital paraense tornava-se cada vez mais difícil, a ponto de um articulista da Folha do Norte ter assegurado que Belém tinha se tornado uma "cidade agonizante” vivendo sob o "pregão" de um “luto". 59

Octavio Meira, que nasceu em 1908, ao escrever suas memórias faz referência às dificuldades que se enfrentava em Belém, em função da crise econômica decorrente do declínio da economia da borracha. Ele, que era filho de um funcionário público, afirma que foram "tempos difíceis de crise" em virtude do atraso nos pagamentos do funcionalismo público. Em decorrência disso o memorialista lembra-se de que "os taberneiros, leiteiros, pedreiros já não podiam fiar”. E continuando afirma “Num tempo em que um professor de Direito como meu pai ganhava 360 mil réis por mês, pode acumular 30 contos de atrasados no Tesouro (...). A avenida Nazareth, a melhor da cidade tinha dezenas de casas vagas, para alugar". 60

Em 1915 por exemplo, alguns comerciantes de Belém ameaçavam fechar suas portas em "protesto contra a exorbitância do imposto de consumo" que o governo havia estabelecido. ${ }^{61}$ Em janeiro do mesmo ano, a Folha do Norte trazia uma lista de produtos consumidos no município de Belém sobre os quais eram taxados impostos que contribuíram para a receita daquele ano. Se, por um lado, fica evidente que esses acréscimos de impostos acabavam sendo em última instância repassados para o consumidor, por outro lado, a listagem dos produtos que chegavam ao porto de Belém, vindos de outros países ou estados brasileiros ou do interior do próprio Pará, é indicativa de outras perspectivas para se pensar a vida local. Vêse que mesmo em declínio econômico, a borracha continuava a figurar na lista dos produtos. Além disso, circulavam pelo comércio da capital paraense uma variedade de produtos que, apesar da crise, faziam parte do dia-a dia da população. Esses produtos são indicativos de hábitos de alimentação, de vestuário de higiene, de práticas medicinais, de atividades de trabalho na construção de prédios, em manufaturas, e inclusive de formas de diversão, experimentadas pelos moradores de Belém:

“Aniagem, Aguardente, Álcool, Algodão em rama, algodão em casca, Açúcar, Alfafa, Barbante, Bebidas, Biscoito em lata, Borracha, breu, botões, carvão vegetal, cabos alcatroados, cabos de

\footnotetext{
${ }^{59}$ Folha do Norte. Belém, 15 de janeiro de 1914, p. 1.

${ }^{60}$ MEIRA, Octavio. Memórias do quase ontem. Rio de Janeiro: Lidador, 1976. p. 141.

${ }^{61}$ Folha do Norte. Belém, 23 de março de 1915, p. 1.
} 
manilha, cacau, café, caibros, cal, calçado, carnaúba, cartas de jogar baralho, castanhas, cera em velas, cerveja, chapéus de qualquer qualidade (palha, carnaúba, de sol,) chifre ou casco, confetes e serpentinas, charque, chocolate, cigarros, charutos, cocos, couro de boi e de veludo, cumaru, carne, camisas, ceroula, calças, cobertores, doces, dormentes, estacas, esteios, estopa, estopilha, escovas, espanadores, falcas de qualquer madeira, fio de vela, frechaes de acapú, farelo, farinha, feijão, flores e grinaldas artificiais, fio para rede, folhas de arumã, buriti, jacilara, umboassu, ou titica, gado cavalar e muar, grude de peixe, gravatas, instrumentos de qualquer qualidade, impressos, lanças perfumes e bisnagas, livros em branco e de leitura, madeiras, manteiga de tartaruga e de vaca, mobílias, mel, milho, medicamentos, meias, óleos de copaíba, andiroba, vegetais ou animais, de rícino; obras de encadernação; peixe seco ou em salmora; peles; perna mancas; piassava; fósforos, pentes, papel pautado, queijo, rapadura, ripas, redes, roupas feitas, sabão, stearinas (velas); sabonetes, sebo, serrapilheira, sola, sapatos, telhas, tijolos, tabaco, vigas, vinhos". ${ }^{2}$

Mas não só acerca das dificuldades para a compra de alimentos os moradores da cidade se manifestaram preocupados, numa clara demonstração de outras necessidades, como as voltadas para serviços públicos que viriam a facilitar a vida da população, inclusive dos mais pobres, no seu trânsito pela capital paraense. A partir de 1896, com a implementação da energia elétrica, uma questão que caminhou lado a lado com a da própria carestia é a que diz respeito à iluminação da cidade, entendida como mais um sinônimo dos progressos da modernização da capital. De acordo com Ernesto Cruz na primeira metade do século XIX o Pará ainda mantinha “o mesmo e precário sistema de iluminação dos tempos coloniais”. Em 1861 o Presidente da Província contratou "a iluminação de Belém por meio de gás hidrogênio", que começou a funcionar a partir de 1863 culminando em 1896 com o fornecimento da "luz elétrica à capital”, considerada pelo autor mais um "passo a separar Belém dos enraizados costumes coloniais". ${ }^{63}$ Nesse mesmo ano, em tom de sátira, um colaborador da Folha do Norte, chamado Juvenal, publicava na sessão “Gargalhadas” algumas quadrinhas que revelavam problemas com as primeiras experiências com a iluminação elétrica em Belém. Criticando a companhia fornecedora de energia, Juvenal sugere que antes da implementação da luz elétrica, a cidade não estava tão às escuras:

Eu de há muito tencionava

Fazer boa criação

De morcegos, mas lutava

A' falta de escuridão.

\footnotetext{
${ }^{62}$ Folha do Norte. Belém, 5 de janeiro de 1915, p. 3.

${ }^{63}$ CRUZ, Ernesto. Procissão dos Séculos: Vultos e Episódios da História do Pará, pp. 116-118.
} 
Agora, porém, que a Urbana

Vem trevas nos fornecer

Vou mui breve, pra semana

Privilégio requerer

E pr'a que, em por brinquedo,

Me venha trevas a faltar

Tenho que ir, mas muito cedo,

luz c'a Urbana contratar. ${ }^{64}$

Além das dificuldades para o fornecimento da energia elétrica, é possível percebermos que a própria população também buscava experimentar e entender esse novo processo de iluminação artificial, com o qual começava, aos poucos, a conviver. Marcel Roncayolo enfatiza que "a cidade sempre procurou dominar a luz, sinal de originalidade técnica do mundo urbano, primeiro elemento, talvez, de sua 'artificialidade”. O desenvolvimento dessa técnica que se dá paralelo ao da industrialização se situa, segundo esse autor entre $1850 \mathrm{e}$ 1950, e vem se "misturar às mudanças que, exercendo-se em todos os domínios - modos de vida, poder, técnica e sensibilidade -, caracterizam essa época” ${ }^{65}$ Em Belém nesses primeiros momentos, foram comuns acidentes provocados pela utilização inadequada de descarga elétrica, em virtude do desconhecimento das pessoas. Foi o que aconteceu, por exemplo, com um homem na Travessa 2 de Dezembro, que "querendo experimentar o efeito da iluminação pública passou um arame por entre os fios”. ${ }^{66}$ Não muito diferente foi o caso do maranhense Candido Pereira, que "sofreu queimaduras de diversos graus, produzidas pelas correntes da iluminação". 67

Apesar dos problemas com algumas paralisações no fornecimento da energia, não se pode negar a admiração dos moradores de Belém diante da cidade iluminada. Numa pequena nota da coluna Ecos e Notícias, do jornal Folha do Norte, pode-se ler que a luz elétrica "em alguns pontos esteve magnífica de claridade e firmeza" ou ainda, que embora com algumas "intermitências curtas", em geral, "era bom o aspecto das praças iluminadas". 68 Os

\footnotetext{
${ }^{64}$ Folha do Norte. Belém, 5 de fevereiro de 1896, p. 1.

${ }^{65}$ RONCAYOLO, Marcel. "Transfigurações noturnas da cidade: o império das luzes artificiais". Projeto História, no 18 (maio 1999), p. 97.

${ }^{66}$ Folha do Norte. Belém, 1 de fevereiro de 1896, p. 2.

${ }^{67}$ Folha do Norte. Belém, 2 de fevereiro de 1896, p. 3.

${ }^{68}$ Folha do Norte. Belém, 3 de fevereiro de 1896, p. 2.
} 
primeiros tempos de introdução da energia elétrica em Belém não foram fáceis, sendo muito comuns críticas dirigidas à "Companhia Urbana". Pouco mais de um ano do início da iluminação elétrica, em abril de 1897, o recém-lançado jornal O Holofhote, ao reclamar de uma lâmpada queimada na Rua d'Alfama, não poupava a companhia fornecedora de energia, chamando-a de "indecentíssima" e ainda que diante de tantos pedidos que "a imprensa diária fazia”, afirmava que a "Urbana”, não tinha mesmo era “vergonha”. 69

Em 1900, a imprensa igualmente não deixou de reclamar de uma lâmpada na Travessa Quintino Bocaiúva, esquina da Rua Tiradentes, que "há mais de doze noites não dava luz”. Buscando criticar as ações dos poderes públicos, a Folha do Norte insistia em que isso acontecia porque "lá não se perdeu o fiscal (...) do contrário teria procurado providências". ${ }^{70}$ Um mês depois, a Folha do Norte mais uma vez não poupava o Intendente Municipal. Em uma coluna apropriadamente chamada de "Lição a Intendência”, expunha aos seus leitores algumas ações de moradores da capital em busca de resolver problemas que os poderes públicos não solucionavam. Citavam para isso moradores que se "juntam para fazer limpeza”, ou aqueles que tencionavam "alumiar-se a candeeiros de petróleo por conta própria", considerando que não lhes chegava a iluminação. ${ }^{71}$ Dez anos depois, os problemas continuavam e a Folha do Norte, numa pequena nota intitulada "Iluminação Pública", afirmava que somente em Belém se observava o "curioso espetáculo" de uma "cidade por noites repetidas completamente à escuras", com um serviço "sofrível”, com muitas "lâmpadas apagadas”, que atingia muitas ruas e às vezes até "bairros inteiros". 72

De questões aparentemente simples, como uma lâmpada que não acendia numa travessa qualquer da cidade, aos acidentes provocados pelo desconhecimento e pela curiosidade em relação à corrente elétrica, aos problemas de infra-estrutura maiores, que envolviam o fornecimento de energia para toda uma capital, em pleno processo de modernização, percebem-se as formas como a população da cidade de Belém convivia com a energia elétrica. Assim, das primeiras críticas ao fornecimento de energia em 1896 (como as de Juvenal, colaborador da Folha do Norte, que em tom jocoso dizia que pretendia fazer uma "criação de

\footnotetext{
${ }^{69}$ O Holophote. Belém, 29 de abril de 1897, p. 1.

${ }^{70}$ Folha do Norte. Belém, 20 de julho de 1900, p. 2

${ }^{71}$ Folha do Norte. Belém, 22 de agosto de 1900, p. 1.

${ }^{72}$ Folha do Norte. Belém, 13 de janeiro de 1910, p. 1.
} 
morcegos”, diante da cidade às escuras), às preocupações com as muitas ruas da capital paraense às escuras em 1910, vemos a incorporação da luz elétrica ao dia-a-dia da população e, igualmente, os significados atribuídos a essa experiência.

Ora, essas transformações, absorvidas pelos moradores das cidades que buscavam se afirmar como modernas nos primeiros anos do século XX, são também repletas de contradições. A mesma Folha do Norte, que criticava acirradamente o "espetáculo" da cidade às escuras em janeiro de 1910, poucos meses depois, em tom ufanista, visando também a demonstrar o grau de civilização que a sociedade de Belém ia adquirindo, chamava atenção com o título "O que se diz de nossa terra”. Na ocasião, apresentava a seu público um texto supostamente publicado num suplemento do "Figaro", em maio desse mesmo ano. Das linhas escritas por um paraense que vivia na Europa, surge como símbolo do progresso e, certamente para impressionar o leitor estrangeiro, uma cidade bem iluminada com uma intensa vida noturna, mas ao mesmo tempo segura e tranqüila, bem diferente daquela vista anteriormente em que bairros inteiros não tinham iluminação:

“À noite passeia-se na cidade bem iluminada à eletricidade; nas igrejas celebram-se casamentos (por causa do calor intenso estas cerimônias são feitas à noite); os clubes organizam bailes, há récitas nos teatros, as crianças brincam com fogos de artifício, mas a 1 hora a grande cidade dorme e somente debaixo do céu estrelado, imóvel a arma ao ombro, a sentinela vigia pela segurança pública”. ${ }^{73}$

Durante a noite, entretanto, Belém não era uma cidade tão tranqüila assim. Alguns delitos, não muito graves, registrados sobretudo entre os grupos mais pobres, como muitos migrantes cearenses, sugerem uma vida cotidiana bastante difícil. Pequenas contendas nesse contexto, muitas vezes, eram geradoras de situações violentas que tinham como ponto final a Chefatura de Polícia. Esse foi o caso do cearense Francisco Xavier, que, indo, na noite de 2 de maio de 1904, "pagar uma conta que devia ao taverneiro", na Rua 22 de Junho, canto com a Rua Conceição, acabou discutindo com o mesmo. O taverneiro, segundo declarou Francisco, não “ficando satisfeito”, dirigiu-lhe “algumas palavras insultuosas”, querendo espancá-lo com “uma foice que tinha sob seu balcão”. Francisco Xavier alegou que para se defender, feriu o taverneiro com a tal foice. ${ }^{74}$

\footnotetext{
${ }^{73}$ Folha do Norte. Belém, 25 de junho de 1910, p. 1.

${ }^{74}$ APEP - Chefatura de Policia - Autos crimes - 1904 (jan-jun) - Auto de perguntas feitas a Franciso Xavier de Souza, autor de ferimentos na pessoas de José Tavares da Silva Valente. Belém, 5 de maio de 1904.
} 
As tavernas, entre o final da tarde e o início da noite, revelam-se em alguns momentos um espaço propício para esses conflitos. Muitos trabalhadores paravam nesses espaços no caminho que faziam entre o trabalho e a casa, para tomarem alguma bebida ou um café, para fazerem compras, e possivelmente, como foi o caso da briga entre Francisco Xavier e José Tavares, para o pagamento de dívidas contraídas nesses estabelecimentos. Francisco, que no seu depoimento declarou ser pedreiro, quem sabe?, teria recebido o pagamento por algum trabalho feito, e em longa dívida com o taberneiro, resolvera quitar seu débito naquela ocasião, o que segundo ele, foi a fonte do conflito.

Foi também indo a uma taberna na mesma Rua 22 de junho, só que canto com a Rua da Constituição, que um outro cearense, João Romão Capistrano, alguns anos antes, em 1899, "tendo largado o seu trabalho as cinco horas da tarde" e passado ali para "fazer algumas compras”, acabou sendo “espancado" com “diversas cacetadas”, por dois homens, um português e um brasileiro tido "na conta de valentão". ${ }^{75}$ Dessas ocorrências, embora não ficando muito claros os motivos das brigas, tem-se a impressão de um mundo de conflitos em plena ebulição, pronto para eclodir ao primeiro sinal de alguma pequena desavença. Não resta dúvida de que os grupos mais pobres eram solidários entre si, mas ao mesmo tempo, não se pode esquecer que a luta pela sobrevivência diária acirra os conflitos na busca, muitas vezes, pela demarcação de territórios urbanos e de poder. Note-se que do depoimento prestado por outro cearense, Joaquim Pereira de Mesquita (que era o dono da taberna onde aconteceu a briga), sabe-se que o português que espancou João também era taberneiro nessa mesma rua. Não estaria o taberneiro português buscando um acerto de contas com um antigo freguês que poderia estar deixando de comprar em seu estabelecimento?

Da Belém noturna, emerge também um mundo urbano do qual prostituição e bebedeiras acabam por ser práticas geradoras de conflitos. Nesse contexto, brigas entre casais e disputas entre mulheres envolvidas no meretrício em ruas mal iluminadas, revelam uma vida noturna não tão atraente como a cidade descrita no "Figaro". Foi justamente nesse contexto que os desentendimentos entre dois vizinhos, fruto das bebedeiras do cearense João Bapstista de Oliveira, conhecido como um "sujeito turbulento, sempre disposto a querer brigar prometendo sempre de lutar e espancar”, chegou à policia pela queixa de Ambrosio Tomas

\footnotetext{
${ }^{75}$ APEP - Chefatura de Policia - Autos Crimes - 1899 (jul-dez) - Auto de Diligência Policial exoficio acerca do ferimento feito na pessoas de João Romão Capistrano.
} 
Delfino, fluminense, ferido a faca. Consta no depoimento que o cearense João Baptista costumava espancar a mulher; intervindo numa dessas brigas é que Ambrósio levou uma facada. $^{76}$

Meses depois, no mesmo ano de 1905, o foco dos conflitos são duas mulheres que viviam na zona do meretrício em Belém. Trata-se da cearense Antônia Rodrigues e da maranhense Frederica da Conceição. Antônia declarou à autoridade policial que estava "jantando à Rua Lauro Sodré no Hotel Estrela”, quando ali chegou Frederica. Achando-se “conversando e rindo com outras amigas”, Antônia diz ser surpreendida por uma navalhada no nariz que lhe foi dada por Frederica, que a insultou e estava com muita raiva. ${ }^{77}$ Frederica, por sua vez, declara que estando de "relações cortadas" com Antonia, ao chegar no Hotel Estrela, foi recebida com "insultos”, dirigidos pela cearense. ${ }^{78}$ As bebedeiras, às vezes muito ruidosas, ao som de "serenatas", de "tocatas de violão", e o mundo em volta desses hotéis baratos dão indícios de uma vida noturna bastante dinâmica e nem um pouco tranqüila. Emerge desse submundo, também construidor da cidade moderna, variadas experiências sociais. Bêbados, prostitutas, jogadores de cartas, vigaristas, seringueiros, garçons, cozinheiros, varredores, são fundamentais nessas muitas relações que se fundem na noite da cidade, como veremos adiante.

Eugen Weber descreve, referindo-se à França, um mundo de conflitos, no qual estão presentes alcoolismo, uso de drogas, violências, e todo tipo de desordens, no chamado "finde-siècle”, fruto de transgressões muitas vezes demarcatórias de identidade entre grupos letrados por exemplo, mas também de busca de sobrevivência entre os pobres, tanto em Paris como em pequenas aldeias francesas. $\mathrm{O}$ autor chama atenção para um aspecto importante na divulgação desses comportamentos, que é o papel da imprensa que na França de populariza cada vez mais "ávida de notícias emocionantes, ansiosa por aumentar a importância e impacto das mesmas e com meio de fazê-lo. Desordem, assalto e agressão, homicídio, roubo, mendicância e violência sexual (...) passam então a receber tratamento sensacionalista, o

\footnotetext{
${ }^{76}$ APEP - Chefatura de Policia - Autos Crimes - 1905 - Auto de Diligências policiais procedidas acerca do ferimento na pessoa de Ambrosio Delfino da Costa por João Baptista de Oliveira.

77 APEP - Chefatura de Policia - Autos Crimes - 1905 - Auto de Declaração feito por Antonia Rodrigues do Carmo.

${ }^{78}$ APEP - Chefatura de Policia - Autos Crimes - 1905 - Auto de perguntas feitas a Frederica Maria da Conceição.
} 
que os tornava cada vez mais assustadores". ${ }^{79}$ Sem dúvida, no caso de Belém, o crescimento desses problemas se evidencia mais com as mudanças e aumento populacional da cidade. A imprensa não deixa de dar uma visão emocionante aos casos, tornando-os mais interessantes aos seus leitores, e construindo assim uma imagem da experiência desses sujeitos sociais.

Se, para esses moradores da cidade, a noite é o espaço da diversão e da busca da sobrevivência, não raro por meios ilícitos, para muitos moradores da cidade, a noite era reservada para o repouso. Assim, essa movimentação noturna não passou despercebida e muitos eram aqueles que se sentiam incomodados com a algazarra que se estabelecia em alguns pontos da cidade, perturbando o "repouso noturno". Em 1914, um leitor da Folha do Norte escrevia para esse jornal, pedindo providências à policia contra os "abusos" cometidos ao longo da noite e que se constituíam em "verdadeiros atentados contra o bem estar" da população belenense. Os abusos a que se referia o irritado leitor dirigiam-se "a certos viandantes" que, em seus automóveis, alarmavam "os residentes das nossas principais avenidas e estradas", ao som de fortes buzinas e também "soltando berros estridentes, ou assoviando e cantando canções brejeiras em alta voz". ${ }^{80}$

Ao que tudo indica, pelo fato de serem possuidores de carros muitos dos envolvidos nessas algazarras, acredita-se que esses abusos eram cometidos por jovens dos grupos mais abastados. ${ }^{81}$ Não obstante, encontramos também envolvidos nessas pândegas noturnas grupos de vigaristas, às custas do dinheiro de seringueiros de passagem por Belém, mas isso é assunto para mais adiante. No entanto, vale destacar, que em todo o noticiário pesquisado acerca desse problema, não encontramos uma só detenção de rapazes dos grupos privilegiados. De fato, quando a polícia age em relação a esses abusos noturnos, seu alvo predileto são os seringueiros e, quando muito, alguns dos vigaristas envolvidos com eles, o

\footnotetext{
${ }^{79}$ WEBER, Eugen Joseph. França fin-de-siècle. São Paulo: Companhia das Letras, 1988, p. 58

${ }^{80}$ Folha do Norte. Belém, 3 de junho de 1914, p. 1.

${ }^{81}$ Octavio Meira (1908) ao referir-se a Belém nas suas memórias, ao contrário do leitor da Folha, lembra-se de uma cidade pouco movimentada. "Belém de minha infância era uma cidade triste. Poucos automóveis: lembro-me de um barulhento, do Guilherme de La Rocque, que não tinha silencioso, era um playboy daqueles tempos e passava muitas vezes pelo nosso colégio em alta velocidade. Afora esse só quem tinha automóvel era o inglês da Pará Eletric, o inglês da Booth e o dr. Cascaes. Havia muitos carros a cavalo, (...). Não havia caminhões, a não ser dois ou três gigantes franceses, de rodas maciças, da Fábrica de Cerveja Paraense. Tudo era feito de carroças e estas tinham ponto como os automóveis hoje”. MEIRA, Octavio. Memórias do quase ontem, p. 136.
} 
que demonstra diferenciação na forma de se lidar com os delitos cometidos pelos moradores da cidade. A marca dessa distinção é justamente a origem social do envolvido no delito. Passemos para os seringueiros na capital paraense e para suas muitas experiências.

\section{Seringueiros}

Em fevereiro de 1915, quando já se pressentia que mais uma seca flagelaria os sertanejos cearenses, a Folha do Norte publicava um texto intitulado "Alma cearense". Seu autor, Terencio Porto (ao que tudo indica, já falecido à época da publicação), tomando como ponto de partida uma cena de Macbeth, de Shakespeare, que fala da floresta em "marcha para esmagar um homem”, advertia ao leitor que conhecia de fato essa "tragédia" que trazia à tona uma “desigualdade monstruosa”. Seu título, em letras destacada, aparecia: "AMAZÔNIA”. Como o enredo de uma peça de teatro, o autor descreve seus personagens. Nesse cenário, o sertanejo, em seu "duelo" com a floresta, aliena-se do próprio "nome” para entrar no “anonimato calado e humilde das generalidades: é o seringueiro". Ao final, ele é vencido pelo "apedrejamento" da chuva, pela água, que deixa de ser "boa e santa” para se tornar "insidiosa e maligna”, pelo "coro assassino das febres perversas". ${ }^{2}$

Embora com uma visão extremamente trágica da vida dos seringueiros na Amazônia, um dos aspectos destacados merece reflexão. Trata-se da questão do anonimato, da perda de uma identidade, em que, sem nome, todos são chamados de seringueiros. Ora, se todos são seringueiros (a historiografia reforçou essa idéia ao longo dos anos, como se discutiu no primeiro capítulo), esses trabalhadores são pensados de forma homogênea e não em sua diversidade, e não a partir de experiências que são sociais, mas que também são individuais e que, portanto, são mais complexas do que a simples exploração sofrida por esses homens. ${ }^{83}$

Mas as idéias de Terencio Porto não eram tão novas assim. José Veríssimo, com outras palavras, e sem dúvida dando conta de esboçar um perfil da sociedade dos seringais, em artigo publicado no Jornal do Brasil no início da década de 1890, também não deixou de se referir

\footnotetext{
${ }^{82}$ Folha do Norte. Belém, 23 de fevereiro de 1915, p. 1.

${ }^{83}$ Foot Hardman também não deixa de ver o seringueiro, e sobretudo os trabalhadores da MadeiraMamoré, alvo de sua pesquisa, dentro de uma visão extremamente trágica, como se a vida desses homens se resumisse apenas ao mundo da floresta, são como vítimas das quimeras capitalistas. HARDMAN, Francisco Foot. Trem fantasma: a modernidade na selva.
} 
ao seringueiro como um homem não necessariamente preso à floresta, mas a um patrão, ao qual devia dinheiro e obrigações. Tal qual na metáfora de Terencio Porto, essas dívidas também o impediam de deixar a floresta. Veríssimo lembrava que “até 1877”, a extração da borracha na Amazônia era uma atividade feita pelo "caboclo ou tapuio e o mameluco". A mudança nesse processo acontece, na visão do intelectual, de "1878 em diante”, quando os “seringais foram invadidos pelos 'retirantes' cearenses, acossados pela seca". ${ }^{84}$

Para o autor, “invadido" era o termo correto para explicar a chegada dos cearenses em áreas como a do Rio Juruá. Em pouco tempo, segundo Veríssimo, essa região teve "suas margens cobertas por uma população de cerca de quarenta mil pessoas”, envolvidas na exploração do látex. ${ }^{85}$ A seca de 1877 é um marco importante para a saída de cearenses rumo à Amazônia, uma vez que se, de um lado, como vimos anteriormente, existe um fenômeno climático que exige a saída do sertanejo, de outro, a valorização da borracha, ao longo do século XIX, coloca a Amazônia como um espaço de atração para os migrantes.

De forma simples, assim poderia ser explicado o processo de migração, restringindo-se a experiência dos seringueiros ao espaço da floresta onde trabalhavam retirando o látex. Esses espaços são descritos por Veríssimo como de “incrível carestia” ou ainda como uma região de “miséria, de privações e de penúrias”. Na floresta, sem nunca equilibrar suas finanças, o seringueiro, por essa visão, é um resignado que contenta-se em receber, a preços exorbitantes, “café, açúcar, farinha, peixe, carne seca, tabaco, cachaça, alguma roupa grossa de algodão etc" ${ }^{86}$ Não resta dúvida, esse é apenas um lado da história dos seringueiros na Amazônia. ${ }^{87}$ Suas atitudes diante de seu trabalho, diante das formas que utilizavam para gastar o seu dinheiro, longe da floresta e das cadernetas de contas dos seringais, revelam que a história de muitos desses homens de forma alguma foi tão somente a de trabalhadores explorados e resignados à solidão da floresta.

O destaque para os seringueiros, aqui, é fruto de reflexões, a exemplo das de Porto e Veríssimo, em que os migrantes são entendidos quase sempre como homens que viviam nos

\footnotetext{
${ }^{84}$ VERÍSSIMO, José. “A Amazônia (aspectos econômicos)”, p. 178.

${ }^{85}$ Ibidem, p. 178.

${ }^{86}$ Ibidem, pp. 180-181.

${ }^{87}$ Para o entendimento dessa visão clássica do seringueiro ver por exemplo: REIS, Arthur Cezar Ferreira. O seringal e o seringueiro.
} 
seringais na floresta, distante dos centros urbanos da Amazônia. O rastreamento de sua experiência social no Pará, entretanto, demonstra que apesar de toda a exploração sofrida no trabalho de extração do látex, a fronteira que os separava de Belém, por vezes, foi muito fluída. Na cidade, criava-se também uma verdadeira rede de interesses comerciais ou não, quando da chegada de seringueiros a Belém, pois depois de dias no trabalho de coleta da borracha, esses trabalhadores eram consumidores vorazes de tudo aquilo que a vida urbana pudesse lhes oferecer, como diversões, bebedeiras, boa comida, prostituição, além de roupas e acessórios modernos que lhes dessem distinção social.

Assim, na crônica urbana de Belém do Pará de finais do século XIX e início do século XX, os seringueiros (o que não quer dizer que todos eram cearenses) são figuras sempre muito presentes. Além desses, encontram-se também outros grupos de cearenses compondo o espaço da cidade. Nesse contexto, mulheres, crianças, pequenos comerciantes, mendigos, arruaceiros, trabalhadores em geral compõem a vida urbana, buscando as mais variadas formas de sobrevivência e igualmente de viver bem. Esses desdobramentos da experiência urbana dos seringueiros não querem, de forma alguma, negar a espoliação vivida por esses trabalhadores nos seringais, mas permitem entrever outras complexidades dessas relações.

A imprensa não se cansou de trazer para seus leitores as dificuldades enfrentadas pelos seringueiros na floresta. A Folha do Norte relatava os fracassos dessas idas aos seringais. Essas histórias obedecem a um mesmo enredo, que passa pelo momento antes da chegada ao seringal, no qual prevalece o sonho do "El Dourado", pelo momento da fixação na floresta e finalmente pelo fracasso dessa empreitada. Para dar maior credibilidade ao caso, o jornal utiliza-se do artigo definido "o", que aproxima o leitor do seringueiro. Assim, ao publicar em 1899 a história de um seringueiro maranhense que foi trabalhar em um seringal do Rio Purus, o redator da Folha do Norte, como se tudo tivesse visto, atesta: “O Doroteu atirou-se ao trabalho com afinco inigualável”. No ano de 1897, chegou ao Purus, levando “como capital uma vontade intensa de trabalhar uma saúde de ferro e seus vigorosos vinte e cinco anos”. Para completar a imagem de Doroteu, afirma-se que ele trabalhava "como uma besta de carga e não via o fruto do seu trabalho". ${ }^{88}$

Dois anos depois, na outra parte da história contada pela Folha do Norte, Doroteu é a imagem do fracasso. Doente das "febres palustres", é internado num leito do hospital da

\footnotetext{
${ }^{88}$ Folha do Norte. Belém, 11 de janeiro de 1899, p. 1.
} 
Santa Casa. É descrito como "sem roupa, sem saúde e sem vintém”, a maldizer o "momento em que deixou sua terra e sua família para correr atrás de uma visão mentirosa”. ${ }^{89}$ Casos semelhantes são de alguns menores, a exemplo de "um rapazito” que "ouvindo falar na facilidade com que se obtém fortuna no rio Madeira”, partiu para essa região. Tal qual Doroteu, foi enganado por seu patrão. Ao retornar a Belém, depois de seu fracasso, nas palavras da Folha do Norte, "estava louco o desventurado petiz".90

Diante desses fracassos, a imprensa parece condenar a "ambição da riqueza" que fazia com que vários homens pobres se lançassem a um "veio d'ouro como muitos chamam o seringal". ${ }^{91} \mathrm{Na}$ verdade, aqueles que se dirigiam aos seringais para trabalhar como seringueiros subvertiam a ordem do que estava estabelecido para a suas vidas. A esses trabalhadores - em sua maioria, pobres -, não restavam muitas opções, fossem eles cearenses ou paraenses, além de se ocuparem na agricultura ou em serviços urbanos que não lhes dariam grandes proventos quando conseguiam aqueles postos. Ao deixarem seus espaços nativos e se lançarem na coleta do látex na floresta amazônica, mesmo que tudo desse errado nessa verdadeira aventura, tais trabalhadores manifestavam claros indícios de que não estavam tão passivos assim diante de sua situação de pobreza. Não resta dúvida de que essa decisão incomodava aos gestores públicos paraenses e cearenses. Ao mesmo tempo, se as autoridades desses dois estados usufruíam dessa mão de obra que ia para os seringais (no Pará através dos lucros auferidos com a extração do látex, no Ceará com a saída de uma massa de desocupados que perturbavam a ordem vigente), criticava-se também a própria saída para aqueles espaços.

Além disso, o trabalho nos seringais era pensado como uma ocupação mais fácil. $\mathrm{O}$ extrator do látex, diferentemente de um agricultor, não precisava, por exemplo, preparar o solo para a sua produção, tendo ainda a possibilidade de maiores lucros nesse tipo de trabalho. Tal particularidade sempre atraiu muita gente, sobretudo jovens, dispostos a mudar de vida. Contudo, as incríveis distâncias entre seringais e centros urbanos como Belém e Manaus permitiam que as áreas dos seringais constituíssem também espaços com códigos de condutas próprios e poderes locais que se estabeleciam à força.

\footnotetext{
${ }^{89}$ Folha do Norte. Belém, 11 de janeiro de 1899, p. 2.

${ }^{90}$ Folha do Norte. Belém, 9 de fevereiro de 1899, p. 2.

${ }^{91}$ Folha do Norte. Belém, 9 de fevereiro de 1899, p. 1.
} 
Pouco mais de um ano depois de publicar a história de Doroteu e do pobre "rapazito", o mundo cruel dos seringais vinha novamente à baila. Dessa vez, com um título que resumia muito bem o teor da reportagem: 'Horrível! Diversas pessoas mortas a fome”. Tratava-se de um episódio acontecido no Amazonas, em lugar conhecido como Porto Antunes, no Rio Jutaí, afluente do Solimões. Idelfonso Antunes, dono do seringal localizado nessa área, tinha sob seu comando, na sua maioria, empregados "moços de família por ele levados (...) sob promessas de (...) remunerada colocação". Idelfonso era conhecido como "O professor" provavelmente, numa alusão aos castigos a que submetia a seus jovens empregados. Não raro, conforme informou a Folha do Norte, seus trabalhadores eram "acorrentados" e surrados com "pele de peixe-boi” ou cipós cheios de espinhos. Idelfonso não fornecia a alimentação mínima a seus trabalhadores, que, com o passar do tempo, diante dos muitos trabalhos e dos maus tratos, acabavam morrendo. Para se ter uma idéia, segundo o jornal "Comércio do Amazonas”, que primeiro noticiou o caso, de 14 pessoas que seguiram para o seringal do "Professor", apenas "sobreviveram aos maus tratos 6, que se achavam quase todas doentes". 92

Próximo ao Natal de 1910, o jornal noticiava mais uma dessas atrocidades, dessa vez com a morte de um jovem de 18 anos, assassinado pelo gerente do seringal "Boca do Acre". Ao noticiar tal caso, a Folha do Norte evidenciava o fato de que "há muito” chegavam ao conhecimento da imprensa as notícias da forma como se lidava com trabalhadores nos seringais nas “inóspitas regiões do Amazonas”. Nessas regiões, imperavam como lei “o rifle e o tronco". ${ }^{93}$ Aspecto importante nesse trabalho nos seringais era a presença de trabalhadores que, ainda jovens, se lançavam à extração do látex. Sem dúvida, as oportunidades lucrativas que essa ocupação oferecia, além de ser um trabalho que, pela sua própria natureza, exigia muita vitalidade e uma boa dose de coragem, explicavam a quantidade de jovens nos seringais.

Não resta duvida de que a exploração na região dos seringais se tornava mais intensa e igualmente mais difícil de ser controlada pelo fato de que, em boa parte deles, os proprietários, a fim de resguardarem suas propriedades e seus lucros, criavam organizações de segurança próprias, com a utilização de capangas que cumpriam as ordens de seus patrões.

\footnotetext{
${ }^{92}$ Folha do Norte. Belém, 31 de julho de 1900, p. 1.

${ }^{93}$ Folha do Norte. Belém 20 de dezembro de 1910, p. 1.
} 
Arthur Cezar Ferreira Reis descreve O "patrão”, como a principal autoridade do seringal, “disciplinador por excelência”, mostrando-se “violento, indo mesmo à barbárie no trato com seus homens". Por isso mesmo, é acusado de "desumano, explorador do sangue de seus jurisdicionado, barão feudal”. Essa “aspereza” dos patrões é justificada pelo autor em função do meio em que este vive. Nesse espaço ainda segundo Reis, os patrões agiam "sem freios". Desse modo, o autor afirma ainda sobre as autoridades legais o fato de que " $A$ autoridade do magistrado civil ou militar que vive na sede da Comarca e, pela distância a falta de elementos materiais, quase não pode chegar ao seringal para o policiamento moralizador e disciplinador". 94

Assim, intervenção da polícia nem sempre era aceita no espaço dos seringais. Nesse mesmo ano de 1910, a Folha do Norte acusava as autoridades do município de Breves de “violentas", em conseqüência de um despejo feito no barracão do seringal "Santa Júlia”, no Rio Tajapuru, que, feito de forma inadequada, de acordo com o que declarava um dos sócios da casa, causou um prejuízo de “cerca de 8:000\$000”. O proprietário, que parecia ter problemas com as autoridades locais, dirigiria-se, inclusive, “ao governador do Estado" para pedir providências quanto ao acontecido. ${ }^{95}$ Isso nos permite falar em uma rede de poderes e de interesses que se estabelecia entre as autoridades locais e os donos dos seringais e, até mesmo, entre os últimos e o próprio governo do estado do Pará.

Se é verdade que a força policial oficial, por muitas vezes, foi ausente e negligente em relação às "leis" peculiares, marcadas pela força e violência, que regiam os seringais, em alguns momentos, a atenção para essas áreas se fez muito presente. Um bom exemplo disso é quanto aos casos de mulheres que possivelmente iam como escravas para a região do Alto Amazonas. Esse tipo de delito parece ter estado na mira das autoridades, que até em

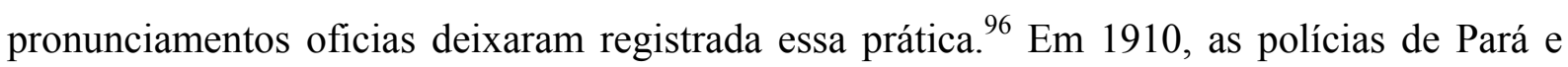
Amazonas investigavam a chegada à região do Rio Juruá de uma menor cearense, Raimunda

\footnotetext{
${ }^{94}$ REIS, Arthur Cezar Ferreira. O seringal e o seringueiro,, pp. 222-224.

${ }^{95}$ Folha do Norte. Belém, 9 de maio de 1910, p. 1.

${ }^{96}$ Mensagem do Presidente do Estado Coronel Dr. José Freire Bezerril Fontenelle à Assembléia Legislativa do Ceará em sua $3^{a}$ sessão ordinária da $2^{a}$ Legislatura. Fortaleza: Typ. d'A Republica, 1894, p. 7
} 
Rodrigues, que possivelmente “fora vendida no Ceará por sua própria mãe”, por 20\$ a um negociante português ligado ao comércio da borracha. Diante do caso, a policia afirmava:

"não era de hoje que existem indivíduos que seduzem não só no Ceará como no Rio Grande do Norte, Paraíba e interior do Maranhão e até na capital do Pará, não só menores como meretrizes para vendê-las no Alto Amazonas" 97

Na ocasião, uma mulher do Rio Grande do Norte, Martinha Barbosa, que também viera no vapor Goiás com Raimunda Rodrigues, do Ceará até Belém, afirmou que o comerciante português a tinha contratado para prestar serviços “em casa de sua família”. Declarou que sabia que a menina cearense estava sendo "iludida" e que a finalidade de sua ida ao rio Juruá era bem diferente da que era exposta pelo português no Ceará. No vapor Esperança, que seguiu do porto do Pará ao do Amazonas, também existiam outras mulheres a bordo. Segundo o depoimento de Martinha Barbosa, era “costume de João Caetano aparecer, de quando em vez pelo Estado do Ceará comprando mulheres com o fim de vendê-las no interior do Amazonas". 98

Diante desse caso, mais do que a ida de mulheres envolvidas com prostituição para a região dos seringais - o que era uma prática comum, e da qual se tinha conhecimento, considerando que não havia proibições para o deslocamento de mulheres para essa região -, o que chamou a atenção daqueles que tomaram conhecimento do caso, em 1910, foi sem dúvida o fato de que a menina cearense teria sido negociada por sua própria mãe. Não fica comprovado se de fato a menina Raimunda fora vendida pela mãe, e, se isso aconteceu, quais motivos a teriam levado àquela atitude. 1910 não foi um ano de seca, o que poderia justificar a saída da menina, mas apesar disso, sabe-se muito bem que a situação dos grupos pobres cearenses era bastante complicada diante da falta de melhores oportunidades de vida. Teriam a mãe e a própria menina também sonhado com o “El Dourado” dos seringais?

Poderíamos fazer mil conjecturas a esse respeito e todas elas ficariam no campo da especulação. $\mathrm{O}$ que talvez fique de mais concreto desse episódio são as representações que podem ter surgido diante da publicação da história da cearense Raimunda. A possível atitude da mãe da menina coloca em xeque o papel que se atribui ideologicamente às mães, que é o de dever de cuidar de e proteger os filhos. A vinda da menina, desacompanhada de familiares para uma região estranha e longe de sua terra natal, fere completamente esses argumentos. É

\footnotetext{
${ }^{97}$ Folha do Norte. Belém, 12 de maio de 1910, p. 1.

${ }^{98}$ Folha do Norte. Belém, 12 de maio de 1910, p. 1.
} 
possível que a imagem da mãe que vende a própria filha reflita inclusive na forma como muitos passam a ver a figura das mulheres cearenses, que podem ter sido pensadas como desapegadas da família e, mais que isso, desprovidas de valores maternais. ${ }^{99}$

Isso não se pode dizer de uma viúva, também cearense, chamada Cândida Maria José, que, em abril de 1908, denuncia na Chefatura de Policia de Belém o desaparecimento de seu filho Francisco Fernandes da Silva, desde janeiro daquele ano. A viúva denunciava o proprietário de um hotel, que tinha articulado para que seu filho, que era menor de idade, embarcasse para o rio Juruá em companhia de um homem que, segundo soube, tinha "por costume levar pessoal desse estado para vender nos seringais do Alto Juruá”. Dos depoimentos prestados pela viúva e pelo dono do hotel, João Pinto Nogueira, o João de Ouro, como era conhecido, que aliás também era cearense, vemos que o rapaz havia dito a sua mãe que pretendia “trabalhar a bordo”, e não em seringais, e que por fim, Francisco Fernandes teria "embarcado obrigado", pois teria se arrependido de seguir para aquele lugar, conforme contou para Cândida um empregado do hotel. Em sua defesa, "João de Ouro” argumentava que "não costuma embarcar para os seringais pessoas menores de idade". 100

Evidencia-se aqui uma estreita rede de relações em torno da ida de menores e mulheres para os seringais. Essas pessoas nem sempre iam por vontade própria. Agenciadores de trabalhadores, donos de hotéis na capital paraense, especuladores que transitam na redondeza desses hotéis, e até mesmo famílias de migrantes, desesperadas, sem meios para prover o sustento familiar, participavam ativamente desse processo. Tal qual a menina Raimunda, que teria ficado, “durante uns oito dias”, hospedada em um hotel em Belém, consta que o menor Francisco Fernandes, antes de embarcar, passou aproximadamente 6 dias no hotel de “João

\footnotetext{
${ }^{99}$ Sobre o papel das mulheres na sociedade há uma vasta bibliografia sobre a temática. Dentre esta citamos apenas alguns: SAMARA, Eni de Mesquita. As mulheres, o poder e a família (São Paulo, Século XIX). São Paulo: Marco Zero/Secretaria do Estado da Cultura de São Paulo, 1989; DIAS, Maria Odila Leite da Silva. Quotidiano e poder em São Paulo no século XIX; DEL PRIORE, Mary. A Mulher na história do Brasil. São Paulo: Contexto, 1988; ENGEL, Magali. Meretrizes e doutores, saber médico e prostituição no Rio de Janeiro (1840-1890). São Paulo: Brasiliense, 1989; ALGRANTI, Leila Mezan. Honradas e devotas: mulheres na colônia. Rio de Janeiro: José Olympio, 1993; ABREU, Marta. Meninas perdidas: o cotidiano do amor na Belle Époque. Rio de Janeiro: Paz e Terra, 1889; sobre a temática em Belém ver: CANCELA, Cristina Donza. Adoráveis e dissimuladas: as relações amorosas das mulheres das camadas populares na Belém do final do século XIX e início do século XX. Campinas: Dissertação de Mestrado (Antropologia), Universidade Estadual de Campinas, 1997.

${ }^{100}$ APEP - Secretaria de Policia da Província - Autos Crimes - 1908 (Jan-jun). Auto de Perguntas feitas a Cândida Maria José e a João Pinto Nogueira - 30 de abril de 1908.
} 
de Ouro", à espera do vapor que o levaria para o Juruá. Talvez isso explique seu desaparecimento, pois depois de tantos dias, o menor desistira de embarcar, mas não tendo como pagar o que devia, acabou tendo que ir obrigado. ${ }^{101}$

Contudo, nem sempre, essas transações davam certo. Em 1910, por exemplo, o dono do Hotel do Porto, ao aumentar o débito de Horácio Pereira, um seringueiro cearense que havia se hospedado em seu hotel, com uma “rapariga com quem estava amasiado”, propõe a este que deixe, em troca do débito excedente, a mulher que o acompanhava. Horácio Pereira declarou que, "para não fazer uma desgraça", foi queixar-se à policia. ${ }^{102}$ Também em 1916, quando a cidade de Belém recebia muitos cearenses, vítimas da seca de 1915, noticiou-se que um cearense, chamado Vicente Ferreira Lopes, negociara “dois filhos por 12\$000”, meninos de 12 e 11 anos, num casarão na Travessa São Mateus, “rotulado de Hotel Guajará”. Vicente vinha de uma longa jornada com sua família, que era formada por ele, sua mulher, Raimunda Alves Bezerra, e mais "10 filhos menores". Naturais do Crato, tinham se deslocado para Fortaleza em dezembro de 1915, permanecendo nessa cidade até março de 1916, quando “tomaram” o paquete Olinda até Belém. Ao desembarcarem em Belém, hospedaram-se no tal "Hotel Guajará", descrito como um espaço insalubre, "onde os hospedes, à falta de lugar, tem redes atadas até no corredor na porta da rua" ${ }^{103}$ Estando a família "atrasada em $12 \$ 000$ de hospedaria”, um homem, que sabia dessa situação, propôs pagar a conta em troca de dois dos filhos de Vicente. Segundo apurou a imprensa, Vicente pretendia fechar o negócio. Sua mulher, entretanto, “não se conformando com a transação deu o alarma”. Na ocasião, juntou-se gente na frente do hotel, "e o comprador de criança desapareceu”. ${ }^{104}$

Como que para concluir essas histórias de negociações de pessoas, a trajetória da família de Vicente e Raimunda é bastante emblemática, pois sintetiza o que movia muitas famílias a

101 Sobre denúncias dos maus tratos sofridos por imigrantes presentes na imprensa operária ver MARSON, Adalberto. "Reflexões sobre o procedimento histórico". In: SILVA, Marcos Antônio da (org). Repensando a História. $2^{\mathrm{a}}$ edição. São Paulo: ANPUH/Marco Zero, s/d, pp.60-61. Marcos Antonio Silva lembra que dentre as exigências dos marinheiros revoltosos, em 1910, estava a de não serem tratados como escravos e nem espancados. Ver: SILVA, Marcos Antônio. Contra a Chibata: marinheiros brasileiros em 1910. $2^{\mathrm{a}}$ edição. São Paulo: Brasiliense, 2002.

${ }^{102}$ Folha do Norte. Belém, 16 de fevereiro de 1910, p. 1.

${ }^{103}$ As descrições acerca das péssimas condições desses hotéis destinados às pessoas pobres de passagem pela cidade são constantes.

${ }^{104}$ Folha do Norte. Belém, 21 de março de 1916, p. 2. 
embarcarem para o Pará e ali buscar meios de sobreviver. É possível imaginarmos as agruras de Vicente, depois de um ano de seca, e com tantas crianças para alimentar. E é igualmente possível imaginar o escândalo de Raimunda, a mãe das crianças, à porta do "Hotel Guajará". Ora, Raimunda percebe que depois de tantas dificuldades, exatamente no lugar que lhes parecia ser sua última chance, a capital paraense, estava prestes a perder dois de seus dez filhos. Por mais cruel que possa ter sido a atitude de Vicente, parece que tanto ele como Raimunda tinham os mesmos objetivos: salvar os filhos que, desde o Crato, os acompanhavam nessa incerta jornada para a Amazônia.

A vinda ao Pará, as longas estadias nos seringais e até mesmo situações adversas não acabavam com os vínculos familiares. Muitos migrantes apontavam a presença de familiares na região como um elemento fundamental em sua decisão de migrar para a Amazônia. Depois de passar 14 anos trabalhando como extrator de borracha no Alto Purus, o cearense Raimundo Teles de Menezes, que estava hospedado no "Hotel e Restaurante Duas Nações", no Boulevard da República, colocara um anúncio no jornal, à procura de sua mãe. Raimundo conta que havia deixado a mãe no Ceará, mas tinha informações de que, nesse ano de 1910, ela se encontrava em Belém. Provavelmente, algum conterrâneo de Raimundo o informou da presença de sua mãe na cidade. Assim, uma se de suas primeiras providências foi encontrá-la. Através de seu anúncio, sabemos que Raimundo havia chegado do Purus no dia anterior à publicação da notícia.

Depois do período que passavam trabalhando na extração do látex, muitos seringueiros chegavam à cidade de Belém trazendo dinheiro em espécie, ou uma ordem de pagamento que lhes permitia receber em firmas ligadas ao seringal o saldo de seu trabalho. Essas ordens, na cidade, tinham o mesmo valor de dinheiro, sendo também vistas como garantia de que seu portador tinha alguma posse. Em caso que veremos a seguir, em que um seringueiro acaba por enganar uma mulher num vapor que partira da região dos seringais, ele apresenta como garantia para empréstimo em dinheiro o fato de ter uma ordem de pagamento na mala. ${ }^{105}$

Muitos eram os vigaristas interessados em roubar essas ordens. Em janeiro de 1899, por exemplo, a polícia fazia "sindicâncias" sobre o roubo de dinheiro e de uma "ordem em favor

\footnotetext{
${ }^{105}$ Folha do Norte. Belém, 12 de fevereiro de 1899, p. 2.
} 
de um conto de réis" de um seringueiro hospedado no Hotel Sete Nações. ${ }^{106}$ Em 1910, a cearense Francisca Coelho de Araújo, de 25 anos de idade, que havia chegado de Vila Nova no Acre, muito doente de malária (que resultaria em sua morte), acompanhada de uma filha pequena e "sem recurso algum, a não ser uma conta a receber de $H$. Moreira \& $C^{a}$ Nova Empresas" no valor de “5.000\$000 e tanto", vende essa ordem por “200\$000” para um seringueiro, dinheiro com o qual adquiriu uma passagem para Fortaleza no paquete Brasil. ${ }^{107}$ De posse dessas ordens, os seringueiros, numa forma de demonstração de seu poder aquisitivo, acabavam por fazer referência às mesmas. Guardadas, nas malas dos seringueiros em hotéis suspeitos da capital, não raro, eram roubadas.

Em função desse dinheiro ou dessas contas a receber, forma-se em torno dos recémchegados do seringal uma verdadeira rede de interesses, que ia desde trapaceiros aliados a donos de hotéis, de lojas, carregadores, prostitutas e até ciganas, que abusando da boa-fé dos extratores de látex, criavam variados artifícios para enganar esses homens logo que desembarcam dos vapores e aportavam na capital paraense. Além desses interesses escusos, diante da importância que a borracha tinha na economia local, não faltavam na imprensa propagandas voltadas para facilitar a vida e o trabalho nos seringais, ou para o consumo em função dos lucros com a borracha.

Desse modo, em 1910, a casa "Petit Paris", em grandes letras, publicava um anúncio intitulado "REGOSIJO GERAL", em que informava às "famílias desta capital e do interior", sua grande "variedade de fazendas finas" da "última moda”, e de cortes bordados”, do que havia de mais “rico e moderno em Paris e Londres" e “muito outros artigos”, vendidos a preços reduzidos, “em vista da grande subida da borracha”. ${ }^{108}$ Além disso, anúncios de poções com efeitos curativos contra a malária, ou de poções químicas, como a "Água botânica”, um "maravilhoso preparado vegetal”, que prometia conservar "liquido por mais

\footnotetext{
${ }^{106}$ Folha do Norte. Belém, 26 de janeiro de 1899, p. 2. Em 1910 o português Joaquim Alves roubou uma ordem de pagamento de um seringueiro, no valor de "1.400\$000 para receber em casa de Adalbert [?] Limited" que ficava no boulevard da República. Sendo os administradores da casa "Adalbert" avisados do roubo pelo seringueiro, Joaquim foi interceptado e entregue à patrulha quando “apresentou-se no caixa da referida casa”. Cf.Folha doNorte, Belém, 29 de abril de 1910, p. 1.

${ }^{107}$ Folha do Norte. Belém, 7 de fevereiro de 1910, p. 1.

${ }^{108}$ Folha do Norte. Belém, 7 de fevereiro de 1910, p. 2.
} 
de 24 horas" o leite da seringueira, e que estava ao alcance do mais pobre seringueiro"109, demonstram o grande interesse do comércio local com proventos advindos dos negócios da borracha. ${ }^{110}$

Embora com essas outras nuanças, a ênfase dada às situações vexatórias em que os seringueiros se envolviam sempre fez parte do noticiário local. Ao longo dos anos, a imprensa foi trazendo para seus leitores os muitos casos de vigarices e extorsões em que eram envolvidos os seringueiros. A ponto de que, em 1918, quando a corrida aos seringais estava decrescendo, sob o título "É uma vergonha”, o jornal católico A Palavra ainda denunciava os mesmos problemas enfrentados pelos seringueiros ao chegarem em Belém.

“Diz-se que nos seringais não há autoridade, não há justiça, não há proteção para direito algum, mas na verdade é que os seringueiros trazem de lá o seu dinheirinho, ganho tão penosamente, e onde são roubados é aqui, na capital às barbas dos primeiros representantes do poder público!

Antes de saltar em terra; a bordo dos vapores, já eles se vem presos na malha da rede formada por um aparelho, completo de espoliação que vai desde os aliciadores agentes dos hotéisespeluncas até os contistas que trabalham por fora. Se os míseros deixam o seu dinheiro nas malas fechadas a chave, no quarto que ocupam desaparecem como por encanto, sem que os criados e os donos do estabelecimento saibam nunca explicar o milagre”. 111

Note-se que essas questões ocorriam com maior freqüência no início do ano. Sendo um período de muitas chuvas na Amazônia e de subida dos rios, o trabalho do corte das seringueiras muitas vezes ficava prejudicado, era o momento privilegiado para os seringueiros se retirarem da floresta com o dinheiro ganho ao longo de um ano de trabalho. Muitos ficavam em Belém por alguns dias, à espera de vapores que os pudessem levar para o Ceará. $\mathrm{Na}$ capital paraense, durante esse período de “férias" imposto pela natureza, é que ocorria toda sorte de confusões envolvendo os seringueiros.

Em janeiro 1899, tal qual a descrição que faria anos mais tarde A Palavra, o jornal Folha do Norte apresentava como que um roteiro do assédio que os seringueiros sofriam ao chegar

\footnotetext{
${ }^{109}$ Folha do Norte. Belém, 5 de outubro de 1900, p. 4.

${ }^{110}$ A leitura de Roy Porter acerca das linguagens do charlatanismo na Inglaterra, embora dirigida às questões do curanderismo e da medicina, além de se referir a um outro contexto, é sugestiva para se pensar as articulações de uma linguagem do comércio local (Belém), para induzir os seringueiros às compras, para se pensar enfim em um discurso construído por uma variedade de vigaristas que viviam na cidade, a fim de ludibriarem os seringueiros. PORTER, Roy. "A linguagem do charlatanismo na Inglaterra, 1660-1800”. In: BURKE, Peter e PORTER, Roy. História social da linguagem, pp. 83-119.

${ }^{111}$ A Palavra. Belém, 7 de março de 1918, p. 1.
} 
na capital paraense, por parte de grupos de interesseiros. Classificava como principais embusteiros os chamados "rebocadores", que eram

"assalariados de donos de hotéis inferiores e de certas lojas de segunda ordem para atraírem os ditos seringueiros a fim de se hospedarem n'aqueles e comprarem nestas".

Além desses, os “cicerones”, qualificados como indivíduos que se apresentavam aos seringueiros “obsequiosamente oferecendo-lhes para levá-los aqui e acolá e para indicarlhes os meios de não serem enganados". ${ }^{112}$ Em chusma, esses trapaceiros corriam ao encalço dos extratores de látex a lhes oferecer tudo que a vida moderna na capital tinha: passeios pela cidade, os “cavalinhos no Largo da Pólvora", sem contar os muitos "hotéis onde se hospedavam mulheres de vida equivocada". ${ }^{113}$

Ao mesmo tempo em que a imprensa local pedia que a polícia agisse contra esses abusos em relação aos seringueiros, ela própria se encarregava também de desrespeitá-los. No que se refere às formas como os seringueiros são apresentados na imprensa, pode-se tomar como ponto de reflexão as discussões de Lilia Moritz Schwarcz sobre as representações dos negros na imprensa paulista. A autora lembra que, ao selecionar as notícias, estas são interpretadas não “enquanto situações que 'realmente' aconteceram e cuja veracidade” deveria se comprovada. Para Schwarcz, as notícias devem ser pensadas

"enquanto situações plenas de significação, sendo nesse sentido mais relevante apreender como se produziram, difundiram e repercutiram às vezes diversas interpretações de um mesmo fato". ${ }^{114}$

Essas reflexões da Antropóloga não deixam de ser bem pontuadas para se pensar as imagens que a imprensa paraense constrói dos seringueiros. Ao narrar as ciladas em que esses homens se viam envolvidos, produzia-se um texto de maneira a tornar o episódio cômico. Num misto de drama e comédia, expunha-se o caso de forma a tornar grotesca a experiência daqueles trabalhadores na cidade. Além disso, expressões como “paspalho”, “babaquara”,

\footnotetext{
${ }^{112}$ Folha do Norte. Belém, 27 de janeiro de 1899, p. 1.

${ }^{113}$ Folha do Norte. Belém, 13 de janeiro de 1899, p. 1.

${ }^{114}$ SCHWARCZ, Lilia Moritz. Retrato em branco e negro: jornais, escravos e cidadãos em São Paulo no final do século XIX. São Paulo: Companhia das Letras, 2001, pp. 15-16.
} 
“caipira”, "matuto", "pobre pato” e "bilontra” serviam para designar esses trabalhadores e criar também uma imagem extremamente pejorativa deles. ${ }^{115}$

Bom exemplo disso é a história do seringueiro Pedro Machado. Numa linguajem vulgar, ele é apresentado ao público leitor como alguém que havia se envolvido "em um rolo em que deu e recebeu pancada”. Em tom de extrema ironia, a Folha do Norte afirma que Pedro Machado, na capital paraense,

"desforra-se o tempo que serviu de pasto às muriçocas e carapanãs e falando grosso porque afinal quando o sujeito mostra o dedo quilotado pelo fumo do Urucuí é prova que tem dinheiro e quem tem dinheiro manda chover grosso ou fino a vontade". 116

A imagem de um homem incauto, que não conhecia o valor do dinheiro que possuía, não pode ser desvinculada da figura dos seringueiros que aportavam em Belém. Na maioria das vezes, eles foram descritos na crônica policial desse período como “ingênuos homens”, por se deixarem enganar por aproveitadores interessados nos proventos economizados na longa estadia de trabalho nos seringais. ${ }^{117}$ Entretanto, essas mesmas ações trazem à tona a figura de pessoas que chegavam a Belém com dinheiro, em busca de conforto, de diversões, de prazeres, fugindo da imagem cristalizada do semi-escravo.

Uma boa parte dos conflitos e embustes nos quais os seringueiros se viam envolvidos estava relacionada com o consumo exagerado de álcool, que ia muitas vezes do "mais modesto paraty até o mais aristocrático champangne”. ${ }^{118}$ A partir daí e incentivados por seus “cicerones”, esses homens estavam prontos para a diversão. Falavam alto, gritavam pelas ruas, pagavam rodadas de bebidas e comidas em bares suspeitos, e comumente eram presos quando a patrulha noturna chegava e os pegava já bêbados, ao passarem, como em tom irônico se dizia, “uma tremenda descompostura na humanidade”, numa alusão às algazarras. ${ }^{119} \mathrm{Ou}$ ainda, nessas situações de bebedeiras, dizia-se que os seringueiros comiam e bebiam "fradescamente", a desforrarem-se dos 365 dias em que haviam passado no Purus, a

\footnotetext{
${ }^{115}$ Essas expressões foram colhidas em notícias publicadas no jornal Folha do Norte entre 1898 e 1916.

${ }^{116}$ Folha do Norte. Belém, 17 de janeiro de 1899, p. 1.

${ }^{117}$ Folha do Norte. Belém, 27 de janeiro de 1899, p. 1.

${ }^{118}$ Folha do Norte. Belém, 17 de janeiro de 1899, p. 2.

${ }^{119}$ Folha do Norte. Belém, 17 de janeiro de 1899, p. 2.
} 
“marchar no jabá e no pirarucu”. ${ }^{120}$ A diversão desses homens não passava por estar sempre em um mesmo bar, ou hotel, onde poderiam receber mulheres. Em 1910, por exemplo, com a presença de automóveis na cidade, símbolos de luxo e modernidade, vemos um seringueiro a sair com um vigarista em um carro com chauffeur, parando "em cada botequim que deparavam aberto". 121

Nessas ocasiões de bebedeiras, quando os seringueiros estavam envolvidos com a diversão, é que os chamados "parasitas de frege" - homens que estavam sempre atentos à chegada de um seringueiro endinheirado em um hotel da cidade - agiam de forma ilícita. Esses "parasitas", além de usufruírem, às custas dos seringueiros, de bebidas e comidas consumidas em grande quantidade, os levavam a bares, hotéis, casas de jogos. De comum acordo com os proprietários desses estabelecimentos, e certamente tendo algum lucro, aumentavam-se a preços exorbitantes bebidas e comidas, além de se exagerar o consumo do seringueiro. Esse foi o caso do cearense Anastácio Braga, que, chegando do Acre, hospedouse num "frege" em Belém antes de seguir para Fortaleza. De acordo com a Folha do Norte, ele tencionava "divertir-se um pouquinho no teatro circo, no Bar, no 'Moulin Rouge, etc". No fim de sua estadia, ao pedir a conta, lhe foi apresentado "um fabuloso débito de ... 1 conto, seiscentos e tanto mil réis! Quase tudo quanto possuía!”. Não podendo mais seguir para o Ceará, alistou-se com uma turma de trabalhadores, que iam retornar para um seringal. O contratante, sabendo do caso, verificou que se tratava de uma conta "fantástica”, voltou com Anastácio ao "frege", e lá verificou nas folhas do livro de conta gastos absurdos, como “50 garrafas de champangne”, bebida que o seringueiro não havia tomado. ${ }^{122}$

Além das bebedeiras e do envolvimento com prostitutas, na linha das contravenções, estava ainda o jogo, diversão que constantemente era alvo da polícia. Desde os vapores que saíam da região dos seringais até Belém, muitos seringueiros já vinham se envolvendo em jogo e muitas vezes em função disso, também eles próprios se aproveitavam da boa fé de outros passageiros. Esse foi o caso de uma mulher chamada Rosa Maria da Conceição, que depois de juntar algum dinheiro no Alto Juruá, acabou sendo enganada por um homem chamado Manoel Menezes, que, no vapor, “dizia-se seringueiro importante, dispondo de

\footnotetext{
${ }^{120}$ Folha do Norte. Belém, 10 de fevereiro de 1899, p. 2.

${ }^{121}$ Folha do Norte. Belém, 14 de fevereiro de 1910, p. 1

${ }^{122}$ Folha do Norte. Belém, 10 de abril de 1910, p. 1.
} 
capitais e que vinha ao Pará a fim de divertir-se”. Menezes, que ao longo da viagem "meteuse no jogo", ia pedindo dinheiro emprestado a Rosa, dando como garantia o fato de que “dispunha de 12:000\$000 cuja ordem trazia na mala”. Rosa, vendo que foi enganada, levou o caso a polícia. ${ }^{123}$ No mesmo ano de 1910, divertindo-se em uma "banca de bacarat", no Cassino Paraense, um seringueiro é igualmente ludibriado por um dos freqüentadores do cassino, perdendo todo seu dinheiro. ${ }^{124}$

De fato, entre os grupos populares de Belém, essa era uma diversão comum, e não raro a imprensa pedia providências à policia em relação ao que chamava de "botequins de ordem inferior”. Acreditava-se que boa parte da desordem das ruas era produzida nesses espaços, vistos como "núcleos de vagabundagem perigosa". ${ }^{125}$ É nesse mundo que se concentravam as casas de jogos que, muitas vezes, tinham como freqüentadores os seringueiros. Além disso, esses eram espaços onde jovens pobres da sociedade também se reuniam. Reclamava-se que estes passavam horas da noite em "desenfreada jogatina e libações desregradas (...) em torno da mesa do vício". ${ }^{126}$ Nesses espaços, consentia-se muitas vezes, segundo a imprensa, que “rapazolas de 16 anos desempregados” jogassem desde o "bilhar até as cartas". 127

Se essas práticas são consideradas como um entrave ao progresso, outras formas de diversão são entendidas como um reflexo da introdução na sociedade paraense de "costumes europeus". Conforme asseverou Álvares da Costa em 1898, elas eram resultado de "florescentes e prósperas associações", como o "Club Universal”, o "Sport Club”, a "Associação Recreativa Dramática Beneficente”, a “Assembléia Paraense”, o "Club Euterpe" o "Ateneu Comercial”, entre outras, que buscavam desenvolver o que Costa chamou de "vasto campo da vida elegante" de Belém. Citava como exemplo dessa "vida elegante" a franca decadência em que se encontrava o "Jockey Club" e as "touradas", uma vez que esses divertimentos eram considerados arcaicos, além de pouco apreciados "pelos grandes centros”, que preferiam “distrações menos bárbaras”. ${ }^{128}$

\footnotetext{
${ }^{123}$ Folha do Norte. Belém, 12 de fevereiro de 1899, p. 2.

${ }^{124}$ Folha do Norte. Belém, 15 de março de 1910, p. 1.

${ }^{125}$ Folha do Norte. Belém, 7 de dezembro de 1898, p. 2.

${ }^{126}$ Folha do Norte. Belém, 29 de dezembro de 1898, p. 1.

${ }^{127}$ Folha do Norte. Belém, 27 de janeiro de 1899, p. 1.

${ }^{128}$ Folha do Norte. Belém, 3 de março de 1898, p. 1.
} 
Essas distrações que se gozavam nos “centros mais importantes do ultramar" e que, segundo o articulista, passavam a fazer parte da vida urbana de Belém eram o "ciclismo”, descrito como um "gênero de esporte elegante", praticado sobretudo aos domingos e feriados nas estradas e praças da cidade. Nesses dias, nas palavras de Álvares da Costa, as ruas se viam como que "invadidas e cruzadas por essas luzentas máquinas". Além disso, festas como a "batalha das flores”, os "bailes infantis”, as "recepções do Club Universal”, com a introdução do "aristocrático cotillon”, os "torneios de bilhar do Sport Club” e os "saraus", promovidos por várias associações, expressavam a vida urbana de uma cidade que, na visão das elites, civiliza-se inclusive a partir das distrações de sua população. ${ }^{129}$

Percebe-se que o discurso em torno de práticas como a jogatina, que é uma oposição às diversões elegantes das elites, é bastante moralizador. Afirmava-se claramente ser o jogo como "um escárnio ao progresso e à moralidade". ${ }^{130}$ As casas onde se davam jogos como os de cartas, roletas ou bilhar eram lugares onde se concentravam pessoas nem sempre com ocupação fixa. Na ótica republicana da civilização, esses eram espaços perigosos e, portanto, alvo constante das autoridades paraenses.

A imprensa também mostrava para seu público as visitas e apreensões que a policia fazia nesses estabelecimentos. Apesar da vigilância, a prática da jogatina, que era fonte de renda para muita gente, mas também de diversão, se mantinha. Às vezes, em pequenos grupos de pessoas, como em 1910, quando alguns homens foram presos por estarem “jogando dados". ${ }^{131}$ Noutras ocasiões, em grupos maiores e mais estruturados, como um cassino doméstico, com o qual a polícia se deparou em 1900, a partir de uma denúncia de uma casa suspeita na Rua Padre Prudêncio. Na ocasião, foram apreendidos "um pano verde, uma roleta pequena, sacos com fichas e cartões, uma mesa e cadeiras". ${ }^{132}$

O ano de 1916 é marcado por várias intervenções das autoridades nesses espaços, por onde circulava muita gente das classes mais pobres. Bom exemplo disso é a visita que o Dr. Dias Gomes, da “Inspetoria Geral de Profilaxia da Febre Amarela”, fazia em hotéis, casas de pensão, casas de cômodo, estalagens e outras habitações coletivas, além de padarias em

\footnotetext{
${ }^{129}$ Folha do Norte. Belém, 3 de março de 1898, p. 1.

${ }^{130}$ Folha do Norte. Belém, 7 de dezembro de 1898, p. 2.

${ }^{131}$ Folha do Norte. Belém, 7 de janeiro de 1910, p. 1.

${ }^{132}$ Folha do Norte. Belém, 8 de junho de 1916, p. 2.
} 
Belém, a fim de proceder a uma inspeção sanitária nesses estabelecimentos. ${ }^{133}$ A Folha do Norte, que noticiou amplamente essas visitas, e que teve inclusive um repórter, Júlio Lobato, participando dessa campanha de desinfecção, meses depois, anunciava a "Repressão à jogatina”. Segundo publicou, diante da “jogatina desenfreada” estabelecida na capital, a policia resolveu sair em diligência, percorrendo "vários bairros”. Diante dos apetrechos para jogos aprendidos pela policia, percebemos uma maior modalidade desses divertimentos, onde se destacavam o “jaburu, bacaral, loto, bicho rápido, pipo,", bem como uma sofisticação de objetos usados para tal. Nessa ocasião, além da inutilização de vários “aparelhos de jogo”, foram aprendidos

"roda 'fichete', pano verde numerado, (...) um 'tableau', uma roleta, vários aparelhos destinados à jogatina da loto, grande quantidade de ficha, aparelhos destinados ao jogo do bicho rápido". ${ }^{134}$

Com todas essas opções de divertimentos, que funcionavam exatamente com apostas em dinheiro, não resta dúvida de que os seringueiros eram um alvo fácil e, sobretudo, muito atraente.

Além das diversões e do envolvimento em bebedeiras e comilanças exageradas, o consumo de produtos que dessem status social também fazia parte das experiências dos seringueiros na cidade. Circulando e consumindo pelas ruas de Belém, muitos seringueiros nada tinham de andrajosos, como quase sempre se imagina a sua figura, quando sertanejos, associada aos períodos da seca, ou mesmo no seu trabalho cotidiano na floresta. Em fevereiro de 1899, o seringueiro Abel Cristiano Pontes, por volta de 11 horas da manhã, resolve parar no Hotel "Duas nações” a fim de almoçar. Ao entrar, dependurando seu paletó “num cabide”, teve o mesmo roubado. ${ }^{135}$ Foi do "bolso do paletó" do seringueiro Paulo Nogueira que uma cigana, fazendo uso de um tipo de "narcótico” para o manter desacordado, retirou uma razoável

\footnotetext{
${ }^{133}$ Essas visitas foram publicadas diariamente na Folha do Norte, entre os dias 24 de março de 1916 até o dia 4 de abril de 1916, sempre com o título "A Higiene na Cidade". No dia 17 de junho de 1916, publica-se a parte referente às padarias intitulada "Visita sanitárias as padarias de Belém". Por fim o repórter Júlio Lobato publica-as conjuntamente, nesse mesmo ano de 1916 em um livro. Ver: LOBATO, Júlio. Notas de um repórter: A vida de um repórter, reportagens nos hotéis e padarias de Belém. Belém Typ. F. Lopes, 1916.

${ }^{134}$ Folha do Norte. Belém, 7 de junho de 1916, p. 2.

${ }^{135}$ Folha do Norte. Belém, 22 de fevereiro de 1899, p. 2.
} 
quantia de dinheiro. ${ }^{136}$ Também com “colete” e um "relógio de ouro com corrente” é que se encontrava um seringueiro, quando teve que pagar, justamente com seu precioso relógio, uma noitada de divertimentos, depois de perder todo o seu dinheiro na taberna de um espanhol. ${ }^{137}$

Aliás, nesse contexto, os relógios aparecem como um sinônimo de distinção social. $\mathrm{O}$ seringueiro João Liberalino, que no final de janeiro de 1899, havia chegado do Rio Javary, queixou-se ao subprefeito do $4^{\circ}$ distrito de que “indo fazer umas compras na loja Noiva”, que ficava na rua Santo Antonio, venderam-lhe por um preço exorbitante um "pequeno relógio de ouro e corrente por 500\$000". Ao ponderar com os donos da loja sobre o preço do produto, os mesmos não quiseram atendê-lo. ${ }^{138}$

Para se ter uma idéia da exorbitância do preço, tomamos como referência um outro atrito envolvendo um relógio, nesse mesmo ano de 1899. Na ocasião, comparecia à Chefatura de Polícia a pernambucana Virgínia Cabral. A mulher contou que estava em seu quarto numa casa de cômodos, quando passou "pelo corredor da casa" um "vendedor estrangeiro" de jóias, que vendeu a um homem que estava com ela um relógio por "cento e cinqüenta mil réis”. Posteriormente, o vendedor considerando o preço inferior, passou a cobrá-lo de Virgínia, que, por esse motivo, queixava-se à polícia. ${ }^{139}$ Assim, percebe-se o quanto o relógio de João Liberalino havia custado caro. Também, em outra queixa policial movida contra Álvaro Ferreira de Aragão, que era estivador, constava o furto de "uma corrente de ouro de um relógio" do seringueiro cearense Ângelo de Barros. Na verdade, esse caso, que não foge à regra de outros, chama atenção pelo número de envolvidos, cinco pessoas, que aparecem a testemunhar o que sabiam do caso e a indicar o suspeito, revelando a importância que o roubo do tal relógio teve entre esse grupo de conhecidos pobres. ${ }^{140}$

\footnotetext{
${ }^{136}$ Folha do Norte. Belém, 10 de fevereiro de 1910, p. 1. Esse mesmo episódio também é narrado por Sarges, ao falar dos grupos populares na cidade de Belém. SARGES, Maria de Nazaré. "Os populares no 'fim de festa': a participação de mulheres nos conflitos de rua em Belém (1910/1912)". Cadernos do Centro de Filosofia e Ciências Humanas, vol. 12, nos 1-2 (janeiro-dezembro 1993), p. 59.

${ }^{137}$ Folha do Norte. Belém, 14 de fevereiro de 1910, p. 1.

${ }^{138}$ Folha do Norte. Belém, 26 de janeiro de 1899, p. 2.

${ }^{139}$ APEP - Chefatura de Policia - Autos Crimes 1899 (jan-jun) - Auto de Perguntas a Virgínia Cabral -15 de julho de 1899.

${ }^{140}$ APEP - Chefatura de Policia - Autos Crimes 1906 (fev-jun) - Auto de Diligências Policiais procedidas a acerca dos crimes de furto e ferimentos dos quais foi autor Álvaro Ferreira de Aragão também conhecido por Paulo Muniz.
} 
Mas na cidade de Belém, os seringueiros não foram tão somente vítimas das espertezas de vigaristas. Há situações em que eles também se aproveitavam da boa fé de alguns de seus contratantes Assim, em algumas vezes, os seringueiros firmavam contrato para ir trabalhar em um seringal, desistindo em seguida, mesmo quando já tinham até recebido um adiantamento em dinheiro. Em 1899, foi o que aconteceu com Mariano José Amorim, contratante estabelecido em Tefé (Amazonas), que tinha a seu serviço, segundo a Folha do Norte, “numeroso pessoal”, empregado na extração da goma elástica. Indo até o Hotel Portugal, em busca de trabalhadores, contratou dois seringueiros "vindos do Purus", que declararam estar “à procura de um patrão”, e se interessavam pelo contrato com Amorim, desde que ele lhes pagasse as despesas com o hotel, o que foi aceito. No dia de seguirem para Tefé, Amorim foi ao hotel e soube que logo após o contrato, os seringueiros haviam se mudado do estabelecimento. ${ }^{141}$ Caso semelhante é de Antonio Bevilaqua, que “adiantou 200\$000”, a um seringueiro por ele contratado, que não queria mais seguir viagem para o rio Madeira, sendo o caso levado à polícia, e o contrato liquidado. ${ }^{142}$

Esses episódios esporádicos envolvendo seringueiros, mesmo que, em número, não sejam significativos, servem para apontar outras possibilidades das experiências sociais dos seringueiros, que aqui aparecem aprendendo a consumir, a se divertir e a sobreviver numa cidade grande. Boa parte dos migrantes cearenses que chegavam a Belém saíam de pequenas cidades ou localidades do sertão, além de se declararem lavradores, indicando-nos a figura de homens que, a princípio, tinham pouco contato com o que os grupos elitizados chamavam de civilização. Entretanto, suas vivências em Belém são bastante instigantes, pelo mundo urbano que lhes é revelado e igualmente pelos significados que esses seringueiros davam à vida na cidade. Encontrar familiares, ter contatos amorosos com mulheres, comer e beber em abundância, divertir-se, fazer compras em lojas, sem dúvida alguma, são alguns dos elementos que revelam muito do que era se viver na cidade para esses visitantes que periodicamente aportavam em Belém. Vale lembrar que, além dos seringueiros, outros grupos de migrantes circulavam pela cidade.

\footnotetext{
${ }^{141}$ Folha do Norte. Belém, 10 de fevereiro de 1899, p. 2.

${ }^{142}$ Folha do Norte. Belém, 12 de fevereiro de 1899, p. 2.
} 


\section{Cenas da vida cearense na capital do Pará}

Em 1897, o Dr. José Ferreira Teixeira, Chefe de Segurança Pública, apresentava ao governador do Estado do Pará, Paes de Carvalho, um relatório referente àquele ano. $\mathrm{Na}$ ocasião, explicava o papel da polícia como uma instituição que "previne ou faz cessar toda perturbação na economia da sociedade constituída e organizada”. Ao mesmo tempo, destacava o fato de que as ações da polícia, para serem eficazes, dependiam de um bom “sistema penitenciário", da "existência de asilos” onde fossem

"recolhidos os mendigos (...) e os inválidos para receberem o benefício de uma caridade bem entendida" e igualmente, "escolas correcionais para a infância culposa e vadia";

por isso, afirmava que era "complexa” a reforma das instituições policiais. ${ }^{143}$ Pela visão do Dr. José Teixeira, fica evidente seu ideário civilizatório, em que a ordem na capital paraense seria assegurada não somente pelas ações da polícia, mas igualmente por outras ações de controle social, a partir de instituições como os asilos e as escolas criados para esse fim. ${ }^{144} \mathrm{Na}$ cidade de Belém, a preocupação com mendigos e vadios circulando pela rua será uma constante.

Nesse contexto, o Chefe da Segurança Pública não deixou de dedicar um item de seu relatório à relação que existia entre o que chamou de "criminalidade e os fatos econômicos". Acreditava que apesar das dificuldades "de medir tal influência”, a "freqüência dos crimes" estava associada a problemas como a "abundância ou carestia dos comestíveis”, às “dificuldades para encontrar trabalho" e às “condições econômicas do país”. Diante dessas premissas, Belém se apresentava, segundo o Dr. José Teixeira, como um espaço propício para ações mais enérgicas da policia e de outras instituições, correcionais uma vez que já

\footnotetext{
${ }^{143}$ Conselho Estadual de Cultura - Biblioteca "Orlando Bitar". Relatório apresentado ao Sr. Dr. Governador do Estado pelo Chefe de Segurança Pública Dr. José Ferreira Teixeira em 30 de novembro de 1911. Belém: Diário Oficial, 1898, pp. 4-5.

${ }^{144}$ Para uma compreensão mais ampla dessa questão ler por exemplo: FOUCAULT, Michel. Vigiar e punir: nascimento das prisões. Petrópolis: Vozes, 1987; CUNHA, Maria Clementina Pereira. O espelho do mundo; de acordo com Sarges em 1899, deu-se início à construção do asilo da mendicidade, que teve seus trabalhos concluídos em 1901. SARGES, Maria de Nazaré. Belém: Riquezas produzindo a Belle-Époque (1870-1912), p. 126.
} 
experimentava com intensidade esses vários problemas. ${ }^{145}$ Além disso, o Chefe de Segurança queixava-se de que não se punia com rigor a vagabundagem que crescia na cidade.

“O preço das mercadorias em geral está triplicado. A vida já é difícil para todos e especialmente para os pobres. A lavoura em nosso Estado é pequena e não produz o suficientemente para satisfazer as necessidades da população sempre crescente. (...). Uma considerável parte da população de Belém emprega-se de verão na extração da goma elástica e de inverno passa a vida ociosa e de vagabundagem nas ruas da capital (...). E os vagabundos enchem a ruas de Belém, formando um exército, donde saem a maior parte dos criminosos contra as pessoas e a propriedade!". ${ }^{146}$

Vista como uma "praga”, como um “cancro", que corrompia o "organismo social”, a vagabundagem, segundo o Dr. José Teixeira, deveria a todo custo ser combatida pelo trabalho, sobretudo na agricultura, através, inclusive, da formação de "colônias agrícolas correcionais”. Por esse pensamento, a ocupação na agricultura resolveria ao mesmo tempo dois problemas sérios para a tranqüilidade da capital, a questão do abastecimento e a retirada de grupos considerados vadios das ruas de Belém. ${ }^{147}$ Dentre esses, o Chefe de Segurança fazia referência a vadios de uma maneira geral, e também aos capoeiras. ${ }^{148}$ Apesar das pretensões

${ }^{145}$ Sobre o papel da policia na construção da ordem urbana ver: BRETAS, Marcos Luiz. Ordem na cidade: o exercício cotidiano da autoridade policial no Rio de Janeiro, 1907-1930. Rio de Janeiro: Rocco, 1997. SANTOS, Marco Antonio Cabral dos. "Polícia: homens da lei na metrópole do café". In: DEL PRIORE, Mary (org.). Revisão do Paraíso, pp. 277-300.

${ }^{146}$ Conselho Estadual de Cultura - Biblioteca "Orlando Bitar". Relatório apresentado ao Sr. Dr. Governador do Estado pelo Chefe de Segurança Pública Dr. José Ferreira Teixeira, em 30 de novembro de 1911. Belém: Diário Oficial, 1898, pp. 37-38.

${ }^{147}$ Essa não foi uma compreensão apenas do Chefe de Segurança Pública do Pará, Maria Stela Bresciani, a partir da leitura de vários literatos a exemplo de Victor Hugo, Baudelaire, Zola e Eugène Sue, aponta preocupações semelhantes em Londres e Paris no século XIX, onde a multidão nas ruas é vista, segundo a autora diante de "espanto, indignação, fascínio, medo". BRESCIANI, Maria Stela. Londres e Paris no século XIX: o espetáculo da pobreza, p. 9.

${ }^{148}$ Sobre capoeira em Belém, ver: SALLES, Vicente. "A defesa pessoal de negro. A capoeira no Pará". In: SALLES, Vicente. O negro na formação da sociedade paraense. Belém: Paka-Tatu, 2004, pp. 113-141. DE CAMPOS, Ribeiro (1905-1995). "Ginastas da valentia". In: Gostosa Belém de outrora (reedição fac-símile). Belém: SECULT, 2005, pp. 51-55. LEAL, Luiz Augusto Pinheiro. Amolando as gambias: significados e práticas da capoeira em Belém (1840-1853). Monografia de conclusão de curso (História). Universidade Federal do Pará, 1997. 
civilizatórias das autoridades paraenses, esses grupos continuavam a circular pelas ruas da cidade, inventando variadas formas de sobrevivência. ${ }^{149}$

Além da presença de tais grupos em Belém, o crescimento populacional provocado pelo "entusiasmo, em busca de fortuna", que trazia para a capital uma "corrente de imigrantes estrangeiros e nacionais de todos os Estados, e em maior escala do Ceará”, era apontado pelo responsável da Cadeia de São José, em relatório enviado ao Chefe de Segurança Pública, como um grave problema para o "crescimento do número de criminosos”, que tornava a cadeia deficiente tanto em segurança, como em acomodação para os detentos, uma vez que as suas instalações não admitiam mais de "150 presos". ${ }^{150}$ Os principais motivos de detenção apontados nesse momento eram: embriaguez, desordens, roubos, ofensas à moral pública, vagabundagem, gatunagem, usos de armas proibidas e exercer profissão ilícita. Vale lembrar que os maiores índices de desordens e embriaguez se concentravam entre os meses de janeiro e fevereiro, justamente o tempo em que muitos seringueiros saíam dos seringais para um período de "férias" na capital. ${ }^{151}$

Além dos delitos cometidos na capital, na cadeia de São José, também ficavam detidos muitos presos que vinham do interior do estado, notadamente, de áreas de seringais. É o que se pode perceber através das notícias de uma fuga de presos dessa cadeia. Em setembro de 1898, a Folha do Norte dava destaque para a evasão dos presos da “cela $n^{\circ} 11$ ”, armados das facas que usavam nos seus trabalhos de sapateiro, esses detentos atacaram e renderam a guarda por volta das uma e meia da madrugada e evadiram-se, deixando para trás "grandes manchas de sangue", resultado da luta entre "praças e fugitivos". 152

${ }^{149}$ Conselho Estadual de Cultura - Biblioteca "Orlando Bitar". Relatório apresentado ao Sr. Dr. Governador do Estado pelo Chefe de Segurança Pública Dr. José Ferreira Teixeira, em 30 de novembro de 1911. Belém: Diário Oficial, 1898, p. 38.

150 "Relatório de todas as ocorrências havidas na Cadeia de São José, no decurso de $1^{\circ}$ de janeiro a 30 de setembro do ano de 1897". In: Relatório apresentado ao Sr. Dr. Governador do Estado pelo Chefe de Segurança Pública Dr. José Ferreira Teixeira, em 30 de novembro de 1911. Belém: Diário Oficial, 1898.

151 "Secretaria de Segurança Pública do Pará - Mapa demonstrativo das detenções efetuadas pelas autoridades de segurança no período de $1^{\circ}$ de janeiro a 30 de setembro de 1897". In: Relatório apresentado ao Sr. Dr. Governador do Estado pelo Chefe de Segurança Pública Dr. José Ferreira Teixeira, em 30 de novembro de 1911. Belém: Diário Oficial, 1898.

${ }^{152}$ Folha do Norte. Belém, 4 de setembro de 1898, p. 1. 
O que chama atenção para esse caso é que dos 10 detentos que fugiram, 8 eram cearenses, vindos para a capital em função de homicídios cometidos em conflitos em áreas de seringais como Breves, Melgaço, Muaná, Afuá, Curralinho, ou áreas agrícolas, como Viseu. A fim de facilitar na captura dos evadidos, a Folha do Norte dava a seus leitores uma pequena descrição de cada um dos presos, que em sua maioria eram jovens com idade entre 19 e 21 anos (apenas dois tinham 48 e 32 anos), indicando suas características físicas, a naturalidade, o crime cometido, o tempo da pena que cumpriam e às vezes até o tipo de comportamento que o preso tinha na cadeia. Essa descrição, certamente, deixou a população assustada, diante de tantos homens apresentados na imprensa como perigosos, soltos e acuados pela cidade. Logo, correu a notícia de que alguns desses presos teriam sido vistos na "travessa do Jurunas", ou num "lamaçal que havia no bairro da Pratinha”, o que a polícia pretendia investigar, fazendo diligência em um subúrbio da capital. Considerando-se que não era possível saber em quais circunstâncias os fugitivos haviam cometido seus crimes nessas áreas dos seringais, que, como vimos anteriormente, eram espaços que, por sua natureza, acabavam por criar "leis" e ordenamentos próprios, a imprensa acabava por expor tão somente a figura dos cearenses como homens violentos, que resolviam suas contendas com a morte de seu opositor. ${ }^{153}$

A listagem dos presos era a seguinte ${ }^{154}$ :

1) João Anselmo de Queiroz, 48 anos, casado, natural do Ceará “alto cheio de corpo, usando cavanhaque, branco, cabelos e olhos pretos e mãos de tamanho regular". Condenado a 30 anos por homicídio, por processo em Viseu;

2) Misael Francisco de Lima, 19 anos, solteiro, cearense, “estatura regular, lavrador, analfabeto, cabelos pretos lisos, olhos da mesma cor, pálido, pés e mãos regulares, sem barba, rosto crivado de espinhas”, vindo de Breves, por homicídio cometido em Melgaço;

3) Vicente Timóteo da Silva, 32 anos, solteiro, cearense, lavrador, não sabendo ler nem escrever, caboclo, cabelos e olhos pretos, pouca barba, estatura regular, pés e mãos de tamanho comum, vindo de Muaná, por homicídio;

\footnotetext{
${ }^{153}$ Folha do Norte. Belém 4 de setembro de 1898, p. 1.

${ }^{154}$ Folha do Norte. Belém, 4 de setembro de 1898, p.1.
} 
4) Vicente Felix da Silva, 20 anos, cearense, lavrador, acaboclado, de cor pálida, pouca barba, cabelos baixos, corpo e altura regulares, vindo de Breves, condenado a 11 anos por homicídio;

5) Raymundo Antonio dos Anjos Morares, 35 anos, solteiro, paraense, seringueiro, mulato, cabelos crespos e pretos e olhos desta cor, não sabendo ler nem escrever;

6) Francisco Chagas de Mello, 21 anos, solteiro, cearense, trabalhador, analfabeto, moreno, barbado, cabelos pretos, estatura regular, condenado por homicídio a 7 anos;

7) Eugenio Borges dos Santos, 21 anos, solteiro, maranhense da Comarca de Guimarães, lavrador, não sabendo ler nem escrever, pardo, cabelos e olhos pretos, estatura alta, vindo de Viseu, cumpria pena de 6 anos;

8) Francisco de Souza Lima, 21 anos, cearense, solteiro, sem saber ler nem escrever, cabelos pretos e crespos, pouca barba, estatura mediana vindo de Afuá, condenado a 7 anos e 6 meses por crime de homicídio;

9) Francisco Rodrigues de Mattos, 19 anos, cearense, solteiro, lavrador, analfabeto, cabelos e olhos pretos, pouca barba, estatura regular pés e mãos de tamanho comum vindo de Curralinho, comarca de Muaná, cumprindo pena de 17 anos e 6 meses por crime de homicídio;

10) Belarmino Ferreira Lima, acusado de ter assassinado um homem por "frívolos motivos" e depois atear fogo sobre o cadáver (já capturado não aparecia a sua descrição).

Sobreviver em Belém, entretanto, também era algo muito complicado para a população mais pobre. A carestia e a falta de ocupação permanente, não raro, levavam à mendicância. $\mathrm{E}$ o pedir esmolas era tomado como uma forma de não trabalho mas, ao mesmo tempo, e apesar dos olhares reprovadores diante dessa prática, não era uma atividade considerada criminosa.

Vista numa fronteira muito próxima da vadiagem, entretanto, a mendicância sempre foi alvo de grandes críticas na imprensa. ${ }^{155}$ Os cearenses, nesse contexto, iam buscando se adequar às exigências da vida urbana. A história de Francisco Pinto de Mesquita Magalhães, cearense, envolvido em uma acusação de roubo em 1899, é modelar nesse sentido.

\footnotetext{
${ }^{155}$ Tomando Londres e Paris como exemplo, portanto uma realidade diferente da aqui experimentada, Bresciani, chama atenção para algo também vivenciado em Belém, o fato de que "o incômodo causado pelos mendigos e pelos vagabundos isoladamente só se vê suplantado pelo medo deles em multidão”. BRESCIANI, Maria Stela. Londres e Paris no século XIX: o espetáculo da pobreza, p. 39.
} 
Em busca de sua sobrevivência, ele vive num misto de vadiagem e mendicância, além da feitura de pequenos trabalhos. Morando em Mosqueiro, em “casa de um seu patrício”, que lhe fornecia "alimentação", Francisco, que não sabia ler nem escrever, não tinha também uma ocupação fixa, vivendo de trabalhos esporádicos entre Belém, a Vila do Mosqueiro e a Vila do Pinheiro. Dentre suas atividades, estavam as de "desembarcar no porto uma saca de gelo", ou fazer alguns fretes "quando por ventura os achava”, o que lhe rendia algo em torno de "dois mil réis em pagamento", que não davam para grande coisa (note-se como vimos anteriormente que em 1898, um quilo de carne custava entre 1300 e 2000 réis) mas que lhe permitia, entre outras atividades, freqüentar uma taberna para “comprar um charuto”. Além dessas ocupações, Francisco já tinha sido “empregado do circo Providência”, emprego que havia deixado por não poder "resistir ao serviço por ser homem doente", conforme afirmou em seu depoimento. Nos momentos em que não conseguia trabalho, e quando the faltavam "inteiramente os recursos", Francisco declarou à autoridade policial que pedia "mesmo algumas esmolas". 156

Por ocasião da seca de 1900, o cearense Antonio José de Oliveira, hospedado com a mãe e um irmão no Hotel Nacional, na Travessa Fructuoso Guimarães, e que havia “chegado há pouco do Ceará com destino aos seringais do Purus”, buscava meios de sobrevivência por meio da mendicância. Acompanhado de um “irmão pequeno”, chamado Cícero, de 6 anos de idade, que se fazia passar por “mudo", percorriam as ruas de Belém, “esmolando a caridade pública”. A farsa foi descoberta, possivelmente pelo fato de que ao passar por uma loja com brinquedos, o menino teria dito “- Olha mano como são bonitos”. Na ocasião, a Folha do Norte criticava a atitude de Antonio José, chamando-o de "patife", em função da “exploração" a que expunha o seu irmão menor. ${ }^{157}$

Em ambos os casos, vemos uma fronteira muito próxima entre pobreza, mendicância e vadiagem. Isso deixava as autoridades atentas, além de que a própria imprensa agia como um canal importante para demonstrar seu desprezo e seu medo diante de tantos desocupados, engendrando sobrevivência em uma cidade que pretendia ser civilizada.

Entre os próprios migrantes, havia uma disputa por espaços de sobrevivência na capital paraense. Conflitos, que aparentemente não têm um motivo sério, acabam por revelar um

\footnotetext{
${ }^{156}$ APEP - Chefatura de Policia - Autos Crimes 1899 (jul-dez). Auto de perguntas feitas a Francisco Pinto de Mesquita Magalhães.

${ }^{157}$ Folha do Norte. Belém, 18 de agosto de 1900, p. 2.
} 
cotidiano construído por muitas lutas, em busca de se demarcar um espaço na cidade. Em setembro 1904, o cearense Honório Rosa de Oliveira, um “preto” de 45 anos de idade, se viu envolvido em um grave conflito em que ele foi acusado de ter esfaqueado Joaquim [?], paraense de 22 anos de idade, que era "marítimo", nas proximidades de um "botequim no mercado de ferro".

O cenário da contenda é o centro da cidade, no Ver-o-Peso, onde o acusado afirma que fazia "sua comida”, em companhia de outros homens, entre estes, a vítima da facada, que também teria participado da "referida refeição". Nesse espaço em que transitava muita gente, ponto de partida e chegada na cidade, se misturavam às atividades de trabalho próprias de um porto, jogatina, bebedeiras, e muitos homens que, sem ocupação fixa, circulavam por essa área fazendo fretes, como era o caso de Francisco Pinto Mesquita, ou praticando alguns delitos, como embriaguez, seguida de desordens.

$\mathrm{Na}$ disputa por espaço, o cearense Honório e o paraense Joaquim acabam se desentendo. Em seu depoimento, Honório assegurou que ambos "se achavam embriagados". Daí, para que surgissem as agressões, que eles registraram como injúrias, "bofetadas”, "pancadas com uma bengalinha” e por fim a facada, foi só um passo. Joaquim afirmara, entretanto, que conversava com um "seu companheiro”, quando apareceu inesperadamente

"o conhecido vagabundo Honório Rosa de Oliveira, conhecido por Cambraia (...) acompanhado de um grupo de meninos". ${ }^{158}$

No depoimento de ambos, as versões são diferentes, ficando em comum apenas o fato de que se conheciam. Cada um, à sua maneira, trabalhava nas imediações do Ver-o-Peso, buscando ali meios de sobreviver.

Por trás da contenda estabelecida entre esses dois homens e de suas versões sobre o fato, há indícios de uma vida bastante movimentada nas imediações do porto, que sugerem perguntas como: Por que Joaquim, que era marítimo, fizera sua refeição junto com um grupo de vagabundos, ali mesmo no porto? Por que Honório teria ido tomar satisfações com Joaquim? Quem era e de onde vieram os meninos que acompanhavam Honório? Na verdade, o que fica desses conflitos é a imagem de uma sobrevivência muita árdua na capital paraense,

\footnotetext{
158 APEP - Chefatura de Policia - Autos Crimes 1904 (jul-dez). Auto de diligências policiais procedida acerca do ferimento praticado na pessoa de Joaquim Gonçalves Garcia de que é autor Honório Rosa de Oliveira.
} 
em que, muitas vezes em nome daquilo em que se acreditava, em nome de um espaço nessa cidade, se tolerava muito pouco uns dos outros.

Nesses embates por sobrevivência, a disputa em torno do espólio da cearense Francisca Borges de Lima também é elucidativa e envolve inclusive a família dela, que ficara no Ceará. Em 1906, Francisca morava em Belém, no Hotel Beira Mar, com outra cearense, Raymunda Rosa. Tendo adoecido, foi morar na casa da alagoana Josepha de Assis Braga, onde veio a falecer. Essa questão veio à tona pelo fato de que a família de Francisca, no Ceará, ao saber de seu falecimento, pedia, através de um procurador, que lhe fosse enviado seu espólio. ${ }^{159}$

Nos trâmites para tal processo, foram interrogadas as duas mulheres. Josepha declarou à policia que Raimunda "ficou com a bagagem da falecida" e que entre os objetos deixados, faltavam "12 camisas de malhas, sete anéis e uma toalha de banho”. Além de que, já no dia do falecimento de Francisca, Raimunda "começou a usar roupas” do uso de Francisca e de a terem visto "também com anéis". Dessas acusações, Raimunda alegou que "vestiu de Francisca uma roupa para acompanhar ao cemitério, por não ter roupa descente para esse fim”, tendo depois guardado a referida roupa. ${ }^{160}$

O espólio de Francisca, que não passava de objetos de seu uso pessoal, acabou por chamar a atenção e por ser foco de interesse, não só das amigas que a acompanharam nos seus últimos dias, mas, sobretudo, de sua família cearense. Ao mesmo tempo, vemos que, para uma mulher que vivia só em Belém, em um quarto de hotel, Francisca, que não sabemos em que trabalhava, possuía muitas coisas que tanto faziam parte da sua toillete pessoal, como uma grande variedade de roupas, que também lhe permitiam viver com certo conforto, num quarto de hotel. Sua família, mesmo estando no Ceará, de alguma maneira, sabia o que se passava com ela em Belém, inclusive sabia dos bens que ela possuía; do contrário, não teria acionado a Justiça do Ceará a fim de tomar posse de seus bens. Assim, através da Secretaria dos Negócios da Justiça do Ceará, solicita-se à polícia paraense que entregue a um procurador o espólio da mesma, que seria usufruído em Fortaleza por Joana Borges de Lima, “única herdeira da falecida”. O espólio de Francisca era o que segue:

“02 redes, 01 mosquiteiro, 21 saias de diversas fazendas, 18 casacos de diversas fazendas, 05 colchas de cores, 07 anáguas, 16 camisas brancas e de cores, 06 camisões, 01 chapéu de sol,

\footnotetext{
159 APEP - Chefatura de Policia - Autos Crimes 1906 (fev-jun). Auto de diligencias policiais procedidas acerca do espólio de Francisca Borges de Lima.

160 APEP - Chefatura de Policia - Autos Crimes 1906 (fev-jun). Auto de diligencias policiais procedidas acerca do espólio de Francisca Borges de Lima.
} 
06 toalhas de feltro, 01 corpinho, 03 fronhas, 01 espelho pequeno, 07 colarinhos, 03 lenços de seda, 06 pares de meia, 03 pares de botinas, 03 quadros com retratos, 01 relógio prata dourada para senhoras, 01 corrente de ouro, 01 maço de diversos papéis, 01 dedal de prata, 01 cordão de ouro com cinco tetéias, 12 anéis de diferentes feitios, 1 tesoura para unhas, 1 par de ligas para meias, uma mala menor contendo 01 urinol, 01 escarradeira, 01 cabide madeira, 01 bacia esmaltada". ${ }^{161}$

Mas se o espólio da cearense Francisca era ponto de grandes interesses, ter em casa tantos objetos de uso pessoal, como ela possuía, não era a regra comum. Os migrantes que viviam em Belém sobreviviam com dificuldades, muitas vezes na indigência, e isto era algo que muito incomodava às autoridades locais, a ponto de muitos migrantes serem mandados de volta para o Ceará, ou mesmo solicitarem o seu retorno até em tempos de seca, diante das péssimas condições de vida em Belém. Para se ter uma idéia disso, em 1889, ao mesmo tempo em que a Província do Pará recebia grande número de migrantes saídos do sertão cearense, vemos também grupos de pessoas voltando para a Província do Ceará, pelo fato de serem consideradas “indigentes cearenses”, que voltavam por "não poderem continuar aqui pelo seu mau estado de saúde”. ${ }^{162}$ Através do quadro abaixo, com passagens solicitadas nos meses de junho, julho, setembro, outubro e novembro de 1889, é possível visualizarmos um pouco do caminho de volta para o Ceará.

Retorno para o Ceará $(1889)^{163}$

\begin{tabular}{|l|l|}
\hline \multicolumn{1}{|c|}{ Número de pessoas } & \multicolumn{1}{c|}{ Motivos do retorno para o Ceará } \\
\hline 14 soldados e 1 aprendiz de marinheiro & "se acham sofrendo de beribéri” \\
\hline 1 soldado & “conclusão de tempo" \\
\hline $\begin{array}{l}15 \text { pessoas, e duas "listas” sem o número de } \\
\text { pessoas. }\end{array}$ & $\begin{array}{l}\text { “indigentes cearenses que não podem } \\
\text { continuar aqui pelo seu mau estado de saúde” }\end{array}$ \\
\hline 229 pessoas e 6 "listas” sem o número de pessoas & não apresentam o motivo do retorno. \\
\hline
\end{tabular}

161 APEP - Chefatura de Policia - Autos Crimes 1906 (fev-jun). Auto de diligencias policiais procedidas acerca do espólio de Francisca Borges de Lima.

${ }^{162}$ APEP - Secretária da Presidência da Província Códice 1963. Minutas de Ofício da Presidência às Companhias de Navegação 1/6/1889 a 15/11/1889. Ofícios das Companhias de Navegação - $2^{\circ}$ semestre de 1889.

${ }^{163}$ APEP - Secretária da Presidência da Província Códice 1963. Minutas de Ofício da Presidência às Companhias de Navegação 1/6/1889 a 15/11/1889. Ofícios das Companhias de Navegação - $2^{\circ}$ semestre de 1889. 
Se a indigência e o mau estado de saúde poderiam levar ao retorno de muitos migrantes ao Ceará, não menos transtornos causava a mendicância, sendo alvo constante da imprensa. Em 1910, A Folha do Norte reclamava, por exemplo, que Belém era “uma vasta colméia de malandrins e mendigos”, que abordavam os transeuntes “nas vias públicas, à porta dos cafés, na paradas de bonde" e nas casas a pedir esmolas. Esses pedintes eram vistos como uma "vadiice parasitária", que era fruto da "falha de vergonha e de policiamento". Para o articulista tais mendigos deveriam ser "varridos das vias públicas" e colocados em "estabelecimentos" onde se aplicasse a "disciplina" e se exercesse a "coerção". ${ }^{164}$ Com um olhar higienista e civilizador, o articulista, com habilidade, consegue representar os tipos que andavam pelas ruas a implorar a caridade pública. Como se fossem personagens de um romance, por essa descrição, é possível imaginá-los pelas ruas de Belém, a cometer pequenas trapaças e recitarem mentiras em busca de meios para continuarem vivendo:

“Ora, é uma viúva, óssea e seca, embicada num chalé, abatida numa enigmática prostração, de choros, e possuidora duma clamorona ninhada de filhos, que nos aborda na rua ou vai ter à nossa casa, farejando a nossa liberalidade; outras vezes, é um tipo apressado a quem morrera a mãe e, como a sua situação financeira é precária, vem recorrer à nossa caridade para fazerlhe o enterro; outras é um homem inutilizado para o trabalho por um a acidente qualquer, ou um outro que precisa retirar-se para fora a fim de tratar a saúde e logo em seguida são as mulheres despidas de escrúpulos religiosos, sobraçando imagens com as quais exploram a ingenuidade dos católicos". ${ }^{165}$

Em 1915, por ocasião da chegada de muitos migrantes na cidade, e apesar das constantes ações em prol dos flagelados pela seca, levadas adiante pela "Assistência aos flagelados da seca”, a situação era muito semelhante, como indicam as palavras da imprensa local, que pedia que as autoridades retirassem das ruas esse "vezo prejudicial”. ${ }^{166} \mathrm{O}$ jornal A Tarde, que pedia essas providências, alegava que os mendigos "sentados às soleiras das portas ou orlando os passeios" eram como uma "vegetação macabra". ${ }^{167}$ A solução para esse “espetáculo" seria a mesma de outros tempos: o policiamento e confinamento dos grupos de indesejados em instituições apropriadas. No início de 1916, o número de pedintes pelas ruas da cidade se mantinha, apesar dos apelos da imprensa contra esse grupo.

\footnotetext{
${ }^{164}$ Folha do Norte. Belém, 21 de maio de 1910, p. 1.

${ }^{165}$ Folha do Norte. Belém, 21 de maio de 1910, p. 1.

${ }^{166}$ A Tarde. Belém, 10 de novembro de 1915, p. 1.

${ }^{167}$ A Tarde. Belém, 8 de dezembro de 1915, p. 2.
} 
Tal situação foi inclusive utilizada em uma inusitada promoção da "Cerveja Amazonense", que propunha a seus clientes que não dessem "mais esmolas em dinheiro" aos pobres encontrados no caminho, mas sim uma "cápsula da cerveja Amazonense”, que os mesmo poderiam trocar no "Aurora Bar", à Rua Santo Antonio. Com isso, acreditavam os anunciantes que os apreciadores da bebida não seriam mais importunados com os "sórdidos vinténs azinhavrados, portadores de micróbios”, além do que o consumidor da cerveja não teria que se preocupar com o "dispêndio de dinheiro em esmolas diárias". Por fim, para celebrar tal idéia, fazia como que uma convocação: "Protegei a pobreza com cápsulas da cerveja Amazonense”. 168

Não resta dúvida de que, por mais absurdo que possa parecer a promoção da "cerveja Amazonense", as idéias aqui suscitadas revelam a forma como de uma maneira geral se pensava a pobreza e os grupos de mendigos que andavam por Belém. Estes são vistos como portadores de doenças, como representantes do que mais feio se tinha, a ponto de um articulista do jornal $A$ Tarde, diante dos mendigos nas ruas, afirmar que isto não se tratava apenas de um "caso moral, um caso penal”, mas também de uma "questão estética”, equiparando assim feiúra a pobreza, que não poderia continuar, para "conforto da população". Os grupos de pedintes colocavam em xeque o processo civilizatório empreendido em Belém, expondo às vistas de todos suas contradições. ${ }^{169}$

Mesmo com um caráter ensaístico, as interpretações de Berman, não deixam de ser ponto para reflexão no que se refere às contradições da modernidade. Desse modo, o poema escrito por Baudelaire "Família de olhos", e interpretado por Berman, é exemplar para se pensar a presença de pobres pelas ruas de Belém. O autor lembra que a "a família em farrapos" a circular pelo novo boulevard, descrita por Baudelaire acaba por "se colocar no centro da cena”, na medida embora sendo pedintes “Eles também querem um lugar sob a luz”. ${ }^{170}$ Essa conclusão parece bastante pertinente quando pensamos nos muitos, mendigos, migrantes pobres a exigir um espaço na cidade de Belém Num contexto como esse, os migrantes cearenses que aportavam em Belém também engrossavam as fileiras desses pobres, que nem sempre recebiam auxílios das autoridades.

\footnotetext{
${ }^{168}$ Folha do Norte. Belém, 5 de fevereiro de 1916, p. 4.

${ }^{169}$ Folha do Norte. Belém, 8 de dezembro de 1916, p. 2.

${ }^{170}$ BERMAN, Marshall. Tudo que é sólido desmancha no ar: a aventura da modernidade. São Paulo: Companhia das Letras, 1988, pp. 148.
} 
Em 1915, através de algumas notas denominadas “Natalidade e mortalidade em Belém”, a Folha do Norte trazia aos seus leitores alguns dados sobre falecimentos e nascimentos ocorridos em Belém. De 340 óbitos ocorridos no mês de março, 176 “eram indigentes”. 171 Em julho desse mesmo ano, o número de óbitos era de 333, sendo que desses, 175 eram considerados indigentes. ${ }^{172}$ Em setembro, a Folha do Norte registrava que de 261 óbitos, 136 eram de indigentes. ${ }^{173}$ Embora o jornal não especifique quais eram os critérios para qualificar alguém de indigente e nem tão pouco indique de onde retirou seus dados, essas informações fragmentadas chamam atenção pelo grande número de indigentes e por um alto índice de mortalidade entre crianças. Por outro lado, além do impaludismo, sempre presente nesses dados, uma outra causa de morte era de doenças que se instalavam em ambientes insalubres, mal iluminados, sem ventilação, sem higiene, e em pessoas com deficiência alimentar, a exemplo de moléstias como tuberculose, bronquite, pneumonia, meningite, gastroenterite, lepra, entre outras. ${ }^{174}$

Entre os meses de janeiro e março de 1916, através de uma pequena coluna que esporadicamente saía no jornal A Tarde, intitulada "Sem assistência", e que tratava de pessoas falecidas sem atendimento médico, vemos que, em sua totalidade, tratam-se de migrantes cearenses e de outros estados (Maranhão, Alagoas e Rio Grande do Norte). Embora essas notas sobre falecimentos não fossem diárias, e nem tão pouco o levantamento aqui apresentado seja extensivo, elas nos permitem minimamente perceber a situação desse grupo em Belém. ${ }^{175}$

\footnotetext{
${ }^{171}$ Folha do Norte. Belém, 24 de abril de 1915, p. 1.

${ }^{172}$ Folha do Norte. Belém, 1 de agosto de 1915, p. 2.

${ }^{173}$ Folha do Norte. Belém, 1 de outubro de 1915, p. 3.

${ }^{174}$ A título de exemplo são algumas causa de óbitos: “impaludismo, gastroenterite, infecção intestinal, phymatose pulmonar, tuberculose, pneumonia, bronquite, congestão cerebral, hemorragia cerebral, acesso pernicioso, anquilostomiase, arteriosclerose, lepra, atrepsia, nephrite, uremia, puerpério, sífilis, meningite polinevrite, cirrose, peritonite; mielite, septicemia, desinteira, cachexia, carcinomatose, pleurisia, mal de Brighit, difteria, epitelioma no útero, úlcera no estômago, asistolia, diabatetes, asciteasthenia geral, esincope cardíaca, erisipela, tifo, alcoolismo; lesão traumática, gangrena perfuração do crânio por arma de fogo, hemorragia por ferimento de arma de fogo (ambos suicídios), hemorragia por ferimento de arma branca (assassinato), tosse convulsa, asfixia branca, tétano dos recém-nascidos, diarréia”. Folha do Norte. Belém, 2 de abril de 1915, p. 1.

${ }^{175}$ Dados retirados do jornal A Tarde. Belém, janeiro a março de 1916.
} 


\begin{tabular}{|c|c|c|c|c|c|c|}
\hline Doença & Idade & Cor & Sexo & Origem & $\begin{array}{c}\text { Local onde } \\
\text { morava em Belém }\end{array}$ & Profissão \\
\hline Phimatose pulmonar & 20 & Parda & Fem & $\mathrm{CE}$ & Marco da Légua & Lavadeira \\
\hline Impaludismo & 3 & Preta & Fem & $\mathrm{CE}$ & Marques de Herval & $\begin{array}{l}\text { Pai extrator de } \\
\text { borracha }\end{array}$ \\
\hline Gastroenterite & 9 & Branca & Fem & $\mathrm{CE}$ & Hotel Sulamérica & ? \\
\hline $\begin{array}{l}\text { Arteriosclerose } \\
\text { generalizada }\end{array}$ & 9 & Parda & Fem & CE & Rua da Indústria & ? \\
\hline ? & 6 & Parda & Fem & $\mathrm{RN}$ & $\begin{array}{l}\text { "barraca" Marco } \\
\text { da Légua }\end{array}$ & ? \\
\hline ? & $\begin{array}{c}10 \\
\text { meses }\end{array}$ & Pardo & Masc & MA & $\begin{array}{l}\text { "casebre" à rua } 22 \\
\text { de junho }\end{array}$ & ? \\
\hline Impaludismo & 18 & Branco & Masc & $\mathrm{CE}$ & $\begin{array}{l}\text { Tv. Soares } \\
\text { Carneiro }\end{array}$ & Embarcadiço \\
\hline Pneumonia & 52 & Preto & Masc & AL & Tv. Castelo Branco & Carroceiro \\
\hline Impaludismo & 8 & Pardo & Masc & $\mathrm{CE}$ & 22 de junho & $?$ \\
\hline Infecção intestinal & 31 & Branca & Fem & $\mathrm{CE}$ & 14 de abril & Lavadeira \\
\hline Phimatose pulmonar & ? & Pardo & Masc & $\mathrm{CE}$ & Marco da Légua & Jornaleiro \\
\hline Pneumonia & 60 & Pardo & Masc & $\mathrm{CE}$ & Barão de Mamoré & Lavrador \\
\hline Impaludismo & 45 & Branco & Masc & $\mathrm{RN}$ & $?$ & Jornaleiro \\
\hline $\begin{array}{l}\text { Phimathose } \\
\text { pulmonar }\end{array}$ & 25 & Parda & Fem & $\mathrm{CE}$ & Canudos & Lavadeira \\
\hline
\end{tabular}

Essas foram as contradições sociais constituidoras de uma parte da historia de Belém do Pará, notadamente num período em que a borracha tinha grande importância na economia regional da Amazônia. Desde finais do século XIX, os moradores dessa cidade convivem com práticas e costumes considerados mais civilizados, como os bondes, as idas ao teatro e até mesmo as comemorações com champagne no "pavimento superior Café da Paz”, como fizeram em 1900 "um grupo de distintos filhos do Ceará”, para saudarem a chegada ao poder do novo governador do Ceará, Pedro Borges, indicando a existência de cearenses abastados 
que ali viviam. ${ }^{176}$ Por outro lado, convive-se também, com práticas culturais que permitiam que um episódio como a história de Francisco, “o ermitão do cacaualinho”, já em 1910, ganhasse uma grande importância para os moradores da cidade de Belém.

Viu-se que, em notas diversas ou através de textos de seus colaboradores, a Folha do Norte, por exemplo, não se descuidava de apontar para o público os muitos problemas que a cidade de Belém tinha. Na imprensa, construía-se também um retrato de Belém como uma cidade moderna, que progredia e onde, cada vez mais, seus moradores adquiriam hábitos de vida civilizados. Além disso, migrantes cearenses e de outros estados nordestinos, imigrantes estrangeiros, mendigos, embusteiros e outros grupos populares circulavam pelas ruas da cidade e, de variadas formas, buscavam disputar e construir o seu espaço nessa cidade.

São essas contradições de uma capital que se urbaniza, ao lado de espaços com hábitos considerados pouco civilizados, que podem explicar as muitas práticas cotidianas dos vários segmentos sociais que a construíram, na virada do século XIX para o XX.

${ }^{176}$ Folha do Norte. Belém, 14 de julho de 1900, p. 2. 


\section{Migrantes cearenses e colonização.}

“(...) tudo fizeram ao mesmo tempo: desbravaram florestas, destocaram terrenos, criaram barrancos artificiais, construíram pontes, abriram cortes, assentaram trilhos, e das próprias árvores que baqueavam (...), como a maçaranduba, e a jarana, foi feito parte dos dormentes sobre os quais hoje descansam os trilhos (...). Como os titãs da mitologia grega não escalaram o Firmamento, nem como o Hércules da lenda removeram montanhas. Fizeram mais talvez, removem jazidas, pouco a pouco contribuindo por diversas formas, para o engrandecimento do Estado e derrubam a mata virgem, assentando trilhos (...)”. ${ }^{1}$

Em julho de 1914 e em novembro de 1915, o literato Rocha Moreira viajou de trem pela chamada zona bragantina do estado do Pará. Como repórter do jornal Folha do Norte, saiu de Belém em visita a uma jazida de granito, na região de Quatipuru, quase no final da linha do trem, já perto da cidade de Bragança, cuja concessão de exploração pertencia a um amigo seu. As palavras acima, publicadas na Folha do Norte, quando de sua viagem no ano de 1915, referem-se especificamente a suas observações dos trabalhadores da firma de granito "Ribeiro \& Coelho”, dentre estes, muitos migrantes do meio norte. Contudo, suas impressões não deixam de sintetizar muito do trabalho feito anos antes na zona bragantina pelos grupos de migrantes sertanejos que saíram sobretudo do Ceará, e que, ao lado de imigrantes estrangeiros, a exemplo dos espanhóis, foram pioneiros no desbravamento desta parte do Pará na virada do século XIX para o XX.

Esse espaço das jazidas de granito, em que a floresta é descrita com o seu "intricado labirinto” com “pequiás gigantescos” e “cedros majestosos” que pareciam “dormir o sono dos séculos”, juntamente com um igarapé, afluente do rio Quatipuru, que serpenteava por entre a mata, "fazendo correr a doce linfa" que amenizava "a sede dos homens" e dos outros animais, chamou tanto a atenção de Rocha Moreira, a ponto de ele dedicar parte de seu texto à exaltação dessas belezas naturais. ${ }^{2}$

Igualmente impactante para o literato foi o trabalho dos homens que, diariamente, "de torso desnudo e suarentos” e manejando "pesados machados”, abriam caminhos no meio da mata para o assentamento de trilhos do ramal que levava às pedreiras. Um trabalho árduo, iniciado "às primeiras horas da manhã" e encerrado "ao por do sol”, indicativo, na visão do

\footnotetext{
${ }^{1}$ Folha do Norte. Belém, 12 de novembro de 1915, p. 1.

${ }^{2}$ Folha do Norte. Belém, 11 de agosto de 1914, p. 1.
} 
autor, de uma "vida rústica”, onde não raro até os concessionários da firma de granito, faziam “as refeições” no próprio local de derrubada das árvores. Diante das dificuldades para o trabalho em meio à floresta, o literato lembrava para seus leitores da Folha do Norte que essa tarefa da derrubada da mata, para edificação da produção das jazidas de granito, tratavase de um trabalho muito mais espinhoso do que as missões impostas aos heróis da mitologia grega. $^{3}$

Essa foi também a tarefa determinada a um bom número de migrantes cearenses que, entre 1889 e 1916, foram se instalando nesse espaço da chamada zona bragantina. Tarefa de transformar a floresta em um espaço considerado civilizado, através produção agrícola, não menos árduo do que o trabalho nos seringais.

As palavras de Rocha Moreira não deixam de ter razão, considerando o quão dificultosa foi a empreitada de ocupação da chamada zona bragantina. A virada do século XIX para o XX foi marcada no Pará, como já se evidenciou anteriormente, pela euforia dos negócios da borracha e igualmente por uma preocupação com a produção agrícola.

Para os poderes públicos, a maneira de alcançar tal intento foi a ocupação e a colonização do vasto território paraense. Em 1877, por exemplo, ano de seca no Ceará e em que muitos migrantes se deslocaram para a Amazônia, o Presidente da Província do Pará, Bandeira de Mello, destacava a extensão da Província por ele governada: “1.149, 612 Km”. Expunha preocupação com a sua pequena população de “apenas 259,821 habitantes”, que segundo ele não tinham meios para explorar as riquezas do seu “fertilíssimo solo”. Diante desse problema, acreditava que somente a colonização seria “o meio de preencher esse desiderato”. Bandeira de Mello sabia, entretanto, que esse processo não seria "obra de um dia". 4

A Fala de Bandeira de Mello encontraria eco em vários outros pronunciamentos oficiais, tanto dos governos provinciais como dos governos republicanos. Para se ter uma idéia disso, em todas as Mensagens dos anos de 1889 a 1916, a colonização e a produção agrícola não deixam de ter algum tipo de referência. ${ }^{5}$ Assim, ainda em 1883, ao iniciar-se a colocação dos

\footnotetext{
${ }^{3}$ Folha do Norte. Belém, 11 de agosto de 1915, p. 1.

${ }^{4}$ Fala com que o Excelentíssimo Senhor Dr. João Capistrano Bandeira de Mello Filho abriu a $2^{\mathrm{a}}$ sessão da $20^{\circ}$ Legislatura da Província do Pará em 15 de fevereiro de 1877, pp. 157-158.

${ }^{5}$ Palma Muniz dedica a parte principal de seu estudo sobre imigração e colonização no Pará, publicado nesse ano de 1916, justamente a esse período de 1889 a 1916, chamado por ele de "Período
} 
primeiros trilhos da "Estrada de Ferro de Bragança" - ferrovia considerada pelos poderes públicos o grande marco de desenvolvimento dessa região, ligava a capital do Pará à cidade de Bragança, uma distância de aproximadamente 293 quilômetros, em uma área bem pouco povoada. $^{6}$-, o então presidente da Província do Pará, o Barão de Maracaju, acreditava firmemente na chegada do povoamento e conseqüentemente de "civilização" nos caminhos percorridos pelo trem. ${ }^{7}$ Do mesmo modo, o jornal o Liberal do Pará não deixava de apontar o que se esperava da ferrovia, acreditando no povoamento dessa "extensa zona" cortada por floresta e na possibilidade de se provir com "abundantes frutos" o "mercado da capital” com a "barateza dos produtos" que teriam o trem para o seu transporte. ${ }^{8}$ Note-se que antes da ferrovia, o acesso principal à capital era por rio, por caminhos mais longos e de acesso nem sempre tão fácil. Eugênia Gonçalves Égler enfatiza que ainda na primeira metade do século XIX a via marítima “apesar de perigosa e demorada, ainda representava importância ponderável”. Para a autora essa rota marítima foi responsável pela formação de vários povoados na costa do Pará Quatipuru, São João de Pirabas, Salinas, Maracanã, Marapanim, Curuçá, São Caetano de Odivelas, Vigia e Pinheiro. ${ }^{9}$

A colonização dessa região, e igualmente de outras áreas do Pará, diante da grande extensão de terras a serem cultivadas, necessitava de mão-de-obra. A busca de "braços laboriosos”, como lembrava o presidente Bandeira de Mello ainda em 1877, torna-se-ía um apelo comum nos relatórios dos poderes públicos. ${ }^{10}$ Nesse sentido, em 1889, o governo provincial buscava firmar contratos para a introdução de "imigrantes lavradores" em terrenos

da república”. MUNIZ, João de Palma. Estado do Grão-Pará. Immigração e Colonisação. História e Estatística 1616-1916. Belém: Imprensa Oficial do Estrado do Pará, 1916. pp. 55-108.

${ }^{6}$ Sobre essa ferrovia ver CRUZ, Ernesto. A estrada de Ferro de Bragança: visão social, econômica e política. Belém: Falângola, 1955.

${ }^{7}$ O Liberal do Pará. Belém, 26 de junho de 1883, p. 1. Sobre as muitas contradições para a implementação dos caminhos de ferro e o chamado processo civilizatório da Amazônia, boas leituras são os trabalhos de Hardman sobre a implementação da ferrovia Madeira-Mamoré e de Laura Maciel sobre a implementação das linhas de telégrafo pela Comissão Rondon. Ver: HARDMAN, Francisco Foot. O trem fantasma; e MACIEL, Laura Antunes. A nação por um fio.

${ }^{8}$ O Liberal do Pará. Belém, 26 de junho de 1883, p. 2.

9 ÉGLER, Eugênia Gonçalves. "A Zona Bragantina no Estado do Pará”. Revista Brasileira de Geografia. São Paulo, no 3 (julho-setembro 1961), p. 528.

${ }^{10}$ Fala com que o Excelentíssimo Senhor Dr. João Capistrano Bandeira de Mello Filho abriu a $2^{\mathrm{a}}$ sessão da $20^{\circ}$ Legislatura da Província do Pará em 15 de fevereiro de 1877, p. 157. 
agrícolas de Igarapé Miry para o cultivo da cana de açúcar, ou às margens da estrada de ferro de Alcobaça. Ao mesmo tempo, também cancelava contratos firmados anteriormente para a “exploração e fundação" de engenhos, uma vez que nada havia sido feito para a introdução de imigrantes. ${ }^{11}$ De fato, as tentativas de se desenvolver a agricultura no Pará, na virada do século XIX para o XX, são marcadas por variadas assinaturas de contratos para a introdução de migrantes e imigrantes e igualmente pela ruptura desses contratos em função de seus fracassos. Suprir essa deficiência seria uma constante nos pronunciamentos oficiais que se dividiam entre a utilização de trabalhadores nacionais e o incentivo à vinda de imigrantes estrangeiros. $^{12}$

Em um ponto pelo menos os poderes públicos concordavam: para a região, deveriam vir colonos "sadios, morigerados e aptos para o serviço de agricultura". ${ }^{13}$ No afã de civilização, nem sempre estas características foram vistas pelos poderes públicos no migrante nacional. Até mesmo o governador Paes de Carvalho, um dos grandes incentivadores do trabalho com migrantes brasileiros, não deixou de acreditar que a vinda de imigrantes europeus, considerados bons trabalhadores, ajudaria na "formação e desenvolvimento da aptidão profissional entre os nossos compatriotas". ${ }^{14}$ Seu pensamento seria importante para a formação de vários núcleos coloniais às margens da Estrada de Ferro de Bragança em que conviveram espanhóis e cearenses, questão que veremos a seguir. No que se refere à presença de imigrantes estrangeiros nos núcleos coloniais, Eugênia Égler afirma que enquanto no "sul do país o grosso da corrente imigratória constituía-se de alemães e italianos, no Pará os contingentes destas nacionalidades foram reduzidos prevalecendo os espanhóis (...). Isto porque os contratos no continente europeu eram feitos através de Paris e Lisboa”, onde

${ }^{11}$ Fala com que o exmo. Snr. Dr. Miguel José de Almeida Peranambuco abrio a $2^{\mathrm{a}}$ sessão de $26^{\mathrm{a}}$ Legislatura Provincial do Pará em 2 de fevereiro de 1889. Pará, Typ. de A. F da Costa, 1889, pp. 6469.

${ }^{12}$ Sobre os debates travados na imprensa paraense acerca da utilização de imigrantes nacionais ou estrangeiros nos trabalhos de colonização entre 1877 e 1888, ver: QUEIROZ, Jonas Marçal. "Trabalho Escravo, imigração e colonização no Grão-Pará (1877-1888)". In: QUEIROZ, Jonas Marçal \& COELHO, Mauro Cezar. Amazônia: modernização e conflitos (séculos XVIII e XIX). Belém/Macapá: UFPA/NAEA/UNIFAP, pp. 81-116.

${ }^{13}$ Fala com que o exmo. Snr. Dr. Miguel José de Almeida Pernambuco abriu a $2^{\mathrm{a}}$ sessão de $26^{\mathrm{a}}$ Legislatura Provincial do Pará em 2 de fevereiro de 1889. Pará, Typ. de A. F da Costa, 1889, p. 64.

${ }^{14}$ Mensagem dirigida ao Congresso Republicano paraense pelo Governador do Estado do Pará Dr. José Paes de Carvalho. Pará: Diário Official, 1897, p. 25. 
segundo a autora se desenvolveu "intensa propaganda no sentido da emigração para o Brasil”. Predominaram nesse sentido os espanhóis “entrando até 1900 pouco mais de 12 mil colonos desta nacionalidade”. ${ }^{15}$

Em relação à localização dos migrantes nos núcleos, sempre pairou um discurso em torno do colono que se queria. ${ }^{16}$ Em um artigo publicado na Folha do Norte em 1898, que fez parte de uma série de textos intitulados "Pelo Futuro da Amazônia", dos quais já falamos anteriormente, o articulista, delineou muito bem o tipo de colono que se pretendia para o desenvolvimento agrícola do Pará:

"Em lugar de bandos de vadios e mandriões, que como até aqui, só tem servido para aumentar as estatísticas das nossas cadeias e hospitais, adquirir-se-iam devidamente garantida a sua subsistência e o seu bem estar e de suas famílias - trabalhadores rurais, homens honestos, sóbrios, com hábitos do trabalho e da disciplina, com família e com princípios de economia". ${ }^{17}$

A vivência nos núcleos coloniais demonstraria que esse colono europeu idealizado estava longe de existir. Não raro, as próprias condições dos espaços onde esses migrantes eram colocados já era razão suficiente para explicar os sucessivos fracassos da colonização. Assim, preocupações com um imigrante que tivesse aptidões agrícolas sempre estiveram muito presentes como um discurso que explicou as dificuldades para a implementação da produção. Nos momentos em que ficava mais difícil o abastecimento dos mercados da cidade de Belém, esse problema também vinha à tona na imprensa local. Em 1898, diante das dificuldades que "pelas manhãs as famílias de Belém” tinham em abastecer-se de "verdura”, mais uma vez "a falta de braços" - conseqüência, segundo a Folha do Norte de um desvio dos "melhores trabalhadores" para a indústria extrativa - era colocada em evidência. A solução ainda era a formação de núcleos coloniais, com colonos que tivessem "especiais aptidões", além de interesse em entregar-se a agricultura. ${ }^{18}$

A instalação de trabalhadores nacionais na zona bragantina, entretanto, foi bem anterior ao governo de Paes de Carvalho. A seca de 1889, no Ceará, que coincide no Pará com a

\footnotetext{
${ }^{15}$ ÉGLER, Eugênia Gonçalves. “A Zona Bragantina do Estado do Pará”, pp. 530-531.

${ }^{16}$ Lauro Sodré no inicio de seu mandato afirmava: "A primeira necessidade” para o "ressurgimento de nossa produção agrícola só pode provir de uma corrente de imigração bem e racionalmente dirigida”. Mensagem dirigida pelo Senr. Governador Dr. Lauro Sodré ao Congresso do Estado do Pará em sua primeira reunião, em 30 de outubro de 1891. Belém: Typ. do Diário Official, 1891, p. 21.

${ }^{17}$ Folha do Norte. Belém, 15 de março de 1898, p. 1.

${ }^{18}$ Folha do Norte. Belém, 6 de dezembro de 1898, p. 1.
} 
construção de trechos da Estrada de Ferro de Bragança, foi marcante nesse sentido. Grande número de cearenses que aportou no Pará se utilizou naquele momento da ferrovia para se dirigir aos locais já cortados pelo trem, onde iam se formando pequenos povoados. ${ }^{19}$ Os lugares para os quais os migrantes se dirigiam eram Benevides, Colônia Santa Isabel, Colônia Araripe, Americano e Apeú, última estação do trem naquele momento. A presença de grupos familiares entre os migrantes cearenses é representativa, indicando provavelmente o interesse do grupo em permanecer na região pela possibilidade de adquirir terras. ${ }^{20}$

Os ofícios da Presidência da Província do Pará, enviados ao Diretor dessa ferrovia, são reveladores, na medida em que indicam que no ano de 1889 , muitos migrantes iam se instalando ao longo da linha do trem, "onde pretendiam fixar residência”, como possivelmente teria afirmado o cearense Vicente José da Silva, que seguiu em julho de 1889, na $3^{\text {a }}$ classe do trem, acompanhado de sua mulher e mais 9 filhos, para o "núcleo colonial de Santa Isabel", 21

Embora com alguns núcleos coloniais já instalados e com a ferrovia já circulando por lugares onde antes só existiam matas, o discurso em relação à ocupação e colonização das terras paraenses era o mesmo de anos anteriores. Bom exemplo disso são as Mensagens do governador Lauro Sodré, que, em 1891, afirmava que o território paraense jazia “abandonado

${ }^{19}$ Palma Muniz afirma que a seca que atingiu o Ceará em 1888, e levou a saída de muitos cearenses forçou na Província do Pará a "administração pública a localizá-los ainda que precariamente, na zona da Estrada de Bragança". MUNIZ, João de Palma. Estado do Grão-Pará. Immigração e Colonisação, p. 60.

${ }^{20}$ É possível perceber a presença de famílias através de ofícios da Presidência da Província solicitando ao Diretor da Estrada de Ferro de Bragança, passagens para "retirantes cearenses" que pretendiam se estabelecer nessa área. Ver nesse sentido: APEP - Palácio da Presidência da Província do Pará Minutas de ofícios a diversas autoridades. $N^{o} 777-2^{\mathrm{a}}$ secção -6 de fevereiro de $1889 ; 2^{\mathrm{a}}$ secção 22 de fevereiro de 1889; $\mathrm{N}^{\mathrm{o}} 2449$ - $4^{\mathrm{a}}$ secção - 1 de junho de 1889; $\mathrm{N}^{\mathrm{o}} 2555$ - $4^{\mathrm{a}}$ secção -7 de junho de 1889; 2580 - $4^{\mathrm{a}}$ secção -8 de junho de 1889 ; $\mathrm{N}^{\mathrm{o}} 2604$ - $4^{\mathrm{a}}$ secção -10 de junho de 1889 ; $\mathrm{N}^{\mathrm{o}} 2602-4^{\mathrm{a}}$ secção - 10 de junho de 1889 ; $\mathrm{N}^{\circ} 2678$ - 4 a secção - 14 de junho de 1889 ; $\mathrm{N}^{\mathrm{o}} 2693$ - 4 secção -14 de junho de 1889; $\mathrm{N}^{\mathrm{o}} 4270$ - $4^{\mathrm{a}}$ secção - 29 de agosto de 1889. De acordo com o Presidente da Província do Pará, Roso Danin (1889): “3.480 indivíduos (...) percebiam socorros” do Estado. Esses migrantes instalaram-se nos seguintes lugares: Apeú: 930; Araripe: 680; Santa Isabel: 670; Benevides: 1200. Fala com que José de Araujo Roso Danin, $1^{\circ}$ Vice- presidente da Província do Pará passou a administração da mesma ao Exm. Sr. Dr. Antonio José Ferreira Braga, presidente nomeado por Dec. De 22 de julho de 1889. Pará: Typ. de A. Fructuoso Costa, 1889, p. 28.

${ }^{21}$ APEP - Palácio da Presidência da Província do Pará - Minutas de Ofícios a diversas autoridades. $N^{\circ}$ 3360 - $4^{\text {a }}$ secção - 15 de julho de 1889. 
e inculto (...) reclamando braços”, para a sua transformação. ${ }^{22}$ Em todas as suas Mensagens, Lauro Sodré apontou a necessidade de se desenvolver a lavoura, uma vez que acreditava ser este o "melhor sinal” da "riqueza” de um país. ${ }^{23}$

No ano de 1893, seu pensamento não seria diverso, e a imagem de um território em "sua quase totalidade inculto", com “terrenos voltados ao abandono” e necessitando de braços, dava a tônica de seu discurso. Descrevia um estado cuja produção de maior peso era a voltada para a extração do látex. ${ }^{24}$ Em 1897, ao expirar seu mandato, Lauro Sodré era enfático na última Mensagem, ao considerar o "povoamento" e a "aquisição de braços capazes de explorá-lo" como o "máximo entre os maiores" dos problemas que os poderes públicos paraenses teriam de enfrentar. ${ }^{25}$

Essa parece ter sido uma das principais metas do governo do sucessor de Lauro Sodré, Paes de Carvalho, que, sobretudo a partir de 1898, tomaria a colonização do Pará como uma das principais tarefas dos seus quatro anos de mandato, entre 1897 e 1901.

Num certo sentido, a solução para tal problema já havia sido pensada anteriormente pelo antecessor de Lauro Sodré, o Tenente Bacellar Pinto Guedes, que propunha para o povoamento da Guiana Brasileira e para colônias do rio Araguary a procura nos "estados mais pobres, como Maranhão, Ceará, Rio Grande do Norte e Paraíba”, de "famílias de imigrantes” ${ }^{26}$ A vinda desses grupos de migrantes, entretanto, não seria algo fácil, pois, se de um lado implicava no desejo e na motivação para que os migrantes saíssem de seu lugar de origem no Ceará, implicava também na montagem de uma infra-estrutura para o recebimento desses grupos de migrantes no Pará. Nesse sentido, não de pode pensar a questão de maneira simples, resumindo-a apenas à pobreza do nordeste e à necessidade de braços na Amazônia.

\footnotetext{
${ }^{22}$ Mensagem dirigida pelo Senr. Governador Dr. Lauro Sodré ao Congresso do Estado do Pará em sua primeira reunião, em 30 de outubro de 1891. Belém: Typ. do Diário Official, 1891, p. 12.

${ }^{23}$ Mensagem Dirigida pelo Senr. Goverandor Dr. Lauro Sodré ao Congresso do Estado do Pará em sua segunda reunião em $1^{\circ}$ de julho de 1892. Belém: Typ. do Diário Official, 1892, p. 21.

${ }^{24}$ Mensagem dirigida pelo Senr. Governador Dr. Lauro Sodré ao Congresso do Estado do Pará em $1^{\circ}$ de fevereiro de 1893. Belém: Typ. do Diário Oficial, 1893, p. 22.

${ }^{25}$ Mensagem dirigida ao Congresso do Estado do Pará pelo Dr. Lauro Sodré Governador do Estado ao expirar o seu mandato, no dia $1^{\circ}$ de fevereiro de 1897. Pará: Diário Oficial, 1897, p. 23.

${ }^{26}$ Relatório com que o capitão Tenente Duarte Huet Bacellar Pinto Guedes passou a administração do Estado do Pará em 24 de junho de 1891 ao Governador Dr. Lauro Sodré, eleito pelo Congresso Constituinte em 23 do mesmo mês. Belém: Typ. do Diário Oficial, 1891, p. 47.
} 
A noção de despovoamento do Estado e da falta de produção, tão presente nos pronunciamentos dos poderes públicos, se por um lado revela a intensidade de uma economia extrativista, por outro, indica ainda um desconhecimento do próprio Pará, na medida em que os grupos indígenas por exemplo, não são pensados nesse contexto, e nem tão pouco os lavradores paraenses com "pequenas áreas de plantações” de cacau, tabaco, cereais em lugares como Bragança, Abaeté, Igarapé Miry, Acará, Óbidos, Santarém, Cametá. ${ }^{27}$ A preocupação com a produção em larga escala e igualmente em povoar áreas pouco habitadas também revela um ideário de se demarcar espaços com a presença do Estado, que levaria para os mais longínquos lugares do Pará a civilização e, conseqüentemente, a ordem e o progresso, fundamentos da própria instituição da República. Nos lugares distantes da capital paraense, esse processo se daria com a implementação de núcleos coloniais.

De acordo com Palma Muniz são núcleos coloniais fundados antes do período republicano na área da Estrada de Ferro: Benevides (1875), Santa Isabel, Apeú, Americano e Benevides (tem seus lotes demarcados entre 1885 e 1886) Castanhal (1889) ${ }^{28}$ Ernesto Cruz identifica na Estrada de Ferro de Bragança os seguintes núcleos coloniais criados no período Republicano: Marapanim (1893), Jambuassú (1894), Benjamin Constant (1894), José de Alencar (1898), Santa Rosa (1898), Ferreira Penna (1898), Anita Garibaldi (1898) Ianetama (1898), Inhangapi (1898). Vale lembrar que muitos desses núcleos quando emancipados, ou quando se tornaram municípios ou povoados maiores passaram a agregar outras colônias ao seu redor. A exemplo de Jambuassú e Santo Antonio do Prata que estavam ligados a Igarapé-Assú, quilômetro 112 da Estrada de Ferro. Saindo da área da Estrada de Ferro de Bragança tem-se os seguintes núcleos: Monte Alegre (1894) Óbidos (1895), Curuçá (Couto de Magalhães) (1895) Acará (1898), Cametá (1898) Salvaterra (1898), Alenquer (1900). Núcleo indígena de Santo Antonio do Maracanã (1898). ${ }^{29}$

\footnotetext{
${ }^{27}$ Mensagem dirigida ao Congresso do Estado pelo Dr. Paes de Carvalho governador do Estado em 7 de abril de 1899. Belém: Typ. do Diário Oficial, 1899, p. 20.

${ }^{28}$ Ver: MUNIZ, João de Palma. Estado do Grão-Pará. Immigração e Colonisação, pp. 35, 44, 65, respectivamente.

${ }^{29}$ CRUZ, Ernesto. Colonização do Pará, pp. 85-131. Não há uma precisão exata dessas datas de fundação dos núcleos, podendo haver algumas distorções de um ano para outro. Tome o leitor as datas como um período para situar-se e não como um marco cronológico fechado, o mesmo pode acontecer com a fundação dos núcleos coloniais, correndo-se o risco de termos esquecido algum.
} 
Não é por acaso que, em 1898, o governador Paes de Carvalho reorganiza o serviço de imigração, visando justamente a levar adiante a colonização no estado do Pará, sobretudo nas áreas da zona bragantina, em parte da região do Salgado e em lugares do chamado Baixo Amazonas. ${ }^{30}$ Desse modo, em junho de 1898, o governador Paes de Carvalho sancionava a lei $\mathrm{n}^{\mathrm{o}} 583$, que buscava legalizar a situação de migrantes nacionais e estrangeiros, bem como incentivar, mas ao mesmo tempo disciplinar, os migrantes que pretendiam, espontaneamente ou por meio de contratos, localizar-se no Pará como “agricultores". Esses migrantes deveriam "escolher o seu destino" entre os "núcleos coloniais", os "estabelecimentos agrícolas ou industriais" de iniciativa particular, e em "terras devolutas". 31

Ao mesmo tempo, em que o governador sancionava essa lei, ele também partia em abril do mesmo ano para um período de visitas a cidades, vilas, povoados e núcleos coloniais, numa espécie de reconhecimento do estado do Pará. O objetivo principal dessas viagens, de acordo com Mario Cattaruzza, correspondente da Folha do Norte, que acompanhou muitas delas, era o de conhecer-se "de perto todas as localidades principais do Estado", a fim de desenvolvê-las, sobretudo através da agricultura. Entendida como um dever patriótico, a jornada de Paes de Carvalho foi traduzida para os leitores da Folha do Norte como "mais um cometimento da iniciativa republicana", fazendo parte, assim, de um "vasto plano administrativo agrícola” que o governador se empenhou em colocar em prática e que os leitores puderam acompanhar diariamente nas páginas desse periódico. ${ }^{32}$

Não podemos perder de vista que essas viagens de Paes de Carvalho, em 1898, se inseriram também num ideário republicano de tomada de posse e de demarcação de territórios, que o Império já “conhecia” - e que, no caso do Pará, já tinha inclusive mostrado a sua presença, quando da luta para desarticular, por exemplo, possíveis focos de rebeldia no período posterior à Cabanagem - e nos quais a República precisava se inserir cada vez mais. ${ }^{33}$ Talvez até os episódios de Canudos, ocorridos no ano anterior (1897), e que davam conta de

\footnotetext{
${ }^{30}$ APEP - Pará - Obras Públicas Terras e Colonização. Lei no 583 de 21 de junho de 1898 Reorganiza o Serviço de Imigração e Colonização do Estado.

${ }^{31}$ APEP - Pará - Obras Públicas Terras e Colonização. Lei no 583 de 21 de junho de 1898 Reorganiza o Serviço de Imigração e Colonização do Estado.

${ }^{32}$ Folha do Norte. Belém, 20 de julho de 1898, p. 1.

${ }^{33}$ Sobre o período pós-Cabanagem, ver por exemplo: FULLER, Claudia Maria. "Os corpos de trabalhadores: política de controle social no Grão-Pará”. Belém: Fascículos LH, no 1, 1999.
} 
um Brasil por ser descoberto, tenham inspirado o governador a partir nessa sua expedição de reconhecimento do Pará. Ora, ele, que sempre fora ardoroso defensor da República e que inclusive teria recebido o "encargo de contribuição de tropas para o Governo da República combater o levante de Canudos”, certamente acreditava em sua missão civilizadora em nome desses ideais. $^{34}$

Os acontecimentos de Canudos ultrapassaram as fronteiras do sertão baiano e repercutiram em todo o Brasil através de coberturas jornalísticas, como o trabalho de Euclides da Cunha que, diretamente do front, escrevia para o jornal "O Estado de São Paulo" em 1897. ${ }^{35}$ Em Belém, por exemplo, não se deixou de apontar para a população as conseqüências desse episódio, uma vez que algumas famílias haviam sido atingidas diretamente pelo conflito. Em janeiro de 1898, por exemplo, a Folha do Norte, na primeira página e em letras de destaque, convidava os seus leitores a participarem de uma quermesse "em favor das famílias das vítimas do dever". Ao mesmo tempo, convocava "viúvas, mães ou filhos dos oficiais e soldados do Regime Militar do Pará" que haviam sido mortos "nos combates em Canudos” a se habilitarem para receberem a "cota” do resultado da quermesse. ${ }^{36}$

Até mesmo em propagandas, a memória desse episódio era recorrente, como o fez a “Drogaria Nazareth", afirmando que com a mesma "fúria” com que a "Igreja de Canudos”, um "baluarte de jagunços”, havia sido derrubada pelos “canhões da legalidade”, as "Pílulas de Pião" atacariam as "moléstias da pele". ${ }^{37}$ Em abril desse mesmo ano, o medo de um "novo Canudos” é evocado com a notícia do aparecimento em Jaguary (Minas Gerais) de "um novo profeta”, que fazia "sermões", praticava "milagres” e era seguido, no dizer da Folha do Norte, baseado em relatos da "imprensa do sul”, por "fanáticos e ignorantes".38 Nesse contexto, não seria absurdo falar das preocupações de Paes de Carvalho, diante da

\footnotetext{
${ }^{34}$ Dados Biográficos dos senadores do Pará: 1826-1997. Brasília: Senado Federal, Secretaria de Informação e Documentação, 1997, p. 109.

${ }^{35}$ CUNHA, Euclides da. "A campanha de Canudos (Série de reportagens publicadas em o Estado de S. Paulo, de agosto a outubro de 1897, enviadas do teatro de operações no sertão da Bahia)". In: Canudos e outros temas. Brasília: Senado Federal, Conselho Editorial, 2003, pp. 15-109.

${ }^{36}$ Folha do Norte. Belém, 3 de janeiro de 1898, p. 1.

${ }^{37}$ Folha do Norte. Belém, 27 de janeiro de 1898, p. 1.

${ }^{38}$ Folha do Norte. Belém, 10 de abril de 1898, p. 1.
} 
extensão territorial do Pará, do vazio populacional, e de uma ausência do poder republicano em muitos desses lugares.

A civilização e o progresso, para os poderes públicos paraenses, tinham então, como caminho privilegiado, o amanho da terra e a fixação, nesses espaços considerados vazios, de trabalhadores disciplinados. Não resta dúvida de que as “excursões” de Paes de Carvalho pelos sertões paraenses refletiram essa estratégia republicana de tentativa de controle, e de domínio desse território, sobretudo das áreas distantes da capital. Por outro lado, esses trajetos do governador e de sua comitiva revelavam também uma variedade de experiências sociais, dos grupos de migrantes que viveram nessas terras. Para além das preocupações dos poderes públicos, expressas nas Mensagens anuais com a produção e com o povoamento, esses grupos de colonizadores imprimiram seus próprios significados a esse internamento no meio da mata, como principais artífices, a sua própria maneira, dessa civilização idealizada pela nascente República.

Nesse contexto é que, entre abril e setembro de 1898, o governador Paes de Carvalho ora em vapores, ora de trem, outras vezes a cavalo e a pé, debaixo de sol escaldante ou de chuva, se embrenhou pelos mais longínquos lugares do Pará, sempre acompanhado de uma comitiva formada de homens ilustres. Era o caso de várias autoridades, a exemplo do "cônsul do Brasil em Gênova”, do desembargador Napoleão Simões, de juízes, do diretor de obras públicas, de um químico do Laboratório de Higiene, cuja função era de “examinar a água”. Acompanhavam também a comitiva outros que teriam o papel de registrar essas “expedições”, como os correspondentes de jornais, entre eles João Marques de Carvalho, fotógrafos, a exemplo de Felippe Fidanza, que colhia "preciosas fotos para o álbum de propaganda do Estado" 39 , e até mesmo, em alguns momentos, por um dos “melhores auxiliares do Restaurante Coelho", encarregado do preparo de jantares servidos de "maneira esplendida” em casas rústica dos núcleos coloniais. ${ }^{40}$

$\mathrm{Na}$ medida em que o governador se lançou nessa empreitada, ele criava também para si a imagem de um grande empreendedor, do grande incentivador da colonização e de um governador até mesmo bondoso, um "médico humanitário", conforme escreveria anos mais

\footnotetext{
${ }^{39}$ Folha do Norte. Belém, 24 de abril de 1898,p. 2.

${ }^{40}$ Folha do Norte. Belém, 3 de setembro de 1898, p. 1.
} 
tarde Ricardo Borges, no livro Vultos notáveis do Pará. $^{41}$ A imprensa, nesse sentido, foi importante, na medida em que, diariamente, através das “notas de viagem” de Cataruzza, que chegavam a Belém por telegramas, expunham-se ao público os itinerários, ações do governador e impressões dessas vistas. De uma maneira geral, o protocolo das viagens se iniciava com a saída de Belém, em um vapor "elegante, com excelentes acomodações" em "trem especial” da Estrada de Ferro de Bragança ${ }^{43}$, e se complementavam com a chegada ao local de destino, nas conversas com os intendentes municipais ou as lideranças locais e, finalmente, quando existiam no local inspecionado, com uma visita aos núcleos coloniais.

Não se deixou de registrar a aproximação do governador com os grupos menos privilegiados, como colonos cearenses e espanhóis, embrenhados no meio da floresta. Em meio a esses grupos, chamados pelo correspondente da Folha do Norte de "baixas camadas da sociedade", o governador é descrito como "ameno e de fino trato". ${ }^{44} \mathrm{Na}$ ocasião, com cerca de 48 anos de idade, Paes de Carvalho tinha vigor suficiente para enfrentar longas viagens, não raro por "caminho difícil”, como foi aquele feito em Monte Alegre, quando o governador e sua comitiva se deslocaram a cavalo, rumo à colônia Tajury, "no alto silêncio da madrugada". 45

Paes de Carvalho, que era médico, personificava ainda a figura do político que se aproximava da população através da Medicina. Assim, por ocasião da sua ida à colônia Benjamin Constant, enquanto membros de sua comitiva inspecionavam lotes agrícolas, ele "visitava diversos doentes que recorriam ao saber clínico". 46

A “expedição" comandada por Paes de Carvalho, que sempre tinha Belém como ponto de partida, percorreu lugares como Monte Alegre, em visita “à colônia Tajury”, depois seguiu pela "região do Salgado”, passando por locais como Vigia, Colares, Arapiranga, Vila Porto Salvo, São Caetano de Odivelas, Marapanim, Maracanã, Curuçá, povoado do Abade, Salinas,

\footnotetext{
${ }^{41}$ BORGES, Ricardo. Vultos notáveis do Pará, p. 176

${ }^{42}$ Folha do Norte. Belém, 3 de maio de 1898, p. 1.

${ }^{43}$ Folha do Norte. Belém 3 de setembro de 1898, p. 1.

${ }^{44}$ Folha do Norte. Belém, 3 de maio de 1898, p. 1.

${ }^{45}$ Folha do Norte. Belém, 3 de maio de 1898, p. 1.

${ }^{46}$ Folha do Norte. Belém, 2 de maio de 1898, p. 1.

${ }^{47}$ Folha do Norte. Belém, 3 de maio de 1898, p. 1.
} 
vila de São João de Pirabas $^{48}$, Colônia Benjamin Constant ${ }^{49}$, Bragança, Viseu ${ }^{50}$, Alto Quatipurú. Na região da Estrada de Ferro de Bragança, os lugares visitados foram as colônias de Castanhal, Marapanim, Jambuassu. Além desses sítios, visitou-se Acará, Abaeté, Baião, Mocajuba, Cametá. ${ }^{51}$

Esses momentos de visita constituíram também momentos para se firmar alianças com os políticos locais, necessárias para o plano desenvolvimentista do governador. Desse modo, em visita a Curuçá, por exemplo, o intendente municipal "ofereceu logo terras para o estabelecimento de um núcleo colonial”. O mesmo aconteceria em Cintra, com o oferecimento de "terras para colocação de 20 lotes. $^{52}$

Em meio à euforia das visitas do governador, o correspondente da Folha do Norte registrava também as homenagens que se faziam à República, quando se rememoravam "os inúmeros benefícios” prestados, por exemplo, a Bragança pelos "patrióticos governos” republicanos. ${ }^{53}$ Da mesma forma, nos brindes que se levantaram nas festas na sede das intendências não se deixou de evocar - em meio a “inúmeros fogos”, e da banda de música tocando o hino nacional -, como o fez o intendente municipal de Cametá, coronel Siqueira Mendes, "vivas à República ao Estado do Pará e ao sr. governador". 54 Pensadas como parte integrante do "programa da (...) ressurreição agrícola” do Pará, essas viagens também não deixaram de ser vistas como um momento de celebração do poder republicano. O governador Paes de Carvalho soube fazer isso muito bem. ${ }^{55}$

Tais viagens - ou, como as chamou a imprensa, “excursões” - expuseram, para o leitor atento da Folha do Norte, um interior do Pará muito distante dos anseios de progresso e modernidade tão caros aos poderes públicos paraenses. Através delas, é possível dizer-se que se a vida nos seringais era cheia de adversidades para os migrantes, a vida nos núcleos

\footnotetext{
${ }^{48}$ Folha do Norte. Belém, 25 de julho de 1898, p. 1.

${ }^{49}$ Folha do Norte. Belém, 23 de julho de 1898, p. 1.

${ }^{50}$ Folha do Norte. Belém, 28 de julho de 1898, p. 1.

${ }^{51}$ Folha do Norte. Belém, 24 de setembro de 1898, p. 1.

${ }^{52}$ Folha do Norte. Belém, 21 de julho de 1898, p. 1.

${ }^{53}$ Folha do Norte. Belém, 2 de agosto de 1898, p. 1.

${ }^{54}$ Folha do Norte. Belém, 2 de setembro de 1898, p. 1.

${ }^{55}$ Folha do Norte. Belém, 3 de setembro de 1898, p. 1.
} 
coloniais não era menos difícil. Isso talvez explique a procura de muitos trabalhadores pela atividade extrativista e a euforia da imprensa diante da abertura de novas frentes de colonização. Em agosto de 1898, depois das visitas de Paes de Carvalho à região do Salgado, a Folha do Norte creditava à "louvável iniciativa” do governador os "lisonjeiros resultados” dos trabalhos de colonização, em virtude das "animadoras" notícias recebidas de que o "povo aflui apressadamente a ocupar" as margens da estrada que havia sido aberta entre Santa Isabel e Vigia. A animação da Folha do Norte refletia a idéia de que com o povoamento e colonização, o Pará progrediria. ${ }^{56}$

Apesar dos interesses pelos imigrantes estrangeiros em 1899, logo após as suas visitas ao interior, o governador Paes de Carvalho lembrava que, desde o início de seu mandato (1897), se mostrara favorável à utilização de colonos nacionais para o povoamento do Pará. Seu pronunciamento não revela exatamente uma atenção especial pelos migrantes cearenses, mas pelos caboclos da própria região. A "fatalidade" da seca se encarregaria de mudar seu discurso, com o grande número de flagelados aportando em Belém. ${ }^{57}$ Buscando destacar seus esforços em relação à colonização do Pará, ao apresentar a proposta de orçamento da receita e despesa para o exercício de 1899/1900, afirmou ter recebido, no ano de 1898, "12 mil colonos nacionais”, que foram localizados em “diversas zonas agrícolas e pastoris”. 58

Em 1900, o governador Paes de Carvalho, em tom ufanista, pintava um retrato da zona bragantina bastante alvissareiro, onde parecia pulsar uma produção diversificada, em dinâmico progresso. Como "prova” de que não estava fantasiando em suas observações, o governador apontava a "valorização de lotes rurais contíguos à ferrovia”:

“Quem viaja na Estrada de Ferro de Bragança, de Belém a Jambuassú, no percurso de 120 quilômetros, observa uma série ininterrupta de lotes mais ou menos cultivados, diversos engenhos de cana, fábricas, alambiques, serrarias em plena atividade industrial e muitas outras

\footnotetext{
${ }^{56}$ Folha do Norte. Belém, 3 de agosto de 1898, p. 1. Esse como viu-se era um problema fundamental na administração Paes de Carvalho. Na sua Mensagem do ano de 1899 afirmava que "O problema do povoamento do Pará, ocupou lugar conspícuo na nossa vida administrativa durante o ano último". Mensagem dirigida ao Congresso do Estado pelo Dr. Paes de Carvalho governador do Estado em 7 de abril de 1899. Belém: Typ. do Diário Oficial, 1899, p. 49.

${ }^{57}$ Mensagem dirigida ao Congresso do Estado pelo Dr. Paes de Carvalho governador do Estado em 7 de abril de 1899. Belém: Typ. do Diário Oficial, 1899, p. 49.

${ }^{58}$ Mensagem dirigida ao Congresso do Estado do Pará pelo Dr. José Paes de Carvalho Governador do Estado em 15 de Abril de 1899 apresentando a proposta de orçamento da receita e despesa para o exercício de 1899-1900. Belém: Typ. do Diário Official, 1899, p. 25.
} 
em construção e uma certa movimentação de braços e capitais que prometem deixar aquela zona em magníficas condições econômicas. Surgem novas povoações, a edificação de prédios faz-se por toda a linha, valorizam-se as terras e mata a dentro, a uma certa distância do eixo da estrada, já são escassos os lotes devolutos". ${ }^{9}$

Maria Thereza Schorer Petrone, aponta como um dos elementos fundamentais para a criação de núcleos coloniais nas regiões sudeste e sul do Brasil a valorização das terras a partir do desbravamento e cultivo das mesmas pelos imigrantes. Para a autora "a valorização fundiária foi o objetivo constante em toda a história da imigração durante o século passado [XIX] até as primeiras décadas do século $X X$ ”. Embora o governador do Pará se pronuncie a esse respeito, não creio que no Pará conforme temos apontado, a colonização tenha se consolidado por esse prisma tão somente. Por outro lado, nesse contexto também semelhante ao que acontece com a questão da imigração na historiografia, a Amazônia sequer é lembrada O trabalho de Petrone, mesmo em se tratando de um texto bastante introdutório também não deixa de refletir isto. ${ }^{60}$

A preocupação com a produção é constante, e os poderes públicos não deixaram de expressar seu empenho e nem tão pouco o sucesso de suas ações em prol dessa empreitada. Não raro, o ufanismo, bem traduzido nessa Mensagem do ano de 1900 de Paes de Carvalho, é o ponto alto desses registros oficiais.

Os anos passam-se e o discurso dos poderes públicos não se tornava diferente em relação à agricultura. Em 1908, na administração de Augusto Montenegro, que ainda evocava a memória do trabalho de Paes de Carvalho, afirmando sua importância diante da "campanha civilizadora”, pelo desenvolvimento do Pará, enfatizava-se, tal qual seus antecessores, a “necessidade inelutável” de aproveitamento do solo paraense. ${ }^{61}$ Em 1910, com a Estrada de Ferro de Bragança terminada, o número de "núcleos coloniais do estado" também havia aumentado e o governo expedia vários títulos de terra para os colonos que viviam nessas

\footnotetext{
${ }^{59}$ Mensagem dirigida ao Congresso do Estado do Pará pelo Dr. José Paes de Carvalho governador do Estado em 1 de fevereiro de 1900. Belém: Typ do Diário Official, 1900, p. 73.

${ }^{60}$ PETRONE, Mara Thereza Schorer. O imigrante e a pequena propriedade (1824-1930). São Paulo: Brasiliense, 1982, p. 32.

${ }^{61}$ Mensagem dirigida em 7 de setembro de 1908 ao Congresso Legislativo do Pará pelo Dr. Augusto Montenegro Governador do Estado. Belém: Imprensa Oficial do Estado do Pará, 1908, p. 54.
} 
localidades cortadas pelo trem, acreditando num desenvolvimento da produção. ${ }^{62}$ Em 1916, a situação não era muito diferente e o governador Enéas Martins sugeria uma “intervenção mais enérgica no fomento da agricultura". ${ }^{3}$

Assim, entre 1915 e 1916, ao mesmo tempo, em que o governador Enéas Martins se deparava com a chegada de muitos flagelados pela seca, circulavam na imprensa as mesmas dificuldades de abastecimento de anos anteriores, dessa vez ocasionada pela falta de açúcar na praça de Belém. ${ }^{64}$ A solução para o problema, tal qual em 1889, viria junto com a seca de 1915, na medida em que boa parte dos trabalhadores que se dedicavam a desenvolver essa produção agrícola eram migrantes cearenses que aqui aportaram naquele ano. Não sem razão é que o Diretor da Estrada de Ferro de Bragança, em junho de 1915, através da imprensa, fazia "público" um "aviso" para os “imigrantes desejosos de se fixarem na zona bragantina”, afirmando que estes seriam transportados "gratuitamente”. ${ }^{65}$

O resultado disso pode ser percebido na Mensagem do governador Enéas Martins, que afirmou ter fornecido passagens de trem para "11.337” migrantes, “com destino a 29 localidades da Estrada de Ferro de Bragança”. Nesse contexto, segundo o governador, teriam sido também distribuídos "além dos necessários instrumentos de lavoura, lotes de terras agrícolas”. ${ }^{66}$ Dentro desse mesmo conjunto de medidas, em 1916, a imprensa anunciava a criação do núcleo colonial de Iracema, cuja justificativa não diferia das demais.

\footnotetext{
${ }^{62}$ Nesse período os principais povoados com colonos eram: Anhanga, Antita Garibaldi, Benjamin Constant, Couto de Magalhães, Curuçá, Estrada de Curuçá, Granja América, Ferreira Pena, Ianetama, Igarapé-Assu, Ihangapy, José de Alencar, Marapanim, Outeiro, Pinheiro, São Luiz, Santa Rosa e Santa Rita do Caranã. Mensagem dirigida em 7 de setembro de 1910 ao Congresso Legislativo do Pará pelo Dr. João Antônio Luiz Coelho Governador do Estado. Belém: Imprensa Official do Estado do Pará, 1910, p. 185.

${ }^{63}$ Mensagem dirigida em 1 de agosto de 1916 ao Congresso Legislativo do Pará pelo Dr. Enéas Martins Governador do Estado. Belém: Imprensa Oficial do Estado do Pará, 1916, p. 93.

${ }^{64}$ Em 1916, as preocupações eram as mesmas diante da "falta de entrada de açúcar" na praça de Belém, indicativo do que a Folha chamava de "pobreza agrícola lamentável", que exigiria naquele momento a utilização de "rapaduras e melaços da Estrada de Ferro de Bragança”. Folha do Norte. Belém, 11 de julho de 1916, p. 1.

${ }^{65}$ Folha do Norte. Belém, 19 de junho de 1915, p. 1.

${ }^{66}$ Mensagem dirigida em 1 de agosto de 1916 ao Congresso Legislativo do Pará pelo Dr. Enéas Martins Governador do Estado. Belém: Imprensa Oficial do Estado do Pará, 1916, pp. 85-86.
} 
Considerava-se para tal empreendimento "a necessidade de dar localização às famílias retirantes" que procuravam o estado do Pará para “dedicarem-se ao trabalho de lavoura" ${ }^{67}$

As tentativas de implementação do povoamento e da lavoura no Pará, entre 1889 e 1916, ocuparam páginas e páginas dos pronunciamentos oficiais. Apesar de um discurso que apontava as vantagens dos estrangeiros, teve na migração de retirantes sertanejos, sobretudo nos períodos de seca, sua mão-de-obra principal. A complexidade dessas relações, entretanto, não pode ficar restrita apenas aos significados que os poderes públicos construíram dessa história. Uma incursão pela estruturação dos núcleos coloniais e igualmente pelas muitas experiências dos colonos neste espaço nos parece um caminho profícuo para refletirmos sobre a presença dos migrantes cearenses nesse mundo agrícola, dando conta de outros desdobramentos da presença desse grupo no Pará.

\section{Núcleos coloniais}

A estruturação de um núcleo colonial não era uma tarefa fácil e a chegada dos migrantes a esses espaços se dava concomitantemente a essa organização. Em março de 1889, por exemplo, o governo provincial nomeava uma "comissão”, formada pelo Engenheiro Fiscal da Estrada de Ferro de Bragança, pelo Procurador da Secretaria de Fazenda e pelo Fiscal da Imigração, cujo objetivo era o de “cuidar da recepção, agasalho e colocação dos imigrantes cearenses em terrenos à margem da estrada de ferro de Bragança” ${ }^{68}$ Antes disso, entretanto, muitos migrantes cearenses já haviam seguido de trem para essas terras.

Este foi o caso de Manoel José da Cruz, que, em fevereiro de 1889, antes mesmo da formação da tal “comissão”, recebia do governo provincial "vinte passagens no trem que

\footnotetext{
${ }^{67}$ Folha do Norte. Belém, 12 de julho de 1916, p. 2.

${ }^{68}$ APEP - Obras Públicas Terra e Colonização. Oficio $N^{o} 976$ - $4^{a}$ secção - $1^{\circ}$ de março de 1889. Em sua Fala de fevereiro de 1889 o Presidente da Província do Pará, Miguel José de Almeida Pernambuco, faz referência também às inspeções para o prolongamento da Estrada de Ferro de Bragança que deveriam ser feitas pela comissão "incumbida de receber e colocar no terrenos da margem da referida estrada os retirantes cearenses vítimas da seca”. Fala com que o exmo. Snr. Dr. Miguel José de Almeida Peranambuco abrio a $2^{\mathrm{a}}$ sessão de $26^{\mathrm{a}}$ Legislatura Provincial do Pará em 2 de fevereiro de 1889. Pará, Typ. de A. F da Costa, 1889, p. 64.
} 
seguia para Benevides" ${ }^{69}$ Nesse mesmo contexto, vemos o caso da viúva Thereza Paulina da Conceição dirigindo-se de trem para o povoado do Apeú, com suas quatro filhas. ${ }^{70}$

A história da "retirante cearense” Thereza Paulina é modelar para pensarmos o processo de introdução dos migrantes nos núcleos coloniais e povoados às margens da Estrada de Ferro de Bragança e, igualmente, as dificuldades deles nesses lugares onde tudo estava começando, como era o caso do povoado do Apeú, para onde essas cinco mulheres se dirigiram. $\mathrm{Na}$ verdade, a trajetória delas havia começado bem antes. Naturais de Sobral, elas haviam embarcado em 16 de fevereiro de 1889, em Camocim, no Ceará, a bordo do "vapor inglês Augustine”, que singrava para os portos do norte com 120 famílias cearenses, num total de 561 pessoas. Ao que tudo indica, no mesmo dia em que desembarcaram em Belém, já conseguiram as passagens para a zona bragantina. Quase ao final do mês fevereiro, já encontramos referências de Thereza Paulina e as filhas seguindo no trem rumo ao povoado de Apeú. $^{71}$

O grupo familiar chefiado pela viúva Thereza Paulina, de 53 anos de idade, era bastante peculiar, uma vez que suas filhas Raimunda Maarão 29 anos, Angélica de Oliveira 25 anos, Maria dos Anjos 22 anos e Maria Catarina 20 anos, fugiam à trajetória comumente vivida pelas mulheres de seu tempo, considerando que na relação de passageiros, todas aparecem como solteiras. Por outro lado, seus sobrenomes são diferentes, o que pode indicar outros relacionamentos da viúva Thereza Paulina, ou até mesmo outro tipos de proximidade entre essas mulheres que não laços consangüíneos, apontando um erro na forma do registro de seus nomes.

Note-se que na mesma listagem do vapor, encontramos, seguindo para Belém, outras quatro mulheres com o sobrenome da viúva Thereza Paulina e com idades semelhantes à das anteriores. Esse detalhe não nos parece tão fundamental e nem tão pouco muda os questionamentos feitos, logo que nos deparamos com o ofício as encaminhando para o

\footnotetext{
${ }^{69}$ APEP - Palácio da Presidência da Província. Ofício No 777 - 2a secção - 6 de fevereiro de 1889.

${ }^{70}$ APEP - Palácio da Presidência da Província. Ofício No [?] - 2 $2^{\mathrm{a}}$ secção - 22 de fevereiro de 1889.

71 APEC - Caixa Palácio do Governo do Ceará - Companhia de Vapores - Emigração para o Norte. 1889 Fev. Livro 484 - "Emigração para o Norte. Vapor inglês Augustine. Saído no dia 16 de fevereiro de 1889". Os mesmo dados também aparecem NOZOE, Nelson, BASSANEZI, Maria Silvia C. Beozzo \& SAMARA, Eni de Mesquita. (orgs.). "Embarques para o norte". In: Os refugiados da seca. Emigrantes cearenses 1888-1889 (CD-ROM). São Paulo/Campinas: NEHD/NEPO/CEDHAL, 2003, p. 423.
} 
povoado do Apeú. O que elas iriam fazer ali, num mundo predominantemente agrícola? Seguiam a trilha já traçada anteriormente por outros seus conterrâneos, tendo parentes ou amigos já instalados no Apeú? Ou se lançavam à sorte, buscando outra ocupação? Seja lá como for, não se pode negar o comportamento ímpar dessas mulheres, que, no início de 1889 , embarcavam em um trem que cortava alguns poucos povoados encravados no meio da mata, dirigindo-se sós para uma frente pioneira de colonização no interior do Pará. ${ }^{72}$

À medida que os colonos iam se instalando nesses espaços de colonização, eles próprios também se inseriam nos trabalhos de estruturação das áreas de colonização. Em 1889, o Presidente da Província, a fim de manter ocupados os migrantes cearenses que recebiam “socorros públicos”, lembrava, em sua Fala, que esses deveriam ser “aproveitados” em trabalhos na Estrada de Ferro de Bragança. Referia-se, na ocasião, aos migrantes que se achavam “localizados” nas colônias de Araripe, Santa Isabel e Benevides e que, para esse serviço, receberiam um salário de mil e duzentos a dois mil réis diários. ${ }^{73}$ As ocupações desses migrantes e imigrantes eram "a construção de casas, barracões, derrubada e destocamento dos terrenos" além de "outros serviços relativos”. Em 1891, o governador Lauro Sodré fazia referência a "duzentos e setenta e tantos imigrantes trabalhando" na estruturação da colônia de Castanhal, recebendo “uma diária de mil réis”. Nessa ocasião, já existiam 44 casas de taipa, "cobertas com telhas de madeira, de chão batido e mais duas de construção semelhantes, porém assoalhadas”, além de “6 galpões”. ${ }^{4}$ Note-se que esses trabalhos se davam antes mesmo da chegada dos trilhos a essa colônia, que só se efetivou em 1893.

$\mathrm{Na}$ verdade, a organização de núcleos coloniais e de lotes agrícolas para a produção, mesmo que na maioria das vezes não passasse de uma estrutura muito precária ou apenas da demarcação de terrenos para a localização de colonos, foi uma atividade constante dentre as tarefas desenvolvidas pelos poderes públicos em relação à colonização. Em 1895, por exemplo, de forma semelhante às “comissões” de 1889, o governador convocava alguns

\footnotetext{
${ }^{72}$ Embora se referindo a um outro contexto, as fazendas de café paulista do final do século XIX, o trabalho de Marina Maluf é uma boa leitura para refletirmos sobre a participação das mulheres nessas frentes de colonização. MALUF, Marina. Ruídos da memória. São Paulo: Siciliano, 1995.

${ }^{73}$ Fala com que o exmo. Snr. Dr. Miguel José de Almeida Peranambuco abrio a $2^{\mathrm{a}}$ sessão de $26^{\mathrm{a}}$ Legislatura Provincial do Pará em 2 de fevereiro de 1889. Pará, Typ. de A. F da Costa, 1889, p. 64.

${ }^{74}$ Mensagem dirigida pelo Senr. Governador Dr. Lauro Sodré ao Congresso do Estado do Pará em sua primeira reunião, em 30 de outubro de 1891. Belém: Typ. do Diário Official, 1891, p. 46.
} 
funcionários públicos para a "organização e discriminação do núcleo colonial de Bragança e Piriá”. ${ }^{75}$ Do mesmo modo, em 1910, o governador João Coelho reafirmava o seu interesse de “continuar a colonização nas terras da Estrada de Ferro de Bragança”, mandando proceder à discriminação de lotes na área de Capanema, com a medição de 271 lotes. ${ }^{76}$ Essa política de criação de áreas de produção agrícola se baseava na crença da prosperidade do Pará a partir da lavoura. Nesse sentido, em 1914, quando a Economia regional passava por grandes abalos, decorrentes, sobretudo, da desvalorização do látex no mercado internacional, um articulista da Folha do Norte, preocupado com o "presente e o futuro da Amazônia”, acreditava que o “fomento da riqueza agrícola” devia ser constituído “antes de tudo" no "estabelecimento de núcleos criteriosamente organizados". ${ }^{77}$

Para além da composição das comissões para o reconhecimento das áreas onde os núcleos iam ser instalados, a chegada e permanência nesses locais de mata densa era uma tarefa bastante complicada, imposta aos migrantes sertanejos, que, nessa região, se depararam com uma paisagem bastante diversa da que viviam em seu lugar de origem, sendo-lhes dada a obrigação de civilizá-la e de fazê-la produzir. De fato, não raro os poderes públicos imputavam aos colonos o fracasso dos projetos agrícolas, como se somente a eles coubesse o progresso desses projetos. ${ }^{78}$

O governador Lauro Sodré, por exemplo, diante de problemas no núcleo colonial de Castanhal, afirmou, em 1891, que a saída dos colonos era resultado “do péssimo pessoal imigratório”. Isso é bastante questionável, na medida em que é o próprio governador quem lembra de dois problemas importantes que assolaram o núcleo: a falta de verbas e uma epidemia de febre amarela, que levou à saída de "grande número de famílias e indivíduos

\footnotetext{
${ }^{75}$ APEP - Diretoria das Obras Públicas, Terras e Colonização - Minutas e Ofícios Janeiro/ Dezembro 1895. Ofício No $3276-2^{\text {a }}$ Secção -8 de julho de 1895.

${ }^{76}$ Mensagem dirigida em 7 de setembro de 1910 ao Congresso Legislativo do Pará pelo Dr. João Antônio Luiz Coelho Governador do Estado. Belém: Imprensa Official do Estado do Pará, 1910, p. 184.

${ }^{77}$ Folha do Norte. Belém, 9 de maio de 1914, p. 1.

${ }^{78}$ Ver nesse sentido SANTOS, Roberto. História econômica da Amazônia (1800-1920). Zuleica Alvin referindo-se à imigração nas regiões sul/sudeste no século XIX adverte que "Não bastava vontade política para garantir o bom andamento dos núcleos coloniais” uma vez que o governo não tinha verbas suficientes para arcar com as despesas dos colonos. Sem dúvida esse é um problema verificado no Pará também. ALVIM, Zuleica. "Imigrantes: a vida privada dos pobres do campo", p. 232.
} 
solteiros”. ${ }^{79}$ Diante disso, não seria ilógico pensar que, tal qual no trabalho nos seringais, os migrantes também experimentavam um difícil embate com a natureza na zona bragantina.

Modelar nesse sentido foi a tentativa frustrada do governador Paes de Carvalho de visitar, em setembro de 1898, a parte da "colônia Marapanim" onde viviam os cearenses. De acordo com o articulista da Folha do Norte, que acompanhou a visita, o caminho que levaria a comitiva aos cearenses estava "completamente intransitável pela aglomeração de árvores derrubadas”, o que exigia que os colonos fizessem "milagres acrobáticos e de fadiga para abrir-se uma passagem". Somava-se a tudo isso "a natureza eminentemente alagadiça do solo", que tornou indispensável "o assentamento de estivas" na estrada, "mal amarradas com os célebres 'pregos do Brasil' - liames de cipó”. De acordo com a Folha do Norte, esse tortuoso caminho cansava e aborrecia o cavaleiro, "que depois de meia hora de viagem nessas condições", se achava "realmente enfadado". 80

A Estrada de Ferro de Bragança, um dos empreendimentos fundamentais para a estruturação dos núcleos colônias no nordeste paraense, também foi alvo de vários debates na imprensa diante do atraso na sua construção, ocasionado muitas vezes pelas dificuldades para o andamento dos trabalhos. Desse modo, em junho de 1898, o engenheiro encarregado da construção da estrada, face às críticas quanto à morosidade no andamento da colocação dos trilhos, defendia-se rememorando sua participação na construção de outras ferrovias; ao mesmo tempo, enfatizava as dificuldades para esse tipo de trabalho em "paragens remotas onde tudo falta e tudo estar por criar". A própria chegada do material que saía de Belém, até aos arredores de Jambuassú, era uma tarefa das mais complexas, que exigia, além da utilização do trem, o transporte em "costas de animais, canoas e batelões”, o que, segundo o engenheiro, acarretava sempre "muitas despesas e prejuízos". ${ }^{81}$

Meses depois dessas justificativas do engenheiro, em novembro de 1898, a Folha do Norte trazia aos seus leitores, através de informações recebidas de uma "pessoa insuspeita" que transitava pela Estrada de Ferro de Bragança, o dado de que o trecho dessa estrada que decorria “da sede da colônia Jambuassú até próximo a 'parada"” estava "quase de novo convertido em mata". Para completar, o informante da Folha do Norte dizia ainda que os

\footnotetext{
${ }^{79}$ Mensagem dirigida pelo Senr. Governador Dr. Lauro Sodré ao Congresso do Estado do Pará em sua primeira reunião, em 30 de outubro de 1891. Belém: Typ. do Diário Official, 1891, p. 46.

${ }^{80}$ Folha do Norte. Belém, 4 de setembro de 1898, p. 1.

${ }^{81}$ Folha do Norte. Belém, 13 de junho de 1898, p. 1.
} 
aterros constituíam "verdadeiro precipício" para quem, no futuro, fosse transitar de trem por ali, uma vez que essa parte da obra teria sido feita "quase toda com pedaços de madeira por sob as primeiras camadas de terra", que, com o tempo, poderiam apodrecer, fazendo o aterro ceder" ${ }^{82}$ Mesmo considerando as críticas aos poderes públicos presentes nas informações da Folha do Norte, não se pode perder de vista a insalubridade e sobretudo a dificuldade de acesso a esses espaços onde se pretendia instalar a ferrovia e, conseqüentemente, os povoados agrícolas.

A dificuldade de acesso a muitos desses lugares não pode ser descartada como uma das barreiras no desenvolvimento agrícola da zona bragantina. Os trens, por exemplo, nem sempre eram eficientes e não raro a utilização desse transporte aparece como foco de conflitos e de querelas políticas. Esse pode ter sido o caso de José de Oliveira dos Santos, um colono de Santa Isabel que queixou-se à Folha do Norte dos "vexames" do engenheiro da estrada de ferro, que teria negado a ele "um carro para transportar certa quantidade de madeira”, pelo simples fato de ter tido algumas contendas com o comprador da madeira vendida por José. ${ }^{83}$ Não muito diferente era a denúncia que a Folha do Norte trazia em 1900, de que os produtos transportados no trem eram "trazidos numa lentidão desesperadora e prejudicial (...) produzindo o embaraço das transações comerciais”. Segundo a Folha do Norte, era comum as "cargas acumularem-se por dias e meses", pelo fato de que os vagões eram insuficientes. Além disso, muitas das vezes eram "cedidos por camaradagem aos apaniguados". 84 Esses problemas revelam as dificuldades que os poderes públicos tinham em fiscalizar serviços de infra-estrutura, em lugares distantes da capital. Revelam ainda uma variedade de relações sociais que são gestadas nesses lugares de colonização recente, e que não deixam de refletir formas de se lutar pela sobrevivência, mas também de se criar redes de poderes e de lideranças políticas locais.

Ao mesmo tempo em que percebemos uma ausência dos poderes públicos nesses espaços da colonização no que diz respeito, por exemplo, ao funcionamento da ferrovia, vemos também uma centralização de poderes em Belém, o que provavelmente influenciava na forma de se administrar e de se viver nos núcleos coloniais. Assim, de questões mais amplas, como a demarcação de lotes agrícolas ou a emissão de títulos de posse de terras, vemos também a

\footnotetext{
${ }^{82}$ Folha do Norte. Belém, 5 de novembro de 1898, p. 1.

${ }^{83}$ Folha do Norte. Belém, 11 de janeiro de 1899, p. 1.

${ }^{84}$ Folha do Norte. Belém, 31 de agosto de 1900, p. 2.
} 
Repartição de Obras Públicas Terras e Colonização ocupando-se, por exemplo, com o pagamento de funcionários das colônias, como o "agrimensor da colônia Castanhal” " Até mesmo a simples venda de um cavalo ou a limpeza do braço de um rio eram decisões tomadas em Belém. ${ }^{86}$

Assim, é possível percebermos alguns desses problemas na administração da colônia Castanhal, que em 1893 tem o seu diretor advertido em função da venda de um cavalo que “fazia o serviço da carroça” sem a autorização da repartição. ${ }^{87}$ Dias depois, vemos um ofício em que o chefe dessa repartição comunicava que, por ordem do governador, o diretor da colônia Castanhal deveria entregar "todo material e mais bem inventariados", uma vez que cessava o seu serviço nessa colônia. ${ }^{88}$ Não fica claro se a exoneração do diretor da colônia era fruto da venda do cavalo, mas é de se estranhar que, depois disso, ele tenha deixado o seu cargo.

Se, para os administradores dos núcleos coloniais, o dia a dia parecia bastante difícil, imaginemos o caso dos migrantes vindos de lugares distantes e tendo que se adaptar a esse novo espaço. Em 1898, o público leitor da Folha do Norte se depara com as agruras encontradas pelos imigrantes das colônias Tajury (Monte Alegre), Benjamin Constant (Bragança), e Marapanim (Estrada de Ferro de Bragança).

A colônia de Monte Alegre, em 1898, tinha um estado tão ruim que o articulista da Folha do Norte a descrevia como dando a "impressão de uma aldeia africana com as suas senzalas entregues ao abandono", em decorrência do próprio aspecto da casas, “choupanas” de "pau e barro cobertos de palha e de raízes". Essa impressão somente se modificava diante da "limpeza", do "asseio" e da "boa ordem" que "brilhavam" na "habitação pobre e modesta" de uma família de espanhóis. O espaço da colônia parecia tal qual a colônia de Marapanim, com áreas bastante insalubres, necessitando se "aterrar trechos alagadiços” e inclusive da “abertura de caminhos” para a comunicação entre os lotes agrícolas. Nessas condições, não era de se estranhar que muitos imigrantes espanhóis não tenham ficado na colônia. Dos seus

\footnotetext{
${ }^{85}$ APEP - Repartição de Obras Públicas Terras e Colonização - Ofício $N^{\circ} 49$ - 21 de fevereiro de 1893.

${ }^{86}$ APEP - Repartição de Obras Públicas Terras e Colonização - 2 ${ }^{a}$ Secção - Ofício No 3358 - 13 de julho de 1895 .

${ }^{87}$ APEP - Repartição de Obras Públicas Terras e Colonização - Ofício No 163 - 3 de junho de 1893.

${ }^{88}$ APEP - Repartição de Obras Públicas Terras e Colonização - Ofício No 178 de 14 de junho de 1893.
} 
122 lotes, na ocasião da visita, a colônia contava com "apenas 34 famílias todas espanholas" 89

No trecho da colônia Marapanim que foi possível visitar, a situação não era tão diferente da de Monte Alegre. Logo na entrada da colônia, aguardando seguir para os lotes agrícolas, a comitiva de Paes de Carvalho se deparou com um "barracão” sem condições de acomodação e higiene, "repleto de famílias nacionais, quase todas procedentes do Ceará”. A situação daqueles futuros colonos era bastante desoladora, e não diferia em nada das descrições feitas do grupo quando ainda estava no Ceará, o que coloca em xeque a idéia da boa acolhida aos retirantes da seca, sempre tão presentes nos pronunciamentos oficiais:

"O espetáculo de toda aquela indigência reunida no barracão, aquele sem número de redes a balouçar-se por todos os cantos, as crianças suspensas no colo das mães; outras a gritarem, tudo isso impressionou-nos deveras". ${ }^{90}$

Na colônia Benjamin Constant, que à primeira vista tinha até um aspecto "bonito", com seus "158 lotes com famílias neles já colocadas" e outros à espera de mais "50 famílias", essa imagem logo se modificava quando o visitante observava as casas preparadas para receber os colonos. ${ }^{91}$ Segundo o colunista da Folha do Norte, muitos imigrantes espanhóis, ao chegaram nesse núcleo, encontraram "um lote ainda por preparar”, o que os desanimou, uma vez que eram “pouco habituados a criar novos campos cultivados através de matas”. Para completar, encontraram para morar "palhoças impossíveis". 92

Por essa descrição da colônia Benjamin Constant, torna-se muito fácil entender o "desânimo" e "grave desalento" que os migrantes apresentavam logo que chegavam a esse espaço:

“(...) cada lote tem a sua casinha para o colono. Essas casinhas são a nota feia e desoladora da colônia. Aquilo que ali está não são habitações descentes que respondam aos mais comezinhos princípios de higiene e de decência. Umas tábuas mal reunidas através das quais passam o vento e a chuva pretendem ser as paredes que sustentam uns telhados [?] inservíveis,

\footnotetext{
${ }^{89}$ Folha do Norte. Belém, 3 de maio de 1898, p. 1.

${ }^{90}$ Folha do Norte. Belém,3 de setembro de 1898, p. 1.

${ }^{91}$ Folha do Norte. Belém, 23 de julho de 1898, p. 1

${ }^{92}$ Folha do Norte. Belém, 1 de agosto de 1898, p. 1. Ainda em 1955, o geógrafo Dirceu Lino de Mattos, em viagem pela zona bragantina, comentou sobre dois elementos da paisagem que destacavam a pobreza da região: as casas e os roçados. As casas desse período, que segundo Lino de Mattos, eram caracterizadas por uma "construção frágil", talvez não diferissem tanto das dos colonos do final do século XIX. MATTOS, Dirceu Lino. "Impressões de uma viagem à zona bragantina do Pará". Boletim Paulista de Geografia, no 30 (1958), pp. 53-54.
} 
a reparar os moradores da violência do sol nas horas quentes do dia e da fúria das intempéries. Além do que constituem perigo de incêndio e depõe contra o grau de civilização que o Pará conseguiu legitimamente tornar reconhecido por todos os estrangeiros que visitam este Estado". ${ }^{93}$

Esse núcleo teve "quase que exclusivamente" imigrantes vindos da Espanha, o que justifica as afirmações anteriores do correspondente da Folha do Norte, ao esboçar preocupações com a imagem que se faria do Pará na Europa, diante do aspecto desolador da colônia, questão que sempre foi muito cara aos poderes públicos. Contudo, também viveram nesse espaço colonos cearenses, como Antonio Caetano Vianna, que tinha "uma grande zona aberta e plantada de cana, mandioca, arroz, milho e feijão”. Antonio Caetano, quando da visita de Paes de Carvalho, teria pedido ao governo "recursos para chamar para a colônia sua mulher os seus três filhos e 2 cunhados". Outros colonos cearenses ali residentes, segundo a Folha do Norte, também faziam o mesmo pedido, a fim de se juntarem a suas famílias, que estavam em Viçosa e Camocim, no Ceará. ${ }^{94}$

Em 1900, também em viagem às colônias localizadas nas cidades de Óbidos e Alenquer, o Inspetor de Terras descrevia a colônia de Óbidos, formada por "46 famílias cearenses com 202 pessoas", com casas “desocupadas e reservadas" para "duas famílias prestes a chegarem do Ceará" e que pertenciam a "famílias ali localizadas”. O mesmo acontecia com a colônia de Alenquer, que oferecia "próspero aspecto" e que, nessa ocasião, tinha "36 casas prontas para as primeiras famílias". 95 Esses indícios nos permitem dizer que se, de um lado, a vinda de migrantes para os núcleos coloniais fez parte dos projetos agrícolas dos poderes públicos, por outro, a vinda de futuros colonos para o Pará era marcada também pelas relações que os migrantes que já estavam nos núcleos coloniais mantinham com a família que havia ficado, por exemplo, no Ceará, dando conta de que, tal qual o governo paraense, esse grupos também buscavam gerir a sua vida na Amazônia.

As famílias, ao chegarem aos núcleos coloniais, deveriam receber ajuda do governo, nos primeiros seis meses, tempo que se dava para que o colono começasse a produzir. Em 1889 o Presidente da Província do Pará destacava os seguintes gastos com os colonos nos núcleos coloniais: “Alimentação, roupa, medicamento, materiais para reparos de alguns alojamentos

\footnotetext{
${ }^{93}$ Folha do Norte. Belém, 1 de agosto de 1898, p. 1.

${ }^{94}$ Folha do Norte. Belém, 3 de agosto de 1898, p. 1.

${ }^{95}$ Folha do Norte. Belém, 28 de setembro de 1900, p. 3.
} 
e construção de outros, ferramenta para o serviço de campo, utensílios e transporte de imigrantes e gêneros" além de "honorários do médico". ${ }^{96}$ Diante das situações apontadas acima, não e difícil supor o quanto esse prazo era curto para que os colonos tivessem condições de se manter sem ajuda do Estado. Conforme observou Cataruzza, em 1898, os colonos recebiam os seguintes objetos para iniciarem a sua vida quando chegavam aos núcleos coloniais:

" 1 bule, 1 caçarola, 1 chaleira, 1 cobertor, 1 concha, 1 faca de cortar, 1 pote de folha, 1 púcaro, 1 terrina, 1 alvião, 1 ferro de cova, 1 pá, 1 pedra de amolar, 2 trempes de ferro, 2 enxadas, 3 pratos travessas, 3 a 6 canecos, 3 a 6 panelas. Toda pessoa de mais de 3 anos recebe 1 par de colheres de sopa, 1 dito de chá, 1 par de pratos rasos, outro de pratos fundos, $e$ 2 redes. Toda a pessoa que tiver mais de 7 anos recebe, enfim um talher e a do sexo feminino um machado e u m terçado cada um". ${ }^{97}$

Além desses utensílios, os colonos também recebiam alimentos, fornecidos pelo governo do estado. De acordo com a Folha do Norte, os moradores da colônia de Monte Alegre, por exemplo, aqueles cuja situação de moradia era bastante desoladora, recebiam

"semanalmente (...) calculando-se as rações por adulto e por dia (...)"açúcar 800 gramas; café 300; arroz 500; bacalhau 600; batatas 1:000; carne verde: 1000; carne seca 800; feijão 600; pão 1500; azeite 1 quartilho; vinagre $\frac{1}{2} 2$ quartilho; querosene 1 quartilho, sal 1/2 litro". 98

Reveladores de hábitos alimentares dos europeus, esses alimentos expressam ainda uma preocupação maior com o adulto em idade produtiva do que com as crianças pequenas, que sempre estiveram presentes entre as famílias. Quanto às crianças, Mario Cattaruzza destaca, em uma de suas viagens com Paes de Carvalho, um número maior de mortes do que de nascimentos na colônia Benjamin Constant, explicado "pela existência do grande número de menores entre os habitantes da colônia”. Nesses espaços, não resta dúvida de que a alimentação, as condições de higiene e moradia eram fatores importantes a contribuírem com a mortalidade entre os menores. ${ }^{99}$

\footnotetext{
${ }^{96}$ Fala com que José de Araujo Roso Danin $-1^{\circ}$ Vice- presidente da Província do Pará passou a administração da mesma ao Exm. Sr. Dr. Antonio José Ferreira Braga, presidente nomeado por Dec. De 22 de julho de 1889. Pará: Typ. de A. Fructuoso Costa, 1889, p. 28.

${ }^{97}$ Folha do Norte. Belém, 3 de maio de 1898, p. 1.

${ }^{98}$ Folha do Norte. Belém, 3 de maio de 1898, p. 1.

${ }^{99}$ No século XIX, mesmo em lugares mais urbanizados como São Paulo, a mortalidade infantil é muito elevada. Ver sobre a questão: SAMARA, Eni de Mesquita. As mulheres o poder e a família. São Paulo, século XIX, pp. 46-69.
} 
Em 1916, por exemplo, dentre as denúncias feitas quanto à situação dos migrantes na região da Estrada de Ferro de Bragança, se destacava o grande número de mortes entre as crianças. Segundo um correspondente da Folha do Norte, elas viviam "à míngua de alimentação (...) maltrapilhas anêmicas e sujas”, o que levava a muitas mortes. ${ }^{100}$ Nesse mesmo ano de 1916, sem meias palavras, o jornal dizia que a fome continuava a perseguir o migrante nas terras paraenses, a ponto de um médico, que a pedido do próprio governo visitou a área da estrada de ferro, constatar que "a causa mais freqüente de mortalidade (...) eram as moléstias ligadas à nutrição". ${ }^{101}$

Ainda quanto ao fornecimento das "rações", parece que se, de um lado os poderes públicos sempre se reportaram à necessidade de mão-de-obra, por outro, sempre tiveram esses fornecimentos, que, aliás, eram previstos em lei, como um favor que prestavam ao imigrante e como um peso do qual deveriam se livrar o mais rápido possível. Em 1900, a Folha do Norte divulgava uma pequena nota sobre os gastos com as "rações das colônias do Estado", elogiando a atuação da Inspetoria de Terras na medida em que havia diminuído essas cifras. Contudo, essa informação por si só não dá conta de explicar os sucessos da produção dos núcleos e nem tão pouco revela eficiência na chegada desses fornecimentos aos núcleos coloniais.

Em agosto de 1900, a Inspetoria de Terras e Colonização, se via às voltas com denúncias quanto ao atraso no fornecimento de gêneros para a colônia Benjamin Constant. A fim de justificar-se, o Inspetor de Terras enviou um ofício ao governador do estado, onde declarava que havia remetido suprimentos necessários não só para o mês de julho, mas também "para os primeiros dias" de agosto, e que o retardo se dava em função das "irregularidades inevitáveis no serviço”. Diante das denúncias, o Inspetor de Terras busca construir uma imagem do colono como um indisciplinado, na medida em que o administrador da colônia havia lhe comunicado que “diversas famílias não queriam mais continuar na colônia” e que pediam inclusive "a sua remoção para outra”. ${ }^{102}$

\footnotetext{
${ }^{100}$ Folha do Norte. Belém, 26 de fevereiro de 1916, p. 1.

${ }^{101}$ Folha do Norte. Belém, 14 de maio de 1916, p. 1.

102 Os gêneros fornecidos aos colonos eram os seguintes: "20 barricas de açúcar, 21 sacas de café, 23 de arroz, 46 fardos de cana, 55 sacas de feijão, 34 caixas de querosene, 29 sacas de farinha, 27 caixas de sabão, 1 caixa de [...], 3 sacas de sal na importância de 16.685\$850”. Folha do Norte. Belém, 9 de agosto de 1900, p. 2.
} 
A saída dos migrantes das colônias sempre foi pensada como um problema de incapacidade do migrante de se adaptar, e não como uma falha na infra-estrutura desses espaços. Mesmo quando se constatava a falta dos meios necessários para o progresso das terras nesses lugares, se acreditava que somente com o trabalho dos migrantes esse problema poderia ser sanado. $^{103}$

As famílias, que segundo o Inspetor desejavam se retirar da colônia, haviam sido “embarcadas no Ceará especialmente destinadas para Bragança”. Seu pedido de saída do núcleo soava absurdo, como um "abuso” aos poderes públicos, uma vez que, afirmava-se, ao saírem do Ceará, sabiam "para onde vinham, o que as esperava e em que condições trabalhariam”. Quanto a seu pedido de saída, a inspetoria evocava o direito da livre circulação do migrante: “podiam sair quando quisessem”, afirmava o Inspetor de Terras. Contudo, ameaçava-as que estariam "desamparadas por sua culpa" diante da "situação difícil por elas procuradas”. 104

Depois de um longo caminho até o Pará, esses migrantes, acostumados às agruras da seca, pareciam lutar ainda mais a fim de não se permitirem uma vida de tantas dificuldades, pedindo assim uma mudança de colônia. Não sabemos se esse grupo de cearenses de fato deixou Benjamin Constant, entretanto essa atitude revela um inconformismo com uma situação que lhes era imposta.

Os poderes públicos nunca aceitaram essas atitudes de indisciplina dos colonos. Paes de Carvalho, por exemplo, mesmo depois das suas “expedições” de 1898, e de ter visto a situação dos núcleos, ainda assim caracterizava como “ultra-protecionista”o sistema de colonização no Pará, que, ao dispensar variados "favores" além de "alimentação escolhida e abundante", habituava o migrante a "far-niente". ${ }^{105}$ Além disso, um outro tipo de "delito", que sempre se evocou em relação aos migrantes era o fato de que estes, sobretudo os estrangeiros, serviam-se da "passagem" que lhes concedia o governo e faziam "visitas a

\footnotetext{
${ }^{103}$ Eugênia Égler analisando problemas na colonização da zona bragantina lembra que nos relatórios oficiais "Causas locais, como baixa fertilidade dos solos, dificuldades climáticas ou incidência de pragas na lavoura não são referidas”. ÉGLER, Eugênia Gonçalves. "A Zona Bragantina do Estado do Pará", p. 533.

${ }^{104}$ Folha do Norte. Belém, 9 de agosto de 1900, p. 2.

${ }^{105}$ Mensagem dirigida ao Congresso do Estado do Pará pelo Dr. José Paes de Carvalho governador do Estado em 1 de fevereiro de 1900. Belém: Typ do Diário Official, 1900, p. 68.
} 
parentes”, uma vez que seu “estado de pobreza” não lhes permitia. ${ }^{106}$ Essas estratégias utilizadas pelos "estrangeiros" e "sertanejos", de que tanto reclamava o governo paraense, na verdade, apontam a fragilidade do controle sobre o processo de imigração por parte do Estado, além de revelar os sentidos que os próprios migrantes e imigrantes davam aos seus deslocamentos. Estes não mediam esforços para chegarem aos núcleos coloniais, e igualmente para saírem destes, quando a vida que lhes era imposta nesses espaços não lhes agradava, ou quando decidiam seguir para um outro espaço.

Não se pode perder de vista também que a propaganda de atração ao migrante não raro transformava essas frentes de colonização em lugares bem melhores do que de fato eram. Nesse mesmo ano de 1900, é publicado o livro O Pará em 1900, destinado a apresentar o Estado do Pará a outras partes do Brasil e do exterior. Em um texto intitulado "Geografia Política do Estado do Pará”, Ignacio Moura descreve alguns trechos das vilas da Estrada de Ferro de Bragança como espaços de grande prosperidade. A colônia de Benjamin Constant, cujos colonos reclamavam das dificuldades e algumas famílias pretendiam sair é descrita como uma colônia em grande desenvolvimento com "cerca de dois mil colonos espanhóis e nacionais". Segundo o autor "o florescimento da Benjamin Constant chegou ao ponto de alguns colonos terem montado, à sua custa, engenhos para a moagem de cana dentro dos quais um movido a vapor". 107

Nesse contexto de busca de sobrevivência, as redes de solidariedade que os colonos se viam obrigados a criar também são fundamentais para pensarmos as vivências desses grupos. Em 1916, a mesma imprensa que se encarregava de noticiar a criação dessas áreas de colonização, e das ações em prol dos retirantes que aportavam em Belém, não deixava de apontar outras nuances desse processo de localização de flagelados pela seca na zona bragantina. Um correspondente da Folha do Norte escrevia diretamente do povoado de Igarapé-Assú, com uma acirrada crítica ao governo de Enéas Martins, cujo auxílio aos migrantes se limitava a "fazê-los transportar em carros de cargas e jogá-los nos povoados à margem da Estrada [Estrada de Ferro de Bragança]”. Nesses lugares, onde, de acordo com o correspondente, a vida era “caríssima”, essas pessoas se encontravam "mal abrigadas e sem

\footnotetext{
${ }^{106}$ Mensagem Dirigida pelo Senr. Goverandor Dr. Lauro Sodré ao Congresso do Estado do Pará em sua segunda reunião em $1^{\circ}$ de julho de 1892. Belém: Typ. do Diário Official, 1892, p. 22.

${ }^{107}$ MOURA, Ignácio. “Geografia Política do Estado do Pará”. In: GOVERNO DO PARÁ. O Pará em 1900, p. 178.
} 
trabalho" com que pudessem prover a sua subsistência. Os migrantes que haviam chegado nessa área com tempo de “fazer roçados e encontraram dos moradores auxílios”, apesar das dificuldades, viviam de maneira menos precária. Entretanto, outros viviam em péssimas condições, morrendo inclusive de fome, uma vez que os moradores locais, que "há muitos meses" viviam de “distribuir esmolas”, não tinham mais "recursos para beneficiar a tantos necessitados”. 108

Alguns meses depois dessas denúncias, em maio de 1916, a situação não era diferente e um articulista da Folha do Norte escrevia que os flagelados pela seca, instalados na Estrada de Ferro de Bragança, em localidades como Benevides, Santa Izabel, Castanhal e São Luiz, "talvez fossem menos desventurados na terra natal”, diante do "cruel desamparo" em que se encontravam. Se valiam para sobreviver quase sempre da "caridade espontânea". 109

As graves denúncias que a Folha do Norte trazia aos seus leitores, se de um lado remetem a uma pesada crítica política ao governo de Enéas Martins, por outro, revelam que nessas frentes de produção agrícola a sobrevivência dos migrantes dependia grandemente das redes de solidariedade dos colonos já instalados. Considerando as parcas "rações" patrocinadas pelo governo, é provável que até que a família recém-chegada pudesse plantar o seu próprio roçado e dele extrair seus frutos, ficasse na dependência dos seus conterrâneos.

\section{Produção}

Não resta dúvida de que a principal função reservada aos colonos que viviam nesses núcleos coloniais era a produção agrícola. Não é exagero, inclusive, dizer que essa era a própria razão de ser dessas frentes de colonização. Se, nos discursos dos poderes públicos, a falta de braços para a lavoura aparece como um entrave a seu desenvolvimento, lugar comum são também as críticas que os próprios poderes públicos fizeram às formas do colono lidar com a terra. Desse modo, ao falarem da lavoura, essa é tida em boa parte das Mensagens dos poderes públicos como feita com processos de plantio muito rudimentares. Expressões como

\footnotetext{
${ }^{108}$ Folha do Norte. Belém, 26 de fevereiro de 1916, p. 1.

${ }^{109}$ Folha do Norte. Belém, 14 de maio de 1916, p. 1.
} 
“atrasadíssima lavoura”, “estacionária nos tempos colônias”, povoam os relatórios oficiais, caracterizando a atividade e, por conseguinte, o colono que cuidava dessa terra. ${ }^{110}$

Compreende-se por esse pensamento um preconceito que recaía sobre o colono, na medida em que só a seus métodos era imputado o fracasso da lavoura. ${ }^{111}$ Para se ter uma idéia disso, uma boa leitura são as observações feitas pelo auxiliar científico da secção botânica do Museu Goeldi, C. F. Baker, que em 1907, elaborou um relatório sobre as plantações de tabaco na região de Irituia. Segundo Baker, plantava-se tabaco por métodos "primitivos", desprezandose a terra depois da colheita, sem a aproveitar para outras culturas. Ainda segundo o professor Baker, nessa região, “charruas, grades e cultivadores” eram instrumentos agrícolas “desconhecidos”. Para completar sua análise, a fim de demonstrar o quão arcaicas eram as formas de produção, Baker afirmava que em Irituia, os métodos agrícolas pareciam "ser mais ou menos os mesmos que existiam entre os índios, antes da chegada dos brancos”. ${ }^{112}$

A julgar por essas informações, não nos parece que nos núcleos coloniais as práticas agrícolas fossem muito mais desenvolvidas que estas. Se tomarmos como referência as ferramentas que o governo dava aos colonos quando chegavam ao núcleo, não fíca muito difícil imaginar como eram ainda bastante limitados os métodos empregados para o amanho da terra.

${ }^{110}$ Essas expressões são encontradas respectivamente nas seguintes Mensagens: Mensagem dirigida ao Congresso do Estado do Pará pelo Dr. José Paes de Carvalho Governador do Estado em 15 de Abril de 1899 apresentando a proposta de orçamento da receita e despesa para o exercício de 1899-1900. Belém: Typ. do Diário Oficial, 1899, p. 24. Mensagem dirigida ao Congresso do Estado do Pará pelo Dr. José Paes de Carvalho governador do Estado em 1 de fevereiro de 1900. Belém: Typ do Diário Official, 1900, p. 69.

${ }^{111}$ Antonio Rocha Penteado destaca que com "o extrativismo desenfreado e as queimadas as roças (...) passaram a substituir as primitivas matas da Região Bragantina" transformando-as numa paisagem de "capoeiras raquíticas". "Os mesmos processos agrícolas conhecidos no nordeste foram repetidos na região 'e o machado e caixa de fósforo' simbolizavam bem esta agricultura predatória”. PENTEADO. Antonio Rocha. Problemas de colonização e de uso da terra na região Bragantina do Estado do Pará, vol. I, p. 139. Enumerando vários problemas na colonização da zona Bragantina Roberto Santos afirma que "o colono que chegou do Nordeste não passava por nenhum treinamento ou seleção. Ainda que sem consciência disso logo se tornava um fazedor de deserto” em função das queimadas feitas para a plantação. SANTOS, Roberto. História econômica da Amazônia (1800-1920), p. 105.

112 "Relatório sobre uma viagem a Irituia, apresentado ao Diretor do Museu pelo Porfessor C.F. Baker, M.A. Auxiliar científico da secção botânica do Museu Goeldi”. In: Mensagem dirigida em 7 de setembro de 1908 ao Congresso Legislativo do Pará pelo Dr. Augusto Montenegro Governador do Estado. Belém: Imprensa Official do Estado do Pará, 1908, pp. 218-219. 
Em 1898, por ocasião das visitas de Paes de Carvalho, a Folha do Norte apresentava a seus leitores, através das notícias enviadas por seu correspondente, o que se produzia nos diversos lugares por onde a comitiva do governador passava. Considerando, as dificuldades enfrentadas para essa produção, é de admirar-se o que se fez na colônia Tajury, que tinha “vistosas e opulentas plantações de milho", plantações de café, "abundante plantação de cacau”, além de "feijões de tipos diferentes", tabaco, mandioca, cana de açúcar, algodão e também "uma criação de galinhas bastante numerosa". ${ }^{113}$ Em Benjamin Constant, além de plantações de tabaco e mandioca, milho, feijão, arroz, cacau, laranjeiras, café, batatas, bananeiras, cana-de-açúcar e "grande variedade de legumes", o correspondente da Folha do Norte foi surpreendido por um "gracioso jardim em flor". ${ }^{114}$

A produção das colônias era praticamente a mesma. Em 1900, na colônia Inhangapy, “entregue a trabalhadores cearenses" que tinham "gosto pela lavoura” e que enfrentavam as “mais duras tarefas rurais”, era possível ver-se, de acordo com um jornalista que a visitou, "belas plantações de mandioca, de cana, de arroz, de tabaco". ${ }^{115}$ Nesse mesmo ano, na colônia do Acará, o Inspetor Geral de Terras e Colonização, observava que esse núcleo, com 35 casas, tinha vários “lotes prontos para receberem imigrantes”, escolhidos entre cearenses que "esperavam” em Fortaleza. Os colonos já residentes plantavam mandioca, cana, arroz, batata. Segundo o Inspetor, essa colônia era “aproveitadíssima”, uma vez que bem próximo às casas dos colonos, existiam igarapés que forneciam "água sã e boa a todos”. ${ }^{116}$

Ainda seguindo a trilha da viagem de Paes de Carvalho em 1898, também em Monte Alegre, é possível perceber uma vida doméstica com hábitos de cordialidade e sociabilidade (como no caso dos jardins e criações de galinhas já citados), que iam sendo gestados no meio da mata, a exemplo de "uma chávena de café”, servida à comitiva do governador por uma família, e das preocupações com a organização das choupanas em que os imigrantes moravam, descritas como de uma "limpeza holandesa”. Em uma dessas casas, foram observados pelos visitante adornos em tecido “bordados”, feitos por uma moça espanhola,

\footnotetext{
${ }^{113}$ Folha do Norte. Belém, 3 de maio de 1898, p. 1

${ }^{114}$ Folha do Norte. Belém, 2 de agosto de 1898, p. 1 e Folha do Norte. Belém, 4 de agosto de 1898, p. 1

${ }^{115}$ Folha do Norte. Belém, 10 de julho de 1900, p. 1.

${ }^{116}$ Folha do Norte. Belém, 17 de julho de 1900, p. 1.
} 
“normalista diplomada pela Universidade de Salamanca”, que de tão belos, segundo o correspondente da Folha do Norte, eram "dignos de brilhar em aposentos menos humildes". ${ }^{117}$ Embora elogioso, o comentário parece tratar a beleza como coisa fora do lugar, como algo que deveria restringir-se a um outro espaço que não o dos núcleos coloniais provavelmente.

A preocupação do colono em manter em seu lote agrícola elementos como galinhas, jardins, árvores frutíferas, água próxima às casas, bem como a limpeza e até a ornamentação de miseráveis choupanas sugerem um interesse em fixação na terra, e igualmente a construção de uma vida doméstica que, a duras penas, ia se consolidando nessas frentes de colonização. Por outro lado, aponta para o fato de que, preocupados com uma produção em larga escala, importante, sobretudo, para o abastecimento da cidade de Belém, os poderes públicos sentiam-se frustrados, diante do investimento feito, com uma produção que, nos primeiros anos, mal dava para a subsistência dos próprios colonos, não percebendo a importância da pequena produção e não deixando assim de apontar, em seus pronunciamentos, os fracassos dessa produção agrícola, sempre tão decantados em estudos sobre o tema. ${ }^{118}$

O quadro abaixo nos permite visualizar o número de colonos envolvidos com trabalhos na lavoura em 1900. ${ }^{119}$ Note-se que muitas colônias já não recebiam auxílio do estado, uma vez que produziam e eram consideradas emancipadas. Além disso, é possível percebermos a presença de imigrantes estrangeiros e nacionais nesses espaços. Um outro aspecto, do qual falaremos a seguir, são os chamados burgos agrícolas, que eram empreendimentos de iniciativa particular.

\footnotetext{
${ }^{117}$ Folha do Norte. Belém, 3 de maio de 1898, p. 1.

118 Em 1877 por exemplo, o Presidente da Província queixava-se de que dois anos depois de inaugurada a colônia Benevides produzia em "tão pequena escala que nenhum proveito tem auferido de modo a tornar seguro e independente o seu viver". Fala com que o Dr. João Capistrano Bandeira de Mello Filho abrio a $2^{\mathrm{a}}$ sessão da $20^{\circ}$ Legislatura da Província do Pará em 15 de fevereiro de 1877, p. 159. Podemos citar nesse sentido: PENTEADO. Antonio Rocha. Problemas de colonização e de uso da terra na região Bragantina do Estado do Pará, vol. I, 1967; e SANTOS, Roberto. História econômica da Amazônia (1800-1920).

119 "Imigração no Pará". Dados apresentados no jornal Folha do Norte e colhidos em "fonte oficial". Folha do Norte. Belém, 16 de agosto de 1900, p. 1.
} 


\begin{tabular}{|c|c|c|c|c|}
\hline Colônia & Fundação & Emancipação & Famílias & Outras informações \\
\hline Jambuassú & 1895 & 1900 & $\begin{array}{l}189 \text { brasileiros, } 1149 \text { pessoas } \\
135 \text { espanhóis, } 647 \text { pessoas } \\
2 \text { portugueses, } 10 \text { pessoas }\end{array}$ & \\
\hline Monte Alegre & 1896 & 1900 & $\begin{array}{l}57 \text { brasileiros, } 310 \text { pessoas } \\
53 \text { espanhóis, } 248\end{array}$ & \\
\hline Benjamin Constant & 1896 & 1900 & $\begin{array}{l}383 \text { brasileiros, } 1945 \text { pessoas } \\
191 \text { espanhóis, } 950 \text { pessoas }\end{array}$ & \\
\hline Marapanim & 1896 & 1900 & $\begin{array}{l}118 \text { brasileiros, } 708 \text { pessoas } \\
68 \text { espanhóis, } 405 \text { pessoas }\end{array}$ & \\
\hline José de Alencar & 1898 & - & $\begin{array}{l}212 \text { brasileiros, } 1292 \text { pessoas } \\
3 \text { espanhóis, } 13 \text { pessoas }\end{array}$ & $\begin{array}{l}\text { Desmembrada da colônia de } \\
\text { Marapanim em } 1898\end{array}$ \\
\hline Inhangapy & 1898 & 1900 & 117 brasileiros, 711 pessoas & \\
\hline Santa Rosa & 1898 & - & $\begin{array}{l}74 \text { brasileiros, } 458 \text { pessoas } \\
104 \text { espanhóis, } 624 \text { pessoas } \\
1 \text { alemão, } 3 \text { pessoas }\end{array}$ & \\
\hline Ferreira Penna & 1899 & - & $\begin{array}{l}52 \text { brasileiros, } 330 \text { pessoas } \\
34 \text { espanhóis, } 145 \text { pessoas, }\end{array}$ & \\
\hline Anita Garibaldi & 1898 & 1900 & $\begin{array}{l}\text { 124, brasileiros } 746 \text { pessoas } \\
25 \text { espanhóis, } 131 \text { pessoas } \\
7 \text { italiano, } 37 \text { pessoas } \\
1 \text { belga, } 3 \text { pessoas }\end{array}$ & $\begin{array}{l}\text { Contrato rescindido em janeiro de } \\
1900 \text { com Mario Cattaruzza. }\end{array}$ \\
\hline Yanetama & 1899 & - & $\begin{array}{l}89 \text { brasileiros, } 502 \text { pessoas } \\
7 \text { espanhóis, } 32 \text { pessoas } \\
3 \text { italianas, } 14 \text { pessoas }\end{array}$ & $\begin{array}{l}\text { Contratado rescindido com } \\
\text { Salvador Nicóssia }\end{array}$ \\
\hline
\end{tabular}




\begin{tabular}{|l|c|c|l|l|}
\hline \multicolumn{1}{|c|}{ Colônia } & Fundação & Emancipação & \multicolumn{1}{|c|}{ Famílias } & \multicolumn{1}{|c|}{ Outras informações } \\
\hline Couto de Magalhães & 1899 & - & $\begin{array}{l}3 \text { brasileiros, 16 pessoas } \\
15 \text { espanhóis, 58 pessoas }\end{array}$ & \\
\hline Salvaterra & 1898 & 1900 & 42 brasileiros, 226 pessoas & \\
\hline Núcleo Modelo & 1898 & - & $\begin{array}{l}8 \text { espanhóis, 29 pessoas } \\
\text { italiana, 7 pessoas } \\
1 \text { portugueses, 5 pessoas }\end{array}$ & \\
\hline Acará & - & - & 7 brasileiros, 35 pessoas & Núcleo Suburbano \\
\hline Óbidos & - & - & 48 brasileiros, 232 pessoas & \\
\hline Monsarás & - & - & - & Núcleo suburbano \\
\hline Cametá & - & - & - & Núcleo Suburbano \\
\hline Alenquer & - & - & - & Núcleo suburbano \\
\hline S. Antonio de Maracanã & - & - & 23 brasileiros, 108 pessoas & “Na aldeia do Prata” \\
\hline Granja América & - & - & 30 brasileiros, 176 pessoas & Burgo Agrícola \\
\hline Marapanim & - & - & - & Burgo Agrícola \\
\hline Itacayunas & - & - & - & Burgo Agrícola \\
\hline Santa Rita do Caranan & - & - & - & Burgo Agrícola \\
\hline
\end{tabular}


Ao lado dos projetos custeados pelo governo, como os núcleos coloniais, os migrantes se inseriram nessas frentes de colonização em empreendimentos agrícolas financiados por proprietários particulares, que assinavam contratos com o Estado, a fim de desenvolverem com algum tipo de produção áreas ainda pouco exploradas. Dentre essas atividades, podemos destacar os engenhos para moagem de cana e fabricação de aguardente, iniciativas de produção caracterizadas pela policultura, e até mesmo a extração de granito, descrita por Rocha Moreira.

Nesse contexto, em 1893, o engenho da colônia Castanhal era arrendado por 10 anos para dois investidores que pretendiam, ao que tudo indica, se instalar nessa região. Ao avaliar a proposta de Philadelpho de Oliveira Conduru e Julio Christo, o diretor da Repartição de Obras Públicas, Terras e Colonização julgava que, "somente sob administração particular”, poderia a produção dessa colônia se desenvolver. Quando assinou o arrendamento do engenho, entretanto, o Diretor lembrou que deveriam ser protegidos "os interesses dos agricultores estabelecidos naquela localidade", tabelando-se os preços dos produtos da serraria e igualmente da aguardente que os colonos fabricavam. ${ }^{1}$ Percebe-se que, independentemente dessa iniciativa privada, o núcleo já tinha migrantes produzindo. Provavelmente, eram remanescentes da seca de 1889, que haviam se instalado nessa localidade quando se iniciavam os trabalhos de sua infra-estrutura. A preocupação com os colonos sugere que esses já tinham um domínio sobre essa terra, e que mudanças na forma de produção poderiam acarretar problemas. A Diretoria de Obras Públicas parecia querer evitá-los, do contrário, não faria muito sentido a preocupação com as possíveis perdas dos colonos.

Situação semelhante pode ser percebida em relação a um pedido, dirigido ao governador do estado e depois encaminhado à Repartição de Obras Públicas, de “diversos cidadãos” que requeriam "terrenos na estrada de ferro de Bragança”. As petições feitas deveriam ser atendidas por recomendação do governador, "sem prejuízos dos trabalhos anteriores (...) a bem dos interesses da colonização". Tal qual no caso do arrendamento do engenho de Castanhal, essas novas atividades pretendidas para a outra área não poderiam entrar em choque com os trabalhos dos colonos já fixados na terra a partir da iniciativa do governo paraense, supostamente para evitar conflitos. Mesmo quando essa colônia foi emancipada, em

\footnotetext{
${ }^{1}$ Repartição de Obras Públicas Terras e Colonização - Oficio No 109 - 12 de setembro de 1893. Repartição de Obras Públicas Terras e Colonização - Ofício No 111 - 15 de setembro de 1893.
} 
1893, ainda permaneceu uma preocupação com a manutenção da "garantia dos colonos”, o que se explica em parte por "forte corrente de vida que manifestou-se para a povoação". ${ }^{2}$

Em 1898, Paes de Carvalho visitou uma fazenda, a "Santo Antonio", com 1.180 hectares, nas duas margens do rio Quatipuru, que ficava distante quatro léguas e meia de Bragança, cujos proprietários a exploravam “há mais de trinta anos”. Seu principal produto era o tabaco, "entregue a 38 famílias de colonos, 21 cearenses e 17 espanhóis”, que eram empregados da fazenda. Cuidavam aproximadamente de 10 mil pés de tabaco. Nessa fazenda, os migrantes recebiam "o terreno e a casa”, cultivavam a terra, trabalhando por "conta própria" e “vendendo à casa Pereira Irmãos \& $C^{a}$ todo o produto de seus lotes”. Esse tipo de trabalho foi entendido pelo correspondente da Folha do Norte como um empreendimento que permitia a prosperidade dos migrantes, uma vez que ali havia um colono que possuía “avultada quantia de 50 contos ganhos no cultivo do tabaco". ${ }^{3}$ No texto publicado pelo jornal não se fala em que bases se sustentavam os contratos entre os colonos e os donos da fazenda. Há, entretanto, a obrigatoriedade de venda da produção para os proprietários das terras, o que certamente criava redes de dependência e de poder. Por outro lado, em espaços com tantas terras devolutas, que de acordo com o Estado deviam ser colonizadas e povoadas, esses colonos, reforçando a idéia das dificuldades enfrentadas para a colonização, se viam na contingência de dependerem de um grande proprietário para produzirem.

Um outro empreendimento de iniciativa privada, que muito chamou atenção de Paes de Carvalho, foi o burgo Marapanim, situado às margens da Estrada de Ferro de Bragança. Bem diferente da colônia Marapanim - onde quase não havia "vestígios de cultivação”, conforme constatou a comitiva de Paes de Carvalho $^{4}$-, esse burgo com uma superfície de 36 quilômetros quadrados, foi descrito pelo colunista da Folha do Norte como "soberbo espécimen de agricultura nessa região”. Essa pujança das plantações era entendida como resultado de "capital inteligentemente empregado". 5

\footnotetext{
${ }^{2}$ Conselho Municipal de Cultura - Relatório Apresentado pelo Diretor de Obras Públicas Terras e Colonização, Henrique A. Santa Rosa In: Relatório Apresentado ao Sr. Governador do Estado do Pará. Dr.Lauro Sodré pelos chefes das repartições estaduais. Belém: Typ do Diário Oficial, 1894, p. 296.

${ }^{3}$ Folha do Norte. Belém, 8 de agosto de 1898, p. 1.

${ }^{4}$ Folha do Norte. Belém, 3 de setembro de 1898, p. 1.

${ }^{5}$ Folha do Norte. Belém, 5 de setembro de 1898, p. 1.
} 
Buscando demonstrar a importância desse empreendimento particular - e talvez, até com o fim de incentivar outras famílias a se dedicarem com afinco ao amanho da terra -, o correspondente da Folha do Norte destacava o caso de uma "família de imigrantes cearenses”, que do trabalho da exploração nesse burgo, já teria se emancipado e se tornado "proprietária do solo", fazendo inclusive "algumas economias". Para os observadores desse burgo, que tinha o "aspecto simpático de uma vilasinha”, o auxílio prestado aos colonos que na sua maior parte eram “antigos imigrantes de há muito estabelecidos nessa zona”, e já dispunham de "algumas economias" - pelos proprietários era fundamental para seu desenvolvimento. Além disso, um outro fator de atração de imigrantes eram a "ordem, o bom sistema, e a seriedade de sua administração". ${ }^{6}$

Essas impressões do colunista da Folha do Norte sobre o "burgo agrícola de Marapanim” reforçam a questão de possíveis conflitos entre tais projetos de iniciativa particular e os pequenos lavradores, notadamente imigrantes, já estabelecidos na região. Com investimento de capitais, no caso do burgo "agrícola de Marapanim”, que teve "uma escritura mercantil de 200 contos de réis”, não resta dúvida de que esses investidores tinham interesse em logo auferir lucros a partir da produção. ${ }^{7}$ Nesse caso, a solução encontrada foi a utilização de colonos locais no empreendimento. Isto sugere que, diante das dificuldades enfrentadas para produzirem em seus próprios lotes nos núcleos coloniais, muitos agricultores se viam obrigados a deixar de trabalhar em sua própria terra, para se tornarem empregados desses grandes proprietários.

Embora não tenhamos maiores elementos sobre a questão, as preocupações dos poderes públicos quando do arrendamento do engenho de Castanhal e a utilização da mão-de-obra de imigrantes na "fazenda Santo Antonio" e no "burgo agrícola de Marapanim” são boas pistas para pensarmos sobre a formação de grupos de trabalhadores rurais que, numa região de extensas áreas a serem cultivadas, não eram proprietários de suas terras, mas lavradores das terras de outros que, com maiores investimentos, também buscavam se firmar nessas frentes de colonização e povoamento, a exemplo da chamada zona bragantina.

Nesse contexto, entretanto, não se pode pensar em um exclusivismo da produção agrícola em contraposição ao extrativismo da borracha por exemplo, sempre tão idealizado pelos

\footnotetext{
${ }^{6}$ Folha do Norte. Belém, 5 e setembro de 1898, p. 1.

${ }^{7}$ Folha do Norte. Belém, 5 de setembro de 1898, p. 1.
} 
poderes públicos paraenses. A região cortada pela Estrada de Ferro de Bragança teve na extração desordenada de madeiras uma das fontes de produção. ${ }^{8}$ Essa atividade assumiu quase a mesma importância que a agricultura e ocupou muitos migrantes nacionais e imigrantes estrangeiros, uma vez que essa indústria apresentava, pela sua própria natureza, resultados mais imediatos.

Ainda em 1886, o presidente da Província do Pará, Tristão de Alencar Araripe, nas suas “informações para os imigrantes" que desejassem se estabelecer no Pará, além de apontar as muitas vantagens que eles teriam no Brasil, como os seus “direitos respeitados” e com o amparo e "proteção das leis", advertia-os quanto às melhores "indústrias recomendáveis aos imigrantes": a agricultura e a criação de animais, como vacas, carneiros, galinhas. Por essa ótica, a dedicação a outras atividades, como o "corte e serragem de madeiras”, somente deveria ocorrer quando ao imigrante fosse "antipática a vida rural". ${ }^{10}$ Não foi por mero acaso que a epígrafe inicial desse trabalho era um trecho de Louis Agassiz, em que esse naturalista exortava a fertilidade e a salubridade do "magnífico vale do Amazonas" e que, por essas qualidades, deveria ser o "foco de uma numerosa imigração". 11

Provavelmente, muito mais pelas dificuldades experimentadas nos núcleos coloniais da Estrada de Ferro de Bragança do que por uma antipatia à vida rural, alguns anos depois das recomendações de Tristão de Alencar Araripe, muitos colonos dessa região se dedicavam exatamente à indústria extrativa da madeira. Num tempo em que trens e fogões eram movidos a lenha e numa área de povoamento onde tudo estava sendo feito, como a construção de casas e de mobiliário, não faltavam compradores para os colonos envolvidos com esse extrativismo. Em 1889, por exemplo, um deputado, requeria, através da Assembléia Legislativa Provincial, informações do Diretor da Estrada de Ferro de Bragança a respeito de pagamento de passagens e dos "fretes dos carros de condução de madeira e outros produtos". Embora tal

\footnotetext{
${ }^{8}$ Roberto Santos referindo-se a região bragantina em finais do século XIX enfatiza que "com $o$ crescimento demográfico da capital (...) o suprimento alimentar e de lenha passou a constituir-se um problema sério. Surgiu então a idéia de usar a enorme área como a zona de agricultura de alimentos e de obtenção de lenha”. SANTOS, Roberto. História econômica da Amazônia (1800-1920), p. 103.

${ }^{9}$ Dados Estatísticos e Informações Para os Imigrantes. Publicado por ordem do Exm. Sr. Conselheiro Tristão de Alencar Araripe, Presidente da Província do Pará. Pará: Typ. do Diário de Notícias, 1886, p. 151.

${ }^{10}$ Ibidem, pp. 178-180.

${ }^{11}$ Ibidem, p. 1.
} 
solicitação possa até sugerir algum tipo de irregularidade na cobrança das passagens, chama atenção aqui o transporte de madeiras como uma atividade de destaque. ${ }^{12}$

À medida que cresceu o povoamento nas margens da Estrada de Ferro de Bragança, cresceu também a extração de madeira como uma lucrativa fonte de renda. O núcleo colonial de Marapanim é modelar nesse sentido, o que pode ser percebido, através da descrição da visita de Paes de Carvalho a essa parte da ferrovia. O "abandono" desse núcleo era creditado aos colonos espanhóis, que preferiram “dedicar-se à exploração de madeira” que era muito “abundante nos lotes”, deixando de se aplicarem aos trabalhos agrícolas, segundo teria declarado ao governador Paes de Carvalho o diretor do núcleo. ${ }^{13}$ A situação do núcleo deixou o governador e sua comitiva indignados. E o correspondente da Folha do Norte, numa espécie de desabafo, escreve aos seus leitores:

"os espanhóis derrubam a seu talante, as matas tiram o melhor das suas riquíssimas madeiras põem-nas à venda e zombando das obrigações assinadas, transformam-se de agricultores em exploradores e negociantes de madeira". ${ }^{14}$

A impressão que se tem à chegada de Paes de Carvalho à colônia Marapanim é de um desapontamento causado justamente pelo desconhecimento da situação dos colonos e de suas atividades. Ao mesmo tempo que os poderes públicos buscavam manter um controle do povoamento, não raro se descuidavam dessa fiscalização abrindo brechas para que os colonos tomassem o rumo que melhor lhes aprouvesse. Em 1895, por exemplo, diante da ausência de verbas para o serviço de “fiscalização de terras públicas”, sobrecarregava-se um único funcionário para a verificação de "toda a zona da Estrada de Ferro de Bragança e ramal de Salinas". ${ }^{15}$ Por problemas como esse e diante do árduo trabalho, em áreas que antes da colonização eram apenas matas, não é de se admirar o pouco empenho de muitos colonos com a lavoura. Por outro lado, a não fixação na terra com o trabalho agrícola sugere, ainda, um desejo de retorno à terra natal, que poderia ser assegurado com maior rapidez com os rendimentos do extrativismo da madeira.

\footnotetext{
${ }^{12}$ Palácio da Presidência da Província. Oficio No 1105 - 4 secção - 12 de março de 1889.

${ }^{13}$ Folha do Norte. Belém, 3 de setembro de 1898, p. 1.

${ }^{14}$ Folha do Norte. Belém, 3 de setembro de 1898, p. 1.

${ }^{15}$ Repartição de Obras Públicas Terras e Colonização - $3^{\text {a }}$ Secção - Ofício 3335 - 10 de julho de 1895.
} 
Há uma retórica do governador e da imprensa, que trata os colonos como dotados de uma missão povoadora, espécie de redenção do Pará. Não se pode perder de vista entretanto, que eles estavam querendo ganhar a vida, quer plantando, quer praticando diferentes tipos de extrativismo. Nesse sentido, se de um lado a imposições de normas de outro lado os colonos procuravam gerir a sua sobrevivência, bem como os seus anseios de vida no Pará.

A atividade de extração da madeira tornou-se tão importante na zona da estrada de ferro, em detrimento da agricultura, a ponto de em 1900, o governo proibir o "embarque de madeira nos quilômetros $n^{\circ}$ 85, 87, 89 e 91", justamente para "evitar que os colonos de Marapanim" se ocupassem "quase que exclusivamente" dessa atividade, conforme divulgava a Folha do Norte na coluna "Ecos e Notícias". ${ }^{16}$ Essa medida, certamente, não foi vista com bons olhos pelos colonos envolvidos com o extrativismo da madeira, gerando algum tipo de protesto. Menos de um mês depois desse ato do governo, a Folha do Norte anunciava a seus leitores um grave acidente de trem, provocado supostamente por um "descarrilamento criminoso", em virtude de "diversos toros de madeira" que propositadamente "haviam sido lançados na linha por colonos”. O jornal não atestava a veracidade do fato, advertindo que se presumia que o lamentável acidente, que deixou vários feridos e inclusive mortos, teria sido planejado em "desforço" pela medida tomada pelo governo, que proibira o "embarque de madeiras procedentes daquela colônia”. ${ }^{17}$

Até onde pudemos apurar desse fato, sabemos apenas que seria aberto um inquérito policial para investigações. Não temos maiores informações sobre o episódio. Contudo, podemos fazer algumas observações. A primeira delas é que, se de fato o descarrilamento do trem fora provocado por colonos que se sentiam prejudicados em seus negócios, temos indícios claros de um constante embate entre os poderes públicos e os colonos, que não se furtaram da utilização de meios violentos para expressarem seu descontentamento nessas frentes de colonização. Um outro aspecto que não pode ser desconsiderado, e que talvez seja complementar a este, são os possíveis conflitos entre migrantes nacionais, notadamente cearenses, e imigrantes estrangeiros, no caso os espanhóis, uma vez que aqueles aparecem como mais identificados com o trabalho agrícola do que estes. Note-se que nos vagões que descarrilaram, ao que tudo indica, viajavam migrantes cearenses e do Rio Grande do Norte,

\footnotetext{
${ }^{16}$ Folha do Norte. Belém, 20 de agosto de 1900, p. 2.

${ }^{17}$ Folha do Norte. Belém, 1 de setembro de 1900, p. 2.
} 
ocupados nessa área como funcionários da ferrovia, a exemplo do foguista que veio a falecer, que era natural de Ceará Mirym, no Rio Grande do Norte, e de um menor, cearense de 14 anos, cuja mãe residia em Belém, que "ia à venda de bananas em Jambuassú". ${ }^{18}$ As zonas de povoamento e colonização não deixaram de ser palco de conflitos que tiveram como cerne da questão a posse da terra.

Quanto à extração de madeira, tal qual o correspondente da Folha do Norte, em 1901, o governador, ao fazer um balanço das atividades dos núcleos coloniais, afirmava que a colônia Marapanim “atrasou-se por algum tempo em sua lavoura” em função de seus colonos, que ocuparam-se grandemente da extração da madeira. Lembrava então que havia tomado medidas nesse sentido, a fim de "evitar esta devastação tão prejudicial às nossas florestas", e igualmente que havia se normalizado a vida da colônia, que marchava "como as outras, entregue à faina agrícola". ${ }^{19}$ É possível que os olhares aparentemente atentos dos poderes tenham provocado alguma mudança no corte e na negociação da madeira, mas nada que provocasse grandes transformações na forma de se lidar com a produção agrícola. ${ }^{20}$ Não sem razão, em 1908, o governador Augusto Montenegro diante da pequena produção agrícola advertia:

"Ide a um de nossos lotes coloniais e nada neles vereis que aconselhe a quem quer que seja a procurar, na cultura do solo, a vida desembaraçada e sã que deve ser aspiração das nossas populações rurais". ${ }^{21}$

O registro de Augusto Montenegro, escrito oito anos depois da proibição do comércio de madeiras na colônia Marapanim, explica um pouco do caminho seguido por muitos extratores de madeiras nos núcleos coloniais. Essa foi uma atividade muito presente em várias localidades do Pará. Em 1915, o engenheiro Algot Lange, embora não se referindo

\footnotetext{
${ }^{18}$ Folha do Norte. Belém, 1 de setembro de 1900, p. 2.

${ }^{19}$ Mensagem dirigida ao Congresso do Estado do Pará pelo Dr. José Paes de Carvalho, Governador do Estado em 1 de fevereiro de 1901. Belém: Imprensa Oficial, 1901, p. 74.

${ }^{20}$ Acerca da paisagem da zona bragantina Mattos lembrava em 1958 que "a devastação da mata, na região bragantina vem se processando desde há muitas décadas. É natural que um período tão longo de exploração dos recursos florestais e derrubadas e queimadas para a prática da agricultura tenha reduzido esta região da Hiléia a uma paisagem vegetal menos rica e exuberante que a das regiões onde dominam as florestas". MATTOS, Dirceu Lino. "Impressões de uma viagem à zona bragantina do Pará", p. 45-46.

${ }^{21}$ Mensagem dirigida em 7 de setembro de 1908 ao Congresso Legislativo do Pará pelo Dr. Augusto Montenegro Governador do Estado. Belém: Imprensa Official do Estado do Pará, 1908, p. 53.
} 
exatamente à região bragantina, em artigos publicados na Folha do Norte, apontava a necessidade de se desenvolver o comércio de exportação de madeiras com os EEUU, uma vez que não raro a madeira amazônica era recusada nesse país, em virtude do péssimo estado em que chegava ao destino. O fracasso desse comércio, segundo o engenheiro, era “culpa” do comerciante, que mandava “o mateiro derrubar a madeira (...) numa estação imprópria”, o que causava uma "deterioração gradual” dos toros, inutilizando-os. ${ }^{22} \mathrm{O}$ engenheiro concluía que esse problema era fruto da "ignorância dos exportadores". 23

Não ficam muito claros os interesses do engenheiro com a exportação da madeira. Suas informações, entretanto, demonstram a força que essa atividade extrativa tinha, na medida em que era visada inclusive por um mercado internacional. Além disso, as observações de Algot Lange apontam uma retirada indiscriminada de madeira que, além do desmatamento causado por métodos inadequados, acabava nem sendo negociada. Esse problema talvez não tenha se dado na zona bragantina, uma vez que a madeira extraída era vendida em boa parte como lenha para a ferrovia, o que indica, entretanto, uma grande contradição. O mesmo Estado que combatia o desmatamento servia-se dele para o funcionamento de sua ferrovia.

Note-se que em 1914, quando de sua visita às jazidas de granito de Quatipuru, o literato Rocha Moreira, descrevendo essa viagem, não deixa de fazer referência a Ananindeua, povoado fronteiriço a Belém, que ele já conhecia em função de "sua grande serraria” e de "seu igarapé de água cristalina”, o que demonstra que o corte de madeiras nessa região se manteve como uma atividade importante para seus moradores. ${ }^{24}$ Do mesmo modo, em 1916, quando da visita de Hannibal Porto, representante da Sociedade Nacional de Agricultura, ao Pará, em um estabelecimento "industrial agrícola”, espécie de modelo de atividades agrícolas promissoras, e que possuía “aperfeiçoados maquinismos” para beneficiamento de arroz, milho, algodão, açúcar, não de deixou de fazer referências a uma serraria como um dos empreendimentos importantes da "Granja Eremita" ${ }^{25}$ Isso reforça o pensamento de que mesmo em estabelecimentos com próspera produção, o extrativismo da madeira, diante da

\footnotetext{
${ }^{22}$ Folha do Norte. Belém, 12 de janeiro de 1915, p. 1.

${ }^{23}$ Folha do Norte. Belém, 25 de janeiro de 1915, p. 2.

${ }^{24}$ Folha do Norte. Belém, 10 de agosto de 1914, p. 1.

${ }^{25}$ Folha do Norte. Belém, 6 de janeiro de 1916, p. 1.
} 
grande área de matas nativas nas frentes de colonização, era uma atividade tão importante quanto a agricultura.

Se as preocupações com uma produção diária, fosse ela extrativista ou agrícola, marcam a vida dos migrantes e imigrantes da chamada zona bragantina, no mesmo contexto dessas relações, constroem-se também outras práticas sociais, a exemplo de conflitos entre os variados grupos que viviam nesse espaço. Para além disso, um mundo de diversões, com variadas festas, com banhos de igarapés e pescarias, também compõe a experiência de se viver numa frente de colonização na virada do século XIX para o XX.

\section{Conflitos e Festas}

Se rastrear os significados que os poderes públicos deram à colonização e povoamento da zona bragantina não é uma tarefa complicada, considerando o grande número de registros a esse respeito, o mesmo não se pode dizer dos significados que os migrantes que viviam nesses núcleos coloniais deram a sua experiência. Entretanto, através de registros dispersos, é possível nos determos nessa questão. Embora, não raro, a atividade extrativa tenha ocupado muitos colonos, a preocupação em manter-se produzindo em seu lote de terras também fez parte das aspirações dos migrantes que viviam e construíam esses espaços.

No ano de 1901, o jornal Folha do Norte, destacava em seu noticiário o caso de um colono italiano, Frediano Francisco, que "há cerca de 26 anos” vivia em Benevides. Conforme declarou, tinha sido um dos "primeiros imigrantes”, localizados na área da estrada de ferro. Ali, foi aclimatando-se, “casando-se com uma colona cearense”, constituindo assim uma família com 13 filhos. Viviam todos do trabalho na terra, o que permitiu ao grupo lograr "uma prosperidade relativa" diante de uma lavoura que era uma das "mais opulentas do local". Os problemas desse grupo familiar começaram, conforme declarou Frediano Francisco, à Folha do Norte, a partir de um desentendimento seu com um fiscal da estrada de ferro, Joaquim Pereira, cerca de nove anos antes. ${ }^{26}$

O motivo do desentendimento, segundo teria contado Frediano Francisco, era o fato de que ele havia reclamado dos "estragos que os animais de Pereira lhe faziam nas roças". Para completar a antiga contenda, um dos filhos de Frediano Francisco teria "prendido um cavalo

\footnotetext{
${ }^{26}$ Folha do Norte. Belém, 7 de janeiro de 1901, p. 1.
} 
que lhe estragava a lavoura”, pertencente ao fiscal da estrada. Joaquim Pereira teria ido tomar satisfações, armado. De acordo com a Folha do Norte, o italiano, sua mulher cearense e seus filhos consideravam os que lhes acontecia a mais "clamorosa injustiça". Na ocasião com 60 anos de idade, Frediano Francisco, pelas impressões da Folha do Norte, parecia se sentir impotente diante do caso e "resolvido a abandonar o trecho de terra". ${ }^{27}$

Alguns aspectos chamam a atenção na história de Frediano Francisco, e que certamente perante ele próprio, e igualmente ao próprio público leitor da Folha do Norte, o legitimaram a lutar pelas terras conquistadas por ele e sua família. Um desses pontos é o seu tempo de permanência nesse espaço, por “26 anos”. Note-se que o caso se passa em 1901; portanto, Frediano, conforme ele mesmo lembrou, fora um dos primeiros moradores de Benevides, tendo se instalado nesse núcleo por volta de 1875, antes mesmo do início da construção da Estrada e Ferro de Bragança. Seu descontentamento vem justamente do fato de que, vivendo havia tanto tempo na terra, ele se via obrigado a deixá-la em função de perseguições provocadas por um vizinho, que aliás era funcionário do próprio Estado, dotado, portanto, de um poder especial. Embora o destaque seja dado na notícia à figura do italiano, não se pode esquecer que sua prosperidade na terra, como a Folhado Norte fez questão de lembrar, era fruto também do trabalho de sua mulher, uma cearense, que igualmente chegou à região em busca de terra. A união do casal sugere ainda que nessas frentes de colonização e povoamento, variadas relações sociais surgiam entre os colonos nacionais e estrangeiros, inclusive uniões matrimoniais.

Em relação à contenda entre os vizinhos de roça, a impressão que se tem é que de um desentendimento inicial aparentemente simples, ao longo dos anos, foi-se criando uma animosidade maior entre esse grupo de moradores de Benevides. Pelo olhar da Folha do Norte, sempre pronta a lançar suas críticas aos poderes públicos, no caso da Estrada de Ferro de Bragança, não raro seus trabalhadores exerciam de forma arbitrária as funções, privilegiando usuários da ferrovia em detrimento de outros. No caso em questão, o próprio fiscal da estrada também tinha terras com animais soltos, a prejudicar as roças do vizinho.

Somente por essas notas da Folha do Norte, não é possível aprofundarmos as versões sobre o fato, o que nos dá margem para afirmarmos que para além da história publicada, fica muito clara a importância que a terra tem para a família de Frediano Francisco, tanto que, para

\footnotetext{
${ }^{27}$ Folha do Norte. Belém, 7 de janeiro de 1901, p. 1.
} 
dar legitimação ao pedido de ajuda, ele evoca sua história de vida nesse lugar, indicando o tempo em que ali morava como prova de seu trabalho. Diante da contenda com seu vizinho e da possibilidade de inclusive retirar-se de sua terra, talvez Frediano Francisco tenha recordado o seu passado ao se estabelecer na zona bragantina, lembrando de que antes mesmo da chegada do trem, ele já havia se instalado na região, e que em 1901, se via quase na obrigação de sair de sua propriedade justamente pelo fiscal da ferrovia que ele viu ser construída e que, certamente, tanto esperou, acreditando no progresso que ela lhe traria.

Em 1904, num outro extremo da Estrada de Ferro de Bragança, um cearense de 54 anos de idade, casado, lavrador, chamado Simplício de Barros, foi agredido pelo subprefeito do lugar conhecido por "Segredinho", no Município de Quatipurú, Comarca de Bragança, com a afirmação de que "havia de persegui-lo até que se retirasse dali”, uma vez que Simplício, que era "um negro tinha mais lavoura do que ele que era subprefeito". Na verdade, esse seria o desfecho de uma contenda envolvendo o cearense e o subprefeito, e o início de uma grande perseguição ao lavrador, que sentiu-se obrigado a fugir de "Segredinho", acompanhado de dois amigos que também se viram envolvidos no caso, e vir queixar-se em Belém, na Chefatura de Polícia. A partir do depoimento que Simplício de Barros prestou na capital paraense, é possível entendermos vários aspectos da sua luta pela posse da terra e, igualmente, os abusos de poder da autoridade local.

Ele afirmou que, em 1892, recebeu de José Lopes de Queiroz um "terreno onde tinha uma pequena barraca para morar e tratar da limpeza”, sabendo que ao lado desse terreno existia um “outro devoluto”, foi aconselhado pelo mesmo José Queiroz que ali fizesse “benfeitoria para depois requerer o registro do governo”. Simplício contou na Chefatura de Polícia que "roçou o mato desse terreno e fez duas roças". Algum tempo depois, foi surpreendido pelo subdelegado, que exigia sua saída, afirmando que faria a demarcação dessas terras devolutas. Diante da intimação do subprefeito, Simplício teria lhe dito que "depois de feita a plantação e a colheita ele entregaria o terreno". Tomando essa resposta como um desacato à autoridade, o subdelegado tentou inclusive prender Simplício e remeteu presos para Quatipuru dois maranhenses que trabalhavam com ele. Posteriormente, cercou a casa com "um praça e vários paisanos", além de invadi-la e saqueá-la, retirando “duas espingardas, uma faca” e 
até "quatro quilos de carne de xarque”, que um dos amigos de Simplício trazia no momento do cercamento da casa. ${ }^{28}$

Aos 54 anos de idade, Simplicio de Barros já não é um homem jovem, e entretanto ainda não tinha terra para produzir, o que nos leva a perguntar: estariam ele e sua família há muito tempo no Pará, ou eram migrantes recém-chegados? Ao que tudo indica, a pujança das plantações e a futura colheita de Simplicio, faz crescer o interesse por terras que até então não tinham donos. A ausência de documentos que apontassem Simplicio como proprietário das terras, apesar de suas benfeitorias, o colocava em uma situação de extrema fragilidade em relação a sua posse. E ele sabia disso. Seu depoimento é revelador nesse sentido, pois pela sua versão, ele não esboça dificuldades em deixar a terra, pedindo apenas tempo para a colheita.

Além disso, um outro aspecto que não pode ser desprezado é a discriminação sofrida por Simplicio em função de ser negro. De acordo com seu depoimento e com o de Lúcio Vieira e Manoel Pereira de Brito, ambos maranhenses, tem-se a impressão de que o fato de Simplicio ser negro e estar produzindo em terras que poderiam vir a ser sua propriedade, fora do jugo de um patrão, era algo que incomodava o subprefeito, e que parece inclusive legitimar as perseguições sofridas por esse grupo de lavradores pobres. Diferente da atitude de Frediano Francisco, que toma a imprensa como porta-voz das injustiças sofridas, o cearense Simplício dá outro rumo a sua história, vindo até Belém denunciar as agressões e ameaças sofridas.

Não deve ter sido fácil o deslocamento do grupo até Belém, considerando que estavam sendo vigiados pelo subdelegado, que deve ter seguido trechos da viagem a pé, outro de canoa e finalmente de trem, em viagens demoradas e sem nenhum conforto. Enfrentando tudo isso, entretanto, esses três homens, que viviam exclusivamente do trabalho da terra e que nem sequer sabiam ler e escrever, conseguiram chegar a Belém e fazer sua denúncia. Não foi possível saber o desfecho da história. Fica, contudo, a marca da luta do grupo para produzir pelo menos por um certo tempo em terras devolutas, numa região que tinha preocupações com produção agrícola e em um lugar onde existiam variadas extensões de terra desocupadas.

Ainda seguindo a trilha do trem, o ano é 1915, mas a situação de alguns migrantes, chamados na Folha do Norte de "lavradores espoliados", é muito semelhante à de Simplício

\footnotetext{
${ }^{28}$ APEP - Chefatura de Policia - Autos Crimes,1904. Auto de diligências policiais acerca da agressão sofrida por Simplício [?] de Barros.
} 
e seus companheiros. ${ }^{29}$ Ao mesmo tempo que muitos cearenses aportavam em Belém em busca de terras para trabalhar, um grupo de seus conterrâneos, já estabelecidos no Pará, na localidade de "Peixe Boi”, é alvo de controvérsias na imprensa. O caso se estende por alguns dias no jornal, a partir de um debate entre Mâncio Ribeiro, que se apresentava como defensor dos direitos dos trabalhadores na "tribuna da imprensa", e G. de La Roque, que duvidava da inocência desses colonos, afirmando que depois de notificados para saírem das terras, permaneciam apenas “como nunca deixa de haver, um pequeno grupo de valientes”, que entenderam de "reagir". 30

A Folha do Norte, que a pedido dos lavradores publicava os acontecimentos para "deixar passar o eco da voz dos oprimidos”, a fim de sensibilizar os seus leitores, evocava o passado de árduo trabalho deles na zona bragantina, afirmando que esses lavradores "enfrentaram $a$ floresta em Peixe Boi. Desbravaram o matagal sem que ninguém os incomodasse”. Por essa versão da Folha do Norte, o interesse pela demarcação e apropriação dessas terras, que aparentemente eram devolutas, surgiu apenas quando os colonos "começavam a colher os frutos insano do trabalho". E diante disso, perguntava o articulista: "Por que se apresenta somente agora?". 31

Mais esclarecedor sobre a origem e ocupação dessas terras era um outro artigo, também intitulado "Lavradores espoliados", em que o articulista historiava a tomada de posse das terras

"quando a construção da estrada de ferro passava por essa localidade em 1905, os trabalhadores da estrada perguntaram ao sr. dr. Inocêncio Holanda (engenheiro) se podiam estabelecer-se (...) de ordem do governador podiam estabelecer-se porquanto era melhor que terrenos incultos fossem cultivados, sendo depois as posses legalizadas”. ${ }^{32}$

Para a retomada das terras, os que se diziam proprietários dos "terrenos de Peixe-Boi" alegavam gastos com a demarcação dos terrenos no valor de "três contos e seiscentos mil réis”. Como uma resposta a essa alegação, o articulista fazia referência à produção feita na área pelos colonos: plantações variadas de coqueiros, abacateiros, laranjeiras, e até mesmo

\footnotetext{
${ }^{29}$ Folha do Norte. Belém, 7 de janeiro de 1915, p. 2.

${ }^{30}$ Folha do Norte. Belém, 13 de janeiro de 1915, p. 4.

${ }^{31}$ Folha do Norte. Belém, 7 de janeiros de 1915, p. 2.

${ }^{32}$ Folha do Norte. Belém, 12 de janeiro de 1915, p. 2.
} 
“milhares de pés de seringueiras". Ao que perguntava: “tudo isso não tem valor?”. ${ }^{33}$ Diante da contenda sobre as terras, um outro articulista afirmava que "as famosas propriedades” não passavam de "barracas horrivelmente edificadas em terras d'outrem". 34

Para além de um debate em que a imprensa apontava ou não a legitimação da posse das terras, fica muito evidente a luta de grupos de colonos com o fim de permanecerem em terrenos por eles cultivados, sem entretanto terem o termo de posse dessas terras. Essas práticas sugerem que se, de um lado, os discursos dos poderes públicos insistiam num incremento à produção, por outro, não esboçavam grande interesse na legitimação de terras que iam sendo ocupadas de forma não oficial. Sem dúvida, esse assentamento e povoamento de áreas devolutas por trabalhadores da Estrada de Ferro de Bragança demonstra um interesse de permanência no referido espaço, de fixação na terra a partir do trabalho na lavoura. Isso remete a uma colonização construída sem apoio do Estado, mas a partir do próprio interesse do lavrador. Não raro, a exemplo de casos como o de Simplício e dos lavradores de PeixeBoi, se apresentavam os "verdadeiros" proprietários das terras logo que estas começavam a produzir, levando a conflitos reveladores dos significados que os muitos migrantes envolvidos nesse processo davam ao seu próprio trabalho como lavradores. As histórias de Frediano Francisco, Simplício e dos trabalhadores de Peixe-Boi, que na imprensa são chamados apenas como lavradores, contam um pouco disso. ${ }^{35}$

Além desses conflitos pela posse da terra, uma variedade de contendas cotidianas também levou a ações de violência entre os colonos, dando conta de disputas, de relações de poder, de amizade e de solidariedade. Pode-se perceber isto, por exemplo, a partir das possíveis ameaças sofridas, no ano de 1900, por Antonio da Silva Cabral, agrimensor residente na vila de Apeú. Segundo declarou perante o juiz substituto dessa vila, ele era "constantemente insultado com palavras ofensivas e ameaçado de agressão" por Francisco Pereira Nascimento, que era natural da Paraíba. Através dos depoimentos de cinco cearenses, residentes na vila do Apeú, testemunhas do queixoso, é possível sabermos um pouco mais

\footnotetext{
${ }^{33}$ Folha do Norte. Belém, 12 de janeiro de 1915, p. 2.

${ }^{34}$ Folha do Norte. Belém,13 de janeiro de 1915, p. 2.

${ }^{35}$ Uma leitura sobre a posse da terra e os conflitos na Amazônia na segunda metade do século XX pode ser: MARTINS, José de Souza. "A vida privada nas áreas de expansão da sociedade brasileira". In: SCHWARCZ, Lilia Moritz (org.). História da vida privada no Brasil: contrastes da intimidade contemporânea. São Paulo: Companhia das Letras, 1998, vol. 4, pp. 659-726.
} 
sobre o caso. Assim, de acordo com o que declarou Lourenço Ignácio de Souza, comerciante cearense de 39 anos de idade, “a causa da inimizade” era "uma casa” que o réu pretendia “fazer fora do alinhamento", o que, supõe-se, não foi permitido pelo agrimensor, gerando a querela. $^{36}$

Sendo a vila do Apeú um pequeno povoado formado por migrantes, na sua grande maioria por agricultores, não demorou para que a história da contenda se espalhasse por entre os moradores. Chamado para depor, o cearense Miguel informou ao juiz substituto que sabia do fato "por ouvir dizer", numa alusão às conversas que circulavam na vila. Um outro depoente, o cearense João Ferreira Lima, também afirmou, ao ser interrogado, que "tinha ouvido dizer por populares”, e que era “voz pública” que o réu fazia constantes ameaças de agressões” a Antonio Cabral. ${ }^{37}$

Como não temos a fala de Francisco Pereira do Nascimento, tomando apenas por base as declarações dos depoentes, tem-se a impressão de que, na impossibilidade de erguer sua casa da maneira pretendida, Francisco passa a reclamar nos lugares que passa. Na taberna de Lourenço Ignácio de Souza, possivelmente, teria dito para o comerciante para que ele rezasse pela “alma de um amigo e compadre”. Assim, não resta dúvida de que, diante das possíveis ameaças ao agrimensor da vila, um grupo de pelo menos cinco cearenses se une para defendêlo. Além disso, se de fato procediam os motivos da querela, ou mesmo que fossem outros, evidencia-se, em relação à vila do Apeú, uma preocupação com a sua organização espacial, na medida em que se faz referência ao alinhamento das casas. ${ }^{38}$

Três anos depois, em 1903, próximo à vila do Apeú, no povoado de Americano, vários colonos são chamados a depor em função do defloramento de uma menor chamada Maria Albina Monteiro. ${ }^{39}$ Desses depoimentos, surgem, além de códigos de honra e de moralidade, um cotidiano no qual a vida privada dos moradores parece ter uma fronteira muito tênue, que permite a interferência de uns sobre os outros. Tal qual na vila do Apeú, percebe-se uma

\footnotetext{
${ }^{36}$ APEP - Chefatura de Policia - Autos Crimes - 1900 - Juízo Substituto da Vila de Apeú.

${ }^{37}$ APEP - Chefatura de Policia - Autos Crimes - 1900 - Juízo Substituto da Vila de Apeú.

${ }^{38}$ APEP - Chefatura de Policia - Autos Crimes - 1900 - Juízo Substituto da Vila de Apeú.

39 Cristina Cancela estudando caso de defloramentos na cidade de Belém do Pará, onde muitos cearenses aparecem envolvidos afirma que é comum a "recorrência de testemunhas que residiam em locais bastante próximos, senão contíguos, que possuíam a mesma naturalidade”. CANCELA, Cristina Donza. Adoráveis e dissimuladas.
} 
constante circulação de boatos no pequeno povoado, o que certamente era fonte para conflitos e desavenças. O caso do defloramento da menor Maria Albina é exemplar na medida em que todos os interrogados dão conta da conduta da menina, indicando uma constante vigilância em torno das atitudes dos moradores do lugar. Através de expressões como "tinha ouvido falar", “ouvido falar por boatos do povo", "em conversação lhe houvera dito”, as testemunhas de acusação davam a sua versão do fato. O próprio responsável por Maria Albina afirmou em seu depoimento que tomou conhecimento do defloramento "por pessoas do povo". 40

O acusado do defloramento, Antonio Symphronio Pinheiro, que era natural do Rio Grande do Norte, 16 anos de idade, caixeiro de uma taberna do povoado, diante da acusação, a fim de apontar sua inocência, apresenta algumas pessoas como testemunhas que dão conta de indicar várias atitudes da menina a partir de observações do seu dia-a-dia. Dentre essas práticas, citam-se o fato de Maria Albina ter sido vista “às sete horas da noite mais ou menos conversando" com um outro morador do lugar. Em outro depoimento prestado pelo cearense João Machado Pinto, confirma-se uma história contada por outra moradora de Americano, de que Maria Albina teria sido vista com “uma latada de Maracujá junto com três indivíduos”. Um outro cearense confirma a mesma história, afirmando que um dos homens que acompanhava Maria "na latada de Maracujá” havia desaparecido "escondidamente sem dizer para onde ia deixando rede e roupas de seu uso". Esses depoimentos serviram para livrar Symphronio da acusação do defloramento, uma vez que, diante das testemunhas que ele apresentou, o subprefeito de Americano considerou "improcedente” a denúncia. ${ }^{41}$

Assuntos como o defloramento de uma moça moradora do povoado e que, sem dúvida, eram motivos de conversa para vários dias entre os colonos também colocavam em evidencia valores como a honestidade feminina, além das muitas relações que se estabeleciam entre os homens do lugar. ${ }^{42}$ Alguns anos antes do caso de Maria Albina, em 1899, próximo dali

\footnotetext{
${ }^{40}$ APEP - Chefatura de Policia - Autos Crimes - 1903 - Auto de diligências policiais, procedidas acerca do crime de defloramento da menor Maria Albina Monteiro e do qual e autor Antonio Symphronio Pinheiro - Subprefeitura de Segurança Pública da colônia de Americano.

${ }^{41}$ APEP - Chefatura de Policia - Autos Crimes - 1903 - Auto de diligências policiais, procedidas acerca do crime de defloramento da menor Maria Albina Monteiro e do qual e autor Antonio Symphronio Pinheiro - Subprefeitura de Segurança Pública da colônia de Americano.

${ }^{42}$ Há uma vasta produção historiográfica sobre a questão da honra feminina: ver por exemplo: ESTEVES, Martha de Abreu. Meninas Perdidas: os populares e o cotidiano do amor no Rio de Janeiro da Belle Époque. Rio de Janeiro: Paz e Terra, 1989; MEZA, René Salinas "El ideario
} 
mesmo, no quilômetro 51 da Estrada de Ferro de Bragança, uma outra família se viu às voltas com o defloramento de uma moça de 17 anos, Maria Dias de Lucena. O pai da moça, que era cearense, sentia-se traído pelo namorado da filha, acreditando que ele havia abusado de sua “confiança”. O que o fazia pensar assim era o fato do acusado, que era seu "trabalhador”, ter inclusive morado em sua casa, antes de seguir para a sua própria moradia, o que aconteceu quando ele, de acordo com um outro cearense, que depôs sobre o caso, mudou-se "para uma casinha fronteira” ao terreno do pai de Maria Lucena. Semelhante ao que supostamente faria anos mais tarde, o namorado de Maria Albina, Benvindo Leite Figueira, retira-se “depois para Manaus”, correndo assim contra ele um processo ex-officio. ${ }^{43}$

$\mathrm{Na}$ verdade, o que aqui nos interessou mais não foi a questão do defloramento de Maria Albina e de Maria de Lucena, mas sim essas muitas relações sociais da vida cotidiana dos migrantes que puderam ser percebidas no espaço de colonização. Questões como trabalho, amizade, moralidade, surgem desses depoimentos, indicando muito do padrão de comportamento que deveria ser seguido por esses migrantes. Sem dúvida, a quebra dessas normas foi sempre ponto de conflitos entre eles.

Mudanças nas regras que regiam as relações de dependência do grupo com o comerciante local foram certamente o que motivou o assassinato de um lavrador na localidade de Anhangá, também caminho do trem, em 1916. A querela foi motivada pelo fato de que o lavrador Cândido Pastor, que "retirava mercadorias a crédito", sendo sempre "pontual no pagamento das mercadorias", acabou por atrasar, o que gerou conflitos com o proprietário da venda, marcados por discussões e desentendimentos quando se encontravam. A pretexto de se defender de um espancamento praticado pelo lavrador, acabou por matá-lo. De acordo com a versão do jornal A Tarde, o "coronel Sr. Raynundo José” como era conhecido, vendia para

femenino chileno, entre la tradición y la modernidad (Siglos XVIII al XX)". Estudos CEDHAL, $\mathrm{n}^{\circ} 8$ (1993); SAMARA, Eni de Mesquita. "Mistérios da 'fragilidade humana': o adultério feminino no Brasil, séculos XVIII e XIX". Revista Brasileira de História, vol. 15, no 29 (1995), pp. 57-71; NAZZARI, Muriel. "Sem perda da honra: a preservação da reputação feminina no Brasil colonial" In: SILVA, Maria Beatriz Nizza da (org.). Sexualidade família e religião na colonização do Brasil. Lisboa: Livros Horizonte, 2001, pp. 65-75.

${ }^{43}$ APEP - Chefatura de Polícia do Estado - Autos crimes, 1899, (jul-dez) Auto de diligencias policiais procedidas ex-officio contra Benvindo Leite Figueira pelo crime de defloramento da menor Maria Dias de Lucena. Registrado em 22/9/1899 em Belém do Pará. 
todos os "moradores dali". ${ }^{44}$ A situação vivida por Cândido Pastor sugere que muitos colonos não produziam o suficiente para se manter, necessitando comprar a crédito, o que acabava por criar vínculos de sujeição a comerciantes mais prósperos do lugar.

Vale lembrar que nas áreas de colonização, as tabernas sempre foram um ponto importante de socialização entre os colonos. Logo que se firmava um povoado, negociantes acabavam se localizando nesses espaços, fazendo todo tipo de comércio. Na região do Alto Quatipuru, em 1898, observava-se uma taberna de propriedade de "um judeu marroquino”, que ali vivia “explorando o seu limitado comércio de gêneros aos colonos”, mas que também fazia "comércio da diamba”, que de acordo com o correspondente da Folha do Norte era uma "erva venenosa", que constituía-se uma verdadeira "praga” por aqueles sítios. Na mesma região, um outro "pequeno negociante à margem da estrada” se dedicava também a tal comércio. Conforme publicou a Folha do Norte, Paes de Carvalho recomendou que os comerciantes abandonassem "esse ramo de comércio", a fim de evitarem "males maiores". 45

Indicativa de hábitos dos colonos, da sua própria socialização nessas regiões longínquas, a utilização da "diamba” nesse contexto não é vista como um caso de segurança pública, e nem exatamente como um problema moral, mas muito mais, diante das possíveis conseqüências que o uso dessa erva poderia ter na vida do grupo. ${ }^{46} \mathrm{Da}$ forma como a questão é apontada, tem-se a impressão de que esse uso era uma prática comum, a história de um namoro considerado escandaloso parece que chamava muito mais a atenção dos colonos do que o uso da “diamba”, por algum deles.

Além desses conflitos, que tinham um caráter pessoal, mas que acabavam se desenrolando numa esfera mais pública, existiam outros que diziam respeito à vida do grupo de migrantes nos núcleos coloniais. Os colonos não deixaram de reclamar de problemas que interferiam no seu dia-a-dia. Em 1898, por exemplo, os moradores da vila de Castanhal enviavam ao

\footnotetext{
${ }^{44}$ A Tarde. Belém, 27 de outubro de 1916, p. 3.

${ }^{45}$ Folha do Norte, 8 de agosto de 1898, p. 1.

${ }^{46}$ Sobre a lavoura de fumo na zona bragantina faz-se referência em 1959 ao fato de que muitos trabalhadores envolvidos nessa cultura por vezes trabalhavam "intoxicados de cachaça ou maconha ('diamba' como é conhecida a erva)". Esses lavradores "lavram, plantam e colhem em um impressionante estado de inconsciência”. Estudo de Desenvolvimento Regional (Pará). Série Levantamento e Análises, 16. Rio de Janeiro: CAPES, 1959, p. 26. Sobre lavoura de fumo na região bragantina ver: PENTEADO, Antonio Rocha. O uso da terra na região bragantina, Pará. São Paulo: Instituto de Estudos Brasileiros/USP, 1968, pp. 45-50.
} 
governador do estado, Paes de Carvalho, um abaixo-assinado remetido por 65 moradores da vila que pediam o afastamento do professor da localidade em virtude de suas atitudes que não correspondiam, de acordo com alguns moradores, com os ideais de "moralidade $e$ edificação” que caberiam a um docente. Dentre as acusações que recaíam sobre ele, constavam “injúrias verbais a um freguês”, uma vez que ele mantinha um estabelecimento comercial contíguo à escola; o fato de ter deixado de “dar aulas por alguns dias”, não visar os mapas escolares e não comparecer às aulas da escola noturna. ${ }^{47}$

A lista dos moradores que reclamavam era encabeçada pelas autoridades da vila, como o juiz substituto, o subprefeito, um fiscal e um tenente coronel, vindo em seguida empregados públicos, como telegrafista, vários comerciantes e um grande número de agricultores. Para esses moradores de Castanhal, as infrações cometidas pelo professor eram muito graves, pois implicavam na formação de seus filhos ou, como foi apontado pela imprensa, nos ensinamentos que eram repassados à “infância castanhalense”. Essa preocupação com a educação das crianças da vila revelou a importância que muitos desses homens, que não sabiam ler nem escrever, atribuíam ao futuro de seus filhos. ${ }^{48}$

Nos povoados que se formaram às margens da Estrada de Ferro de Bragança, algumas escolas foram parte integrante da infra-estrutura de seus espaços. Nos dias de festa, em que as autoridades vindas de Belém visitavam esses lugares, com certo orgulho, diante das descrições que temos, os alunos eram apresentados recitando poesias, cantando ou simplesmente recebendo com esmero os visitantes ilustres. Segundo o correspondente da Folha do Norte, em outubro de 1898, Paes de Carvalho, que não deixou de visitar as "duas escolas públicas da vila”, com 50 meninos e 86 meninas matriculadas, de passagem por Castanhal, encontrou a sua espera "grande massa de povo apinhada na plataforma da gare". 49 Pode-se perceber um pouco disso também na festa de emancipação da colônia "Ferreira Pena”, em setembro de 1900. Nesse dia, representando as crianças da escola, a “pequetita Maria Feliz Torres” recitou com “extrema correção e graciosidade” felicitações ao governador e a sua comitiva, “a fim de agradecer tantos benefícios”. Entoaram uma canção bastante elucidativa a respeito de como os professores eram vistos. Num dos trechos se cantou:

\footnotetext{
${ }^{47}$ Folha do Norte. Belém, 14 de outubro de 1898, p. 4.

${ }^{48}$ Folha do Norte. Belém, 14 de outubro de 1898, p. 4.

${ }^{49}$ Folha do Norte. Belém, 5 de outubro de 1898, p. 1.
} 
"Sem rigor, sem vis castigos

Rindo, a escola nos atrai

Tem o mestre em nós amigos,

Temos nele amigo e pai". 50

Com esse tipo de pensamento, não é de estranhar-se o abaixo-assinado dos moradores de Castanhal diante das acusações que pesavam contra o professor da vila. Não se pode esquecer que a escola não era apenas imposta pelo Estado; era também solicitada e querida pela população diante de uma crença no poder redentor da educação.

Mesclando-se, assim, a um mundo de violências e de árduo trabalho, numa luta constante para produzir e fixar-se na terra como lavrador, existia também um mundo de festas e atividades lúdicas, que foram igualmente fundamentais na construção desses espaços na zona bragantina. É possível encontrarmos indícios disso nos primeiros anos de chegada dos cearenses a essa região.

As bandas de música, por exemplo, são referências constantes em vários momentos festivos, evidenciando uma vida muito mais complexa do que um cotidiano apenas de trabalho.

Em 1889, num momento ainda de estruturação de núcleos coloniais, era solicitado pelo Palácio da Presidência da Província o transporte gratuito, até à colônia, de Benevides, da “banda de música do Instituto de Educação de Artífices Paraenses”, que, ao que tudo indica, participaria de alguma festa na colônia, uma vez que, segundo o ofício, retornaria apenas no "trem do dia seguinte". 51

Em 1898, quando das visitas de Paes de Carvalho à região do Alto Quatipuru, o governador e sua comitiva foram saudados, segundo o correspondente da Folha do Norte, com uma "marcha alegre e festiva", executada por uma "uma banda de música composta de dez rapazes trigueiros trajando um paletó encarando e pantalona preta com um chapéu de jóquei”. A inusitada apresentação, quase no meio da mata, por caminhos por onde passavam lavradores com "utensílios rurais aos ombros", chamou atenção da comitiva, uma vez que o "pequeno corpo musical" que se intitulava, para orgulho do governador, "Paes de Carvalho", era formado por "lavradores que trabalhavam nos arredores". 52

\footnotetext{
${ }^{50}$ Folha do Norte. Belém, 11 de setembro de 1901, p. 1.

${ }^{51}$ APEP - Palácio da Presidência da Província do Pará. Ofício No 2048 - 2a secção - 9 de maio de 1889

${ }^{52}$ Folha do Norte. Belém, 6 de agosto de 1898, p. 1.
} 
Em regiões distantes da capital, voltadas quase que exclusivamente para agricultura, povoadas em sua maioria por lavradores, a presença de um grupo de músicos parece algo incomum, quando se entende esse contexto exclusivamente voltado para o trabalho. Grupos musicais formados pelos colonos, entretanto, parecem ter feito parte da vida dos moradores dessas frentes de colonização na região, na medida em que estavam totalmente inseridos na vida dos moradores. ${ }^{53}$ Em 1900, por exemplo, em visita à colônia de Inhangapy, o Inspetor da Repartição de Terras assistiu a "vários batizados" e à celebração de uma “missa”, ao som da "banda de música do Castanhal”. 54

As celebrações religiosas fizeram parte constante da história da colonização, uma vez que a emancipação de uma colônia - momento em que os colonos deixavam de receber auxílios do governo e, mesmo que precariamente, passavam a se manter por conta própria - era vista como um momento importante na vida do grupo, e que deveria ser comemorado. ${ }^{55}$ Nessas ocasiões, não raro, foram comuns cerimônias de batismo e casamentos, além da celebração da missa.

Em 1900, quando se inaugurou na colônia Jambuassú o "engenho de moer cana e a máquina de fazer farinha de mandioca”, os colonos prepararam uma grande festa, que teve inclusive a "bênção" das máquinas por um padre. De acordo com a Folha do Norte, uma "multidão de imigrantes da colônia” participou da festa, e para essa ocasião, se apresentaram “nos seus garridos trajes domingueiros”.

Nota-se que essas festas se revestiam de um caráter de grande importância, que se refletia, inclusive, na forma de se vestir do colono, como bem evidenciou a Folha do Norte. ${ }^{56}$

\footnotetext{
${ }^{53}$ Vicente Salles lembra que muitas "bandinhas" estiveram "espalhadas pelas cidades e vilarejos do interior paraense, conjuntos sempre aplaudidos e apreciados pelo povo". Segundo o autor na "Região Bragantina, várias comunidades possuíram - e algumas ainda possuem - bandas regularmente organizadas: Bragança, Igarapé-Açu, Castanhal, Benevides, Ananindeua etc.”. SALLES, Vicente. Música e músicos do Pará. Belém: Conselho Estadual de Cultura, 1970, p. 32.

${ }^{54}$ Folha do Norte. Belém, 29 de agosto de 1900, p. 2.

${ }^{55}$ Referindo-se às vivências dos colonos nas fazendas em São Paulo Zuleika Alvim lembra que as festas religiosas longe de representarem apenas a busca "pura e simples de conforto para a alma" também era para muitos colonos um "dos raros momentos em que podiam encontrar seus conterrâneos e ter o mínimo convívio social, quebrando a monotonia que caracterizava as fazendas”. ALVIM, Zuleika. "Imigrantes: a vida privada dos pobres do campo", p. 265.

${ }^{56}$ Folha do Norte. Belém, 11 de novembro de 1900, p. 1.
} 
Cerimônia e festa semelhante pode se vista em janeiro do ano seguinte, 1901, quando da inauguração de outro engenho, desta vez na colônia “José de Alencar”, que também contou com celebração da missa, com a "bênção das máquinas", além do batismo de "várias crianças filhos de colonos" e de um "almoço na casa da diretoria”. Esses momentos de festa também podem ser pensados como situação em que se aproveitava para lembrar aos colonos a importância de seu empenho na colonização, além de se comemorar e agradecer os "favores” recebidos do Estado. Foi certamente nesse sentido que se dirigiu o sermão do Padre Leitão nesse dia, que, após a leitura do Evangelho, exortou os presentes "ao trabalho porfiado e persistente para que a terra que lhe foi confiada" produzisse. ${ }^{57}$

As festas serviam para celebrar também as ações do Estado em prol dos colonos, como uma celebração do caráter civilizatório, presente nos ideários da colonização. Bom exemplo disso foi uma festa realizada na colônia Maracanã em 1900, em que foram premiados os alunos que obtiveram "melhores notas". ${ }^{58}$ Dentre os meninos que receberam "prêmios", constavam, entre índios, paraenses, piauienses, pernambucanos e rio-grandenses do norte, os cearenses Miguel Yaco, Francisco das Chagas, Manoel da Costa, João Gomes e Manoel Pereira, que, juntamente com outros alunos, cantaram em “coro" na missa celebrada "na capelinha da colônia”, o que foi visto com bastante ufanismo pela Folha do Norte, na medida que alguns dos meninos que viviam na colônia, diante do "bons exemplos" dos frades, inclusive se regeneravam de uma vida voltada para a delinqüência. ${ }^{59}$

Mas as festas não tinham apenas um caráter religioso. Que o digam os colonos cearenses no dia da emancipação da colônia Ferreira Penna, em 1900. E igualmente os trabalhadores da jazida de granito visitada pelo literato Rocha Moreira, imortalizados em um "baile dos cassacos”, em 1915.

\footnotetext{
${ }^{57}$ Folha do Norte. Belém, 2 de janeiro de 1901, p. 1.

${ }^{58}$ Ernesto Cruz faz referência à lei 588 de 23 de junho de 1898 "decretada pelo Congresso estadual e sancionada pelo Governador Paes de Carvalho" que "autorizava a fundação" de núcleos voltados para o recolhimento e educação de filhos de indígenas e de menores considerados "desvalidos". Segundo Ernesto Cruz citando um trecho dessa a lei, a mesma objetivava formar "cidadãos úteis à pátria e família”. Um desses espaços foi o núcleo "Santo Antonio do Maracanã". CRUZ, Ernesto. Colonização do Pará, p. 131. Fernando Lourenço, enfatiza referindo-se às últimas décadas do século XIX em São Paulo aos "internatos agrícolas", idealizados como uma forma de "desarmar", as ações dos grupos perturbadores da ordem como menores pobres, filhos de operários, agitadores que faziam greves. LOURENÇO, Fernando Antonio. Agricultura ilustrada, p. 169.
}

${ }^{59}$ Folha do Norte. Belém, 7 de janeiro de 1901, p. 1. 
Na colônia Ferreira Penna, além da celebração da missa em um altar improvisado na "varanda ou alpendre da casa” do administrador da colônia, outras atividades marcaram a importância do evento, a exemplo de cuidados que foram desde a "distribuição de uma ração de 3 quilos de carne de vaca e uma garrafa de vinho" a cada uma das 85 famílias ali localizadas, até à ornamentação da casa principal com "palmeiras e pequenos ramos de flores silvestres”. Além disso, na noite do domingo, um “baile ao ar livre organizado pelos colonos cearenses" marcava a celebração desse dia ao "som de harmônicos manejados com perícia notável" por esses colonos, que inclusive, em homenagem ao governador do Pará, Paes de Carvalho, "executaram o hino nacional" ${ }^{60}$ Percebe-se a importância do evento, tanto para o poder público como para os colonos, o que se pode no perceber nos cuidados com organização da festa, nas manifestações de gratidão, na louvação à República com o hino nacional, e igualmente pela presença na comitiva de Paes de Carvalho de políticos locais influentes como Augusto Montenegro, que chegaria a governador do Pará, e de Arthur Lemos, na época, deputado estadual.

Bem mais modesta, pelo menos quanto à participação de autoridades, que não estiveram presentes, foi a festa observada por Rocha Moreira em 1915, em Quatipurú, num “samba que durou doze horas”, organizado pelos cassacos para festejar o final da construção da estrada que levaria às jazidas de granito. $\mathrm{O}$ autor, que era cearense, não se esqueceu de fazer referência a origem dos cassacos, chamando-os de "nômades patrícios". Descreveu-os como homens rústicos, que não tinham "família nem pouso certo", fixando-se nos lugares a partir de seu próprio trabalho. Além disso, referia-se à valentia deles, que segundo o literato, para defender-se, utilizavam-se de “cacete e a faca” e até cometiam "desinteligências", quando se sentiam provocados. Em contraponto a esse aspecto violento, mas ainda como sinônimo se sua rusticidade, Rocha Moreira enfatizava que corria na boca desses seus conterrâneos " $a$ pilhéria e o dito de espírito". ${ }^{61}$

Para além dessas impressões que os enquadravam num perfil pré-estabelecido, as próprias observações do literato sugerem que esses homens, aparentemente tão rústicos, tinham sensibilidade suficiente para a dança e a festa, e eram suficientemente respeitados por seus vizinhos, que acorriam para a festa por eles organizada. Nessa ocasião de festa, marcando a importância do momento, num calendário diário de árdua faina, depois de um dia de trabalho

\footnotetext{
${ }^{60}$ Folha do Norte. Belém, 11 de setembro de 1901, p. 1.

${ }^{61}$ Folha do Norte. Belém, 10 de novembro de 1915, p. 1.
} 
e de um "excelente banho" em águas do igarapé, os cassacos da jazida de granito apareceram no "grande barracão" onde aconteceriam as comemorações vestidos em "fatos de linho e de mescla, com o pescoço algemado por gravatas de cores berrantes". Num misto de sensibilidade de poeta e de observador acurado, o literato transcreve detalhadamente para os leitores da Folha do Norte a festa e seus muitos convidados, sendo possível perceber relações de amizade dos cassacos com moradores dos arredores, que vinham para a festa "acompanhados das respectivas famílias, em que estavam crianças de meses". Essa participação sugere que nesses espaços se criavam regras de comportamento próprias, que permitiam que uma festa organizada por homens pudesse ser freqüentada por mulheres, e crianças, famílias enfim, que se deslocavam caminhando por "quilômetros de viagem a pé" a fim de se divertirem:

"Às sete horas da noite, acompanhando os músicos um clarinetista e um violoncelista surgiram as primeiras convidadas. Eram a Marocas, a Laura e a Carlota. (...)E em pouco tempo o imenso barracão de se enchia,(...) O clarinete soluçou sons inarticulados. O violoncelista afinava o instrumento. E momentos após um tango, quente e buliçoso, convidava os pares para a dança. O primeiro a tirar dama foi o Gonçalo, que casava a sua cor de azeviche à de uma pretinha de Bragança, afeita às festas de cassacos”." ${ }^{2}$

Além da dança, distribuíram-se entre os homens "canecas de aguardente pura", produzida em alambiques da própria região, e para as mulheres era servido café em "uma pequena mesa com seis xícaras diferentes uma das outras”, o que denota precariedade de utensílios domésticos nesse espaço. Pode-se destacar aqui também uma separação de gêneros que determinava o comportamento das mulheres na festa, onde se aceitava como algo comum a bebedeira masculina. $\mathrm{O}$ ponto alto da festa, entretanto, não foi apenas a distribuição do aguardente entre os homens, mas a dança da mazurca, do tango e de uma quadrilha anunciada por um dos cassacos, que gritava:" - Meus senhores, tirem as damas; vai começar a quadrilha". A festa, que, segundo o literato, se prolongou pela "noite afora", só terminou "seis horas do dia", quando tocou o "derradeiro tango". 63

Num espaço de tanto trabalho, a animação dos trabalhadores da pedreira e de seus convidados sugere que esses momentos de festa eram fundamentais na vida de tais homens e mulheres. Nessas ocasiões especiais, os migrantes extravasavam sentimentos como gentileza, amizade e até saudades da terra natal, na medida em que, nesse dia de festa, através da música

\footnotetext{
${ }^{62}$ Folha do Norte. Belém, 10 de novembro de 1915, p. 1.

${ }^{63}$ Folha do Norte. Belém, 10 de novembro de 1915, p. 1.
} 
e da dança, se evocava uma memória do passado e fortaleciam-se, sem dúvida, os laços identitários com os lugares de origem.

Se, na história dos migrantes cearenses no Pará, foi marcante um embate com a natureza, na região dos seringais, não menos importante foi o embate travado nessas áreas de colonização, a exemplo da zona bragantina, para a permanência do migrante nessas terras. Nota-se que se, no caso dos seringueiros, que viviam em áreas tão distantes, foi possível rastrear uma experiência que extrapolava o domínio dos seringais, no caso dos colonos, isso não é marcante, uma vez que estes - que, a princípio, não deviam obrigação a um patrão estavam muito mais presos à terra do que seus conterrâneos que seguiam para os seringais.

Mesmo tendo um lote de terra que lhes pertencia, as dificuldades para desenvolvê-lo, com a preparação dos roçados e a espera das colheitas, demarcava uma vida de poucos proventos para o migrante cearense que viveu do amanho da terra, sobretudo nos primeiros tempos da colonização. Isso se refletiu, por exemplo, nas poucas viagens desses lavradores a Belém, apesar de viverem numa região como a bragantina, que era cortada pelo trem. Se os seringueiros, por vezes, tinham acesso ao consumo de bens variados, o que marca a sua vida na cidade, tomando como referência a documentação pesquisada, a presença de colonos consumindo na capital paraense não foi comum, o que nos leva a pensar que, pelo menos para o período trabalhado, a não-consolidação econômica de sua produção não lhes permitia as extravagâncias dos seringueiros, restringindo-se assim a sua experiência muito mais a esse mundo agrícola.

A historiografia consagrou o migrante que se tornou seringueiro como um homem extremamente explorado, esquecendo-se até mesmo de fazer referência aos migrantes cearenses que, no Pará, foram lavradores.

Seguindo o caminho oposto a esse raciocínio e buscando entender a complexidade dessas relações, o migrante-colono foi, sem dúvida, marcado por uma luta constante para sobreviver, com a família, em espaços que não eram menos inóspitos do que a região dos seringais. 


\section{Perspectivas}

No segundo semestre do ano de 2005, sobretudo entre os meses de setembro e outubro, através da TV, os brasileiros, acostumados com as mazelas do nordeste, se depararam com imagens de trechos da Amazônia por onde corriam rios, agora secos como se fossem trechos de riachos e açudes de sertões cearenses. As imagens da terra rachada e da ausência de água davam a tônica de um noticiário que demonstrava que a estiagem de chuva, em uma parte da Amazônia, havia levado à seca de braços de rios e à morte de animais. $\mathrm{O}$ expectador desavisado, ao primeiro olhar, é bem provável que tenha imaginado se tratar de mais uma seca a assolar os sertões do Ceará. Os mais atentos, diante da floresta virando sertão, quem sabe, não evocaram a memória das possíveis profecias de Antonio Conselheiro de que o mar ia virar sertão.

Essas imagens contemporâneas remetem a histórias acontecidas também entre 1889 e 1916, que ligavam o Ceará ao Pará e que busquei elucidar nesta tese, uma vez que seca, chuva, floresta, cidade, sertão, rio, mar e gentes foram elementos evocados ao longo deste trabalho, na tentativa de elucidar a vinda de cearenses para o Pará, bem como o modo de viverem nesse espaço.

A memória de uma pobre vítima da seca, de corpos andrajosos esqueléticos e famintos, parece representar, em vários momentos, a sina dos cearenses quando, ao longo do tempo, se vêem envolvidos pela seca. No rastro dessa calamidade, quando tomamos como referência o período compreendido entre 1889 e 1916, a fuga para a Amazônia e a vida de trabalho árduo nos seringais de florestas e rios insalubres, sempre presos a um patrão desejoso de grandes lucros, sintetizaram, sem dúvida nenhuma, a vida dos migrantes cearenses no Pará, em muitos estudos, conforme vimos ao longo da tese.

Sem pretender negar esses problemas, busquei enfatizar outros aspectos de tal experiência, dando ênfase a outras nuances desse processo, querendo tirar dos migrantes a imagem tão solidificada de alguém que não tinha condições de gerir a sua própria vida. Desse modo, se dor, sofrimentos, fome, medo, e exploração fizeram parte da história de vida desses homens, mulheres e crianças que tentei interpretar na tese, não tenho dúvida de que, como vimos, outros desdobramentos mais complexos também integraram essa experiência. 
Embora avalie que, em vários trechos da tese, alcancei meus objetivos, sei igualmente que algumas questões poderão ser, no futuro, ainda mais trabalhadas ou melhor elucidadas. Dentre esses problemas, destaco a questão da identidade, ou seja, as formas buscadas pelos migrantes para reconstruir, no Pará, sua identidade. É possível adentrar, por exemplo, nas festas religiosas nas tradições alimentares, os modos de fazerem o roçado, as formas de falar, que os migrantes viveram, por exemplo, na região dos núcleos coloniais. O mesmo pode ser dito das relações que eles foram estabelecendo com estrangeiros que viviam nesses espaços. É o caso de, também, interligar os lugares de origem dos migrantes com as tradições por eles reconstruídas no Pará.

As fontes que trabalhei acabaram por me levar ao encontro dos grupos mais pobres de migrantes. O período pesquisado (1889-1916) remete ao início da colonização na chamada zona Bragantina, o que não me permitiu, portanto, perceber a formação de grandes proprietários enriquecidos nessa frente de colonização. De todo modo, a utilização de outra documentação, como registros de casamentos, batismos, inventários, testamentos, registros de terras, permitirá, em futuras pesquisas, outros matizes desse processo, indicando a formação de redes de fortuna, de alianças familiares de grandes proprietários rurais para a manutenção da terra, na área dos seringais ou nas áreas de colonização.

Uma outra questão que também poderá ser explorada é a construção ao longo do tempo de uma memória da migração, rastreada através da oralidade.

Uma tese, não raro, mais do que dar respostas, acaba sendo um ponto de partida para outros estudos que venham a se debruçar sobre o tema.

Nesse sentido, ao longo deste trabalho, eu me propus a repensar a história da migração de cearenses para o estado do Pará, buscando entendê-los a partir de uma complexidade das relações que o grupo estabelecia desde sua saída do Ceará até sua chegada a Belém.

Persegui, ao longo do trabalho, a construção de outros entendimentos dessa questão, que não aqueles solidificados na historiografia, buscando dar dinamismo à vida desses homens e mulheres, buscando tirá-los da exclusiva imagem de sofredores, buscando identificar os sentidos que deram a sua trajetória no Pará. De alguma maneira, isso acabou sendo possível. As tentativas de se juntar à família no Pará, as redes de solidariedades nos vapores, os seringueiros consumindo e se divertindo na cidade, os agricultores lutando para preservar sua terra, as mulheres dizendo o que queriam e pensavam, e diante de tudo isso a construção de novos espaços no Pará foram alguns desses caminhos. 


\section{Fontes}

\section{Arquivo Público do Estado do Pará}

Secretaria de Segurança Pública

Autos-Crimes - Chefatura de Policia (1898-1916)

Secretaria da Presidência da Província

Códice 1963 -1889 - Minutas de ofícios da Presidência às Companhias de Navegação (1/6 a $15 / 11$ de 1889$)$

Códice 1963 - 1889 - Ofícios das Companhias de Navegação - 2º semestre de 1889

Secretaria da do Governo do Estado

Códice 2124 - 1897 - Ofícios Diversos.

Biblioteca Pública do Estado do Pará

Hemeroteca (Setor de Microfilmagem)

Jornal Folha do Norte (1898-1916)

Jornal O Holophote (1897)

Jornal O Liberal do Pará (1889)

Hemeroteca (periódicos não microfilmados)

Jornal A Tarde (1915-1916)

Jornal A Palavra (1918)

\section{Conselho Estadual de Cultura}

[atualmente esta documentação se encontra na Biblioteca Pública do Estado do Pará]

Relatório apresentado ao Sr. Dr. Governador do Estado pelo Chefe de Segurança Pública Dr. José Ferreira Teixeira em 30 de novembro de 1911. Belém: Diário Oficial, 1898 


\section{Arquivo Público do Estado do Ceará}

Caixa: Palácio do Governo do Ceará, Companhia de Navegação e Vapores - Emigração para o Norte (1889-1915), N.471, 479, 477, s/n.

Caixa: Cia. Brasileira de Navegação e Vapor - Emigração para o norte e diversas partes desta Província-Fevereiro, N. 452, 480, 476.

Caixa: Comp. Brasileira de Navegação e Vapor - Imigração para o norte - 1889, N.467,470,486.

Caixa: Companhia de Vapores - Emigração para o norte - maio, N.468, 474.

Caixa: Palácio do Governo do Ceará - Companhia de Vapores - Emigração para o norte, 1889 , fevereiro.

Caixa: Relação dos emigrantes de 1915 - Relação dos emigrantes que se destinam aos portos do norte e sul em diversos vapores -1915 .

Ala 19, Estante 407, $\mathrm{n}^{\mathrm{o}} 35$ - Ministro dos Negócios da Agricultura, Comércio e Obras Públicas ao presidente da Província do Ceará, avisos. 1886-1888.

Caixa: Inspetoria Geral de Emigração - Relação de Emigrantes norte-sul. 1888-1889

Caixa: Governo da província do Ceará - Ofícios - emigração. 1889

337-B Minutas de ofícios da Secretaria do Governo da província do Ceará, dirigidos aos presidentes de várias províncias e secretários. 1886-1885.

347 Minutas dos Ofícios da Secretaria do Governo da província do Ceará, dirigidos ao secretario dos Negócios do Império, à Secretaria de Agricultura Comércio e Obras Públicas. 1887- 1889.

363-B Minutas dos ofícios da Secretaria do Governo da província do Ceará, dirigidos ao ministro dos Negócios Estrangeiros, ao ministro do Império, ao ministro da Justiça, ao ministro da Marinha. 1888

381-B Minutas dos ofícios da Secretaria do Governo da província do Ceará, dirigidos aos Ministérios. 1889

389-B Minutas de ofícios da Secretaria do Governo da província do Ceará, dirigidos ao diretor da Estrada de Ferro de Baturité, aos agentes da Companhia Brasileira de Navegação a Vapor. 1889.

Ala 19, Estante 405, n⿳3 316 - Registro de dados demográficos do Ceará e informações para o anuário. 1918-1920. 


\section{Instituto Histórico e Geográfico do Ceará}

Almanach Estatístico, Administrativo, Mercantil Industrial e Literário do Estado do Ceará para o anno de 1897 - confeccionado por João Câmara. Fortaleza: Typ. D’A Republica, 1896.

Almanach Administrativo, Estatístico, Mercantil, Industrial e Litterário do Estado do Ceará para o ano de 1905 confeccionado por João Camara Anno 11º. Fortaleza: Emreza Tipographica, 1904.

Almanach Administrativo, Estatístico, Mercantil, Industrial e Litterário do Estado do Ceará para o ano de 1906 confeccionado por João Camara Anno 12. Fortaleza: Typo. Lithographia a vapor, 1906.

Almanach Administrativo, Estatístico, Mercantil, Industrial e Litterário do Estado do Ceará para o ano de 1907 confeccionado por João Camara Anno 11º. Fortaleza: Typo Lithographia a vapor, 1907.

Almanach Estatístico, Administrativo, Mercantil Industrial e Literário do Estado do Ceará para o anno de 1916 organizado por Sophocles Torres Câmara anno de $19^{\circ}$ - Fundado por João Câmara em 1895. Fortaleza: Typ. Moderna - Carneiro \& C, 1916.

Almanach Estatístico, Administrativo, Mercantil Industrial e Literário do Estado do Ceará para o anno de 1918 - Director e Organizador Sophocles Torres Câmara. Fortaleza: Typ. Moderna - Carneiro \& C., 1918.

Almanach Estatístico, Administrativo, Mercantil Industrial e Literário do Estado do Ceará para o anno de 1919 - Director e Organizador Sophocles Torres Câmara. Fortaleza: Typ. Moderna - Carneiro \& C., 1919.

Almanach Estatístico, Administrativo, Mercantil Industrial e Literário do Estado do Ceará para o anno de 1920 - Director e Organizador Sophocles Torres Câmara. Fortaleza: Typ. Moderna - Carneiro \& C., 1920.

Falas e mensagens dos presidentes de província e governadores (http://wwwcrl.uchicago.edu/content/brazil)

Presidentes da província e governadores do Estado do Pará (1877, 1889-1916)

Fala com que o Dr. João Capistrano Bandeira de Mello Filho abrio a $2^{\mathrm{a}}$ sessão da $20^{\circ}$ Legislatura da Província do Pará em 15 de fevereiro de 1877.

Fala com que o exmo. Snr. Dr. Miguel José de Almeida Peranambuco abrio a $2^{\mathrm{a}}$ sessão de $26^{\mathrm{a}}$ Legislatura Provincial do Pará em 2 de fevereiro de 1889. Pará, Typ. de A. F da Costa, 1889 .

Fala com que José de Araujo Roso Danin $-1^{\circ}$ Vice- presidente da Província do Pará passou a administração da mesma ao Exm. Sr. Dr. Antonio José Ferreira Braga, presidente nomeado por Dec. De 22 de julho de 1889. Pará: Typ. de A. Fructuoso Costa, 1889. (1889-1) 
Relatório com que o capitão Tenente Duarte Huet Bacellar Pinto Guedes passou a administração do Estado do Pará em 24 de junho de 1891 ao Governador Dr. Lauro Sodré, eleito pelo Congresso Constituinte em 23 do mesmo mês. Belém: Typ. do Diário Oficial, 1891.

Mensagem dirigida pelo Senr. Governador Dr. Lauro Sodré ao Congresso do Estado do Pará em sua primeira reunião, em 30 de outubro de 1891. Belém: Typ. do Diário Official, 1891.

Mensagem Dirigida pelo Senr. Goverandor Dr. Lauro Sodré ao Congresso do Estado do Pará em sua segunda reunião em $1^{\circ}$ de julho de 1892. Belém: Typ. do Diário Official, 1892.

Mensagem dirigida ao Congresso do Estado do Pará pelo Dr. José Paes de Carvalho Governador do Estado em 7 de abril de 1898. Belém: Typ. do Diário Oficial, 1898.

Mensagem dirigida pelo Senr. Governador Dr. Lauro Sodré ao Congresso do Estado do Pará em $1^{\circ}$ de fevereiro de 1893. Belém: Typ. do Diário Oficial, 1893.

Mensagem dirigida pelo Sr. Governador Dr. Lauro Sodré ao Congresso do Estado do Pará em 7 de abril de 1894. Belém: Typ. do Diário Oficial, 1894.

Mensagem dirigida pelo Sr. Governador Dr. Lauro Sodré ao Congresso do Estado do Pará em 7 de abril de 1895. Belém: Diário Official, 1895.

Mensagem Dirigida pelo Sr. Governador Dr. Lauro Sodré ao Congresso do Estado do Pará em sua reunião em $1^{\circ}$ de fevereiro de 1896. Belém: Diário Oficial, 1896.

Mensagem dirigida ao Congresso do Estado do Pará pelo Dr. Lauro Sodré Governador do Estado ao expirar o seu mandato, no dia $1^{\circ}$ de fevereiro de 1897. Pará: Diário Oficial, 1897.

Manifesto ao Estado do Pará pelo governador Dr. José Paes de Carvalho. Belém: Typ. do Diário Oficial, 1897.

Mensagem dirigida ao Congresso Republicano paraense pelo Governador do Estado do Pará Dr. José Paes de Carvalho. Pará: Diário Official, 1897.

Mensagem dirigida ao Congresso Legislativo pelo Governador do Estado do Pará Dr. José Paes de Carvalho. Belém: Typ. do Official, 1897.

Mensagem dirigida ao Congresso do Estado do Pará pelo Dr. José Paes de Carvalho. Governador do Estado em 7 de Abril de 1898. Belém: Diário Oficial, 1898.

Mensagem dirigida ao Congresso do Estado do Pará pelo Dr. José Paes de Carvalho, governador do Estado em 15 de abril de 1898 Apresentando a Proposta de Orçamento da Receita de despesa para o exercício de 1898-1899. Belém: Typ. do Diário Oficial, 1898.

Mensagem enviada à Praça do Comércio do Pará pelo Governador Dr. José Paes de Carvalho em $1^{\circ}$ de fevereiro de 1899. Pará: Imprensa Oficial, 1899.

Mensagem dirigida ao Congresso do Estado pelo Dr. Paes de Carvalho governador do Estado em 7 de abril de 1899. Belém: Typ. do Diário Oficial, 1899. 
Mensagem dirigida ao Congresso do Estado do Pará pelo Dr. José Paes de Carvalho Governador do Estado em 15 de Abril de 1899 apresentando a proposta de orçamento da receita e despesa para o exercício de 1899-1900. Belém: Typ. do Diário Official, 1899.

Mensagem dirigida ao Congresso do Estado do Pará pelo Dr. José Paes de Carvalho governador do Estado em 1 de fevereiro de 1900. Belém: Typ do Diário Official, 1900.

Mensagem dirigida ao Congresso do Estado do Pará pelo Dr. José Paes de Carvalho, governador do Estado em 5 de fevereiro de 1900 apresentando a proposta de Orçamento da receita e da despesa para o exercício de 1900-1901. Belém: Typ. do Diário Official, 1900. $(1900-1)$

Mensagem dirigida ao Congresso do Estado do Pará pelo Dr. José Paes de Carvalho, Governador do Estado em 1 de fevereiro de 1901. Belém: Imprensa Oficial, 1901.

Mensagem dirigida em 7 de setembro de 1902 ao Congresso Legislativo do Pará pelo Dr. Augusto Montenegro, Governador do Estado. Belém: Imprensa Oficial, 1902.

Mensagem dirigida em 7 de setembro de 1903 ao Congresso Legislativo do Pará pelo Dr. Augusto Montenegro Governador do Estado. Belém: Imprensa Official, 1903.

Mensagem dirigida em 7 de setembro de 1904 ao Congresso Legislativo do Pará pelo Dr. Augusto Montenegro Governador do Estado. Belém: Imprensa Oficial, 1904.

Mensagem dirigida em 7 de setembro de 1905 ao Congresso Legislativo do Pará pelo Dr. Augusto Montenegro Governador do Estado. Belém: Imprensa Official, 1905.

Mensagem dirigida em 7 de setembro de 1906 ao Congresso Legislativo do Pará pelo Dr. Augusto Montenegro Governador do Estado. Belém: Imprensa Oficial, 1906.

Mensagem dirigida em 7 de setembro de 1907 ao Congresso Legislativo do Pará pelo Dr. Augusto Montenegro Governador do Estado. Belém: Imprensa Oficial, 1907.

Mensagem dirigida em 7 de setembro de 1908 ao Congresso Legislativo do Pará pelo Dr. Augusto Montenegro Governador do Estado. Belém: Imprensa Official do Estado do Pará, 1908 .

Mensagem dirigida em 7 de setembro de 1909 ao Congresso Legislativo do Pará pelo Dr. João Antônio Luiz Coelho Governador do Estado. Belém: Imprensa Oficial do Estado do Pará, 1909.

Mensagem dirigida em 7 de setembro de 1910 ao Congresso Legislativo do Pará pelo Dr. João Antônio Luiz Coelho Governador do Estado. Belém: Imprensa Official do Estado do Pará, 1910.

Mensagem dirigida em 7 de setembro de 1911 ao Congresso Legislativo do Pará pelo Dr. João Antônio Luiz Coelho Governador do Estado. Belém: Imprensa Oficial do Estado do Pará, 1911.

Mensagem dirigida em 7 de setembro de 1912 ao Congresso Legislativo do Pará pelo Dr. João Antônio Luiz Coelho Governador do Estado. Belém: Imprensa Oficial do Estado do Pará, 1912. 
Mensagem dirigida em 7 de setembro de 1913 ao Congresso Legislativo do Pará pelo Dr. Enéas Martins Governador do Estado. Belém: Imprensa Oficial do Estado, 1913.

Mensagem dirigida em 1 de agosto de 1915 ao Congresso Legislativo do Pará pelo Dr. Enéas Martins Governador do Estado. Belém: Imprensa Oficial do Estado do Pará, 1915.

Mensagem dirigida em 1 de agosto de 1916 ao Congresso Legislativo do Pará pelo Dr. Enéas Martins Governador do Estado. Belém: Imprensa Oficial do Estado do Pará, 1916.

Presidentes da província e governadores do Estado do Ceará (1877, 1889-1916)

Relatório com que o Exm. Sr. Enéas de Araujo Torreão passou a administração da Província do Ceará ao Exm. Sr. Dr. Antonio Caio da Silva Prado no dia 21 de abril de 1888. Fortaleza: Typ. Constitucional, 1888.

Fala com que o Exm. Sr. Senador Henrique Francisco d'Avila presidente da Província do Ceará, abriu a $2^{\mathrm{a}}$ Sessão da Assembléia Legislativa Provincial no dia 15 de julho de 1889. [Ceará] Typ. da Gazeta do Norte, 1889.

Relatório com que o Exm. Snr. Conselheiro Henrique D'Avila senador do Império e Presidente do Ceará passou a administração desta Província ao Exm. Sr. Fortaleza: Typographia Econômica, 1889. (1889-1)

Estado do Ceará - Mensagem que o Exmo. Sr. General de Divisão do Estado do Ceará leu perante o respectivo Congresso em sessão ordinária de $1^{\circ}$ de outubro de 1891.Fortaleza: Typ. do Estado do Ceará, 1891.

Mensagem do Presidente do Estado Tenente Coronel Dr. José Freire Bezerril Fontenelle à Assembléia Legislativa do Ceará em sua $2^{\mathrm{a}}$ sessão ordinária da $1^{\mathrm{a}}$ Legislatura. Fortaleza: Typ da República, 1893.

Mensagem do Presidente do Estado Coronel Dr. José Freire Bezerril Fontenelle à Assembléia Legislativa do Ceará em sua $3^{\mathrm{a}}$ sessão ordinária da $2^{\mathrm{a}}$ Legislatura. Fortaleza: Typ. d'A Republica, 1894.

Mensagem do Presidente do Estado do Ceará C.el dr. José Freire Bezerril Fontenelle à Respectiva Assembléia Legislativa em sua $4^{\mathrm{a}}$ sessão ordinária da $1^{\mathrm{a}}$ Legislatura. Fortaleza: Typ. d'A República, 1895.

Mensagem do Presidente do Estado do Ceará C.el. dr. José Freire Bezerril Fontenelle à respectiva Assembléia Legislativa em sua $5^{\text {a }}$ Sessão Ordinária da $1^{\text {a }}$ Legislatura. Fortaleza: Typ. D’A República, 1896.

Mensagem apresentada à Assembléia Legislativa do Ceará. Pelo Presidente do Estado Dr. Antonio Pinto Nogueira Accioly em $1^{\circ}$ de julho de 1897. Fortaleza: Typ. d'A República, 1897.

Mensagem apresentada à Assembléia Legislativa do Ceará pelo presidente do Estado Dr. Antonio Pinto Nogueira Accioly em 4 de julho de 1898. Fortaleza: Typographia Econômica, 1898. 
Mensagem apresentada a Assembléia Legislativa do Ceará pelo Presidente do Estado Exmo. Sr. Dr. Antonio Pinto Nogueira Accioly em $1^{\circ}$ de julho de 1900. Fortaleza: Typ. D’A Republica, 1900.

Mensagem apresentada à Assembléia Legislativa do Ceará em $1^{\circ}$ de julho de 1901 pelo Presidente do Estado Dr. Pedro Augusto Borges. Fortaleza: Typ. Econômica, 1901.

Mensagem apresentada a Assembléia Legislativa do Ceará em $1^{\circ}$ de julho de 1902 pelo Presidente do Estado Dr. Pedro Augusto Borges. Ceará - Fortaleza: Typ. Minerva, 1902.

Mensagem apresentada à Assembléia Legislativa do Ceará em $1^{\circ}$ de julho de 1903 pelo Presidente do Estado Dr. Pedro Augusto Borges. Fortaleza: Typ. Minerva, 1903.

Mensagem apresentada à Assembléia Legislativa do Ceará em $1^{\circ}$ de julho de 1904 pelo Presidente do Estado Dr. Pedro Augusto Borges. Fortaleza: Typ. Minerva, 1904.

Mensagem dirigida à Assembléia Legislativa do Ceará em $1^{\circ}$ de julho de 1905 pelo Presidente do Estado Dr. Antonio Pinto Nogueira Accioly. Fortaleza: Typo - Litographia a Vapor, 1905.

Mensagem dirigida à Assembléia Legislativa do Ceará em $1^{\circ}$ de julho de 1906 pelo Presidente do Estado Dr. Antonio Pinto Nogueira Accioly. Fortaleza: Typo - Litographia a Vapor, 1906.

Mensagem apresentada à Assembléia Legislativa do Ceará em $1^{\circ}$ de julho de 1907 pelo Presidente do Estado Dr Antonio Pinto Nogueira Accioly. Fortaleza: Typo - Litographia a Vapor, 1907.

Mensagem dirigida à Assembléia Legislativa do Ceará em $1^{\circ}$ de julho de 1908 pelo Presidente do Estado Dr. Antonio Pinto Nogueira Accioly. Fortaleza: Typo - Litographia a Vapor, 1908.

Mensagem dirigida à Assembléia Legislativa do Ceará em $1^{\circ}$ de julho de 1909 pelo Presidente do Estado Dr. Antonio Pinto Nogueira Accioly. Fortaleza: Typo-Litographia A Vapor, 1909.

Mensagem dirigida à Assembléia Legislativa do Ceará em $1^{\circ}$ de julho de 1910 pelo Presidente do Estado Dr. Antonio Pinto Nogueira Accioly. Fortaleza: Typo-Litographia A Vapor, 1910.

Mensagem dirigida à Assembléia Legislativa do Ceará em $1^{\circ}$ de julho de 1911 pelo Presidente do Estado Dr. Antonio Pinto Nogueira Accioly. Fortaleza: Typo-Litographia A Vapor, 1911.

Mensagem dirigida à Assembléia Legislativa do Ceará em $1^{\circ}$ de julho de 1912 pelo Presidente do Estado Cel. Antonio Frederico de Carvalho Motta.. Fortaleza: Typ. Cahenceler, 1912.

Mensagem dirigida à Assembléia Legislativa do Ceará em $1^{\circ}$ de julho de 1914 pelo Presidente do Estado Coronel Benjamin Liberato Barroso, Fortaleza: Typogravura, A. C. Mendes, 1914. 
Mensagem dirigida à Assembléia Legislativa do Ceará em $1^{\circ}$ de julho de 1915 pelo Presidente do Estado Coronel Benjamin Liberato Barroso. Fortaleza: Typ. Moderna, 1915.

Mensagem dirigida à Assembléia Legislativa do Ceará em $1^{\circ}$ de julho de 1916 pelo Presidente do Estado Coronel Benjamin Liberato Barroso. Fortaleza, 1916.

Outras fontes

NOZOE, Nelson, BASSANEZI, Maria Silvia C. Beozzo \& SAMARA, Eni de Mesquita. (orgs.). Os refugiados da seca - emigrantes cearenses 1888-1889. São Paulo/Campinas: NEHD, NEPO, CEDHAL, 2003 (CD-ROM).

Paróquia de São José - Livro de Tombo da Freguesia de São José de Castanhal, 1911.

Dados Estatísticos e Informações Para os Imigrantes. Publicado por ordem do Exm. Sr. Conselheiro Tristão de Alencar Araripe, Presidente da Província do Pará. Pará: Typ. do Diário de Notícias, 1886 


\section{Bibliografia}

ABREU, Marta. Meninas perdidas: o cotidiano do amor na Belle Époque. Rio de Janeiro: Paz e Terra, 1889.

Adalberto, Príncipe da Prússia (1811-1873). Brasil: Amazonas e Xingu. Belo Horizonte: Itatiaia; São Paulo: EDUSP,1977.

ALGRANTI, Leila Mezan. Honradas e devotas: mulheres na colônia. Rio de Janeiro: José Olympio, 1993.

AGUIAR, Keila de Sousa. Trabalho, Família e Habitação: cotidiano dos migrantes nordestinos na capital paraense (1898-1908). Belém: Monografia de Conclusão de Curso (História), Universidade Federal do Pará, 2001.

ALBUQUERQUE JÚNIOR, Durval. Falas de astúcia e de angústia: a seca no imaginário nordestino - de problema a solução. Campinas: Dissertação de Mestrado (História), Universidade Estadual de Campinas, 1988b.

"Palavras que calcinam, palavras que dominam: a invenção da seca no Nordeste". Revista Brasileira de História, vol. 14, nº 28 (1994), pp. 111-120.

A invenção do nordeste e outras artes. Recife: Fundação Joaquim Nabuco/Editora Massangana, São Paulo: Cortez, 1999.

ALENCASTRO, Luiz Felipe \& RENAUX. Maria Luiza. "Caras e modos dos migrantes e imigrantes”. In: ALENCASTRO, Luiz Felipe (org.). História da vida privada no Brasil, 2. São Paulo: Companhia da Letras, 1997, pp. 291-335.

ALVIM, Zuleika. "Imigrantes: a vida privada dos pobres do campo". In: SEVCENKO, Nicolau (org.). História da vida privada no Brasil. República: da Belle-Époque à era do Rádio. São Paulo: Companhia das Letras, 1998, vol. 3, pp. 215-287.

ARIÈS, Philippe. História da morte no Ocidente: da idade média aos nossos dias. Rio de Janeiro: Franciso Alves, 1977.

BAENA, Antonio Ladislau Monteiro (1782-1850). Ensaio corográfico sobre a Província do Pará. Brasília: Senado Federal, 2004.

BALCÃO, Lier Ferreira. "A cidade das reclamações: moradores e experiência urbana na imprensa paulista (1900-1913)”. In: FENELON, Déa Ribeiro (org.). Cidades. São Paulo: PUC/Olho d'Água, 1999, pp. 225-256.

BARBOSA, Marta Emísia Jacinto. Famintos do Ceará: imprensa e fotografia entre o final do século XIX e início do século XX. São Paulo: Tese de doutorado (História), Pontifícia Universidade Católica de São Paulo, 2004. 
BARREIRO, José Carlos. Imaginário e viajantes no Brasil do século XIX: cultura e cotidiano, tradiçao e resistência. São Paulo: UNESP, 2002.

. "O Materialismo Histórico e a questao da cultura". Revista Brasileira de História, vol. 9 (setembro 1989-fevereiro 1990), pp. 209-218.

BASSANEZI, Maria Silvia C. Beozzo. "Migrantes no Brasil na segunda metade do século XIX”. Anais do XII Encontro Nacional de Estudos Populacionais da ABEP. Caxambu: ABEP, 2000, vol. 1, pp. 1-24.

BATES, Henry Walter (1825-1892). Um naturalista no rio Amazonas. Belo Horizonte: Itatiaia; São Paulo: EDUSP, 1979.

BENCHIMOL, Samuel. Romanceiro da Batalha da Borracha. Manaus: Imprensa Oficial, 1992.

Amazônia - Formação Social e Cultural. Manaus: Valer, 1999.

BERMAN, Marshall. Tudo que é sólido desmancha no ar: a aventura da modernidade. São Paulo: Companhia das Letras, 1988.

BORGES, Ricardo. Vultos notáveis do Pará. $2^{\mathrm{a}}$ edição revista e aumentada comemorativa ao centenário de nascimento do autor. Belém: CEJUP,1986.

BRAGA, Theodoro. O município de Breves (1783-1910). Monografia organizada com o estudo feito sobre documentos oficiais e obras vulgarizadas. Belém: Livraria Gillet de Torres e Comp., 1911.

BRESCIANI, Maria Stella. Londres e Paris no século XIX: o espetáculo da pobreza. São Paulo: Brasiliense, 1982.

BRETAS, Marcos Luiz. Ordem na cidade: o exercício cotidiano da autoridade policial no Rio de Janeiro, 1907-1930. Rio de Janeiro: Rocco, 1997.

BRUNO, Ernani Silva. História do Brasil - Geral e Regional 1. Amazônia. São Paulo: Cultrix, 1966.

BURKE, Peter e PORTER, Roy. História social da linguagem. São Paulo: Fundação Editora da UNESP/Cambridge, 1997.

CHALHOUB, Sidney. Trabalho, Lar e Botequim: o cotidiano dos trabalhadores pobres no Rio de Janeiro na belle-époque. São Paulo: Brasiliense, 1986.

—. "Classes Perigosas". Trabalhadores, nº 6 (1990), pp. 2-22.

A cidade febril: cortiços e epidemias na corte imperial. São Paulo: Companhia das Letras, 1996. 
CHARLOT, Monica \& MARX, Roland. Londres, 1851-1901: a era vitoriana ou o triunfo as desigualdades. Rio de Janeiro: Jorge Zahar, 1993.

CAMPOS, Humberto. "Rosa de Jericó". In: Fatos e Feitos. Apresentação de Henrique de Campos. São Paulo: Gráfica Editora Brasileira LTDA, 1949.

CANCELA, Cristina Donza. Adoráveis e dissimuladas: as relações amorosas das mulheres das camadas populares na Belém do final do século XIX e início do século XX. Campinas: Dissertação de Mestrado (Antropologia), Universidade Estadual de Campinas, 1997.

CASCUDO, Luis da Câmara. Contos tradicionais do Brasil (compilados por Câmara Cascudo). 12ª edição. São Paulo: Global, 2003.

- Vaqueiros e cantadores. Belo Horizonte: Itatiaia, São Paulo: EDUSP, 1984.

-. Superstição no Brasil. Belo Horizonte: Itatiaia; São Paulo: EDUSP, 1985.

CASTRO, José Maria Ferreira de. A Selva [1914]. 39ª edição. Lisboa: Guimarães Editores, 2002.

CONCEIÇÃO, Maria de Fátima Carneiro da. Políticas e Colonos na Bragantina, Estado do Pará: um trem, a terra e a mandioca. Campinas: Dissertação de Mestrado (Sociologia), Universidade Estadual de Campinas, 1991.

CORPES, Raimundo Silva. Migrantes e Imigrantes no Pará da virada do século (18981908). Belém: Monografia de Conclusão de Curso (História), Universidade Federal do Pará, 2002.

COSTA, Maria de Fátima. A História de um país inexistente: Pantanal entre os séculos XVI e XVIII. São Paulo: Estação Liberdade: Kosmos, 1999.

COUDREAU, Henri (1859-1899). Viagem ao Xingu. Belo Horizonte: Itatiaia; São Paulo: EDUSP, 1977.

COUDREAU, Henri (1859-1899). Viagem ao Tapajós. Belo Horizonte: Itatiaia; São Paulo: EDUSP, 1977.

CRUZ, Ernesto. A estrada de Ferro de Bragança: visão social, econômica e política. Belém: Falângola, 1955.

Colonização do Pará. Belém: Conselho Nacional de Pesquisas/Instituto Nacional de Pesquias da Amazônia, 1958.

. História de Belém. Belém, UFPa, 1973, 2 vols. 
. Procissão dos Séculos: Vul
Imprensa Oficial do Estado, 1999.

CRUZ FILHO. História do Ceará - Resumo Didático. São Paulo: Melhoramentos, s.d.

CRUZ, Heloísa de Faria. “A cidade do reclame: propaganda e periodismo em São Paulo". Projeto História, no 13 (junho 1996), pp. 81-92.

CUNHA, Euclides (1886-1909). Os sertões. Campanha de Canudos. 28 a edição. Rio de Janeiro/Brasília: Francisco Alves/INL, 1979.

Um paraíso perdido: ensaios, estudos e pronunciamentos sobre a Amazônia. $2^{\mathrm{a}}$ edição. Organização, introdução e notas Leandro Tocantins. Rio de Janeiro: José Olympio, 1994.

- "A campanha de Canudos (Série de reportagens publicadas em o Estado de S. Paulo, de agosto a outubro de 1897, enviadas do teatro de operações no sertão da Bahia)". In: Canudos e outros temas. Brasília: Senado Federal, Conselho Editorial, 2003, pp.15109.

CUNHA, Maria Clementina Pereira. O espelho do mundo. Juquery, a história de um asilo. Rio de Janeiro: Paz e Terra, 1986.

Dados Biográficos dos senadores do Pará: 1826-1997. Brasília: Senado Federal, Secretaria de Informação e Documentação, 1997.

DAVIS, Natalie Zemon. Culturas do povo: sociedade e cultura no início da França moderna: oito ensaios. [1975]. Rio de Janeiro: Paz e Terra, 1990.

DEAN, Warren. A luta pela borracha no Brasil: um estudo de História ecológica. São Paulo: Nobel, 1989.

DEL PRIORE, Mary. A Mulher na história do Brasil. São Paulo: Contexto, 1988.

— (org.). História da criança no Brasil. São Paulo: Contexto, 1991.

— (org.). História das crianças no Brasil. São Paulo: Contexto, 1999.

(org.). Revisão do Paraíso: os brasileiros e o estado em 500 anos de história. Rio de Janeiro: Campus, 2000.

DE CAMPOS, Ribeiro (1905-1995). Gostosa Belém de outrora (reedição fac-símile) Belém: SECULT, 2005.

DIAS, Edinéa Mascarenhas. A ilusão do fausto - Manaus 1890-1920. Manaus: Valer, 1999. 
DIAS, Maria Odila Leite da Silva. Quotidiano e poder em São Paulo no século XIX. São Paulo: Brasiliense, 1984.

ÉGLER, Eugênia Gonçalves. “A Zona Bragantina no Estado do Pará”. Revista Brasileira de Geografia, no 3 (julho-setembro 1961), pp. 527-555.

ENGEL, Magali. Meretrizes e doutores, saber médico e prostituição no Rio de Janeiro (18401890). São Paulo: Brasiliense, 1989.

Estudo de Desenvolvimento Regional (Pará). Série Levantamento e Análises, 16. Rio de Janeiro: CAPES, 1959.

FARIAS, William Gaia. A construçao da República no Pará (1886-1897). Rio de Janeiro: Tese de Doutorado (História Social), Universidade Federal Fluminense, 2005.

FAUSTO, Boris. (org.). Fazer a América. A imigração em massa para a América Latina. São Paulo: EDUSP, 2000.

- "Imigração: cortes e continuidades". In: SCHWARCZ, Lilia Moritz (org.). História da Vida privada no Brasil: contrastes da intimidade contemporânea. São Paulo: Companhia da Letras, 1998, pp. 13-61.

FENELON, Déa Ribeiro (Org.). Cidades. São Paulo: PUC/Olho d’Água, 1999.

FIGUEIREDO, Aldrin Moura de. A cidade dos encantados: pajelanças, feitiçarias e religiões afro-brasileiras na Amazônia. A constituição de um campo de estudo, 1870-1950. Campinas: Dissertação de mestrado (História), Universidade Estadual de Campinas, 1996.

FOUCAULT, Michel. Vigiar e punir: nascimento das prisões. Petrópolis: Vozes, 1987.

FURTADO, Celso. Formação econômica do Brasil [1959]. 22 $2^{\mathrm{a}}$ edição. São Paulo: Companhia Editora Nacional, 1987.

FREITAS, Marcos Cezar (org.). História social da infância no Brasil $3^{\mathrm{a}}$ edição revista e ampliada. São Paulo: Cortez, Universidade São Francisco, 2001.

FULLER, Claudia Maria. "Os corpos de trabalhadores: política de controle social no GrãoPará”. Belém: Fascículos LH, nº 1, 1999.

GIRÃO, Raimundo. História econômica do Ceará. Fortaleza: Editora do Instituto do Ceará, 1947.

GIRÃO, Raimundo \& MARTINS FILHO, Antônio. O Ceará. Fortaleza: Editora Fortaleza, 1939.

GEREMEK, Bronislaw. A piedade e a forca. História da miséria e da caridade na Europa. Lisboa: Terramar, 1986. 
GODINHO, Victor \& LINDENBERG, Adolpho. Norte do Brasil. Através do Amazonas, do Pará e do Maranhão. Rio de Janeiro/São Paulo: Laemmert \& C., 1906.

GOVERNO DO PARÁ. O Pará em 1900. Belém: Imprensa de Alfredo Augusto Silva, 1900.

GOVERNO DO PARÁ. Belém da Saudade: A memória de Belém do início do século em Cartões-Postais. $2^{\text {a }}$ edição, revista e aumentada. Belém: Secult, 1998.

GUILLEN, Isabel Cristina Martins. Errantes da selva: histórias da migração nordestina para a Amazônia. Campinas: Tese de Doutorado (História), Universidade Estadual de Campinas, 1999.

IGLÉSIAS, Francisco. Historiadores do Brasil: capítulos de historiografia brasileira. Rio de Janeiro: Nova Fronteira; Belo Horizonte: UFMG/IPEA, 2000.

HARDMAN, Francisco Foot. Trem Fantasma; a modernidade na selva. São Paulo: Companhia das Letras, 1988.

HEGEL, Georg. W. F. Leçons sur la philosophie de l'histoire. Paris: Libraire Philosophique J. Vrin, 1979.

HOBSBAWN, Eric \& RANGER, Terence (orgs.). A invenção das tradições. Rio de Janeiro: Paz e Terra, 1984.

KIDDER. Daniel P. (1815-1891). Reminiscências de Viagens e Permanência no Brasil (Província do Norte). Compreedendo notícias históricas e geográficas do Império e das diversas províncias. São Paulo: Livraria Martins, 1943.

KLEIN, Herbert S. "Migração internacional na história das Américas". In: FAUSTO, Boris (org.). Fazer a América. A imigração em massa para a América Latina. São Paulo: EDUSP, 2000, pp. 13-31.

LACERDA, Franciane Gama. Em Busca dos campos perdidos: uma história de trem e cidade. São Paulo: Dissertação de mestrado (História), Pontifícia Universidade Católica de São Paulo, 1997

\footnotetext{
XX)". In: BEZERRA NETO José Maia \& GUZMÁN, Décio de Alencar (Orgs.). Terra matura: historiografia e história social na Amazônia. Belém: Paka-Tatu, 2002, pp. 395406. Encontro Nacional de História Oral. São Paulo: Associação Brasileira de História Oral/CNPq/Departamento de História da FFLCH/USP, 2002, (CD ROM).
} 
- "A vida e o trabalho nos seringais". In: FONTES, Edilza (org.). Contando a história do Pará: da Conquista à sociedade da borracha (sécs. XVI-XIX). Belém: E.motion, 2003, Vol. I, pp. 293-316.

. "Requerendo passagem para si e sua família: mulheres migrantes no Para da virada do século XIX”. Projeto História, no 27 (dezembro 2003), pp. 305-320.

LEAL, Joaquim Ponce. Os homens e as armas: o conflito campo-cidade no Brasil. Belo Horizonte: Itatiaia; Rio de Janeiro: Rio Arte, 1988.

LEAL, Luiz Augusto Pinheiro. Amolando as gambias: significados e práticas da capoeira em Belém (1840-1853). Monografia de Conclusão de Curso (História). Universidade Federal do Pará, 1997.

LENHARO, Alcir. Colonização e Trabalho no Brasil: Amazônia, Nordeste e Centro- Oeste. Campinas: Editora da UNICAMP, 1985.

LOBATO FILHO (General). A Borracha da Amazônia (sugestões para a solução prática de seus problemas). Rio de Janeiro: Irmãos Pongetti, 1951.

LOBATO, Júlio. Notas de um repórter: A vida de um repórter, reportagens nos hotéis e padarias de Belém. Belém Typ. F. Lopes, 1916.

LOURENÇO FILHO, Joaseiro do Pe. Cícero. Scenas e quadros do fanatismo no nordeste. São Paulo: Melhoramentos, s/d.

LOURENÇO. Fernando Antonio. Agricultura ilustrada: liberalismo e escravismo nas origens da questão agrária brasileira. Campinas: Editora da Unicamp, 2001.

MACIEL, Laura Antunes. A nação por um fio. Caminhos, práticas e imagens da "Comissão Rondon”. São Paulo: EDUC, 1998.

MALUF, Marina. Ruídos da memória. São Paulo: Siciliano, 1995.

Barão de MARACAJU. A Amazônia. As Províncias do Pará e Amazonas. Lisboa: Typographia Minerva, 1883.

MARSON, Adalberto. "Reflexões sobre o procedimento histórico". In: SILVA, Marcos Antônio da (org.). Repensando a história. $2^{\mathrm{a}}$ edição. São Paulo: ANPUH/Marco Zero, s/d., pp. 37-64.

MARTINS, José de Souza. “A vida privada nas áreas de expansão da sociedade brasileira”. In: SCHWARCZ, Lilia Moritz (org.). História da vida privada no Brasil: contrastes da intimidade contemporânea. São Paulo: Companhia das Letras, 1998, vol. 4, pp. 659-726. 
MATTOS, Dirceu Lino. "Impressões de uma viagem à zona bragantina do Pará". Boletim Paulista de Geografia, no 30 (1958), pp. 38-62.

MAUÉS, Raymundo Heraldo. Padres, pajés, santos e festas: catolicismo popular e controle eclesiástico. Belém: Cejup, 1995.

MEIRA, Octavio. Memórias do quase ontem. Rio de Janeiro: Lidador, 1976.

MEZA, René Salinas “El ideario femenino chileno, entre la tradición y la modernidad (Siglos XVIII al XX). Estudos CEDHAL, nº 8 (1993).

MELlO, Alcino Teixeira de. Nordestinos na Amazônia. Rio de Janeiro: Instituto Nacional de Imigração e Colonização/Departamento de Estudos e Planejamento, 1956.

MORAES, Raymundo. Na planície amazônica. $7^{\mathrm{a}}$ edição. Belo Horizonte/São Paulo: Itatiaia/Editora da Universidade de São Paulo, 1987.

MOURA, Esmerada Blanco Bolsonaro de. "Imigrantes italianos em São Paulo na passagem para o século XX”. In: DEL PRIORE, Mary. Revisão do Paraíso: os brasileiros e o estado em 500 anos de história. Rio de Janeiro: Campus, 2000.

MOURA, Denise Aparecida Soares de. "Andantes de Novos Rumos: a vinda de migrantes cearenses para fazendas de café paulistas em 1878". Revista Brasileira de História, vol. 17, no 34 (1997), pp. 119-132.

MORAIS FILHO, Melo. Festas e Tradições Populares do Brasil. Brasília: Senado Federal, 2002.

MUNIZ, Joao de Palma. Estado do Grão-Pará. Imigração e Colonisação. História e Estatística 1616-1916. Belém: Imprensa Oficial do Estrado do Pará, 1916.

Adesão do Grão-Pará à independência e outros ensaios. $2^{\mathrm{a}}$ edição. Belém: Conselho Estadual de Cultura, 1973.

NAZZARI, Muriel. "Sem perda da honra: a preservação da reputação feminina no Brasil colonial" In: SILVA, Maria Beatriz Nizza da (org.). Sexualidade família e religião na colonização do Brasil. Lisboa: Livros Horizonte, 2001, pp. 65-75.

NEVES, Frederico de Castro. A multidão e a história: saques e outras ações de massas no Ceará. Rio de Janeiro: Relume Dumará, 2000.

NEVES, Frederico de Castro. "A seca e a cidade: a formação da pobreza urbana em Fortaleza (1880-1900)". In: SOUZA, Simone de \& NEVES, Frederico de Castro (orgs.). Seca. Fortaleza: Edições Demócrito Rocha, 2002, pp. 75-104. 
NUNES, Francivaldo Alves. A trajetória do imigrante nordestino na cidade de Belém (18771889). Belém: Monografia de Conclusão de Curso (História), Universidade Federal do Pará, 1999.

OBELKEVICH. James. "Provérbios e História social”. In: BURKE, Peter e PORTER, Roy. História social da linguagem. São Paulo: Fundação Editora da UNESP/Cambridge, 1997, pp. 43-81.

OLIVEIRA, João Pacheco de. "O caboclo e o Brabo. Notas sobre duas modalidades de forçade-trabalho na expansão da fronteira amazônica no século XIX”. Encontros com a civilização brasileira, vol. 11 (1979), pp. 101-140.

OLIVEIRA, Lúcia Lippi. O Brasil dos imigrantes. Rio de Janeiro: Jorge Zahar Ed., 2001.

PECHMAN, Robert Moses (Org.). Olhares sobre a cidade. Rio de Janeiro: EdUFRJ, 1994.

PENTEADO, Antônio Rocha. Problemas de colonização e de uso da terra na região Bragantina do Estado do Pará. Belém: Universidade Federal do Pará, 1967.

. O Uso da Terra na Região Bragantina, Pará. São Paulo: Instituto de Estudos Brasileiros/USP, 1968.

PERROT, Michelle. Os excluídos da História: operários, mulheres e prisioneiros. Rio de Janeiro: Paz e Terra, 1992.

PETIT, Pere. Chão de promessas: elites políticas e transformações econômicas no estado do Pará pós-1964. Belém: Paka-Tatu, 2003.

PETRONE, Mara Thereza Schorer. O imigrante e a pequena propriedade (1824-1930). São Paulo: Brasiliense, 1982.

PORTER, Roy. “A linguagem do charlatanismo na Inglaterra, 1660-1800”. In: BURKE, Peter e PORTER, Roy. História social da linguagem. São Paulo: Fundação Editora da UNESP/Cambridge, 1997, pp. 83-119.

PRADO JÚNIOR, Caio. História econômica do Brasil [1945]. 35 a edição. São Paulo: Brasiliense, 1987.

PRADO, Maria Ligia \& CAPELATO, Maria Helena Rolim “A borracha na economia brasileira da Primeira República” In: FAUSTO, Boris (org). História Geral da Civilização Brasileira. São Paulo: Difel, 1977, vol. 8, pp. 285-307.

QUEIROZ, Jonas Marçal.“Trabalho Escravo, imigração e colonização no Grão-Pará (18771888)". In: QUEIROZ, Jonas Marçal \& COELHO, Mauro Cezar. Amazônia: modernização e conflitos (séculos XVIII e XIX). Belém/Macapá: UFPA/NAEA/UNIFAP, pp. 81-116. 
RAGO. Luzia Maragareth. Do Cabaré ao Lar: a utopia da cidade disciplinar-1890-1930. Rio de Janeiro: Paz e Terra, 1985.

RAMOS, Francisco Régis Lopes. "Juazeiro e Caldeirão". In: SOUZA, Simone de (org.). Uma nova História do Ceará. $2^{\mathrm{a}}$ edição revista e atualizada. Fortaleza: Edições Demócrito Rocha, 2002. pp. 345-380.

REIS, Arthur César Ferreira. O seringal e o seringueiro [1953]. $2^{\mathrm{a}}$ edição revista. Manaus: EdUA/ Governo do Estado do Amazonas, 1997.

. Épocas e visões regionais do Brasil. Manaus: Governo do Estado do Amazonas, 1966.

RONCAYOLO, Marcel. "Transfigurações noturnas da cidade: o império das luzes artificiais". Projeto História, no 18 (maio 1999), pp. 91-61.

RIOS, Kênia Sousa. Campos de concentração no Ceará: isolamento e poder na seca de 1932. Fortaleza: Museu do Ceará/Secretaria da Cultura e Desporto do Ceará, 2001.

ROMERO, Sílvio. Folclore brasileiro: cantos populares do Brasil [1897]. Belo Horizonte: Itatiaia; São Paulo: EDUSP, 1985.

SALLES, Vicente. O negro na formação da sociedade paraense. Belém: Paka-Tatu, 2004. . Música e músicos do Pará. Belém: Conselho Estadual de Cultura, 1970

SAMARA, Eni de Mesquita. As mulheres, o poder e a família (São Paulo, Século XIX). São Paulo: Marco Zero/Secretaria do Estado da Cultura de São Paulo, 1989

"Mistérios da 'fragilidade humana': o adultério feminino no Brasil, séculos XVIII e XIX”. Revista Brasileira de História, vol. 15, nº 29 (1995), pp. 57-71

SANT'ANNA. Denise. Bernuzzi. "Propaganda e História: antigos problemas, novas questões". Projeto História, no 14 (fevereiro 1997), pp. 89-112.

SANTOS, Roberto Araújo de Oliveira. História econômica da Amazônia (1800-1920). São Paulo: T.A. Queiroz, 1980.

SANTOS, Marco Antonio Cabral dos. "Polícia: homens da lei na metrópole do café". In: DEL PRIORE, Mary. Revisão do Paraíso: os brasileiros e o estado em 500 anos de história. Rio de Janeiro: Campus, 2000, pp. 277-300.

SARGES, Maria de Nazaré. Riquezas produzindo a belle époque - Belém do Pará (18701910). Belém: Paka-Tatu, 2000. 
. "Os populares no 'fim de festa': a participação de mulheres nos conflitos de rua em Belém (1910/1912). Cadernos do Centro de Filosofia e Ciências Humanas, vol. 12, $\mathrm{n}^{\text {os }}$ 1-2 (janeiro-dezembro 1993), pp. 55-66.

SCHWARCZ, Lilia Moritz. Retrato em branco e negro: jornais, escravos e cidadãos em São Paulo no final do século XIX [1987]. São Paulo: Companhia das Letras, 2001.

SEVCENKO, Nicolau "prelúdio republicano, astúcias da ordem e ilusões do progresso". In: SEVCENKO, Nicolau (org.). História da vida privada no Brasil. República: da BelleÉpoque à era do Rádio. São Paulo: Companhia das Letras, 1998, vol. 3, pp. 7-48.

—. "A capital irradiante: técnica, ritmos, e ritos do Rio". In: SEVCENKO, Nicolau (org.). História da vida privada no Brasil. República: da Belle-Époque à era do Rádio. São Paulo: Companhia das Letras, 1998, vol. 3, pp. 513-619.

SILVA, Marcos Antônio da. Caricata República: Zé Povo e o Brasil. São Paulo: Marco Zero/ CNPQ, 1990.

—. "A História e seus limites". História \& Perspectivas, nº 6 (janeiro-junho 1992), pp. 59-65.

- "Noticias do Brasilianismo. Saudades da historiografia brasileira". Revista Brasileira de História, vol. 16, n ${ }^{\text {os }}$ 31-32 (1996), pp. 76-88.

2002. . Contra a chibata: marinheiros brasileiros em 1910. 2 ed. São Paulo: Brasiliense, (org.). Repensando a história. $2^{\mathrm{a}}$ edicao. São Paulo: ANPUH/Marco Zero, s/d.

SILVA. Eduardo. As queixas do povo. Rio de Janeiro: Paz e Terra, 1988.

SODRÉ, Nelson Werneck. Formação histórica do Brasil [1962]. $3^{\mathrm{a}}$ edição. São Paulo: Brasiliense, 1964.

SOUZA, Itamar \& MEDEIROS FILHO, João. Os degredados filhos da seca: uma análise sócio-política das secas no nordeste. 2a edição. Rio de Janeiro/Petrópolis: 1983.

SOUZA, Simone de \& NEVES, Frederico de Castro (orgs.). Seca. Fortaleza: Edições Demócrito Rocha, 2002.

SOUZA. Simone de. (org.). Uma nova história do Ceará. $2^{a}$ edição revista e atualizada. Fortaleza: Edições Demócrito Rocha, 2002.

TEOPHILO, Rodolpho. A fome [1890]. Fortaleza: Edições Demócrito Rocha, 2002 . O Paraoara. Ceará: Typ. Moderna, 1899. 
_. "As manchas do sol e as secas. A causa destas e os meios de atenuar seus efeitos". In: Comemorando o Tricentenário da vinda dos primeiros portugueses ao Ceará. 16031903. Ceará, Typ. Minerva, 1903, pp.421-431.

. A seca de 1915. Fortaleza: Moderna, 1919.

TOCANTINS, Leandro. Amazônia. Natureza, homem e tempo: uma planificação ecológica [1960]. $2^{\mathrm{a}}$ edição. Rio de Janeiro: Civilização Brasileira, 1982.

VERÍSSIMO, José. “A Amazônia (aspectos econômicos)” [1892]. In: Estudos Amazônicos. Belém: Universidade Federal do Pará, 1970.

VIANNA, Athur. As epidemias no Pará [1908] 2a edição. Belém: Universidade Federal do Pará, 1975.

VIANNA, Francisco José de Oliveira. Evolução do povo brasileiro. São Paulo: Monteiro Lobato e C ${ }^{\text {a }}$ Editores, [1923].

VIGARELLO. Georges. "O trabalho dos corpos e do espaço". Projeto História, no 13 (junho 1996), pp.7-20.

VILLA. Marco Antônio. Vida e morte no sertão: história das secas no nordeste nos séculos XIX e XX. São Paulo: Ática, 2000.

WALLACE, Alfred Russel (1823-1913). Viagem pelos rios Amazonas e Negro. Belo Horizonte: Itatiaia; São Paulo: EDUSP, 1979.

WANDERLEY, Ezequiel. Poetas do Rio Grande do Norte. Recife: Imprensa Industrial, 1922.

WEBER, Eugen Joseph. França fin-de-siècle. São Paulo: Companhia das Letras, 1988.

WEINSTEIN, Barbara. A Borracha na Amazônia: expansão e decadência (1850-1920). São Paulo: Hucitec/Edusp, 1993.

. "Experiência de pesquisa em uma região periférica: a Amazônia". História, Ciência, Saúde. Manguinhos, vol. 9, n 2 (maio-agosto 2002), pp. 261-72.

WILLIAMS, Raymond. O campo e a cidade: na História e na literatura. São Paulo: Companhia das Letras, 1989.

WISSENBACH, Maria Cristina Cortez. "Da escravidão à liberdade: dimensões de uma privacidade possível". In: SEVCENKO, Nicolau (org.). História da vida privada no Brasil. República: da Belle-Époque à era do Rádio. São Paulo: Companhia das Letras, 1998, vol. 3, pp. 49-130.

WOLFF, Cristina Scheibe. Mulheres da Floresta: uma história: Alto Juruá, Acre (18901945). São Paulo: Hucitec, 1999. 